Prepared in cooperation with Sonoma County Water Agency, City of Santa Rosa, City of Sebastopol, City of Rohnert Park, City of Cotati, Town of Windsor, County of Sonoma, and California American Water

\title{
Simulation of Groundwater and Surface-Water Resources of the Santa Rosa Plain Watershed, Sonoma County, California
}

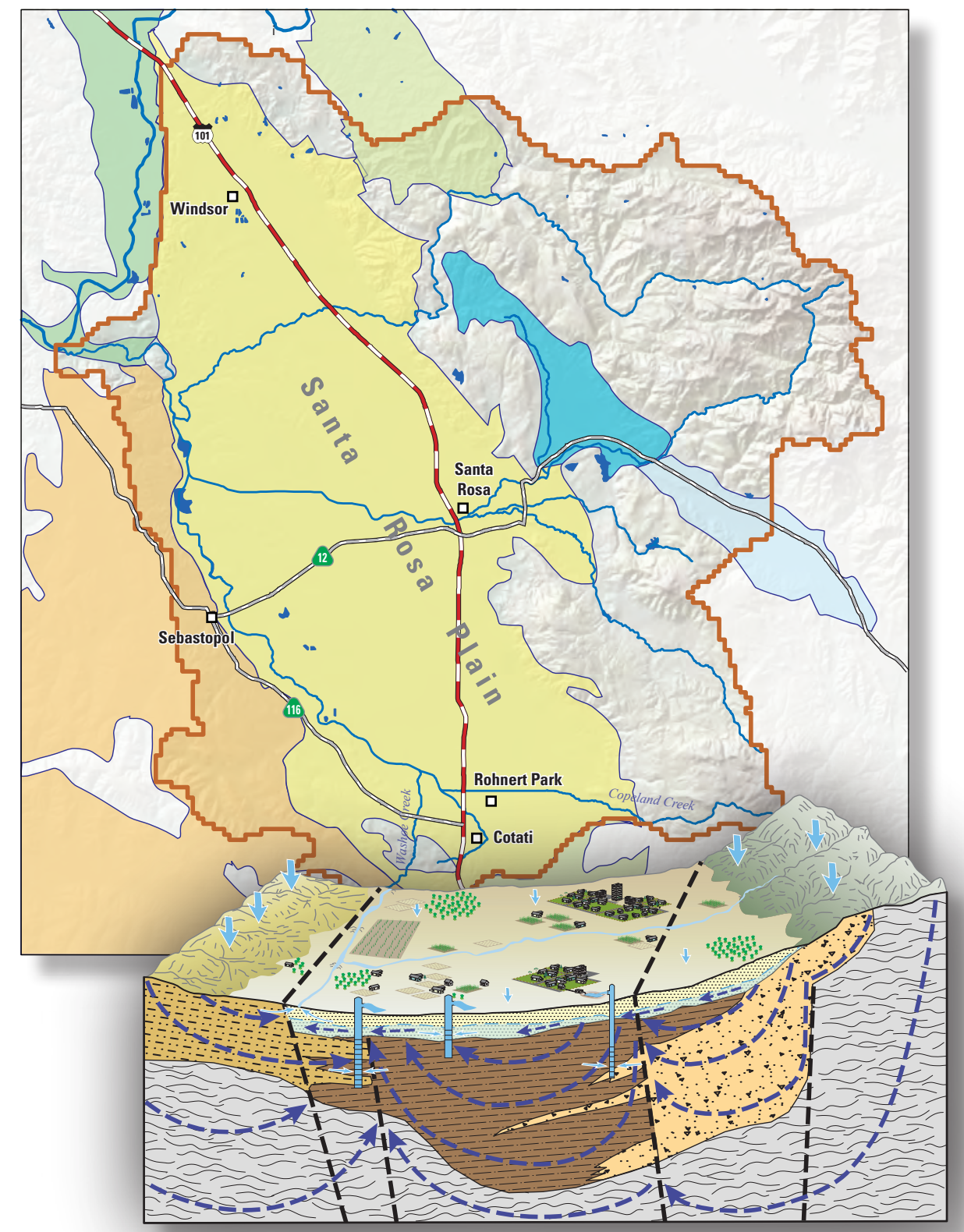

Scientific Investigations Report 2014-5052 
Cover. Conceptual model of the Santa Rosa Plain, Sonoma County, California. 


\section{Simulation of Groundwater and Surface- Water Resources of the Santa Rosa Plain Watershed, Sonoma County, California}

Edited by Linda R. Woolfenden and Tracy Nishikawa

In Cooperation with Sonoma County Water Agency, City of Santa Rosa, City of Sebastopol, City of Rohnert Park, City of Cotati, Town of Windsor, County of Sonoma, and California American Water

Scientific Investigations Report 2014-5052 


\title{
U.S. Department of the Interior SALLY JEWELL, Secretary
}

\section{U.S. Geological Survey Suzette M. Kimball, Acting Director}

\author{
U.S. Geological Survey, Reston, Virginia: 2014
}

For more information on the USGS - the Federal source for science about the Earth, its natural and living resources, natural hazards, and the environment, visit http://www.usgs.gov or call 1-888-ASK-USGS.

For an overview of USGS information products, including maps, imagery, and publications, visit http://www.usgs.gov/pubprod

To order this and other USGS information products, visit http://store.usgs.gov

Any use of trade, firm, or product names is for descriptive purposes only and does not imply endorsement by the U.S. Government.

Although this information product, for the most part, is in the public domain, it also may contain copyrighted materials as noted in the text. Permission to reproduce copyrighted items must be secured from the copyright owner.

Suggested citation:

Woolfenden, L.R., and Nishikawa, Tracy, eds., 2014, Simulation of groundwater and surface-water resources of the Santa Rosa Plain watershed, Sonoma County, California: U.S. Geological Survey Scientific Investigations Report 2014-5052, 258 p., http://dx.doi.org/10.3133/sir20145052

ISSN 2328-0328 (online) 


\section{Contents}

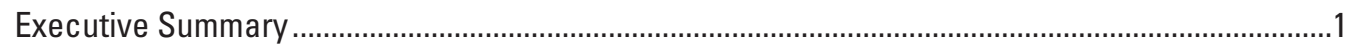

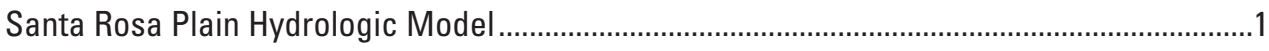

Key Results for Water Years 1976-2010 ……....................................................................

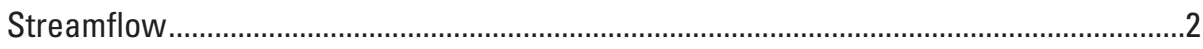

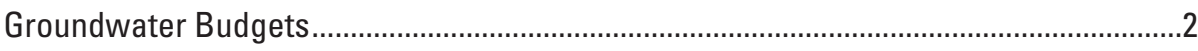

Effects of Pumping on the Hydrologic System.............................................................

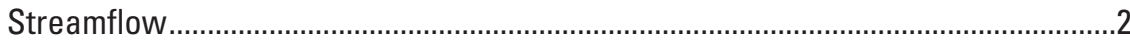

Groundwater-budget components.........................................................................

Key Results for Application of Future-Climate Scenarios........................................................

Future-Climate Scenarios without Pumping .................................................................

Future-Climate Scenarios with Projected Pumpage ...........................................................

Model Limitations and Uncertainty...................................................................................

\section{Chapter A. Introduction}

By Linda R. Woolfenden, Tracy Nishikawa, and Joseph A. Hevesi

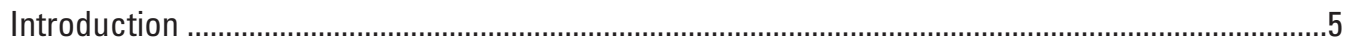

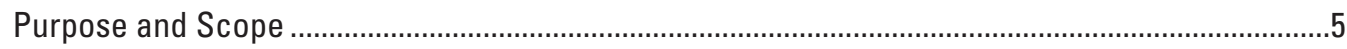

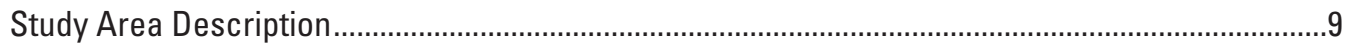

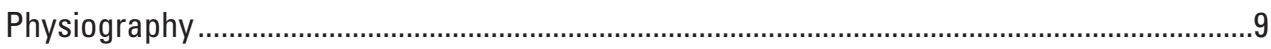

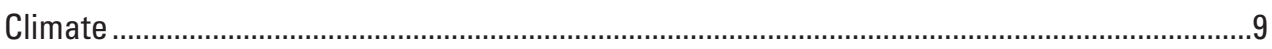

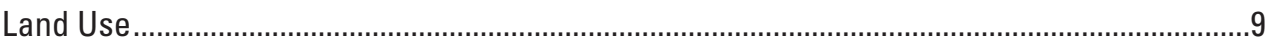

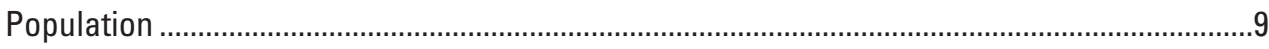

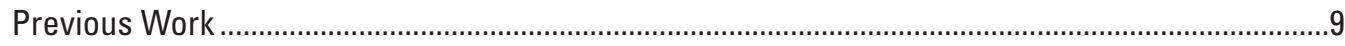

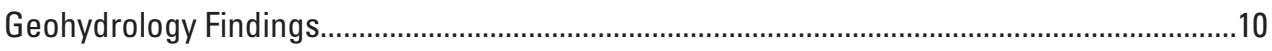

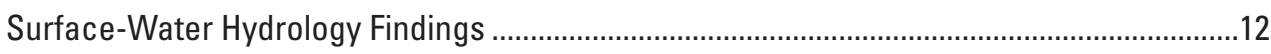

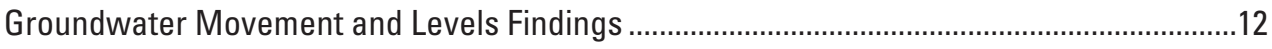

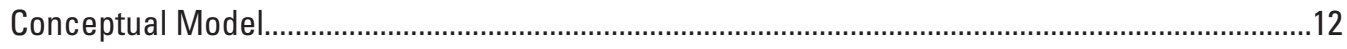

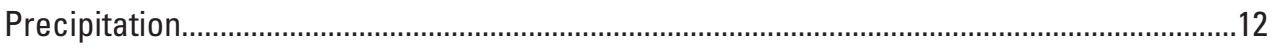

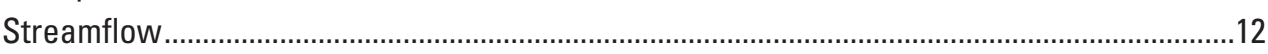

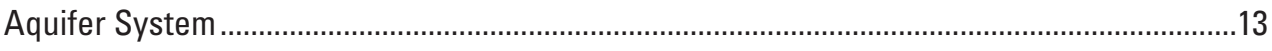

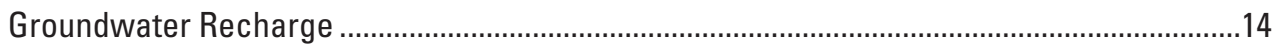

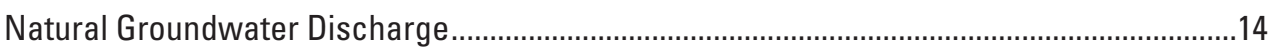

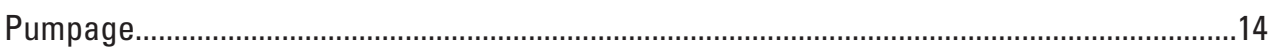

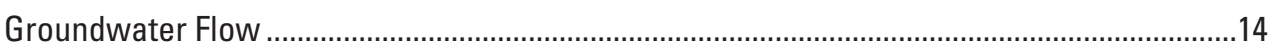

Simulation of Surface-Water and Groundwater Regions ............................................................16

Region 1: Plant Canopy, Land Surface, and Soil Zone ...........................................................17

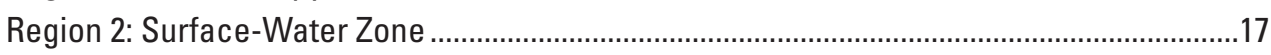

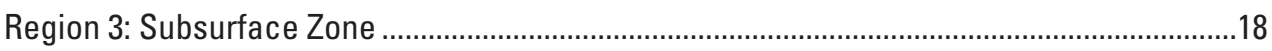

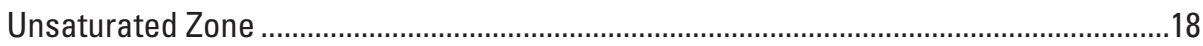

Saturated Zone ..............................................................................................................18

Method Used to Simulate Groundwater and Surface-Water Resources .......................................19

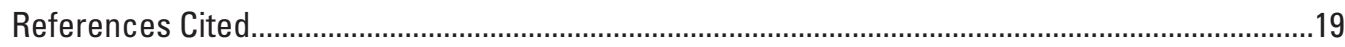




\section{Contents-Continued}

\section{Chapter B. Watershed-Component Model}

By Joseph A. Hevesi

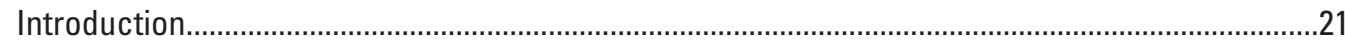

Watershed-Component Model (PRMS) Layout and Discretization...............................................21

Hydrologic Response Unit and Groundwater Reservoir Discretization .................................22

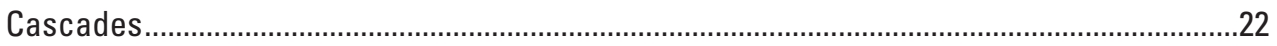

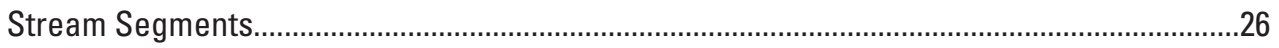

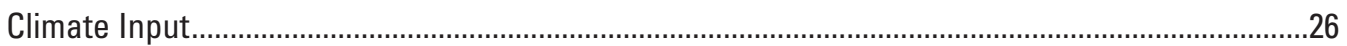

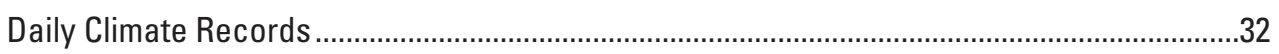

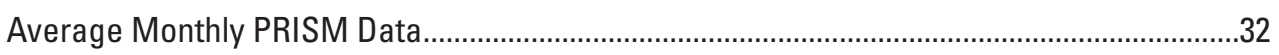

Spatially Interpolated Climate Inputs ..................................................................................32

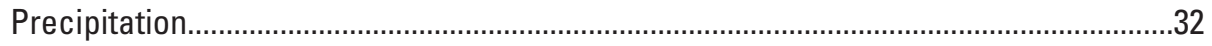

Maximum and Minimum Daily Air Temperature .............................................................32

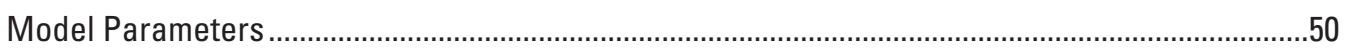

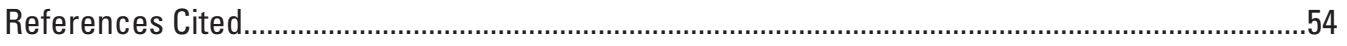

\section{Chapter C. Groundwater-Component Model}

By Linda R. Woolfenden

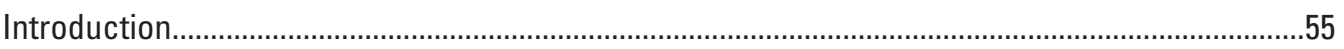

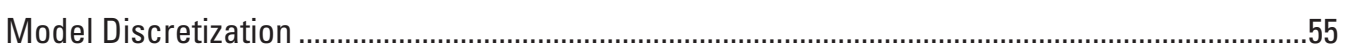

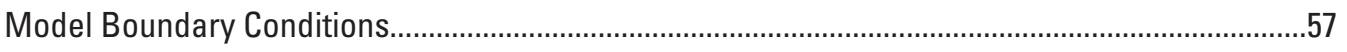

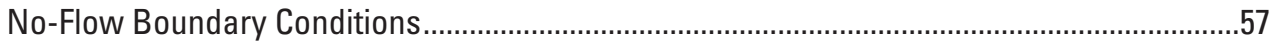

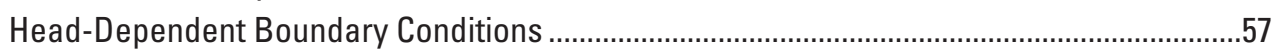

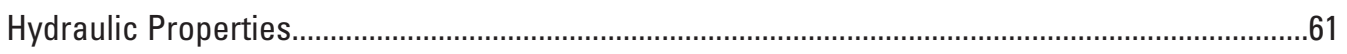

Hydraulic Parameter Zonation ...........................................................................................61

Model Storage Units ...............................................................................................

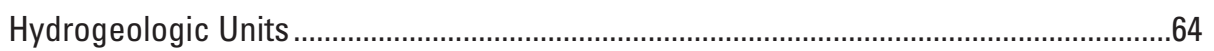

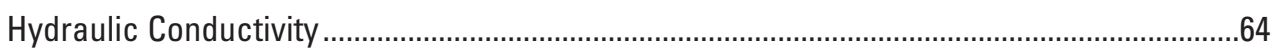

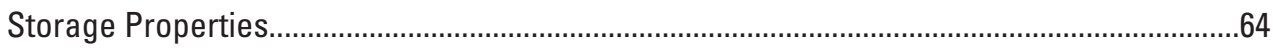

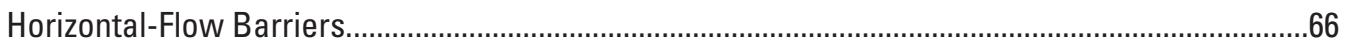

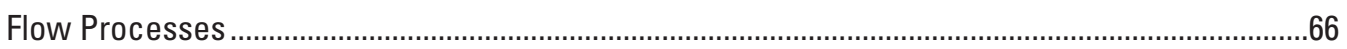

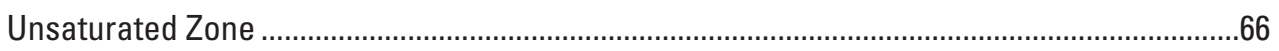

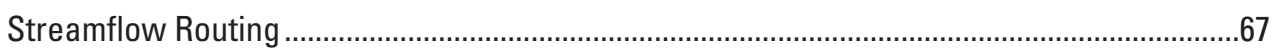

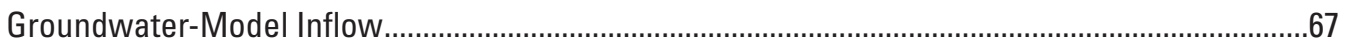

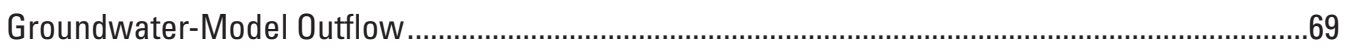

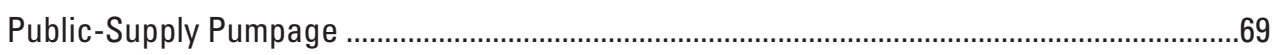

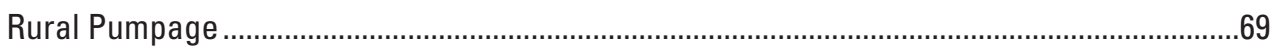

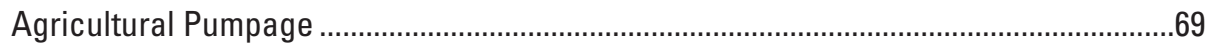

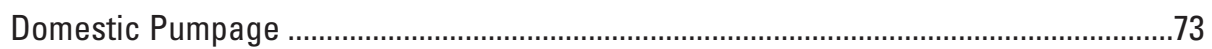

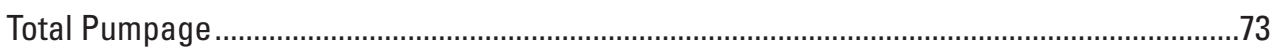

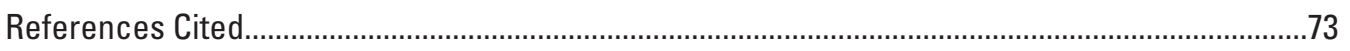




\section{Contents-Continued}

\section{Chapter D. Santa Rosa Plain Hydrologic-Model Calibration}

By Linda R. Woolfenden and Joseph A. Hevesi

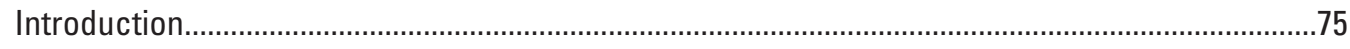

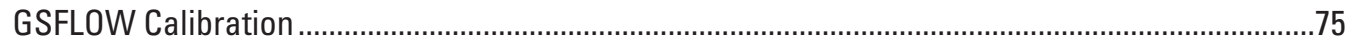

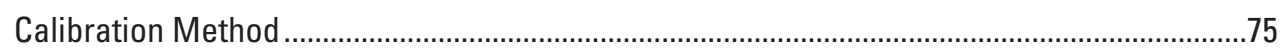

Final Model Input ......................................................................................................76

Watershed-Component Parameters.............................................................................76

Groundwater-Component Parameters ........................................................................76

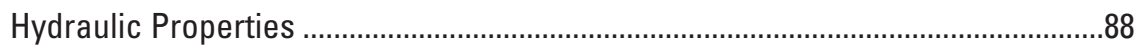

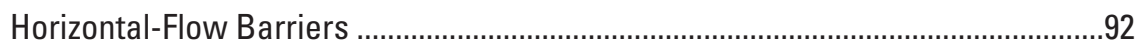

Boundary Conductance ................................................................................92

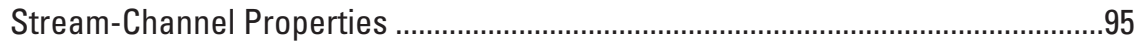

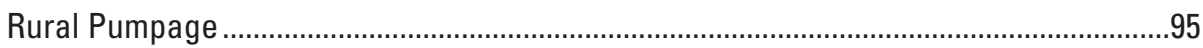

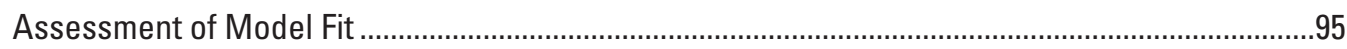

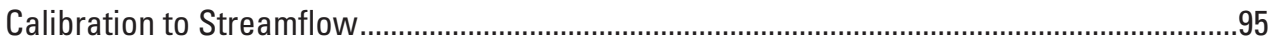

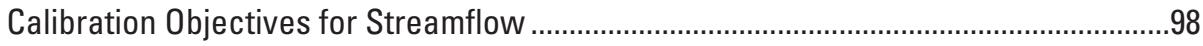

Testing Objectives for Streamflow.........................................................................98

Comparison of Measured and Simulated Streamflow ..................................................99

Calibration to Streamflow Results for Subbasins..........................................................99

Laguna de Santa Rosa Subbasin .......................................................................99

Santa Rosa Creek Subbasin ........................................................................................ 109

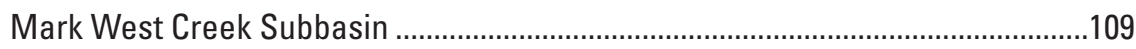

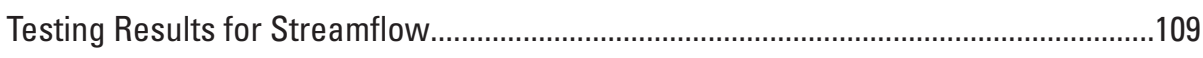

Comparison of Simulated and Measured Annual Streamflow......................................118

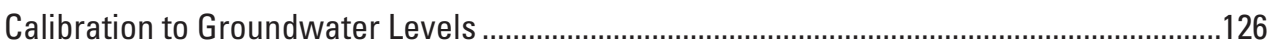

Comparison of Measured Groundwater Levels and

Simulated Hydraulic Heads ............................................................................126

Spatial Distribution: Water Year 2007 .........................................................................127

Simulated Hydrographs .........................................................................................131

Windsor Model Storage Unit .................................................................................131

Santa Rosa Model Storage Unit..........................................................................146

Cotati-North Model Storage Unit .........................................................................146

Cotati-South Model Storage Unit.........................................................................147

Wilson Grove Model Storage Unit ......................................................................147

Rincon-Kenwood, Bennett Valley-Plain, and Bennett
Valley-Mountains Model Storage Units

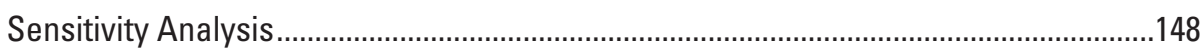

Appropriate Use of the Santa Rosa Plain Hydrologic Model .....................................................149

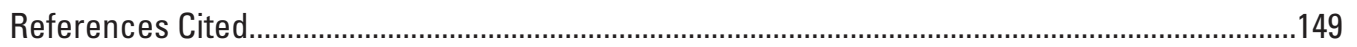




\section{Contents-Continued}

\section{Chapter E. Santa Rosa Plain Hydrologic Model Results}

By Linda R. Woolfenden and Joseph A. Hevesi

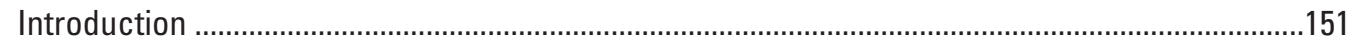

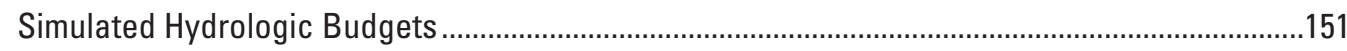

Annual Variations in Evapotranspiration and Streamflow..................................................151

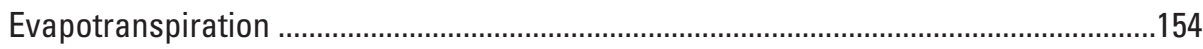

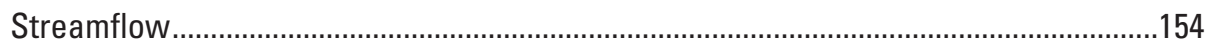

Monthly Variations in Evapotranspiration and Streamflow................................................154

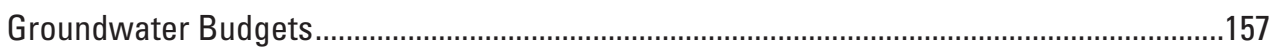

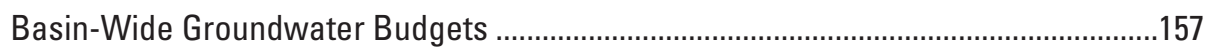

Groundwater Budgets for Subareas ........................................................................158

Spatially Distributed Streamflow and Net Groundwater Flux ...............................................162

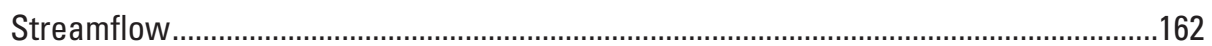

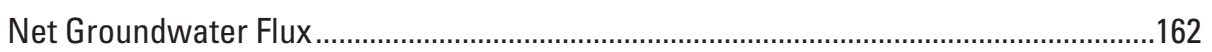

Effects of Pumping on the Hydrologic System......................................................................162

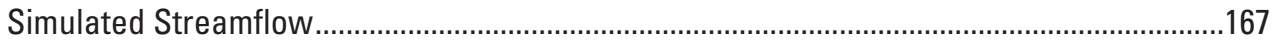

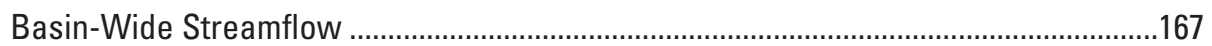

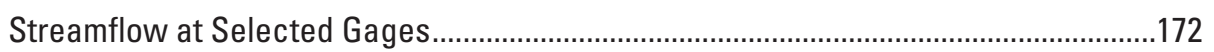

Simulated Groundwater-Budget Components ....................................................................172

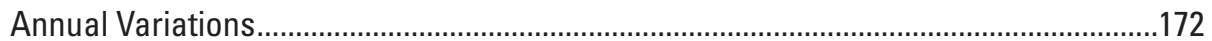

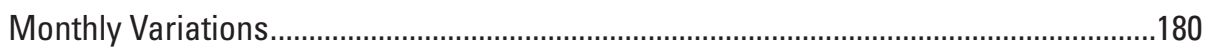

Simulated Groundwater Flow Between Model Layers ........................................................183

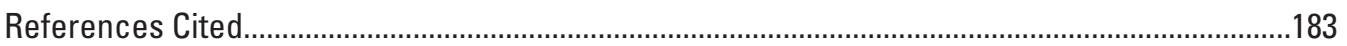




\section{Contents-Continued}

\section{Chapter F. Santa Rosa Plain Hydrologic Model Scenarios}

By Joseph A. Hevesi and Linda R. Woolfenden

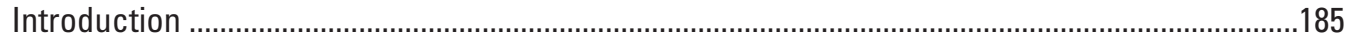

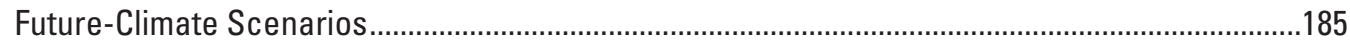

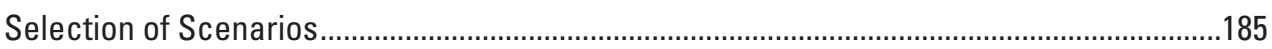

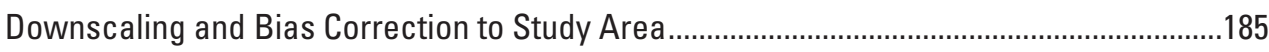

Future-Climate Precipitation .....................................................................................

Future Maximum Daily Air Temperature ......................................................................186

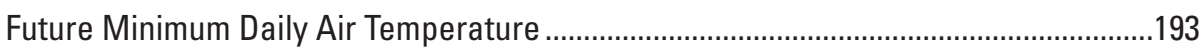

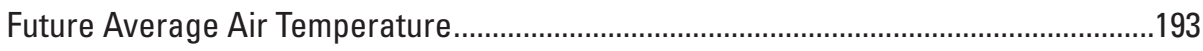

Model Application: Future-Climate Scenarios without Pumping .................................................193

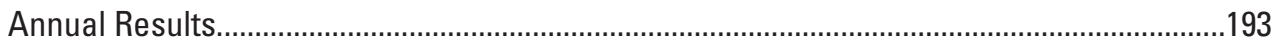

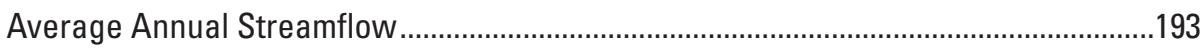

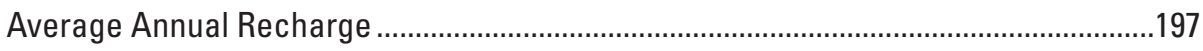

Average Annual Groundwater Discharge to Streams ................................................197

Average Annual Groundwater Evapotranspiration.....................................................197

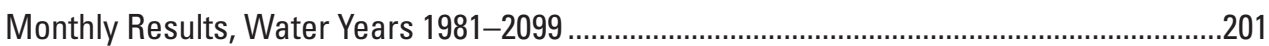

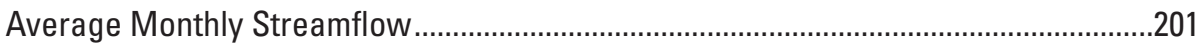

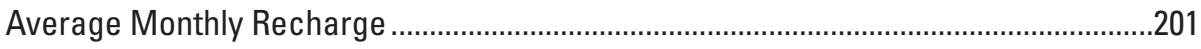

Average Monthly Groundwater Discharge to Streams.................................................201

Average Monthly Groundwater Evapotranspiration.....................................................207

Effects of Future-Climate on the Spatial Distribution of Recharge .......................................207

Effects of Future Climate on the Spatial Distribution of Streamflow.....................................212

Model Application: Future-Climate Scenarios with Projected Pumpage .....................................212

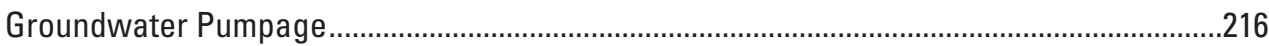

Simulated Groundwater Results for the Future-Climate

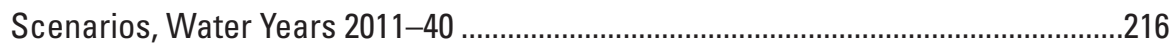

Selected Surface-Water Components and Groundwater Budgets...............................216

Annual Variations in Future-Climate Scenarios..............................................................223

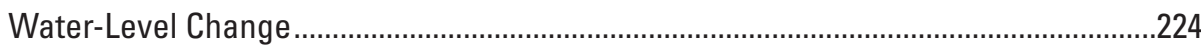

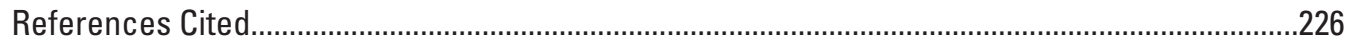




\section{Contents-Continued}

\section{Chapter G. Summary, Model Limitations, and Conclusions}

By Joseph A. Hevesi and Linda R. Woolfenden

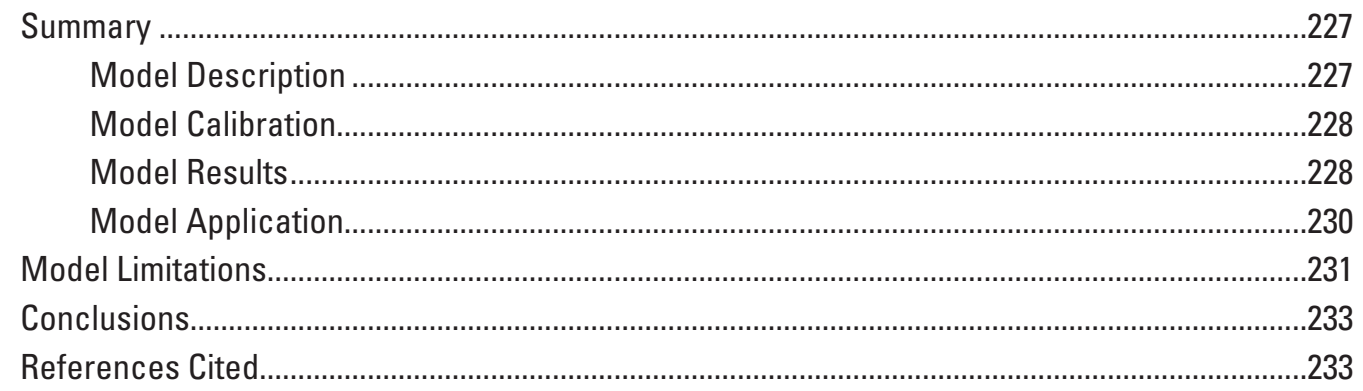

\section{Appendix 1. Supplemental Information}

By Joseph A. Hevesi

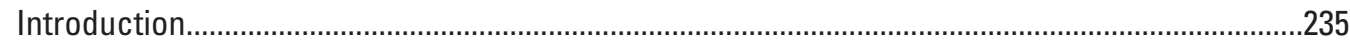

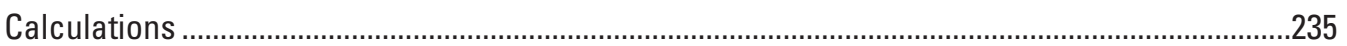

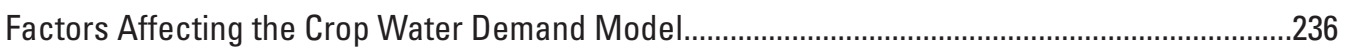

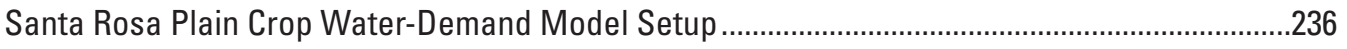

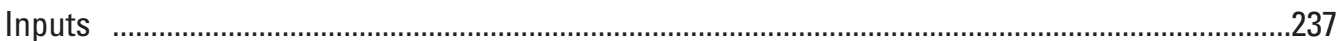

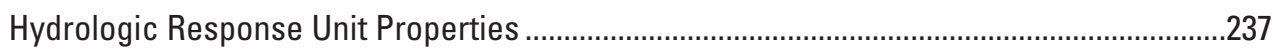

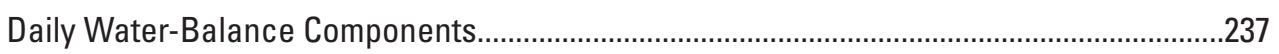

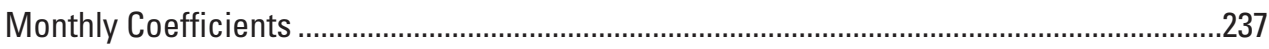

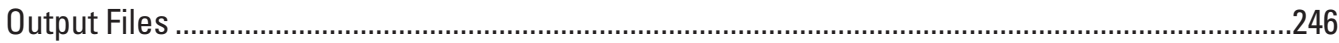

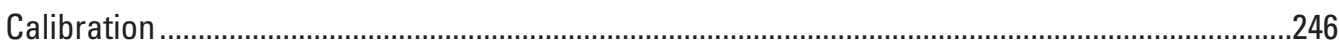

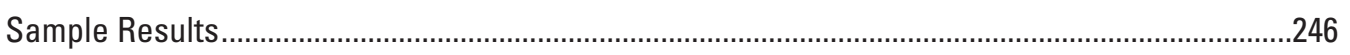

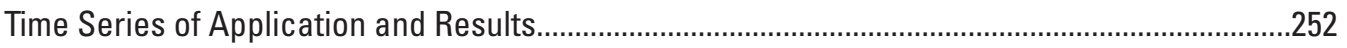

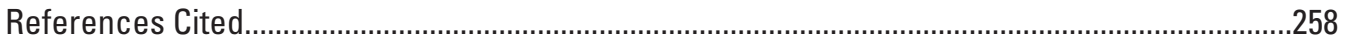




\section{Figures}

\section{Chapter A}

1. Map showing location of the Santa Rosa Plain watershed study area,

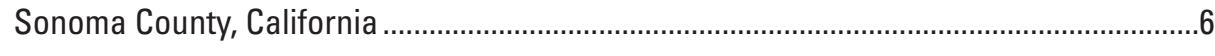

2. Map showing Santa Rosa Plain watershed and surface-water subbasins, Sonoma County, California .................................................................................................

3. Map showing Santa Rosa Plain watershed boundary with groundwater subbasins, Sonoma County, California...

4. Map showing groundwater-level contours for spring 1951, Santa Rosa Plain watershed, Sonoma County, California.

5. Conceptual model showing the groundwater-flow system, Santa Rosa Plain watershed, Sonoma County, California. 13

6. Map showing location of public-supply and rural (agricultural and domestic) wells, Santa Rosa Plain watershed, Sonoma County, California....

7. Graph showing reported public-supply and estimated rural pumpage during 1975-2010, Santa Rosa Plain watershed, Sonoma County, California

8. Schematic diagram showing the general conceptual model of the Santa Rosa Plain watershed hydrologic system, Sonoma County, California

\section{Chapter B}

1. Map showing model grid, active cells, and inactive cells for the watershed component of the Santa Rosa Plain hydrologic model, Santa Rosa Plain watershed, Sonoma County, California

2. Map showing cascade flow-routing network for the watershed-component model, Santa Rosa Plain watershed, Sonoma County, California

3. Map showing stream segments and cascading-flow subdrainage areas contributing to each stream segment of the watershed-component model, Santa Rosa Plain watershed, Sonoma County, California

4. Map showing location of climate stations used to develop daily precipitation, maximum temperature, and minimum temperature inputs, and PRISM 1971-2000 average precipitation for January, Santa Rosa Plain hydrologic model, Santa Rosa Plain watershed, Sonoma County, California

5. Graph showing spatially averaged and maximum and minimum PRISM estimates of monthly precipitation for water years 1971-2000, Santa Rosa Plain watershed, Sonoma County, California

6. Map showing PRISM 1971-2000 average maximum air temperature for January, and the location of climate stations having records used to develop daily climate inputs, Santa Rosa Plain hydrologic model, Santa Rosa Plain watershed, Sonoma County, California ....

7. Map showing PRISM 1971-2000 average minimum air temperature for January, and the location of climate stations having records used to develop daily climate inputs, Santa Rosa Plain hydrologic model, Santa Rosa Plain watershed, Sonoma County, California .

8. Map showing location of land parcels receiving reclaimed wastewater for irrigation, Santa Rosa Plain watershed, Sonoma County, California . 


\section{Figures-Continued}

\section{Chapter B-Continued}

9. Graphs showing total volumes of reclaimed wastewater used for irrigation in the Santa Rosa Plain watershed, Sonoma County, California: $A$, monthly; $B$, annual

10. Graphs showing spatially interpolated precipitation input for water years 1950-2010, averaged over the area of the Santa Rosa Plain watershed, Sonoma County, California, for the Santa Rosa Plain hydrologic model, indicating $A$, total water-year precipitation; $B$, maximum daily precipitation for each water year, and; $C$, cumulative departure from mean annual precipitation

11. Map showing average annual effective precipitation, water years 1950-2010, for the Santa Rosa Plain watershed, Sonoma County, California, calculated by using the daily precipitation and reclaimed-water inputs for the Santa Rosa Plain hydrologic model

12. Graph showing spatially interpolated air-temperature input for the Santa Rosa Plain hydrologic model, averaged over the area of the Santa Rosa Plain watershed, Sonoma County, California, for water years 1950-2010, indicating $A$, average maximum daily air temperature and; $B$, average minimum daily air temperature

13. Graph showing average monthly maximum and minimum air temperature, calculated using the daily air temperature data developed for the Santa Rosa Plain hydrologic model, water years 1950-2010, Santa Rosa Plain watershed, Sonoma County, California

14. Map showing spatially distributed averaged annual maximum daily air temperature, calculated using the daily air temperature inputs for the Santa Rosa Plain hydrologic model, water years 1950-2010, Santa Rosa Plain watershed, Sonoma County, California.

15. Map showing spatially distributed averaged annual minimum daily air temperature, calculated using the daily air temperature inputs for the Santa Rosa Plain hydrologic model, water years 1950-2010, Santa Rosa Plain watershed, Sonoma County, California. 


\section{Figures-Continued}

\section{Chapter C}

1. Map showing model grid, boundary conditions, profile row, and location of horizontal-flow barriers in the groundwater component of the Santa Rosa Plain

hydrologic model, Santa Rosa Plain watershed, Sonoma County, California

2. Graph showing profile along row 74 in the groundwater component of the Santa Rosa Plain hydrologic model, Santa Rosa Plain watershed, Sonoma County, California

3. Maps showing thickness of model layers and in the groundwater component of the Santa Rosa Plain hydrologic model, Santa Rosa Plain watershed, Sonoma County, California, for $A$, layer 1 and $B$, layer 2 .

4. Graphs showing water levels in wells used to estimate boundary heads in the groundwater component of the Santa Rosa Plain hydrologic model, Santa Rosa Plain watershed, Sonoma County, California: $A, 8 N / 9 W-15 B 1$ for the Russian River boundary; and $B, 7 \mathrm{~N} / 9 \mathrm{~W}-26 \mathrm{P} 1$ for the Wilson Grove boundary

5. Graphs showing water levels in wells used to estimate boundary heads in the groundwater component of the Santa Rosa Plain hydrologic model, Santa Rosa Plain watershed, Sonoma County, California, for the eastern end and the middle of the Kenwood boundary, respectively: $A, 7 \mathrm{~N} / 7 \mathrm{~W}-24 \mathrm{~A} 1$; and $B, 7 \mathrm{~N} / 7 \mathrm{~W}-24 \mathrm{~J} 1$.

6. Map showing model storage units in the groundwater component of the Santa Rosa Plain hydrologic model, Santa Rosa Plain watershed, Sonoma County, California

7. Map showing streamflow-routing cells in the groundwater component of the Santa Rosa Plain hydrologic model, Santa Rosa Plain watershed, Sonoma County, California

8. Map showing location of pumping wells in the groundwater component of the Santa Rosa Plain hydrologic model, Santa Rosa Plain watershed, Sonoma County, California

9. Maps showing wells perforated in each layer of the groundwater component of the Santa Rosa Plain hydrologic model, Santa Rosa Plain watershed, Sonoma County, California: $A$, layer $1 ; B$, layer $2 ; C$, layer 3 ; $D$, layer 4 ; $E$, layer $5 ; F$, layer 6 ; and $G$, layers 7-8 


\section{Figures-Continued}

\section{Chapter D}

1. Map showing locations in the Santa Rosa Plain watershed, Sonoma County, California, of $A$, streamgages and surface-water subbasins; and $B$, wells and model storage units used for calibration of the Santa Rosa Plain hydrologic model

2. Map showing distribution of the soil_moist_max parameter in the Santa Rosa Plain hydrologic model, Santa Rosa Plain watershed, Sonoma County, California

3. Map showing distribution of the sat_threshold parameter in the Santa Rosa Plain hydrologic model, Santa Rosa Plain watershed, Sonoma County, California

4. Map showing distribution of the soil_rechr_max parameter in the Santa Rosa Plain hydrologic model, Santa Rosa Plain watershed, Sonoma County, California.

5. Map showing distribution of the hru_percent_imperv parameter in the Santa Rosa Plain hydrologic model, Santa Rosa Plain watershed, Sonoma County, California

6. Map showing distribution of the ssr2gw_rate parameter in the Santa Rosa Plain hydrologic model, Santa Rosa Plain watershed, Sonoma County, California

7. Map showing distribution of the carea_max parameter in the Santa Rosa Plain hydrologic model, Santa Rosa Plain watershed, Sonoma County, California

8. Map showing distribution of the slowcoef_lin parameter in the Santa Rosa Plain hydrologic model, Santa Rosa Plain watershed, Sonoma County, California

9. Map showing distribution of the slowcoef_sq parameter in the Santa Rosa Plain hydrologic model, Santa Rosa Plain watershed, Sonoma County, California

10. Map showing distribution of final horizontal hydraulic conductivity values in the Santa Rosa Plain hydrologic model, Santa Rosa Plain watershed, Sonoma County, California, for $A$, layer $1 ; B$, layer $2 ; C$, layer 3 ; $D$, layer $4 ; E$, layer 5 ; $F$, layer $6 ; G$, layer $7 ; H$, layer 8

11. Map showing location of horizontal-flow barriers in the Santa Rosa Plain hydrologic model, Santa Rosa Plain watershed, Sonoma County, California

12. Map showing distribution of final streambed conductivities in the Santa Rosa Plain hydrologic model, Santa Rosa Plain watershed, Sonoma County, California

13. Graph showing initial and final rural pumpage, water years 1975-2010, Santa Rosa Plain hydrologic model, Santa Rosa Plain watershed, Sonoma County, California

14. Graphs showing comparison of simulated and measured streamflow for the calibrated model at the Copeland Creek at Rohnert Park (COPE) streamgage, 11465660, Santa Rosa Plain hydrologic model, Santa Rosa Plain watershed, Sonoma County, California, water years 2007-10: $A$, daily mean; $B$, monthly mean; $C$ monthly mean at logarithmic scale; $D$, flow duration for daily mean streamflow. 


\section{Figures-Continued}

\section{Chapter D-Continued}

15. Graphs showing comparison of simulated and measured streamflow for the calibrated model at the Laguna de Santa Rosa at Stony Point Road near Cotati (LAGC) streamgage, 11465680, Santa Rosa Plain hydrologic model, Santa Rosa watershed, Sonoma County, California, water years 2004-10: $A$, daily mean; $B$, monthly mean; $C$, monthly mean at logarithmic scale; $D$, flow duration for daily mean streamflow

16. Graphs showing comparison of simulated and measured streamflow for the calibrated model at the Colgan Creek near Santa Rosa (COLU) streamgage, 11465690, Santa Rosa Plain hydrologic model, Santa Rosa Plain watershed, Sonoma County, California, water years 2007-10: $A$, daily mean; $B$, monthly mean; $C$, monthly mean at logarithmic scale; $D$, flow duration for daily mean streamflow

17. Graphs showing comparison of simulated and measured streamflow for the calibrated model at the Colgan Creek near Sebastopol (COLL) streamgage, 11465700 , Santa Rosa Plain hydrologic model, Santa Rosa Plain watershed, Sonoma County, California, water years 1999-2004: $A$, daily mean; $B$, monthly mean; $C$, monthly mean at logarithmic scale; $D$, flow duration for daily mean streamflow

18. Graphs showing comparison of simulated and measured streamflow for the calibrated model at the Laguna de Santa Rosa near Sebastopol (LAGS) streamgage, 11466200, Santa Rosa Plain hydrologic model, Santa Rosa Plain watershed, Sonoma County, California, water years 1999-2004: $A$, daily mean; $B$, monthly mean; $C$, monthly mean at logarithmic scale; $D$, flow duration for daily mean streamflows.

19. Graphs showing comparison of simulated and measured streamflows at the Santa Rosa Creek near Santa Rosa (SRCU) streamgage, 11465800, Santa Rosa Plain hydrologic model, Santa Rosa Plain watershed, Sonoma County, California, water years 1959-65: $A$, daily mean; $B$, monthly mean; $C$, monthly mean at logarithmic scale; $D$, flow duration for daily mean streamflow.

20. Graphs showing comparison of simulated and measured streamflows at the Brush Creek near Santa Rosa (BRSH) streamgage, 11466065, Santa Rosa Plain hydrologic model, Santa Rosa Plain watershed, Sonoma County, California, water years 2006-10: $A$, daily mean; $B$, monthly mean; $C$, monthly mean at logarithmic scale; $D$, flow duration for daily mean streamflow.

21. Graphs showing comparison of simulated and measured streamflows at the Matanzas Creek near Santa Rosa (MATC) streamgage, 11466170, Santa Rosa Plain hydrologic model, Santa Rosa Plain watershed, Sonoma County, California, water years 2005-10: $A$, daily mean; $B$, monthly mean; $C$, monthly mean at logarithmic scale; $D$, flow duration for daily mean streamflow

22. Graphs showing comparison of simulated and measured streamflows at the Santa Rosa Creek at Santa Rosa (SRCS) streamgage, 11466200, Santa Rosa Plain hydrologic model, Santa Rosa Plain watershed, Sonoma County, California, water years 2002-10: $A$, daily mean; $B$, monthly mean; $C$, monthly mean at logarithmic scale; $D$, flow duration for daily mean streamflow. 


\section{Figures-Continued}

\section{Chapter D-Continued}

23. Graphs showing comparison of simulated and measured streamflows at the Santa Rosa Creek at Willowside Road near Santa Rosa (SRCW) streamgage, 11466320, Santa Rosa Plain hydrologic model, Santa Rosa Plain watershed, Sonoma County, California, water years 2004-10:

$A$, daily mean; $B$, monthly mean; $C$, monthly mean at logarithmic scale; $D$, flow duration for daily mean streamflow.

24. Graphs showing comparison of simulated and measured streamflows at the Mark West Creek near Windsor (MWCW) streamgage, 11465500, Santa Rosa Plain hydrologic model, Santa Rosa Plain watershed, Sonoma County, California, water years 2006-10: $A$, daily mean; $B$, monthly mean; $C$, monthly mean at logarithmic scale; $D$, flow duration for daily mean streamflow

25. Graphs showing comparison of simulated and measured streamflows at the Mark West Creek near Mirabel Heights (MWCM) streamgage, 11466800, Santa Rosa Plain hydrologic model, Santa Rosa Plain watershed, Sonoma County, California, water years 2006-10: $A$, daily mean; $B$, monthly mean; $C$, monthly mean at logarithmic scale; $D$, flow duration for daily mean streamflow.

26. Graphs showing comparison of simulated and measured streamflows at the Laguna de Santa Rosa at Stony Point Road near Cotati (LAGC) streamgage, 11465680, Santa Rosa Plain hydrologic model, Santa Rosa Plain watershed, Sonoma County, California, water years 1999-2004:

$A$, daily mean; $B$, monthly mean; $C$, monthly mean using a logarithmic scale; $D$, flow duration for daily mean streamflow

27. Graphs showing comparison of simulated and measured streamflows at the Colgan Creek near Santa Rosa (COLL) streamgage, 11465690, Santa Rosa Plain hydrologic model, Santa Rosa Plain watershed, Sonoma County, California, water years 2004-10: $A$, daily mean; $B$, monthly mean; $C$, monthly mean at logarithmic scale; $D$, flow duration for daily mean streamflow.

28. Graphs showing comparison of simulated and measured streamflows at the Laguna de Santa Rosa near Sebastopol (LAGS) streamgage, 11466200, Santa Rosa Plain hydrologic model, Santa Rosa Plain watershed, Sonoma County, California, water years 2004-10: $A$, daily mean; $B$, monthly mean; $C$, monthly mean at logarithmic scale; $D$, flow duration for daily mean streamflow.

29. Graphs showing comparison of simulated and measured streamflows at the Santa Rosa Creek near Santa Rosa (SRCU) streamgage, 11465800, Santa Rosa Plain hydrologic model, Santa Rosa Plain watershed, Sonoma County, California, water years 1966-70: $A$, daily mean; $B$, monthly mean; $C$, monthly mean at logarithmic scale; $D$, flow duration for daily mean streamflow.

30. Graphs showing comparison of simulated and measured streamflows at the Santa Rosa Creek at Willowside Road near Santa Rosa (SRCW) steamgage, 11466320, Santa Rosa Plain hydrologic model, Santa Rosa Plain watershed, Sonoma County, California, water years 1999-2004: $A$, daily mean; $B$, monthly mean; $C$, monthly mean at logarithmic scale; $D$, flow duration for daily mean streamflow. 


\section{Figures-Continued}

\section{Chapter D-Continued}

31. Graphs showing comparison of simulated and estimated streamflows at the Mark West Creek near Mirabel Heights (MWCM) streamgage, 11466800, Santa Rosa Plain hydrologic model, Santa Rosa Plain watershed, Sonoma County, California, water years 1976-2005: A, moving 3-day average; $B$, monthly mean; $C$, monthly mean at logarithmic scale; $D$, flow-duration for daily mean streamflow.

32. Graphs showing annual mean streamflows for the calibration and testing periods for the Santa Rosa Plain Hydrologic model, Santa Rosa Plain watershed, Sonoma County, California, for the following streamgages: $A$, Laguna de Santa Rosa at Stony Point Road near Cotati (LAGC); $B$, Colgan Creek near Santa Rosa (COLL); C, Laguna de Santa Rosa near Sebastopol (LAGS); D, Santa Rosa Creek near Santa Rosa (SRCU); E, Santa Rosa Creek at Willowside Road near Santa Rosa (SRCW); F, Mark West Creek near Mirabel Heights (MWCM)

33. Graphs showing composite simulated equivalent groundwater levels from the Santa Rosa Plain hydrologic model, Santa Rosa Plain watershed, Sonoma County, California, compared with $A$, measured groundwater levels; and $B$, differences between measured and simulated hydraulic heads (residuals) for transient conditions.

34. Maps showing the distribution of differences between measured and simulated hydraulic heads (residuals) for the Santa Rosa Plain hydrologic model, Santa Rosa Plain watershed, Sonoma County, California: $A$, maximum differences; and $B$, minimum differences.

35. Map showing simulated hydraulic heads for layer 1, groundwater-level contours from measured data, and residuals for spring 2007, Santa Rosa Plain hydrologic model, Santa Rosa Plain watershed, Sonoma County, California

35. Map showing simulated groundwater levels for layer 1, groundwater-level contours from measured data, and residuals for spring 2007, Santa Rosa Plain hydrologic model, Santa Rosa Plain watershed, Sonoma County, California

36. Graphs showing measured and simulated hydraulic heads for wells in the Windsor model storage unit of the Santa Rosa Plain hydrologic model, Santa Rosa Plain watershed, Sonoma County, California: $A, 8 \mathrm{~N} / 9 \mathrm{~W}-13 \mathrm{~A} 2$; $B, 8 \mathrm{~N} / 9 \mathrm{~W}-15 \mathrm{~B} 1 ; C, 8 \mathrm{~N} / 8 \mathrm{~W}-29 \mathrm{C} 3 ; D, 8 \mathrm{~N} / 8 \mathrm{~W}-2001 ; E, 8 \mathrm{~N} / 9 \mathrm{~W}-26 \mathrm{~L} 1 ; F, 8 \mathrm{~N} / 9 \mathrm{~W}-22 \mathrm{R} 1 ;$ G, 8N/8W-32M1; H, 8N/9W-36N1; I, 8N/9W-36P1; J, 7N/8W-3L1; K, 7N/8W-24L1; and $L, 7 \mathrm{~N} / 8 \mathrm{~W}-8 \mathrm{M} 1$

37. Graphs showing measured and simulated hydraulic heads for wells in the Santa Rosa model storage unit of the Santa Rosa Plain hydrologic model, Santa Rosa Plain watershed, Sonoma County, California: $A, 7 \mathrm{~N} / 8 \mathrm{~W}-21 \mathrm{~J} 1 ; B, 7 \mathrm{~N} / 8 \mathrm{~W}-29 \mathrm{M} 2 ; C, 7 \mathrm{~N} / 8 \mathrm{~W}-30 \mathrm{~K} 1 ; D, 7 \mathrm{~N} / 8 \mathrm{~W}-35 \mathrm{~K} 1$; $E, 6 \mathrm{~N} / 8 \mathrm{~W}-7 \mathrm{~A} 2$; and $F, 6 \mathrm{~N} / 8 \mathrm{~W}-401$. .136

38. Graphs showing measured and simulated hydraulic heads for wells in the Cotati-north model storage unit of the Santa Rosa Plain hydrologic model, Santa Rosa Plain watershed, Sonoma County, California: $A, 6 \mathrm{~N} / 7 \mathrm{~W}-17 \mathrm{G} 1 ; B, 6 \mathrm{~N} / 8 \mathrm{~W}-13 \mathrm{~L} 1 ; C, 6 \mathrm{~N} / 8 \mathrm{~W}-15 \mathrm{~J} 3 ; D, 6 \mathrm{~N} / 8 \mathrm{~W}-15 \mathrm{R} 1 ; E, 6 \mathrm{~N} / 8 \mathrm{~W}-27 \mathrm{H} 1 ;$ $F, 6 \mathrm{~N} / 8 \mathrm{~W}-22 \mathrm{R} 1$; and $\mathrm{G}, 6 \mathrm{~N} / 7 \mathrm{~W}-30 \mathrm{C} 1$. 


\section{Figures-Continued}

\section{Chapter D-Continued}

39. Graphs showing measured and simulated hydraulic heads for wells in the Cotati-south model storage unit of the Santa Rosa Plain hydrologic model, Santa Rosa Plain watershed, Sonoma County, California: $A, 6 \mathrm{~N} / 8 \mathrm{~W}-25 \mathrm{~F} 1 ; B, 6 \mathrm{~N} / 8 \mathrm{~W}-26 \mathrm{~L} 1$; and $C, 6 \mathrm{~N} / 7 \mathrm{~W}-30 \mathrm{R} 1$

40. Graphs showing measured and simulated hydraulic heads for wells in the Wilson Grove model storage unit of the Santa Rosa Plain hydrologic model, Santa Rosa Plain watershed, Sonoma County, California: $A, 7 \mathrm{~N} / 9 \mathrm{~W}-15 \mathrm{~K} 1$; $B, 7 \mathrm{~N} / 9 \mathrm{~W}-26 \mathrm{P} 1 ; C, 6 \mathrm{~N} / 9 \mathrm{~W}-1 \mathrm{M} 3 ; 0,6 \mathrm{~N} / 8 \mathrm{~W}-7 \mathrm{P} 2$; and $E, 6 \mathrm{~N} / 8 \mathrm{~W}-18 \mathrm{C} 1$

41. Graphs showing measured and simulated hydraulic heads for wells used in the Santa Rosa Plain hydrologic model, Santa Rosa Plain watershed, Sonoma County, California: $A, 7 \mathrm{~N} / 7 \mathrm{~W}-6 \mathrm{H} 2$ in the Rincon-Kenwood model storage unit (MSU); $B, 7 \mathrm{~N} / 7 \mathrm{~W}-9 \mathrm{P} 1$ in the Rincon-Kenwood MSU; C, 7N/7W-19B1 in the Bennett Valley-plain MSU; $D, 6 \mathrm{~N} / 7 \mathrm{~W}-3 \mathrm{D} 1$ in the Bennett Valley-mountain MSU; and $E, 6 \mathrm{~N} / 7 \mathrm{~W}-3 \mathrm{M} 1$ in the Bennett Valley-mountain MSU.

\section{Chapter E}

1. Graphs showing simulated annual hydrologic-budget components for the Santa Rosa Plain hydrologic model, Santa Rosa Plain watershed, Sonoma County, California, 1976-2010, shown by $A$, line graph; $B$, bar chart

2. Graphs showing annual values of hydrologic-budget components in the Santa Rosa Plain hydrologic model, Santa Rosa Plain watershed, Sonoma County, California, water years 1976-2010: $A$, precipitation, average air temperature, and potential evapotranspiration (PET); $B$, components of total evapotranspiration (ET); $C$, components of total streamflow; and $D$, streambed inflows and outflows.

3. Graphs showing average monthly results for simulated components of the Santa Rosa Plain hydrologic model, Santa Rosa Plain watershed, Sonoma County, California, water years 1976-2010: $A$, evapotranspiration at arithmetic scale; $B$, evapotranspiration at logarithmic scale; $C$, streamflow at arithmetic scale; $D$, streamflow at logarithmic scale.

4. Graphs showing simulated values for water years 1976-2010 for the Santa Rosa Plain hydrologic model, Santa Rosa Plain watershed, Sonoma County, California, for $A$, annual pumpage; $B$, cumulative change in groundwater storage and net stream leakage.

5. Map showing subareas in the Santa Rosa Plain hydrologic model, Santa Rosa Plain watershed, Sonoma County, California

6. Maps showing simulated streamflow for water years 1976-2010, Santa Rosa Plain hydrologic model, Santa Rosa Plain watershed, Sonoma County, California: $A$, average; $B$, maximum; $C$, minimum

7. Maps showing simulated net groundwater-flux distribution from the Santa Rosa Plain hydrologic model, Santa Rosa Plain watershed, Sonoma County, California: $A$, long-term average conditions (1976-2010); $B$, a dry water year (2009); $C$, a wet water year (2006)

8. Pie chart showing annual average simulated hydrologic-budget components affected by pumping for water years 1976-2010, Santa Rosa Plain hydrologic model, Santa Rosa Plain watershed, Sonoma County, California 


\section{Figures-Continued}

\section{Chapter E-Continued}

9. Maps showing spatial distribution of changes in streamflow with and without pumping, water years 1976-2010, Santa Rosa Plain hydrologic model, Santa Rosa Plain watershed, Sonoma County, California: $A$, difference in average streamflow; $B$, percentage decrease in streamflow without pumping

10. Graphs showing comparison of basin-wide total streamflow simulated with and without pumping for water years 1976-2010, Santa Rosa Plain hydrologic model, Santa Rosa Plain watershed, Sonoma County, California: $A$, annual total streamflow; $B$, average monthly streamflow; $C$, average August streamflow.

11. Graphs showing comparison of streamflow simulated with and without pumping at the Copeland Creek at Rohnert Park (COPE) gage, water years 1976-2010, Santa Rosa Plain hydrologic model, Santa Rosa Plain watershed, Sonoma County, California: $A$, average monthly streamflow; $B$, average August streamflow; $C$, flow-duration curve for daily mean discharge.

12. Graphs showing comparison of streamflow simulated with and without pumping at the Laguna de Santa Rosa near Sebastopol (LAGS) gage, water years 1976-2010, Santa Rosa Plain hydrologic model, Santa Rosa Plain watershed, Sonoma County, California: $A$, average monthly streamflow; $B$, average August streamflow; $C$, flow-duration curve for daily mean discharge.

13. Graphs showing comparison of streamflow simulated with and without pumping at gage Mark West Creek near Mirabel Heights (MWCM), water years 1976-2010, Santa Rosa Plain hydrologic model, Santa Rosa Plain watershed, Sonoma County, California: $A$, average monthly streamflow; $B$, average August streamflow; $C$, flow-duration curve for daily mean discharge

14. Graphs showing values for components of the Santa Rosa Plain hydrologic model, Santa Rosa Plain watershed, Sonoma County, California, for water years 1976-2010, demonstrating the effects of pumping on simulated groundwater discharge to streams: $A$, annual precipitation and groundwater pumpage; $B$, annual groundwater discharge to streams simulated with and without pumping; $C$, annual and cumulative differences in groundwater discharge to streams simulated with and without pumping...

15. Graphs showing values for components of the Santa Rosa Plain hydrologic model, Santa Rosa Plain watershed, Sonoma County, California, for water years 1976-2010, demonstrating the effects of pumping on simulated groundwater evapotranspiration: $A$, annual precipitation and groundwater pumpage; $B$, annual groundwater evapotranspiration simulated with and without pumping; $C$, annual and cumulative differences in groundwater evapotranspiration simulated with and without pumping ...

16. Graphs showing values for components of the Santa Rosa Plain hydrologic model, Santa Rosa Plain watershed, Sonoma County, California, for water years 1976-2010, demonstrating the effects of pumping on simulated groundwater storage change: $A$, annual precipitation and groundwater pumpage; $B$, annual groundwater storage change simulated with and without pumping; $C$, annual and cumulative differences in groundwater storage change simulated with and without pumping.. 


\section{Figures-Continued}

\section{Chapter E-Continued}

17. Graphs showing values for components of the Santa Rosa Plain hydrologic model, Santa Rosa Plain watershed, Sonoma County, California for water years 1976-2010, demonstrating the effects of pumping on simulated recharge: $A$, annual precipitation and groundwater pumpage; $B$, annual total recharge, extra-channel recharge, and recharge from streams simulated with and without pumping; $C$, annual and cumulative differences in total recharge, extra-channel recharge, and recharge from streams simulated with and without pumping.

18. Graphs showing average monthly values and results of simulations with and without pumping for the Santa Rosa Plain hydrologic model, Santa Rosa Plain watershed, Sonoma County, California, water years 1976-2010, for $A$, pumping and precipitation; $B$, groundwater discharge to streams; $C$, groundwater evapotranspiration; $D$, groundwater-storage change; $E$, recharge components

19. Graph showing the effect of pumping in model layers 2-8 on flow from model layer 1 to the underlying layers of the Santa Rosa Plain hydrologic model, Santa Rosa Plain watershed, Sonoma County, California

\section{Chapter F}

1. Graphs showing water year precipitation for the historical-climate baseline and the following future-climate scenarios for the Santa Rosa Plain Watershed, Sonoma County, California: $A, \mathrm{GA} 2 ; B, \mathrm{~GB} 1 ; C, \mathrm{PA} 2 ; D, \mathrm{~PB} 1$

2. Graphs showing maximum daily air temperatures for historical-climate baseline and the following future-climate scenarios, Santa Rosa Plain watershed, Sonoma County, California: $A, \mathrm{GA} 2 ; B, \mathrm{~GB} 1 ; C, \mathrm{PA} 2 ; D, \mathrm{~PB} 1$

3. Graphs showing minimum daily air temperatures for the historical-climate baseline and the following future-climate scenarios, Santa Rosa Plain watershed, Sonoma County, California: $A, \mathrm{GA} 2 ; B, \mathrm{~GB} 1 ; C, \mathrm{PA} 2 ; D, \mathrm{~PB} 1$

4. Graph showing comparison of the 10 -year moving average of average daily air temperature for the historical-climate baseline and future-climate scenarios, Santa Rosa Plain watershed, Sonoma County, California

5. Graphs showing average annual total streamflows and 10 -year moving average of streamflows, simulated without pumping for water years 1976-2099, by using the historical-climate baseline and the following future-climate scenarios, Santa Rosa Plain hydrologic model, Santa Rosa Plain watershed, Sonoma County, California: $A, \mathrm{GA} 2 ; B, \mathrm{~GB} 1 ; C, \mathrm{PA} 2 ; D, \mathrm{~PB} 1$

6. Graphs showing average annual total recharge and 10 -year moving average of streamflow simulated without pumping for water years 1976-2099 using the historical-climate baseline and thefollowing future-climate scenarios, Santa Rosa Plain hydrologic model, Santa Rosa Plain watershed, Sonoma County, California: $A, \mathrm{GA} 2 ; B, \mathrm{~GB} 1 ; C, \mathrm{PA} 2 ; D, \mathrm{~PB} 1$ 


\section{Figures-Continued}

\section{Chapter F-Continued}

7. Graphs showing average annual groundwater discharge to streams and 10 -year moving average of total discharge simulated without pumping for water years 1976-2099 using the historical-climate baseline and the following future-climate scenarios, Santa Rosa Plain hydrologic model, Santa Rosa Plain watershed, Sonoma County, California: $A$, GA2; B, GB1; $C, \mathrm{PA} 2 ; \mathrm{D}, \mathrm{PB} 1$

8. Graphs showing average annual groundwater evapotranspiration and the 10-year moving average of groundwater evapotranspiration, simulated without pumping for water years 1976-2099 using the historical-climate baseline and the following future-climate scenarios, Santa Rosa Plain hydrologic model, Santa Rosa Plain watershed, Sonoma County, California: $A, \mathrm{GA} 2 ; B, \mathrm{~GB} 1 ; C, \mathrm{PA2} ; D, \mathrm{~PB} 1$.

9. Graphs showing comparison of 30-year monthly average precipitation using the historical-climate baseline and the following future-climate scenarios, Santa Rosa Plain hydrologic model, Santa Rosa Plain watershed, Sonoma County, California: $A, \mathrm{GA} 2 ; B, \mathrm{~GB} 1 ; C, \mathrm{PA} 2 ; \mathrm{D}, \mathrm{PB} 1$

10. Graphs showing comparison of 30-year monthly average total streamflow, simulated without pumping, using the historical-climate baseline and the following future-climate scenarios, Santa Rosa Plain hydrologic model, Santa Rosa Plain watershed, Sonoma County, California:

$A, \mathrm{GA} 2 ; B, \mathrm{~GB} 1 ; C, \mathrm{PA} 2 ; \mathrm{D}, \mathrm{PB} 1$

11. Graphs showing comparison of 30-year monthly average total streamflows, on a logarithmic scale, simulated without pumping using the historical-climate baseline and the following future-climate scenarios, Santa Rosa Plain hydrologic model, Santa Rosa Plain watershed, Sonoma County, California: $A, \mathrm{GA} 2 ; B, \mathrm{~GB} 1 ; C, \mathrm{PA} 2 ; D, \mathrm{~PB} 1$

12. Graphs showing comparison of 30 -year monthly averages of total recharge simulated without pumping using the historical-climate baseline and the following future-climate scenarios, Santa Rosa Plain hydrologic model, Santa Rosa Plain watershed, Sonoma County, California: $A, \mathrm{GA} 2 ; B, \mathrm{~GB} 1 ; C, \mathrm{PA} 2 ; \mathrm{D}, \mathrm{PB} 1$

13. Graphs showing comparison of 30-year monthly average groundwater discharge to streams simulated without pumping for the following future-climate scenarios, Santa Rosa Plain hydrologic model, Santa Rosa Plain watershed, Sonoma County, California: $A, \mathrm{GA} 2 ; B, \mathrm{~GB} 1$; $C$, PA2; $D, \mathrm{~PB} 1$. .206

14. Graphs showing comparison of 30 -year monthly average groundwater evapotranspiration simulated without pumping for the following future-climate scenarios, Santa Rosa Plain hydrologic model, Santa Rosa Plain watershed, Sonoma County, California: $A, \mathrm{GA} 2 ; B, \mathrm{~GB} 1 ; C, \mathrm{PA} 2 ; D, \mathrm{~PB} 1$. 


\section{Figures-Continued}

\section{Chapter F-Continued}

15. Maps showing difference between 30-year average recharge simulated without pumping for water years 2011-40 and historical-climate baseline conditions (water years 1981-2010), using the following future-climate scenarios, Santa Rosa Plain hydrologic model, Santa Rosa Plain watershed, Sonoma County, California: $A, \mathrm{GA} 2 ; B, \mathrm{~GB} 1 ; C, \mathrm{PA} 2 ; D, \mathrm{~PB} 1$

16. Maps showing difference between 30 -year average recharge simulated without pumping for water years 2041-70 and 30-year average recharge for historical-climate baseline conditions (water years 1981-2010) using the following future-climate scenarios, Santa Rosa Plain hydrologic model, Santa Rosa Plain watershed, Sonoma County, California: $A, \mathrm{GA} 2 ; B, \mathrm{~GB}$; $C$, PA2; $D$, PB1

17. Maps showing difference between 30 -year average recharge simulated without pumping for water years 2070-99 historical-climate baseline conditions (water years 1981-2010) using the following future-climate scenarios, Santa Rosa Plain hydrologic model, Santa Rosa Plain watershed, Sonoma County, California: $A, \mathrm{GA} 2 ; B, \mathrm{~GB} 1 ; C, \mathrm{PA} 2 ; D, \mathrm{~PB} 1$

18. Maps showing 30-year average streamflow simulated without pumping for historical-climate baseline conditions (water years 1981-2010), Santa Rosa Plain hydrologic model, Santa Rosa Plain watershed, Sonoma County, California: $A$, annual; $B$, February; $C$, May; $D$, August

19. Maps showing 30-year average streamflow simulated without pumping for water years 2070-99 in the GA2 future-climate scenario, Santa Rosa Plain hydrologic model, Santa Rosa Plain watershed, Sonoma County, California: $A$, annual; $B$, February; $C$, May; $D$, August

20. Maps showing 30-year average streamflow simulated without pumping for water years 2011-40 in the PB1 future-climate scenario, Santa Rosa Plain hydrologic model, Santa Rosa Plain watershed, Sonoma County, California: $A$, annual; $B$, February; $C$, May; $D$, August

21. Graphs showing estimated agricultural pumpage for the historical-climate baseline period during water years 1981-2010 and the following future-climate scenarios, Santa Rosa Plain hydrologic model, Santa Rosa Plain watershed, Sonoma County, California: $A, \mathrm{GA} 2$; $B, \mathrm{~GB} 1$; $C$, PA2; D, PB1 during water years 2011-40.

22. Graphs showing annual pumpage and precipitation, cumulative groundwater-budget net steam leakage, groundwater evapotranspiration, and groundwater storage change for water years 1981-2010 for the historical-climate baseline period and for water years 2011-40 for the following future-climate scenarios, Santa Rosa Plain hydrologic model, Santa Rosa Plain watershed, Sonoma County, California: $A, \mathrm{GA} 2 ; B, \mathrm{~GB} 1 ; C, \mathrm{PA} 2 ; D, \mathrm{~PB} 1$

23. Maps showing differences in simulated hydraulic heads in model layer 1 between spring 2010 and spring 2040 for the following future-climate scenarios, Santa Rosa Plain hydrologic model, Santa Rosa Plain watershed, Sonoma County, California: $A, \mathrm{GA} 2 ; B, \mathrm{~GB} 1 ; C, \mathrm{PA} 2 ; D, \mathrm{~PB} 1$ 


\section{Figures-Continued}

\section{Chapter G}

1. Diagram showing average water budget for water years 1976-2010,

Santa Rosa Plain hydrologic model, Santa Rosa Plain watershed,

Sonoma County, California

\section{Appendix 1}

1-1. Figure showing example input file: CWDM control file, Santa Rosa

Plain watershed, Sonoma County, California

1-2. Maps showing generalized crop types used as input for the crop water-demand model, Santa Rosa Plain watershed,

Sonoma County, California, based on land-use maps for $A$, 1974;

$B, 1979 ; C, 1986 ; D, 1999$; and $E, 2008$

1-3. Maps showing calculated field-capacity values used as input for the crop water-demand model, Santa Rosa Plain watershed, Sonoma County, California, based on Natural Resources

Conservation Service, Soil Survey Geographic (SSURGO)

soils data, reported crop root depths, and land-use maps for

$A, 1974 ; B, 1979 ; C, 1986 ; D, 1999$; and $E, 2008$

1-4. Figure showing example input file: agricultural-well

parameters, Santa Rosa Plain crop water-demand model,

Santa Rosa Plain watershed, Sonoma County, California

1-5. Figure showing example output file: simulated monthly

irrigation and pumping for agricultural wells, Santa Rosa

Plain crop water-demand model, Santa Rosa Plain watershed,

Sonoma County, California

1-6. Figure showing example output file: simulated monthly irrigation

by crop type, Santa Rosa Plain crop water-demand model,

Santa Rosa Plain watershed, Sonoma County, California

1-7. Figure showing example output file: simulated daily irrigation by crop type,

Santa Rosa Plain crop water-demand model, Santa Rosa Plain watershed,

Sonoma County, California.

1-8. Graph showing cCrop water-demand model (CWDM) calibration

results, water years 1975-84, annual (water year) time-series

comparison to previous estimates by Kadir and McGuire (1987),

Santa Rosa Plain watershed, Sonoma County, California ..

1-9. Graphs showing dDaily crop water-demand model (CWDM)-simulated irrigation for hydrologic response unit (HRU) 16454, water years 1975-76, Santa Rosa Plain watershed, Sonoma County, California, and $A$, daily precipitation and change in the precipitation runoff modeling system (PRMS)-simulated soil moisture; $B$, the PRMS-simulated daily potential evapotranspiration (PET), PRMS-simulated evapotranspiration (ET), and CWDM-calculated available PET; $C$, PRMS-simulated daily soil moisture; and $D$, CWDM-calculated adjusted crop water demand (ACWD). 


\section{Figures-Continued}

\section{Appendix 1-Continued}

1-10. Figure showing ilrrigation periods and period of reclaimed water input used in the crop water-demand model, Santa Rosa Plain watershed, Sonoma County, California

1-11. Graph showing aAnnual variation of crop types used in the crop waterdemand model, Santa Rosa Plain watershed, Sonoma County, California

1-12. Maps showing sSpatially distributed agricultural irrigation estimates simulated using the crop water-demand model (CWDM) Santa Rosa Plain watershed, Sonoma County, California, for water years $A$, 1972-77; $B, 1975-83 ; C, 1981-88 ; D, 1987-93 ; E, 1997-2004$; and F, 2002-10

1-13. Graphs showing eEstimates of irrigation used to estimate monthly agricultural pumpage for water years 1975-2010 for the Santa Rosa hydrologic model, Sonoma County, California: $A$, total monthly irrigation; and $B$, total annual irrigation 


\section{Tables}

\section{Chapter A}

1. Population for the cities and township in the Santa Rosa Plain, Sonoma County,

California, 1950, 1960, 1970, 1980, 1990, 2000, and 2010

\section{Chapter B}

1. Climate stations used to develop the daily precipitation, maximum temperature, and minimum temperature inputs for the Santa Rosa Plain hydrologic model, Santa Rosa Plain watershed, Sonoma County, California .

2. Parameter Regression on Independent Slopes Model (PRISM) estimates of 1971-2000 average monthly and annual data from 109 climate stations having records used to develop the precipitation, maximum daily air temperature, and minimum daily air temperature inputs for the Santa Rosa Plain hydrologic model, Santa Rosa Plain watershed, Sonoma County, California

\section{Chapter C}

1. Layer thickness in the Santa Rosa Plain hydrologic model, Santa Rosa Plain watershed, Sonoma County, California

2. Number of parameter zones in layers 1-8 of the Santa Rosa Plain hydrologic model, Santa Rosa Plain watershed, Sonoma County, California

3. Number of simulated pumping wells in each layer of the groundwater component of the Santa Rosa Plain hydrologic model, Santa Rosa Plain watershed, Sonoma County, California

\section{Chapter D}

1. Summary of final watershed-component parameter values in the Santa Rosa Plain hydrologic model, Santa Rosa Plain watershed, Sonoma County, California

2. Summary of final horizontal hydraulic-conductivity values in the Santa Rosa Plain hydrologic model, Santa Rosa Plain watershed, Sonoma County, California

3. Transmissivity values estimated from aquifer tests and their simulated equivalents for selected wells in the Santa Rosa Plain watershed, Sonoma County, California

4. Final vertical anisotropy ratios for each model storage unit in the Santa Rosa Plain hydrologic model, Santa Rosa Plain watershed, Sonoma County, California

5. Summary of final vertical hydraulic-conductivity values in the Santa Rosa Plain hydrologic model, Santa Rosa Plain watershed, Sonoma County, California 


\section{Tables-Continued}

\section{Chapter D-Continued}

6. Summary of final values for specific yield and specific storage for the Santa Rosa Plain hydrologic model, Santa Rosa Plain watershed, Sonoma County, California.

7. Final values of the horizontal-flow barrier hydraulic characteristic in the Santa Rosa Plain hydrologic model, Santa Rosa Plain watershed, Sonoma County, California

8. Final general-head boundary conductances in the Santa Rosa Plain hydrologic model, Santa Rosa Plain watershed, Sonoma County, California

9. Initial and final rural pumpage from 1982 to 2010, Santa Rosa Plain hydrologic model, Santa Rosa Plain watershed, Sonoma County, California ........97

10. Summary of "goodness-of-fit" statistics for the Santa Rosa Plain hydrologic model, Santa Rosa Plain watershed, Sonoma County, California

11. Summary of model calibration results for daily mean and monthly mean streamflows at selected gages, Santa Rosa Plain watershed, Sonoma County, California.

12. Summary of model testing results for daily mean and monthly mean streamflows at selected gages, Santa Rosa Plain watershed, Sonoma County, California

13. Summary of model-fit statistics for model storage units in the Santa Rosa Plain hydrologic model, Santa Rosa Plain watershed, Sonoma County, California

\section{Chapter E}

1. Average annual hydrologic budgets simulated with and without pumping for the Santa Rosa Plain hydrologic model, Santa Rosa Plain watershed, Sonoma County, California, water years 1976-2010

2. Average precipitation and simulated groundwater budgets for the long-term (water years 1976-2010), the recent short-term (water years 2004-10), a wet year (water year 2006), and a dry year (water year 2009) for the Santa Rosa Plain hydrologic model, Santa Rosa Plain watershed, Sonoma County, California

3. Simulated groundwater budgets for long-term average conditions for selected subareas in the Santa Rosa Plain hydrologic model, Santa Rosa Plain watershed, Sonoma County, California

4. Average simulated streamflow at selected gages with and without pumping, Santa Rosa Plain hydrologic model, Santa Rosa Plain watershed, Sonoma County, California. 


\section{Tables-Continued}

\section{Chapter F}

1. Summary of precipitation and air temperature for future-climate scenarios, Santa Rosa Plain watershed, Sonoma County, California, for water years 2005-99; 2011-40; 2041-70; and 2070-99..

2. Average annual results for selected surface-water components and simulated groundwater budgets for the 1981-2010 historical-climate period, and projected average annual results for 2011-40 for future-climate scenarios GA2, GB1, PA2, and PB1, Santa Rosa Plain hydrologic model, Santa Rosa Plain watershed, Sonoma County, California

\section{Appendix 1}

1-1. Monthly crop coefficients for seven crop types used as input for the calibrated crop water-demand model (CWDM), Santa Rosa

Plain watershed, Sonoma County, California

1-2. Monthly soil moisture crop coefficients for seven crop types used as input for the calibrated crop water-demand model, Santa Rosa Plain watershed, Sonoma County, California 


\section{Conversion Factors}

Inch/Pound to SI

\begin{tabular}{|c|c|c|}
\hline Multiply & By & To obtain \\
\hline \multicolumn{3}{|c|}{ Length } \\
\hline inch (in.) & 2.54 & centimeter $(\mathrm{cm})$ \\
\hline foot $(\mathrm{ft})$ & 0.3048 & meter $(\mathrm{m})$ \\
\hline mile (mi) & 1.609 & kilometer $(\mathrm{km})$ \\
\hline \multicolumn{3}{|c|}{ Area } \\
\hline acre & 4,047 & square meter $\left(\mathrm{m}^{2}\right)$ \\
\hline acre & 0.4047 & hectare (ha) \\
\hline acre & 0.4047 & square hectometer $\left(\mathrm{hm}^{2}\right)$ \\
\hline acre & 0.004047 & square kilometer $\left(\mathrm{km}^{2}\right)$ \\
\hline square foot $\left(\mathrm{ft}^{2}\right)$ & 0.09290 & square meter $\left(\mathrm{m}^{2}\right)$ \\
\hline square mile $\left(\mathrm{mi}^{2}\right)$ & 259.0 & hectare (ha) \\
\hline square mile $\left(\mathrm{mi}^{2}\right)$ & 2.590 & square kilometer $\left(\mathrm{km}^{2}\right)$ \\
\hline \multicolumn{3}{|c|}{ Volume } \\
\hline cubic foot $\left(\mathrm{ft}^{3}\right)$ & 0.02832 & cubic meter $\left(\mathrm{m}^{3}\right)$ \\
\hline acre-foot (acre-ft) & 1,233 & cubic meter $\left(\mathrm{m}^{3}\right)$ \\
\hline acre-foot (acre-ft) & 0.001233 & cubic hectometer $\left(\mathrm{hm}^{3}\right)$ \\
\hline \multicolumn{3}{|c|}{ Flow Rate } \\
\hline acre-foot per month (acre-ft/m) & 0.0005 & cubic meter per second $\left(\mathrm{m}^{3} / \mathrm{s}\right)$ \\
\hline acre-foot per year (acre-ft/yr) & 1,233 & cubic meter per year $\left(\mathrm{m}^{3} / \mathrm{yr}\right)$ \\
\hline acre-foot per year (acre-ft/yr) & 0.001233 & cubic hectometer per year $\left(\mathrm{hm}^{3} / \mathrm{yr}\right)$ \\
\hline cubic foot per second $\left(\mathrm{ft}^{3} / \mathrm{s}\right)$ & 0.02832 & cubic meter per second $\left(\mathrm{m}^{3} / \mathrm{s}\right)$ \\
\hline cubic foot per day $\left(\mathrm{ft}^{3} / \mathrm{d}\right)$ & 0.02832 & cubic meter per day $\left(\mathrm{m}^{3} / \mathrm{d}\right)$ \\
\hline foot per day (ft/d) & 0.3048 & meter per day $(\mathrm{m} / \mathrm{d})$ \\
\hline foot per year (ft/yr) & 0.3048 & meter per year (m/yr) \\
\hline inch per year (in/yr) & 25.4 & millimeter per year (mm/yr) \\
\hline \multicolumn{3}{|c|}{ Hydraulic conductivity } \\
\hline foot per day $(\mathrm{ft} / \mathrm{d})$ & 0.3048 & meter per day $(\mathrm{m} / \mathrm{d})$ \\
\hline \multicolumn{3}{|c|}{ Transmissivity* } \\
\hline foot squared per day $\left(\mathrm{ft}^{2} / \mathrm{d}\right)$ & 0.09290 & meter squared per day $\left(\mathrm{m}^{2} / \mathrm{d}\right)$ \\
\hline
\end{tabular}




\section{Conversion Factors}

SI to Inch/Pound

\begin{tabular}{llll}
\hline \multicolumn{1}{c}{ Multiply } & By & \multicolumn{1}{c}{ To obtain } \\
\hline & Length & \\
\hline kilometer $(\mathrm{km})$ & 0.6214 & mile $(\mathrm{mi})$ & \\
meter $(\mathrm{m})$ & 3.281 & foot $(\mathrm{ft})$ & \\
\hline
\end{tabular}

Vertical coordinate information is referenced to North American Vertical Datum of 1988 (NAVD 88).

Horizontal coordinate information is referenced to the North American Datum of 1983 (NAD 83).

Altitude, as used in this report, refers to distance above the vertical datum.

*Transmissivity: The standard unit for transmissivity is cubic foot per day per square foot times foot of aquifer thickness $\left[\left(\mathrm{ft}^{3} / \mathrm{d}\right) / \mathrm{ft}^{2}\right] \mathrm{ft}$. In this report, the mathematically reduced form, foot squared per day $\left(\mathrm{ft}^{2} / \mathrm{d}\right)$, is used for convenience. 


\section{Abbreviations}

\begin{tabular}{|c|c|}
\hline AAEE & absolute-average-estimation-error \\
\hline $\mathrm{CB}$ & Cotati Basin groundwater storage unit \\
\hline COPE & Copeland Creek at Rohnert Park \\
\hline DEM & digital-elevation model \\
\hline ET & evapotranspiration \\
\hline GCM & global-climate model \\
\hline GFDL & Geophysical Fluid Dynamics Laboratory \\
\hline GHB & general-head boundary \\
\hline GSFLOW & Coupled Groundwater and Surface-Water Flow Model \\
\hline GVR & gravity reservoir \\
\hline GWR & groundwater reservoir \\
\hline HFB & horizontal-flow barrier \\
\hline $\mathrm{HGU}$ & hydrogeologic unit \\
\hline HK & horizontal hydraulic conductivity \\
\hline HRU & hydrologic response unit \\
\hline LAGS & Laguna de Santa Rosa near Sebastopol \\
\hline MATC & Matanzas Creek at Santa Rosa \\
\hline MF-2005 & MODFLOW-2005 \\
\hline MF-NWT & MODFLOW-Newton formulation \\
\hline MODFLOW & Modular Finite-Difference Groundwater Flow Model \\
\hline MODFLOW-NWT & Modular Groundwater Flow Model-Newton Formulation \\
\hline MSU & model storage unit \\
\hline MWCM & Mark West Creek near Mirabel Heights \\
\hline NHD & National Hydrography Dataset \\
\hline NOAA & National Oceanic and Atmospheric Administration \\
\hline NRMSE & normalized root mean square error \\
\hline NSME & Nash-Sutcliffe model efficiency \\
\hline PAEE & percent-average-estimation-error \\
\hline PCM & Parallel Circulation Model \\
\hline PET & potential evapotranspiration \\
\hline PRISM & Parameter Regression on Independent Slopes Model \\
\hline PRMS & Precipitation-Runoff Modeling System \\
\hline RMSE & root mean square error \\
\hline SCWA & Sonoma County Water Agency \\
\hline
\end{tabular}




\section{Abbreviations}

$\begin{array}{ll}\text { SFR } & \text { streamflow routing } \\ \text { SFR2 } & \text { streamflow routing package } \\ \text { SRP } & \text { Santa Rosa Plain } \\ \text { SRPHM } & \text { Santa Rosa Plain hydrologic model } \\ \text { SRPW } & \text { Santa Rosa Plain watershed } \\ \text { SS } & \text { specific storage } \\ \text { SSR } & \text { subsurface reservoir } \\ \text { SSURGO } & \text { Natural Resources Conservation Service, Soil Survey Geographic } \\ \text { SWRAD } & \text { short-wave radiation } \\ \text { SY } & \text { specific yield } \\ \text { UPL } & \text { uplands groundwater storage unit } \\ \text { UPW } & \text { upstream-weighting package } \\ \text { USGS } & \text { U.S. Geological Survey } \\ \text { UZ } & \text { unsaturated zone } \\ \text { UZF1 } & \text { unsaturated-zone flow package } \\ \text { VAL } & \text { Valley groundwater storage unit } \\ \text { VANI } & \text { horizontal-to-vertical anisotropy ratio } \\ \text { VK } & \text { vertical hydraulic conductivity } \\ \text { VKS } & \text { vertical saturated hydraulic conductivity } \\ \text { WB } & \text { Windsor Basin groundwater storage unit } \\ \text { WEL } & \text { well package } \\ \text { WG } & \text { Wilson Grove groundwater storage unit } \\ \text { yr } & \text { year } \\ & \end{array}$




\section{Acknowledgements}

The authors acknowledge the support of Sonoma County Water Agency, city of Santa Rosa, city of Sebastopol, city of Rohnert Park, city of Cotati, town of Windsor, county of Sonoma, and California American Water and their respective personnel.

The authors thank the two USGS colleague reviewers; their comments greatly improved this report. The authors also thank Richard Niswonger and Steven Regan for their guidance in the theory and application of GSFLOW. 


\title{
Simulation of Groundwater and Surface-Water Resources for the Santa Rosa Plain Watershed, Sonoma County, California
}

\author{
By Linda R. Woolfenden, J.A. Hevesi, and Tracy Nishikawa
}

\section{Executive Summary}

Water managers in the Santa Rosa Plain face the challenge of meeting increasing water demand with a combination of Russian River water, which has uncertainties in its future availability; local groundwater resources; and ongoing and expanding recycled water and water from other conservation programs. To address this challenge, the U.S. Geological Survey, in cooperation with the Sonoma County Water Agency, the cities of Cotati, Rohnert Park, Santa Rosa, and Sebastopol, the town of Windsor, the California American Water Company, and the County of Sonoma, undertook development of a fully coupled groundwater and surface-water model to better understand and to help manage the hydrologic resources in the Santa Rosa Plain watershed.

The purpose of this report is to (1) describe the construction and calibration of the fully coupled groundwater and surface-water flow model for the Santa Rosa Plain watershed, referred to as the Santa Rosa Plain hydrologic model;

(2) present results from simulation of the Santa Rosa Plain hydrologic model, including water budgets, recharge distributions, streamflow, and the effect of pumping on water-budget components; and (3) present the results from using the model to evaluate the potential hydrologic effects of climate change and variability without pumpage for water years 2011-99 and with projected pumpage for water years 2011-40.

\section{Santa Rosa Plain Hydrologic Model}

The Santa Rosa Plain hydrologic model was developed by using the U.S. Geological Survey groundwater and surfacewater flow model, GSFLOW. GSFLOW consists of two integrated model components: (1) a watershed-component model developed by using Precipitation Runoff Modeling System (PRMS) and (2) a groundwater-component model developed by using MODFLOW-NWT.

In the Santa Rosa Plain hydrologic model application, the watershed-component model included 16,741 hydrologic response units discretized to match the 660 feet on a side, gridcell layout of the underlying groundwater-component model.
The hydrologic response units were linked into a flow drainage network that routes surface water to 10 locations of outflow on the Santa Rosa Plain watershed boundary. The daily climate input used in the Santa Rosa Plain hydrologic model was distributed to all hydrologic response units to account for spatial variability in precipitation and air temperature. The use of reclaimed water for irrigation from 1990-2010 also was distributed to the appropriate hydrologic response units.

The groundwater-component model characteristics included a finite-difference grid of 168 rows and 157 columns with uniform, square model cells with a dimension of 660 feet on each side. There were eight layers of variable thickness. Aquifer properties were spatially defined by hydrogeologic units on the basis of previously published stratigraphy and sediment texture data. Boundary conditions included no-flow and head-dependent flow boundaries to allow for subsurface flow into or out of the Santa Rosa Plain watershed, as appropriate. Major faults and two unidentified minor faults were simulated in the model as partial barriers to groundwater flow. The Santa Rosa Plain watershed was divided into model storage units to aid in the analysis and calibration of the aquifer properties and boundary conditions. The uplands surrounding the Santa Rosa Plain and Rincon and Kenwood Valleys were designated as separate model storage units. Groundwater inflow included extra-channel recharge (deep percolation of precipitation and irrigation) through the unsaturated to saturated zone, recharge from streams, and subsurface flow from adjacent groundwater basins. Groundwater outflow included pumpage, baseflow, groundwater evapotranspiration, and subsurface flow to adjacent groundwater basins and subbasins.

The Santa Rosa Plain hydrologic model was calibrated by using an iterative trial-and-error approach of adjusting model parameters to achieve a reasonable fit between (1) simulated and measured streamflow and (2) simulated and measured groundwater levels during water years 1975-2010. In addition, calibration to measured streamflow at the Santa Rosa Creek near Santa Rosa streamgage during water years 1960-65 was done by using a separate GSFLOW simulation for water years 1950-1965, in which pumping was excluded from the model. The calibration process for the Santa Rosa Plain hydrologic model included adjusting the initial estimates 
of the land-surface properties, soil-zone properties, streamchannel properties, aquifer properties, general-head boundary properties, and fault characteristics. The calibrated watershedcomponent model was used in decoupled PRMS-only mode to estimate the unreported agricultural-water demand that was used to estimate irrigation and agricultural pumpage.

\section{Key Results for Water Years 1976-2010}

The calibrated Santa Rosa Plain hydrologic model was used to derive components of the groundwater budgets for the water years 1976-2010 (long-term average), with particular attention given to groundwater budgets for a recent period (water years 2004-11), and dry (2009) and wet (2006) water years. The Santa Rosa Plain hydrologic model also was used to assess the effects of pumping on selected hydrologic-budget components.

\section{Streamflow}

During water years 1976-2010, total streamflow (including surface runoff, interflow, and groundwater discharge to streams) in the Santa Rosa Plain watershed varied on an annual and monthly basis. Annual total streamflow ranged from a maximum of about 611,000 acre-feet for the wettest water year (1983) to a minimum of about 26,000 acre-feet for the driest water year (1977). Monthly total streamflow showed strong seasonality, with the highest streamflows during December - March. Surface runoff was the dominant total streamflow component during November - April; after April, decreased precipitation caused surface runoff to decrease. Groundwater discharge to streams (baseflow) was the dominant component of total streamflow from May through October.

\section{Groundwater Budgets}

For the long-term average (water years 1976-2010), a recent period (water years 2004-10), a dry year (water year 2009), and a wet year (water 2006), recharge from streams to groundwater was greater than groundwater discharge to streams, indicating that on average, streams lost more water to the groundwater system than they gained. The primary reason for the overall increase in recharge from losing stream reaches was lowering of the water table from pumpage. Higher precipitation can help mitigate this; however, in the wet year there still was more recharge from losing stream reaches than groundwater discharge to gaining stream reaches.

Groundwater storage was reduced for the long-term average, the recent period, and the dry year. For the wet year, there was an accretion in groundwater storage. Although total recharge (extra-channel and stream) for the recent period was greater than the long-term average, it was not sufficient to offset the higher pumpage in this period. The simulated reduction in groundwater storage for the dry year was about six times that of the long-term average because of much less total groundwater recharge (extra-channel and stream) and greater pumpage. For the wet year, total groundwater recharge was much greater than the long-term average, resulting in an accretion in groundwater storage that was nearly as much as was reduced in the dry year. Overall, however, there was a cumulative groundwater-storage reduction of about 120,000 acre-feet for water years 1976-2010.

\section{Effects of Pumping on the Hydrologic System}

The Santa Rosa Plain hydrologic model was used to simulate the variability in average hydrologic conditions with and without pumping during water years 1976-2010 (longterm) to determine the effects of pumping on components of the hydrologic budget. Hydrologic-budget components include total streamflow, groundwater discharge to streams (baseflow), groundwater evapotranspiration, groundwater storage change, and recharge from streams.

\section{Streamflow}

Simulated results showed that the pumping reduced the average total streamflow (including runoff, interflow, and groundwater discharge to streams) about eight percent and that the relative change in total streamflow generally increased with time, corresponding to a general trend of increased pumpage. The relative reduction in total streamflow was greater for the drier years because groundwater discharge to streams was reduced with pumping and was a greater percentage of total streamflow during those years. Spatially, pumping resulted in an overall decrease in streamflow for most stream segments in the Santa Rosa Plain watershed. Maximum differences in average annual streamflow were 16 to 26 cubic feet per second and took place in the lower sections of the Laguna de Santa Rosa and Mark West Creek. Reductions in streamflow ranged from 2.1 to 15 cubic feet per second for the middle sections of Mark West Creek and Santa Rosa Creek, the upper section of Laguna de Santa Rosa, and the lower section of Matanzas Creek.

\section{Groundwater-budget components}

A decrease in groundwater levels in response to pumping caused a reduction in groundwater discharge to the streams (baseflow), a reduction in groundwater evapotranspiration (riparian), an increase in storage depletion, and an increase in recharge from streams (stream leakage into the groundwater system from losing stream reaches) during water years 19762010. The results indicated that during these years, pumping captured about 300,000 acre-feet of groundwater discharge to streams and about 211,000 acre-feet of groundwater 
evapotranspiration. The total reduction in groundwater storage from pumping was about 204,000 acre-feet; this included the reduction in storage of about 120,000 acre-feet with pumping and the storage accretion of 84,000 acre-feet without pumping. The results also indicated that about 189,000 acre-feet of recharge from streams was induced by pumping.

Pumping reduced groundwater discharge to streams (baseflow), groundwater evapotranspiration, and groundwater storage during the summer (July, August, and September) months. Pumping also induced recharge from streams during the summer months; however, recharge from streams was greater during the winter (January, February, and March) months for both the with- and without-pumping simulations. Pumping resulted in an average increase in groundwater storage of about 1,000 acre-feet per month during the winter months compared with an average reduction of about 2,800 acre-feet per month during the summer months.

\section{Key Results for Application of Future-Climate Scenarios}

Four potential future-climate scenarios, GA2, GB1, PA2, and PB1, based on two global climate models, GFDL (G) and PCM (P), and two projected greenhouse gas forcing scenarios, A2 and B1, were applied for water years 2011-99 without pumpage to estimate the long-term effects of climate change and variability. On average, the GA2 scenario is drier and the PB1 scenario is wetter than the historic-climate baseline period (1981-2010), and all four scenarios are warmer. The combined effect of projected pumpage and future climate on selected surface-water components and the groundwaterflow system also were estimated. This analysis was done for a typical water-management plan time frame (30-years, from water years 2011-40) compared with historic-climate baseline conditions (water years 1981-2010). Future municipal pumpage estimates were based on published data and rural pumpage was estimated.

\section{Future-Climate Scenarios without Pumping}

Overall, average annual simulated streamflows were more variable for all the future-climate scenarios than the historical-climate baseline period. Relatively low annual total streamflows (less than 100,000 acre-feet) occurred with greater frequency in all the future-climate scenarios compared with the historical-climate baseline period. This was most pronounced for the GA2 scenario, which is drier and warmer than the other three scenarios. Average monthly total streamflows showed that, for all four future-climate scenarios, December streamflows decreased and February streamflows increased during at least two of the three 30 -year periods examined. The changes in average monthly total streamflows corresponded to the reduced precipitation in December and increased precipitation in February for these periods.

Results showed that, for two of the future-climate scenarios (GA2 and GB1), total recharge (extra-channel and stream) in the Santa Rosa Plain watershed generally decreased in response to the warming trend; for three of the four scenarios (GA2, PA2, and PB1), groundwater discharge to streams (baseflow) generally decreased; and for all four future-climate scenarios, groundwater (riparian) evapotranspiration generally increased compared to the historical-climate baseline period. The greatest changes were for the warmest and driest scenario, GA2.

Compared to the historical-climate baseline period, annual total recharge declined after water year 2062 and 2055 in the GA2 and GB1 scenarios, respectively, because of increasing air temperatures and potential evapotranspiration during these periods. Annual groundwater discharge to streams was less than the historical-climate baseline period during selected periods after water year 2076 in the GA2, GB1, and PB1 scenarios. The general variability in groundwater discharge to streams in the PA2 scenario was similar to the historical-climate baseline period. Average annual groundwater evapotranspiration generally was higher in all future-climate scenarios compared with the historical-climate baseline period because of the increase in air temperature and corresponding increase in potential evapotranspiration.

\section{Future-Climate Scenarios with Projected Pumpage}

The combined effect of projected pumpage and future climate on selected surface-water components and the groundwater-flow system were estimated for a typical watermanagement plan time frame (30-years, from water years 2011-40) and compared with historic-climate baseline conditions (water years 1981-2010). The lower water table resulting from higher pumpage in the future-climate scenarios caused the reduction in: groundwater discharge to streams (baseflow), groundwater evapotranspiration, and surface leakage (groundwater discharge to the soil zone or land surface), and created more losing stream reaches with greater potential for infiltration of available streamflow, thereby partially offsetting the higher pumpage. For the GA2 and PA2 scenarios, the potential for infiltration of streamflow was limited by runoff and interflow values that were lower than the historical-climate baseline period and the GB1 and PB1 scenarios. The reduction in groundwater storage for the GA2 and PA2 scenarios was lower than the historical-climate baseline and there was storage accretion for the GB1 and PB1 scenarios compared with the historical-climate baseline period. The primary reason for 
the difference in average groundwater storage change between the historical-climate baseline period and the future-climate scenarios during water years 2011-40 is that the total recharge was greater than or about the same for the future-climate scenarios and outflows other than pumpage ranged from about 5 to 23 percent lower than the historical-climate baseline period.

The annual average precipitation and air temperatures for the future-climate scenarios for water years 2011-40 are somewhat different than the historical-baseline climate; these differences are more pronounced as time progresses after water year 2040. The differences after water year 2040 will result in greater agricultural pumpage and, coupled with increasing population, greater total groundwater pumpage, which will lower the water table further, thereby resulting in greater losses of groundwater storage than was simulated for water years 2011-40. After water year 2040, surface-water resources may no longer be able to offset the effects of drier conditions and higher pumpage, and the reduction of groundwater storage may happen at a more rapid rate.

The difference in simulated hydraulic heads between spring 2010 and spring 2040 indicated an overall decline in groundwater levels in the Santa Rosa Plain for the GA2, GB1, and PA2 future-climate scenarios. The decline was most pronounced for the warmer and drier GA2 scenario; the decline in groundwater levels was over a larger area compared with the other scenarios. The simulated groundwater-level difference for the wetter PB1 future-climate scenario indicated an overall increase in groundwater levels for a large part of the Santa Rosa Plain.

\section{Model Limitations and Uncertainty}

Differences between simulated and actual hydrologic conditions arise from a number of sources and are known collectively as model error. Components of model error relate to spatial or temporal discretization. Spatially, the model hydrologic conditions or properties (groundwater level, groundwater flux, evapotranspiration rate, and soil moisture) are represented by a single average value for the entire cell or hydrologic response unit. Therefore, the model potentially is not suitable for many local-scale problems or issues without additional model refinement. Temporally, the models were constructed by using daily time increments; therefore, the model is not suitable for partial-day simulations of individual storm events.
The capability of the Santa Rosa Plain hydrologic model to reliably reproduce hydrologic responses for the calibration period during water years 1975-2010 is related to the accuracy of the input data and the conceptual models used to inform development of the numerical-component models. The most important data limitation of the model is the uncertainty in the estimates of quantity and spatial distribution of rural pumpage (defined as a combination of agricultural and domestic pumpage). Other limitations include uncertainties in the spatial variability of precipitation interpolated over the Santa Rosa Plain watershed because of the limited number of climate stations with available records of daily precipitation, a lack of longterm streamflow records covering the entire period of model calibration, the lack of spatially distributed depth-dependent data, a lack of lithologic and temporal water-level data in the mountains, and a lack of borehole geophysical data. Changes in irrigation practices were not accounted for in the Santa Rosa Plain hydrologic model, and it was assumed that recharge from irrigation in excess of crop requirements was negligible; this is a potential source of error that could cause underestimation of pumpage and recharge. Landscape irrigation in urban areas and water application for other purposes, such as frost protection, were not included as inflows.

Changes in the characteristics of land cover were not addressed for the model application to future-climate scenarios. Additional sources of uncertainty for the futureclimate scenarios include limitations of the empirical method used to simulate potential evapotranspiration, and uncertainty in the spatial distribution of precipitation and air temperature for future climate scenarios. Assumptions used to develop estimates of future pumping also contributed to uncertainty in the application of the Santa Rosa Plain hydrologic model.

In conclusion, the Santa Rosa Plain hydrologic model is a tool that can be used to assess the potential effects of different types of management strategies and future-climate change. When applied carefully, the Santa Rosa Plain hydrologic model can be used for simulating hydrologic responses to various changes in stresses to the groundwater and surface-water flow systems. The Santa Rosa Plain hydrologic model could be used to evaluate sub-regional issues, such as proposed importation or exportation of water to or from the hydrologic system. The detailed lithology database developed previously coupled with water-level elevations make the Santa Rosa Plain hydrologic model particularly useful for assessing artificialrecharge sites. In the future, the Santa Rosa Plain hydrologic model also could be used as a platform to connect the simulation of hydrologic processes with water-allocation and optimization models. 


\section{Chapter A. Introduction}

\author{
By Linda R. Woolfenden, Tracy Nishikawa, and \\ Joseph A. Hevesi
}

\section{Introduction}

The Santa Rosa Plain (SRP), is in Sonoma County, about 50 miles (mi) north of San Francisco, California (fig. 1). About half the population of 484,000 in Sonoma County (U.S. Census Bureau, 2013) resides in the SRP, and the population centers are the cities of Santa Rosa, Rohnert Park, Cotati, Sebastopol, and the town of Windsor (fig. 2). The SRP faces population growth and increasing demand for water. Water managers face the challenge of meeting the water demand with a combination of Russian River water, which has uncertain future availability; local groundwater resources; and ongoing and expanding recycled water and other water conservation programs (Sonoma County Water Agency, 2012). To meet this challenge, water managers are seeking to develop the knowledge and tools needed to understand the likely effects of future groundwater development in the SRP and to identify efficient strategies for surface-water and groundwater management that can ensure the long-term viability of water supply. The U.S. Geological Survey (USGS), in cooperation with the Sonoma County Water Agency (SCWA) and other stakeholders in the area, undertook this study to characterize the hydrology of the SRP and to develop tools to better understand and manage the groundwater system.

The study area is the Santa Rosa Plain watershed (SRPW), which, for the purpose of this study, is a modified form of the Mark West Creek watershed (also referred to in previous studies as the Laguna de Santa Rosa watershed) that includes the Mark West, Santa Rosa, and the Laguna de Santa Rosa subbasins (Cal-Atlas, 2007; fig. 2). To better represent the complete area of the SRP groundwater subbasin, as defined by the California Department of Water Resources (2003), the SRPW boundary extends beyond the Mark West Creek watershed along the northwestern and southern sections of the boundary (fig. 2). In addition, a small area on the west side of the Mark West Creek watershed boundary is included to account for the entire drainage area upstream of the junction with the Russian River. This western addition is not included in some published versions of the Mark West Creek watershed (Cal-Atlas, 2007).

The 262-square-mile $\left(\mathrm{mi}^{2}\right)$ SRPW contains the SRP groundwater subbasin, Rincon Valley groundwater subbasin, the northern half of the Kenwood Valley groundwater subbasin, eastern portions of the Wilson Grove Formation Highlands groundwater basin, the southern part of the Healdsburg area groundwater subbasin, and the southern part of the Alexander Valley groundwater subbasin (California Department of
Water Resources, 1980; Sonoma County Water Agency, 2006; City of Rohnert Park, 2007), and parts of the Mayacmas and Sonoma Mountains (fig. 3). The SRP groundwater subbasin is part of the larger Santa Rosa Valley groundwater basin (fig. 2), which also includes the Healdsburg area and Rincon Valley, and is the largest groundwater subbasin in Sonoma County (California Department of Water Resources, 1980; Sonoma County Water Agency, 2006).

\section{Purpose and Scope}

The purpose of this report is to present the construction, calibration, and results of the fully coupled surface-water and groundwater-flow model for the SRPW, referred to as the Santa Rosa Plain hydrologic model (SRPHM), and to evaluate the potential hydrologic effects of future climate and projected pumpage for the basin. The SRPHM was calibrated to hydrologic conditions during water years 1975-2010. Water year 1975 was considered a "spin-up" period and was eliminated from the analysis of results. Four future-climate scenarios were simulated without pumpage for water years 2011-99 and with projected pumpage for water years 2011-40.

The USGS, in cooperation with the SCWA, the cities of Cotati, Rohnert Park, Santa Rosa, and Sebastopol, the town of Windsor, the California American Water Company, and the County of Sonoma, undertook this study to evaluate the groundwater resources of the SRP and to develop tools to better understand and manage the groundwater system. The objectives of the study are (1) to develop an updated assessment of the hydrogeology and geochemistry of the SRP, (2) to develop a fully coupled surface-water and groundwater flow model for the SRPW, and (3) to evaluate the potential hydrologic effects of alternative groundwater-management strategies for the basin. Nishikawa (2013) described the surface-water and groundwater hydrology, hydrogeology, and water-quality characteristics of the SRPW and developed a conceptual model of the hydrologic system in support of the first objective.

This report is composed of seven chapters. Chapter $A$ (this chapter) summarizes the purpose and scope of the study, provides a description of the study area, presents an overview of previous work, and presents an overview of the SRPW conceptual and numerical models. Chapter $B$ provides a detailed description of the development of the watershedmodel component of the SRPHM. Chapter C provides a detailed description of the development of the groundwatermodel component of the SRPHM. Chapter D presents the calibration results of the SRPHM. Chapter E presents the simulation results from the SRPHM. Chapter $F$ presents the simulated results for various possible future-climate scenarios and projected pumpage. Chapter $G$ presents the summary and conclusions of the report. Appendix 1 describes the development, example input and output, and application of a crop water-demand model that was used to estimate agricultural pumpage. 


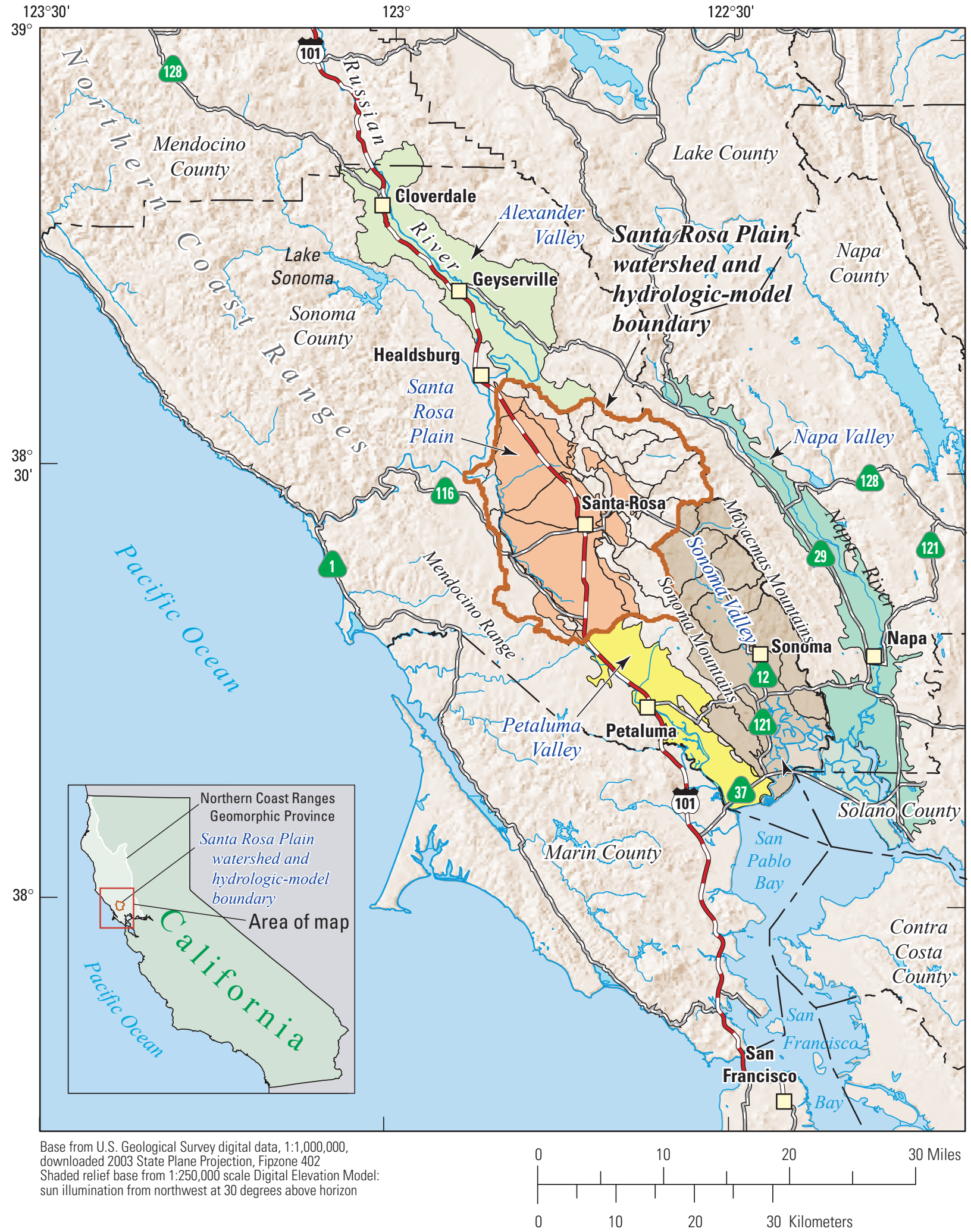

Figure 1. Location of the Santa Rosa Plain watershed study area, Sonoma County, California. 


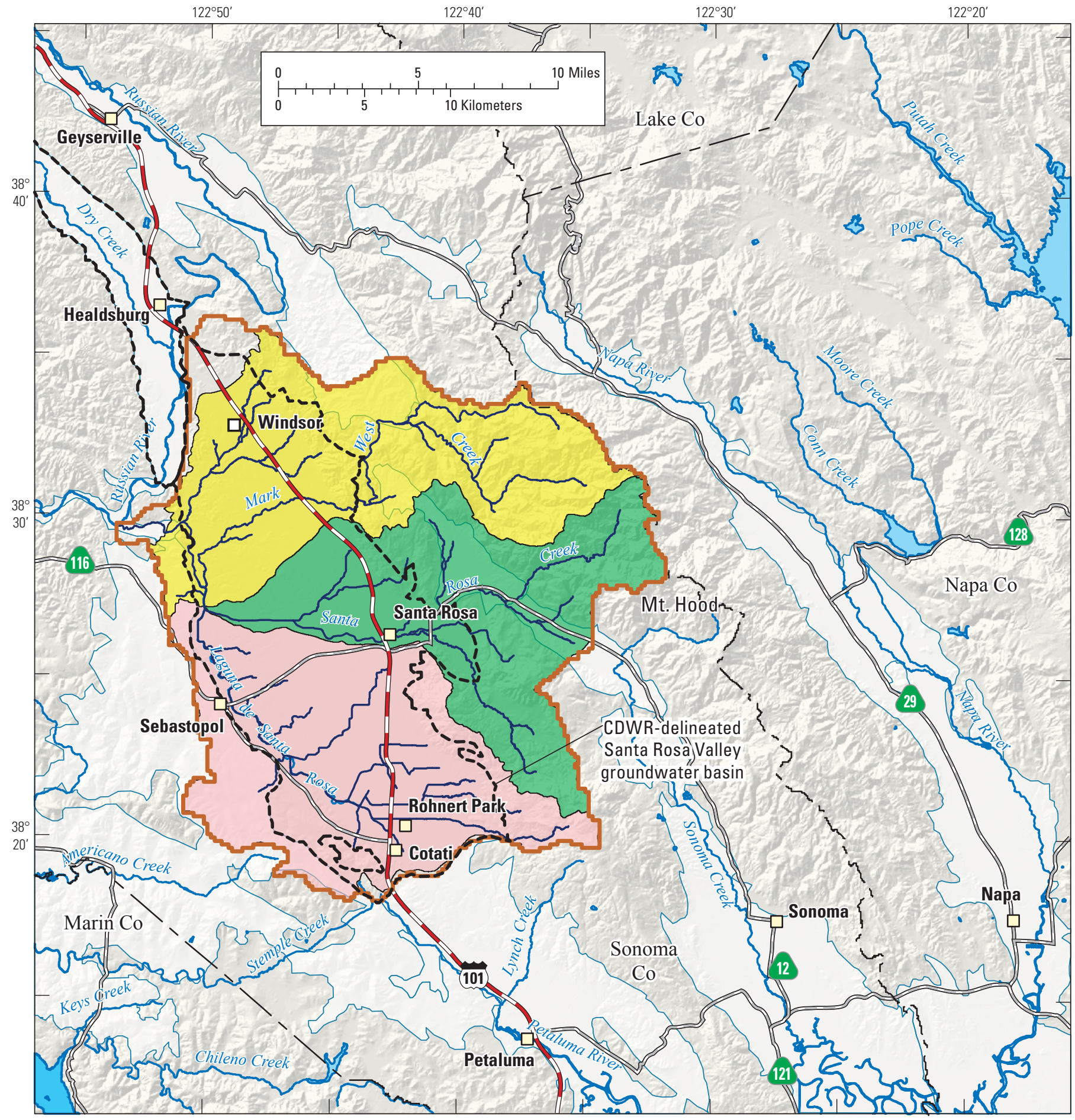

Base from U.S. Geological Survey digital data, 1:1,000,000, downloaded 2003 State Plane Projection, Fipzone 402

Shaded relief base from 1:250,000 scale Digital Elevation Model: sun illumination from northwest at 30 degrees above horizon

\section{EXPLANATION}

Surface-water subbasins

$\square$ Laguna de Santa Rosa
$\square$ Mark West Creek
$\square$ Santa Rosa Creek

Groundwater basin delineated by

California Department of

Water Resources (2003)
Santa Rosa Plain watershed and hydrologic-mode boundary

Major streams

Figure 2. Santa Rosa Plain watershed and surface-water subbasins, Sonoma County, California. 


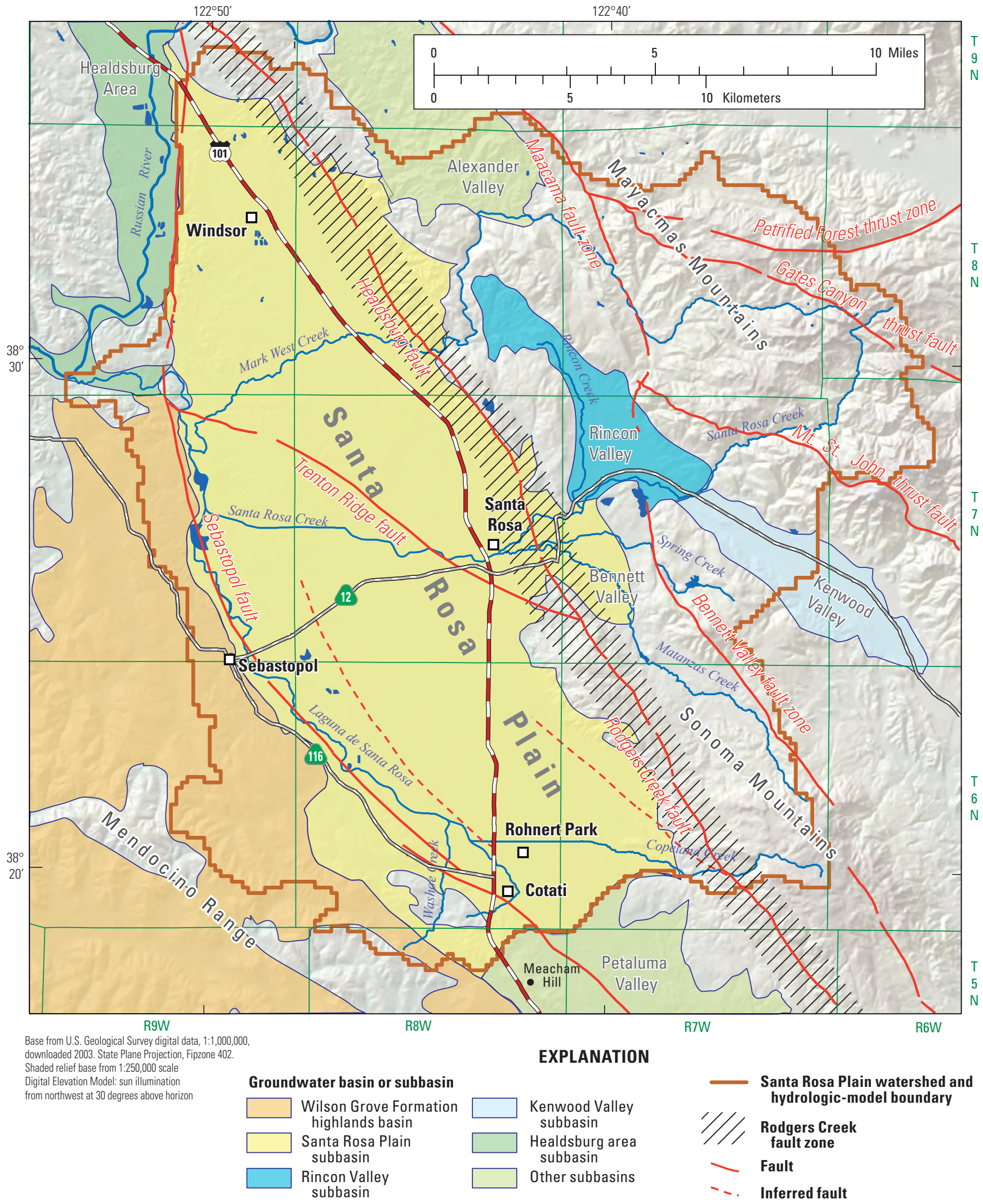

Figure 3. Santa Rosa Plain watershed boundary with groundwater subbasins, Sonoma County, California. 


\section{Study Area Description}

A detailed discussion of the study-area hydrology and subsurface geology is provided by Sweetkind and others (2013). The following description of the study area provides an overview of the physiography, climate, land uses, aquifer system, and groundwater recharge and discharge in the SRPW. The description of physiography includes an overview of geologic controls on landforms in and surrounding the study area. The description of land use provides a brief history of land-use changes and includes an overview of the effect of land-use change on the hydrology of the SRPW, as documented in previous studies.

\section{Physiography}

The SRPW lies in the Northern Coast Ranges geomorphic province (fig. 1) that occupies most of the northwestern edge of California and consists of a series of small mountain ranges and ridges that trend generally northwest-southeast, subparallel to the Pacific coast line (Jenkins, 1938; California Geological Survey, 2002).

SRP is a lowland area of about $90 \mathrm{mi}^{2}$ in a northwest trending structural depression that separates the Mendocino Range to the west from the Sonoma Mountains and Mayacmas Mountains to the east (fig. 3). The valley floor lies mostly between elevations of about 50 and 150 feet (ft). The northnorthwest to south-southeast axis of the valley extends for about $20 \mathrm{mi}$, from near the Russian River on the north to Meacham Hill on the south; the valley ranges mostly from 4 to $7 \mathrm{mi}$ in width. The floor of the valley is relatively flat, compared with the surrounding mountains, but is not without internal topographic features. Most of the valley floor consists of a low, uneven topography (Sowers and others, 1998).

\section{Climate}

Generally, the climate for the study area is Mediterranean, with cool, wet winters; warm, dry summers; and a strong coastal influence that moderates temperature extremes (Sloop and others, 2009). The spatial distribution of mean annual precipitation, which was about 40 inches (in.) from 1971 to 2000 , is strongly affected by topography and varies considerably. Temporal variability in precipitation primarily follows the seasonal pattern of cool, wet winters and warm, dry summers. Similar to precipitation, the spatial and temporal distribution of air temperature also is affected strongly by topography and season.

\section{Land Use}

The long-term trend of changing land use in the SRPW had a dramatic effect on the hydrologic system (Sloop and others, 2009). In general, these changes were (1) the conversion of native vegetation to grassland and agriculture that started in the mid-1800s, and (2) the start of rapid urbanization in the 1940s. Conversion of land cover from native vegetation (perennial bunch grasses and annual forbs) to grassland (for ranching) and agriculture has generally increased the total amount of runoff generated along with the "flashiness" of streamflow, as characterized by a steepening of the streamflow hydrograph (Sloop and others, 2009). Urbanization has increased the percentage of impervious surfaces, which probably also has increased runoff and flashiness of streamflow primarily in areas within and downstream of the more heavily urbanized zones.

Changing land use also affects the groundwater system. The conversion of land cover from native vegetation to agriculture could reduce direct infiltration to the soil zone; however, an increase in runoff, as described previously, also results in increased streambed recharge downstream from the runoff (Sloop and others, 2009). Where agriculture is irrigated, irrigation-return flow is another source of water to the soil zone. Urbanization of agricultural areas affects the quantity and distribution of pumping from the groundwater system, which, in turn, can alter the direction of groundwater movement and groundwater storage. Increased impervious area from urbanization can reduce direct infiltration to, and evapotranspiration from, the soil zone. For additional information regarding the SRPW land use, the reader is referred to Nishikawa and others (2013b).

\section{Population}

Historically, the population in the SRP and the surrounding mountains was mostly rural, and agriculture was the primary developed land use. In 1950, the population of the city of Santa Rosa was about 18,000. At that time, the only other incorporated city was Sebastopol, with a population of about 2,600 (Cardwell, 1958). The main urban and residential areas now include the cities of Santa Rosa, Rohnert Park, Sebastopol, and Cotati, and the town of Windsor. Even though the land-use maps indicate only about 15 percent increase in urban and residential areas from 1974 to 1999 , the populations of these cities and towns increased about 255 percent between 1970 and 2000 (table 1; California Department of Finance, 2012; U.S. Census Bureau, 2013).

\section{Previous Work}

The hydrology of the SRPW has been described in previously published research (for example, Cardwell, 1958; Ford, 1975; Herbst and others, 1982; Kadir and McGuire, 1987; Nishikawa, 2013).

Nishikawa (2013) described the surface-water and groundwater hydrology, hydrogeology, and water-quality characteristics of the SRPW to develop a conceptual model of the hydrologic system as part of this study. These findings are synopsized in the next sections. 
Table 1. Population for the cities and township in the Santa Rosa Plain, Sonoma County, California, 1950, 1960, 1970, 1980, 1990, 2000, and 2010.

[Abbreviation: NR, not reported]

\begin{tabular}{|c|c|c|c|c|c|c|c|}
\hline $\begin{array}{c}\text { City or } \\
\text { township }\end{array}$ & $1950^{1}$ & $1960^{1}$ & $1970^{1}$ & $1980^{1}$ & $1990^{1}$ & $2000^{1}$ & $2010^{2}$ \\
\hline Santa Rosa & 17,902 & 31,027 & 50,006 & 82,658 & 113,313 & 147,595 & 167,815 \\
\hline Rohnert Park & NR & NR & 6,133 & 22,965 & 36,326 & 42,236 & 40,971 \\
\hline Sebastopol & 2,601 & 2,694 & 3,993 & 5,595 & 7,004 & 7,774 & 7,379 \\
\hline Windsor & NR & NR & 2,359 & NR & 13,371 & 22,744 & 26,801 \\
\hline
\end{tabular}

${ }^{1}$ California Department of Finance (2012).

${ }^{2}$ U.S. Census Bureau (2013).

\section{Geohydrology Findings}

- Four principal aquifer units were defined for the study area: (1) the Glen Ellen Formation (including Quaternary alluvial deposits), (2) the Wilson Grove Formation, (3) the Petaluma Formation, and (4) the Sonoma Volcanics. The units were identified through borings, geophysics, and surface exposures.

- Reported hydraulic-conductivity values for the Glen Ellen Formation ranged from 13 to 23 feet per day $(\mathrm{ft} / \mathrm{d})$. Reported specific-yield values for the formation ranged from 3 to 7 percent.

- Reported hydraulic-conductivity values for the Wilson Grove Formation ranged from 2 to $65 \mathrm{ft} / \mathrm{d}$. Estimated and reported specific yield and storativity values for the formation ranged from 10 to 20 percent and from 0.00095 to 0.08 , respectively.

- Reported transmissivity values for the Petaluma Formation ranged from 130 to 1,600 square feet per day $\left(\mathrm{ft}^{2} / \mathrm{d}\right)$.

- Reported transmissivity values for the Sonoma Volcanics ranged from 0.8 to $5,300 \mathrm{ft}^{2} / \mathrm{d}$. Reported specific-yield values for the formation ranged from 0 to 15 percent.

- Geophysical data indicated that two main groundwater subbasins exist beneath the Santa Rosa Plain; the basins are as deep as 4,500 $\mathrm{ft}$ below the town of Windsor and as deep as $10,000 \mathrm{ft}$ beneath Rohnert Park. The two basins are separated by the Trenton Ridge, a buried-bedrock ridge that has a minimum depth of about $1,000 \mathrm{ft}$ below land surface.

- Faults could be barriers to groundwater flow in the SRPW. Recent surface geologic mapping and geophysical studies refined the locations of the major faults within the SRPW.
- Three-dimensional subsurface models of lithologic variations indicated a west-to-east transition from dominantly fine-grained marine sands to heterogeneous continental sediments interbedded with Sonoma Volcanics. In contrast to previous studies, the threedimensional models of the SRPW indicated that the Petaluma Formation extends throughout the deeper parts of the basins beneath the SRP.

- The most consistently productive wells in the study area extract groundwater from the Wilson Grove Formation. The Glen Ellen Formation is heterogeneous and contains large amounts of clay, so groundwater production from this unit is highly variable. Previously, it was reported that the Glen Ellen Formation is as thick as 3,000 ft; however, recent work, incorporated in this report, indicated that the thickness of the formation is variable, but typically is hundreds of feet. The Petaluma Formation is the deepest and thickest aquifer; it is generally less permeable than others, but water is produced from sandy horizons within the formation.

- Five groundwater storage units were defined on the basis of previous work, hydrogeology, and fault locations (fig. 4).

- The Windsor Basin (WB) storage unit is north of the Trenton Ridge fault, west of the Mayacmas Mountain foothills, and east of the Sebastopol fault.

- The Cotati Basin (CB) storage unit is south of the Trenton Ridge fault, west of the Sonoma Mountain foothills, and east of the Sebastopol fault.

- The Wilson Grove (WG) storage unit is between the Mendocino Range and the Sebastopol fault.

- The Valley (VAL) storage unit includes the alluvial fill of the Rincon, Bennett, and Kenwood valleys.

- The Uplands (UPL) storage unit includes the Mayacmas and Sonoma Mountains east of the Rodgers Creek fault zone, but excludes the Valley storage unit. 


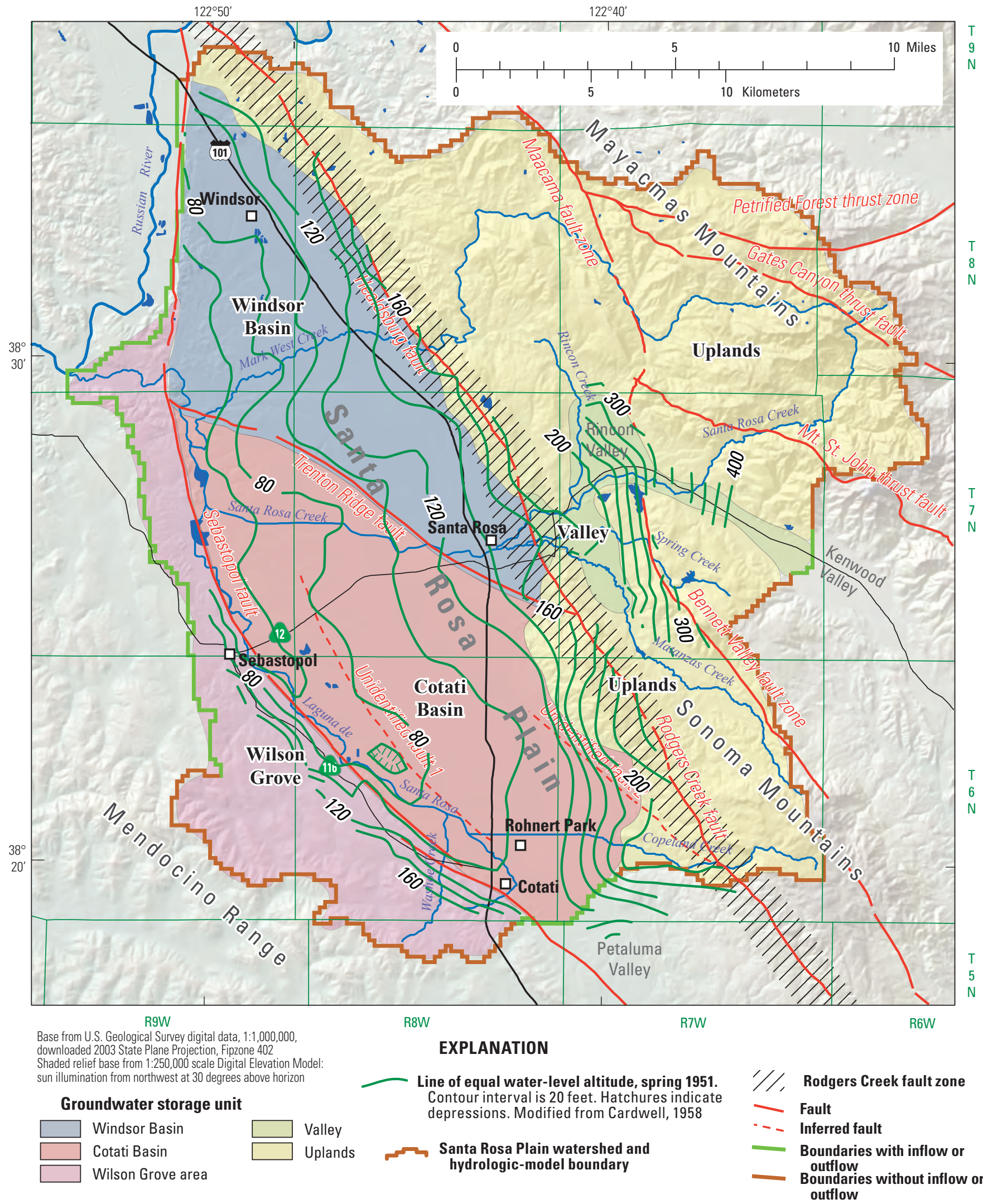

Figure 4. Groundwater-level contours for spring 1951, Santa Rosa Plain watershed, Sonoma County, California. 


\section{Surface-Water Hydrology Findings}

- Highly variable streamflow-Streamflow in the SRPW is variable with the highest monthly mean flows during winter-more than 1,200 cubic feet per second $\left(\mathrm{ft}^{3} / \mathrm{s}\right)$ measured at the Mark West Creek near Mirabel Heights gage - and very low-to-zero monthly mean flow during summer.

- Rapid response to precipitation-Streamflow in the SRPW characteristically responds relatively rapidly to precipitation events.

- Very low summer flows-Baseflow is a minor component of total mean flow, but it constitutes the only flow during the dry, summer months. Most of the stream reaches in the SRPW are intermittent.

- Flooding in the Laguna de Santa Rosa-In the Laguna de Santa Rosa floodplain, streamflow can be affected by backwater from the Russian River. Flow can reverse during periods of flooding on the Russian River.

\section{Groundwater Movement and Levels Findings}

- Important sources of groundwater recharge in the SRPW are infiltration of precipitation, infiltration from streams, and irrigation-return flow.

- Important groundwater outflows are groundwater pumping, evapotranspiration from phreatophytes, and baseflow in streams.

- On a larger scale, groundwater flows from the Mayacmas and Sonoma Mountains, in the UPL storage unit, westward, toward the Laguna de Santa Rosa on the western edge of the SRP, and eastward, from the highlands in the WG storage unit toward the Laguna de Santa Rosa (fig. 4).

- Water-chemistry data analysis indicated that the Rodgers Creek fault zone restricts the lateral movement of water from the UPL and VAL storage units to the WB and CB storage units.

- In general, interpretation of the water-level contour maps indicated that Santa Rosa Creek gains water east of the Rodgers Creek fault zone, and Mark West and Santa Rosa creeks gain water in the western part of the SRP.

- Water-level contours, based on available data, indicated cones of depression in the Cotati and Rohnert Park area and north of Sebastopol from spring 1974 to fall 2001; however, water levels partially recovered in the Cotati and Rohnert Park area by 2007 in response to decreased pumping.
- Water levels in monitoring wells showed response to pumping; the response varied with depth.

- Pumping tests done in 1987 to determine if the Sebastopol fault is a barrier to groundwater flow were inconclusive; however, water-chemistry data indicated little mixing of groundwater across the fault.

- Water-chemistry and isotopic data for water from wells in the WB and CB storage units indicated limited vertical mixing between the upper and lower aquifers; this was attributed to the presence of low-permeability deposits in the Glen Ellen and Petaluma Formations.

- Isotopic data for water from deep wells perforated in the Petaluma Formation indicated a long groundwater flowpath passing through the $\mathrm{CB}$ storage unit.

\section{Conceptual Model}

The conceptual model of the SRPW is based on known and estimated physical and hydrologic characteristics of the surface-water and groundwater systems and how these characteristics influence the flow and storage of water in the SRPW. The conceptual model of the SRPW hydrologic system described in Nishikawa and others (2013a) is summarized here to provide the reader necessary background to understand the construction of the SRPHM.

\section{Precipitation}

The major source of water to the SRPW is precipitation that falls primarily as rain. The estimated mean annual precipitation for the SRPW for 1971-2000 was about 40 in., or about 560,000 acre-feet per year (acre-ft/yr) distributed over the 167,400-acre watershed (Nishikawa and others, 2013b). The highest rates of precipitation, about 42-57 inches per year (in./yr), were in the Mayacmas and Sonoma Mountains of the UPL storage unit; however, because of the low permeability of the basement complex and Sonoma Volcanics that compose these mountains, and the steep slopes, most of the precipitation that falls on this storage unit probably becomes runoff that contributes to streamflow and potential recharge in the downstream storage units.

\section{Streamflow}

Mark West Creek, Santa Rosa Creek, and Laguna de Santa Rosa are the major streams that drain the SRPW. The main channel of Mark West Creek originates in the Mayacmas Mountains and is perennial throughout much of its length in the UPL storage unit; summer flows are maintained by numerous springs near the headwaters. Santa Rosa Creek also originates in steep terrain with mostly natural vegetation 
in the Mayacmas Mountains. The upper part of Santa Rosa Creek and Matanzas Creek, one of its tributaries, are perennial streams in the UPL storage unit. As the streams flow through the VAL storage unit, they lose flow in reaches upgradient and east of the Rodgers Creek fault, where groundwaterlevel contours indicate groundwater from the VAL storage unit discharges to the stream channel. Immediately west and downgradient of the Rodgers Creek fault, groundwaterlevel contours indicate that the Santa Rosa Creek loses water (recharges) to the WB and CB storage units. As Santa Rosa Creek reaches the western end of the SRP, the creek begins to gain flow and is perennial. The Laguna de Santa Rosa, which originates in the southern part of the SRPW, is perennial in most sections.

\section{Aquifer System}

There are two main groundwater subbasins beneath the SRP; the basins are as deep as 4,500 ft below the community of Windsor and as deep as 10,000 ft beneath Rohnert Park (Sweetkind and others, 2013). The two basins include four principal aquifers: the Glen Ellen Formation, the Wilson Grove Formation, the Petaluma Formation, and the Sonoma Volcanics (Sweetkind and others, 2013; fig. 5). In general, the aquifer units transition from Sonoma Volcanics interbedded with the Petaluma Formation in the UPL storage unit east of the Rodgers Creek fault zone, to the Glen Ellen Formation overlying the Sonoma Volcanics in the VAL storage unit, to heterogeneous continental sediments of the Glen Ellen and Petaluma Formations within WB and CB storage units in the
SRP, to dominantly fine-grained marine sands of the Wilson Grove Formation in the WG storage unit on the west (fig. 5). Water-quality data indicate that there is little hydraulic communication between the shallow and deep aquifer systems in the SRP (Martin and others, 2013). The basement complex is characterized by a variety of consolidated rock types that underlie the sedimentary and volcanic rocks and alluvial deposits beneath most of the SRPW and that crop out in parts of the UPL storage unit (Sweetkind and others, 2013). On the basis of data collected for this study, the basement complex yields water locally to domestic wells in the Mayacmas and Sonoma Mountains. The basement complex is at great depths in the SRP and is not a source of water to wells there (Sweetkind and others, 2013).

In general, the fluvial sediments of the Glen Ellen Formation have low-to-moderate permeability and tend to be coarser grained in the VAL storage unit and on the eastern end of the SRP. The predominance of relatively well-sorted marine sand and the low degree of cementation in the Wilson Grove Formation result in moderate permeability and moderate-to-high storativity. The Petaluma Formation is dominated by finegrained materials, either in thick beds or as interstitial material in poorly sorted silty and clayey sands or gravels. The Sonoma Volcanics include a thick accumulation of andesitic and basaltic tuffs containing interbedded lavas and volcaniclastic rocks with a wide range of permeabilities (Ford, 1975) and are an important aquifer in the UPL and VAL storage units locally.

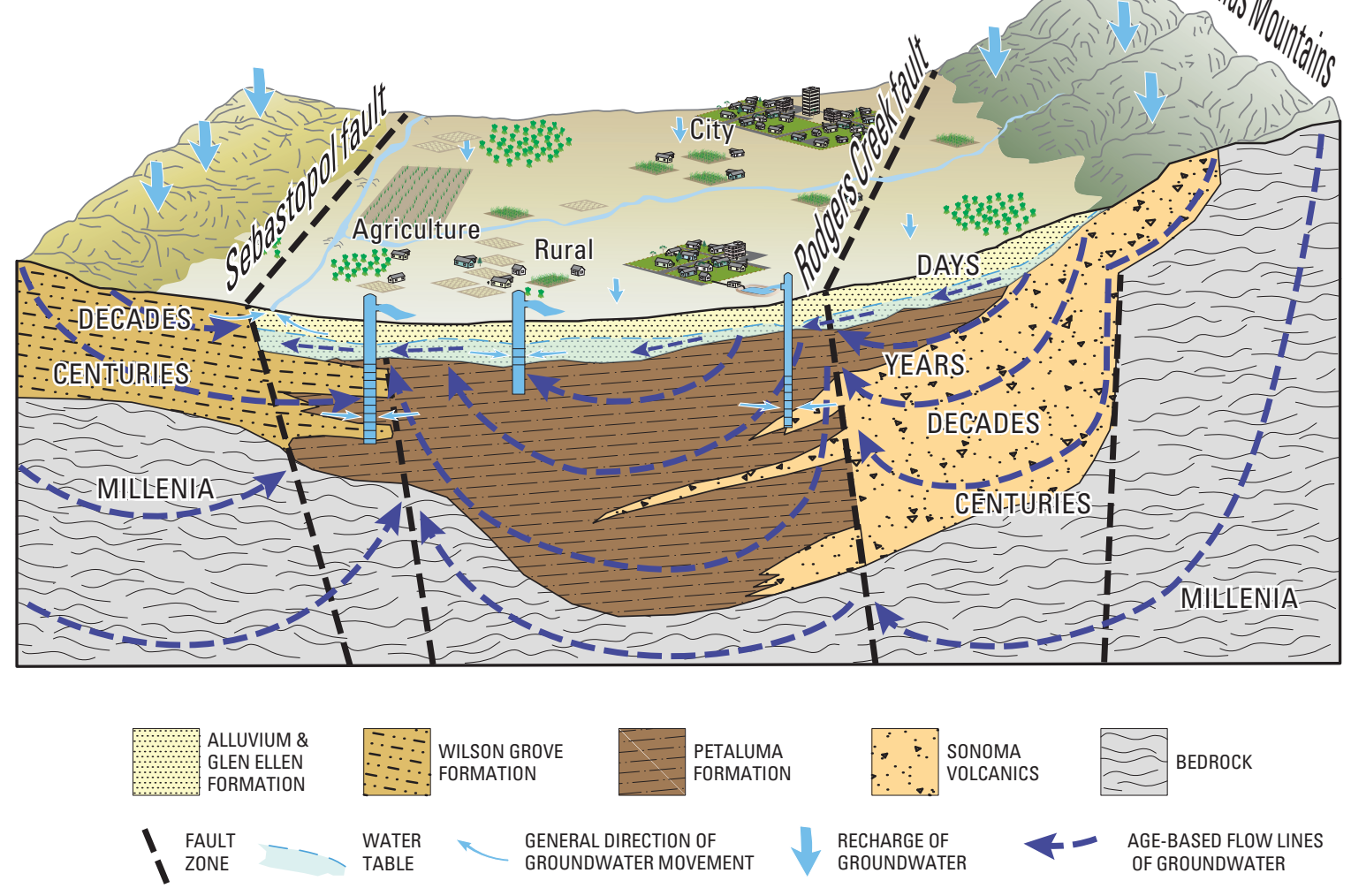

Figure 5. Conceptual model showing the groundwater-flow system, Santa Rosa Plain watershed, Sonoma County, California. 


\section{Groundwater Recharge}

The principal sources of recharge to the groundwater system are direct infiltration of precipitation and infiltration from streams in the SRPW. Herbst and others (1982) reported the average annual recharge flux for the SRP between 1960 and 1975 was about 29,300 acre-ft. Assuming this estimate is correct, the average annual recharge for the SRPW would be greater than this value because the SRPW includes areas not included in the 1982 estimate: Kenwood Valley, the area west of the Sebastopol fault, and the mountains that border the SRP. Water-quality data indicated that the majority of natural recharge occurs on the SRP (Nishikawa, 2013).

Other potential sources of groundwater recharge include boundary flow from the adjacent Healdsburg area groundwater subbasin, and Wison Grove Formation Highlands and Petaluma Valley groundwater basins. Groundwater boundary flow into the SRPW computed by the SRPHM averaged about 7,200 acre-ft/yr for water years 1976-2010 (chapter E, table 2).

Infiltration from septic tanks, leaking water-supply pipes, irrigation water in excess of crop requirements, and crop frostprotection applications were assumed to be minor sources of recharge. Although recharge from excess irrigation sometimes can be an important part of total recharge in some basins, in this study area, it was assumed to be minor (Sweetkind and others, 2013) on the basis of predominantly low nitrate concentrations in the SRPW (Martin and others, 2013).

\section{Natural Groundwater Discharge}

Natural groundwater discharge supplies baseflow in streams (gaining streams), evapotranspiration (ET), spring discharge, and groundwater boundary flow out of the SRPW. Sweetkind and others (2013) reported that in 1951, Santa Rosa Creek east of the Rodgers Creek fault zone in the UPL and VAL storage units, Spring Creek, and Matanzas Creek were receiving water from the groundwater system (gaining streams). About $5 \mathrm{mi}$ west of the Rodgers Creek fault zone, Santa Rosa Creek also was a gaining stream in the western part of the SRP.

Cardwell (1958) estimated that the ET discharge from the Laguna de Santa Rosa ranged from 4,000 to 6,000 acre-ft/yr. Cardwell (1958) did not estimate the baseflow contribution to the Laguna de Santa Rosa. Groundwater discharge to the Laguna de Santa Rosa in excess of that used by plants along the stream is lost to the atmosphere by evaporation or flows to the lower reach of Mark West Creek, which flows out of the study area.

Most of the springs in the study area are gravity springs on the steeper slopes or in gullies, where the water table intersects the land surface; however, some are contact springs, discharging along the contact between permeable and low-permeability beds. Contact springs are relatively common in the Sonoma Volcanics and Glen Ellen Formation (Cardwell, 1958).
Groundwater could flow from the SRPW to the Healdsburg area groundwater subbasin, the Wilson Grove Formation Highlands groundwater basin, and Petaluma Valley groundwater basin. Groundwater boundary flow out of the SRPW computed by the SRPHM averaged about 7,900 acre-ft/yr (chapter E, table 2).

\section{Pumpage}

Groundwater is pumped for public, agricultural, and domestic water supply in the SRPW. Most of the 70 publicsupply wells in the SRP are located in the vicinity of the cities Cotati, Rohnert Park, and Sebastopol (fig. 6). The publicsupply pumpage used in this study was reported and described by Sweetkind and others (2013). Agricultural pumpage initially was estimated by using a preliminary calibrated watershed model of the SRPW with land-use data and monthly crop coefficients, as described in Appendix 1 of this report. Daily irrigation demand was estimated and used to determine the spatial and temporal distribution of average monthly agricultural pumping for 1,072 agricultural wells. Domestic pumpage was not available for this study and was estimated as described in chapter $C$ of this report. These estimates were then distributed to over 3,000 wells throughout the SRPW. Agricultural and domestic pumpage was defined as rural pumpage for this report, and there are a total of 4,192 rural wells (fig. 6). Rural pumpage was modified during model calibration, and the adjusted values are discussed in chapter $D$ of this report.

Public-supply pumpage for water gradually increased during water years 1974-2001 (fig. 7). After water year 2001, pumpage tended to decrease (fig. 7). Public-supply pumpage ranged from about 4,000 acre-ft to about 10,000 acre-ft during water years 1975-2010, and averaged about 7,000 acre-ft/yr. Rural pumpage generally increased during water years 1975-92 (fig. 7). After water year 1993, pumpage sharply increased (fig. 7). The trend of increasing pumpage after water year 1993 was due to an increase in the number of irrigated vineyards (California Department of Water Resources, 1974, 1979, 1986, 1999). Rural pumpage ranged from about 21,000 acre- $\mathrm{ft}$ to about 66,000 acre-ft, during water years 1975-2010, and averaged about 37,000 acre-ft/yr (fig. 7).

\section{Groundwater Flow}

In general, groundwater flows from the mountains in the east through the SRP and from the Wilson Grove Formation Highlands in the west toward the Laguna de Santa Rosa, just east of the Sebastopol fault (fig. 5). Major faults that cut the stratigraphic units of the aquifer system are partial barriers and can affect the direction of groundwater flow (fig. 5).

Hydraulic and geochemical data indicated the following: (1) precipitation and runoff from the Mayacmas Mountains is the probable source of recharge to wells sampled in the UPL and VAL storage units; (2) groundwater movement through the Sonoma Volcanics is relatively slow; (3) the Rodgers Creek 


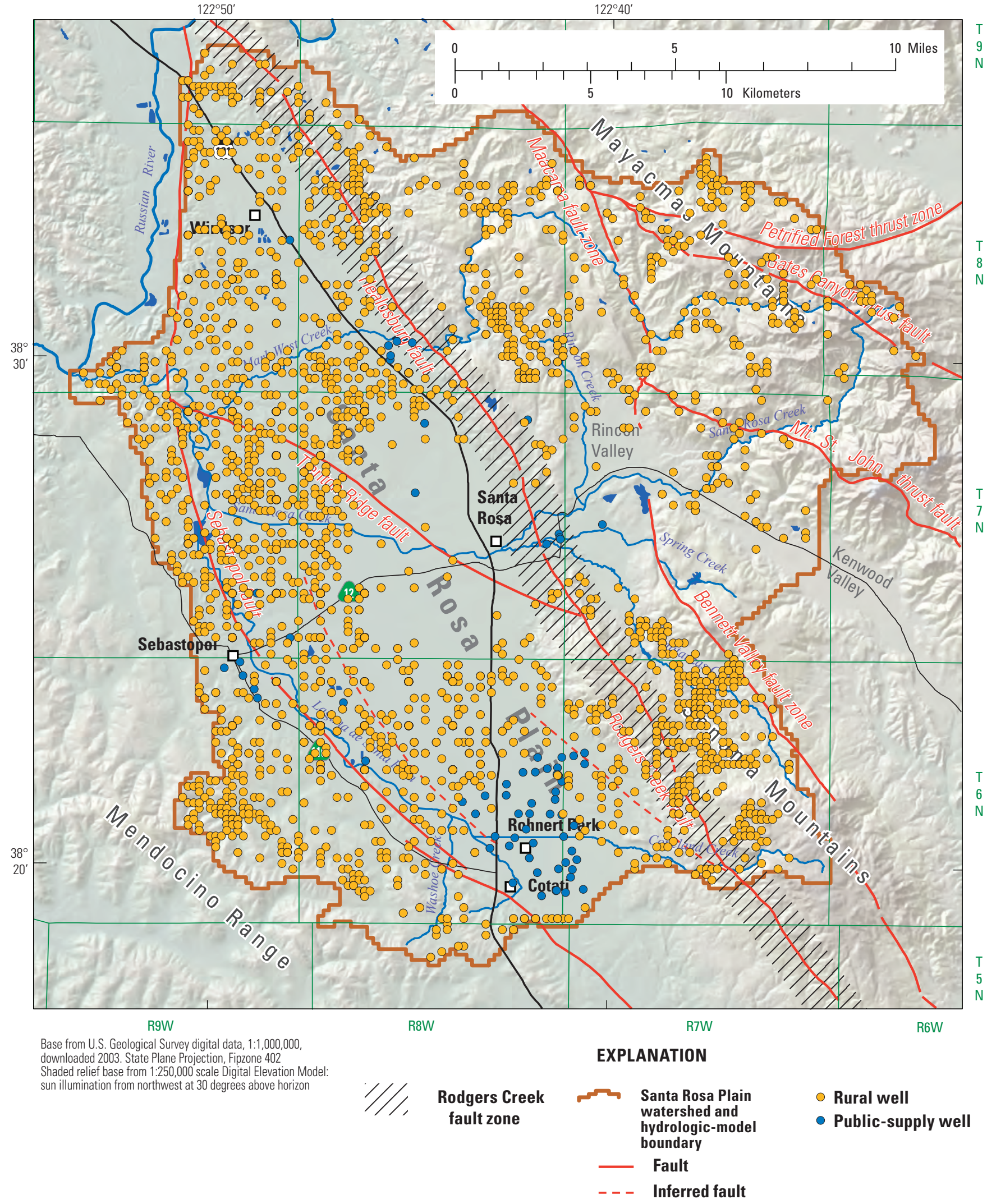

Figure 6. Public-supply and rural (agricultural and domestic) wells, Santa Rosa Plain watershed, Sonoma County, California. 


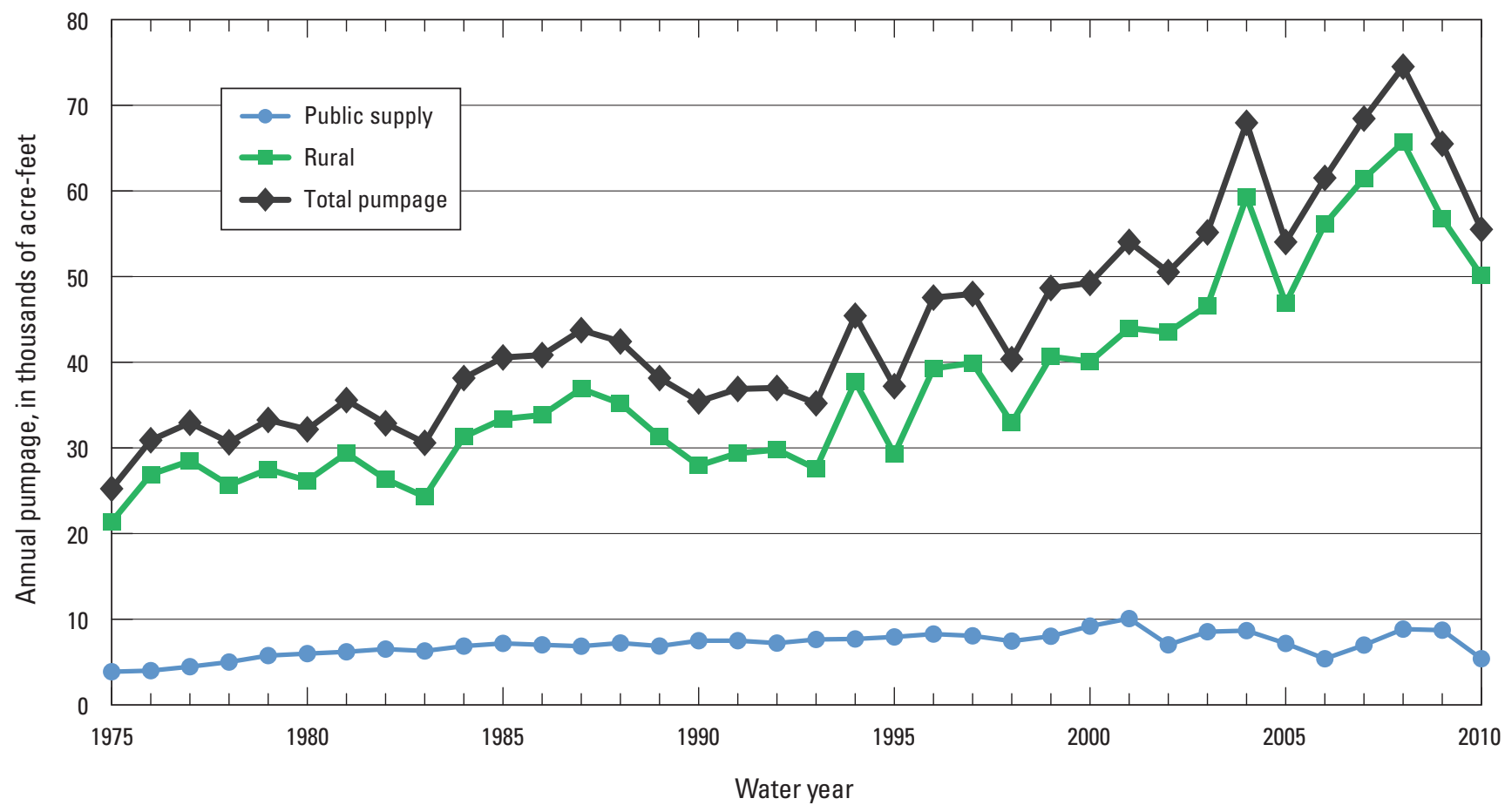

Figure 7. Reported public-supply and estimated rural pumpage during 1975-2010, Santa Rosa Plain watershed, Sonoma County, California.

fault zone is a partial barrier to groundwater flow; (4) deeply circulating groundwater is rising along the east side of the Rodgers Creek fault zone; (5) the Sebastopol fault is at least a partial barrier to groundwater flow; (6) low permeability clay layers in the Petaluma Formation limit the rate of vertical groundwater movement between the Wilson Grove Formation and overlying Petaluma Formation; (7) sources of groundwater recharge in the SRP are precipitation, recharge from streams, and inflows from the UPL and VAL storage units; and (8) vertical migration of recharge in the SRP probably is restricted by the presence of low permeability clay deposits in the Glen Ellen and Petaluma Formations. For additional information regarding the geochemistry of the SRPW and its interpretation with respect to the hydrology of the SRPW, the reader is referred to Martin and others (2013) and Nishikawa and others (2013a).

\section{Simulation of Surface-Water and Groundwater Regions}

The coupled groundwater and surface-water flow model GSFLOW (Markstrom and others, 2008) is defined by boundaries and three inter-connected regions. The three regions in the SRPHM are (1) the plant canopy, the land surface, and the soil zone; (2) streams; and (3) the subsurface unsaturated zone and an underlying saturated zone (fig. 8). The three regions are simulated by two components in GSFLOW.
Region 1 is simulated by the Precipitation-Runoff Modeling System (Leavesley and others, 1983, 2005; PRMS), and regions 2 and 3 are simulated by the Modular GroundwaterFlow Model MODFLOW-NWT (Niswonger and others, 2011; MF-NWT). Water is stored in each region, and the regions are linked by the exchange of flow among them. The flow of water into, out of, and within each region is a function of the processes and properties specific to each region.

The physical boundary for regions 1 and 3 is the surfacewater drainage for the SRPW described in the "Conceptual Model/Streamflow" section of this chapter. The boundaries for region 2 are the lowest elevation of the streambeds and the horizontal extent of the stream channels in the SRPW. The main point of surface-water outflow from the SRPW is where Mark West Creek exits the watershed. Surface-water also outflows at nine other locations. Flow across the bottom of the streambed in region 2 depends on the water-table elevation in the underlying aquifer. Flow across the lateral extent of the stream channels is a function of the quantity of precipitation and channel characteristics. Flow in the unsaturated part of region 3 is assumed to be vertical, so it does not cross the lateral model boundary. About 75 percent of the length of the boundary for the saturated part of region 3 is interpreted to be a no-flow boundary, where the low-permeability basement complex, a groundwater divide, or both limit hydraulic interaction between the SRPW groundwater basin and adjacent groundwater subbasins. The remaining boundary of region 3 includes five segments where there could be groundwater interaction with adjacent groundwater subbasins. 


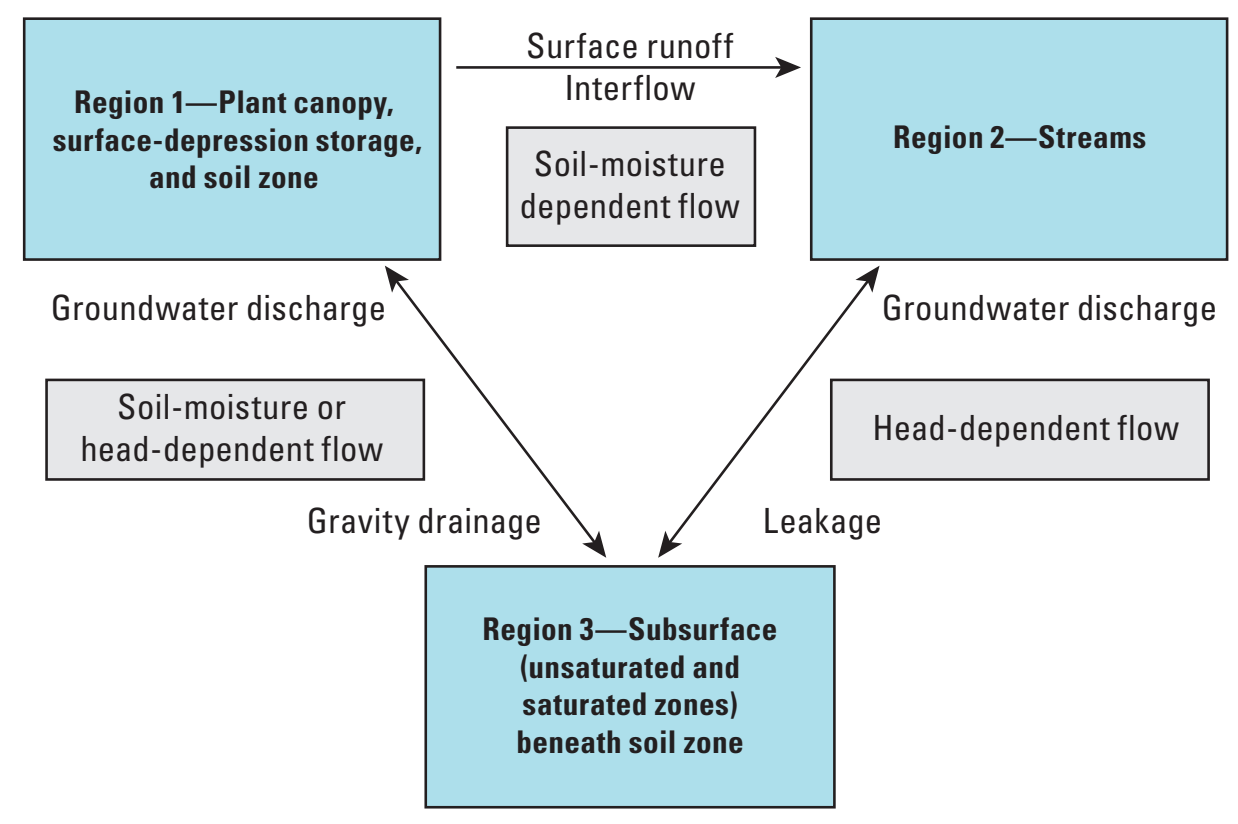

Figure 8. General conceptual model of the Santa Rosa Plain watershed hydrologic system, Sonoma County, California (modified from Markstrom and others, 2008).

\section{Region 1: Plant Canopy, Land Surface, and Soil Zone}

Region 1 of the SRPW includes the plant canopy, land surface, and soil zone and provides the primary link between climatic factors and the SRPW hydrologic system. The plant canopy includes natural vegetation, crops, and landscaped urbanized areas. The three types of land surfaces are (1) covered by soil; (2) naturally exposed bedrock areas free of soil cover; and (3) areas covered by anthropogenic features, such as buildings, roads, and parking lots. The soil zone is conceptually defined as extending from the ground surface to the base of the root zone (Markstrom and others, 2008). The soil zone stores and transmits water between the atmosphere and the underlying unsaturated and saturated zones.

In the SRPW, the primary sources of water to region 1 include (1) precipitation, primarily in the form of rainfall; (2) irrigation; (3) groundwater discharge to the soil zone or land surface; and (4) surface water. Inflows from precipitation and irrigation to the soil zone are restricted to pervious areas and are limited by the infiltration capacity of the soil (or for some locations exposed bedrock). There is no natural surfacewater inflow into the SRPW from surrounding areas; however, on a local scale in the SRPW, surface-water inflows can be laterally distributed by surface runoff (overland flow resulting from either high intensity rainfall or over-saturation of the soil zone) and interflow (water that infiltrates the soil zone and then flows laterally within that zone to a stream). The primary outflows from region 1 include (1) ET, (2) surface-water runoff, and (3) infiltration to the unsaturated zone.
Water in region 1 is stored on and above the land surface as retention storage and below the land surface as soil-zone storage. Retention storage includes three components:

(1) interception storage by the plant canopy, (2) pervious-area depression storage, and (3) impervious-area retention storage (Linsley and others, 1982).

\section{Region 2: Surface-Water Zone}

Streams are the main surface-water feature in region 2 of the SRPW. Three major streams drain the SRPW: (1) Mark West Creek, (2) Santa Rosa Creek, and (3) the Laguna de Santa Rosa. In the SRPW, inflows to region 2 include (1) surface runoff and interflow from region 1, (2) groundwater discharge, (3) precipitation, and (4) reclaimed municipal wastewater. Outflows include (1) surface-water discharge, (2) streambed losses (seepage), (3) evaporation, and (4) diversions. Most other surface-water features in the SRPW, such as lakes and ponds, are less than 10 acres in size (Sweetkind and others, 2013); therefore, it was assumed that these water bodies are not significant regional water sources, sinks, or storage components at the scale of the SRPW.

The primary inflow to region 2 is surface-water runoff from region 1. The surface-water runoff includes surface flow from the precipitation rate in excess of the infiltration rate of the soil that may not be saturated (Hortonian runoff) and surface flow from saturation excess in the soil zone (Dunnian runoff; Markstrom and others, 2008). A secondary source of inflow to region 2 is groundwater discharge; groundwater discharge to streams (baseflow) can be the only inflow to 
region 2 during the dry season. Precipitation and reclaimed municipal wastewater are also inflows to region 2; however, these sources are small compared with the other sources in the SRPW conceptual model. The primary outflow is stream discharge from the SRPW, either to the Russian River watershed to the north or to the Petaluma River watershed to the south (fig. 3). Secondary water outflows from region 2 are infiltration into the underlying unsaturated zone, evaporation, and local diversions of streamflow for irrigation. Storage in region 2 includes channel storage, which changes as a function of inflows and outflows to the stream network.

\section{Region 3: Subsurface Zone}

In the SRPW, the subsurface-zone conceptual model includes the unsaturated and saturated zones. The areally extensive unsaturated zone extends from the bottom of the soil zone in region 1, or the bottom of the streambed in region 2 , to the top of the saturated zone (the water table) and comprises unconsolidated materials, consolidated rock, water, and air. The saturated zone extends from the water table to the top of the low-permeability basement complex and comprises unconsolidated materials, consolidated rock, and water. The thicknesses of the unsaturated zone and saturated zone vary with movement of the water table. At some locations during relatively wet periods, the unsaturated zone can be absent if the water table intersects regions 1 or 2 , creating a groundwaterdischarge zone.

\section{Unsaturated Zone}

Inflow to the unsaturated zone can be infiltration from the overlying soil zone in region 1 , from overlying streambeds in region 2, and from septic-tank effluent. In the SRPW, infiltration from the soil zone in the $\mathrm{WG}, \mathrm{WB}, \mathrm{CB}$, and VAL storage units is the greatest in areas where coarse-grained facies of the Wilson Grove and Glen Ellen Formations are present at land surface (see fig. 1 in chapter B of Sweetkind and others, 2013). In addition, there can be more infiltration where there is more precipitation (for example, the Wilson Grove highlands). Although precipitation is relatively high in the UPL storage unit, the infiltration probably is low because the Sonoma Volcanics and basement complex are present at land surface throughout most of the storage unit. These geologic units generally have low permeabilities, and the land surface is relatively steep, which precludes high infiltration rates (Sweetkind and others, 2013). Infiltration from stream channels likely is greatest in the transition from the UPL storage unit to the WB and $\mathrm{CB}$ storage units, where streamflow is concentrated in the channel, the subsurface tends to be more permeable, and the unsaturated zone is thick. Low basin-wide nitrate concentrations indicate septic-tank effluent is not a primary component of unsaturated-zone inflow (Nishikawa and others, 2013a).
The primary outflow from the unsaturated zone is recharge to the saturated zone, which is dependent on the magnitude and distribution of vertical permeability of the deposits in the unsaturated zone. That is, if the unsaturated-zone deposits are permeable, then there is a high recharge potential. In the SRPW, the largest outflows from the unsaturated zone are in the WG storage unit, where the permeable Wilson Grove Formation is present, and in the WB and CB storage units immediately downgradient (west) of the Rodgers Creek fault zone, where coarse-grained deposits are present along the channels. By contrast, outflows from the unsaturated zone are least in the western parts of the WB and CB storage units because the unsaturated zone is dominated by a fine-grained facies of the Glen Ellen Formation.

Storage in the unsaturated part of region 3 is dependent on properties that determine vertical movement of infiltrating water from regions 1 and 2, and it varies as a function of the elevation of the water table and climate.

\section{Saturated Zone}

Important hydrologic characteristics of the saturated zone of the SRPW groundwater-flow system include those that reflect the ability of the groundwater system to transmit and store (uptake and release) water; those that allow for vertical passage of water between stratigraphic units; and those that control the flow of water across geologic structures or hydrologic boundaries. The movement of water through the saturated groundwater system is controlled by aquifer-system geometry, aquifer and aquitard properties, geologic structures, and the magnitude and distribution of recharge and discharge, including pumping. Aquifer and aquitard properties include hydraulic conductivity and storativity, which principally depend on the type and characteristics of sediments and rocks constituting the matrix of the aquifer system. Geologic structures, such as fault planes or zones, can be either flow barriers or flow conduits, depending on age, orientation, mineralization along the fault, and the juxtaposition of aquifers and aquitards across the fault.

Inflows to the saturated zone of region 3 include groundwater recharge from the unsaturated zone and groundwater boundary flow from adjacent groundwater basins. Outflows from the saturated zone include groundwater ET in riparian areas; discharge to streams; discharge to the soil zone or land surface, where groundwater levels are sufficiently high in the extra-channel areas; pumping; and underflow to adjacent basins. Groundwater stored in the saturated part of region 3 is dependent on aquifer and aquitard properties and changes as a function of recharge and discharge. 


\section{Method Used to Simulate Groundwater and Surface-Water Resources}

The SRPHM is based on the USGS model GSFLOW (Markstrom and others, 2008). There are two components to GSFLOW: a watershed-component model and a groundwatercomponent model. The watershed-component model uses the Precipitation Runoff Modeling System (PRMS; Leavesley and others, 1983, 2005), and the groundwater-component model uses the Modular Groundwater Flow Model MODFLOWNWT (MF-NWT; Niswonger and others, 2011). Development of a calibrated, coupled groundwater and surface-water flow model allows for analysis of the movement of water through the aquifer system underlying the SRPW and the simulated effects of hydrologic stresses or potential stresses on the groundwater and surface-water systems. The USGS coupled groundwater and surface-water model GSFLOW (Markstrom and others, 2008) was used to provide water budgets; to investigate the stream and aquifer interactions; and to simulate the effects of current hydrologic stresses, potential climate change, and projected groundwater pumping stresses on the hydrologic system.

The model constructed by using GSFLOW is a transient model that simulates hydrologic conditions for the period of October 1975 through September 2010 (water years 1975-2010). A decoupled PRMS-only model for water years 1950-74 was run to a provide preliminary calibration of watershed parameters and to provide net-infiltration and residual potential-evapotranspiration rates for a decoupled MF-NWT-only steady-state model. The MF-NWT-only steady-state model provided preliminary calibration of aquifer properties and starting hydraulic heads for the transient model.

\section{References Cited}

Cal-Atlas, 2007, CalWater version 2.2.1-InlandWaters: Sacramento, Calif., State of California Geoportal, accessed September 7, 2007, http://atlas.ca.gov/download.html\#/ casil/inlandWaters.

California Department of Finance, 2012, Population totals by township and place for California Counties: 1860 to 1950: Sacramento, Calif., California Department of Finance, accessed October 18, 2012, http://www.dof.ca.gov/research/ demographic/reports.

California Department of Water Resources, 1974, 1974 Sonoma County land use survey data: unpublished data located at Division of Integrated Regional Water Management, North-Central Region, West Sacramento, California, 1:24,000 scale.
California Department of Water Resources, 1979, 1979 Sonoma County land use survey data: unpublished data located at Division of Integrated Regional Water Management, North-Central Region, West Sacramento, California, 1:24,000 scale.

California Department of Water Resources, 1980, Groundwater basins in California-A report to the Legislature in Response to Water Code Section 12924: Sacramento, Calif., California Department of Water Resources, accessed April 26, 2013, http://www.water.ca.gov/groundwater/bulletin118/ north_coast.cfm.

California Department of Water Resources, 1986, 1986 Sonoma County land use survey data: unpublished data located at Division of Integrated Regional Water Management, North-Central Region, West Sacramento, California, $1: 24,000$ scale.

California Department of Water Resources, 1999, 1999 Sonoma County land use survey data: Sacramento, Calif., California Department of Water Resources, digital map accessed January 28, 2011, http://www.water.ca.gov/ landwateruse/lusrvymain.cfm.

California Department of Water Resources, 2003, California's groundwater: Bulletin 118-Update 2003: Sacramento, Calif., California Department of Water Resources, 246 p., http://www.water.ca.gov/groundwater/bulletin118/ update2003.cfm.

California Geological Survey, 2002, California geomorphic provinces - Note 36: Sacramento, Calif., California Geological Survey, accessed November 16, 2011, http:// www.consrv.ca.gov/cgs/information/publications/cgs_notes/ note_36/Documents/note_36.pdf.

Cardwell, G.T., 1958, Geology and ground water in the Santa Rosa and Petaluma areas, Sonoma County, California: U.S. Geological Survey Water Supply Paper 1427, 273 p., 5 plates.

City of Rohnert Park, 2007, 2005 Urban Water Management Plan: Rohnert Park, Calif., City of Rohnert Park, 108 p., http://www.rpcity.org/index.aspx?page $=416$.

Ford, R.S., 1975, Geologic and hydrologic data, vol. 1 in Bulletin 118-4. Evaluation of ground water resources: Sonoma County: Sacramento, Calif., California Department of Water Resources, 177 p., 1 plate.

Herbst, C.M., Jacinto, D.M., and McGuire, R.A., Santa Rosa plain 1982, vol. 2 in Bulletin 118-4. Evaluation of ground water resources: Sonoma County: Sacramento, Calif., California Department of Water Resources, 107 p., 1 plate. 
Jenkins, O.P., 1938, Geomorphic map of California: Sacramento, Calif., State of California Department of Natural Resources, California Division of Mines and Geology, Bulletin 158, Plate 2.

Kadir, T.N., and McGuire, R.A., 1987, Santa Rosa plain ground water model: Sacramento, Calif., California Department of Water Resources Central District, 318 p.

Leavesley, G.H., Lichty, R.W., Troutman, B.M., and Saindon, L.G., 1983, Precipitation-runoff modeling system-User's manual: U.S. Geological Survey Water-Resources Investigations Report 83-4238, 207 p.

Leavesley, G.H., Markstrom, S.L., Viger, R.J., and Hay, L.E., 2005, U.S. Geological Survey modular modeling system (MMS)_-Precipitation-runoff modeling system (PRMS) MMS-PRMS, in Singh, V.P., and Frevert, D.K., eds., Watershed models: Boca Raton, Fla., CRC Press, P. 159-177.

Linsley, R.K., Kohler, M.A., and Paulhus, J.L.H., 1982, Hydrology for engineers: New York, McGraw-Hill, 508 p.

Markstrom, S.L., Niswonger, R.L., Regan, R.S., Prudic, D.E., and Barlow, P.A., 2008, GSFLOW-coupled groundwater and surface-water FLOW model based on the integration of the precipitation-runoff modeling system (PRMS) and the modular groundwater flow model (MODFLOW-2005): U.S. Geological Survey Techniques and Methods 6-D1, 240 p.

Martin, Peter, Metzger, L.F., Densmore, J.N., and Schroeder, R.A., 2013, Groundwater quality and source and age of groundwater in the Santa Rosa Plain watershed, Sonoma County, California, chap. C of Nishikawa, Tracy, ed., Hydrologic and geochemical characterization of the Santa Rosa Plain watershed, Sonoma County, California: U.S. Geological Survey Scientific Investigations Report 20135118, p. 113-166.

Nishikawa, Tracy, ed., 2013, Hydrologic and geochemical characterization of the Santa Rosa Plain watershed, Sonoma County, California: U.S. Geological Survey Scientific Investigations Report 2013-5118, 178 p.

Nishikawa, Tracy, Hevesi, J.A., Sweetkind, D.S., and Martin, Peter, 2013a, Conceptual model of Santa Rosa Plain watershed hydrologic system, chap. D of Nishikawa, Tracy, ed., Hydrologic and geochemical characterization of the Santa Rosa Plain watershed, Sonoma County, California: U.S. Geological Survey Scientific Investigations Report 2013-5118, p. 167-177.
Nishikawa, Tracy, Hevesi, J.A., Sweetkind, D.S., and Woolfenden, L.R., 2013b, Introduction to the study area, chap. A of Nishikawa, Tracy, ed., Hydrologic and geochemical characterization of the Santa Rosa Plain watershed, Sonoma County, California: U.S. Geological Survey Scientific Investigations Report 2013-5118, p. 7-26.

Niswonger, R.G., Panday, Sorab, and Ibaraki, Motomu, 2011, MODFLOW-NWT, A Newton formulation for MODFLOW-2005: U.S. Geological Survey Techniques and Methods 6-A37, 44 p.

Sloop, Christina; Honton, Joseph; Creager, Clayton; Chen, Limin; Andrews, E.S.; and Bozkurt, Setenay, 2009, Hydrology and sedimentation, chap. 4, of The altered laguna: A conceptual model of watershed stewardship: Santa Rosa, Calif., Laguna de Santa Rosa Foundation, p. 63-110, http:// www.lagunafoundation.org/knowledgebase/?q=node/182.

Sonoma County Water Agency, 2006, 2005 Urban Water Management Plan: Santa Rosa, Calif., Sonoma County Water Agency, 152 p., http://scwatercoalition.org/images/ pdf/2005_uwmp_report.pdf.

Sonoma County Water Agency, 2012, Sonoma County water agency home page: Santa Rosa, Calif., Sonoma County Water Agency, accessed October 16, 2012, at http://www. scwa.ca.gov/index.php.

Sowers, J.M., Noller, J.S., and Lettis, W.R., 1998, Quaternary geology and liquefaction susceptibility, Napa, California 1:100,000 quadrangle; a digital database: U.S. Geological Survey Open-File Report 98-460, 20 p., 1 sheet, scale $1: 100,000$.

Sweetkind, D.S., Hevesi, J.A., Nishikawa, Tracy, Martin, Peter, and Farrar, C.D., 2013, Hydrology of the Santa Rosa Plain watershed, Sonoma County, California, chap. B of Nishikawa, Tracy, ed., Hydrologic and geochemical characterization of the Santa Rosa Plain watershed, Sonoma County, California: U.S. Geological Survey Scientific Investigations Report 2013-5118, p. 27-112.

U.S. Census Bureau, 2013, 2010 population finder: Suitland, Md., U.S. Census Bureau, accessed on November 16, 2013, at http://www.census.gov/popfinder $/ ?$ s $=06$. 


\section{Chapter B. Watershed- Component Model}

\author{
By Joseph A. Hevesi
}

\section{Introduction}

The coupled groundwater and surface-water flow model (GSFLOW) version used to develop the Santa Rosa Plain hydrologic model (SRPHM) consists of two integrated model components: (1) a watershed-component model developed using the Precipitation Runoff Modeling System (PRMS; Leavesley and others, 1983, 2005), and (2) a groundwatercomponent model developed using the Modular GroundwaterFlow Model MODFLOW-NWT (MF-NWT; Niswonger and others, 2011). The watershed-component model simulates the hydrology of the land surface, vegetation, snow cover, and the soil zone. The groundwater-component model simulates the groundwater hydrology of the subsurface underlying the soil zone and the surface-water hydrology of the streams represented in the model. This chapter describes the watershedcomponent model. A detailed discussion of the groundwatercomponent model is provided in chapter $C$ of this report.

Following Markstrom and others (2008), Nishikawa and others (2013) conceptualized the hydrologic system of the SRPW as having three regions: region 1 consists of the plant canopy, surface-depression storage, and the soil zone; region 2 consists of streams; and region 3 is the subsurface that consists of an unsaturated zone (UZ) and an underlying saturated zone (chapter A, fig. 8). The watershed-component model is based on the conceptualization of region 1 . Flow processes in the watershed-component model are simulated by using a defined drainage network where water is routed laterally across the model domain from land areas directly to stream channels (or lakes, when included) or from upstream land areas to adjacent downstream land areas by using cascades. Cascading flow between adjacent land areas can be used to route both surface and subsurface flow across the land areas to better account for (1) complex flow paths, (2) the re-infiltration of surface runoff, and (3) the time delay of subsurface flows. The stream channels are divided into segments to represent changing stream channel characteristics and tributary networks. Streamflow is simulated in PRMS as one-dimensional channelized flow from upstream to downstream stream segments. The watershedcomponent model is discretized horizontally to define the stream channel and cascade drainage network and to represent land areas with consistent hydrologic properties.

A watershed is conceptualized as an interconnected series of reservoirs with collective output and interaction that produces the total hydrologic response. These reservoirs include interception storage in the vegetation canopy, storage in the soil zone (soil-zone reservoir), subsurface storage between the surface of a watershed and the water table (subsurface reservoir, or SSR), and groundwater storage (groundwater reservoir, or GWR). Water that infiltrates into the soil-zone reservoir above field capacity is distributed to the SSR and GWR. Water stored in the SSR is available for gravity drainage to the GWR and for interflow to a stream or lake. Water stored in the GWR is available for baseflow during PRMS-only simulations. During coupled GSFLOW simulations, the GWR is replaced by MF-NWT. For additional information regarding the representation of watershed hydrologic processes by GSFLOW, see Markstrom and others (2008).

This chapter describes the development of the watershedcomponent model that uses PRMS. Development of the watershed-component model includes defining the model layout and discretization, the input parameters used to represent the physical characteristics of the model area, and the daily climate inputs for the transient simulation period (water years 1975-2010). The watershed-component model is calibrated in decoupled PRMS-only mode to develop (1) preliminary estimates of watershed-component model parameters for the coupled GSFLOW simulation; (2) estimates of long-term potential evapotranspiration (PET) and recharge rates used as inputs for the steady-state MF-NWT simulation; and (3) estimates of agricultural irrigation used to define agricultural pumping for GSFLOW simulations, as described in Appendix 1.

\section{Watershed-Component Model (PRMS) Layout and Discretization}

The primary model element used in PRMS discretization is the hydrologic response unit (HRU; Leavesly and others, 1983). Each HRU is used to represent areas with consistent hydrologic properties. Associated with each HRU is an SSR and a GWR, both underlying the HRU. By definition, the HRU and SSR must have the same discretization. The GWR discretization can match the HRU discretization, or a separate discretization can be defined for GWRs. The GWR component of the PRMS model setup is used only with decoupled PRMS-only simulations. As mentioned in the "Introduction," for coupled GSFLOW simulations, the GWR is replaced by MF-NWT.

For this study, the HRU discretization of the watershedcomponent model was done by using a "gridded" approach that has been applied in previous GSFLOW studies (for example, Ely and Kahle, 2012). In the gridded approach, the HRU (and by definition, the SSR) and GWR geometries are matched to the horizontal (map-view) grid-cell geometry of the underlying groundwater-component model, which for the version of GSFLOW used in this study must be defined as a regular grid of rectangular cells.

With GSFLOW, the coupling of the PRMS and MF-NWT models is done by using gravity reservoirs (GVRs; Markstrom and others, 2008), which replace the SSR in PRMS-only 
simulations. The GVRs are defined by the intersection of the HRU and the underlying MF-NWT cell, and are used to provide gravity drainage from the soil zone simulated by PRMS to the unsaturated zone simulated by MF-NWT (Markstrom and others, 2008).

The gridded HRU approach has two advantages for model setup and application. First, the large number of HRUs allows for increased detail and spatial resolution in representing the spatial variability of both climate and watershed characteristics across the model domain. The increased spatial resolution can be important in larger study areas, such as the Santa Rosa Plain watershed (SRPW), with variations in climate, topography, land use, soils, vegetation, and geology. Second, the gridded HRU approach simplifies the coupling of the watershed-component and groundwater-component models used for GSFLOW simulations. When the gridded approach is used for the HRU layout, the two-dimensional horizontal geometries of the HRUs, GVRs, and MF-NWT cells are all identical, thereby minimizing the number of GVRs and simplifying the GVR discretization. With the simplified GVR discretization, the potential for small errors in the simulated water balances between the watershed-component and groundwatercomponent models, which can sometimes arise as a result of complex and very small GVR polygons, is avoided.

A disadvantage of the gridded HRU discretization is that the boundaries and areas of complex hydrographic features sometimes are not accurately represented on the local scale. For example, the areas of narrow riparian zones for smaller channels or the areas of local-scale subdrainages are potentially not accurately defined by using rectangular HRU boundaries, particularly if the size of the hydrographic feature is small relative to the size of the HRUs. In the SRPHM domain, however, the boundaries and areas of hydrographic features, such as subdrainage areas, drainage divides, and riparian zones, are generally well represented by using the gridded HRU approach. The gridded approach also tends to result in a relatively high number of HRUs, SSRs, and GWRs compared with non-gridded approaches.

\section{Hydrologic Response Unit and Groundwater Reservoir Discretization}

The discretization of HRUs and GWRs consists of defining the geometries and routing connections for the network of HRUs and GWRs. For the watershed-component model, the HRU flow-routing connections were identical to the GWR flow-routing connections. The HRU geometry (and thus, the map-view geometry of the underlying MF-NWT cells) was defined as a 660 -ft by $660-\mathrm{ft}$ (10-acre) grid (fig. 1). The regular grid of 10-acre cells covering the area of the SRPW consists of 168 rows in the north-south direction and 157 columns in the east-west direction with 16,741 active cells.

\section{Cascades}

The 16,741 grid cells defining the HRUs, SSRs, and GWRs within the SRPW were connected by using a flowrouting network defined by a combination of cascades and stream segments (fig. 2). Cascades are used to route surface runoff and interflow from upslope HRUs to downslope HRUs (Markstrom and others, 2008). The combined cascade- and stream-segment flow-routing network was developed using a two-step procedure: (1) define an all-cascade routing network for all grid cells, and (2) superimpose a stream-segment routing network onto the cascade flow-routing network. The cascade flow-routing network was defined by using an eightdirectional many-to-one convergent-flow method (also known as the D8 algorithm), where any given cell was allowed inflows from up to seven adjacent upstream cells and allowed outflows to only one adjacent downstream cell (O'Callaghan and Mark, 1984). Internal sinks, where outflows are only net infiltration and evapotranspiration (ET), do not occur in the SRPW. The cascade flow-routing network routes surface water to 10 points of outflow on the boundary of the SRPHM.

The initial drainage network was determined by using a 10-meter (m) digital elevation model (DEM; U.S. Geological Survey, 2001), mapped subdrainages (Cal-Atlas, 2007), and flowlines as defined by the USGS National Hydrography Dataset (NHD; U.S. Geological Survey, 2001) with the D8 algorithm. Downstream HRUs were identified on the basis of the direction of the steepest downstream gradient calculated from the DEM.

The main outflow location of the watershed-component model for the cascade flow-routing network is the grid cell (row 60, column 1) defining the juncture of Mark West Creek with the Russian River (fig. 2). The number of upstream grid cells at this outflow cell is 16,287 , composing a drainage area of 162,870 acres, or about 255 square miles $\left(\mathrm{mi}^{2}\right)$. Nine additional outflow cells were defined for relatively small drainages outside of the Mark West Creek drainage basin. These smaller drainages are located along the northwestern and southern boundaries of the SRPW (fig. 3).

The cascade flow-routing network defines the three main stream channels in the SRPW as having approximately 1,000 or more upstream cells in the network: the Mark West Creek channel in the northern section, the Santa Rosa Creek channel in the central section, and the Laguna de Santa Rosa channel in the southern section (fig. 2). Smaller tributaries, such as Windsor Creek, Colgan Creek, and Copeland Creek, are defined by approximately 500 or more upstream cells. 


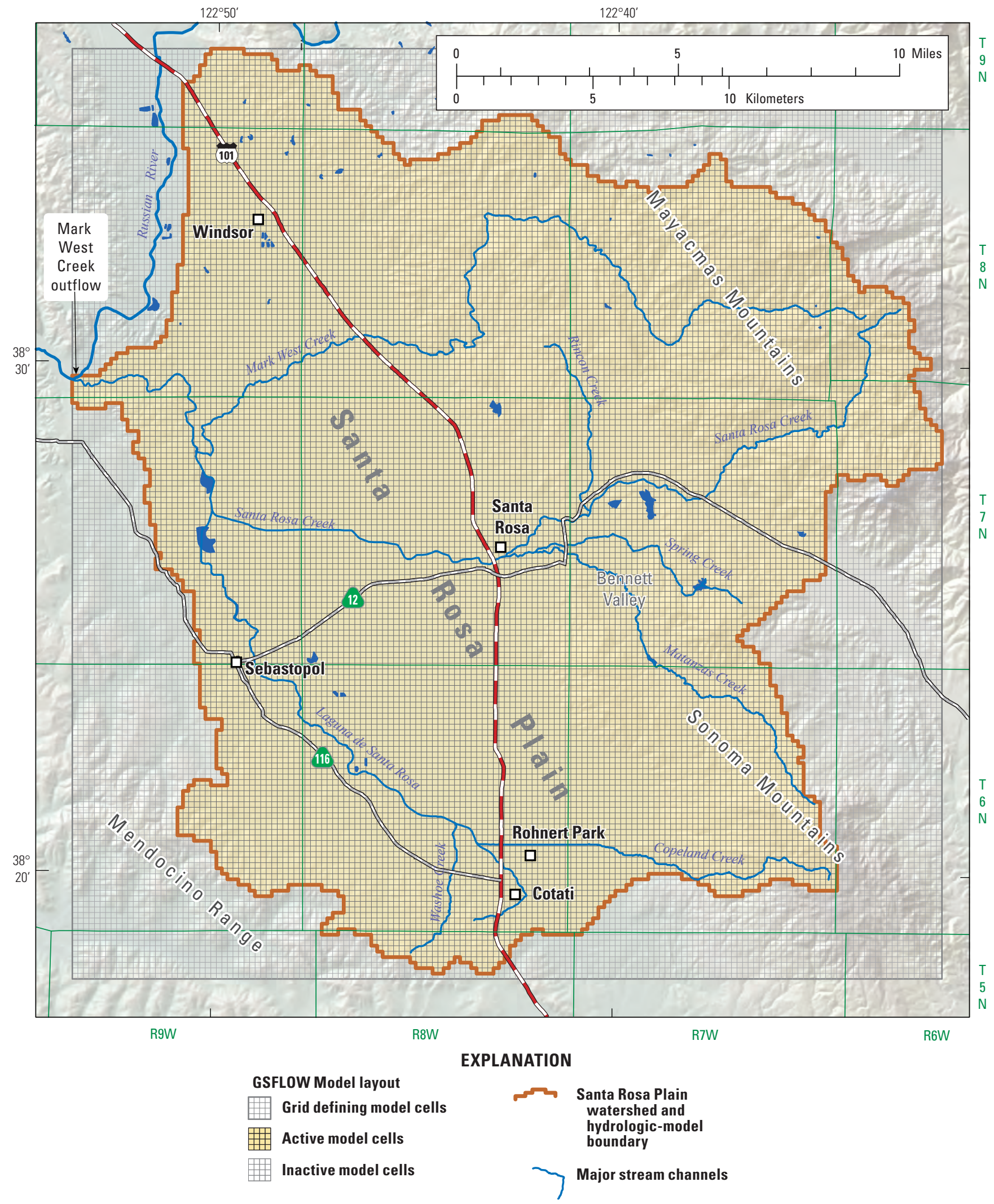

Figure 1. Model grid, active cells, and inactive cells for the watershed component of the Santa Rosa Plain hydrologic model, Santa Rosa Plain watershed, Sonoma County, California. 


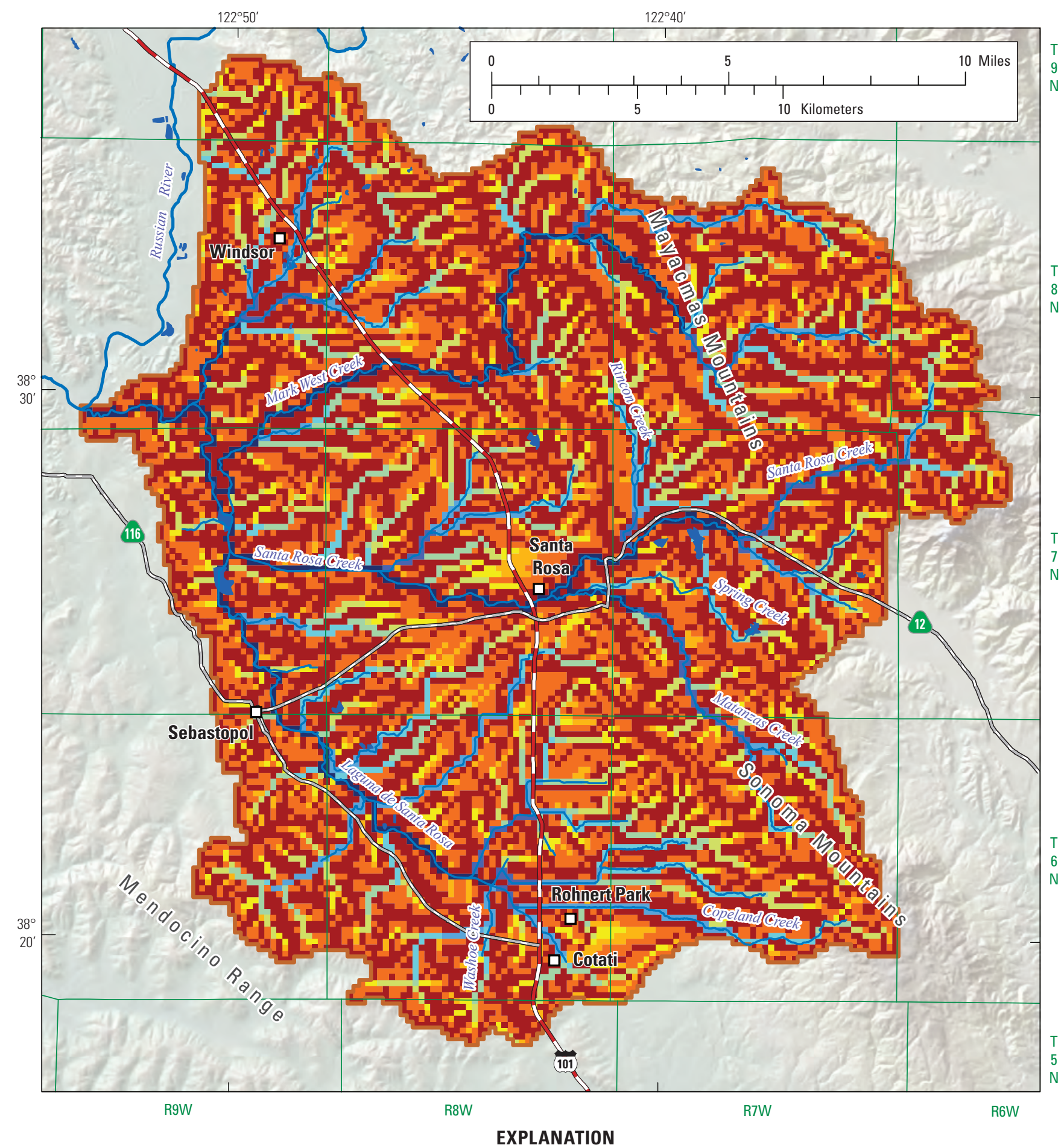

Flow accumulation (number of upstream grid cells)

\begin{tabular}{|c|c|c|c|c|}
\hline 0 & 11 to 20 & 101 to 200 & محم & Santa Rosa Plain \\
\hline 1 to 5 & 21 to 50 & 201 to 500 & & hydrologic-model \\
\hline 6 to 10 & 51 to 100 & 501 to 1,000 & & boundary \\
\hline
\end{tabular}

Figure 2. Cascade flow-routing network for the watershed-component model, Santa Rosa Plain watershed, Sonoma County, California. 

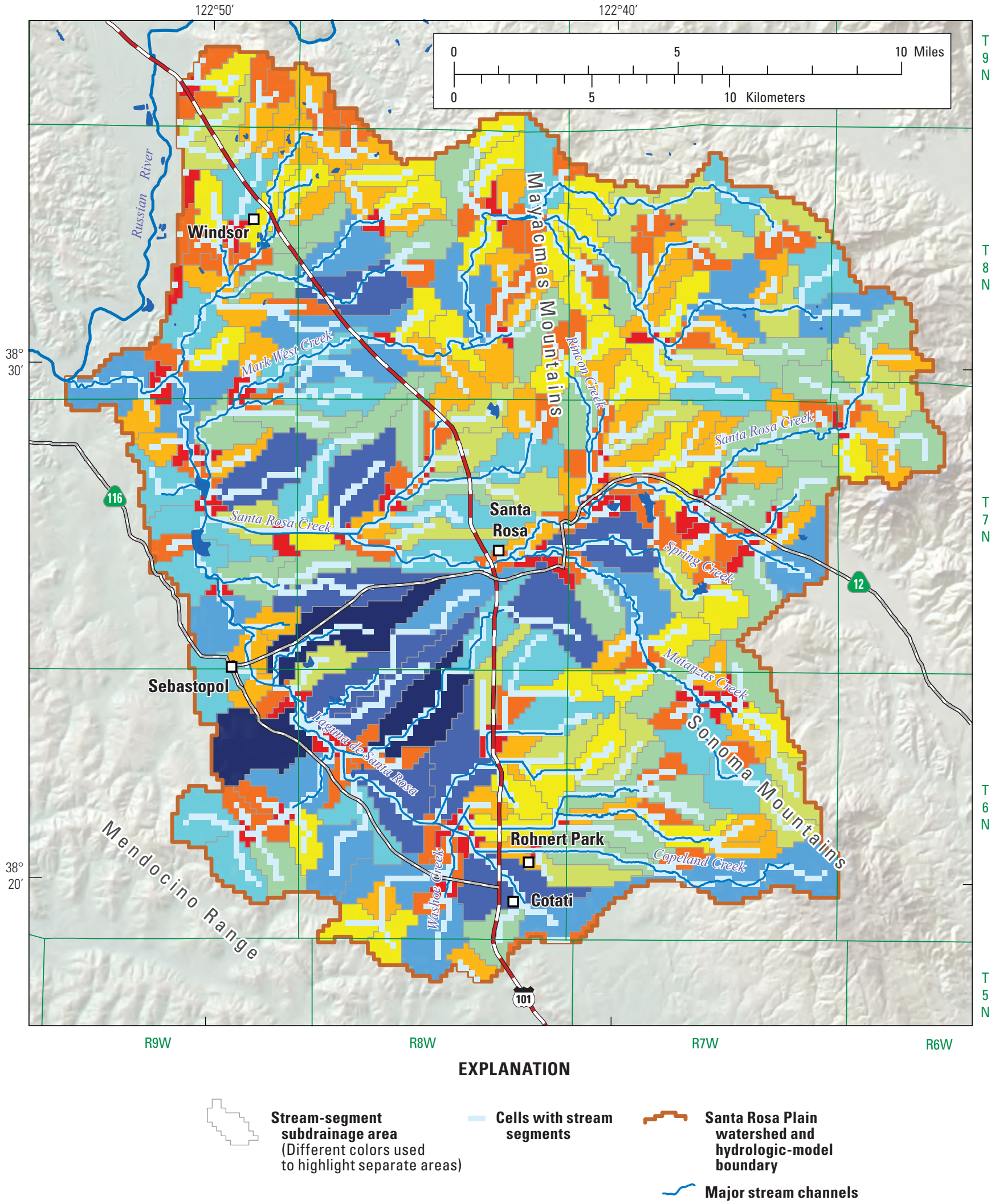

Figure 3. Stream segments and cascading-flow subdrainage areas contributing to each stream segment of the watershed-component model, Santa Rosa Plain watershed, Sonoma County, California. 


\section{Stream Segments}

Stream segments were used to represent the mapped channel features identified as "flowlines" in the NHD (Simley and Carswell, 2009). The NHD flowlines represent intermittent and perennial streams. For the watershed-component model of GSFLOW, stream segments are simple storage compartments that collect runoff from HRUs, interflow from SSRs, and baseflow from GWRs. In PRMS-only simulations, outflow from stream segments is routed as one-dimensional channelized surface-water flow to downstream stream segments and, ultimately, as surface-water discharge from the model domain. For the groundwater-component model of GSFLOW, stream segments are defined in greater detail by using stream reaches and are modeled by using the Streamflow Routing (SFR) package of MF-NWT. A more detailed description of the SFR package, the model inputs used for the SRPW, and the simulation of streamflow by using GSFLOW is provided in the section of this report describing the groundwatercomponent model (chapter C).

Stream segments were initially defined by using a minimum contributing area of 50 cells on the basis of trialand-error, as defined by the cascade flow-routing network at the beginning of streams. The initial configuration provided a good overall match to the location of first-order streams (Chow and others, 1988) indicated by the NHD data. The initial configuration was modified such that only the more prominent first-order streams, identified on the basis of named stream channels (Sonoma County Water Agency, written commun., 2009) were represented as stream segments in the model. The discretization of downstream stream segments was defined on the basis of tributary junctions, with the junctions defining the stream segment endpoints, and then further discretized on the basis of stream-channel characteristics between tributary junctions, the distance between tributary junctions, and the location of streamgages used for model calibration. Stream segments were defined so that streamgages were located at the end of each segment. The criteria prevented duplication of stream channels and homogeneity of streamchannel characteristics. The final layout consists of 324 stream segments and corresponding subdrainage areas (fig. 3). The subdrainage areas define the subset of cells contributing inflow to a given stream segment by cascading flow. The number of cells in the subdrainages varies from 4 to 210 , with the largest subdrainages defining tributaries to the central part of the Laguna de Santa Rosa. The smaller subdrainages generally occur where tributary junctions are close.

\section{Climate Input}

The watershed-model component requires daily precipitation and maximum and minimum daily air temperature input for the duration of the simulation period. Daily precipitation is the primary source of water inflow to the SRPHM and, therefore, is one of the most critical inputs for the transient PRMS and GSFLOW simulations. Daily maximum and minimum air temperature are used by PRMS to define the type of precipitation (rain, snow, or mixed) and when snow melts. Daily air temperature data are also used by PRMS to simulate PET.

For the SRPW and surrounding area, daily-climate records are available from a variety of sources: the California Data Exchange Center (2011), the National Climate Data Center (EarthInfo, Inc., 2011), the Remote Automated Weather System (2011), and the California Irrigation Management Information System (2005). For this study, daily climate records were obtained for eight climate stations in the SRPW (shown in table 1; the locations are shown in fig. 4). For the objectives of the watershed-component model, these available records were considered to be inadequate for representing climate conditions for all periods of interest at all locations in the SRPW because many of the records contain periods of missing data (data gaps), most of the records are relatively short (less than 20 years), and most of the stations are in the lowlands, providing a poor representation of climate at the higher elevations.

To resolve data gaps and account for spatial variability, a spatial-interpolation method, described by Hevesi and others (2011), was applied to estimate the spatial distribution of daily climate inputs over the model domain. The method requires the preprocessing of the climate data to develop spatially distributed daily climate inputs as unique time series for each HRU. In the preprocessing procedure, the daily time series of precipitation, maximum air temperature, and minimum air temperature are estimated for each HRU by using available climate records and a modified inverse-distance squared interpolation. The method incorporates average monthly results from the Parameter-Regression on Independent Slopes Model (PRISM; Daly and others, 2004). Following Hevesi and others (2011), the 1971-2000 average (30-year normal) monthly PRISM estimates were used to adjust the inversedistance-squared weighting factors by the ratio (in the case of precipitation) or difference (in the case of air temperature) in the monthly PRISM values between the HRU and the climate station.

This methodology was used to estimate daily climate data for water years 1948-2010, assuming that the ratios and differences identified from the 1971-2000 data were valid for 1948-1970 and 2001-2010. The daily climate data were estimated for water years 1948-2010 for calibration purposes, which is described in chapter $D$. 


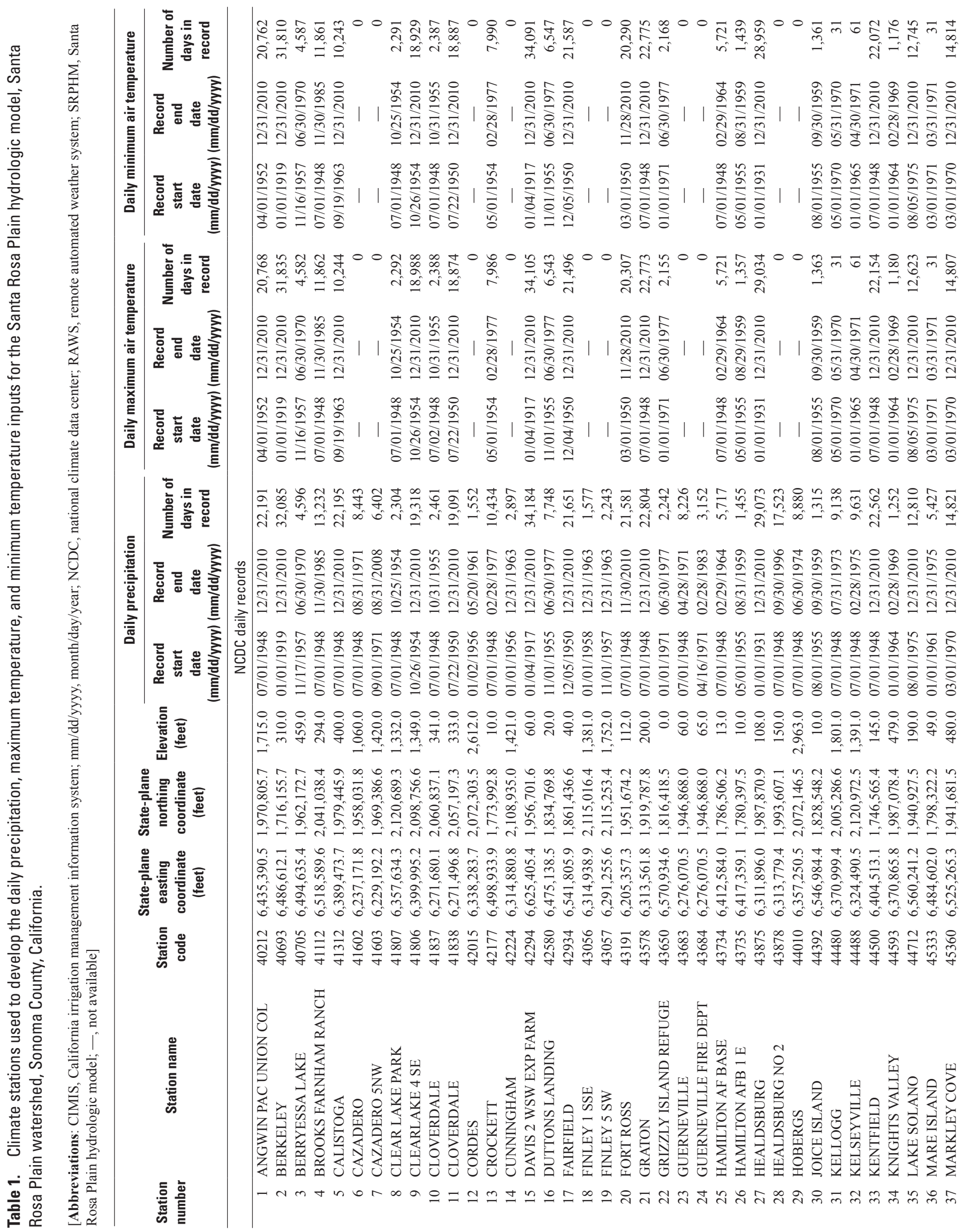




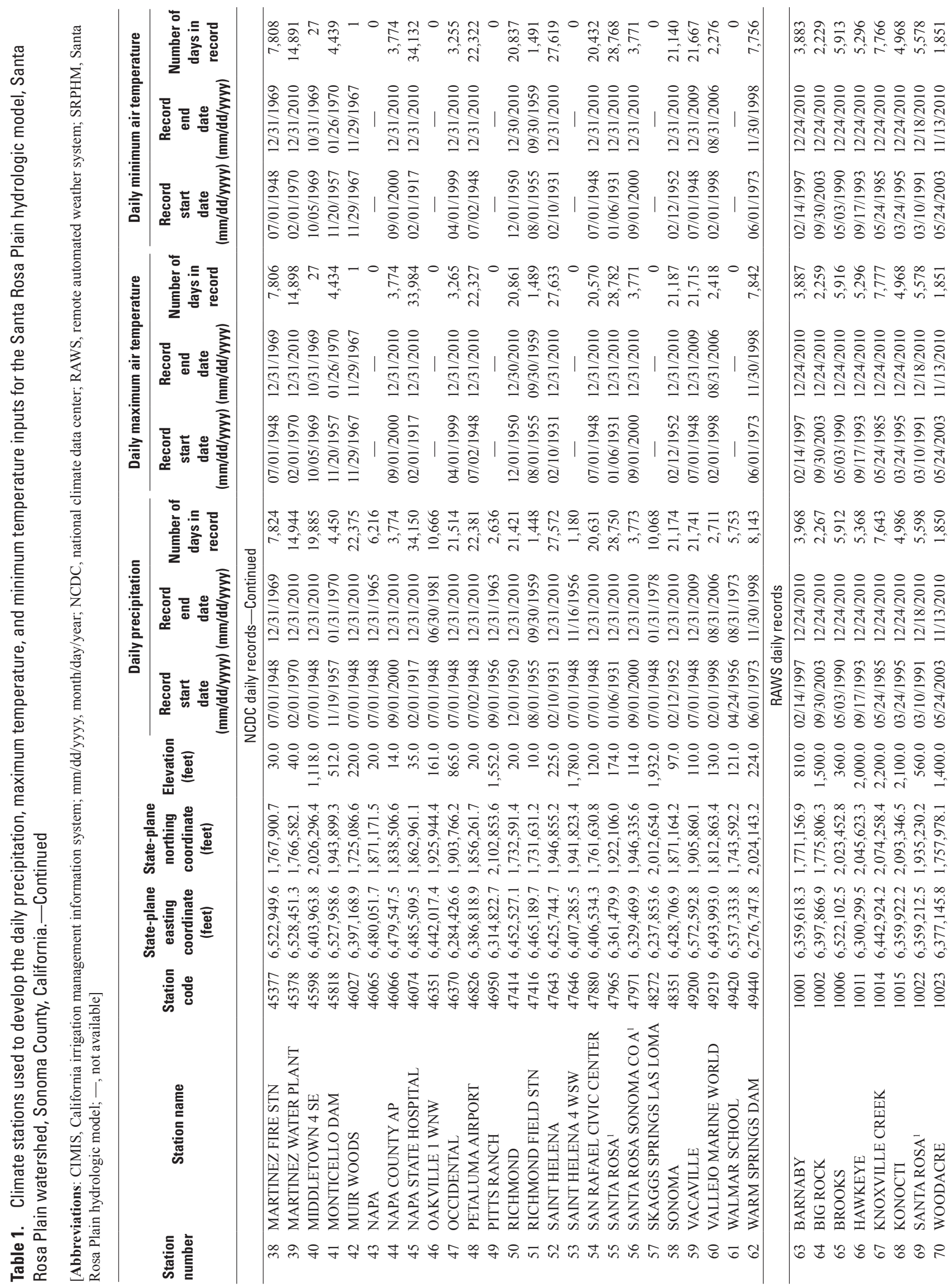




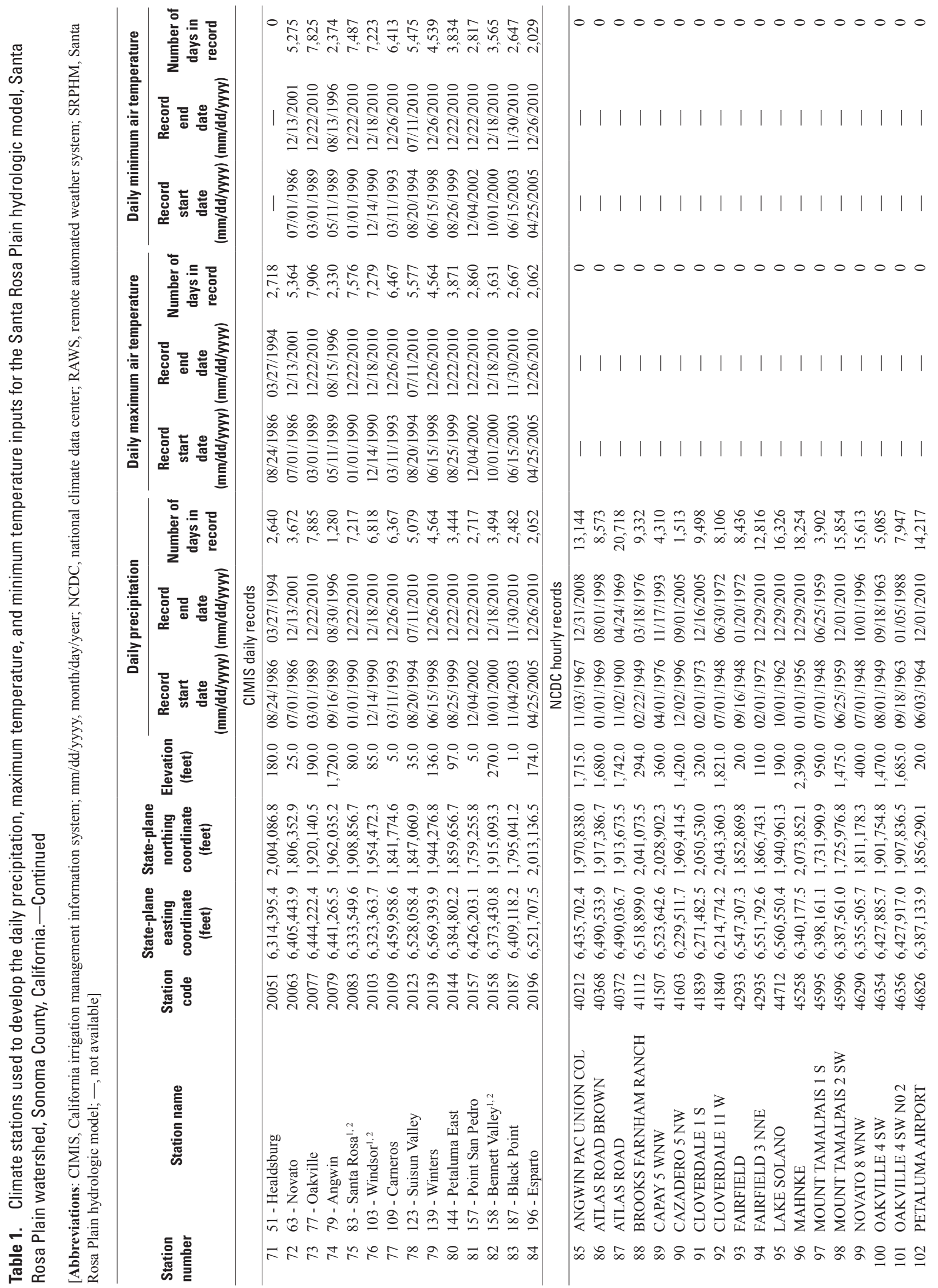




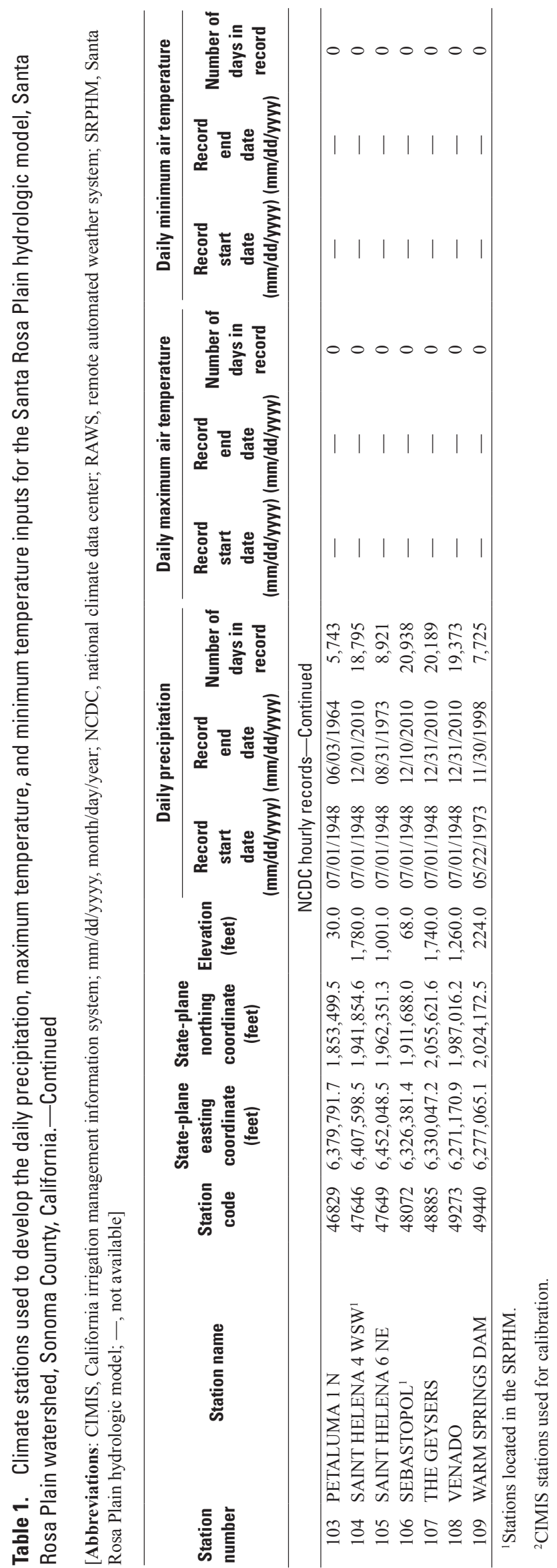




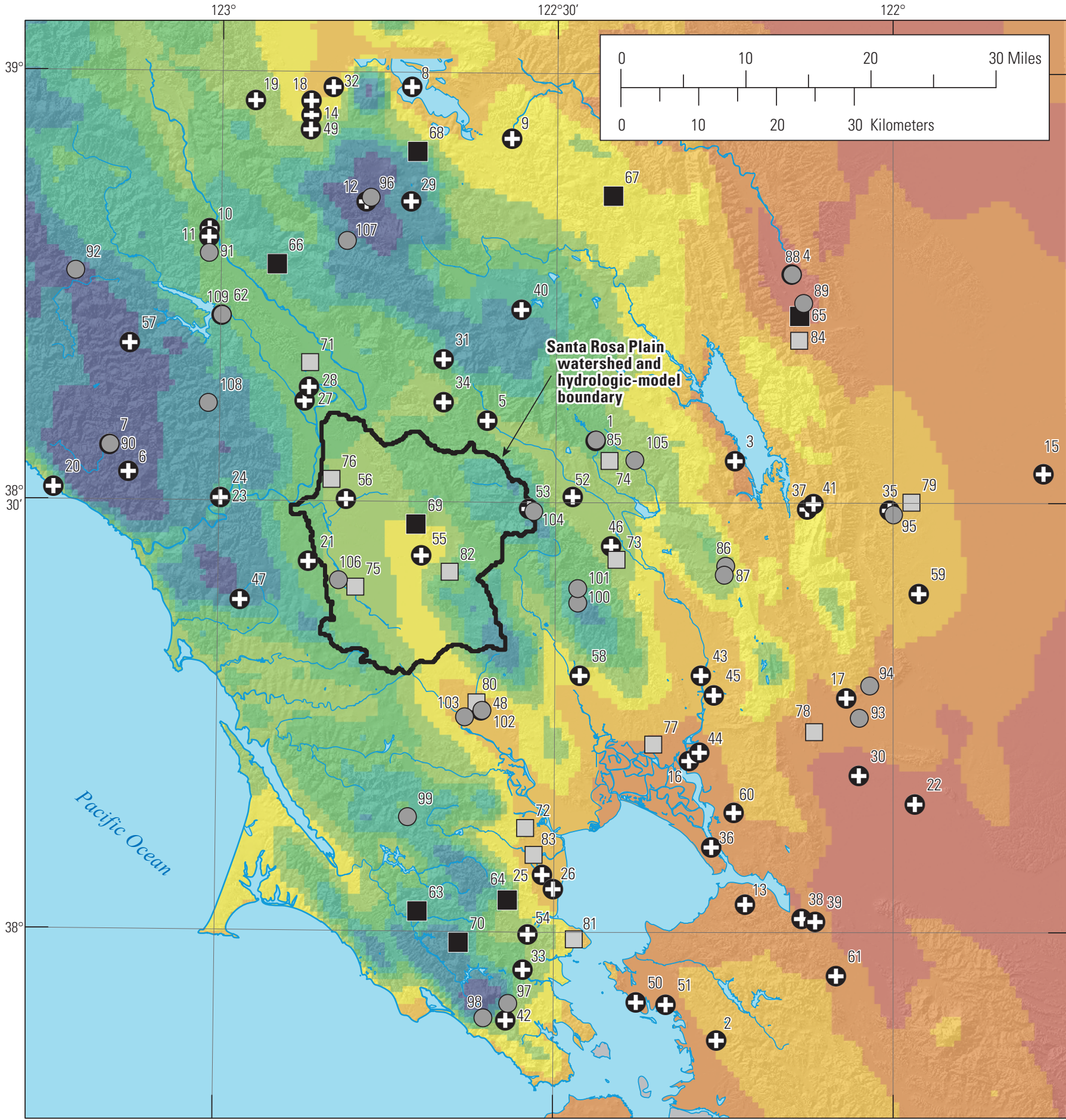

\section{EXPLANATION}

PRISM average January precipitation, in inches

\begin{tabular}{|r|r|r|}
\hline 2.65 to 4 & 6.01 to 7 & 9.01 to 10 \\
\hline 4.01 to 5 & 7.01 to 8 & 10.1 to 12 \\
\hline 5.01 to 6 & 8.01 to 9 & 12.1 to 16.2 \\
\hline
\end{tabular}

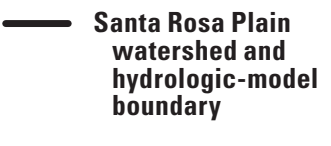

\section{Climate stations}

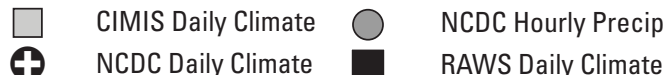

CIMIS is California Irrigation Management Information System; NCDC is National Climate Data Center; RAWS is Remote Automated Weather System

Figure 4. Location of climate stations used to develop daily precipitation, maximum temperature, and minimum temperature inputs, and PRISM 1971-2000 average precipitation for January, Santa Rosa Plain hydrologic model, Santa Rosa Plain watershed, Sonoma County, California. 


\section{Daily Climate Records}

Daily climate records from a regionally distributed network of 109 climate stations (fig. 4; table 1) centered on the SRPW were used to develop the spatially interpolated climate inputs. Data gaps in this early record are prevalent. There are fewer air-temperature records than precipitation records because many of the stations have records for precipitation only. All available records for each station were used to develop the climate inputs for the SRPHM.

\section{Average Monthly PRISM Data}

To develop the climate inputs needed for the watershedcomponent model and SRPHM, the 1971-2000, 30-year, normal monthly PRISM precipitation and maximum and minimum air temperature estimates were used (table 2; Linsley and others, 1982; Daly and others, 2004). The spatial resolution of the PRISM data is $800-\mathrm{m}$; therefore, the climate station was assigned the monthly values associated with PRISM grid cell in which it was located. PRISM data were mapped to the centroids of the 16,741 HRUs without alteration. The daily climate data for each HRU were estimated, as described previously, by using a combination of measured daily data, PRISM data mapped to the climate station, and PRISM data mapped to the HRU.

The average monthly precipitation, including the basinwide average and the maximum and minimum average monthly precipitation for water years 1971-2000, indicates a pronounced seasonal variability for precipitation (fig. 5) as well as considerable spatial variability of precipitation for the SRPW (figs. 4, 6, 7). Average January precipitation, maximum daily air temperature, and minimum daily air temperature for 1971-2000 are examples of estimates made by PRISM. The PRISM maps indicate the spatial variability of climate on the regional scale and in the SRPW.

\section{Spatially Interpolated Climate Inputs}

Analysis of the records for the 109 stations indicated that the earliest starting date for generating a continuous daily climate (precipitation and air temperature) input through September 30, 2010 (end of water year 2010), is October 1, 1917 (beginning of water year 1918). In general, greater uncertainty is associated with the spatially interpolated climate input for the period prior to water year 1948 because of (1) the relatively small number of available climate records prior to water year 1948 (fewer than 10 records per year) and (2) the absence of daily records of both precipitation and air temperature for any of the climate stations in the SRPW prior to water year 1948.
For some locations in the SRPW, reclaimed wastewater is used for irrigation and is incorporated into the spatially distributed, daily precipitation input for those HRUs. Monthly records for reclaimed wastewater, starting in water year 1990, were provided by the town of Windsor and the city of Santa Rosa. The reclaimed wastewater was distributed to approximately 200 land parcels in the vicinity of the town of Windsor and throughout areas of the Laguna de Santa Rosa (fig. 8). The average rate of reclaimed-wastewater application varied monthly, from zero during the winter to a maximum of about 3,000 acre-ft during the spring and summer months (fig. 9A). The annual volume of applied reclaimed water reached a maximum of about 14,000 acre-ft for calendar year 2001 (fig. $9 B$ ). The average rate of reclaimed wastewater used for irrigation was about 10,000 acre-ft/yr. There was a low value for water year 2010 because the only available data were from January through April of 2010.

\section{Precipitation}

The time series of total annual precipitation data for water years 1948 through 2010, calculated by using the spatially distributed, daily precipitation input developed for the SRPHM, indicated a high degree of year-to-year variability in areally averaged precipitation (fig. 10A). Maximum daily precipitation also indicated a high degree of temporal variability (fig. 10B). The cumulative departure from the mean for maximum daily precipitation showed wet and dry periods, as indicated by positive (wet) and negative (dry) slopes (fig. 10C). Average annual effective precipitation (including reclaimed water) for water years 1950-2010 ranged from 30 inches per year (in./yr) in the southern and eastern parts of the SRP to $55 \mathrm{in} . / \mathrm{yr}$ for the summit areas of the Sonoma and Mayacmas Mountains along the eastern boundary of the SRPW (fig. 11). Parcels receiving reclaimed water in the west-central part of the SRP had average annual effective precipitation as much as $69 \mathrm{in} . / \mathrm{yr}$, effectively doubling the precipitation rate for these parcels (fig. 11).

\section{Maximum and Minimum Daily Air Temperature}

Average water-year maximum and minimum daily air temperature, spatially averaged over the SRPW, was calculated by using the daily air temperature input developed for the SRPHM (fig. 12). Daily maximum and minimum air temperature input developed for the SRPHM indicated large monthly variation in temperature (fig. 13), with July being the warmest month and December being the coldest month. 


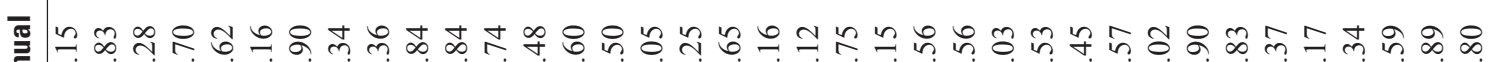

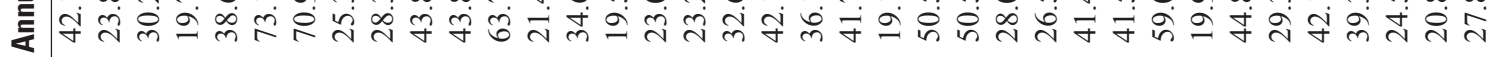

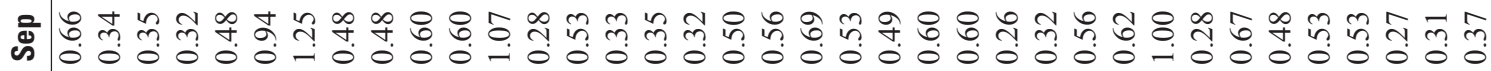

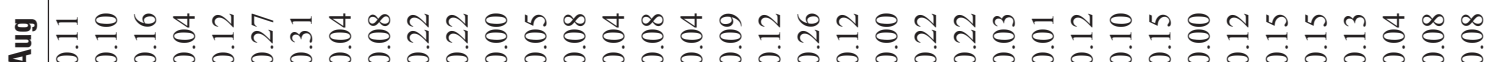

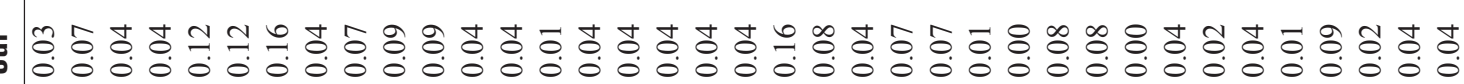

=

元 =

훈

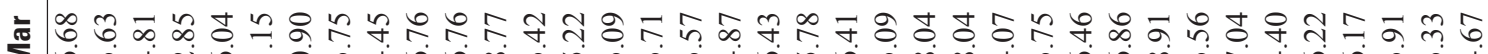

$\Sigma$

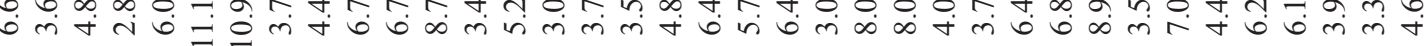

\&

तิ 兹

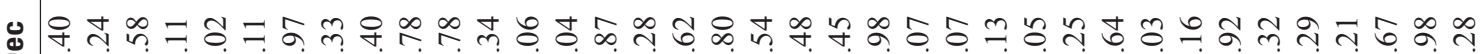

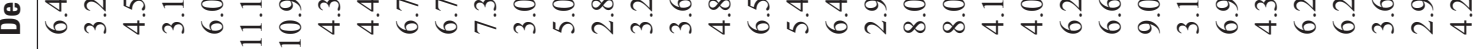

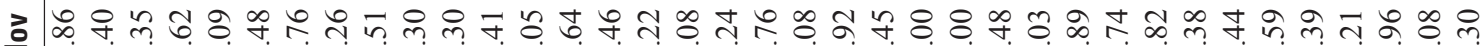

हे

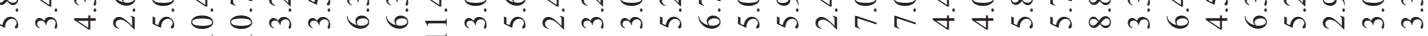

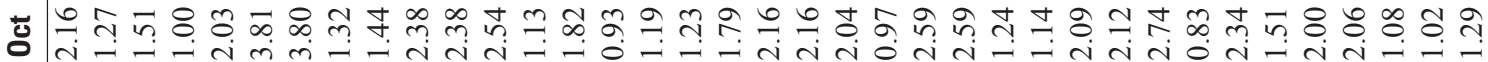

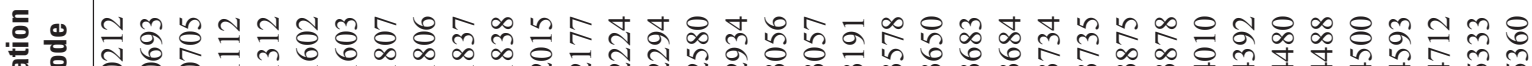

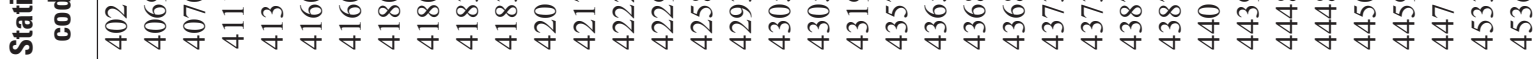

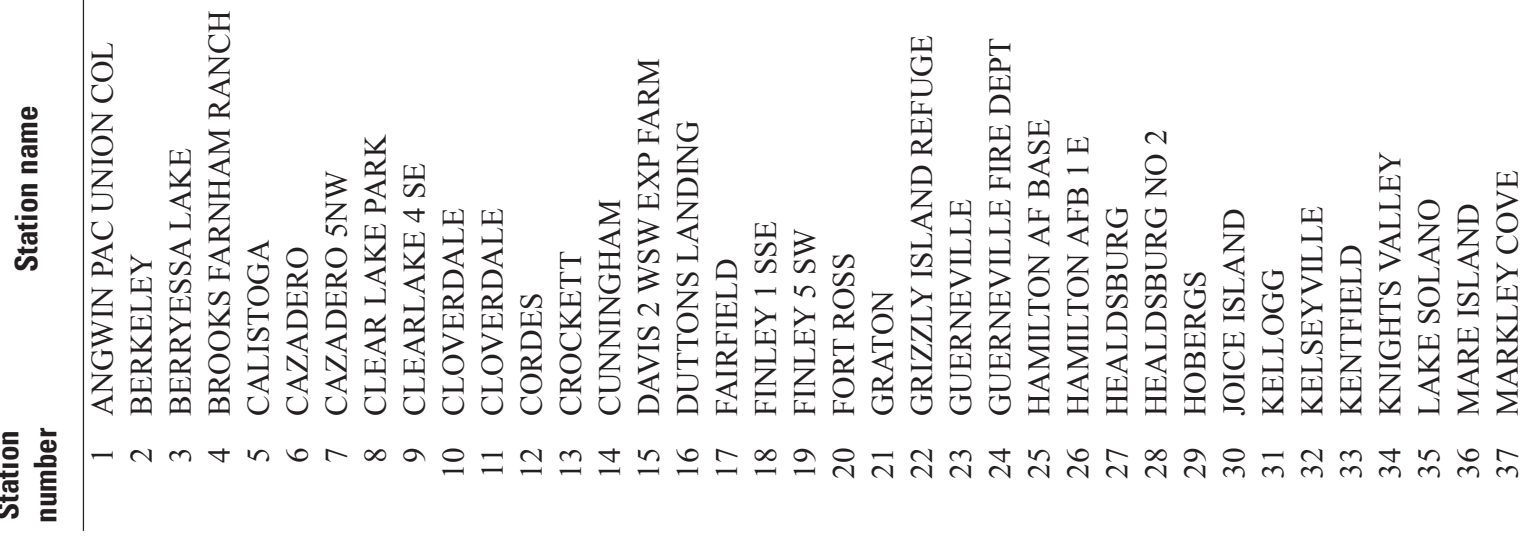




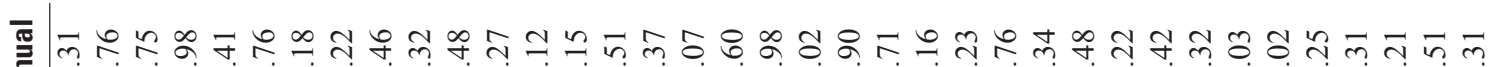

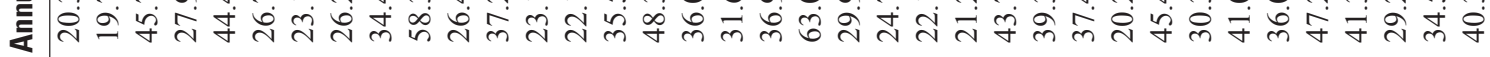

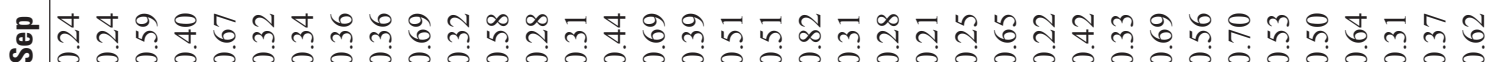

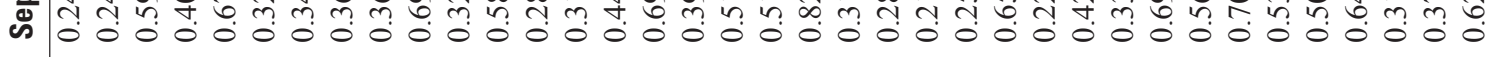

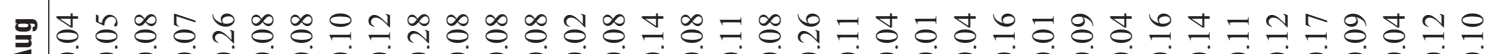

Z

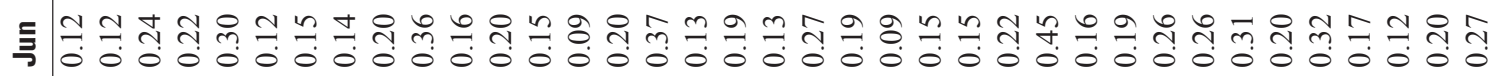

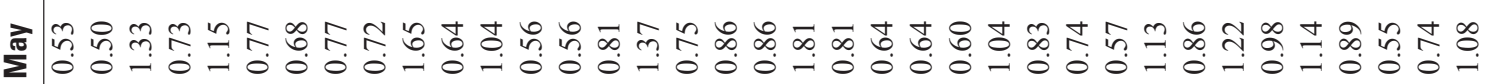

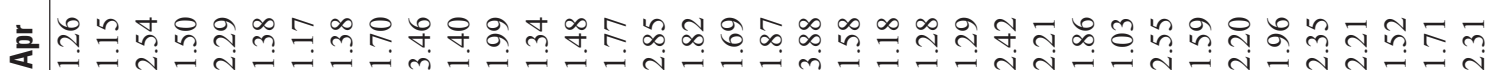

추 ํำ $\sum$ m

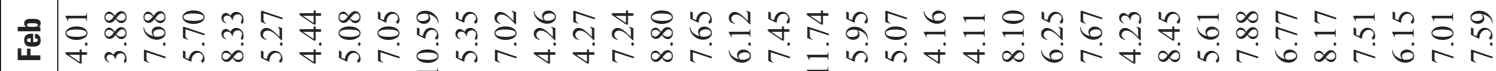

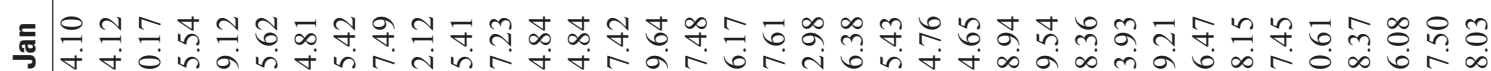
学

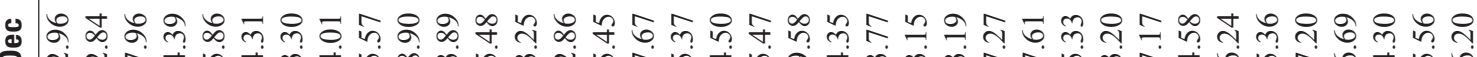
i

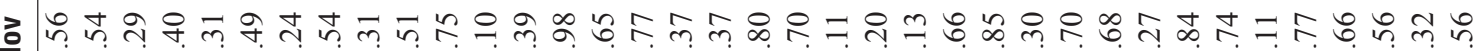
त त

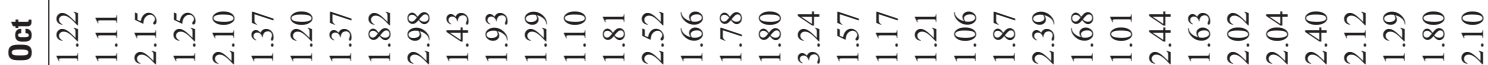

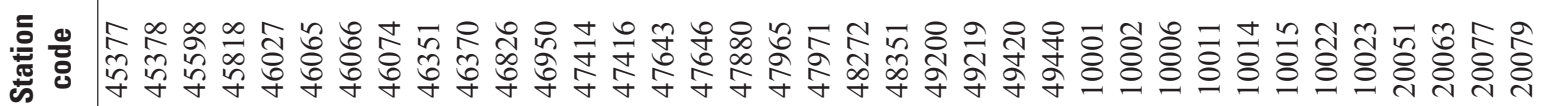
D্ | 


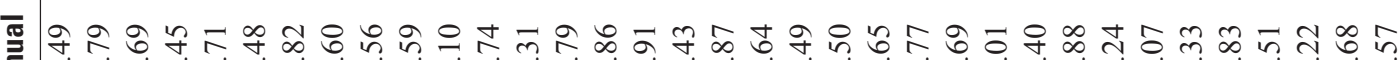

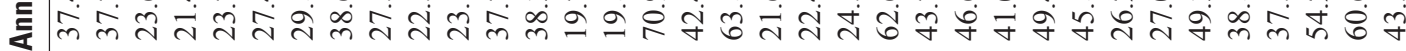

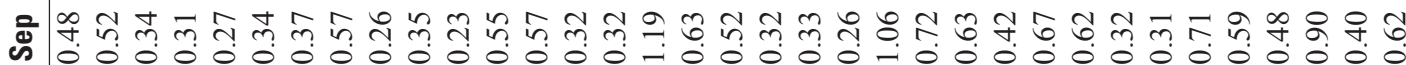

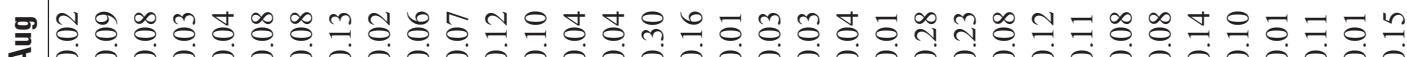

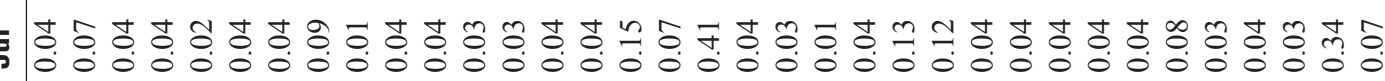

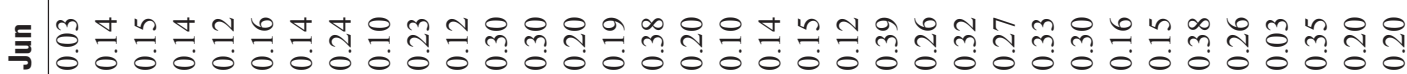
을

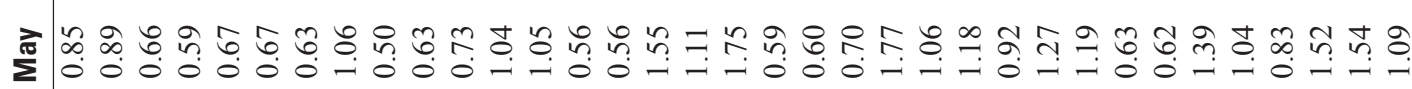

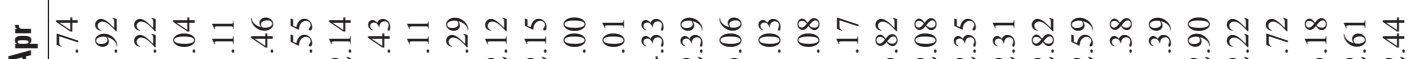

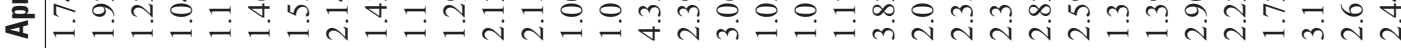

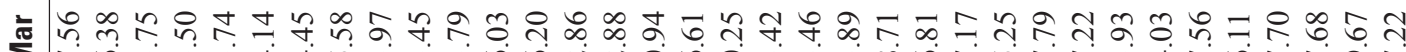
І

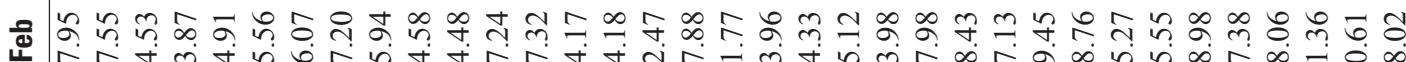
皇

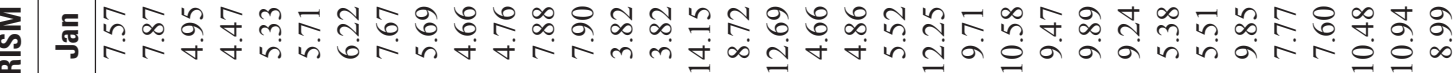
$\frac{x^{2}}{\underline{\alpha}}$

응ำ

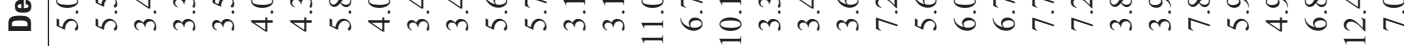

흐

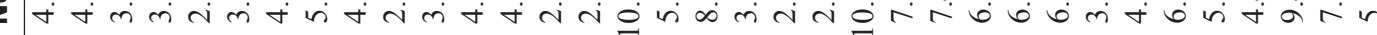

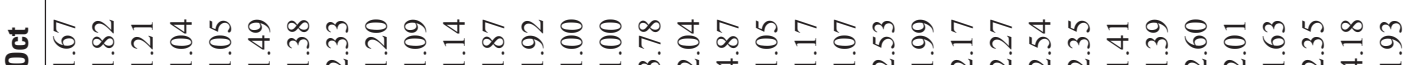

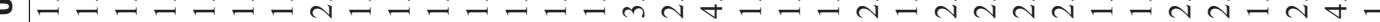

흥

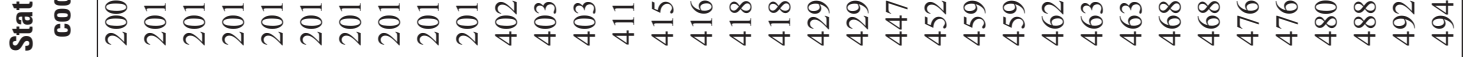

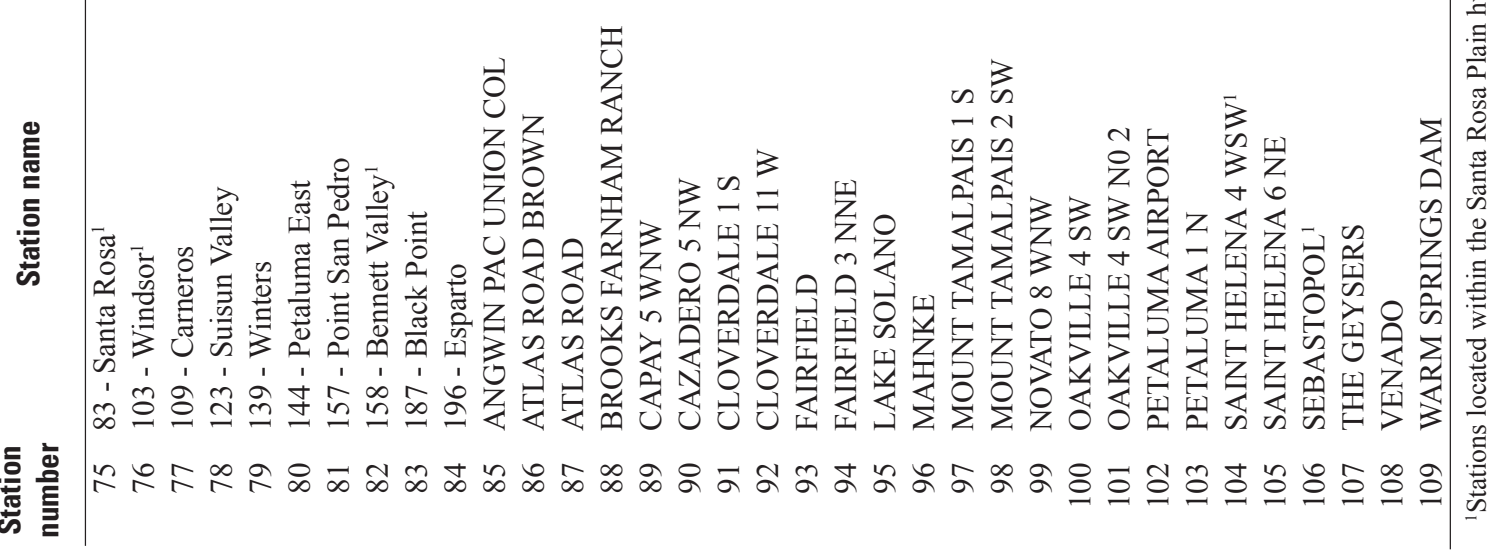


य.

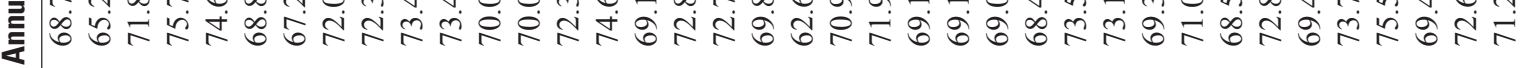

ะ

o 0 .

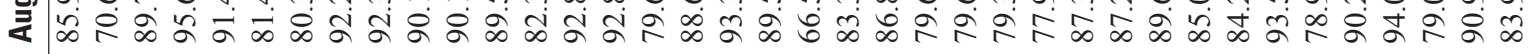

छ

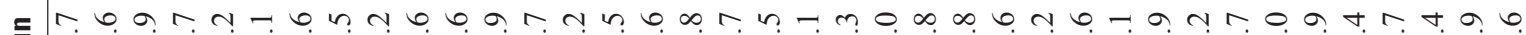

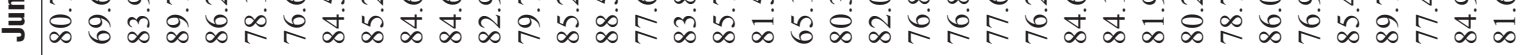

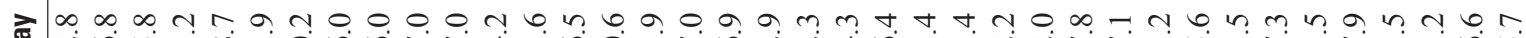

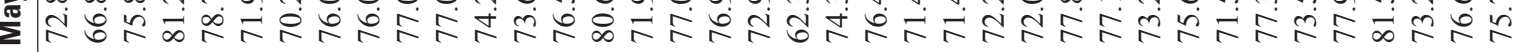

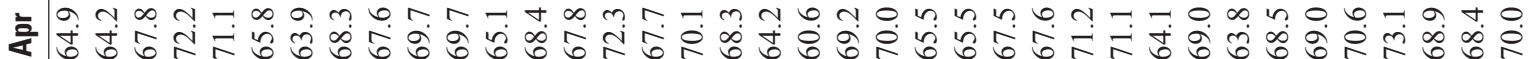

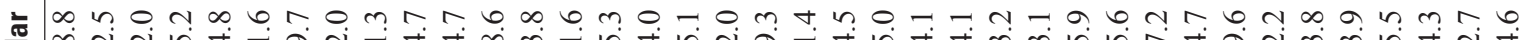
एँ

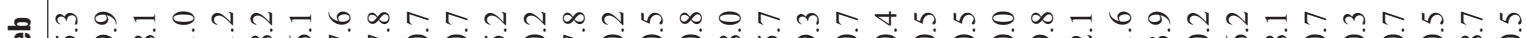

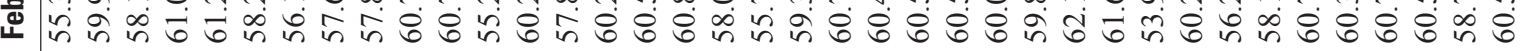

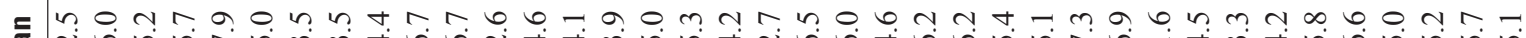

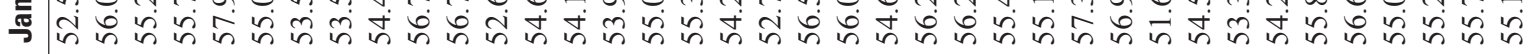

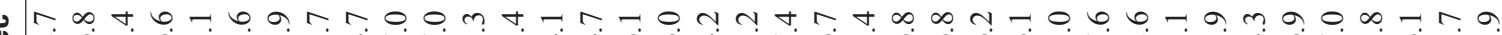

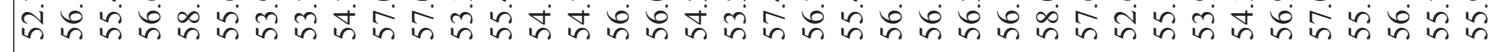

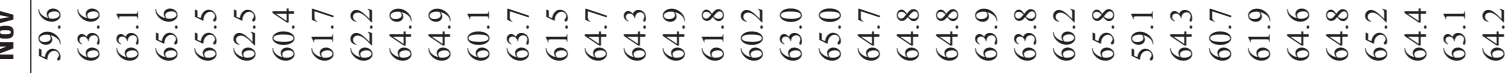

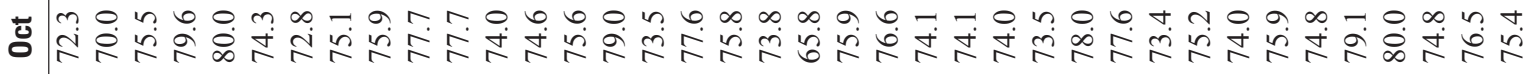

흠 응

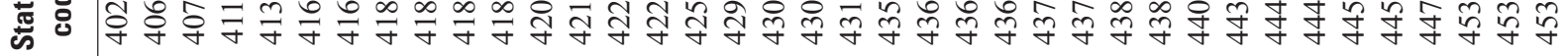

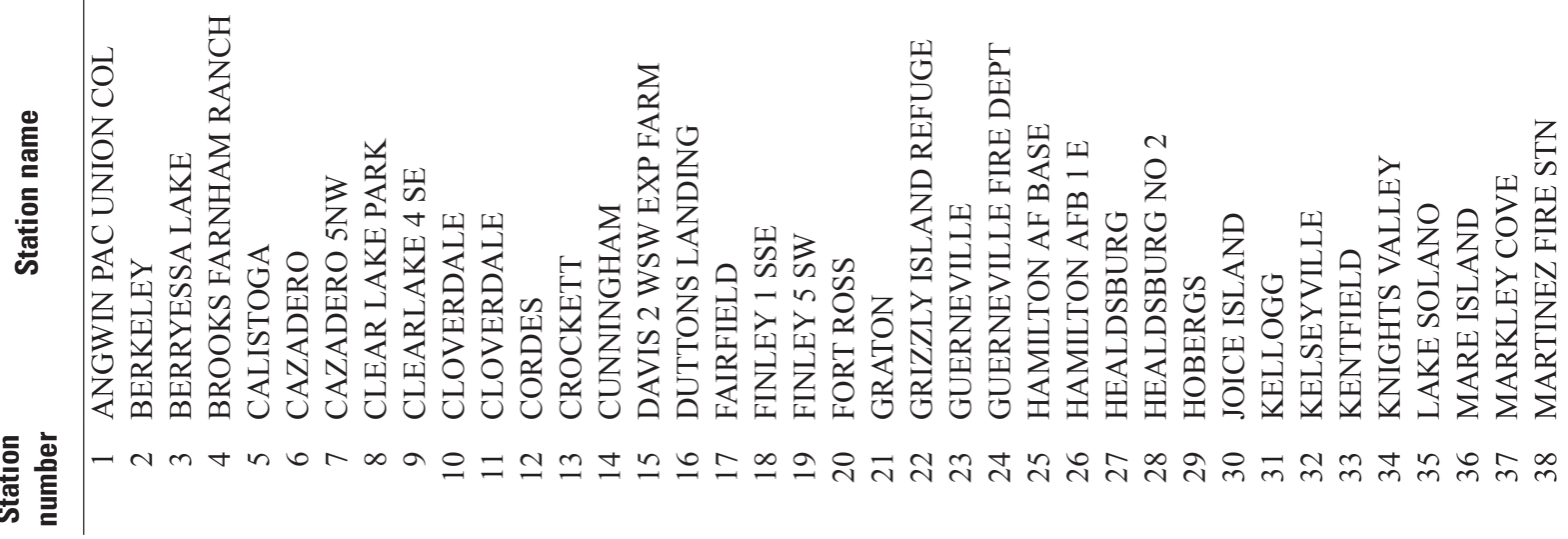




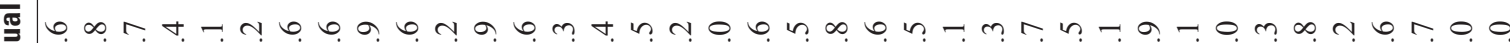

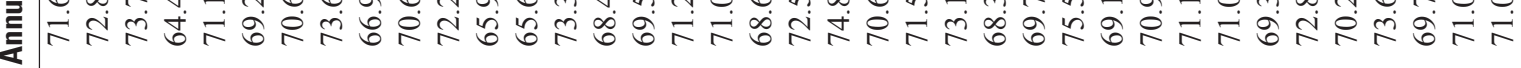

ڤ

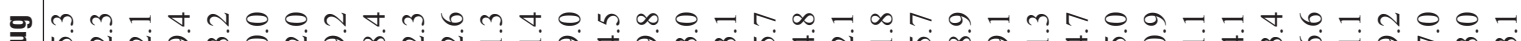
यूर बूं

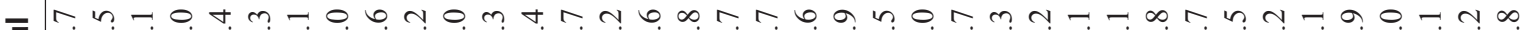

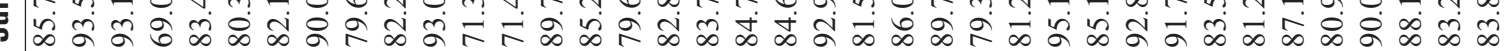

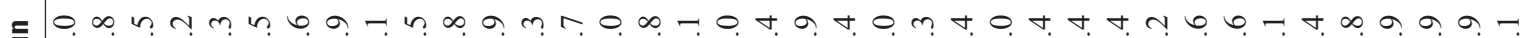

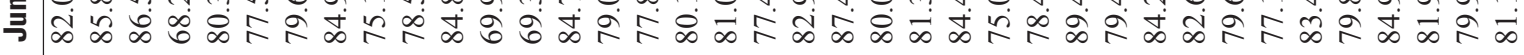

) 0 .

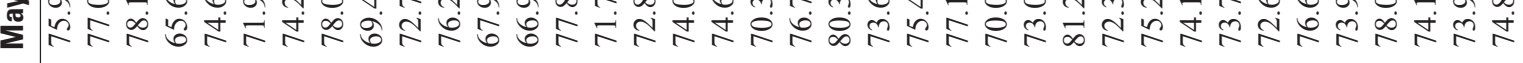

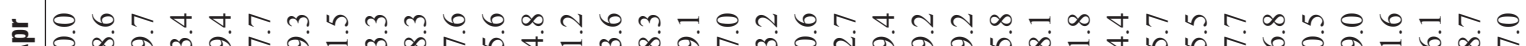

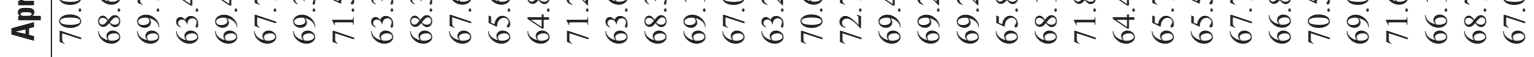

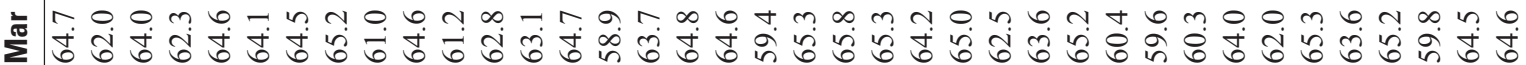
ब

$=$ - $\infty$ m $m$ m 0 .

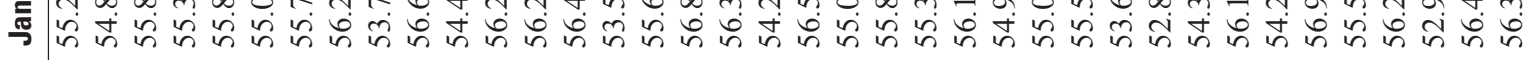

月 $\frac{\sum_{0}}{\frac{\pi}{2}}$

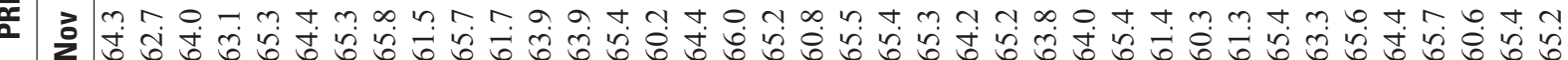

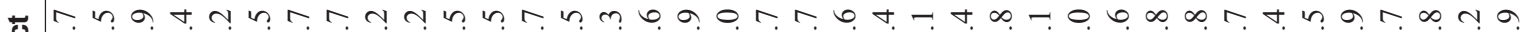

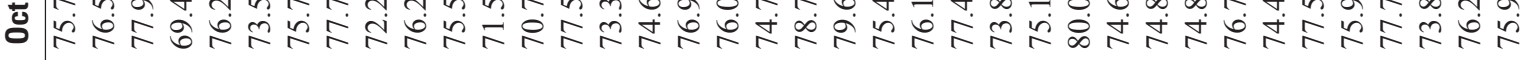

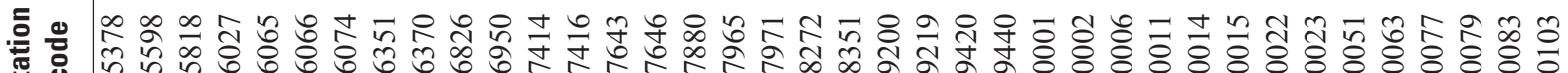

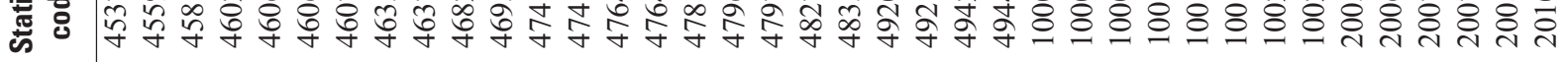

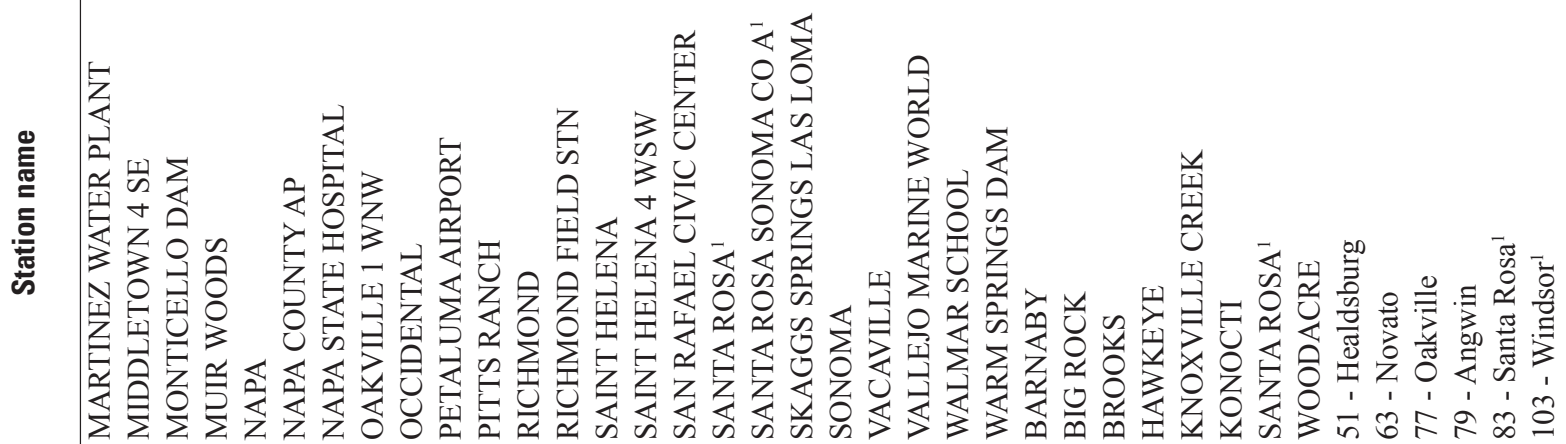




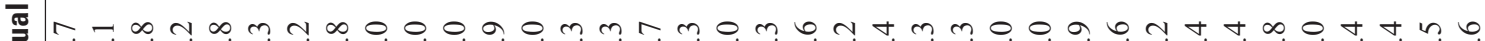

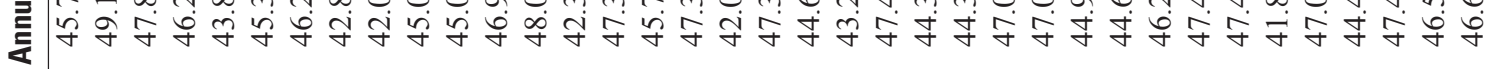

赵

- a r o o r n a 0 .

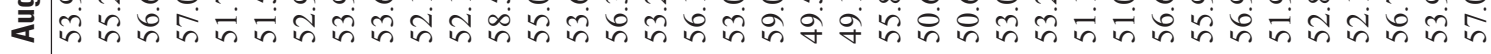

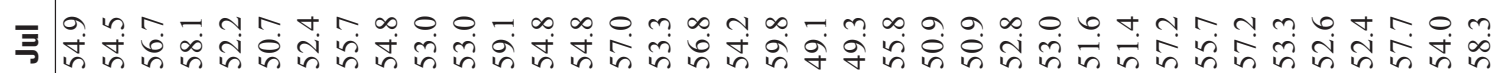

三 -

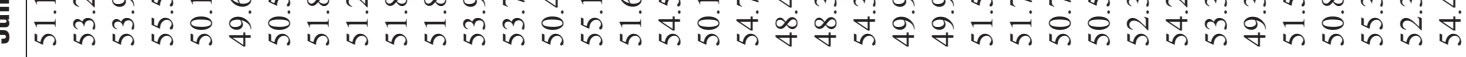

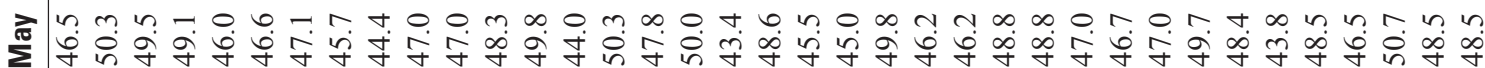

- t t r n 0 .

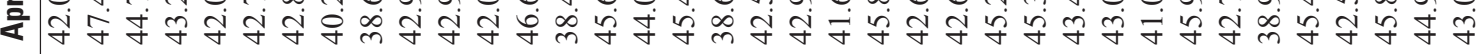

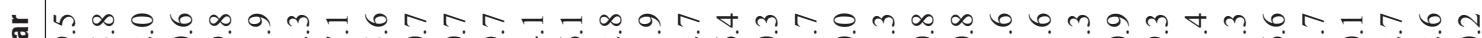
兲全

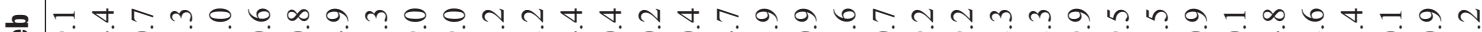

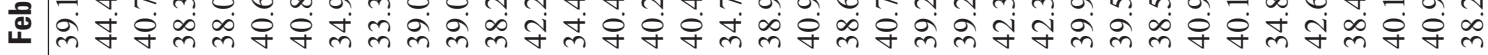

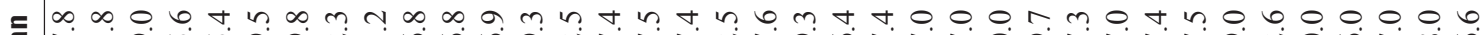

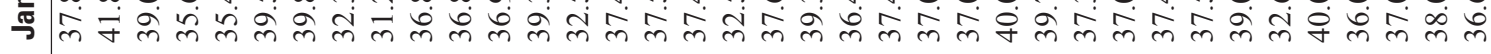

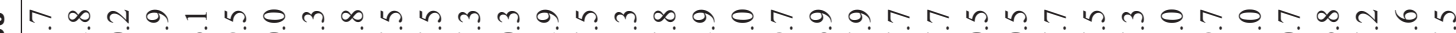

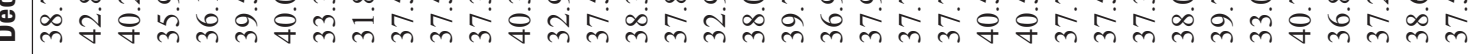

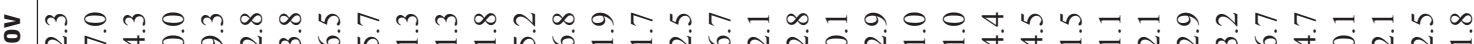

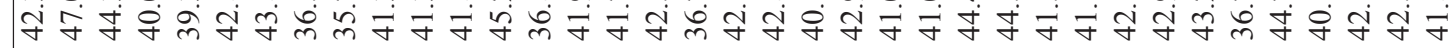

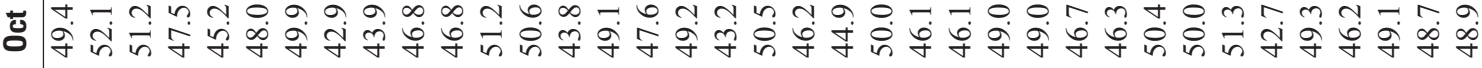

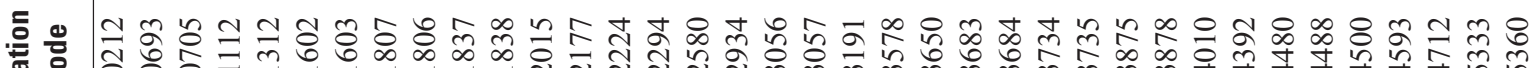

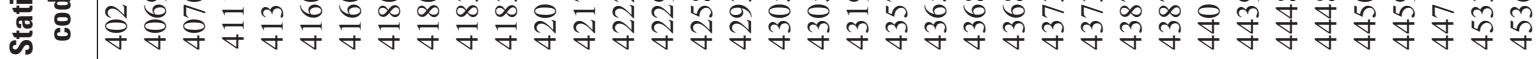

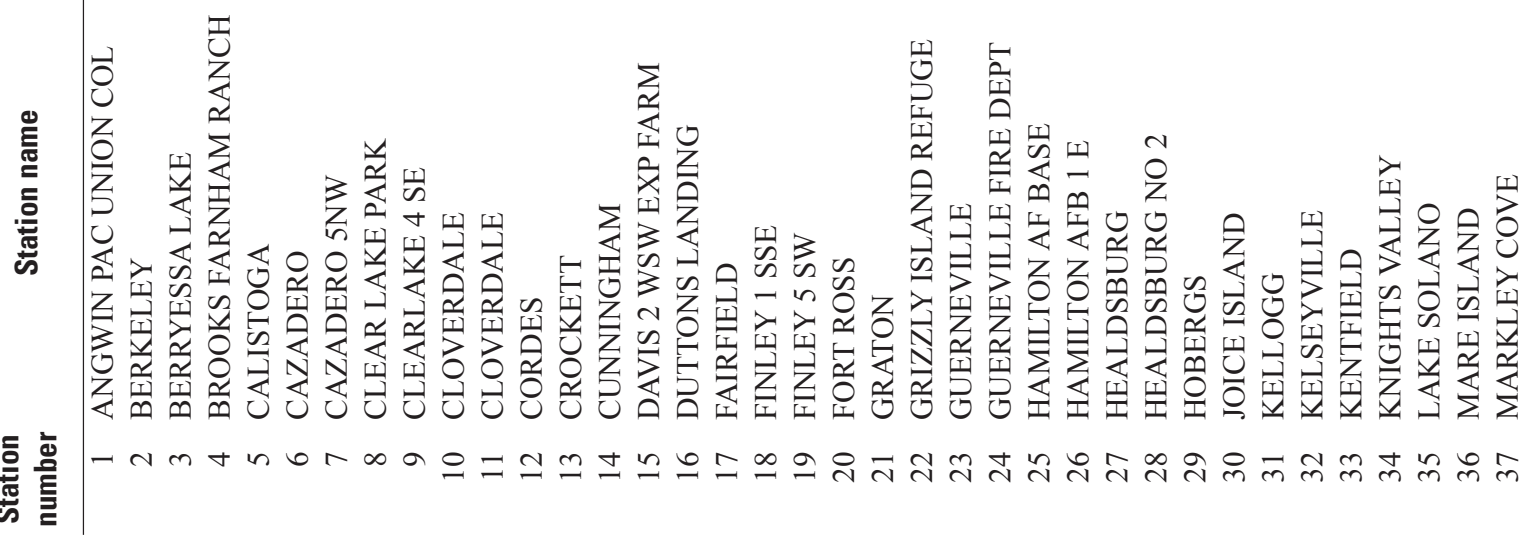




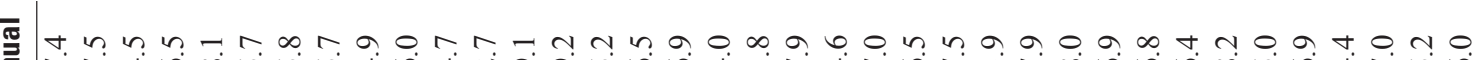

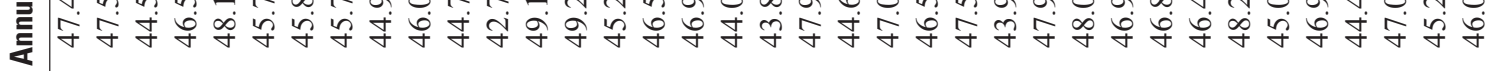

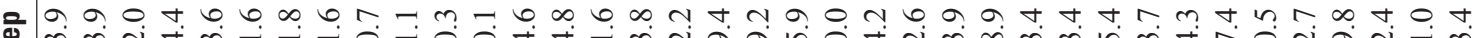

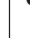

D m

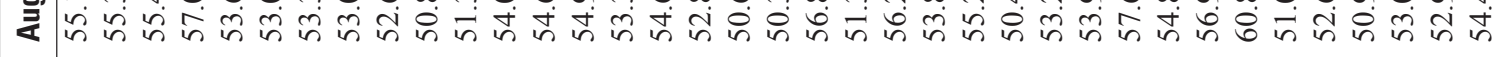

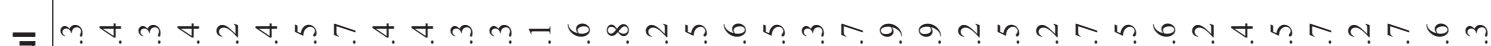

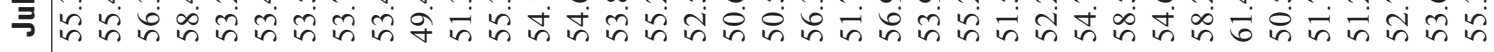

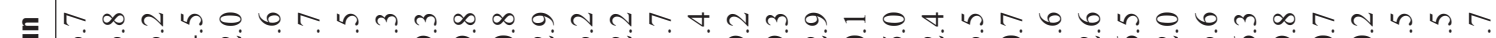

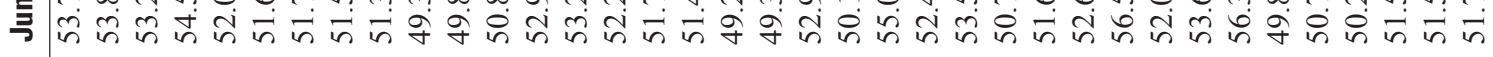

ส

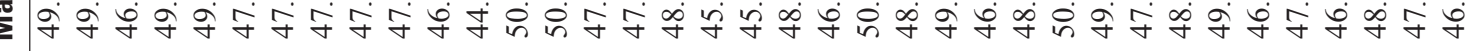

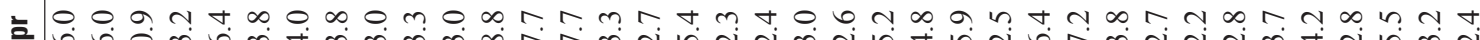

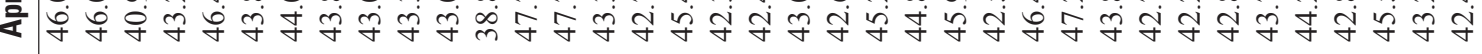

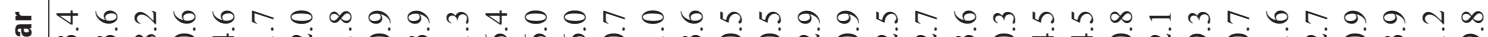

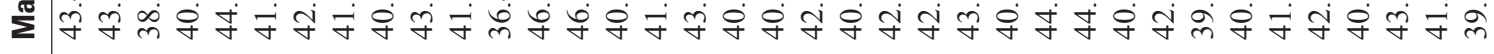

- ก

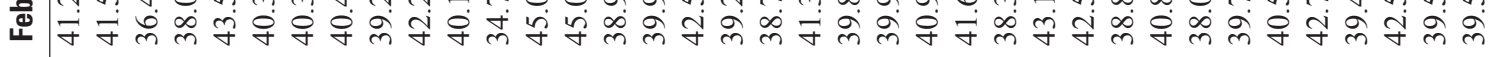

N n t

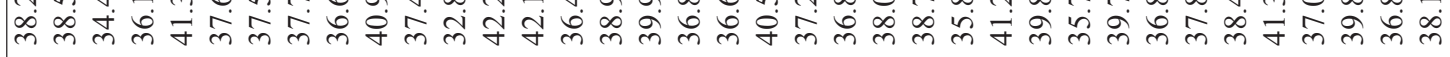

-

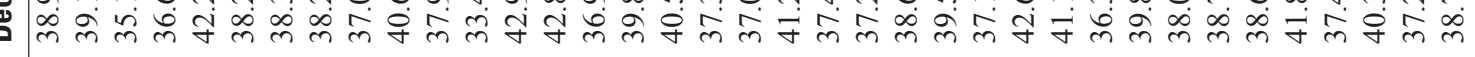

它

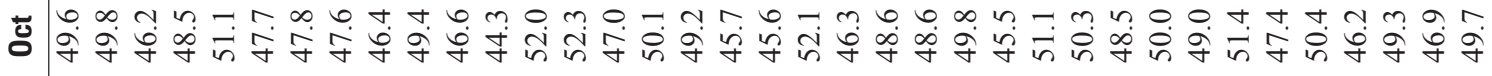

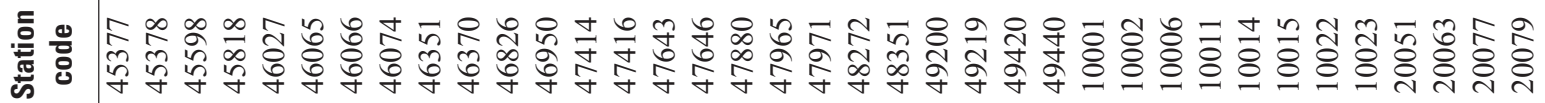


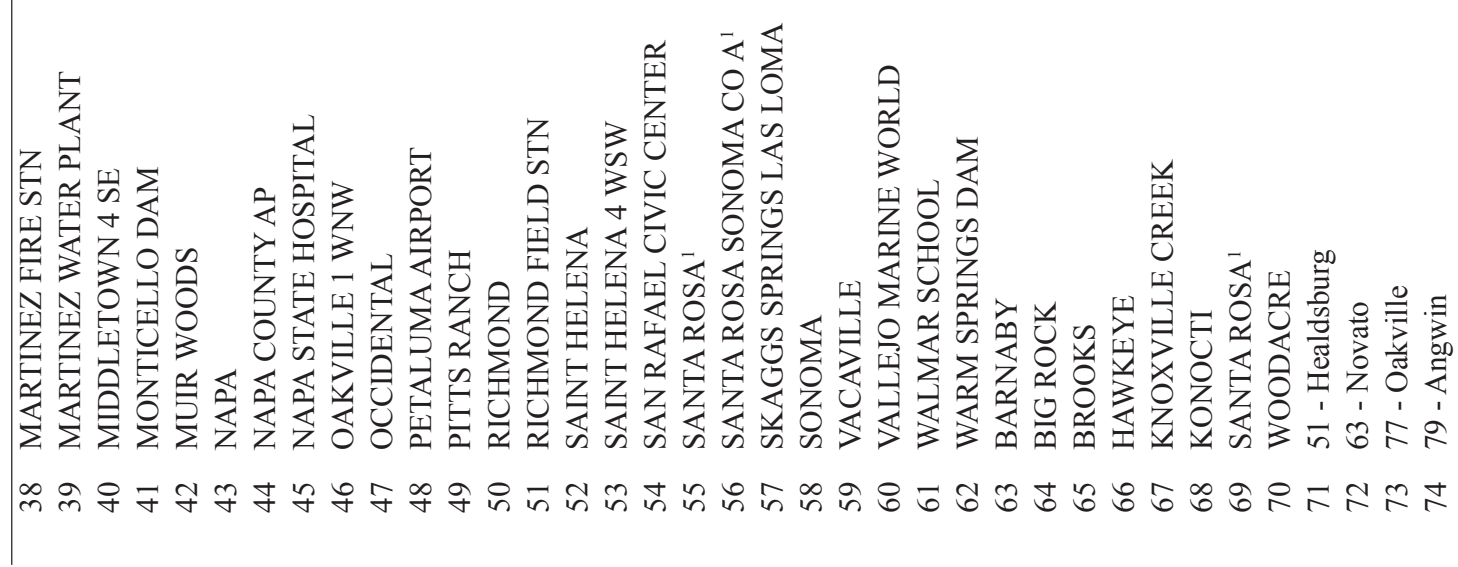




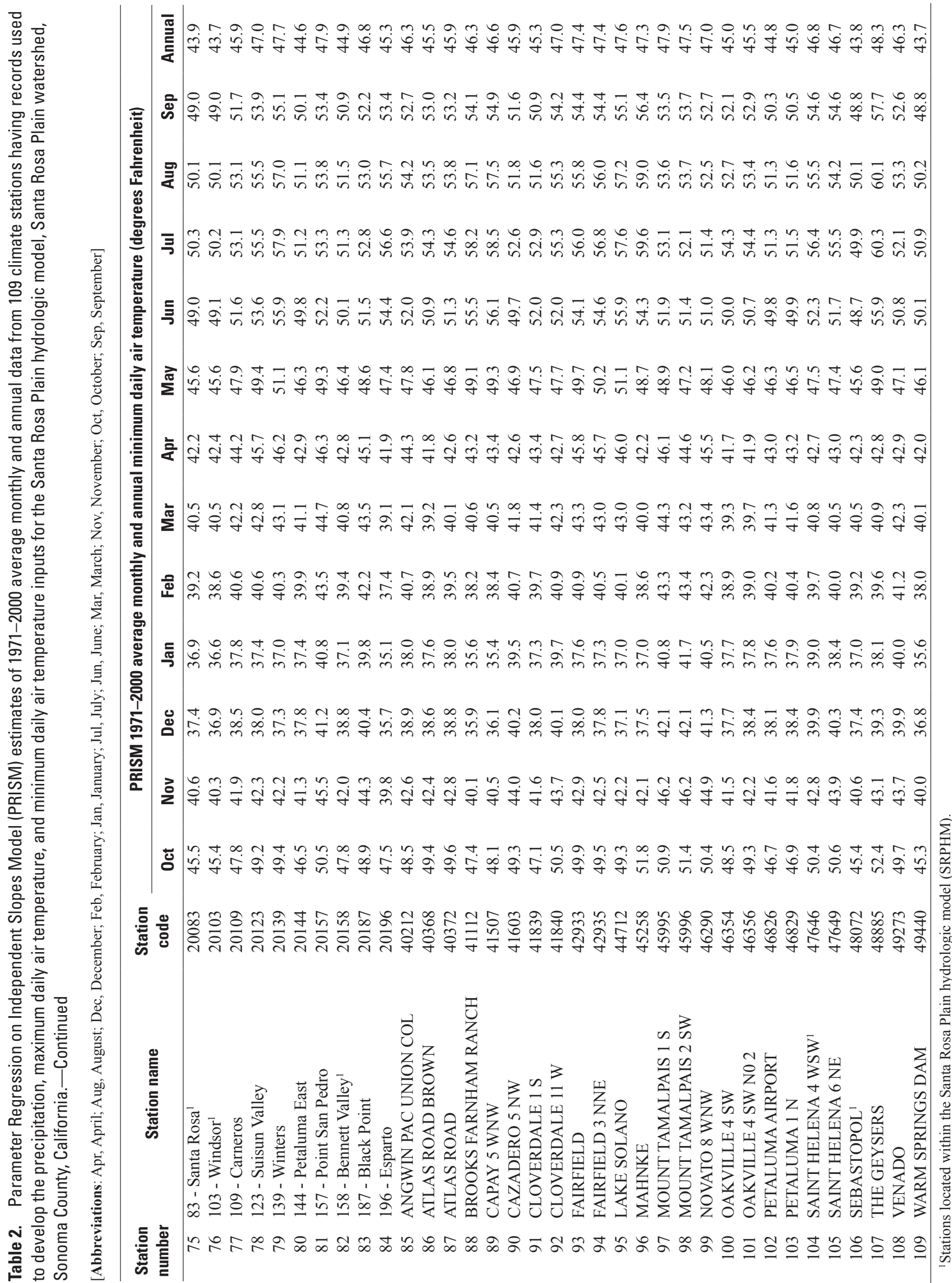




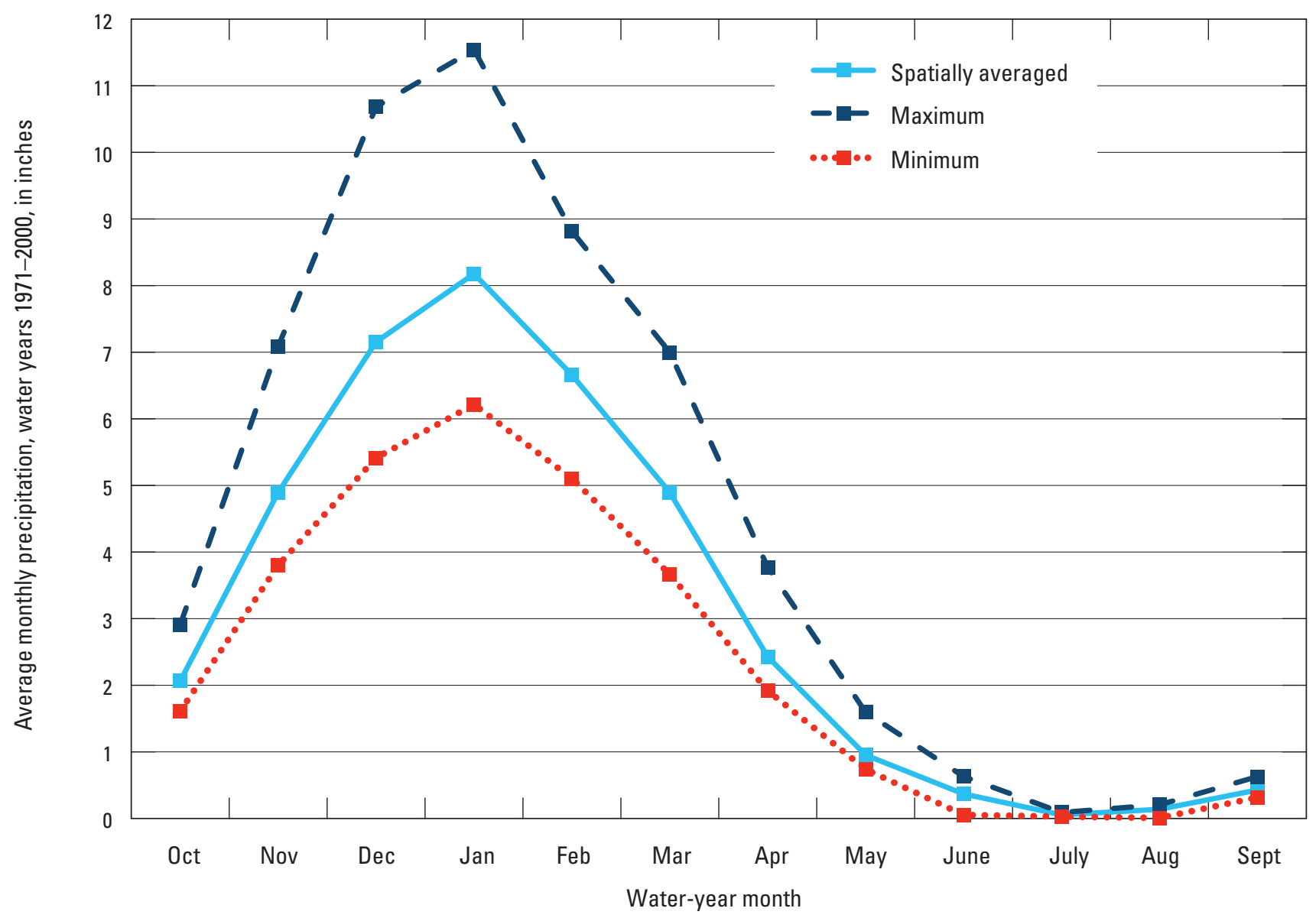

Figure 5. Spatially averaged and maximum and minimum PRISM estimates of monthly precipitation for water years 1971-2000, Santa Rosa Plain watershed, Sonoma County, California. 


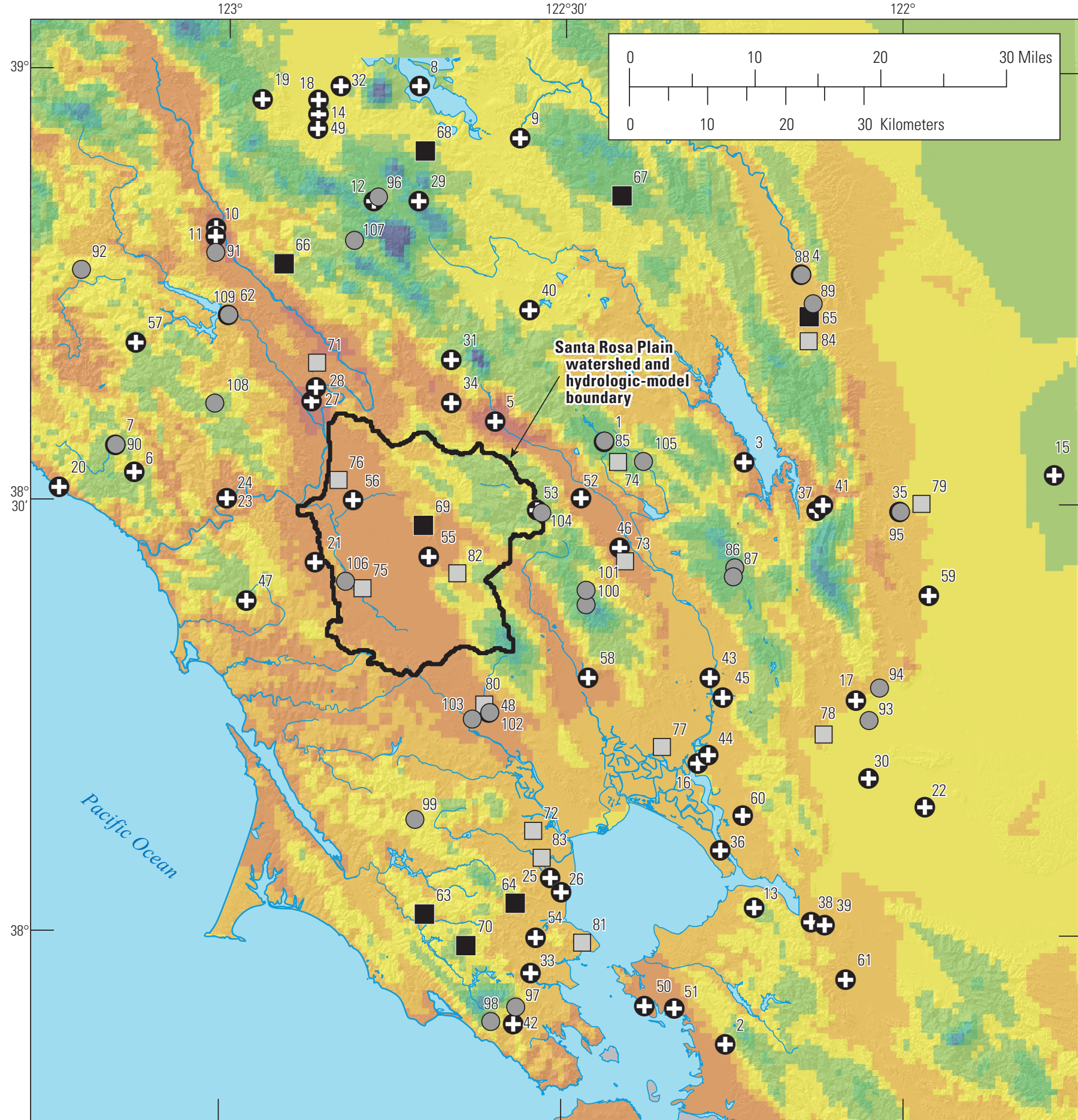

\section{EXPLANATION}

PRISM average January maximum air temperature, in degrees Fahrenheit
48.9 to 50
52.1 to 53
50.1 to 5
53.1 to 54
55.1 to 56
51.1 to 52
54.1 to 55
56.1 to 57
57.1 to 58.1

\section{Santa Rosa Plain Climate stations}

watershed and $\square$ CIMIS Daily Climate $\bigcirc \quad$ NCDC Hourly Precip

hydrologic-mode boundary

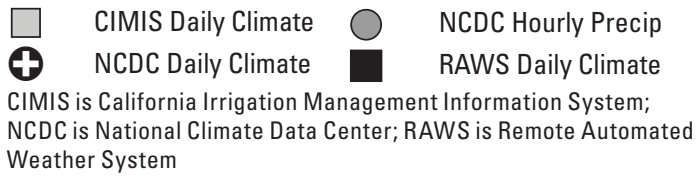

CIMIS is California Irrigation Management Information System; NCDC is National Climate Data Center; RAWS is Remote Automated Weather System

Figure 6. PRISM 1971-2000 average maximum air temperature for January, and the location of climate stations having records used to develop daily climate inputs, Santa Rosa Plain hydrologic model, Santa Rosa Plain watershed, Sonoma County, California. 


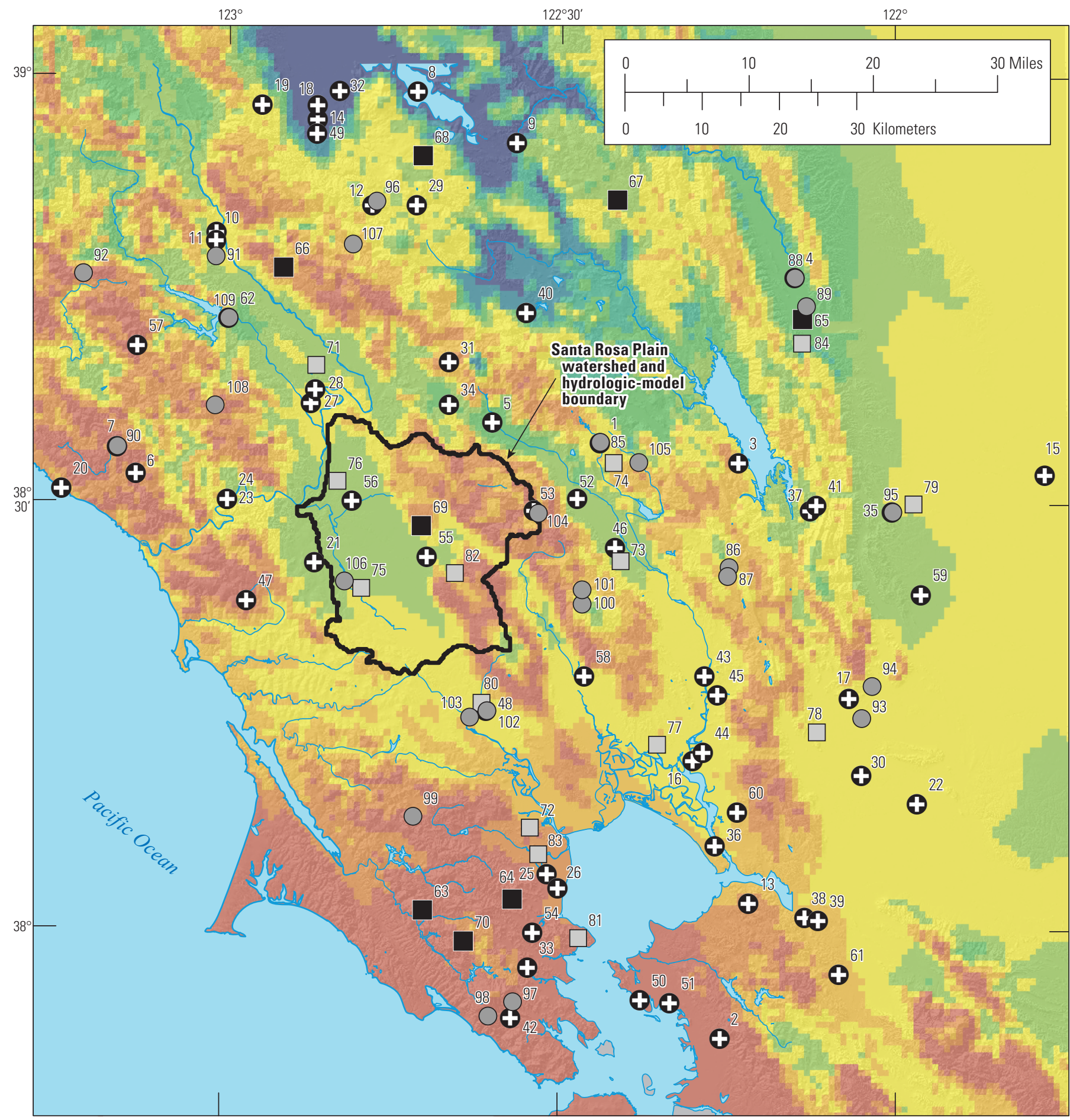

EXPLANATION

PRISM average January minimum air temperature, in degrees Fahrenheit

\begin{tabular}{|r|r|r|}
\hline 31 to 33 & 35.1 to 36 & 38.1 to 39 \\
33.1 to 34 & 36.1 to 37 & 39.1 to 40 \\
34.1 to 35 & 37.1 to 38 & 40.1 to 44.5
\end{tabular}

\section{Santa Rosa Plain Climate stations}

watershed and $\square \quad$ CIMIS Daily Climate $\bigcirc \quad$ NCDC Hourly Precip hydrologic-model boundary CIMIS is California Irrigation Management Information System; NCDC is National Climate Data Center; RAWS is Remote Automated Weather System

Figure 7. PRISM 1971-2000 average minimum air temperature for January, and the location of climate stations having records used to develop daily climate inputs, Santa Rosa Plain hydrologic model, Santa Rosa Plain watershed, Sonoma County, California. 


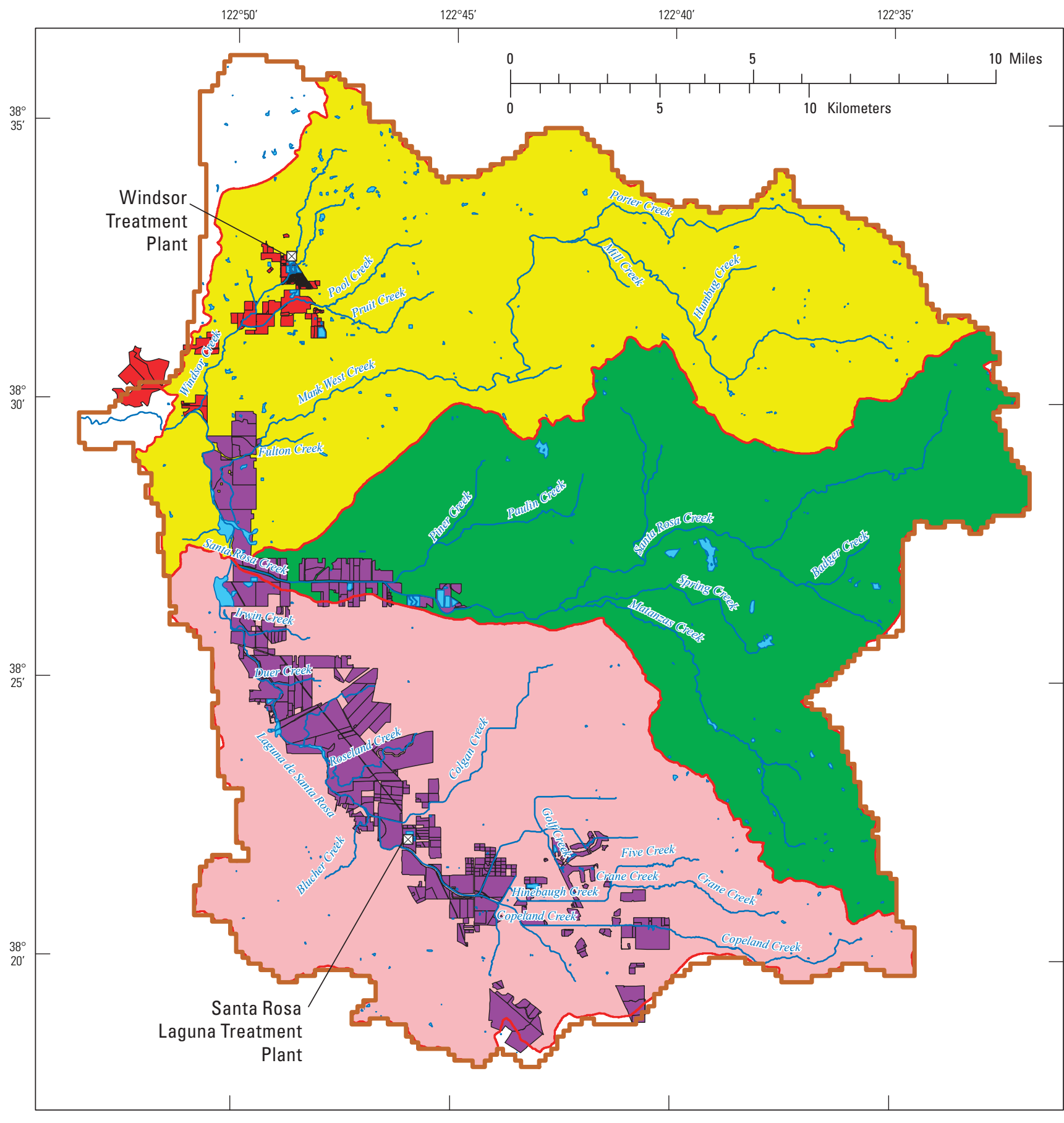

Surface-water subbasins
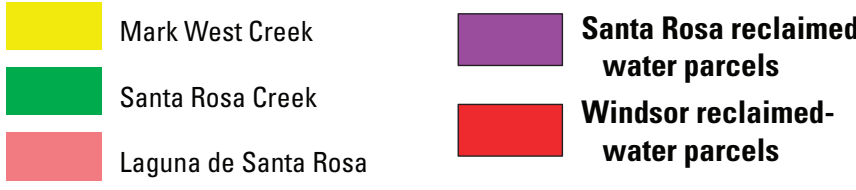

Santa Rosa Plain

watershed and

hydrologic-mode

boundary

Major streams

Figure 8. Location of land parcels receiving reclaimed wastewater for irrigation, Santa Rosa Plain watershed, Sonoma County, California. 

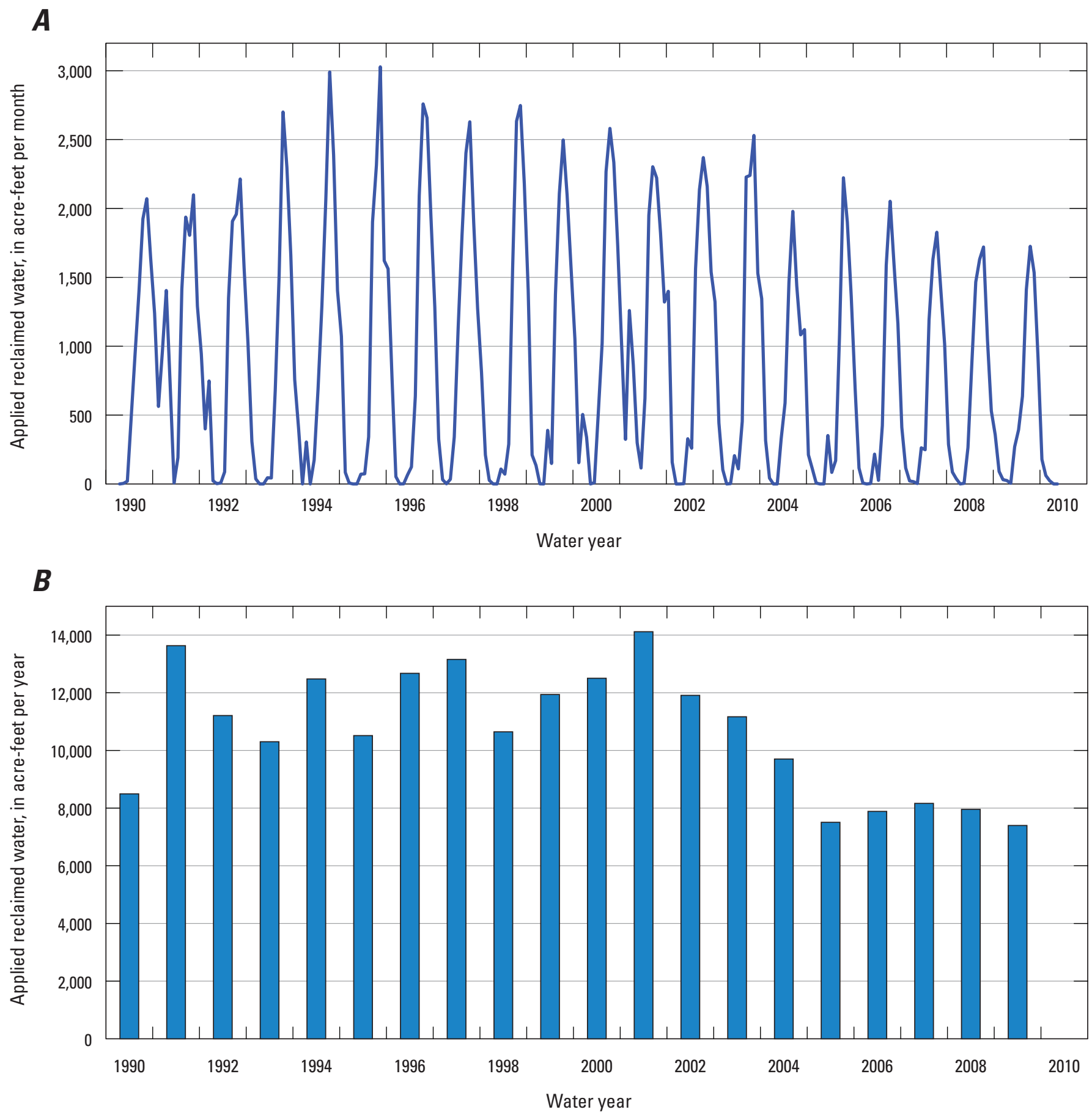

Figure 9. Total volumes of reclaimed wastewater used for irrigation in the Santa Rosa Plain watershed, Sonoma County, California: $A$, monthly; $B$, annual. 

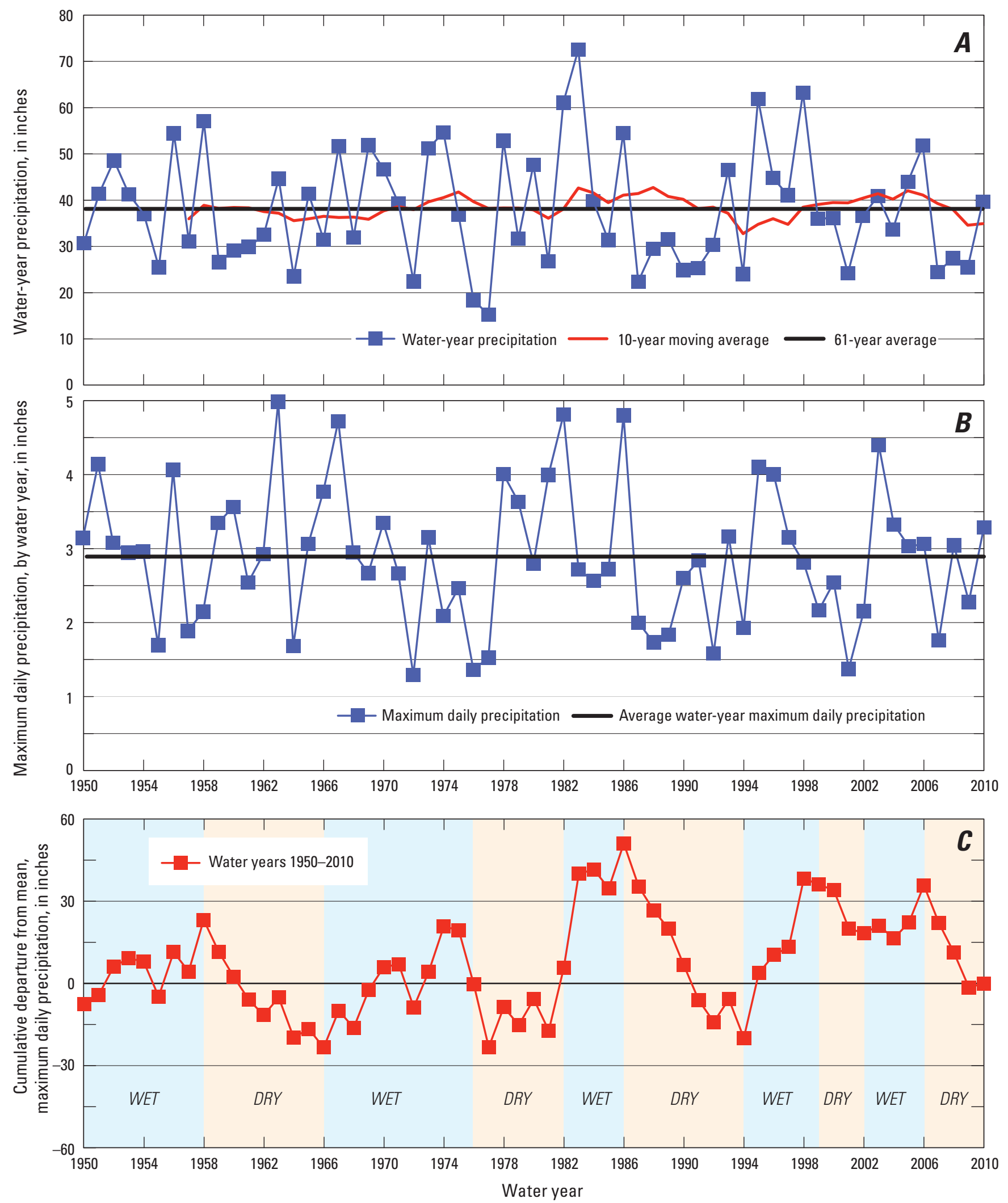

Figure 10. Spatially interpolated precipitation input for water years 1950-2010, averaged over the area of the Santa Rosa Plain watershed, Sonoma County, California, for the Santa Rosa Plain hydrologic model, indicating $A$, total water-year precipitation; $B$, maximum daily precipitation for each water year, and; $C$, cumulative departure from mean annual precipitation. 


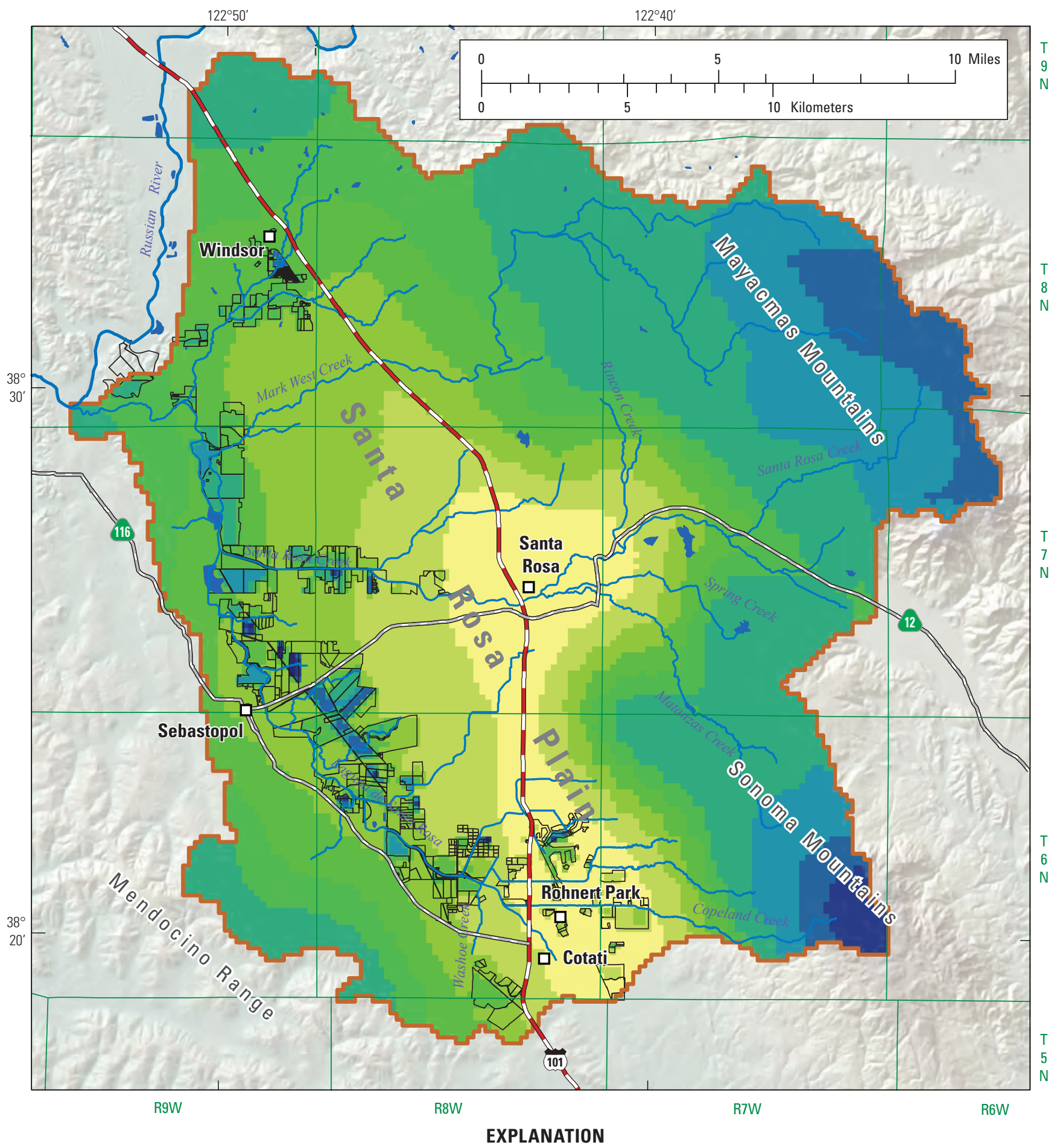

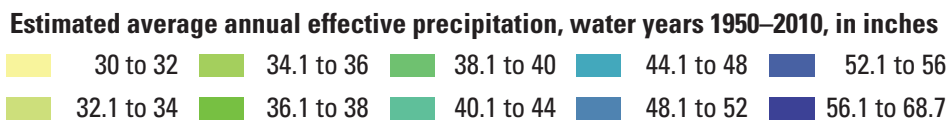

Parcels receiving

reclaimed water Santa Rosa Plain

watershed and

hydrologic-model boundary

Major stream

channels

Figure 11. Average annual effective precipitation, water years 1950-2010, for the Santa Rosa Plain watershed, Sonoma County, California, calculated by using the daily precipitation and reclaimed-water inputs for the Santa Rosa Plain hydrologic model. 

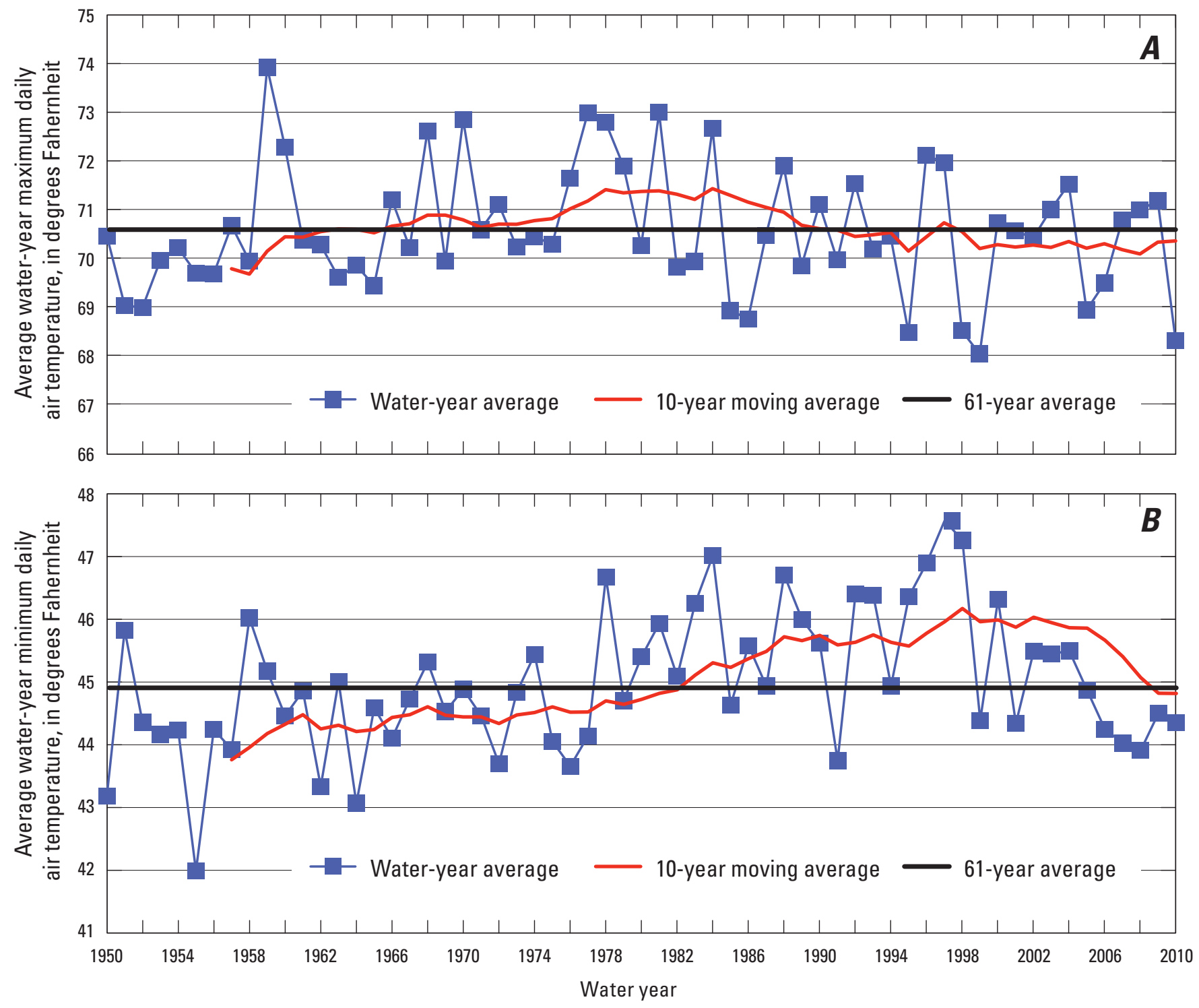

Figure 12. Spatially interpolated air-temperature input for the Santa Rosa Plain hydrologic model, averaged over the area of the Santa Rosa Plain watershed, Sonoma County, California, for water years 1950-2010, indicating $A$, average maximum daily air temperature and; $B$, average minimum daily air temperature. 


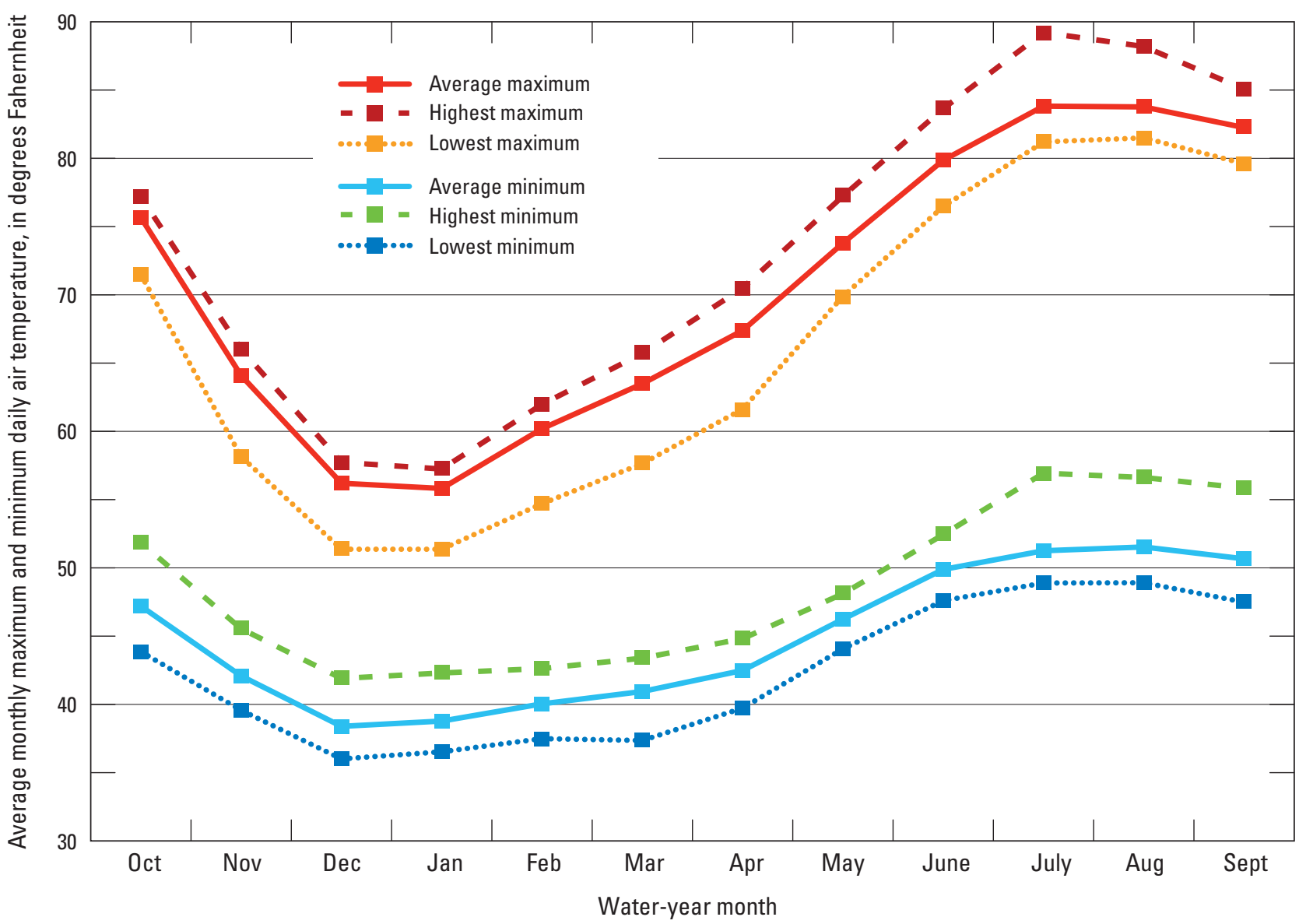

Figure 13. Average monthly maximum and minimum air temperature, calculated using the daily air temperature data developed for the Santa Rosa Plain hydrologic model, water years 1950-2010, Santa Rosa Plain watershed, Sonoma County, California.

Spatially distributed average maximum and minimum daily air temperatures for water years 1950-2010, calculated by using the daily air temperature input developed for the SRPHM, are shown in figures 14 and 15, respectively. In general, the spatial distribution of maximum daily air temperature reflects a negative correlation with elevation combined with a trend of increasing air temperature northward, farther from coastal influences (fig. 14). Unlike the spatial distribution for maximum daily air temperature, the spatial distribution for minimum daily air temperature reflects a positive correlation with elevation, reflecting a climate characterized by common night-time temperature inversions, with the cold air sinking into lower elevations (fig. 15).

\section{Model Parameters}

Watershed-flow processes in the SRPHM are defined in the PRMS portion of GSFLOW. These processes are part of GSFLOW, and more details about the processes, the calibration, and the specified parameters are included in chapter $D$. The flow processes were simulated in decoupled PRMS-only mode to determine preliminary values of model parameters and to provide PET and recharge for the steady-state groundwater-flow model. The watershed-component model was calibrated by using a trial-and-error approach to measured values of simulated short-wave radiation (SWRAD), PET, and streamflow. Calibration was done in two independent steps: (1) calibration of monthly parameters controlling SWRAD and PET, and (2) calibration of parameters controlling simulated streamflow. Once the parameters affecting SWRAD and PET were estimated, they were held constant while the streamflow parameters were estimated. Additional information regarding the parameter-estimation procedures and the GSFLOWcalibrated values and distributions of the 12 critical parameters described in this section is presented in chapter $D$. 


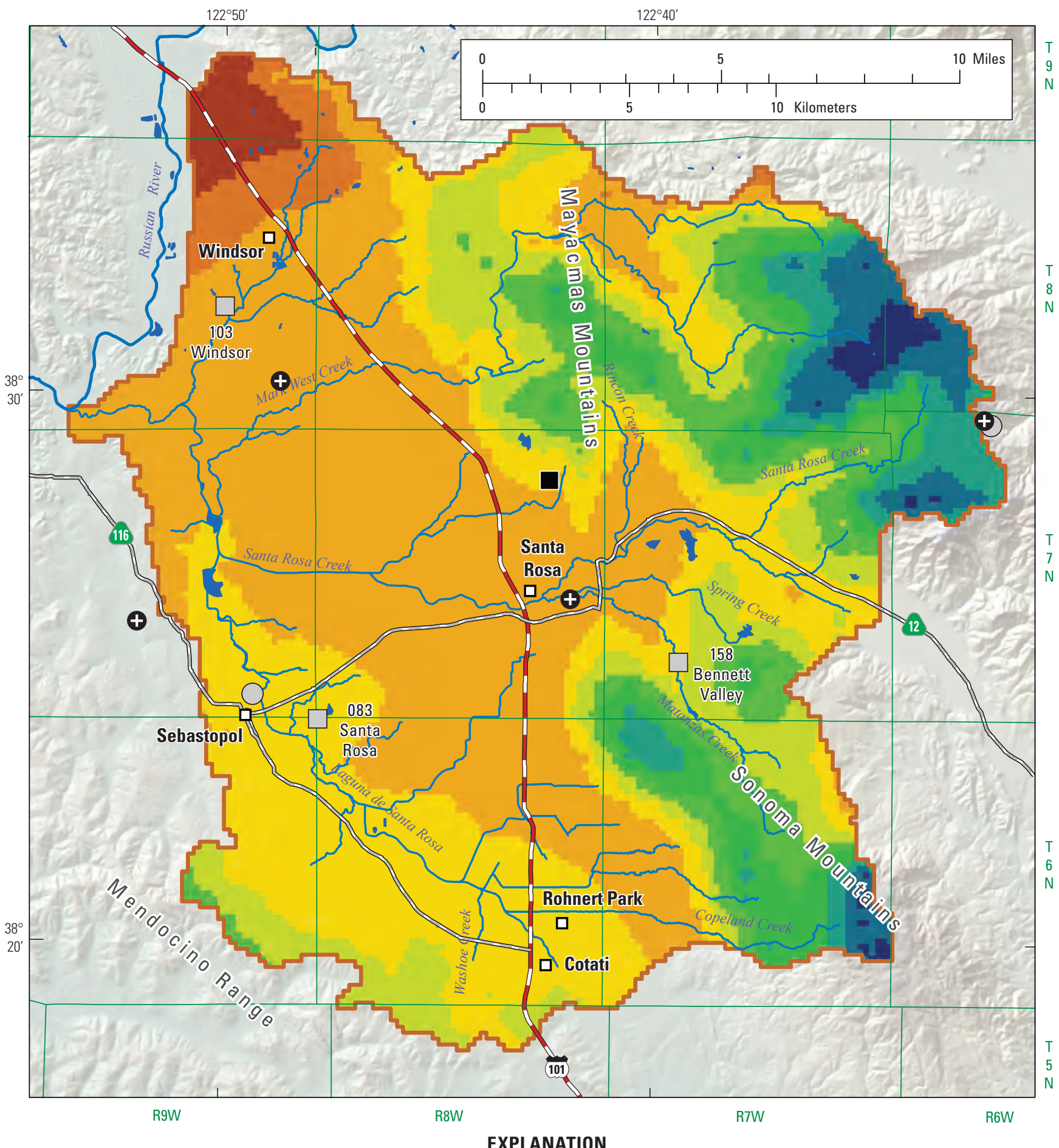

Spatially distributed average maximum temperature, water years 1950-2010, in degrees Fahrenheit

\begin{tabular}{|r|r|r|}
67.5 to 68 & 69.6 to 70 & 71.6 to 72 \\
68.1 to 68.5 & 70.1 to 70.5 & 72.1 to 72.9 \\
68.6 to 69 & 70.6 to 71 & \\
69.1 to 69.5 & 71.1 to 71.5 &
\end{tabular}

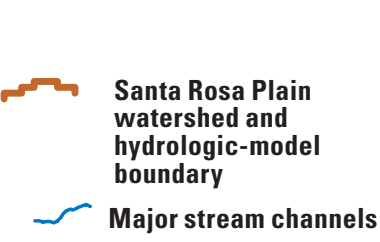

Figure 14. Spatially distributed averaged annual maximum daily air temperature, calculated using the daily air temperature inputs for the Santa Rosa Plain hydrologic model, water years 1950-2010, Santa Rosa Plain watershed, Sonoma County, California. 


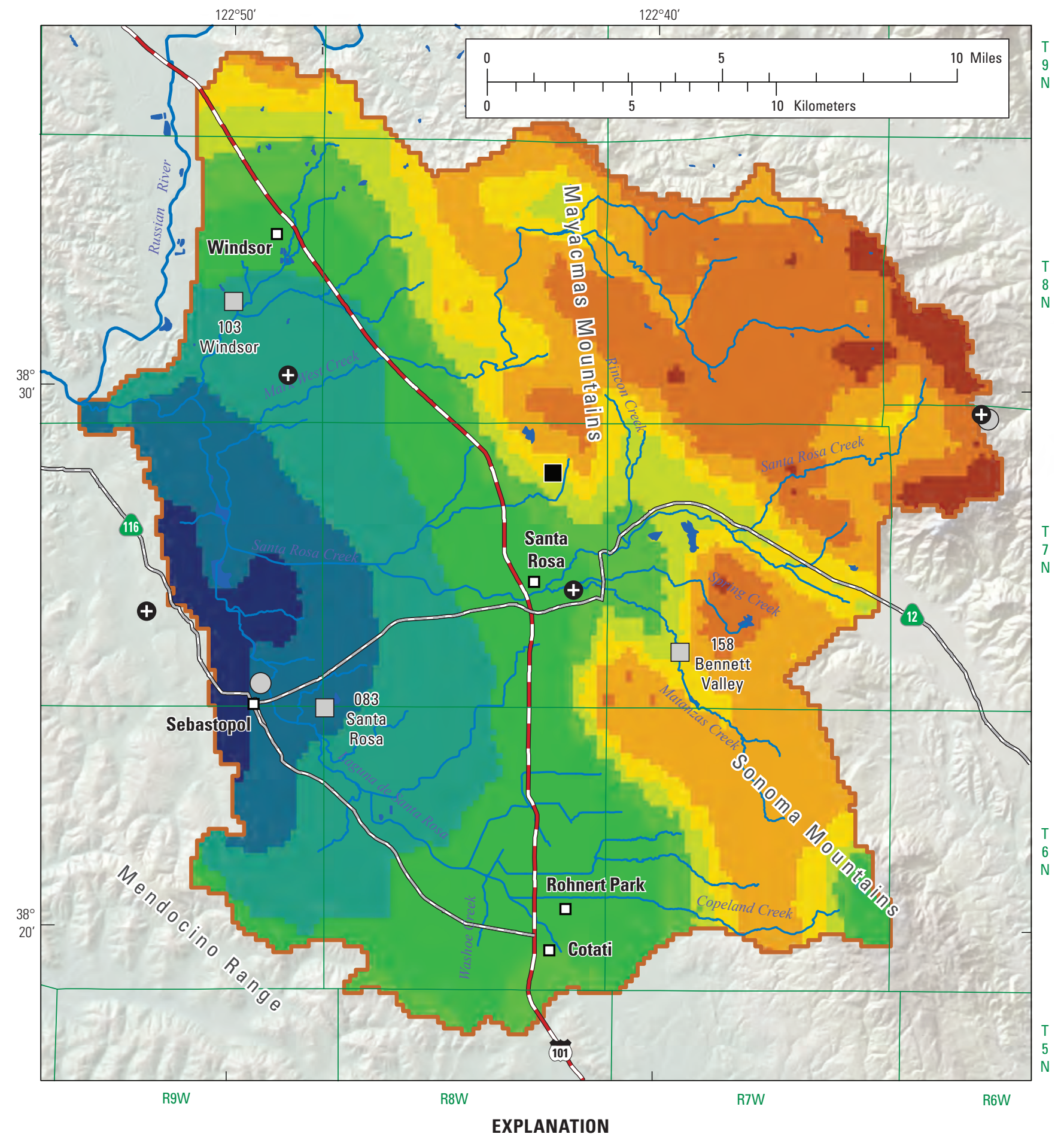

Spatially distributed average minimum temperature, water years 1950-2010, in degrees Fahrenheit

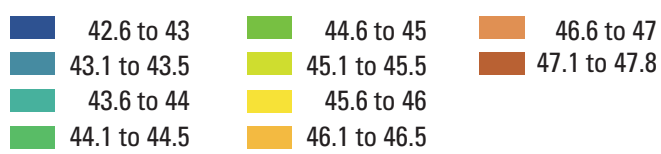

EXPLANATION

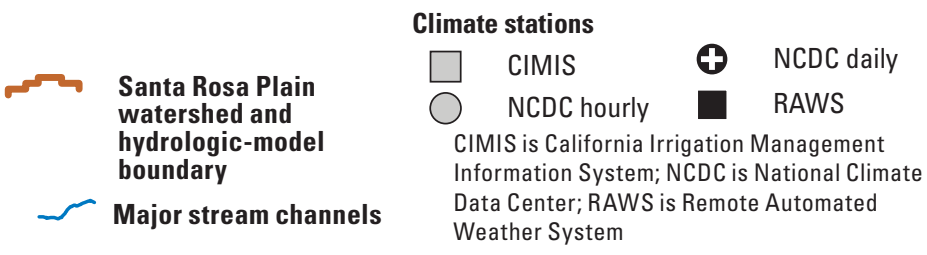

Figure 15. Spatially distributed averaged annual minimum daily air temperature, calculated using the daily air temperature inputs for the Santa Rosa Plain hydrologic model, water years 1950-2010, Santa Rosa Plain watershed, Sonoma County, California. 
PRMS requires a large set of parameters (see Markstrom and others, 2008), and in the SRPHM, there are 73 parameters that define basin-wide and HRU characteristics; however, two basin-wide and 10 spatially varying (HRU) critical parameters were identified during the calibration. The two critical basin-wide parameters, dday_slope and jh_coef, vary monthly. The dday_slope parameter defines the slope of monthly degree-day to temperature relation and affects simulated SWRAD. The jh_coef parameter is a monthly air-temperature coefficient that is used by the Jensen-Haise method in PRMS to simulate PET (Markstrom and others, 2008). PET is calibrated by adjusting this coefficient. The basin-wide parameters are adjusted uniformly (increased or decreased) on a monthly basis during model calibration.

The 10 critical, spatially varying HRU parameters are (1) soil_moist_max, (2) soil_rechr_max, (3) sat_threshold, (4) carea_max, (5) smidx_coef, (6) smidx_exp, (7) hru_percent_imperv, (8) slowcoef_lin, (9) slowcoef_sq, and (10) ssr2gw_rate. The HRU parameters are assumed to be temporally invariant. Estimates of the non-critical parameters were based on default values published in the GSFLOW manual (Markstrom and others, 2008).

The parameters soil_moist_max, sat_threshold, carea_max, smidx_coef, smidx_exp, slowcoef_lin, and slowcoef_sq represent soil characteristics that control soil storage, surface runoff, and interflow. Soil Survey Geographic database (SSURGO) soils data (U.S. Department of Agriculture, 2007) were used to develop initial estimates for these parameters.

The soil_moist_max parameter defines the storage capacity of the capillary reservoir in the soil zone, which strongly affects the magnitude of simulated ET. Preliminary estimates of soil_moist_max made using only SSURGO data resulted in inaccurate spatial distribution of simulated ET, which then resulted in higher simulated streamflow in the uplands. Therefore, additional data, such as vegetation type (including agricultural land use), canopy cover, slope, and soil thickness, were used to augment the SSURGO data, which resulted in improved simulation of ET and, consequently, streamflow. PRMS cannot simulate time-varying land-use; therefore, it was assumed that a 2001 land-use map (Homer and others, 2004) was representative of average land use for the simulation period. The soil_rechr_max parameter controls bare soil evaporation and is used to partition capillary reservoirs into an upper zone that stores water available for evaporation and transpiration and into a lower zone that stores water available for transpiration only. If the value is zero, evaporation does not occur, and total soil-zone ET will decrease.
The sat threshold parameter describes the maximum soil storage capacity. The spatial distribution of the sat_threshold parameter was defined by multiplying soil thickness by saturated soil-water content.

The carea_max parameter describes the maximum fraction of area contributing to runoff for each HRU and affects runoff generation, with greater values resulting in more runoff. The smidx_coef parameter controls the rate of Hortonian runoff generation in conjunction with the carea_max parameter. If both the carea_max and smidx_coef values are high, runoff generation is maximized and soil infiltration is minimized. The spatial distribution of smidx_coef was defined by using a combination of soil permeability (as defined on the basis of SSURGO data) and imperviousness percentage, assuming that soils tend to be more compacted in urbanized and developed areas. The smidx_exp parameter controls, in conjunction with the carea_max and smidx_coef parameters, the runoff generation rate for pervious areas in response to rainfall. The hru_percent_imperv parameter also influences surface runoff and infiltration within an HRU. This parameter effectively removes the soil zone from the covered area, and any precipitation will become runoff. It was assumed that paved surfaces had some storage capacity where the stored water is available for evaporation.

The slowcoef_lin parameter controls the rate of slow interflow through the soil zone, with greater values resulting in faster interflow rates. The spatial distribution of slowcoef_lin was defined by using slope, with greater values corresponding to steeper slopes. The slowcoef_sq parameter, with slowcoef_lin, controls slow interflow. Similar to slowcoef_lin, this parameter was adjusted on the basis of slope with greater values corresponding to steeper slopes.

The parameters soil_rechr_max and ssr2gw_rate represent surface-geology characteristics that control the rates of net infiltration, groundwater discharge to stream segments, and the fraction of net infiltration contributing to recharge. Preliminary values were based on surface-geology data, which included mapped hydrogeologic formations and the associated texture class (Sweetkind and others, 2010). The ssr2gw_rate parameter controls the rate of recharge to the groundwater reservoir in PRMS-only simulations and the rate of net infiltration through the soil zone and into the unsaturated zone for GSFLOW coupled simulations, with larger values resulting in more recharge or higher rates of net infiltration. 


\section{References Cited}

Cal-Atlas, 2007, CalWater version 2.2.1-InlandWaters: Sacramento, Calif., State of California Geoportal, accessed September 7, 2007, http://atlas.ca.gov/download.html\#/ casil/inlandWaters.

California Data Exchange Center, 2011, Station Meta Data: Santa Rosa: Sacramento, Calif., State of California, Department of Water Resources, accessed February 28, 2011, http://cdec.water.ca.gov/cgi-progs/staMeta?station $i d=S R O$.

California Irrigation Management Information System, 2005, Meteorological data: Sacramento, Calif., California Department of Water Resources and University of California at Davis, http://www.cimis.water.ca.gov/.

Chow, V.T., Maidment, D.R., and Mays, L.W., 1988, Applied hydrology: New York, McGraw-Hill, 572 p.

Daly, Christopher, Gibson, W.P., Doggett, Matthew, Smith, Joseph, and Taylor, George, 2004, Up-to-date monthly climate maps for the conterminous United States: American Meteorological Society Conference on Applied Climatology, 14th, Seattle, Wash., 2004, January 13-16, 2004, Proceedings, Paper P5.1, http://www.prism.oregonstate. edu/pub/prism/docs/appclim04-uptodate_monthly_climate_ maps-daly.pdf.

EarthInfo, Inc., 2011, National climate data center summary of the day-West: Boulder, Colo., EarthInfo, Inc., CD ROM West 1.

Ely, D.M., and Kahle, S.C., 2012, Simulation of groundwater and surface-water resources and evaluation of watermanagement alternatives for the Chamokane Creek basin, Stevens County, Washington: U.S. Geological Survey Scientific Investigations Report 2012-5224, 74 p.

Hevesi, J.A., Flint, L.E., Church, C.D., and Mendez G.O., 2011, Application of a watershed model (HSPF) for evaluating sources and transport of pathogen indicators in the Chino Basin drainage area, San Bernardino County, California: U.S. Geological Survey Scientific Investigations Report 2009-5219, $146 \mathrm{p}$.

Homer, Collin, Huang, Chengquan, Yang, Limin, Wylie, Bruce, and Coan, Michael, 2004, Development of a 2001 national land cover database for the United States: Photogrammetric Engineering and Remote Sensing, v. 70, no. 7, p. 829-840, www.mrlc.gov/pdf/July_PERS.pdf.

Leavesley, G.H., Lichty, R.W., Troutman, B.M., and Saindon, L.G., 1983, Precipitation-runoff modeling system-User's manual: U.S. Geological Survey Water-Resources Investigations Report 83-4238, 207 p.
Linsley, R.K. Jr., Kohler, M.A., and Paulhus, L.H., 1982, Hydrology for engineers: New York, McGraw-Hill, 508 p.

Markstrom, S.L., Niswonger, R.G., Regan, R.S., Prudic, D.E., and Barlow, P.M., 2008, GSFLOW-Coupled groundwater and surface-water flow model based on the integration of the Precipitation-Runoff Modeling System (PRMS) and the Modular Ground-Water Flow Model (MODFLOW-2005): U.S. Geological Survey Techniques and Methods 6-D1, 240 p.

Nishikawa, Tracy, Hevesi, J.A., Sweetkind, D.S., and Martin, P., 2013, Conceptual model of the Santa Rosa Plain hydrologic system, chap. D of Nishikawa, Tracy, ed., Hydrologic and geochemical characterization of the Santa Rosa Plain watershed, Sonoma County, California: U.S. Geological Survey Scientific Investigations Report 2013-5118, p. 7-26.

Niswonger, R.G., Panday, Sorab, and Ibaraki, Motomu, 2011, MODFLOW-NWT, A Newton formulation for MODFLOW-2005: U.S. Geological Survey Techniques and Methods 6-A37, $44 \mathrm{p}$.

O'Callaghan, J.F., and Mark, D.M., 1984, The extraction of drainage networks from digital elevation data: Computer Vision, Graphics and Image Processing, v. 28, p. 328-344.

Remote Automated Weather System, 2011, RAWS USA climate archive: Reno, Nev., Western Regional Climate Center, accessed June 15, 2011, http://www.raws.dri.edu/.

Simley, J.D., and Carswell, W.J., Jr., 2009, The national map-Hydrography: U.S. Geological Survey Fact Sheet 2009-3054, 4 p, http://pubs.usgs.gov/fs/2009/3054/pdf/ FS2009-3054.pdf.

Sweetkind, D.S., Taylor, E.M., McCabe, C.A., Langenheim, V.E., and McLaughlin, R.J., 2010, Three-dimensional geologic modeling of the Santa Rosa Plain, California: Geosphere, v. 6, p. 237-274.

U.S. Department of Agriculture, 2007, Natural resources conservation service, soil survey geographic (SSURGO) database for Sonoma County, California: Washington D.C., U.S. Department of Agriculture, Natural Resources Conservation Service, accessed on May 14, 2009, at http://soildatamart. nrcs.usda.gov.

U.S. Geological Survey, 2001, The national map seamless server database: U.S. Geological Survey, accessed January 15, 2008, at http://nationalmap.gov/viewer.html. 


\section{Chapter C. Groundwater- Component Model}

\author{
By Linda R. Woolfenden
}

\section{Introduction}

The construction of the groundwater-component of the Santa Rosa Plain hydrologic model (SRPHM) is described in this chapter. The groundwater-component model was developed by using the MODFLOW-NWT (MF-NWT; Niswonger and others, 2011). The MF-NWT is a modification to MODFLOW-2005 (MF-2005; Harbaugh, 2005) that provides an alternative Newton solver for the groundwater-flow equation. The MF-NWT is a block-centered, finite-difference model that simulates groundwater flow in a three-dimensional, heterogeneous, and anisotropic medium, provided the fluid has constant density (Niswonger and others, 2011).

Following Markstrom and others (2008), Nishikawa and others (2013a) conceptualized the hydrologic system of the Santa Rosa Plain watershed (SRPW) as having three regions: region 1 consists of the plant canopy, the land surface, and the soil zone; region 2 consists of streams; and region 3 is the subsurface that consists of an unsaturated zone (UZ) and an underlying saturated zone (chapter $A$, fig. 8). The groundwater-component model is based on the conceptualization of regions 2 and 3 . Inflow to the unsaturated zone is infiltration from the overlying soil zone in region 1 and from overlying streambeds in region 2 . The primary outflow from the UZ is recharge to the saturated zone, which depends directly on the magnitude and distribution of the vertical permeability of the deposits in the unsaturated zone. Important hydrologic characteristics that control flow through the saturated zone include those that reflect the ability of the groundwater system to transmit and store (uptake and release) water; those that allow for vertical passage of water between stratigraphic units; and those that control the flow of water across geologic structures or hydrologic boundaries. The movement of water through the saturated groundwater system is influenced by aquifer-system geometry, aquifer and aquitard properties, geologic structures, and the magnitude and distribution of recharge and discharge, including pumping (Nishikawa and others, 2013a). This chapter describes the development of the groundwater-component model by using the MF-NWT. Groundwater-component development includes defining the model discretization and boundaries, properties that represent the physical characteristics of the subsurface, flow processes, sources of inflow, and components of outflow.
The principal water-bearing strata simulated in the SRPHM include Tertiary and Quaternary sediments and sedimentary rocks underlying the Santa Rosa Plain (SRP) floor to depths of at least 1,500 ft and permeable zones in Tertiary volcanic rocks in contact with the sedimentary section along the valley margin and interfingered with it beneath the valley floor. The Tertiary material includes the Glen Ellen, Wilson Grove, and Petaluma Formations and the Sonoma Volcanics (chapter A, fig. 5). Geologic materials within the depth range perforated by wells are most commonly fine-grained or poorly sorted sediments that have low hydraulic conductivities and specific yields, which result in low to modest well yields and large drawdowns. In most parts of the study area, shallow groundwater flow is unconfined, but, at depth, groundwater flow is confined. The presence of fine-grained material, either as interbeds within coarser-grained materials or as thick, but not laterally extensive beds, imparts anisotropic hydraulic characteristics typical of layered systems (Sweetkind and others, 2013).

\section{Model Discretization}

The SRPHM domain was based on the SRPW, as defined by Nishikawa and others (2013b), and is shown in figure 1 . The groundwater-component model contains a rectangular grid with uniform grid spacing that is the same as the discretization of hydrologic response units (HRUs) in the watershed-component model. The grid-cell size is $660 \mathrm{ft}$ by $660 \mathrm{ft}$ (10 acres), with a total of 168 rows and 157 columns (fig. 1); there are 16,741 active cells in each of the 8 layers in the model. The horizontal discretization is the same as was used by the textural stratigraphic (strat-text) model described by Sweetkind and others (2010) and is used to assign hydraulic properties to each model cell. Within each cell of the groundwater-component model, the hydraulic properties are homogeneous.

The vertical discretization of the groundwater component of the SRPHM was initially the same as layers 1-14 in the strat-text model with a depth of 2,000 ft (Sweetkind and others, 2010). Layers 15 and 16, as defined by Sweetkind and others (2010), were omitted from the SRPHM because it was assumed that the depth of these layers $(2,000-3,000 \mathrm{ft})$ was below the active groundwater-flow system. Because of numerical instabilities, the number of layers was reduced to eight, and the layers were redefined. The range of thickness for each layer of the final eight-layer model for the Santa Rosa Plain area and uplands is given in table 1. 


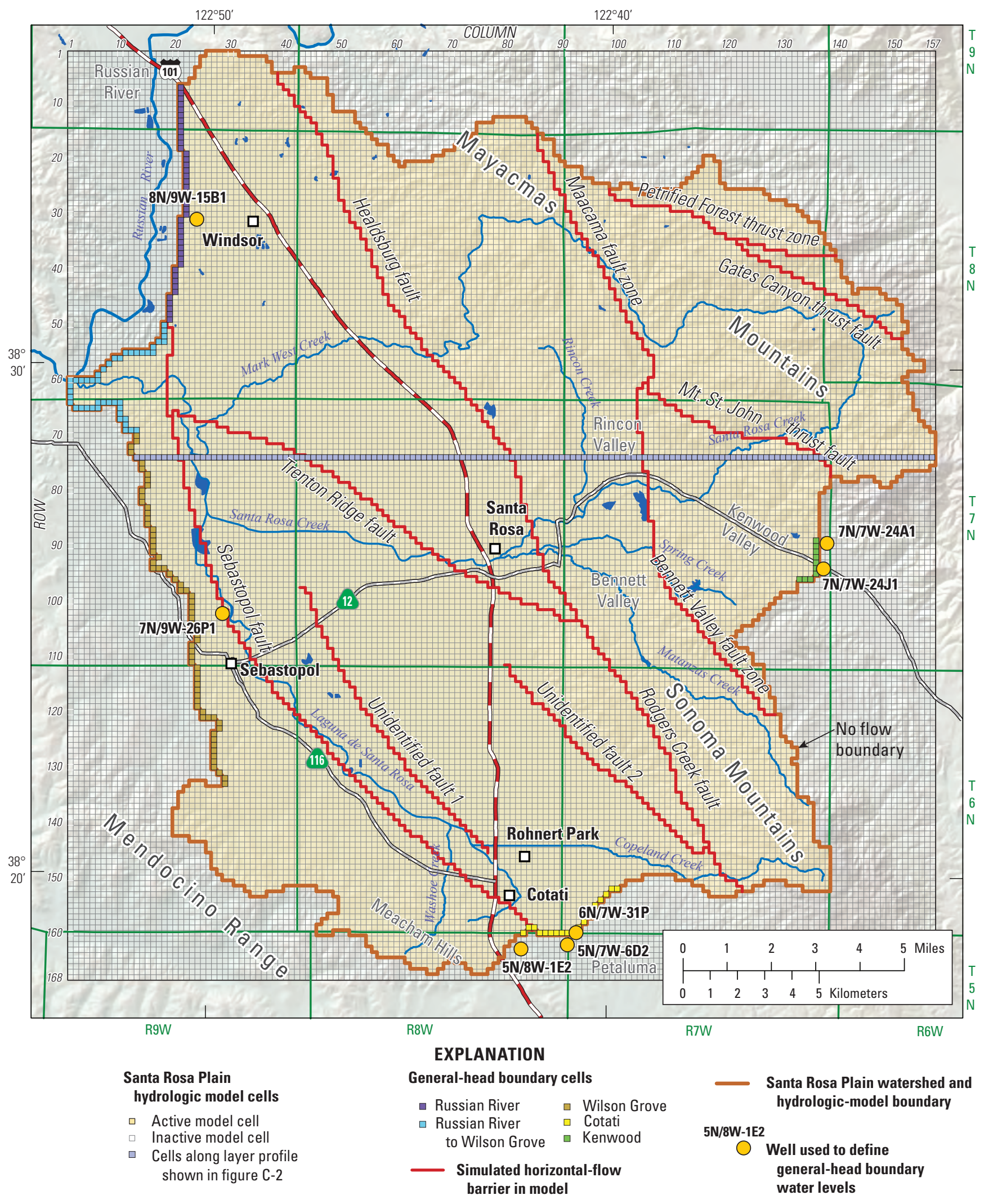

Figure 1. Model grid, boundary conditions, profile row, and location of horizontal-flow barriers in the groundwater component of the Santa Rosa Plain hydrologic model, Santa Rosa Plain watershed, Sonoma County, California. 
Table 1. Layer thickness in the Santa Rosa Plain hydrologic model, Santa Rosa Plain watershed, Sonoma County, California.

\begin{tabular}{ccc}
\hline \multicolumn{3}{c}{ Thickness (feet) } \\
\hline Layer & Santa Rosa Plain area & Uplands \\
\hline 1 & $90-305$ & $91-1,480$ \\
2 & $50-146$ & $50-534$ \\
3 & 150 & 150 \\
4 & 150 & 150 \\
5 & 150 & 150 \\
6 & 150 & 150 \\
7 & 500 & 500 \\
8 & 500 & 500 \\
\hline
\end{tabular}

${ }^{1}$ Includes the Santa Rosa Plain, Rincon Valley, and part of Kenwood Valley.

A profile of layer thickness, depth, and boundary conditions for row 74 in the groundwater-component model is shown in figure 2. The highest elevation in each cell of the UZ defines the elevation at the top of layer 1 in the groundwatercomponent model. The top of the UZ is calculated by subtracting the thickness of the soil zone, which is part of the watershed-component model, from the digital-elevation model (DEM) value for each cell in the model domain. The thicknesses for layers 1 and 2 were calculated differently for the SRP and for the uplands. For the SRP, the lowest elevation in layer 1 was calculated by subtracting the thickness of layer 1 from the top of the UZ, and the lowest elevation for layer 2 was calculated by subtracting the thickness of layer 2 from the lowest elevation of layer 1 . The lowest elevations in layers 1 and 2 in the uplands, and near the boundary between the SRP and uplands, were smoothed by using a moving average to avoid inverted topography in the subsurface, which resulted in variable thicknesses for these layers. The thickness of layer 1 for the final model ranged from 90 to $305 \mathrm{ft}$ in the SRP area and from 91 to $1,480 \mathrm{ft}$ in the uplands (figs. 2, 3A, table 1). The thickness of layer 2 ranged from 50 to $146 \mathrm{ft}$ in the SRP area and from 50 to $534 \mathrm{ft}$ in the uplands (table 1; figs. 2, 3B). The lesser values in the uplands for both layers are in valleys where most of the pumping occurs. The thicknesses of layers 3-8 were constant for each layer and the lowest elevations were calculated by subtracting the layer thickness from the lowest elevations of the overlying layer (fig. 2). The thicknesses are $150 \mathrm{ft}$ for layers $3-6$ and $500 \mathrm{ft}$ for layers $7-8$ (table 1).

\section{Model Boundary Conditions}

Model boundary conditions mathematically define the interaction of the model with locations and associated hydrologic conditions outside of the model. Various types of boundary conditions allow for flow through boundaries, either in specified amounts or at rates dependent on the hydraulic gradient across the boundary. The horizontal boundaries and bottom of this model were defined by either specified-flux or head-dependent boundary conditions. Model stresses, which can affect flow across head-dependent boundaries, are discussed later in this chapter.

\section{No-Flow Boundary Conditions}

No-flow boundary conditions are a type of specified-flux boundary in which the flux is zero, indicating no exchange of water between the model cell and the domain outside the model. No-flow boundaries were used around the modeled area to represent groundwater divides. No groundwater moves across divides, but they are subject to changes in location with changes in hydrologic stresses; flow can be induced as the divide changes location with changing stresses. Flow across groundwater divides were assumed to be static and negligible in this model. The lateral boundaries of the groundwatercomponent model coincided with the SRPW boundary in GSFLOW. It was assumed that about 75 percent of the SRPW boundary has no-flow boundaries that satisfy this constraint (fig. 1). The bottom of the lowest model layer (layer 8) was assumed to correspond to the depth of the active groundwaterflow system, and the geologic units below this depth were assumed to transmit only small amounts of water; therefore, a no-flow boundary condition was used to represent the contact with these deeper units (fig. 2).

\section{Head-Dependent Boundary Conditions}

A general-head boundary condition simulates a source of water outside the model area that either supplies water to, or receives water from, the adjacent cells at a rate proportional to the hydraulic-head differences between the external source (specified head) and the model cell (simulated head). The rate of flow through a general-head boundary is regulated by a specified hydraulic conductance, which is described in more detail in chapter $D$ of this report. Lateral boundaries of the SRPHM that could have interaction with areas outside the model domain were simulated by using the general-head boundary (GHB) package (Harbaugh, 2005). 


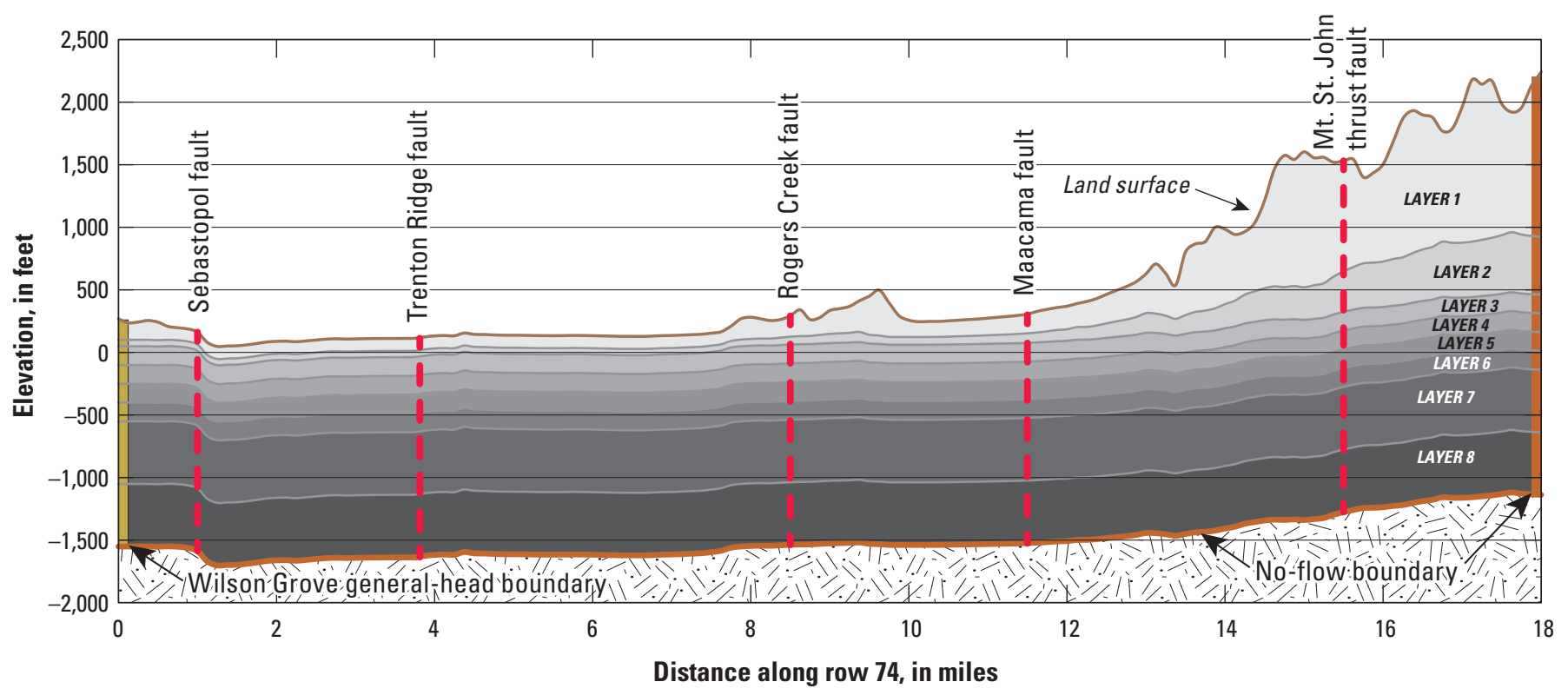

Figure 2. Profile along row 74 in the groundwater component of the Santa Rosa Plain hydrologic model, Santa Rosa Plain watershed, Sonoma County, California. 


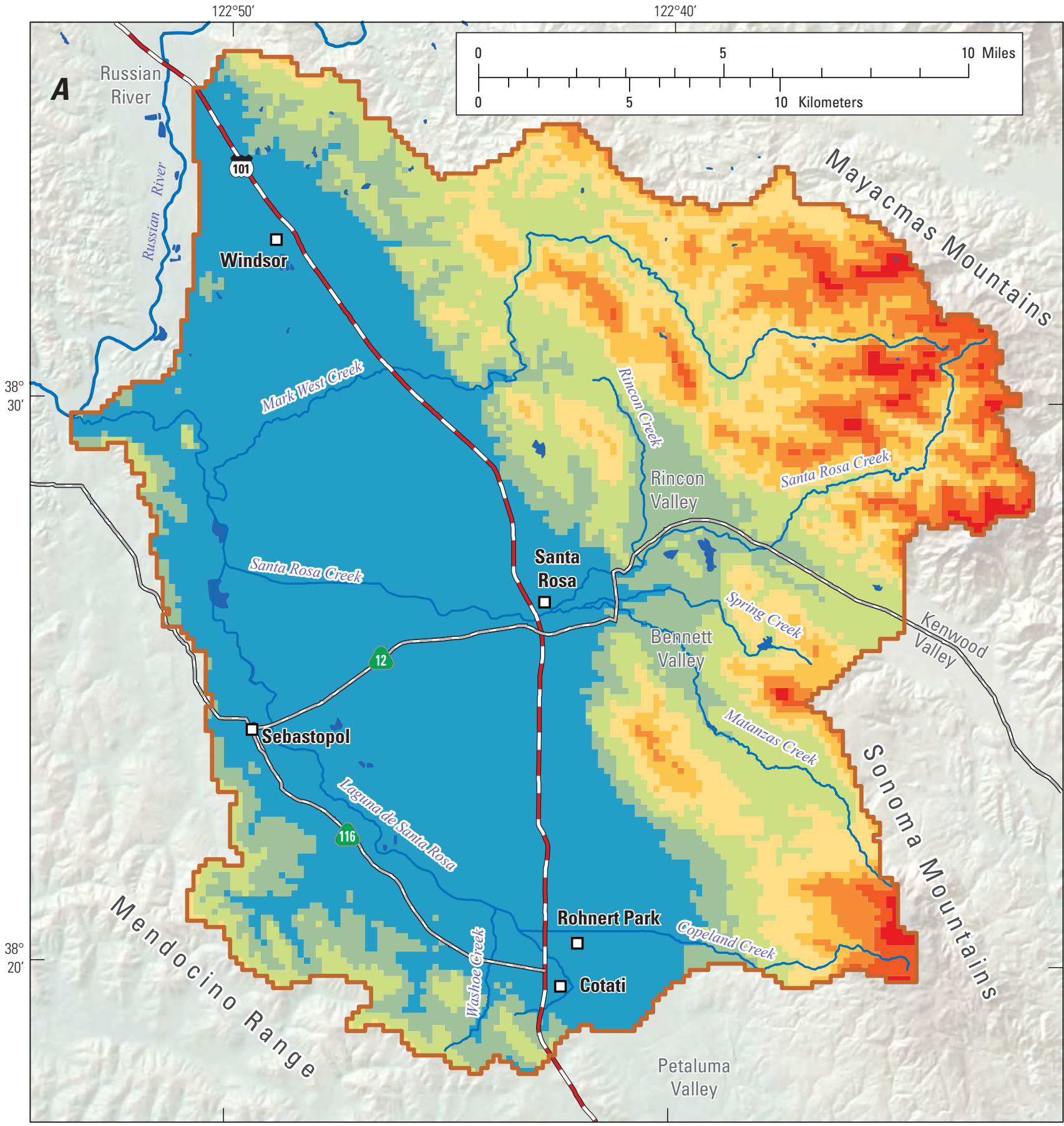

EXPLANATION

Thickness of model layer 1 , in feet

\begin{tabular}{|r|r|r|r|r|r|}
90 to 100 & $>600$ to 800 \\
$>100$ to 200 & $>800$ to 1,000 \\
$>200$ to 400 & $>1,000$ to 1,200 \\
$>400$ to 600 & $>1,200$ to 1,480 \\
\hline
\end{tabular}

Santa Rosa Plain watershed and hydrologic-model boundary

Figure 3. Thickness of model layers and in the groundwater component of the Santa Rosa Plain hydrologic model, Santa Rosa Plain watershed, Sonoma County, California, for $A$, layer 1 and $B$, layer 2 . 


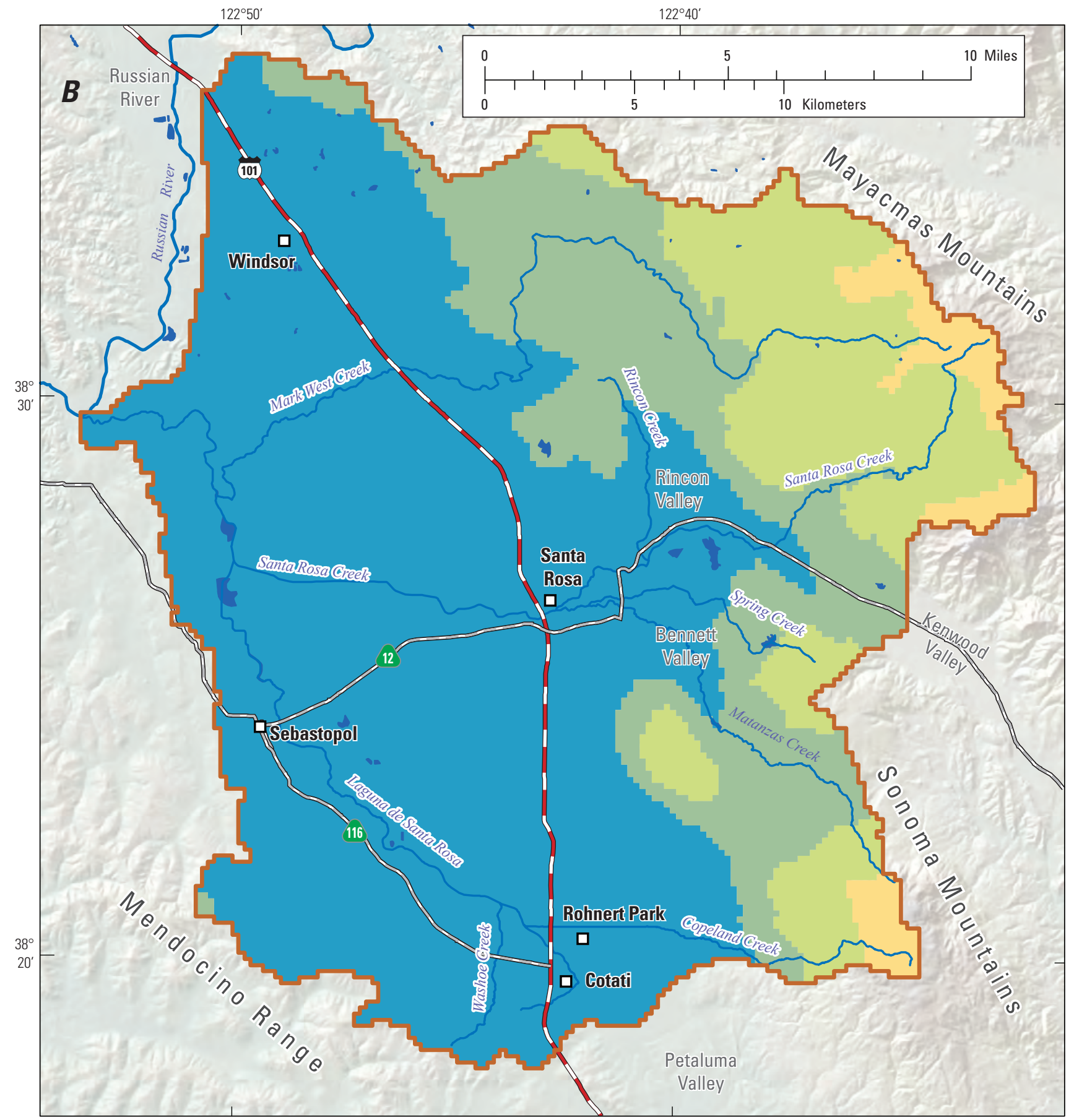

EXPLANATION

Thickness of model layer 2 , in feet

49 to 100

$>100$ to 200

$>200$ to 400

$>400$ to 535

Figure 3. - Continued 
The locations of general-head boundaries in this model are shown in figure 1. Some of the boundaries were in the shallow part of the permeable portions of the aquifer system: layers 1 and 3 at the Russian River boundary, and layer 1 at the Cotati and Kenwood boundaries. The Wilson Grove boundary was in all eight layers of the model (fig. 1). A general-head boundary was not assigned to layer 2 for the Russian River boundary because, in the vicinity of the boundary, the horizontal hydraulic conductivity of this layer is low; therefore, flow across the boundary in layer 2 is assumed to be minimal. An additional general-head boundary (Russian River to Wilson Grove) was added during calibration of the transient model and is described in chapter $D$ of this report. Limited water-level data for water years 1975-2010 were available to define the temporal variation of the general-head boundary heads (fig. 1). The boundary cells in layers not specified as general-head boundaries were designated as no-flow boundaries.

To represent the gradient out of the model, the boundary heads were estimated to be lower than the approximate lowest water levels in wells with temporal water-level data in the vicinity of the Russian River and Wilson Grove boundaries. For the Russian River boundary, the boundary head was determined from water levels in well 8N/9W-15B1 (figs. 1, 4A) and assigned a value of $40 \mathrm{ft}$, except where the boundary head was below the lowest elevation for the boundary cell. In these 24 cells (out of a total of 86 cells), boundary heads were adjusted and assumed to be $20 \mathrm{ft}$ above the lowest elevation of layer 1 for both layers 1 and 3 .

The boundary heads for the Wilson Grove boundary were determined from water levels in well 7N/9W-26P1 (figs. 1, 4B); a value of $25 \mathrm{ft}$ was assigned in all eight layers. The general-head boundary was included in all eight layers because the Wilson Grove Formation extends to the Pacific Ocean, well logs indicate that this stratigraphic unit is relatively permeable, and layers 7 and 8 contain the Wilson Grove Formation throughout their thickness. Where the assumed boundary heads were below the lowest elevation of the boundary cell, which was true for all cells in layers 1 and 2, the boundary heads were assumed to be $20 \mathrm{ft}$ above the lowest elevation of the cell in each layer. Boundary heads were adjusted in this manner for 138 cells in these two layers.

Water-level data were sparse in the vicinity of the Cotati boundary; therefore, pre-1975 water-level data collected from drillers' logs for wells outside the SRPHM domain, but close to the boundary (fig. 1), were used for boundary heads. It was assumed that there were no long-term trends in water levels in the vicinity of this boundary. The water levels in wells 5N/8W-1E2, 5N/7W-6D2, and 6N/7W-31P (fig. 1) were 131,94 , and $85 \mathrm{ft}$, respectively. The heads in the cells between the wells followed linear slopes.

The boundary heads for the Kenwood boundary were defined by the average water levels in wells $7 \mathrm{~N} / 7 \mathrm{~W}-24 \mathrm{~A} 1$ and 7N/7W-24J1 (figs. 1, 5). Although there was a trend of declining values in the data for well 7N/7W-24A1, it was assumed that, because the boundary is a groundwater divide, flow across it was minimal; hence, average values for the period of record were used for each well. The average water level in well 7N/7W-24A1 for 1980-2011 (507 ft) defined the head at the eastern end of the boundary, and the average water level in well 7N/7W-24J1 for 1980-2001 (475 ft) defined the head in the middle of the boundary. The simulated 460 -ft waterlevel contour from the steady-state groundwater-flow model of Sonoma Valley (Farrar and others, 2006) that intersects the boundary was used as a guide to define the head at the western end of the boundary. The heads followed a linear slope between the wells, and simulated values ranged from 460 to $507 \mathrm{ft}$.

\section{Hydraulic Properties}

Hydraulic properties for the groundwater-component model (horizontal and vertical hydraulic conductivity, specific storage, and specific yield) affect the rate at which water moves through the aquifer and the rate and areal extent of changes in groundwater levels caused by groundwater pumping and recharge. Estimates of average hydraulic properties were assigned to the representative cell volume.

\section{Hydraulic Parameter Zonation}

Hydraulic parameter zones were defined by model storage units (MSUs) and hydrogeologic units (HGUs), and were the basis for distributing hydraulic properties to model cells. A parameter zone is comprised of the distribution of HGUs in a given MSU. The SRPW was divided into a total of 102 parameter zones (table 2), and the resulting hydraulicproperty distributions were input to the upstream-weighting (UPW) package (Niswonger and others, 2011) in GSFLOW. The UPW package is used for calculating all terms in the numerical formulation of the groundwater-flow equation and is an alternative to the block-centered flow, layer-property flow, and hydrogeologic unit flow packages (Niswonger and others, 2011).

Table 2. Number of parameter zones in layers 1-8 of the Santa Rosa Plain hydrologic model, Santa Rosa Plain watershed, Sonoma County, California.

\begin{tabular}{cc}
\hline Layer & Number of parameter zones \\
\hline 1 & 14 \\
2 & 13 \\
3 & 13 \\
4 & 13 \\
5 & 13 \\
6 & 12 \\
7 & 12 \\
8 & 12 \\
Total & 102 \\
\hline
\end{tabular}



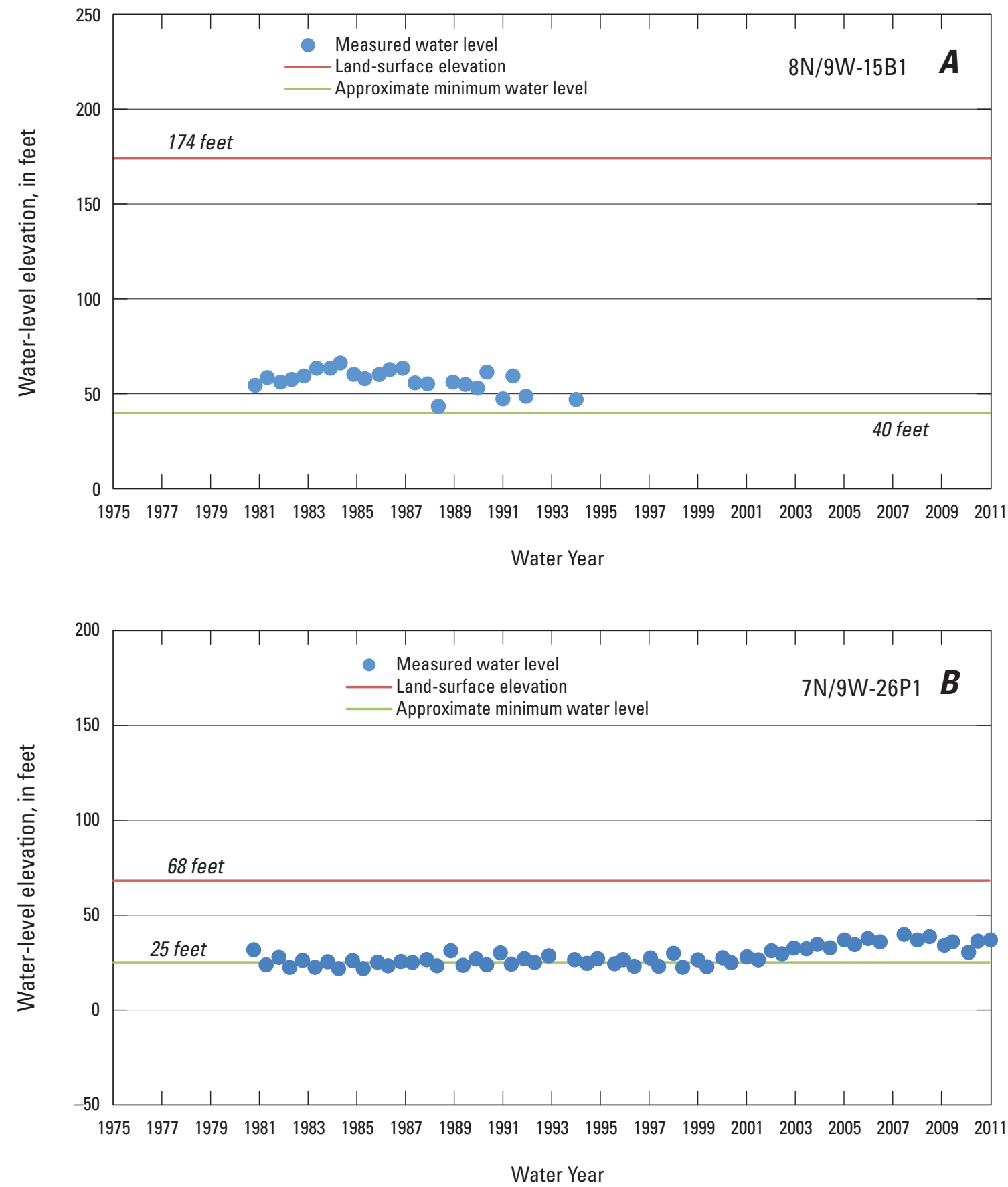

Figure 4. Water levels in wells used to estimate boundary heads in the groundwater component of the Santa Rosa Plain hydrologic model, Santa Rosa Plain watershed, Sonoma County, California: $A$, 8N/9W-15B1 for the Russian River boundary; and $B, 7 N / 9 W-26 P 1$ for the Wilson Grove boundary. 

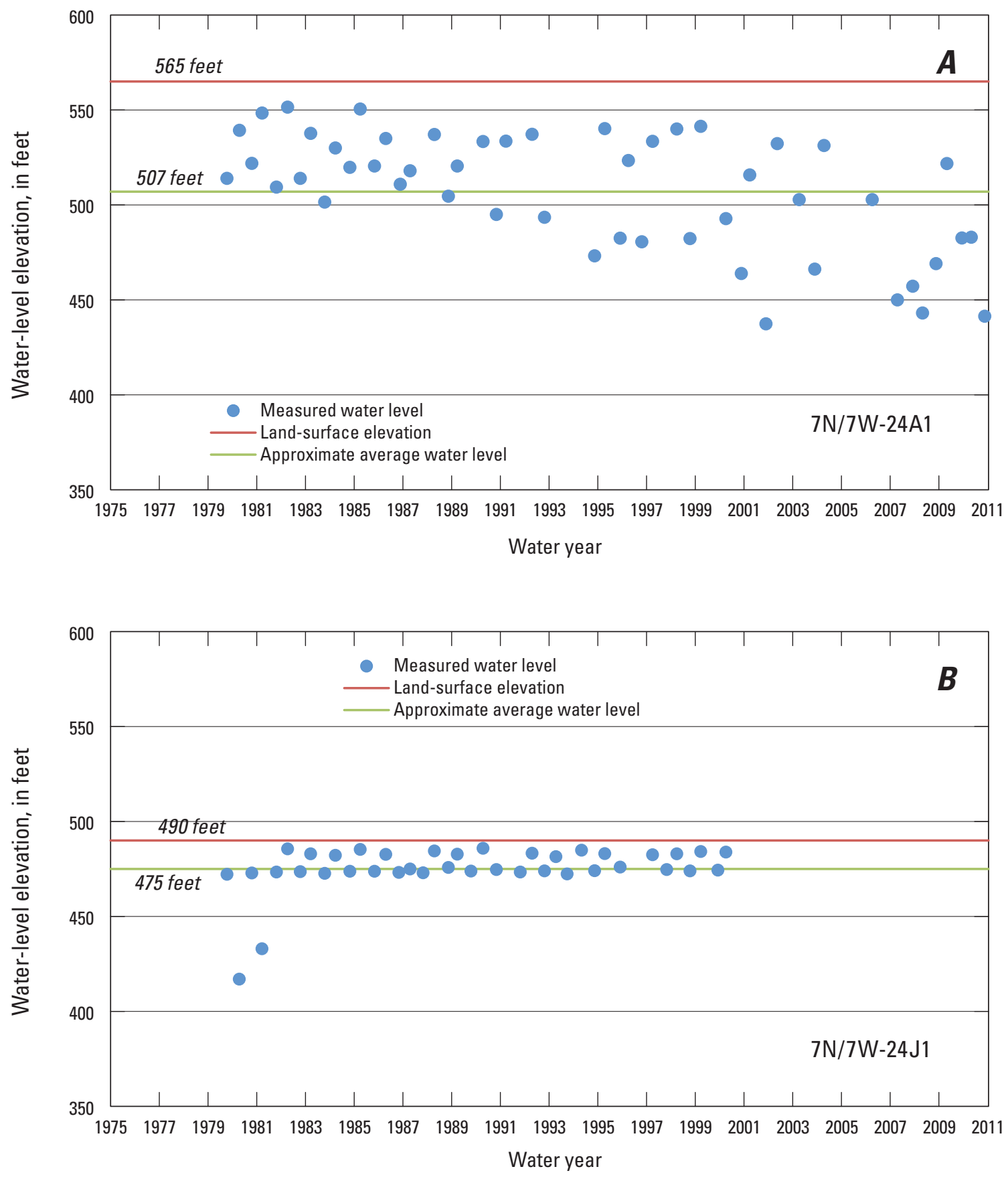

Figure 5. Water levels in wells used to estimate boundary heads in the groundwater component of the Santa Rosa Plain hydrologic model, Santa Rosa Plain watershed, Sonoma County, California, for the eastern end and the middle of the Kenwood boundary, respectively: $A, 7 \mathrm{~N} / 7 \mathrm{~W}-24 \mathrm{~A} 1$; and $B, 7 \mathrm{~N} / 7 \mathrm{~W}-24 \mathrm{~J} 1$. 


\section{Model Storage Units}

To aid in the calibration of hydraulic properties and boundary conditions in the model, the groundwater storage units (Windsor Basin, Cotati Basin, Wilson Grove, Valley, and Uplands) defined by Sweetkind and others (2013) were modified to define 12-14 MSUs for each model layer (table 2). For example, the distribution of MSUs for layer 1 is shown in figure 6. The uplands surrounding the SRP and Rincon and Kenwood Valleys were divided into distinct MSUs, even though the textural stratigraphic classifications defined by Sweetkind and others (2010) are the same as in the SRP. This was done in order to assign values for hydraulic properties to the upland units that reflect a greater degree of weathering than typically would be present in the SRP. In the uplands, the stream cells were designated as a separate MSU for layer 1 (fig. 6) in order to assign hydraulic properties to these model cells that are more consistent with the coarser aquifer material underlying stream channels than those assigned to the neighboring mountain cells and to allow for greater recharge from streams into the upland aquifer. The stream cells are not present in layers 2-8. The basement complex also was designated as a separate unit in all layers in order to assign hydraulic properties consistent with this unit. The number of parameter zones in layers $6-8$ is less than for the overlying layers (table 2) because the MSUs for the Sonoma Mountains and the Mayacmas Mountains in these layers were combined for simplicity.

\section{Hydrogeologic Units}

Hydrogeologic units (HGUs) were the basis for distributing horizontal hydraulic conductivity, vertical anisotropy, specific storage, and specific yield values to the model cells within each MSU. Each model cell in the SRPHM was assigned a single HGU. HGUs were defined by stratigraphic unit and textural properties. The stratigraphic units used in the strat-text model include the Glen Ellen Formation, Wilson Grove Formation, Sonoma Volcanics, Petaluma Formation, and basement complex. Each stratigraphic unit, except for the basement complex, is divided into textural classes. These classes include coarse-grained, intermediategrained, fine-grained, tuff, and basalt (Sweetkind and others, 2010). For HGUs with limited lithologic information, a class without texture assignment was given for each stratigraphic unit (Sweetkind and others, 2010). In the SRPHM, a texture assignment for these HGUs was made on the basis of the predominant texture of the stratigraphic unit. This combination of stratigraphy and texture, including HGUs without texture assignments, resulted in 25 HGUs.

\section{Hydraulic Conductivity}

MF-NWT requires specification of horizontal and vertical hydraulic-conductivity values for each active cell in the model domain. The initial horizontal hydraulic conductivity (HK) distribution for the model was estimated from published values associated with the stratigraphic and lithologic descriptions of the HGUs (Freeze and Cherry, 1979). The final HK values decreased with depth to reflect increasingly consolidated conditions. Most of the model layers in the SRPHM are thicker than those in the strat-text model; hence, the HK values assigned to multiple HGUs for each model layer were arithmetically averaged when the number of model layers was reduced (see "Model Discretization" section of this chapter). The resulting HK distributions became multiplier arrays that were multiplied by a factor (parameter value) for each MSU. The HK values were adjusted by MSU during calibration of the SRPHM; the final HK distributions are given in chapter $D$ of this report.

The vertical hydraulic conductivity (VK) for each model layer is computed in the model by dividing the arithmeticallyaveraged HK values by vertical anisotropy (VANI), where VANI is the vertical anisotropy and is defined as the ratio of HK to VK. For example, a VANI of 10 means that the HK is 10 times greater than the VK. Ideally, the harmonic mean or the lowest HK value would be used to determine VK because the lowest value of VK tends to control vertical flow through a unit, and the arithmetic mean weights the highest $\mathrm{HK}$ values which would yield higher VK values. In the SRPHM, the arithmetically averaged HK values were used for simplicity. The VANI distribution in the groundwater-component model is determined for each MSU in the model during calibration. For example, every cell in the Windsor MSU in a model layer will have the same VANI value. Since the HK distributions vary spatially according to texture (HGU) within each MSU in the SRP, and according to stratigraphy in the uplands, the computed VK values will vary in the same manner.

\section{Storage Properties}

The specific yield (SY) and specific storage (SS) are defined for each cell in the model domain. SY is the volume of water that an unconfined aquifer releases from or takes into storage for each unit of surface area of aquifer for each unit of change in hydraulic head in the water table (Freeze and Cherry, 1979), and SS is the volume of water that a unit volume of confined aquifer releases from or takes into storage for each unit of change in hydraulic head in the confined aquifer. The SY, which represents gravity drainage following a decline in the water table, typically, is orders of magnitude larger than the SS and is the dominant storage parameter volumetrically per unit thickness of aquifer material. 


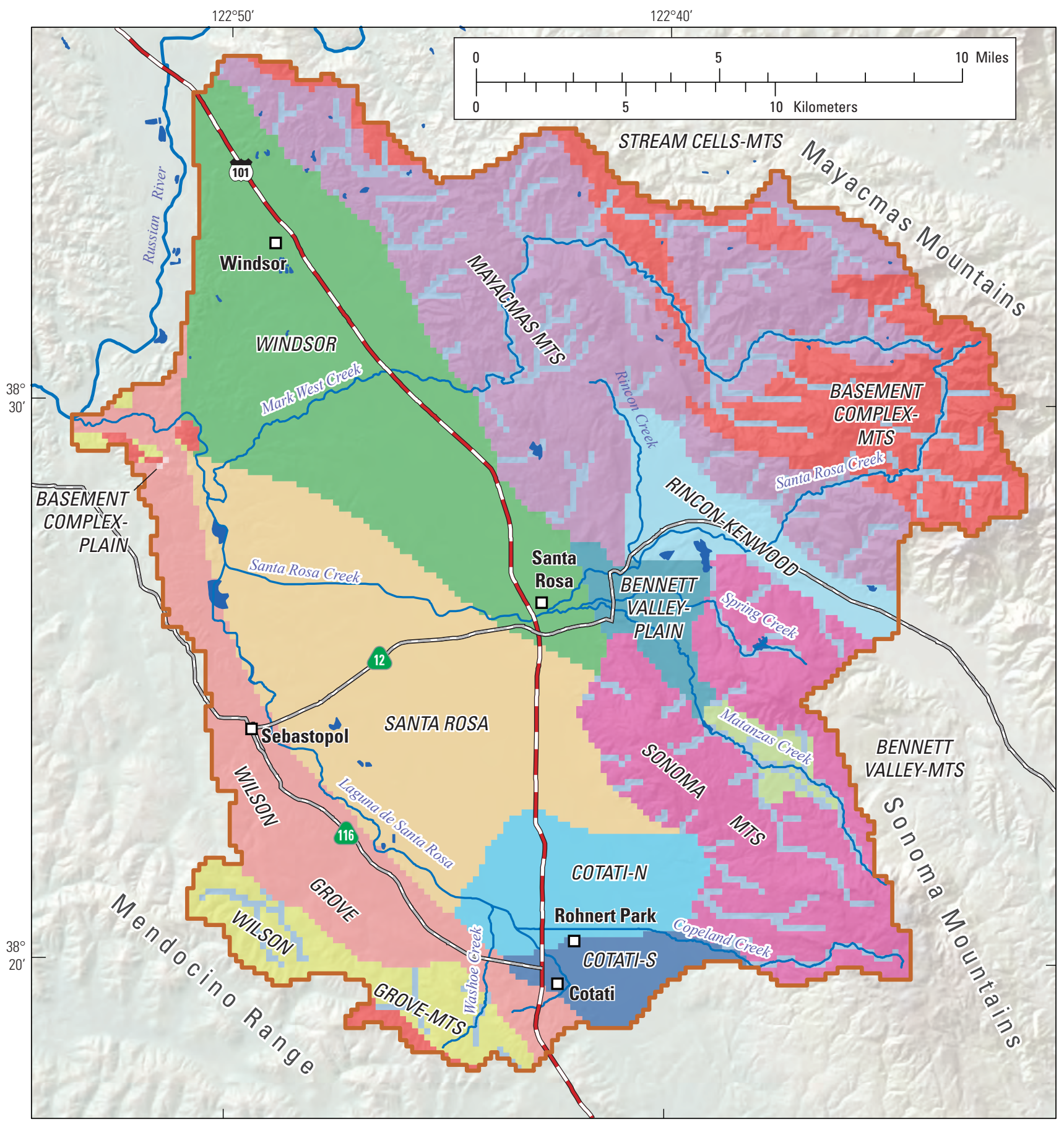

EXPLANATION

Model storage unit

Windsor

Santa Rosa

Cotati-north (Cotati-N)

Cotati-south (Cotati-S)

Rincon-Kenwood
Bennett Valley-plain

Wilson Grove

Basement Complex-plain

Mayacmas Mountains

Bennett Valley-mountains
Sonoma Mountains

Wilson Grove-mountains

Basement Complex-mountains

Mountain-stream cell

in model-separate

storage unit in layer 1
_ Santa Rosa Plain

watershed and hydrologic-model boundary

Figure 6. Model storage units in the groundwater component of the Santa Rosa Plain hydrologic model, Santa Rosa Plain watershed, Sonoma County, California. 
In the UPW package, model layers can be defined as either confined or convertible (Niswonger and others, 2011). In convertible layers, a confined layer becomes unconfined when the head declines below the top of the layer. The SY is used when simulating unconfined (water-table) conditions typical of model layer 1 . All the layers in the groundwatercomponent model of the SRPHM were designated as convertible, thus, SY was defined for all layers, but not necessarily used.

The initial SY distributions were based on values reported by Cardwell (1958), California Department of Water Resources-Central District (1979), and Herbst and others (1982). These values were associated with the stratigraphic and lithologic descriptions of the HGUs. It was assumed that, generally, the SY values in the uplands were lower than those in the SRP. The SY values were arithmetically averaged in the same manner as the HK values when the number of model layers was reduced (see "Model Discretization" section), and the resulting SY distributions became multiplier arrays that were multiplied by a factor (parameter value) for each MSU. It was assumed that SY does not decay with depth. The SY distributions were adjusted by MSU during calibration, and the final values are described in chapter $D$ of this report.

The initial SS distributions were based on the storage coefficients reported by Kadir and McGuire (1987); however, because specific storage is the ratio of the storage coefficient and thickness, the values were not used directly in the model. That is, greater values were associated with coarser lithologic textures of the HGUs, and the lesser values associated with finer lithologic textures; the values then were reduced by as much as five orders of magnitude. It was assumed that the SS values in the uplands were similar to those in the SRP. The SS values were arithmetically averaged in the same manner as the HK values when the number of model layers were reduced, and the resulting SS distributions became multiplier arrays that were multiplied by a factor (parameter value) for each MSU. It is assumed that the SS values do not decay with depth. The SS distributions were adjusted by MSU during calibration; the final values are described in chapter $D$ of this report.

\section{Horizontal-Flow Barriers}

The faults within the SRPW could be barriers to groundwater flow. For simplicity, only major faults and selected minor faults included in the conceptual model were simulated in the SRPHM (fig. 1). In addition to the named faults, two unidentified faults in the southern part of the SRP were included in the model (fig. 1). The existence of unidentified fault 1 was determined from geologic analysis done for this study (Sweetkind and others, 2013). Koenig (1963) mapped the location and extent of unidentified fault 2.
The faults were simulated by using the horizontal-flow barrier (HFB) package (Hsieh and Freckleton, 1993). The HFB package simplifies faults to thin, vertical geologic features that are approximated as a series of horizontal-flow barriers between pairs of adjacent cells in the model grid (Hsieh and Freckleton, 1993). Flow across a simulated fault is proportional to the hydraulic-head difference between cells. The constant of proportionality is the hydraulic characteristic $(1 / \mathrm{d})$ of the barrier, which is equal to the hydraulic conductivity of the barrier divided by its width (the width was assumed to be $1 \mathrm{ft}$ ). The faults included in the SRPHM were simulated in all model layers.

\section{Flow Processes}

The groundwater-flow component of SRPHM includes processes that simulate one-dimensional unsaturated vertical flow below the soil zone and three-dimensional saturated flow below the water table. The unsaturated-zone flow (UZF1) package (Niswonger and others, 2006) is used in GSFLOW to simulate flow through the UZ, groundwater recharge, and groundwater discharge to land surface (Markstrom and others, 2008). MODFLOW-NWT (Niswonger and others, 2011) is used to simulate saturated flow. The layer properties described in previous sections are used by both processes. The streamflow routing (SFR2) package (Niswonger and Prudic, 2005) was used to simulate stream-aquifer interactions and streamflow routing for the major streams and their tributaries. For simplicity, lakes were not simulated, and the Laguna de Santa Rosa was simulated as a stream rather than as a floodplain.

\section{Unsaturated Zone}

Inputs to the UZF1 package are made to each active model cell underlying the corresponding soil-zone HRU in the watershed-component model (fig. 1). These inputs and parameters include the recharge and potential evapotranspiration (PET) rates for the steady-state model that are simulated by the watershed-component model described in chapter $B$, the evapotranspiration (ET) extinction depth, vertical saturated hydraulic conductivity (VKS), the saturated water content, the extinction water content, and the Brooks-Corey epsilon used for the transient simulations (Niswonger and others, 2006). Recharge is the amount of water that remains after percolation through the root zone. In cells with stream channels, the channel width is less than the dimension of the cell; therefore, the recharge rates are applied to the part of the cell without the simulated stream channel. The monthly and daily recharge rates can be much different than those for the percolation through the soil zone as a result of a time delay and damping effect on transient unsaturated flow. 
Residual PET is the unused PET from the watershedcomponent model that is available to the unsaturated zone and groundwater system (Markstrom and others, 2008). The residual PET rates are the maximum rates of ET from the unsaturated and saturated zones. Because the stream covers only part of the model cell, ET only occurs on the stream banks, and there is no ET directly beneath the active channel (Markstrom and others, 2008).

Because it was assumed that subsurface ET occurs only in the simulated riparian areas where there are phreatophytes, nonzero ET extinction depths relative to land surface were specified only for stream cells in the SRPHM. If the simulated head is at or above the top of the unsaturated zone, then the residual PET rates are computed by the watershed-component model (Markstrom and others, 2008). If the simulated head declines below the specified extinction depths, subsurface ET ceases.

VKS influences the rate of groundwater movement through the unsaturated zone to the saturated zone with higher VKS values allowing greater infiltration through the UZ. The HK and VANI values for model layer 1 in the groundwatercomponent model were used to calculate the VKS distribution. These aquifer properties are discussed above in the "Hydraulic Conductivity" section of this chapter.

The saturated water content is used to determine the water content in the UZ when the infiltration rate calculated by the watershed-component model exceeds the VKS. The extinction water content is the minimum value at which ET can be removed from the UZ (Niswonger and others, 2006). The saturated and extinction water contents were given spatially constant values of 0.30 and $0.10\left(\mathrm{ft}^{3}\right.$ of water per $\mathrm{ft}^{3}$ of UZ), respectively. The Brooks-Corey epsilon (dimensionless), which is used to define the relation between the unsaturated hydraulic conductivity and the water content, was given a spatially constant value of 4.0. The values for saturated and extinction water content and the Brooks-Corey epsilon were held constant during calibration of the SRPHM.

\section{Streamflow Routing}

The major streams are Mark West Creek, Santa Rosa Creek, the Laguna de Santa Rosa, Colgan Creek, Brush Creek, Matanzas Creek, and Copeland Creek (fig. 1). The SFR2 package simulates the interaction between the streams and the groundwater system, including the UZ, and tracks the amount of flow in the streams. This head-dependent boundary condition allows for groundwater discharge to streams (gaining stream reaches) and stream infiltration into the underlying aquifer (losing stream reaches). The main factors that determine whether a stream reach is gaining or losing are the simulated hydraulic heads in the aquifer below the stream, the streambed elevation, hydraulic conductivity of the streambed, and the VKS for the UZ underlying the streambed. The length and width of the stream reach and the vertical hydraulic conductivity of the streambed are used to calculate the streambed conductance for the reach.
In GSFLOW, streams superimposed on the aquifer system are divided into segments and reaches (Markstrom and others, 2008). A segment begins where streamflow from surface sources is added to a stream. A reach is the part of a segment that corresponds to an individual model cell in the finite-difference grid used to simulate groundwater flow in the aquifer system. There are 324 segments divided into 2,902 reaches (model cells) in the SRPHM (fig. 7). The stream segments route streamflow to 10 points of outflow on the boundary of the SRPHM (fig. 7). The values for the streambed elevation were determined from the average DEM value in the cell. The values for the streambed conductivity were determined from the maximum Soil Survey Geographic (SSURGO) soil conductivity in each cell, assuming the streambeds were coarser than in the areas bordering the channels (U.S. Department of Agriculture, 2007; Sweetkind and others, 2013). The VKS of the UZ in each model cell underlying the streambed was assumed to have the same value as the streambed conductivity in the same cell. In stream reaches with baseflow, the discharging groundwater is influenced by the VK for model layer 1, described above in the "Hydraulic Conductivity" section of this chapter.

\section{Groundwater-Model Inflow}

Inflow to the saturated zone includes natural and anthropogenic sources. Natural inflow includes leakage from streams, underflow from neighboring groundwater basins, and recharge in areas not containing stream channels. Leakage from streams and groundwater boundary flow from adjacent basins were unknown; however, both were estimated as part of this study. Leakage from streams is a head-dependent boundary simulated by using the SFR2 package, as explained above in the "Streamflow Routing" section of this chapter. Groundwater boundary flow from adjacent groundwater basins is simulated as a head-dependent boundary by using the GHB package, as explained above in the "Model Boundaries" section of this chapter. Groundwater recharge is defined for this report as the net quantity of water that moves through the unsaturated zone. Groundwater recharge is simulated by using the UZF1 package, with inputs from the SFR2 package. The potential sources of inflow to the unsaturated zone include percolation through the bottom of the soil zone and seepage through streambeds (Nishikawa and others, 2013a).

The anthropogenic inflows from treated wastewater (reclaimed water) were reported and were treated as additional areal infiltration to the soil zone by way of precipitation, as described in chapter $B$ of this report. The recharge from irrigation and septic-tank effluent is assumed to be negligible (Nishikawa and others, 2013a) and is not included in the model. 


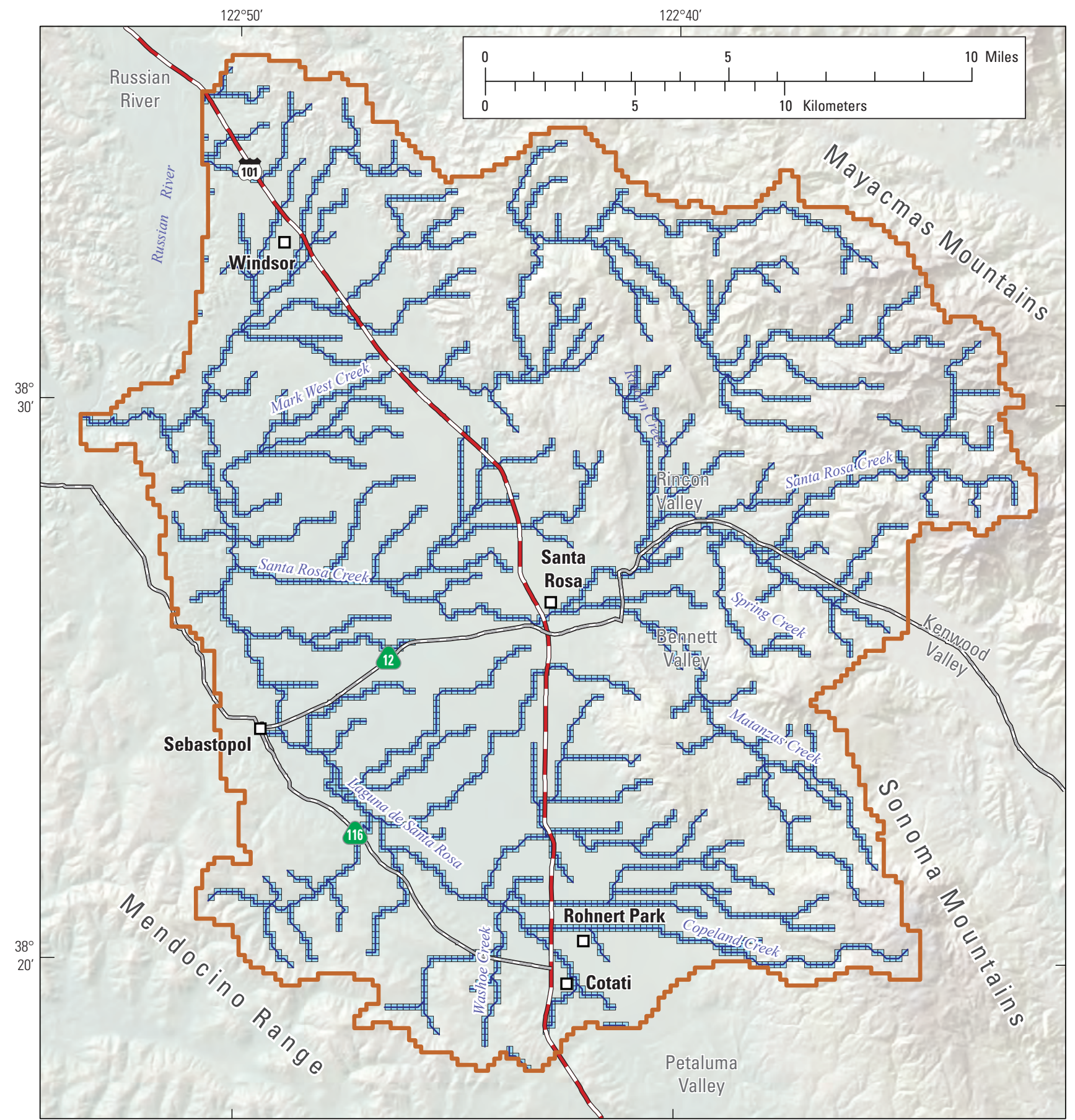

EXPLANATION

$\square \quad$ Streamflow-routing cell

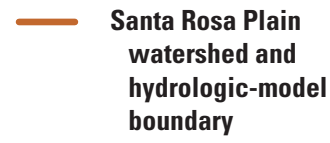

Segment of stream

simulated in mode

boundary

Figure 7. Streamflow-routing cells in the groundwater component of the Santa Rosa Plain hydrologic model, Santa Rosa Plain watershed, Sonoma County, California. 


\section{Groundwater-Model Outflow}

Groundwater outflow from the SRPW is primarily stream discharge, underflow to adjacent groundwater basins, ET, and pumpage (Nishikawa and others, 2013a). With the exception of available measurements of pumpage for public supply, these components of groundwater outflow were unknown, and were estimated as part of this study.

There is demand for fresh water in the SRPW for agricultural irrigation, public-supply, and domestic use. Groundwater is pumped to supplement local surface-water resources for public-supply and agricultural uses and is the main source of water for domestic use. For simplicity, agricultural and domestic pumpage were combined and designated as rural pumpage. Withdrawals were simulated by using the well (WEL) package (Harbaugh, 2005). Pumping rates, well locations, and the depth of perforated intervals were required in order to integrate groundwater pumpage into the model. Construction information was needed to determine the perforated intervals of each well, which are simulated in the model as a series of wells in the same cell, with one for each layer in which the actual well perforates.

The total pumpage for the wells in each cell was applied at the cell center, resulting in 4,262 wells (fig. 8) simulated by pumpage in 7,116 model cells; some wells spanned more than one layer and were simulated as multiple wells. Total pumpage for a well was distributed vertically on the basis of the screened interval of the well and the hydraulic-conductivity value of the model layers in which the well was completed. This determines the quantity of pumpage derived from each model layer and allows for pumpage to be redistributed as the estimates of the hydraulic-conductivity distribution change during model calibration. There was pumpage in all eight layers of the model (table 3, fig. 9), with the largest number of pumping wells in model layers 1-3 (table 3, fig. 9).

Table 3. Number of simulated pumping wells in each layer of the groundwater component of the Santa Rosa Plain hydrologic model, Santa Rosa Plain watershed, Sonoma County, California.

\begin{tabular}{cc}
\hline Model layer & Number of wells \\
\hline 1 & 3,070 \\
2 & 1,806 \\
3 & 1,456 \\
4 & 500 \\
5 & 193 \\
6 & 64 \\
7 & 24 \\
8 & 3 \\
\hline
\end{tabular}

Public-supply pumpage was assigned to 70 wells throughout the SRP (fig. 8), most of which are operated by the cities of Cotati, Rohnert Park, Santa Rosa, Sebastopol, and the town of Windsor. Rural pumpage for the simulation period was assigned to 4,192 wells distributed throughout the SRPW (fig. 8). Although the model uses daily time steps for the transient period, pumpage was specified as a constant rate for each well for each monthly stress period. The monthly value for each well was computed in the SRPHM by multiplying the constant rate by the number of days in a given month.

\section{Public-Supply Pumpage}

Monthly pumpage for public supply was reported for many years, and the well locations are known. If reported monthly pumpage data were not available, pumpage was estimated on the basis of available annual pumpage from California Department of Public Health unpublished data (Janice Thomas, California Department of Public Health, written commun., 2009). The quantities of monthly pumpage were then estimated from these annual values on the basis of reported monthly data. If pumpage data were not available for a given month during the transient simulation period, then data from the same month from a previous year were used. If pumpage for a given public supplier was reported as a total for all wells, the pumpage was divided evenly among the wells.

\section{Rural Pumpage}

Rural pumpage was assumed to be a combination of agricultural and domestic pumpage. There is uncertainty associated with the assumptions made in the estimation of both types of pumpage, and adjustments to rural pumpage were made during model calibration.

\section{Agricultural Pumpage}

The amount of pumpage for agriculture has not been reported; therefore, an estimate of irrigation demand was used as a surrogate for the agricultural component of rural pumpage. Irrigation demand for the model area was reconstructed from areas of irrigated crop types identified in the California Department of Water Resources land-use surveys (California Department of Water Resources, 1974, 1979, 1986, 1999) and from crop types identified in unpublished data from Sonoma County Water Agency for 2008 (Sonoma County Water Agency, written commun., 2008). Because the public record of the locations of irrigation wells is incomplete, the existing record of well locations and well-use types was mapped according to complete or partial tax assessors' parcel numbers, street addresses, or state well-identification numbers. These well locations were used to identify irrigation wells near the area represented by polygons for irrigated land use for each land-use year. These wells were then moved, if necessary, 


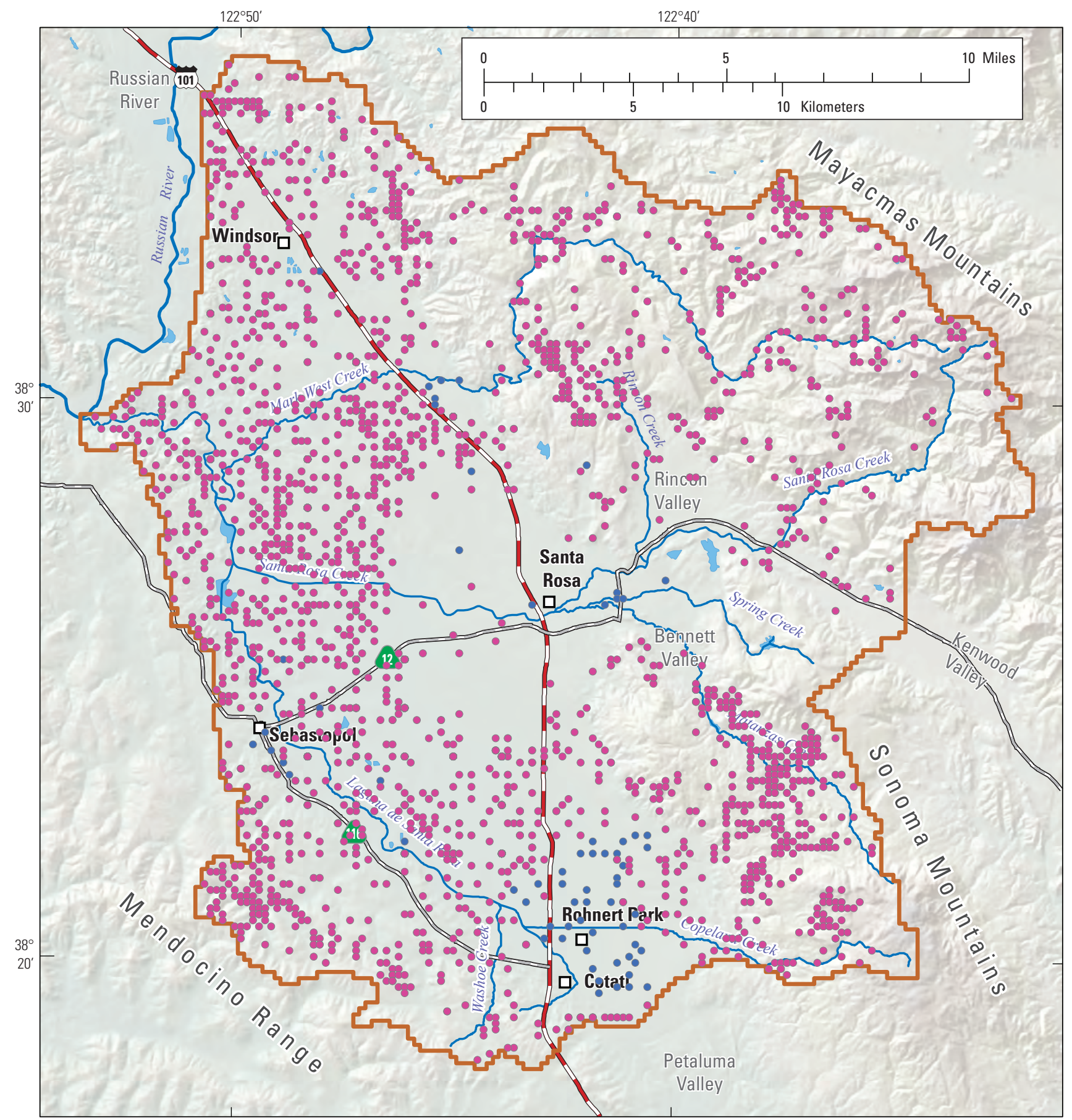

EXPLANATION

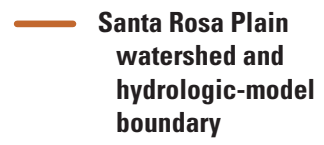

Well

hydrologic-model

- Public-supply

boundary

- Rural

Figure 8. Location of pumping wells in the groundwater component of the Santa Rosa Plain hydrologic model, Santa Rosa Plain watershed, Sonoma County, California. 

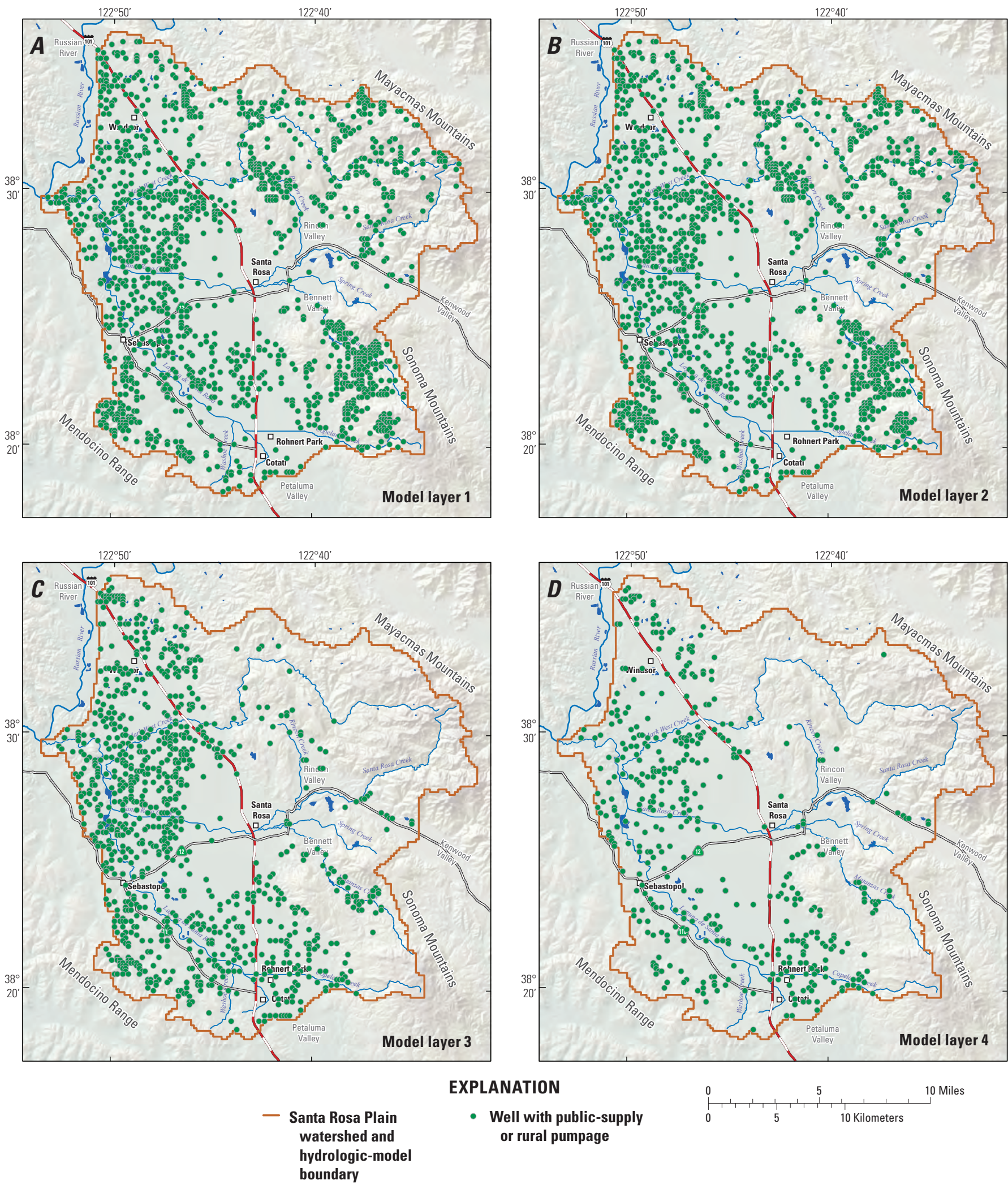

EXPLANATION
- Well with public-supply or rural pumpage

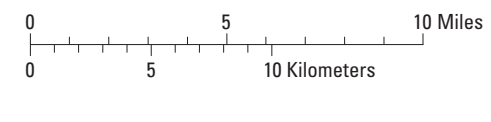

boundary

Figure 9. Wells perforated in each layer of the groundwater component of the Santa Rosa Plain hydrologic model, Santa Rosa Plain watershed, Sonoma County, California: $A$, layer $1 ; B$, layer 2; $C$, layer 3; $D$, layer 4 ; $E$, layer 5 ; $F$, layer 6 ; and $G$, layers $7-8$. 

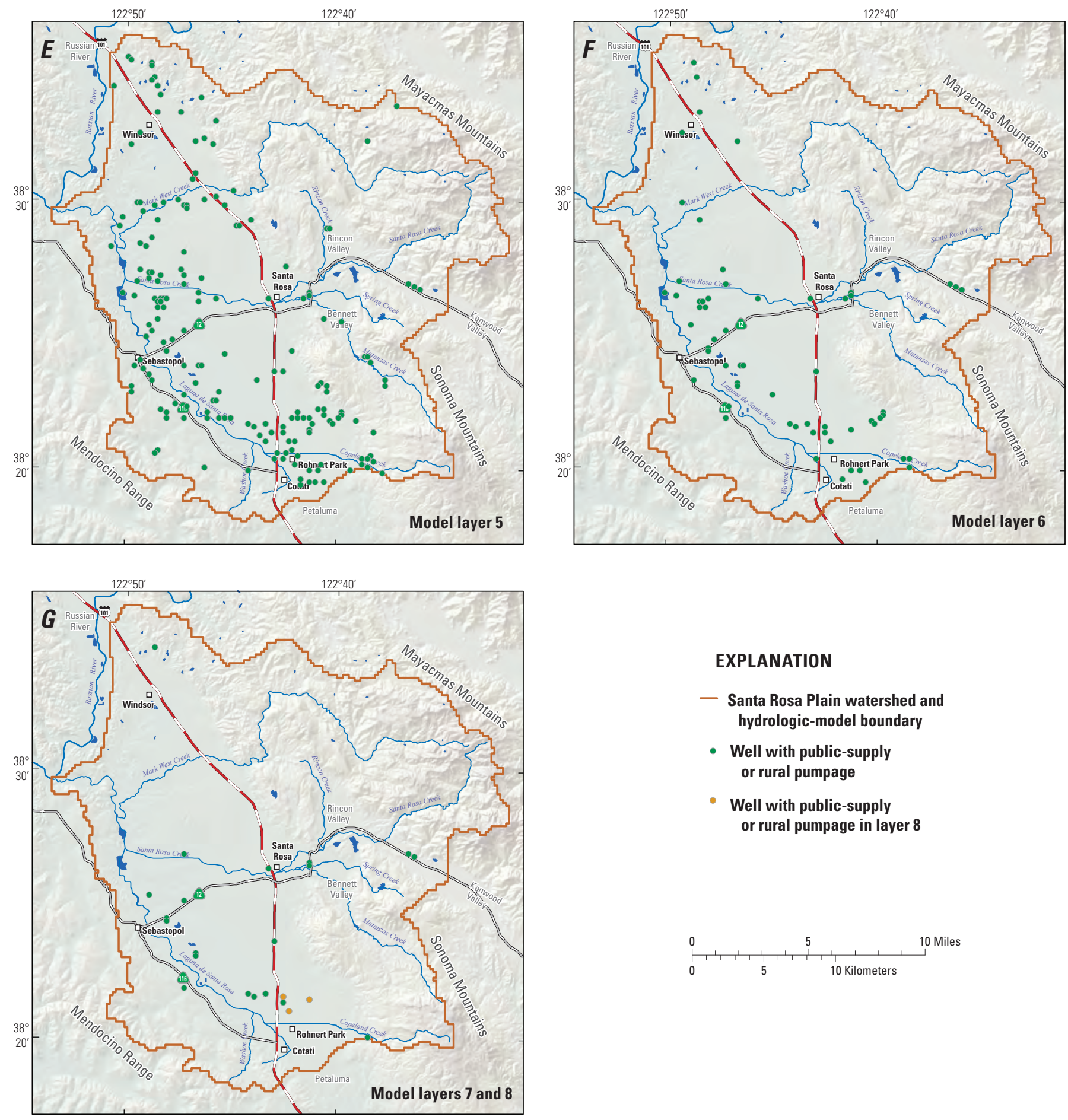

Figure 9. - Continued 
by assigning their location to a model cell in the irrigated polygon, assuming that the location of the irrigated polygon was more accurate than the well location. Construction information, as available, was assumed to be accurate for the new model-grid location. If a known irrigation well was not located near an irrigated polygon, other known wells nearby were used instead. The agricultural irrigation demand was computed for water years 1975-2010 by using the decoupled precipitationrunoff modeling system (PRMS) watershed-component model and a daily crop water-demand model (CWDM), described in Appendix 1 of this report. The total monthly demand for each irrigation area was assigned to a well in or near the area. If the agricultural irrigation polygon was large (about 100 acres or more), demand was assigned to more than one well. If a known agricultural irrigation well or wells were not located in or near the large irrigation polygon at some distance from the original well, other known wells that were not public-supply wells were used instead. If these wells were not located in the irrigated polygon, they were moved.

\section{Domestic Pumpage}

1. It was assumed that residents of semi-rural and rural areas outside the city limits of Santa Rosa, Rohnert Park, Cotati, Sebastopol, and the town of Windsor relied on groundwater for water supply. Water-delivery areas for the cities of Santa Rosa, Rohnert Park, Cotati, and Sebastopol, and the town of Windsor were omitted from census-tracts, as defined by the U.S. Census Bureau, to estimate the semi-rural and rural areas not serviced by public-supply wells. It was assumed that the 1970 census data represented the population for 1975, the 1980 census data represented the population from 1976 to 1985 , the 1990 census data represented the population from 1986 to 1995, and the 2000 census data represented the population distribution from 1996 to 2010 It also was assumed that the city limits did not change during the periods between the census tabulation of population.

2. The semi-rural and rural areas of each census tract defined in step 1 (in square miles) were multiplied by the population density (the number of people per square mile) of each census tract to estimate the total population for each tract.

3. The annual per-capita water demand, assumed to equal 0.19 acre-ft per capita (California Department of Water Resources, 1994), was multiplied by the population per tract from step 2 to obtain the total annual water demand for the domestic wells for each census tract in the SRPW.

4. The total annual water demand per tract from step 3 was divided evenly by month, for simplicity, and by the number of wells with defined locations in each tract to obtain the pumpage during the census periods defined in step 1. If a well location was not available, the pumpage was assigned to a nearby domestic well. The number of wells could be underreported, and this method could locally concentrate withdrawal in fewer wells, but the regional-scale effects on the groundwater system should be representative.

\section{Total Pumpage}

Total annual pumpage for public-supply and rural uses for the simulation period is presented in chapter $A$, figure 7 . The decline in rural (predominantly agricultural) pumpage during 1990 to 1998 was caused by the introduction of reclaimed water for agricultural irrigation. The average total pumpage for the simulation period was about 44,000 acre-ft/yr; there was a trend of increasing total annual pumpage during the simulation period. The greatest demand on groundwater in the model area, about 84 percent on average, was for rural pumping.

\section{References Cited}

California Department of Water Resources, 1974, 1974 Sonoma County land use survey data: unpublished data located at Division of Integrated Regional Water Management, North-Central Region, West Sacramento, California, $1: 24,000$ scale.

California Department of Water Resources, 1979, 1979 Sonoma County land use survey data: unpublished data located at Division of Integrated Regional Water Management, North-Central Region, West Sacramento, California, $1: 24,000$ scale.

California Department of Water Resources, 1986, 1986 Sonoma County land use survey data: unpublished data located at Division of Integrated Regional Water Management, North-Central Region, West Sacramento, California, $1: 24,000$ scale.

California Department of Water Resources, 1994, California water plan update: Bulletin 160-93, October 1994, v. 2, $315 \mathrm{p}$.

California Department of Water Resources, 1999, 1999 Sonoma County land use survey data: digital map accessed on January 28, 2011, at http://www.water.ca.gov/ landwateruse/lusrvymain.cfm.

California Department of Water Resources-Central District, 1979, Meeting water demands in the city of Rohnert Park, $127 \mathrm{p}$.

Cardwell, G.T., 1958, Geology and ground water in the Santa Rosa and Petaluma areas, Sonoma County, California: U.S. Geological Survey Water-Supply Paper 1427, 273 p., 5 pl. 
Farrar, C.D., Metzger, L.F., Nishikawa, Tracy, Koczot, K.M., and Reichard, E.G. 2006, Geohydrologic characterization, water-chemistry, and ground-water flow simulation model of the Sonoma Valley area, Sonoma County, California, with a section on basement complex configuration interpreted from gravity data by Victoria E. Langenheim: U.S. Geological Survey Scientific Investigations Report 20065092, 167 p.

Freeze, R.A., and Cherry, J.A., 1979, Groundwater: Englewood Cliffs, N.J., Prentice-Hall, 604 p.

Harbaugh, A.W., 2005, MODFLOW-2005, the U.S. Geological Survey modular ground-water model - the ground-water flow process: U.S. Geological Survey Techniques and Methods 6-A16, variously paged.

Herbst, C.M., Jacinto, D.M., and McGuire, R.A., 1982, Evaluation of ground water resources, Sonoma County, volume 2: Santa Rosa Plain: California Department of Water Resources Bulletin 118-4, 107 p., 1 plate.

Hsieh, P.A.; Freckleton, J. R., 1993, Documentation of a computer program to simulate horizontal-flow barriers using the U.S. Geological Survey's modular three-dimensional finite-difference ground-water flow model: U.S. Geological Survey Open File Report 92-477, 32 p.

Kadir, T.N. and McGuire, R.A., 1987, Santa Rosa Plain ground water model: California Department of Water Resources Central District, 318 p.

Koenig, J.B., 1963, Geologic map of California: Santa Rosa sheet: California Division of Mines and Geology, 1:250,000, at http://ngmdb.usgs.gov/Prodesc/proddesc_351. htm

Markstrom, S.L., Niswonger, R.G., Regan, R.S., Prudic, D.E., and Barlow, P.M., 2008, GSFLOW-Coupled groundwater and surface-water flow model based on the integration of the Precipitation-Runoff Modeling System (PRMS) and the Modular Ground-Water Flow Model (MODFLOW-2005): U.S. Geological Survey Techniques and Methods 6-D1, $240 \mathrm{p}$.

Nishikawa, Tracy, Hevesi, J.A., Sweetkind, D.S., and Martin, Peter, 2013a, Conceptual model of Santa Rosa Plain watershed hydrologic system, chap. D of Nishikawa, Tracy, ed., Hydrologic and geochemical characterization of the Santa Rosa Plain watershed, Sonoma County, California: U.S. Geological Survey Scientific Investigations Report 2013-5118, p. 167-177.
Nishikawa, Tracy, Hevesi, J.A., Sweetkind, D.S., and Woolfenden, L.R., 2013b, Introduction to the study area, chap. A of Nishikawa, Tracy, ed., Hydrologic and geochemical characterization of the Santa Rosa Plain watershed, Sonoma County, California: U.S. Geological Survey Scientific Investigations Report 2013-5118, p. 7-26.

Niswonger, R.G., and Prudic, D.E., 2005, Documentation of the Streamflow Routing (SFR2) Package to include unsaturated flow beneath streams-A Modification to SFR1: U.S. Geological Survey Techniques and Methods 6-A13, 48 p.

Niswonger, R.G., Prudic, D.E., and Regan, R.S., 2006, Documentation of the Unsaturated-Zone Flow (UZF1) Package for modeling unsaturated flow between the land surface and the water table with MODFLOW-2005: U.S. Geological Survey Techniques and Methods 6-A19, 62 p.

Niswonger, R.G., Panday, Sorab, and Ibaraki, Motomu, 2011, MODLOW-NWT, A Newton formulation for MODFLOW-2005: U.S. Geological Survey Techniques and Methods 6-A37, $44 \mathrm{p}$.

Sweetkind, D.S., Taylor, E.M., McCabe, C.A., Langenheim, V.E., and McLaughlin, R.J., 2010, Three-dimensional geologic modeling of the Santa Rosa Plain, California: Geosphere, v. 6, p. 237-274.

Sweetkind, D.S., Hevesi, J.A., Nishikawa, Tracy, Martin, Peter, and Farrar, C.D., 2013, Hydrology of the Santa Rosa Plain watershed, Sonoma County, California, chap. B of Nishikawa, Tracy, ed., Hydrologic and geochemical characterization of the Santa Rosa Plain watershed, Sonoma County, California: U.S. Geological Survey Scientific Investigations Report 2013-5118, p. 27-112.

U.S. Department of Agriculture, 2007, Natural Resources Conservation Service, Soil Survey Geographic (SSURGO) database for Sonoma County, California, accessed on May 14, 2009, at http://SoilDataMart.nrcs.usda.gov. 


\section{Chapter D. Santa Rosa Plain Hydrologic-Model Calibration}

\author{
By Linda R. Woolfenden and Joseph A. Hevesi
}

\section{Introduction}

This chapter describes the methods and results for calibration of the Santa Rosa Plain Hydrologic Model (SRPHM), developed by using the coupled groundwater and surfacewater flow model (GSFLOW; Markstrom and others, 2008). As described in chapter $A$ of this report, GSFLOW consists of two integrated model components: (1) a watershed-component model developed using Precipitation Runoff Modeling System (PRMS; Markstrom and others, 2008), and (2) a groundwater-component model developed using the Newton formulation of the U.S. Geological Survey (USGS) Modular Groundwater Flow Model (MODFLOW-NWT, or MFNWT; Niswonger and others, 2011). Chapter $B$ describes the watershed-component model, which is used to simulate the hydrology of the land surface, vegetation, snow cover, and the soil zone. Chapter $C$ describes the groundwater-component model, which is used to simulate the groundwater hydrology of the subsurface underlying the soil-zone and the surfacewater hydrology of the streams represented in the SRPHM. The subsurface represented by the groundwater-component model includes the unsaturated zone and the saturated zone.

The boundary conditions, initial conditions, relevant parameters, and model domains for the watershed-component and the groundwater-component models are presented in chapters $B$ and $C$, respectively, of this report. As described in chapter $B$ of this report, the spatial discretization of the watershed-component model uses a gridded approach, where the hydrologic response unit (HRU) geometry was defined as 660 feet (ft) by $660 \mathrm{ft}$ (10-acre) cells. The temporal discretization of the watershed-component model is daily time steps. As described in chapter $C$ of this report, the spatial discretization of the groundwater-component model is consistent with the HRU cell size, and the SRPHM is discretized vertically into eight layers of variable thickness. The SRPHM has 432 monthly stress periods representing water years 1975 2010. The temporal discretization of the groundwater-component model is 1-day time steps for each month. The temporal distribution of GSFLOW is daily time steps; therefore, the 1-day time steps were needed in the groundwater component to synchronize with boundary conditions calculated by PRMS, such as gravity drainage through the base of the soil zone, which changed daily. The conditions for each stress period of the groundwater component were changed on the first day of each month and were constant within each monthly stress period (Markstrom and others, 2008).

\section{GSFLOW Calibration}

In general, model calibration is the process whereby model parameters are adjusted to obtain a reasonable fit between simulated results and measured data. During calibration of the SRPHM, estimated properties of the flow system were constrained on the basis of measured streamflows and groundwater levels. Calibration proceeded until the differences between simulated and measured streamflows and simulated hydraulic heads and measured groundwater levels were acceptable for the intended use of the SRPHM. Throughout the calibration, adjustments were constrained by the conceptual model presented in Nishikawa and others (2013).

\section{Calibration Method}

This chapter describes the calibration of the SRPHM to measured streamflows and groundwater levels. Initial calibration of GSFLOW is often done in decoupled mode (that is, the watershed-component model and the groundwater-component model are calibrated individually; Markstrom and others, 2008; R. Steven Regan, oral communication, 2012). An important advantage of using decoupled mode for calibration is that the simulation runtimes are generally much shorter. Initial calibrations of GSFLOW using decoupled simulations generally result in GSFLOW simulations that are close to being calibrated and only requires some relatively minor parameter adjustment to achieve a final model calibration (Markstrom and others, 2008; R. Steven Regan, oral communication, 2012). Therefore, the decoupled components were initially calibrated separately. These components were then coupled and re-calibrated. This was an iterative calibration process involving multiple de-couplings and re-couplings.

The GSFLOW calibration was accomplished by using a trial-and-error approach. Calibration often is done through automated software such as PEST or UCODE (Doherty, 2005; Hill and Tiedeman, 2007; Poeter and others, 2008; Doherty, 2010; Doherty and others, 2010). Given the long execution time (often in excess of 36 hours) of the SRPHM, this 
approach was deemed impractical. The calibration process for the SRPHM included adjusting the initial estimates of the HRU land-surface properties, HRU soil-zone properties, stream-channel properties, aquifer properties, general-head boundary conductances, and horizontal-flow barrier characteristics. The calibration process involved systematically adjusting these parameters to match simulated and measured streamflows and groundwater levels well; the reasonableness of simulated boundary fluxes also was evaluated. The feedback between the watershed (PRMS) and the groundwater (MF-NWT) components of the SRPHM enhances calibration by rigorously incorporating the interdependent linkages between the two models.

The SRPHM was calibrated to streamflows by adjusting distributed watershed-component parameters using single multipliers that applied to the entire Santa Rosa Plain Watershed (SRPW), except in the streamflow-routing (SFR) cells. The SFR parameters in the groundwater-component model were increased or decreased for stream segments and reaches. Simulated streamflows were compared with measured data at 12 streamgaging stations (fig. $1 \mathrm{~A}$ ). The available data did not support unique adjustment of parameters for individual subbasins in order to improve calibration to streamflows at the streamgage affected by the subbasin. The calibration sequence for streamflows was iterative and generally consisted of calibrating to the upstream streamgages first and then to the downstream ones, and repeating as necessary. The calibration results for the upstream streamgages generally changed during the calibration of the downstream streamgages. Model fit of the simulated streamflows to daily and monthly streamflow records is presented below in the "Calibration to Streamflow" section of this chapter by surface-water subbasin (Laguna de Santa Rosa, Santa Rosa Creek, and Mark West Creek subbasins; fig. 1A). For each subbasin, results for the upstream streamgages are presented first.

The SRPHM was calibrated to measured groundwater levels by trial-and-error. The SRPW was divided into model storage units (MSUs; fig. $1 B$ ), as described in chapter $C$, to aid in the calibration process by using the MSUs as parameter zones (Harbaugh, 2005). Hydraulic properties were calibrated by adjustment of multipliers for each parameter zone. For statistical evaluation of the model fit, hydraulic heads simulated by the SRPHM were compared with measured groundwater levels at 83 wells (fig. 1B); to spring 2007 groundwater-level contours presented in Sweetkind and others (2013); and to measured groundwater levels at 38 hydrographcomparison wells (fig. 1B). Transmissivity data for five wells from Kadir and MacGuire (1987) and one well from Sonoma County Water Agency (Sonoma County Water Agency, written commun., 2009) also were used to constrain horizontal hydraulic conductivity for selected layers in the Windsor, Bennett Valley-plain, Santa Rosa, and Wilson Grove MSUs (fig. 1B). Model fit of simulated hydraulic heads to measured groundwater levels is presented below in the "Calibration to
Groundwater Levels" section of this chapter in the form of statistics and areal distribution of simulated hydraulic heads for the SRPW as a whole, and as hydrographs by well.

\section{Final Model Input}

\section{Watershed-Component Parameters}

Parameters adjusted during the trial-and-error calibration process of the SRPHM included PRMS-HRU parameters controlling runoff, evapotranspiration (ET), and recharge. The final values for the 12 critical parameters identified in chapter $B$ are summarized in table 1 . The dday_slope and jh_coef parameters are average monthly parameters that affect the simulation of potential evapotranspiration. The PRMS-HRU parameters found to improve model fit during calibration of the SRPHM included soil_moist_max, sat_threshold, and soil_rechr_max for controlling ET and runoff; hru_percent_imperv for controlling runoff; and ssr2gw_rate for controlling recharge. These parameters varied spatially, and their final distributions are shown in figures 2-6. The smidx_coef and smidx_exp coefficients for controlling runoff generation were adjusted during calibration and given spatially constant values of 0.01 and 0.8 inches (in.), respectively. The parameters carea_max, slowcoef_lin, and slowcoef_sq (figs. 7, 8, 9, respectively) also were important in simulation of watershed processes, but were not adjusted during calibration.

Calibration of the ssr2gw_rate parameter (fig. 6) is particularly important because it controls infiltration below the root zone and is a key linkage between the watershed-component and groundwater-component models. This parameter was adjusted iteratively between the two GSFLOW components during calibration in order to determine the quantity and distribution of recharge to the groundwater-component model that allows a reasonable match of simulated to measured groundwater levels. Physical characteristics of the geology in the watershed were considered during calibration of ssr2gw_rate. Calibration of this parameter illustrates the usefulness of GSFLOW for reducing the uncertainty in conceptualization of the hydrologic system and in model results and predictions that would not be apparent in MF-NWT-only or PRMS-only simulations.

\section{Groundwater-Component Parameters}

Parameters adjusted during model calibration include hydraulic properties (hydraulic conductivity, specific yield, and specific storage), horizontal-flow barrier characteristics, general-head-boundary conductance, and stream-channel properties. The final values for the groundwater-component parameters are described in the following sections. 


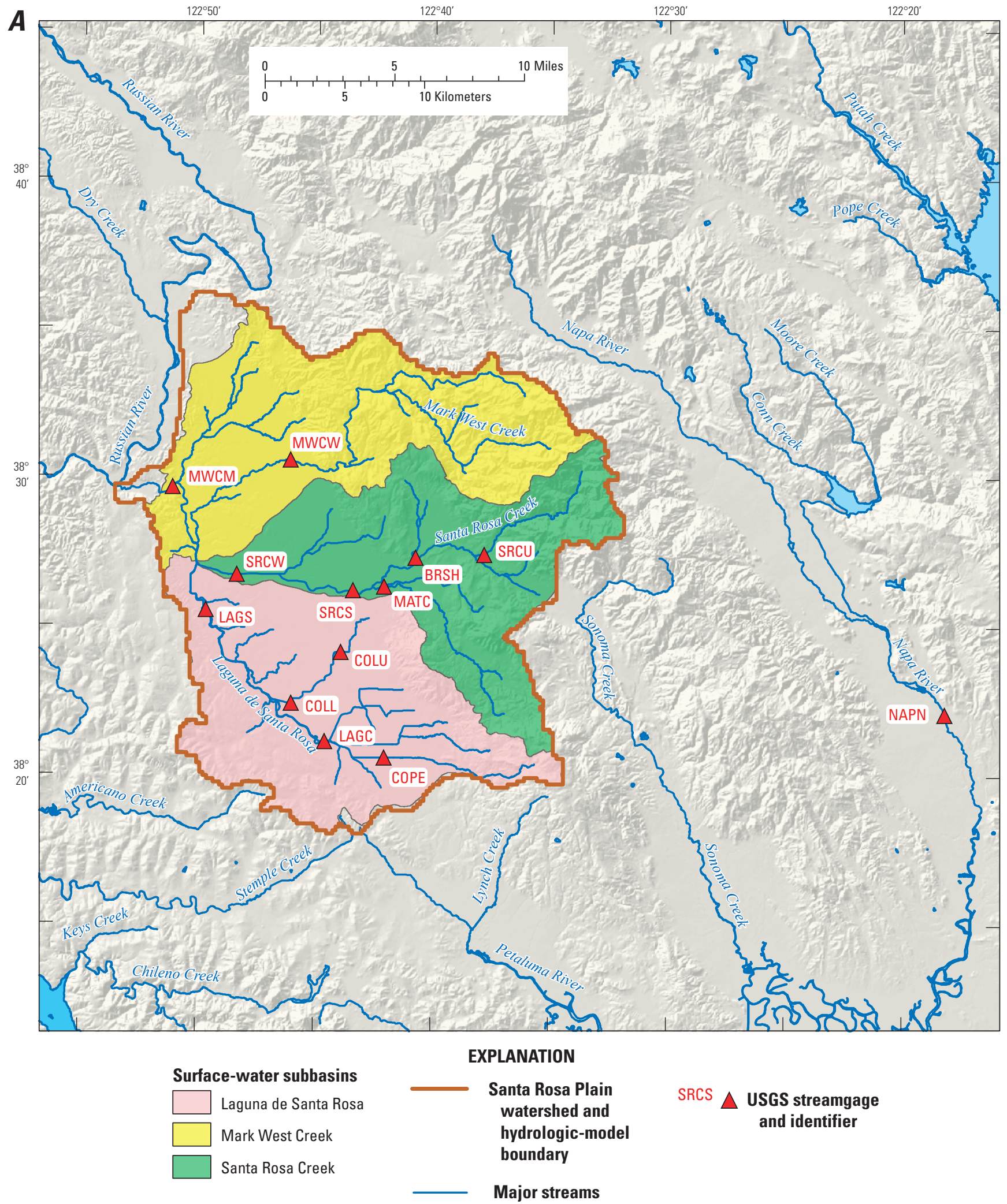

Figure 1. Locations in the Santa Rosa Plain watershed, Sonoma County, California, of $A$, streamgages and surface-water subbasins; and $B$, wells and model storage units used for calibration of the Santa Rosa Plain hydrologic model. 


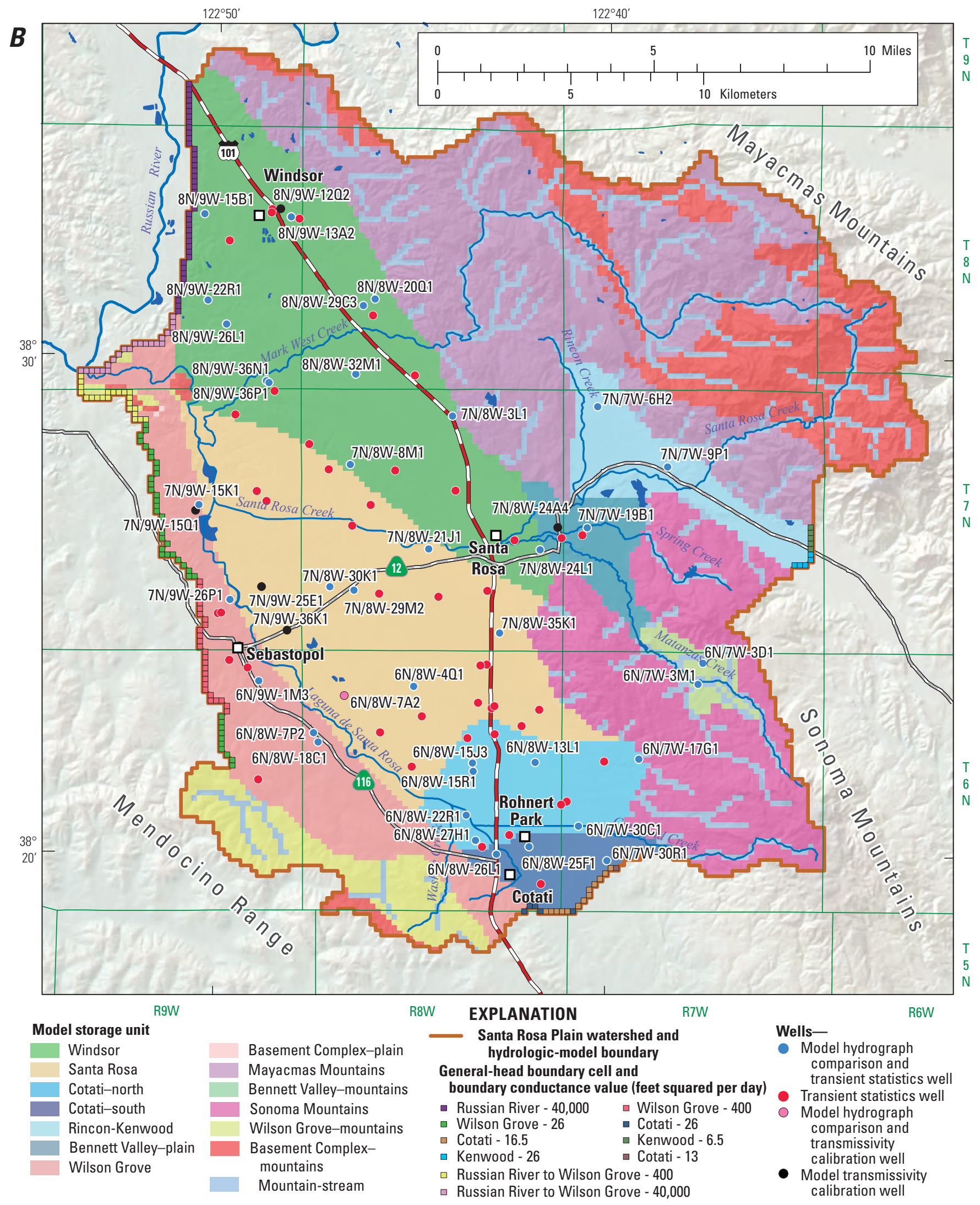

Figure 1. - Continued 
Table 1. Summary of final watershed-component parameter values in the Santa Rosa Plain hydrologic model, Santa Rosa Plain watershed, Sonoma County, California.

[Abbreviations: HRU, hydrologic response unit; MODFLOW, modular groundwater flow model; nmonths, number of months in a year; PRMS, precipitation runoff modeling system]

\begin{tabular}{|c|c|c|c|c|c|}
\hline \multirow{2}{*}{$\begin{array}{l}\text { Parameter } \\
\text { name }\end{array}$} & \multirow{2}{*}{ Units } & \multirow{2}{*}{ Description } & \multicolumn{3}{|c|}{ Final values } \\
\hline & & & Average & Maximum & Minimum \\
\hline dday_slope & nmonths & Slope of monthly degree-day to temperature relation & 0.34 & 0.533 & 0.205 \\
\hline soil_moist_max & inches & $\begin{array}{l}\text { Maximum volume of water per unit area in the capillary reser- } \\
\text { voir }\end{array}$ & 8 & 29 & 0.42 \\
\hline sat_threshold & inches & Maximum volume of water per unit area in the soil zone & 11 & 49 & 0.53 \\
\hline smidx_coef & dimensionless & Coefficient in non-linear contributing area algorithm & 0.01 & 0.01 & 0.01 \\
\hline smidx_exp & $1 /$ inch & Exponent in non-linear contributing area algorithm & 0.8 & 0.8 & 0.8 \\
\hline ssr2gw_rate & inches/day & $\begin{array}{l}\text { Exponent in the equation used to compute gravity drainage to } \\
\text { PRMS groundwater reservoir or } \\
\text { MODFLOW finite-difference cell }\end{array}$ & 0.0227 & 0.055 & 0.00015 \\
\hline carea_max & dimensionless & Maximum possible area contributing to surface runoff & 0.456 & 0.957 & 0.00174 \\
\hline slowcoef_lin & dimensionless & Linear flow-routing coefficient for slow interflow & 0.0203 & 0.308 & 0.00001 \\
\hline slowcoef_sq & 1/(inch-day) & Non-linear flow-routing coefficient for slow interflow & 0.0114 & 0.173 & 0.00001 \\
\hline
\end{tabular}




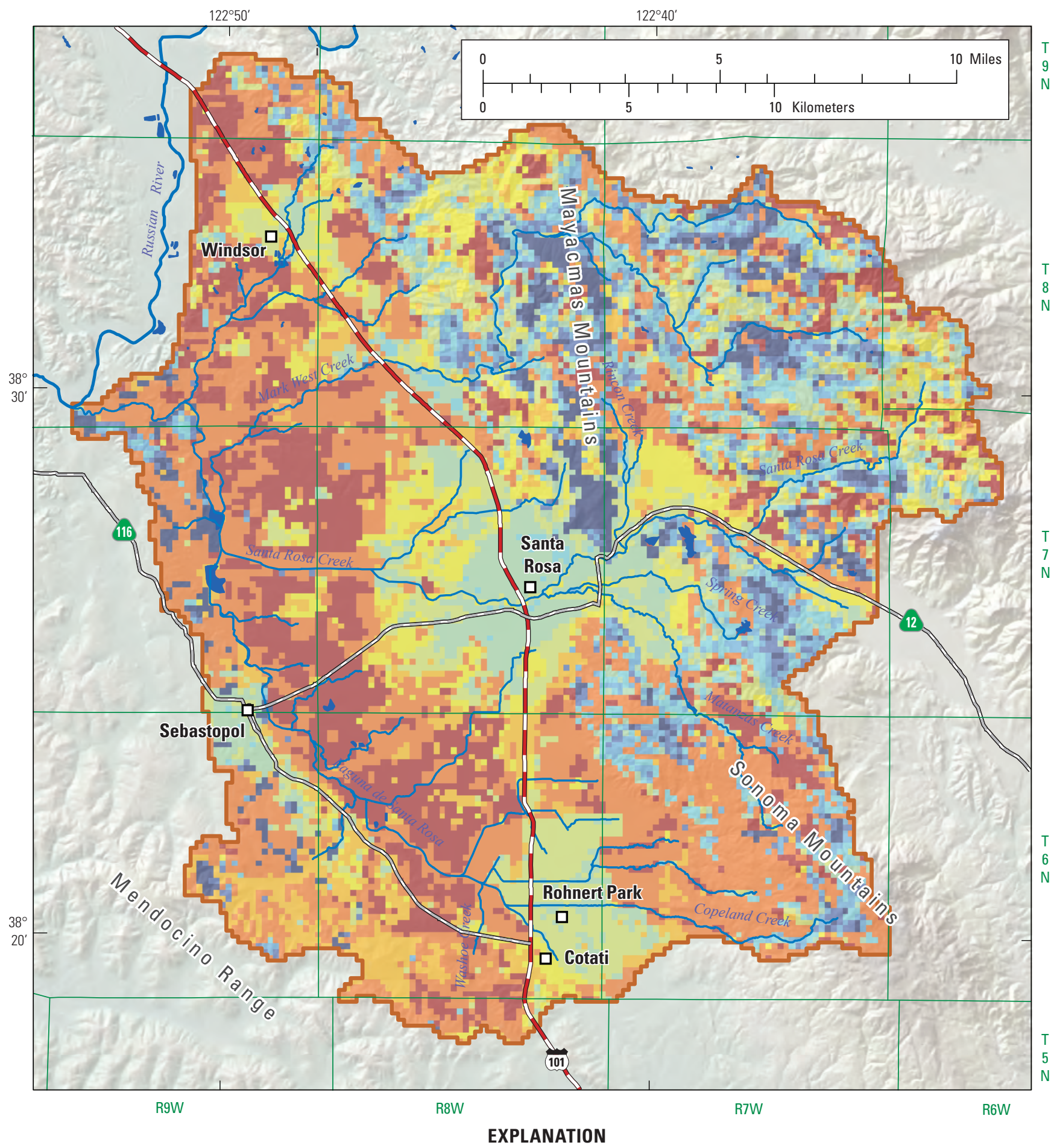

PRMS input parameter: soil_moist_max (inches)

\begin{tabular}{|l|l|l|l|l|l}
0.4 to 3 & 5.01 to 7 & 9.01 to 11 & 13.1 to 15 & 17.1 to 19 & $\begin{array}{c}\text { Sydrologic-model boundary } \\
\text { hyd }\end{array}$ \\
3.01 to 5 & 7.01 to 9 & 11.1 to 13 & 15.1 to 17 & 19.1 to 29.2 & Major stream channels \\
\hline
\end{tabular}

Figure 2. Distribution of the soil_moist_max parameter in the Santa Rosa Plain hydrologic model, Santa Rosa Plain watershed, Sonoma County, California. 


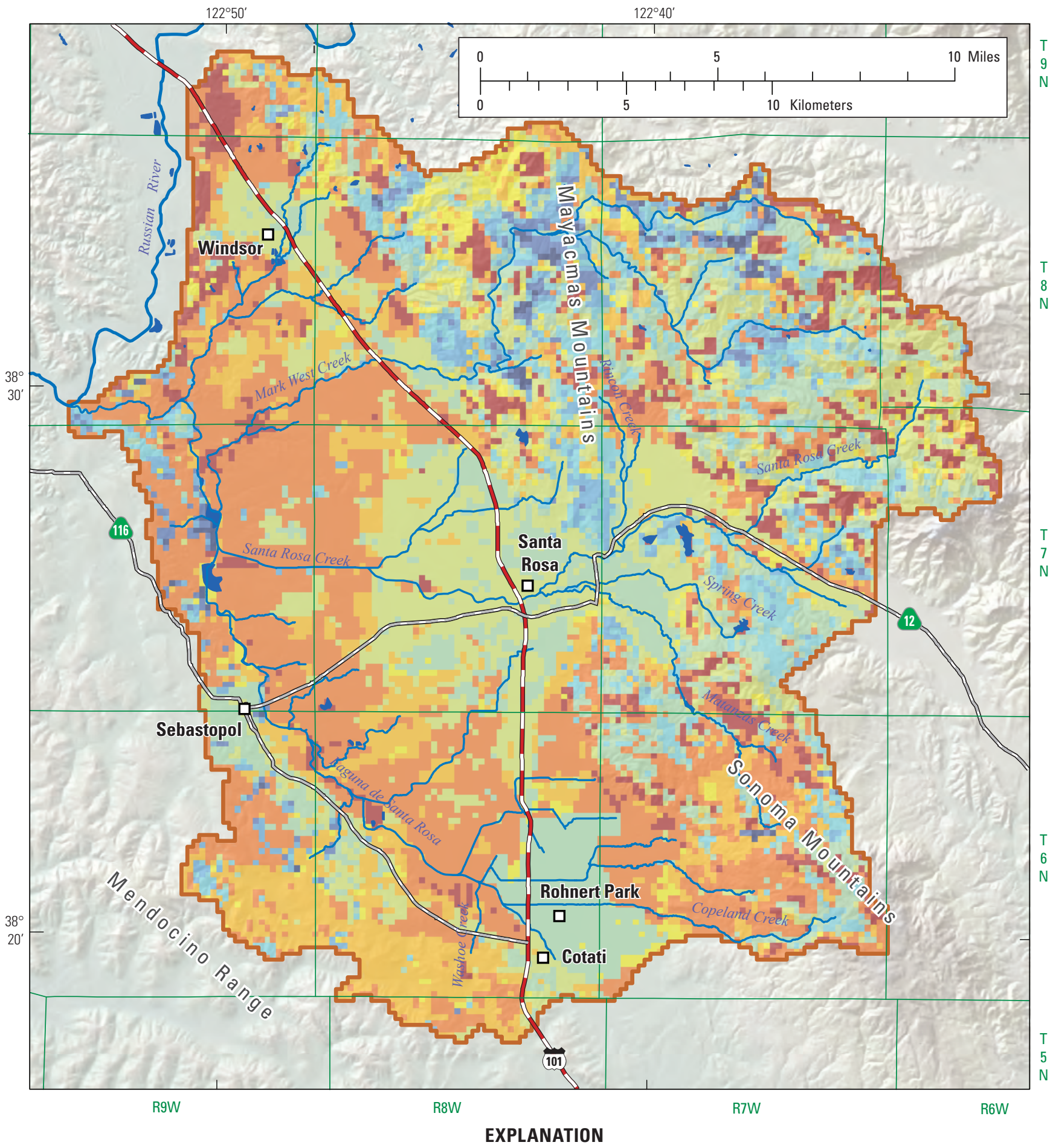

PRMS input parameter: sat_threshold (inches)

\begin{tabular}{|l|l|l|l|l|}
\hline 0.526 to 4 & 6.01 to 8 & 10.01 to 15 & 20.1 to 25 & 30.1 to 35 \\
\hline 4.01 to 6 & 8.01 to 10 & 15.1 to 20 & 25.1 to 30 & 35.1 to 49.1 \\
\hline
\end{tabular}

Santa Rosa Plain watershed and hydrologic-model boundary

Major stream channels

Figure 3. Distribution of the sat_threshold parameter in the Santa Rosa Plain hydrologic model, Santa Rosa Plain watershed, Sonoma County, California. 


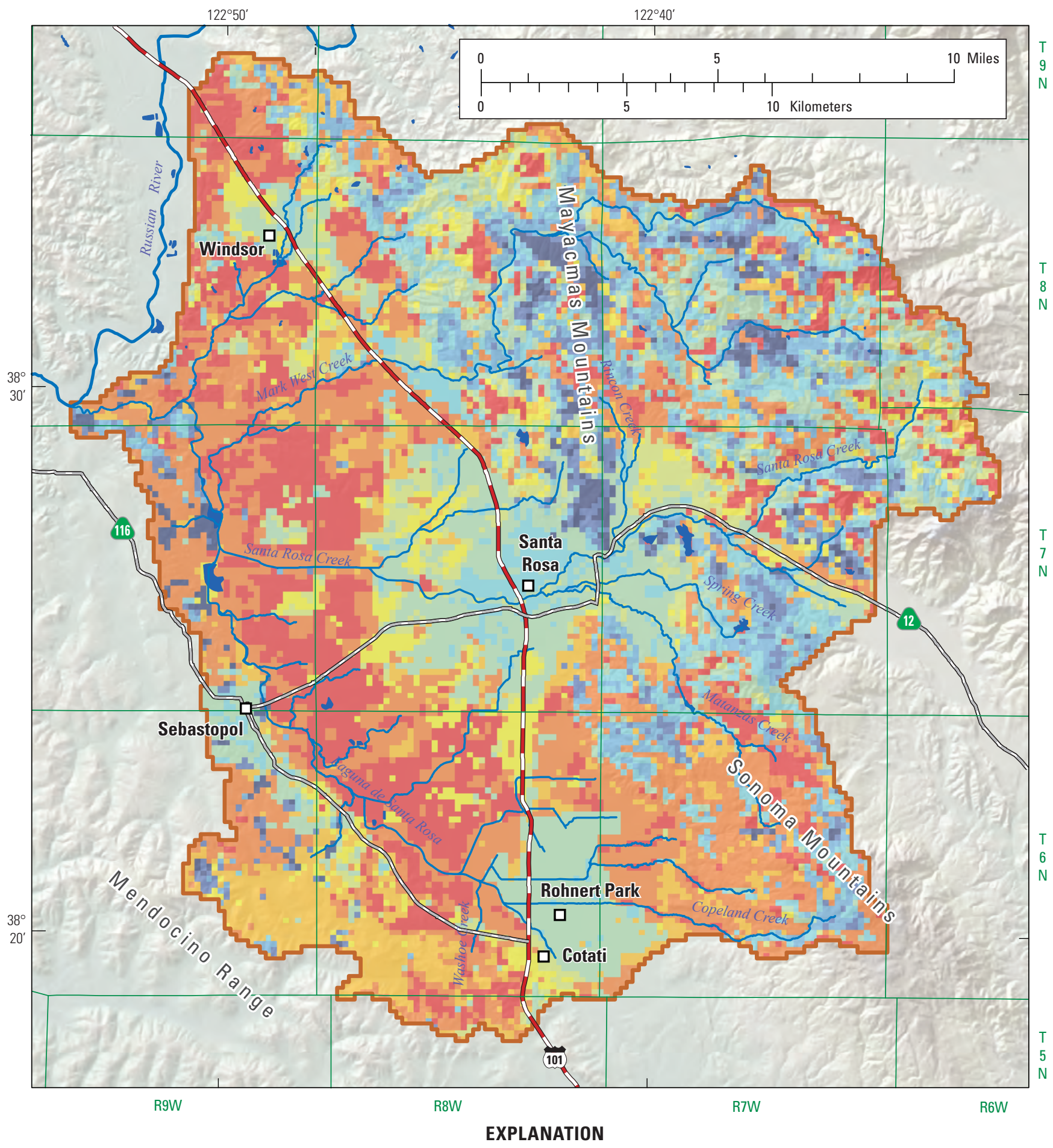

PRMS input parameter: soil_rechr_max (inches)

\begin{tabular}{|l|l|l|l|l|}
\hline 0.14 to 1 & 1.51 to 2 & 2.51 to 3 & 4.01 to 5 & 6.01 to 7 \\
\hline 1.01 to 1.5 & 2.01 to 2.5 & 3.01 to 4 & 5.01 to 6 & 7.01 to 9.73
\end{tabular}

Santa Rosa Plain watershed and hydrologic-model boundary

Major stream channels

Figure 4. Distribution of the soil_rechr_max parameter in the Santa Rosa Plain hydrologic model, Santa Rosa Plain watershed, Sonoma County, California. 


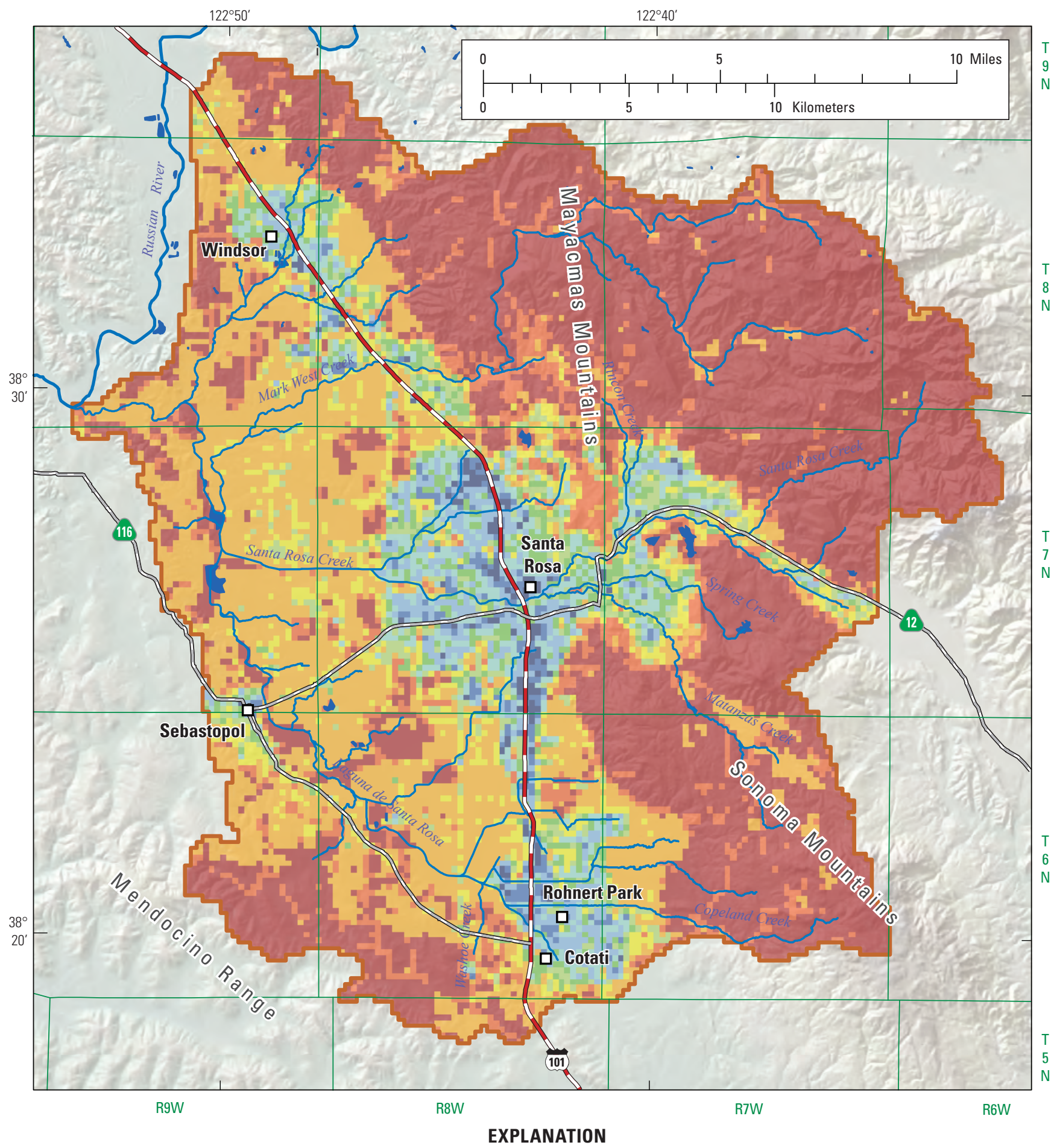

PRMS input parameter: hru_percent_imperv, (dimensionless)

\begin{tabular}{l|l|l|l|l|}
\hline 0 to 0.01 & 0.11 to 0.2 & 0.31 to 0.4 & 0.51 to 0.6 & 0.71 to 0.8 \\
0.011 to 0.1 & 0.21 to 0.3 & 0.41 to 0.5 & 0.61 to 0.7 & 0.81 to 0.87
\end{tabular}

Santa Rosa Plain watershed and hydrologic-model boundary

Major stream channels

Figure 5. Distribution of the hru_percent_imperv parameter in the Santa Rosa Plain hydrologic model, Santa Rosa Plain watershed, Sonoma County, California. 


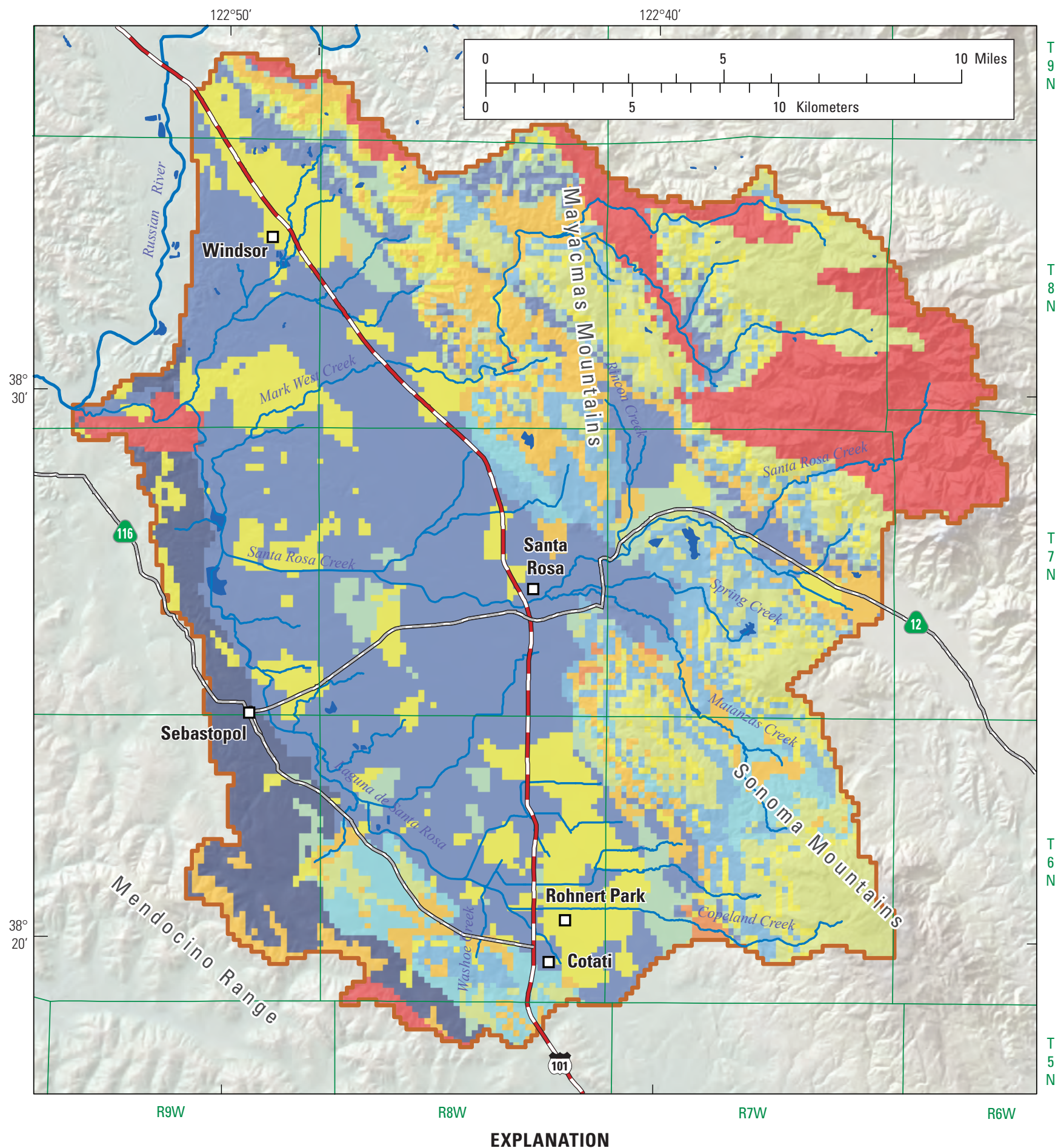

PRMS input parameter: ssr2gw_rate (inches/day)

\begin{tabular}{l|l|l|l|l|l|}
\hline 0.00015 & 0.00051 to 0.001 & 0.0051 to 0.01 & 0.021 to 0.03 & 0.041 to 0.05 \\
\hline 0.000151 to 0.0005 & 0.0011 to 0.005 & 0.011 to 0.02 & 0.031 to 0.04 & 0.051 to 0.055
\end{tabular}

Santa Rosa Plain watershed and hydrologic-model boundary

Major stream channels

Figure 6. Distribution of the ssr2gw_rate parameter in the Santa Rosa Plain hydrologic model, Santa Rosa Plain watershed, Sonoma County, California. 


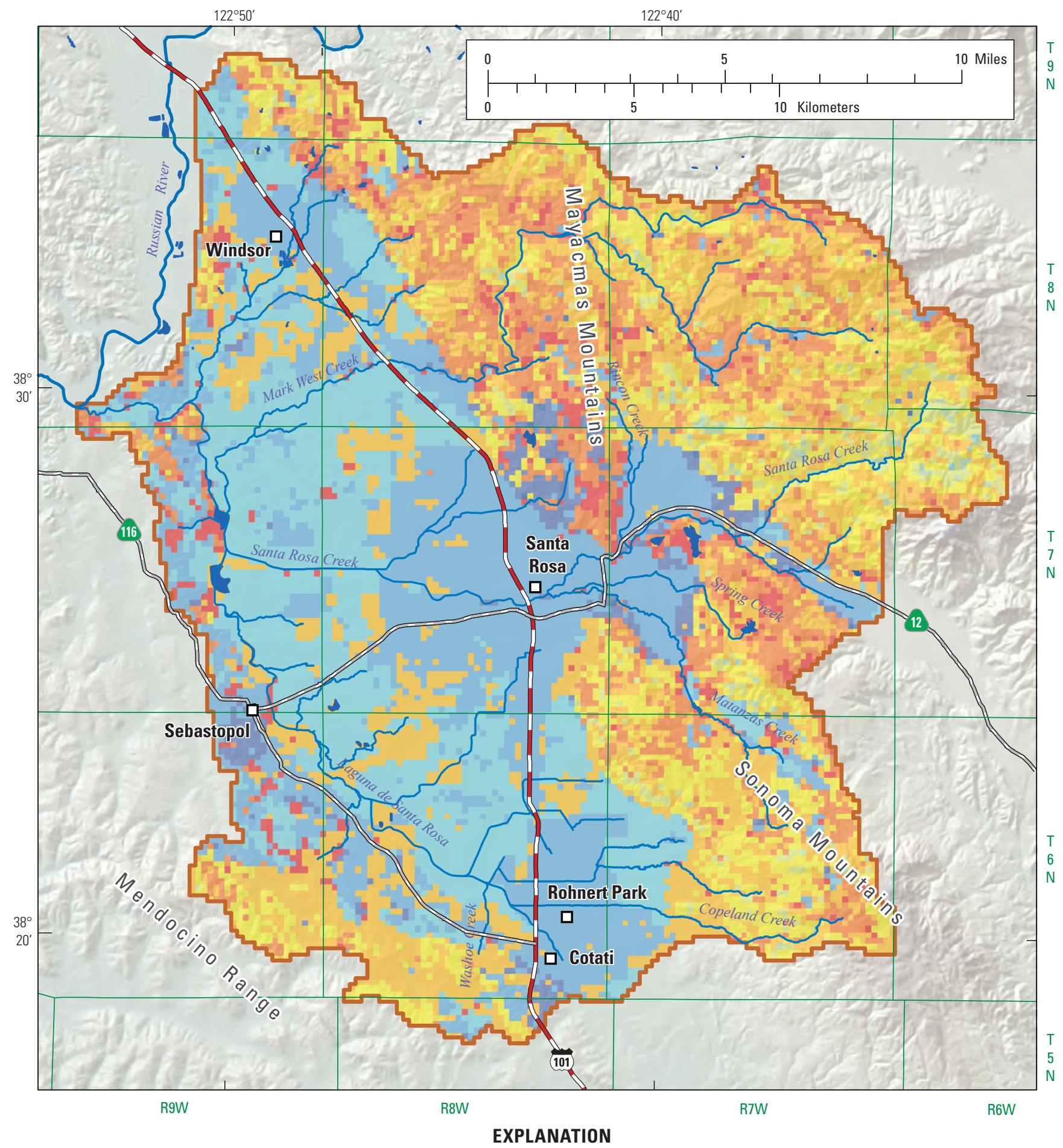

PRMS calibrated input parameter: carea_max (Hydrologic response unit area fraction)

\begin{tabular}{|l|l|l|l|l|}
\hline 0.0017 to 0.1 & 0.21 to 0.3 & 0.41 to 0.5 & 0.61 to 0.7 & 0.81 to 0.9 \\
0.11 to 0.2 & 0.31 to 0.4 & 0.51 to 0.6 & 0.71 to 0.8 & 0.91 to 0.96
\end{tabular}

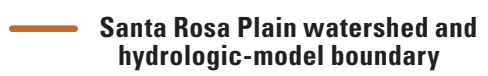
hydrologic-model boundary

Major stream channels

Figure 7. Distribution of the carea_max parameter in the Santa Rosa Plain hydrologic model, Santa Rosa Plain watershed, Sonoma County, California. 


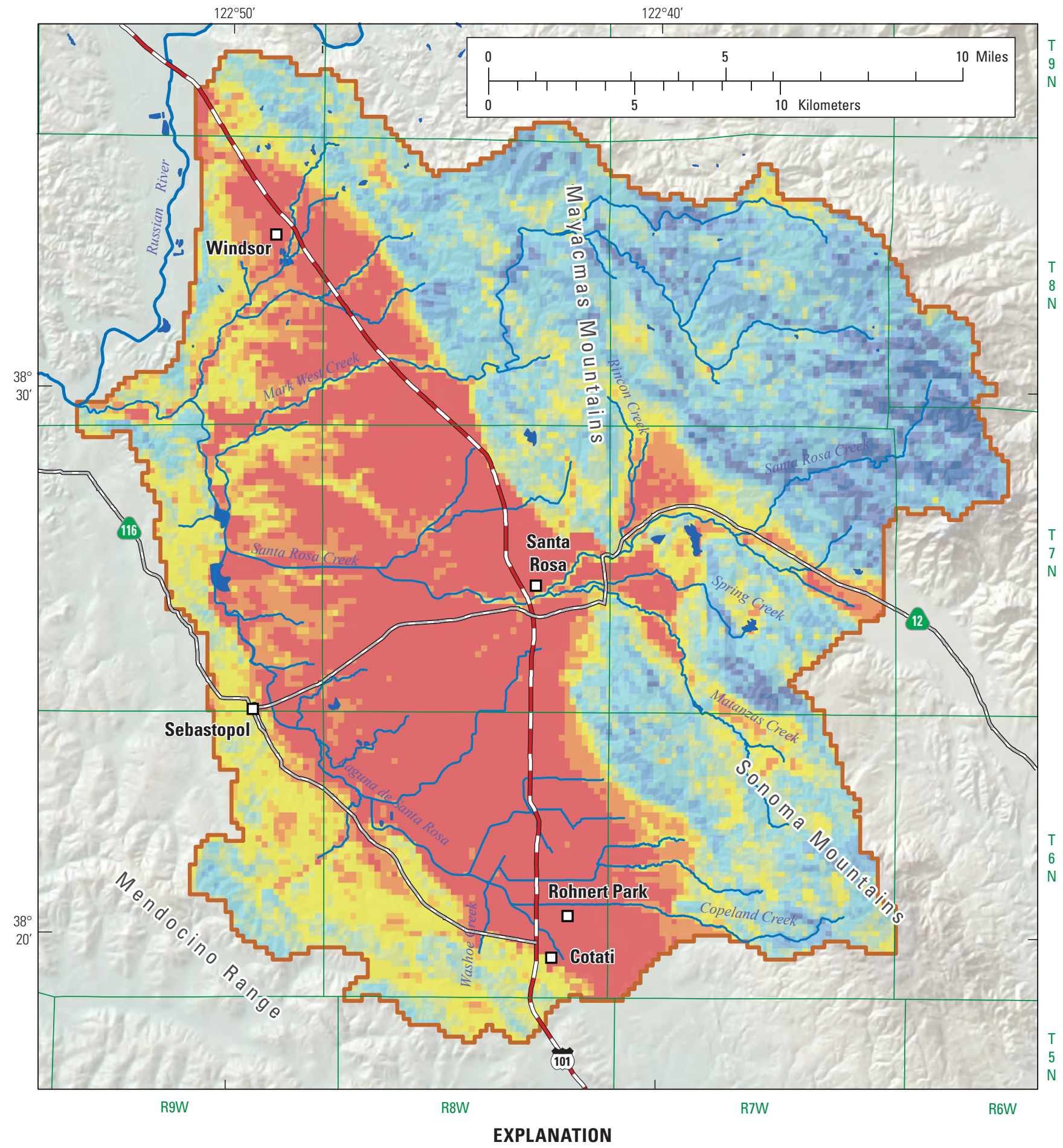

PRMS calibrated input parameter: slowcoef_linear (dimensionless)

\begin{tabular}{l|l|l|l|l|l|l|l}
0 to 0.0001 & 0.00051 to 0.001 & 0.0051 to 0.01 & 0.021 to 0.05 & 0.11 to 0.15
\end{tabular} \begin{tabular}{|l|l|l|l|l|l|l|}
0.00011 to 0.0005 & 0.0011 to 0.005 & 0.011 to 0.02 & 0.051 to 0.1 & 0.16 to 0.31
\end{tabular}
Santa Rosa Plain watershed and hydrologic-model boundary

Major stream channels

Figure 8. Distribution of the slowcoef_lin parameter in the Santa Rosa Plain hydrologic model, Santa Rosa Plain watershed, Sonoma County, California. 


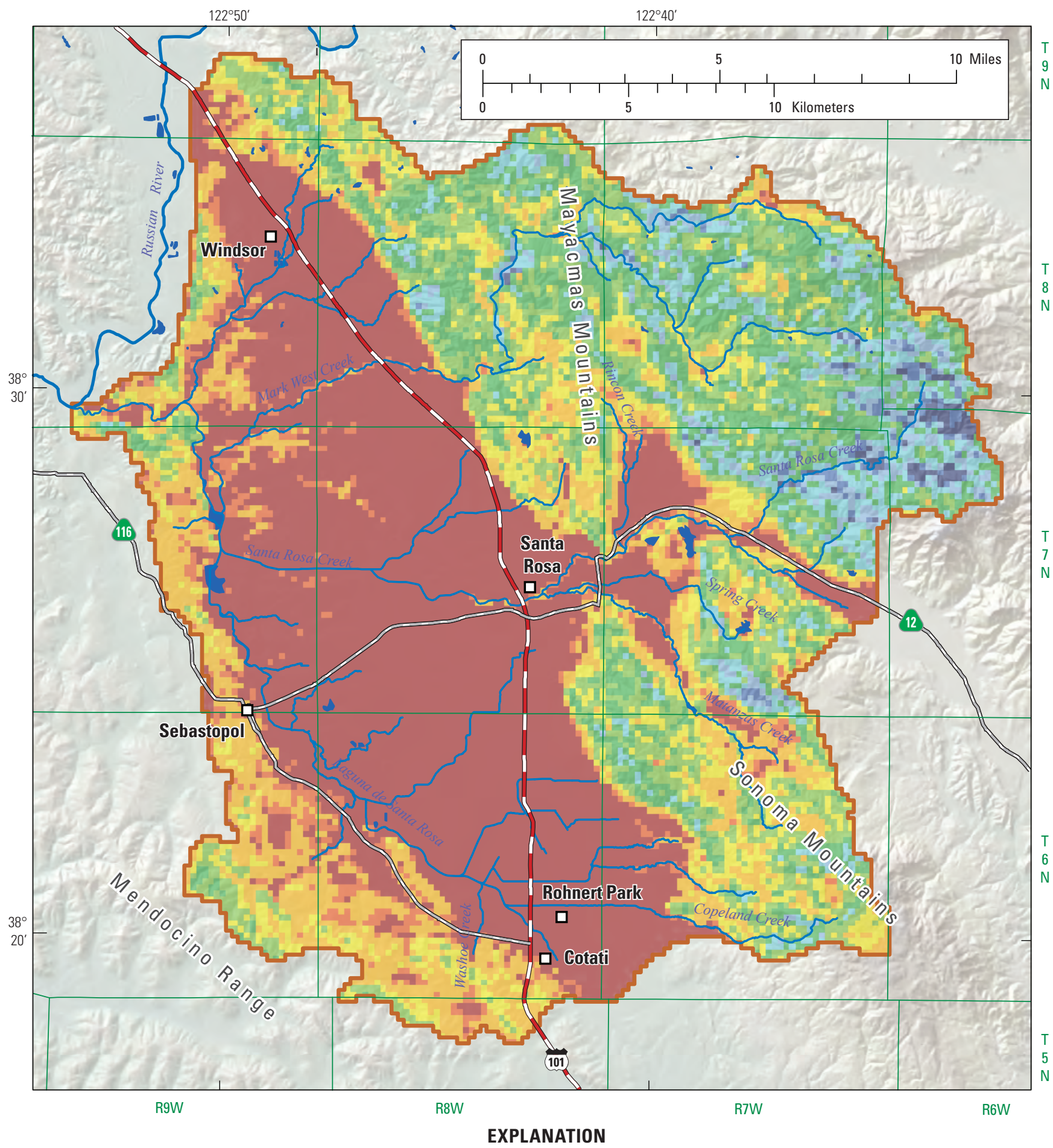

PRMS calibrated input parameter: slowcoef_sq (1/inch-day)

\begin{tabular}{|l|l|l|l|l|}
0.00001 to 0.0005 & 0.0011 to 0.005 & 0.011 to 0.02 & 0.041 to 0.06 & 0.081 to 0.1 \\
0.00051 to 0.001 & 0.0051 to 0.01 & 0.021 to 0.04 & 0.061 to 0.08 & 0.11 to 0.17
\end{tabular}

Santa Rosa Plain watershed and hydrologic-model boundary

Major stream channels

Figure 9. Distribution of the slowcoef_sq parameter in the Santa Rosa Plain hydrologic model, Santa Rosa Plain watershed, Sonoma County, California. 


\section{Hydraulic Properties}

The range and mean for the final values of horizontal hydraulic conductivity at completion of model calibration for the SRPW are given in table 2. The mean and median horizontal hydraulic conductivity values ranged from 0.60 feet per day ( $\mathrm{ft} / \mathrm{d})$ in layer 8 to $16 \mathrm{ft} / \mathrm{d}$ in layer 1 and from $0.54 \mathrm{in}$ layer 8 to $16 \mathrm{ft} / \mathrm{d}$ in layer 1 , respectively. The highest values of horizontal hydraulic conductivity in the SRPW were in layers $1-3$ of the Bennett Valley-plain MSU (fig. 10A-C). These values reflected the very coarse-grained material in this MSU. The lowest horizontal hydraulic conductivity in the SRPW was for the basement complex, which was in all eight layers (fig. 10). The values of horizontal hydraulic conductivity in the uplands generally were lower than in the SRP to reflect the greater degree of weathering and, at depth, consolidation.

Transmissivity values estimated from aquifer tests (Kadir and MacGuire 1987; Sonoma County Water Agency, written commun., 2009) were used as observations for calibrating the horizontal hydraulic-conductivity multiplier in selected layers in the Windsor, Bennett Valley plain, Wilson Grove, and Santa Rosa MSUs (fig. $1 B$ ) so that the simulated transmissivity value matched the estimated transmissivity value at wells (fig. $1 B$ ). The estimated and simulated values of transmissivity are presented in table 3 . The transmissivity values at each location were calculated by multiplying the simulated horizontal hydraulic conductivity by the layer thickness at a given well. The horizontal hydraulic-conductivity multiplier was adjusted until the calculated value of transmissivity approximated the estimated value. The simulated transmissivity values for all wells were within 5 percent of the estimated values.

The vertical hydraulic conductivity (VK) for each model layer in the SRPHM is computed by dividing the horizontal hydraulic conductivity (HK) values, which were arithmetically averaged when the number of model layers was reduced (see "Model Discretization" in chapter C), by the horizontalto-vertical anisotropy ratio (VANI). The VANI values were estimated for each MSU in place of the vertical hydraulic conductivity values; that is, the VANI ratio was homogeneous within an MSU. Because the HK distributions vary spatially, however, the computed VK values vary in the same manner. The VANI ratios were adjusted by MSU to better approximate the vertical gradients observed in wells in the same vicinity perforated at different depths. The VANI ratios at completion of model calibration ranged from 1 , for the basement complex in all layers, to 2,500, in the Windsor and Cotati-north MSUs in layer 2 (table 4). The final vertical hydraulic conductivities calculated by the SRPHM ranged from 0.000007 to $1.2 \mathrm{ft} / \mathrm{d}$ in the SRPW (table 5). The highest values in the SRPHM domain were in the Bennett Valley-plain MSU for layers 1-3; the Santa Rosa MSU for layers 4 and 6; and the Windsor, Santa Rosa, Cotati-south, and Rincon-Kenwood Valley MSUs for layers 7 and 8 . The lowest values of vertical hydraulic conductivity were in the basement complex and in fine-grained units throughout the Santa Rosa Plain (SRP) that have low horizontal hydraulic conductivity and a high VANI.
Table 2. Summary of final horizontal hydraulic-conductivity values in the Santa Rosa Plain hydrologic model, Santa Rosa Plain watershed, Sonoma County, California.

\begin{tabular}{ccccc}
\hline \multirow{5}{*}{ Layer } & \multicolumn{4}{c}{ Final horizontal hydraulic conductivity } \\
& \multicolumn{5}{c}{ Heet per day) } \\
\cline { 2 - 5 } & Lowest & Highest & Mean & Median \\
\hline 1 & $1.0 \mathrm{e}^{-4}$ & 40 & 16 & 16 \\
2 & $1.0 \mathrm{e}^{-4}$ & 40 & 3.5 & 1.2 \\
3 & $1.0 \mathrm{e}^{-4}$ & 124 & 6.0 & 3.7 \\
4 & $1.0 \mathrm{e}^{-4}$ & 16 & 5.3 & 3.8 \\
5 & $1.0 \mathrm{e}^{-4}$ & 11 & 3.5 & 2.9 \\
6 & $1.0 \mathrm{e}^{-4}$ & 5.3 & 2.2 & 2.0 \\
7 & $1.0 \mathrm{e}^{-4}$ & 1.8 & 0.81 & 0.77 \\
8 & $1.0 \mathrm{e}^{-4}$ & 1.8 & 0.60 & 0.54 \\
\hline & & Uplands & & \\
\hline 1 & $1.0 \mathrm{e}^{-4}$ & 2.5 & 0.45 & 0.1 \\
2 & $1.0 \mathrm{e}^{-4}$ & 0.64 & 0.06 & 0.06 \\
3 & $1.0 \mathrm{e}^{-4}$ & 0.42 & 0.04 & 0.04 \\
4 & $1.0 \mathrm{e}^{-4}$ & 3.3 & 0.03 & 0.02 \\
5 & $1.0 \mathrm{e}^{-4}$ & 0.14 & 0.01 & 0.01 \\
6 & $1.0 \mathrm{e}^{-4}$ & 0.09 & 0.006 & 0.007 \\
7 & $1.0 \mathrm{e}^{-4}$ & 0.09 & 0.005 & 0.007 \\
8 & $1.0 \mathrm{e}^{-4}$ & 0.09 & 0.005 & 0.0004 \\
\hline
\end{tabular}

The comparatively low, calibrated vertical hydraulic conductivities (high VANIs) in model layer 2 for the Windsor, Santa Rosa, Cotati-north, and Cotati-south MSUs were consistent with measured groundwater-level data. In the Windsor and Santa Rosa MSUs, measured groundwater levels were 25-50 ft higher in model layer 1 than in the underlying layers.

Specific yield (SY) is defined for all model layers because the layers were designated as convertible (can switch between confined and unconfined). The SY distributions are assigned to model layers as described in chapter $C$ of this report. The values for specific yield were adjusted by MSU during calibration, and the model was sensitive to the changes; however, taken over the area of the MSUs, the changes did not improve the overall model fit appreciably. Therefore, the final values at completion of model calibration (table 6) were the same as the initial values. The specific yield ranged from 0.01 to 0.2 in all layers, and the mean values ranged from 0.043 in layer 8 to 0.124 in layer 1 (table 6). The highest values of specific yield in layer 1 occurred in parts of all the MSUs in the SRPW. The specific yield distributions were based on stratigraphy and texture, as described in chapter $C$ of this report, and followed a pattern similar to that of horizontal hydraulic conductivity (fig. 10). 

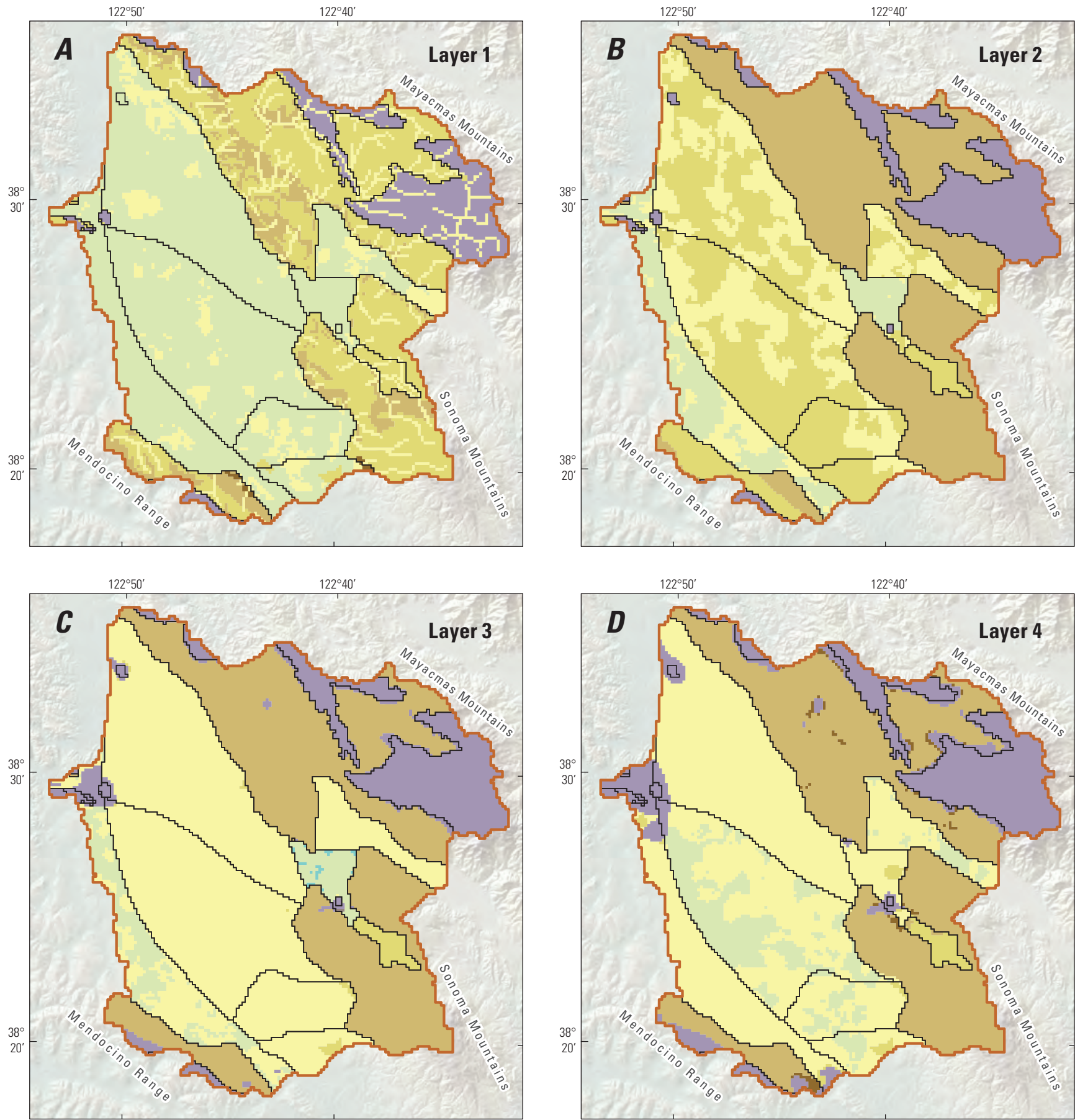

\section{EXPLANATION}

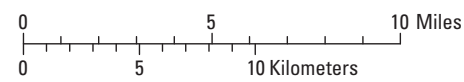

Horizontal conductivity, in feet per day

\begin{tabular}{|r|r|}
\hline 0.00000 to 0.0001 & $>0.1$ to 1.0 \\
$>0.0001$ to 0.001 & $>1.0$ to 10 \\
$>0.001$ to 0.01 & $>10$ to 100 \\
$>0.01$ to 0.1 & $>100$ to 124
\end{tabular}
Santa Rosa Plain watershed and
hydrologic-model boundary

Model storage unit boundary

Figure 10. Distribution of final horizontal hydraulic conductivity values in the Santa Rosa Plain hydrologic model, Santa Rosa Plain watershed, Sonoma County, California, for $A$, layer $1 ; B$, layer 2 ; $C$, layer 3 ; $D$, layer 4 ; $E$, layer 5 ; $F$, layer 6 ; $G$, layer 7 ; $H$, layer 8. 

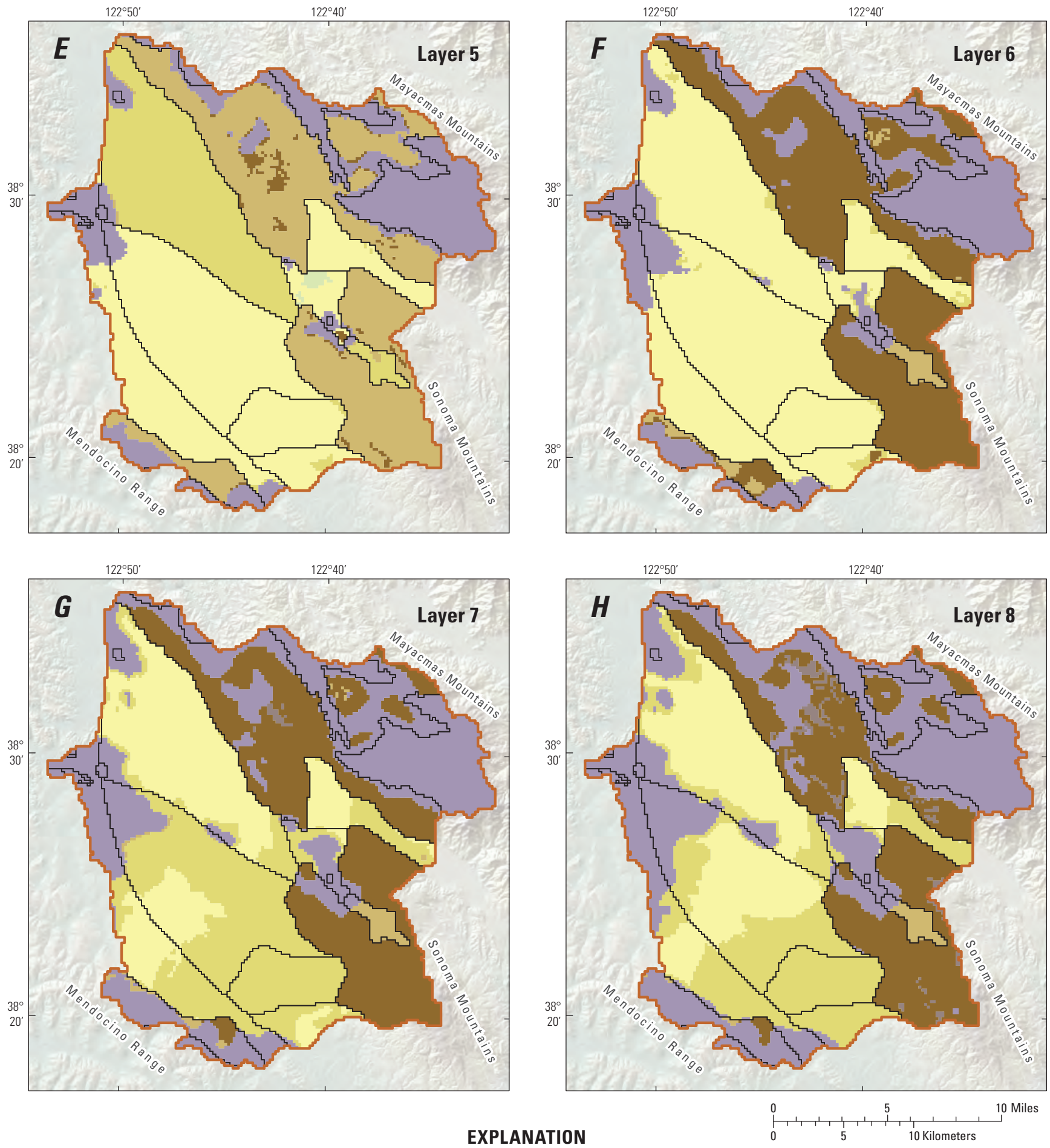

Horizontal conductivity, in feet per day

\begin{tabular}{|r|r|}
\hline 0 to 0.0001 & $>0.1$ to 1.0 \\
\hline$>0.0001$ to 0.001 & $>1.0$ to 10 \\
$>0.001$ to 0.01 & $>10$ to 100 \\
$>0.01$ to 0.1 & $>100$ to 124 \\
\hline
\end{tabular}

\section{EXPLANATION}

$>100$ to 124
_ Santa Rosa Plain watershed and hydrologic-model boundary

Model storage unit boundary

Figure 10. - Continued 
Table 3. Transmissivity values estimated from aquifer tests and their simulated equivalents for selected wells in the Santa Rosa Plain watershed, Sonoma County, California.

\begin{tabular}{ccccc}
\hline $\begin{array}{c}\text { Well } \\
\text { name }\end{array}$ & $\begin{array}{c}\text { Model } \\
\text { storage } \\
\text { unit }\end{array}$ & $\begin{array}{c}\text { Model } \\
\text { layers }\end{array}$ & $\begin{array}{c}\text { Estimated values } \\
\text { (feet squared per day) }\end{array}$ & $\begin{array}{c}\text { Simulated values } \\
\text { (feet squared per day) }\end{array}$ \\
\hline${ }^{1} 8 \mathrm{~N} / 9 \mathrm{~W}-12 \mathrm{Q} 2$ & $\begin{array}{c}\text { Windsor } \\
{ }^{1} 7 \mathrm{~N} / 8 \mathrm{~W}-24 \mathrm{~A} 4\end{array}$ & $3-5$ & 785 & 787 \\
${ }^{1} 7 \mathrm{~N} / 9 \mathrm{~W}-25 \mathrm{E} 1$ & Bennett Valley-plain & $2-7$ & 9,700 & 9,775 \\
${ }^{1} 6 \mathrm{~N} / 8 \mathrm{~W}-7 \mathrm{~A} 2$ & Santa Rosa & $4-7$ & 3,315 & 3,314 \\
${ }^{2} 7 \mathrm{~N} / 9 \mathrm{~W}-36 \mathrm{~K} 1$ & Santa Rosa & $6-7$ & 1,350 & 1,345 \\
${ }^{1} 7 \mathrm{~N} / 9 \mathrm{~W}-15 \mathrm{Q} 1$ & Santa Rosa & $4-7$ & 5,350 & 5,159 \\
\hline
\end{tabular}

${ }^{1}$ Data from Kadir and McGuire (1987).

${ }^{2}$ Data from Sonoma County Water Agency, written commun., 2009.

Table 4. Final vertical anisotropy ratios for each model storage unit in the Santa Rosa Plain hydrologic model, Santa Rosa Plain watershed, Sonoma County, California.

\begin{tabular}{|c|c|c|c|c|c|c|c|c|}
\hline \multirow{3}{*}{$\begin{array}{c}\text { Model } \\
\text { storage } \\
\text { unit }\end{array}$} & \multicolumn{8}{|c|}{ Layer } \\
\hline & 1 & 2 & 3 & 4 & 5 & 6 & 7 & 8 \\
\hline & \multicolumn{8}{|c|}{ Vertical anisotropy ratio (dimensionless) } \\
\hline Santa Rosa & 100 & 1,000 & 100 & 100 & 100 & 100 & 100 & 100 \\
\hline Cotati-north & 100 & 2,500 & 1,000 & 1,000 & 1,000 & 1,000 & 1,000 & 1,000 \\
\hline Cotati-south & 100 & 1,000 & 100 & 100 & 100 & 100 & 100 & 100 \\
\hline Bennett Valley-plain & 100 & 100 & 100 & 100 & 100 & 100 & 100 & 100 \\
\hline Bennett Valley-mountains & 10 & 10 & 10 & 10 & 10 & 10 & 10 & 10 \\
\hline Mayacmas Mountains & 10 & 10 & 10 & 10 & 10 & 10 & 10 & 10 \\
\hline Sonoma Mountains & 10 & 10 & 10 & 10 & 10 & 10 & 10 & 10 \\
\hline Wilson Grove mountains & 10 & 10 & 10 & 10 & 10 & 10 & 10 & 10 \\
\hline
\end{tabular}

Table 5. Summary of final vertical hydraulic-conductivity values in the Santa Rosa Plain hydrologic model, Santa Rosa Plain watershed, Sonoma County, California.

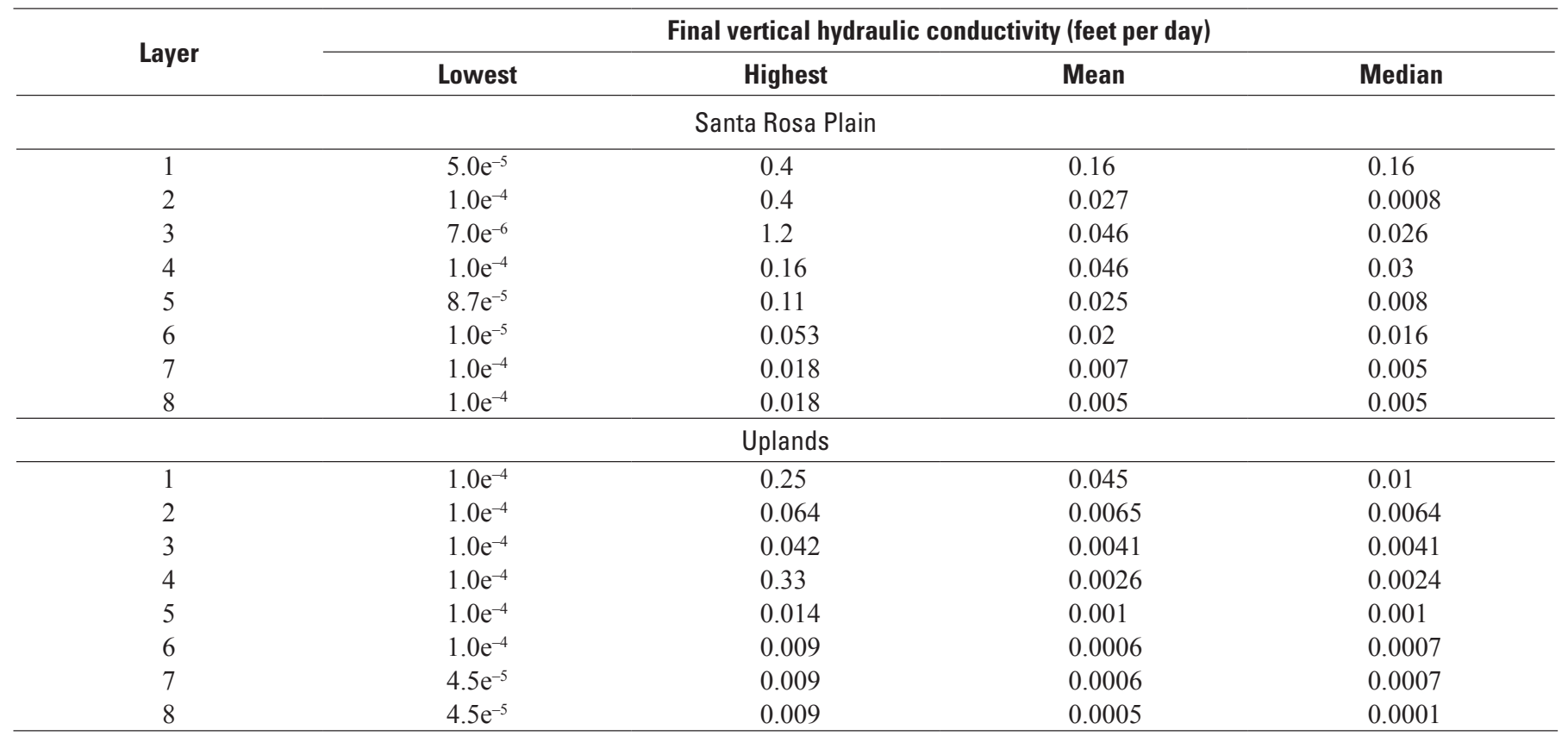


Table 6. Summary of final values for specific yield and specific storage for the Santa Rosa Plain hydrologic model, Santa Rosa Plain watershed, Sonoma County, California.

\begin{tabular}{|c|c|c|c|c|c|c|}
\hline \multirow{2}{*}{ Layer } & \multicolumn{3}{|c|}{ Specific yield (dimensionless) } & \multicolumn{3}{|c|}{ Specific storage (per foot) } \\
\hline & Lowest & Highest & Mean & Lowest & Highest & Mean \\
\hline 1 & 0.01 & 0.2 & 0.124 & $1 \mathrm{e}^{-6}$ & $2 \mathrm{e}^{-6}$ & $1.53 \mathrm{e}^{-6}$ \\
\hline 2 & 0.01 & 0.2 & 0.096 & $1 \mathrm{e}^{-6}$ & $2 \mathrm{e}^{-6}$ & $1.66 \mathrm{e}^{-6}$ \\
\hline 3 & 0.01 & 0.2 & 0.093 & $1 \mathrm{e}^{-6}$ & $2 \mathrm{e}^{-6}$ & $1.64 \mathrm{e}^{-6}$ \\
\hline 4 & 0.01 & 0.2 & 0.083 & $1 e^{-6}$ & $2 e^{-6}$ & $1.62 \mathrm{e}^{-6}$ \\
\hline 5 & 0.01 & 0.2 & 0.079 & $1 e^{-6}$ & $2 \mathrm{e}^{-6}$ & $1.57 \mathrm{e}^{-6}$ \\
\hline 6 & 0.01 & 0.2 & 0.071 & $1 \mathrm{e}^{-6}$ & $2 \mathrm{e}^{-6}$ & $1.53 \mathrm{e}^{-6}$ \\
\hline 7 & 0.01 & 0.2 & 0.082 & $1 \mathrm{e}^{-6}$ & $2 \mathrm{e}^{-6}$ & $1.42 \mathrm{e}^{-6}$ \\
\hline 8 & 0.01 & 0.2 & 0.043 & $1 \mathrm{e}^{-6}$ & $2 \mathrm{e}^{-6}$ & $1.58 \mathrm{e}^{-6}$ \\
\hline
\end{tabular}

The specific storage (SS) distributions were assigned to model layers, as described in chapter $C$ of this report. The values for specific storage were adjusted by MSU during calibration; however, the model was insensitive to the changes, and therefore, the final values at completion of model calibration were the same as the initial values. The specific storage values ranged from 0.000001 to $0.000002 \mathrm{per} \mathrm{ft}$ in all layers, and the mean values ranged from $1.4 \times 10^{-6}$ to $1.7 \times 10^{-6}$ per $\mathrm{ft}$ (table 6 ). Although the specific-storage distributions are based on stratigraphy and texture and vary spatially, the difference between the highest and lowest values is minor.

\section{Horizontal-Flow Barriers}

The faults simulated in the SRPHM are shown in figure 11. Groundwater flow across a simulated fault is proportional to the hydraulic characteristic (Hsieh and Freckleton, 1993), which is the barrier hydraulic conductivity divided by the width of the barrier (assumed to equal $1 \mathrm{ft}$ ). The initial hydraulic characteristics for all faults were 10 per day (1/d), allowing nearly unrestricted hydraulic connection across the faults. To reproduce the measured groundwater levels, it was necessary to decrease the hydraulic characteristic along most segments by 3-20 orders of magnitude (table 7; fig. 11), indicating a range of fault barrier effectiveness from minor to restrictive. The Sebastopol fault, Rogers Creek fault, Bennett Valley fault, and unidentified fault 2 were divided into segments, designated as Sebastopol fault near Windsor, unidentified fault 2-segment, Rodgers Creek fault-segment, and Bennett Valley fault-segment, respectively, to allow for assigning different hydraulic characteristics to selected segments (fig. 11). The most restrictive fault barriers are the Healdsburg and Rogers Creek faults, with a hydraulic characteristic of $1.0 \times 10^{-20} / \mathrm{d}$ in all eight layers of the SRPHM along most of their extents. The Sebastopol fault also is a restrictive barrier along most of its extent, with a hydraulic characteristic of $1.0 \times 10^{-10} / \mathrm{d}$ (table 7). Shallow groundwater levels near the northern end of the Sebastopol fault (near Windsor), and near the Bennett Valley fault, indicated that these faults are not barriers to groundwater flow; however, the effectiveness of these faults to impede groundwater flow in deeper layers (layers 2-8) is unknown, so the hydraulic characteristics were kept the same as for the other segments of these faults (table 7). The hydraulic characteristic for unidentified fault 1 indicates unrestricted flow along its extent. The hydraulic characteristic for unidentified fault 2 in all eight layers also indicates unrestricted flow across most of its extent, except for the segment designated as unidentified fault 2-segment in figure 11 , where the hydraulic characteristic is $1.0 \times 10^{-10} / \mathrm{d}$ in all layers (table 7).

\section{Boundary Conductance}

The initial general-head boundaries were in cells along the edge of layer 2 for the Russian River, Cotati, Wilson Grove, and Kenwood boundaries (fig. 1B). These locations were adjusted during model calibration, and the final generalhead boundaries were in cells along the edge of model layers 1 and 3 for the Russian River boundary and of layer 1 for the Cotati and Kenwood boundaries (fig. $1 B$ ). The vertical faces of cells along the edge of model layers 1-8 are general-head boundaries in the Wilson Grove boundary (fig. 1B). During calibration, the model cells from the southern end of the Russian River boundary to the northern end of the Wilson Grove (Russian River to Wilson Grove or RR-WG) boundary (fig. $1 B$ ) were added as a general-head boundary to match simulated hydraulic heads to measured data better in the vicinity of this boundary.

The Russian River boundary is along the western edge of the Windsor MSU. The calibrated horizontal hydraulic conductivity is low in layer 2 in this MSU; hence, horizontal groundwater flow is negligible in this layer, and the generalhead boundary was omitted. The Cotati and Kenwood generalhead boundaries were reassigned to layer 1 during model calibration for the same reason.

The Wilson Grove general-head boundary was extended to all eight layers to allow groundwater to flow into this MSU and better simulate measured groundwater levels in the calibration. The Wilson Grove Formation, which mostly comprises highly permeable marine sands, is the main stratigraphic unit in the Wilson Grove MSU. The Wilson Grove Formation extends to the Pacific Ocean, and well logs indicate 

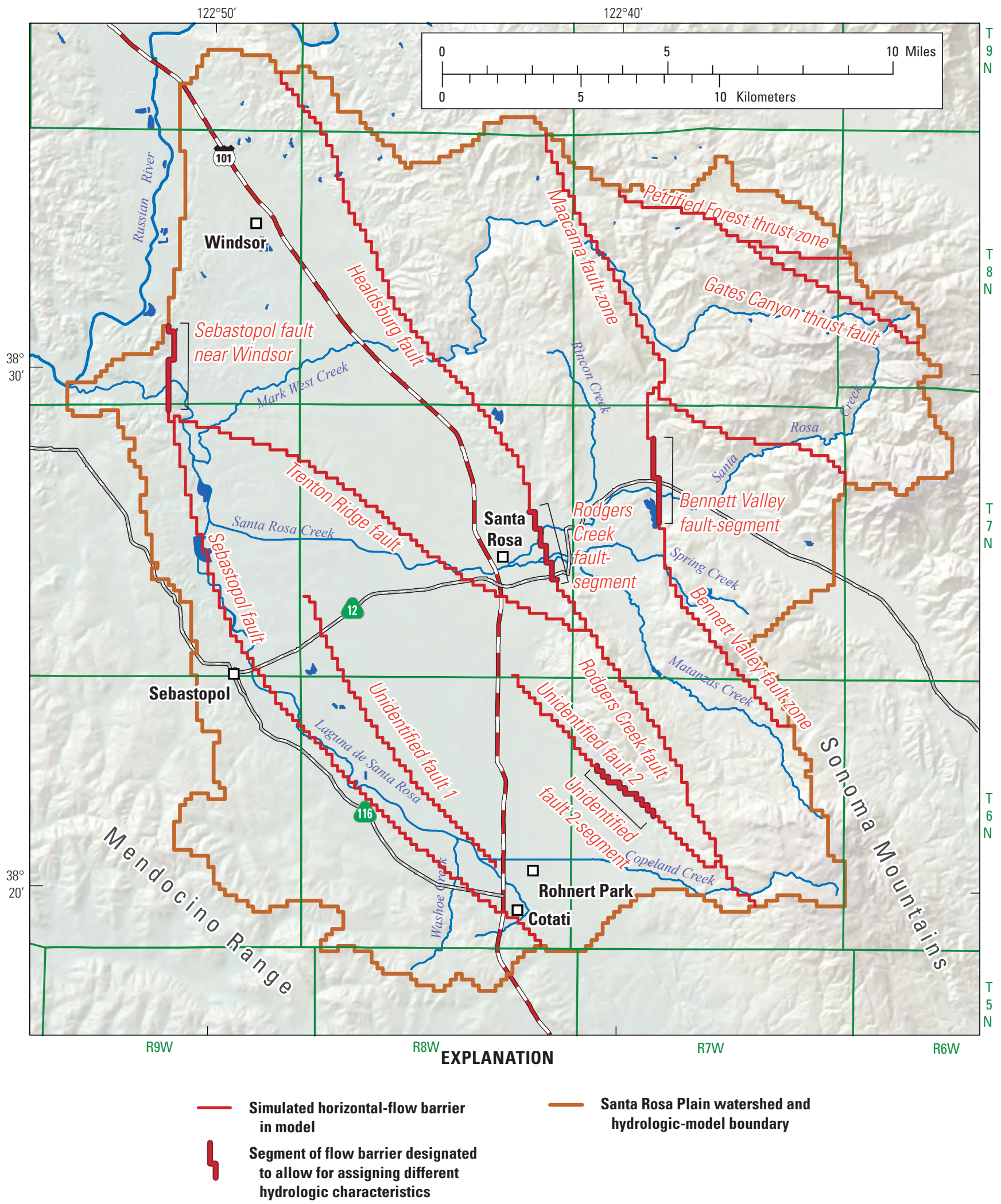

Santa Rosa Plain watershed and hydrologic-model boundary

Figure 11. Location of horizontal-flow barriers in the Santa Rosa Plain hydrologic model, Santa Rosa Plain watershed, Sonoma County, California. 
Table 7. Final values of the horizontal-flow barrier hydraulic characteristic in the Santa Rosa Plain hydrologic model, Santa Rosa Plain watershed, Sonoma County, California.

[Abbreviation: NB, fault is not a barrier to flow]

\begin{tabular}{|c|c|c|c|c|c|c|c|c|}
\hline \multirow{3}{*}{ Fault name } & \multicolumn{8}{|c|}{ Hydraulic characteristic (1/day) } \\
\hline & \multicolumn{8}{|c|}{ Layer } \\
\hline & 1 & 2 & 3 & 4 & 5 & 6 & 7 & 8 \\
\hline Sebastopol Fault & $1 \mathrm{e}^{-10}$ & $1 \mathrm{e}^{-10}$ & $1 \mathrm{e}^{-10}$ & $1 \mathrm{e}^{-10}$ & $1 \mathrm{e}^{-10}$ & $1 \mathrm{e}^{-10}$ & $1 \mathrm{e}^{-10}$ & $1 \mathrm{e}^{-10}$ \\
\hline Trenton Ridge & 0.01 & 0.01 & $1 \mathrm{e}^{-4}$ & $1 \mathrm{e}^{-4}$ & $1 \mathrm{e}^{-4}$ & $1 \mathrm{e}^{-4}$ & $1 \mathrm{e}^{-5}$ & $1 \mathrm{e}^{-5}$ \\
\hline Healdsburg & $1 \mathrm{e}^{-20}$ & $1 \mathrm{e}^{-20}$ & $1 \mathrm{e}^{-20}$ & $1 \mathrm{e}^{-20}$ & $1 \mathrm{e}^{-20}$ & $1 \mathrm{e}^{-20}$ & $1 \mathrm{e}^{-20}$ & $1 \mathrm{e}^{-20}$ \\
\hline Maacama & 0.01 & 0.01 & $1 \mathrm{e}^{-4}$ & $1 \mathrm{e}^{-4}$ & $1 \mathrm{e}^{-4}$ & $1 \mathrm{e}^{-4}$ & $1 \mathrm{e}^{-4}$ & $1 \mathrm{e}^{-4}$ \\
\hline Bennett Valley-segment & 0.01 & 0.01 & 0.01 & 0.01 & 0.01 & 0.01 & 0.01 & 0.01 \\
\hline Bennett Valley & $1 \mathrm{e}^{-10}$ & $1 \mathrm{e}^{-10}$ & $1 \mathrm{e}^{-10}$ & $1 \mathrm{e}^{-10}$ & $1 \mathrm{e}^{-10}$ & $1 \mathrm{e}^{-10}$ & $1 \mathrm{e}^{-10}$ & $1 \mathrm{e}^{-10}$ \\
\hline Carneros & 0.01 & 0.01 & $1 \mathrm{e}^{-4}$ & $1 \mathrm{e}^{-4}$ & $1 \mathrm{e}^{-4}$ & $1 \mathrm{e}^{-4}$ & $1 \mathrm{e}^{-5}$ & $1 \mathrm{e}^{-5}$ \\
\hline Gates Canyon Thrust & 0.01 & 0.01 & $1 \mathrm{e}^{-4}$ & $1 \mathrm{e}^{-4}$ & $1 \mathrm{e}^{-4}$ & $1 \mathrm{e}^{-4}$ & $1 \mathrm{e}^{-5}$ & $1 \mathrm{e}^{-5}$ \\
\hline
\end{tabular}

the formation is as much as $1,000 \mathrm{ft}$ thick (Sweetkind and others, 2010). This includes layers 1-6 and part of layer 7 of the SRPHM. It is assumed that layers 7 and 8 contain the Wilson Grove Formation throughout their thickness, so the general-head boundary was included in all eight layers.

As stated previously, a general-head boundary was added during model calibration from the southern end of the Russian River boundary to the northern end of the Wilson Grove boundary in layer 1 (identified as Russian River to Wilson Grove in figure $1 B$ ). The boundary heads along the RR-WG boundary were unknown, but were assumed to be $40 \mathrm{ft}$, except where these heads were below the lowest elevation of the boundary cell. The 40 -ft boundary head was below the lowest elevation of layer 1 in 35 out of a total of 45 cells, and it was assumed that the boundary heads were $20 \mathrm{ft}$ above the lowest elevation of layer 1 for these cells.

The hydraulic-conductance values for the general-head boundaries were estimated through calibration based on measured groundwater levels. A final hydraulic-conductance value of 40,000 feet squared per day $\left(\mathrm{ft}^{2} / \mathrm{d}\right)$ at completion of model calibration was assigned to both layers 1 and 3 for the Russian River boundary (table 8), indicating that groundwater flow could be relatively unrestricted across this boundary to the Healdsburg area groundwater subbasin. Hydraulicconductance values for the Russian River to Wilson Grove boundary were 400 and $40,000 \mathrm{ft}^{2} / \mathrm{d}$ (table 8 ). The higher hydraulic-conductance value allows for relatively large quantities of subsurface flow out of the SRPW in the vicinity of where Mark West Creek exits the watershed. The final hydraulic-conductance values at completion of model calibration for the Wilson Grove boundary were 2.6 and $400 \mathrm{ft}^{2} / \mathrm{d}$ in layers $1-6$ and 2.6 in layers $7-8$ (table 8 ). The higher hydraulic
Table 8. Final general-head boundary conductances in the Santa Rosa Plain hydrologic model, Santa Rosa Plain watershed, Sonoma County, California.

[Abbreviation: - , not applicable]

\begin{tabular}{cccccc}
\hline \multicolumn{6}{c}{$\begin{array}{c}\text { General-head boundary conductances } \\
\text { (square feet per day) }\end{array}$} \\
\hline \multicolumn{6}{c}{ Boyer } \\
\cline { 2 - 6 } & $\begin{array}{c}\text { Russian } \\
\text { River }\end{array}$ & $\begin{array}{c}\text { Russian River } \\
\text { to Wilson } \\
\text { Grove }\end{array}$ & $\begin{array}{c}\text { Wilson } \\
\text { Grove }\end{array}$ & Cotati & Kenwood \\
\hline 1 & 40,000 & $400,40,000$ & $2.6,400$ & $6.5,13$, and 26 & 6.5 and 26 \\
2 & - & - & $2.6,400$ & - & - \\
3 & 40,000 & - & $2.6,400$ & - & - \\
4 & - & - & $2.6,400$ & - & - \\
5 & - & - & $2.6,400$ & - & - \\
6 & - & - & $2.6,400$ & - & - \\
7 & - & - & 2.6 & - & - \\
8 & - & - & 2.6 & - & - \\
\hline
\end{tabular}

conductance allows limited quantities of groundwater to flow into the SRPW from the Wilson Grove Formation Highlands groundwater subbasin in the vicinity of calibration wells $7 \mathrm{~N} / 9 \mathrm{~W}-15 \mathrm{~K} 1$ and $7 \mathrm{~N} / 9 \mathrm{~W}-26 \mathrm{P} 1$ (fig. $1 B$ ). The final boundary conductance values at completion of model calibration were $6.5,13$, and $26 \mathrm{ft}^{2} / \mathrm{d}$ for the Cotati boundary and were 6.5 and $26 \mathrm{ft}^{2} / \mathrm{d}$ for the Kenwood boundary (table 8). The direction of flow across these boundaries is unknown and, thus, was simulated by the SRPHM. 


\section{Stream-Channel Properties}

The stream-channel properties that were adjusted included the streambed hydraulic conductivity, Manning's roughness coefficient (n), and stream-channel cross-section profile. The initial values of streambed hydraulic conductivity were determined as described in chapter $C$ of this report. The calibrated values of ranged from about 0.007 to $6.5 \mathrm{ft} / \mathrm{d}$ (fig. 12). The greatest values were predominantly in stream channels in the uplands, in the Mark West Creek and Santa Rosa Creek channels, in a segment of the Laguna de Santa Rosa in the Santa Rosa MSU, and in some smaller creeks at the eastern margins of the SRP (fig. 12). The lowest values generally were in the Windsor, Santa Rosa, Cotati-N, and Cotati-S MSUs (fig. 12).

The Manning's roughness coefficient (dimensionless) is defined qualitatively in the SRPHM on the basis of the general roughness characteristics of the main channels and overbank areas described in Chow (1959), Linsley and others (1982), and Maidment (1993). The initial value for the main channels (0.041) was representative of both mountain streams and winding sluggish reaches. For the overbank areas, the initial value (0.111) was representative of riparian areas with heavy vegetation. The Manning's roughness coefficient was adjusted during calibration but was found to be insensitive; hence, the initial and final values were the same.

The initial stream-channel cross-section profile had a constant width for all stream segments. During model calibration, it was found that allowing for a variable wetted perimeter beneath stream reaches improved the calibration. The ICALC2 option of the SFR2 Package (Niswonger and Prudic, 2006) was used in the SRPHM to allow for discretization of a variable cross-section beneath a stream reach. This allows for the wetted perimeter of the stream to change as a function of streamflow and stream depth (Markstrom and others, 2008). The streambed elevations and widths were based on the digital elevation model (DEM), orthophotos, and the number of upstream HRUs. It was assumed that the cross-section of a stream is represented by a uniform six-point shape (Markstrom and others, 2008) for all stream segments and that the width of the stream increases with distance downstream.

\section{Rural Pumpage}

As stated in chapter $C$ of this report, rural pumpage was defined as a combination of agricultural and domestic pumpage. Pumpage for agricultural irrigation was estimated by using the decoupled PRMS model and a daily crop waterdemand model (CWDM), as described in Appendix 1. Parameters were adjusted so that simulated agricultural irrigation approximated the estimates of agricultural pumping from Kadir and MacGuire (1987). Domestic pumpage was estimated from population-density data and a consumptive-use factor, as described in chapter $C$ of this report. In order to match simulated and measured groundwater levels better, adjustments were made to the estimated rural pumpage during model calibration.
The simulated hydraulic heads in most calibration wells in the vicinity of rural wells showed a greater groundwaterlevel decline from 1998 to 2010 than was measured. Adjusting the hydraulic conductivity and storage by the MSU did not improve the overall match between simulated and measured groundwater levels. It was apparent that the estimated quantity of rural pumpage for this period was too high, and, therefore, the quantities of pumpage were reduced by as much as 33 percent from the original values (table 9; fig. 13). The reduction was started in water year 1982 and gradually increased to the maximum value of the reduction.

\section{Assessment of Model Fit}

Comparisons of simulated and measured streamflow and groundwater levels indicate how well the SRPHM replicates the flow system. The methods of analysis described above in the "Calibration Method" section of this chapter, and the calibration objectives described in the following sections help to assess how accurately the SRPHM simulates the quantity of streamflow, groundwater levels, and direction of groundwater flow in the hydrologic system.

\section{Calibration to Streamflow}

The magnitude and variability of simulated streamflow is dependent on many factors and processes, including the following: (1) runoff in direct response to precipitation; (2) ET and recharge from the soil zone; (3) the rate and amount of interflow; (4) groundwater discharge to the soil zone; (5) groundwater discharge directly to stream channels (baseflow); and (6) additional stream-channel properties and processes, such as infiltration through the streambed, precipitation and evaporation, stream-channel storage, and streambed elevation. Comparisons between measured and simulated daily mean, moving 3-day daily mean streamflow, monthly mean streamflow, and annual mean streamflow were made by visually inspecting hydrographs and flow-duration curves and evaluating "goodness-of-fit" statistics.

The SRPHM was calibrated to streamflow records for 12 USGS streamgages (fig. 1A). Calibration using the streamflow records at gages COLL, LAGS, and MWCM was done by using the 3-day average simulated and measured streamflow, rather than daily streamflow, because of potential backwater conditions, primarily caused by high flows in the Russian River, affecting these locations.

The calibrated model was tested for a subset of the period of record for six streamgages. The testing procedure compared simulated with measured data that were independent of the calibration data to determine if the calibrated parameter set was suitable for simulating streamflow in the SRPW. Results from the testing are presented in the "Testing Results for Streamflow" and "Comparison of Simulated and Measured Annual Streamflow" sections. 


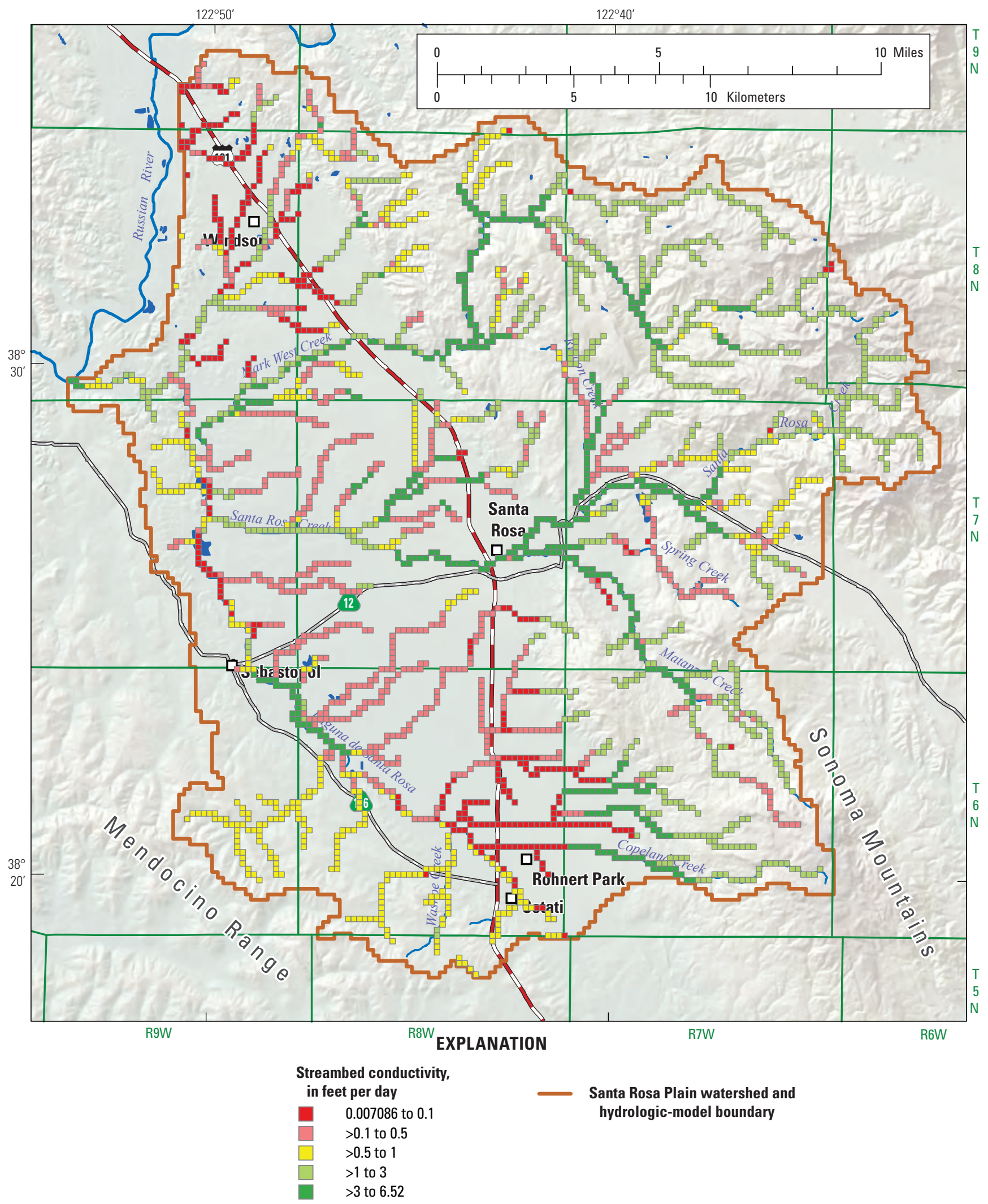

Figure 12. Distribution of final streambed conductivities in the Santa Rosa Plain hydrologic model, Santa Rosa Plain watershed, Sonoma County, California. 
Table 9. Initial and final rural pumpage from 1982 to 2010, Santa Rosa Plain hydrologic model, Santa Rosa Plain watershed, Sonoma County, California.

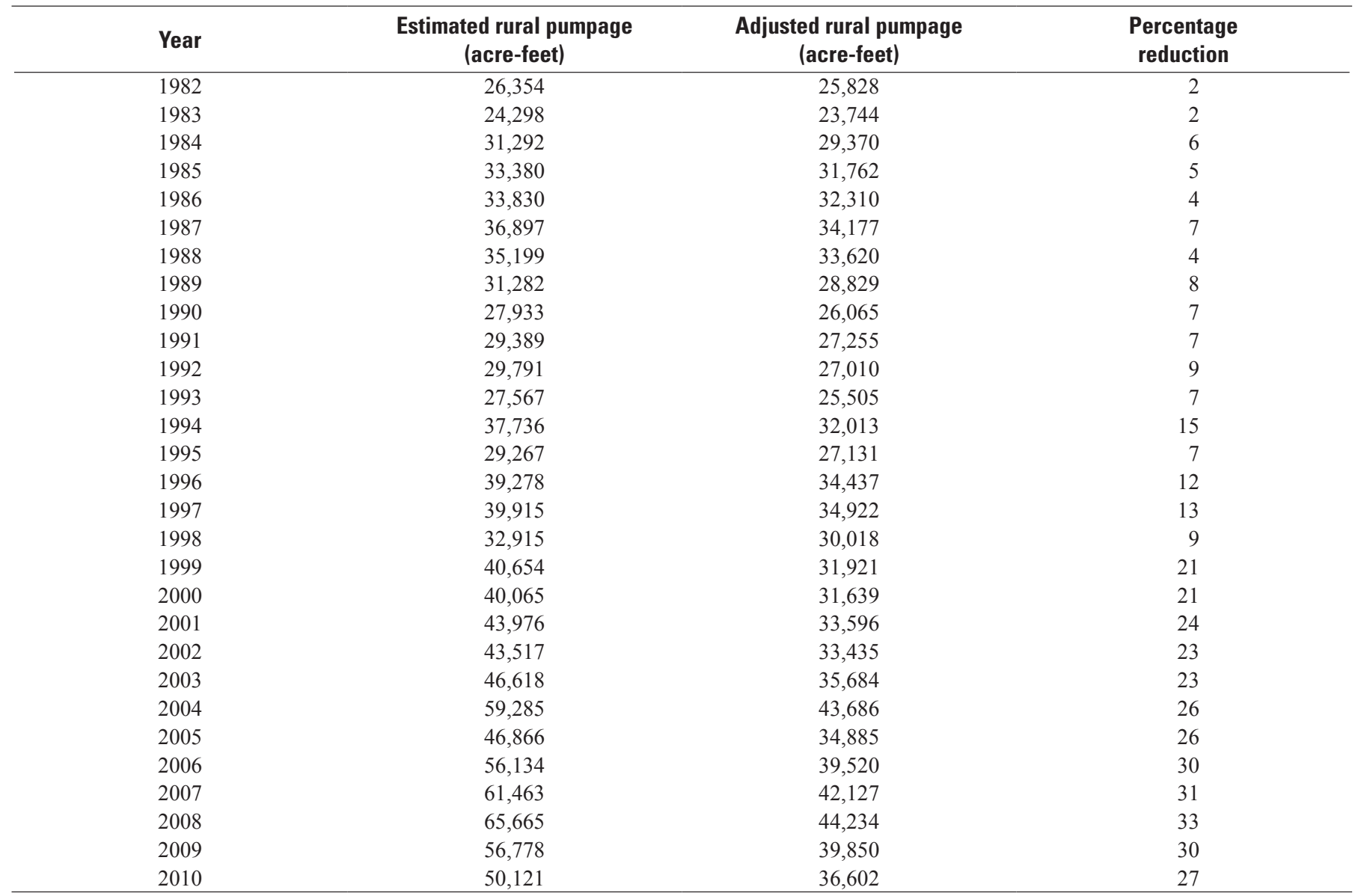

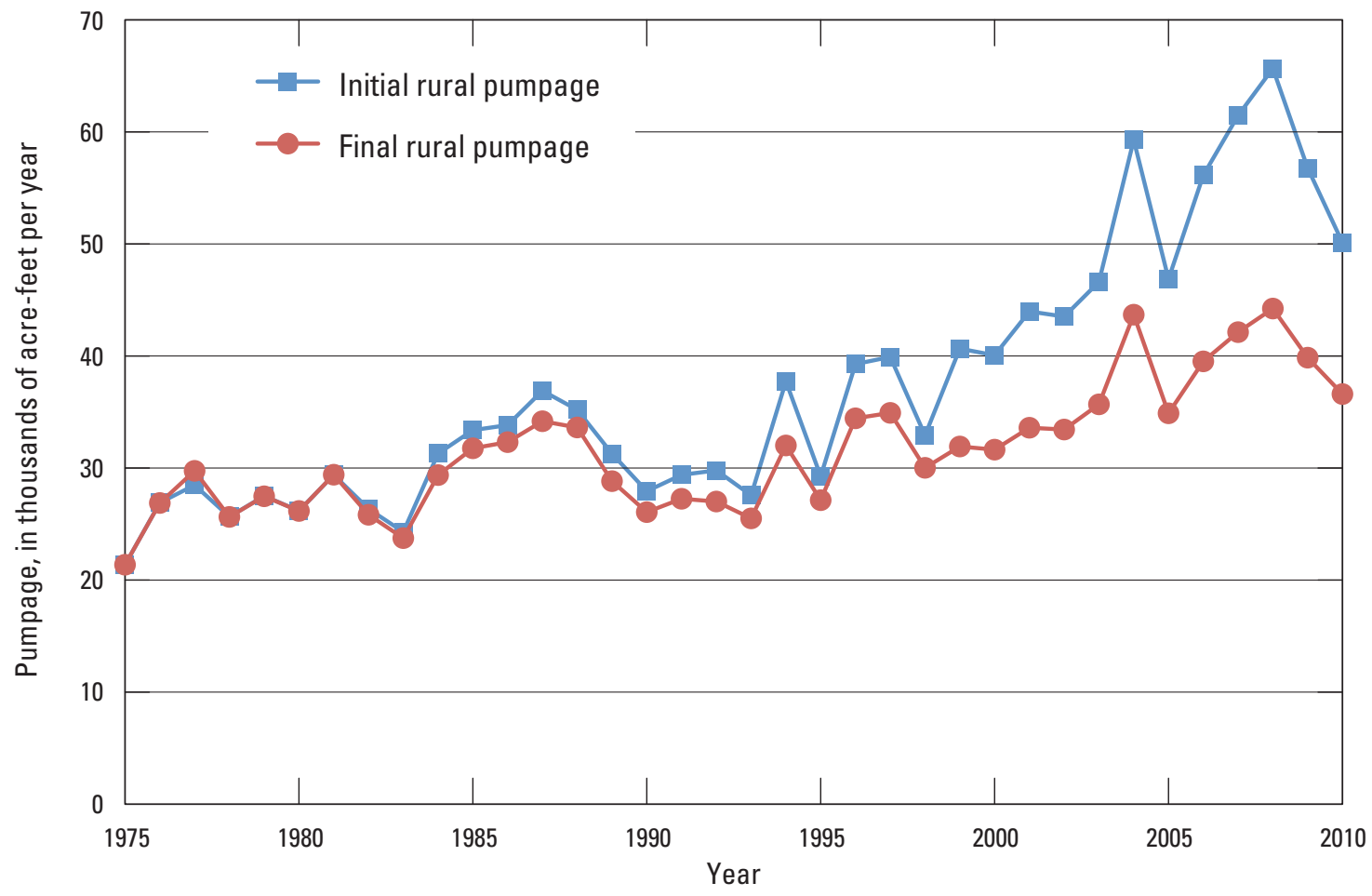

Figure 13. Initial and final rural pumpage, water years 1975-2010, Santa Rosa Plain hydrologic model, Santa Rosa Plain watershed, Sonoma County, California. 
The SRPHM was tested by using streamflow records for the five gages having the longest records (LAGC, COLL, LAGS, SRCU, and SRCW) and the extended MWCM gage record - a total of six gages. The record for the MWCM gage is short (water years 2006-10), and because the drainage area for MWCM accounts for about 96 percent of the SRPW area, the record was extended to water years 1960-2005 by using the MOVE1 technique, as described by Sweetkind and others (2013). The extended MWCM record was used for model testing only and not for calibration.

In general, each streamgage had different calibration and testing periods that were between water years 1975 and 2010 , with the exception of the SRCU gage. Calibration and testing using the streamflow record for the SRCU gage were done for the period that started on August 1959 and ended September 30, 1965 by using a separate GSFLOW simulation for water years 1950-1965, in which pumping was excluded from the SRPHM. The exclusion of pumping for the SRCU gage streamflow simulation was based on the assumption that pumping does not have a large effect on streamflow for this location. This assumption is reasonable because the drainage area of the SRCU gage is an upland catchment on the west side of the Mayacmas Mountains (fig. 1A), and this drainage had only a small number of limited-capacity rural wells during the 1959-65 period.

\section{Calibration Objectives for Streamflow}

The goodness-of-fit statistics used to assess the SRPHM fit to streamflow data included the percent-average-estimationerror (PAEE; Hevesi and others, 1992), the absolute-averageestimation-error (AAEE; defined here as the absolute value of PAEE), and the Nash-Sutcliffe model efficiency (NSME; Krause and others, 2005; Hay and Umemoto, 2006). A perfect model, where the simulated values are identical to the observed values, results in PAEE and AAEE values of zero and an NSME value of 1.0. The PAEE and AAEE statistics provide a measure of model bias or systematic error, but do not by themselves provide a definitive measure of the goodness-of-fit (for example, the sample mean has PAEE and AAEE values of 0 ). The NSME provides a standardized measure of the mean-square error similar to the normalizedroot mean-square error. The sample mean results in an NSME value of 0 , and NSME values greater than 0 indicate an improved fit relative to the sample mean. Unlike the PAEE and AAEE statistics, the NSME by itself can be a good indicator of the goodness-of-fit, especially for NSME values of 0.90 and greater; however, substantial estimation bias can still exist for models having NSME values of 0.7 to 0.9 . For this reason, the PAEE and AAEE statistics are used in conjunction with the NSME to indicate goodness-of-fit.
For this study, guidelines provided in Donigian and others (1984) were used to define target calibration criteria for establishing a calibrated model. For the SRPHM, on the basis of weighted-average statistics for daily and monthly flows at each gage, the model was considered calibrated if (1) PAEE was between -10 and +10 percent, (2) AAEE was less than or equal to 10 percent, and (3) NSME was greater than or equal to 0.7 . In addition to defining model-calibration criteria, the quality of calibration for each streamgage was also qualitatively defined from fair to excellent on the basis of PAEE, AAEE, and NSME values (table 10).

\section{Testing Objectives for Streamflow}

The calibrated SRPHM was tested by using data from the six streamgages that had periods of records greater than 10 years, which allowed the records to be divided into periods for calibration and periods for testing. Three streamgages are in the Laguna de Santa Rosa subbasin (LAGC, COLL, and LAGS) and two streamgages are in the Santa Rosa Creek subbasin (SRCU and SRCW). The periods of record used for testing were withheld from model calibration. In addition, an extended record was developed for the MWCM gage in the Mark West Creek subbasin, so it also was used for model testing. The goodness-of-fit statistics obtained for model testing provide a measure of performance in terms of model predictions. Using the calibrated model, comparisons were made between simulated and measured streamflow for the testing period. Unlike the SRPHM calibration procedure, no adjustments were made to any of the model parameters during testing.

Table 10. Summary of "goodness-of-fit" statistics for the Santa Rosa Plain hydrologic model, Santa Rosa Plain watershed, Sonoma County, California.

[Statistic types are percent-average-estimation-error (PAEE) (Hevesi and others, 1992), the absolute-average-estimation-error (AAEE) (defined here as the absolute value of PAEE), and the Nash-Sutcliffe model efficiency (NSME) (Krause and others, 2005; Hay and Umemoto, 2006. Abbreviations: $\geq$, greater than or equal to; $\leq$, less than or equal to; $\%$, percent]

\begin{tabular}{lccc}
\hline $\begin{array}{l}\text { Goodness-of- } \\
\text { fit category }\end{array}$ & $\begin{array}{c}\text { PAEE } \\
\text { (\%) }\end{array}$ & $\begin{array}{c}\text { AAEE } \\
\text { (\%) }\end{array}$ & NSME \\
\hline Excellent & -5 to 5 & $\leq 0.5$ & $\geq 0.95$ \\
Very good & -10 to -5 or 5 to 10 & 0.5 to 10 & 0.85 to 0.94 \\
Good & -15 to -10 or 10 to 15 & 10 to 15 & 0.75 to 0.84 \\
Fair & -25 to -15 or 15 to 25 & 15 to 25 & 0.6 to 0.74 \\
\hline
\end{tabular}

${ }^{1}$ Based on the weighted-average statistics for daily and monthly flows at each gage, a model was considered calibrated if (1) PAEE was between -10 and 10 percent, (2) AAEE was no greater than 10 percent, and (3) NSME was no less than 0.7 .

${ }^{2}$ Statistics outside of these ranges indicate a poor model fit. 


\section{Comparison of Measured and Simulated Streamflow}

Table 10 shows the "goodness-of-fit" statistics for daily and monthly flows at individual streamgages for a calibrated model. Summary statistics for model calibration and testing were calculated by using weighted averages of the results for the 12 streamgages used in calibration (table 11) and of the 6 streamgages used in testing (table 12). The weighting factors were based on the length of record for each streamgage (streamgages with longer records received a greater weight) and the square root of the drainage area for each streamgage (streamgages with larger drainage areas received a greater weight). The longer records were assigned a greater weight because a larger portion of the total sample was represented. The larger drainage areas also had a greater weight because a larger portion of the SRPW was represented. In addition to quantitatively evaluating the overall fit on the basis of calibration statistics, a graphical evaluation of the SRPHM fit was done by plotting the simulated long-term average streamflows for the period of calibration and testing and the simulated maximum daily discharge with measured and estimated values at all 12 gages; the resulting points were compared with the 1:1 line.

The quantitative categories of "goodness-of-fit" statistics are defined in table 10. The weighted-average PAEE, AAEE, and NSME results for the SRPHM calibration for all streamgages indicated fair to excellent calibration results for daily and monthly streamflow (tables 10,11). Although the goal of model calibration was to develop a model that has an "excellent" fit to the records at all gages, the overall model calibration was based on the collective result for all 12 gages, with a higher priority given to the results for gages with longer records and larger drainage areas. Results obtained for gages COPE, COLU, SRCU, MATC, SRCS, and SRCW were very good in terms of model fit to daily streamflows (tables 10, 11). Results for gages LAGC, COLL, LAGS, BRSH, and MWCM were considered fair, with some diminished fit to daily streamflows. The goodness-of-fit increased when using monthly streamflows; 9 of the 12 gages had a very good fit (tables 10,11 ). Overall, the simulated daily mean and monthly mean streamflows satisfied the calibration criteria used for this study (table 11).

The overall results from model testing indicated at least a fair model fit to measured daily and monthly mean streamflow data (table 12) for five of the six gages (tables 10,12). The SRPHM testing results, generally, were consistent with the calibration results; however, estimation bias was greater in the testing results. In general, the SRPHM calibration and testing results indicated an acceptable model fit for simulating daily mean and monthly mean streamflows (tables 10-12). The details of the calibration to streamflow are given in the following section.

\section{Calibration to Streamflow Results for Subbasins}

\section{Laguna de Santa Rosa Subbasin}

The Laguna de Santa Rosa subbasin contains five USGS streamgages (COPE, LAGC, COLU, COLL, and LAGS) that had daily streamflow records used for model calibration (table 11; fig. 1A). For a description of the Laguna de Santa Rosa subbasin streamgages, see Sweetkind and others (2013).

The match between simulated and measured streamflows was generally good at all five streamgages (figs. 14-18). Note that when calculating the average monthly streamflow, streamflows less than 0.01 cubic foot per second $\left(\mathrm{ft}^{3} / \mathrm{s}\right)$ were assumed to equal zero flow. The daily and monthly hydrographs for these gages indicated that the SRPHM performed well in terms of matching the timing and frequency of the peak streamflows (figs. 14-18; table 11). The simulated streamflows reproduced the "flashy" character of the hydrograph caused by short-duration peak streamflows, including those for the COLL and LAGS streamgages, which used 3-day averages.

The best calibration results, in terms of the statistics, were for daily mean streamflows at COPE and COLU and for monthly mean streamflows at COPE, COLU, and LAGS (table 11). Calibration results to daily mean streamflows for gages LAGC, COLL, and LAGS were less favorable in terms of the NSME result, but the calibrations were considered fair (table 11). Calibration results to monthly mean streamflows for gages LAGC and COLL were less favorable in terms of the PAEE and AAEE results, but the calibrations were considered fair (table 11).

The comparison of simulated and measured flow-duration curves at all five gages in the Laguna de Santa Rosa subbasin indicated that the SRPHM performed well in terms of representing the overall characteristics of streamflow in the subbasin (figs. 14D, 15D, 16D, 17D, 18D); however, some deviation was evident for low streamflows. Streamflows at all streamgages varied by at least three orders of magnitude, and some streamgages had variability of more than four orders of magnitude (figs. 14-18). Although there was some bias in matching the low flows of $10 \mathrm{ft}^{3} / \mathrm{s}$ and less (figs. 14, 15, 17), the intermittent nature of streamflow in this subbasin was represented and is adequate for the appropriate use of the SRPHM (statistically, fair to very good). The SRPHM results indicated that flows of $1 \mathrm{ft}^{3} / \mathrm{s}$ or greater occurred at the COPE, LAGC, COLU, COLL, and LAGS gages about 40, 50, 35, 35, and 90 percent of the time, respectively (figs. $14 D, 15 D, 16 D$, $17 D, 18 D)$. In contrast, the measured records for these gages indicated that $1 \mathrm{ft}^{3} / \mathrm{s}$ or greater occurred about $55,60,35,50$, and 70 percent of the time, respectively (figs. $14 D, 15 D, 16 D$, $17 D, 18 D)$. 


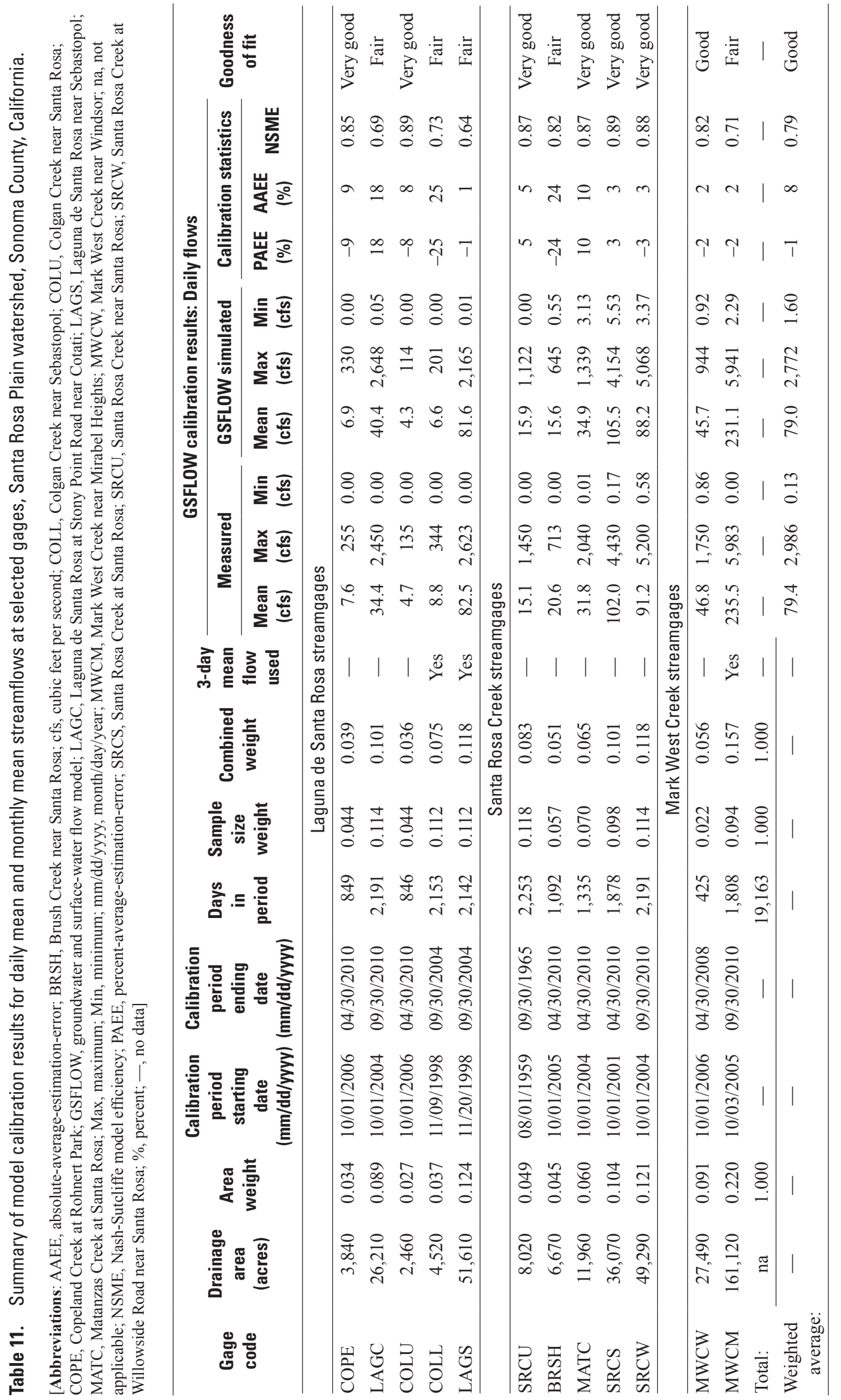




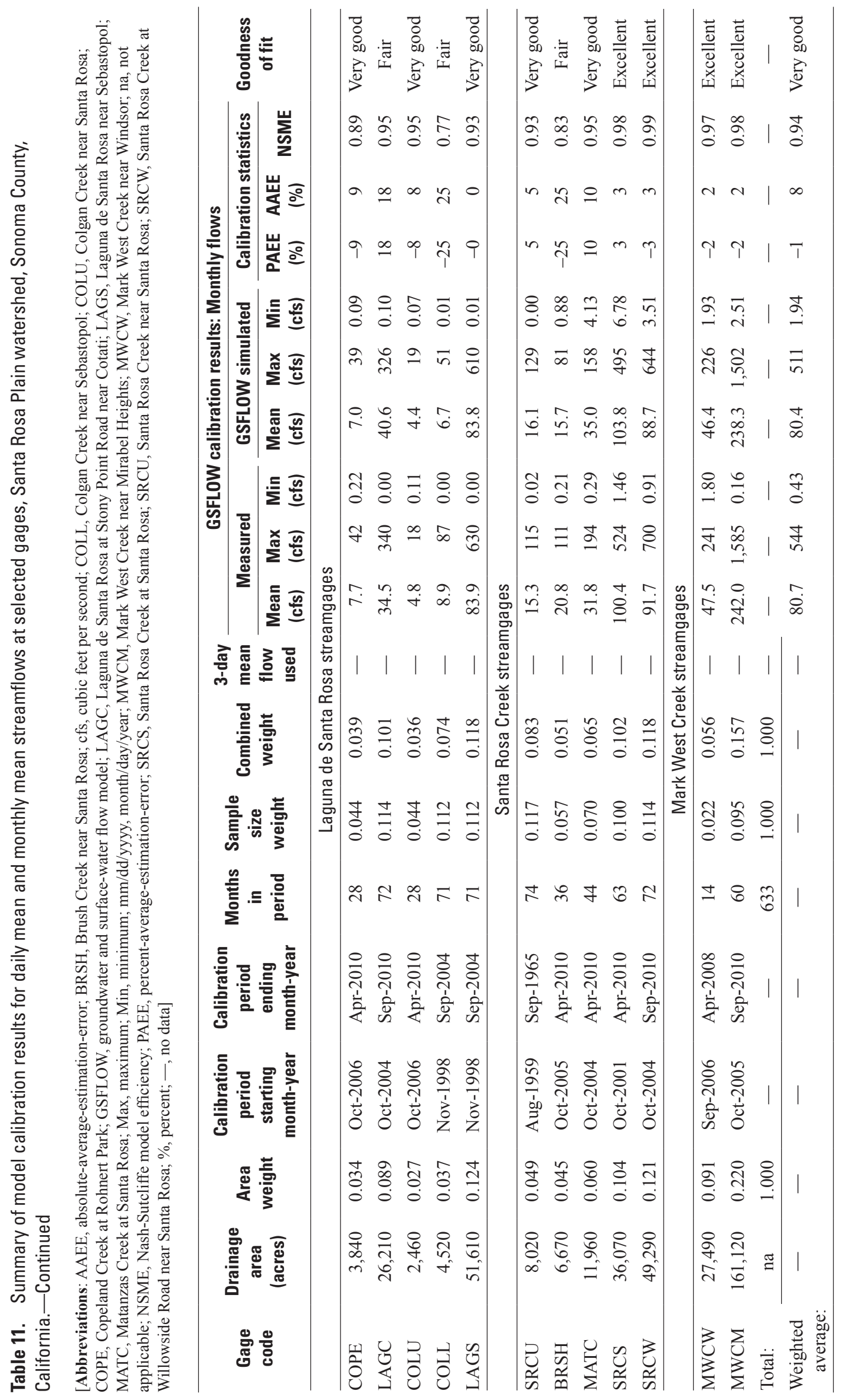




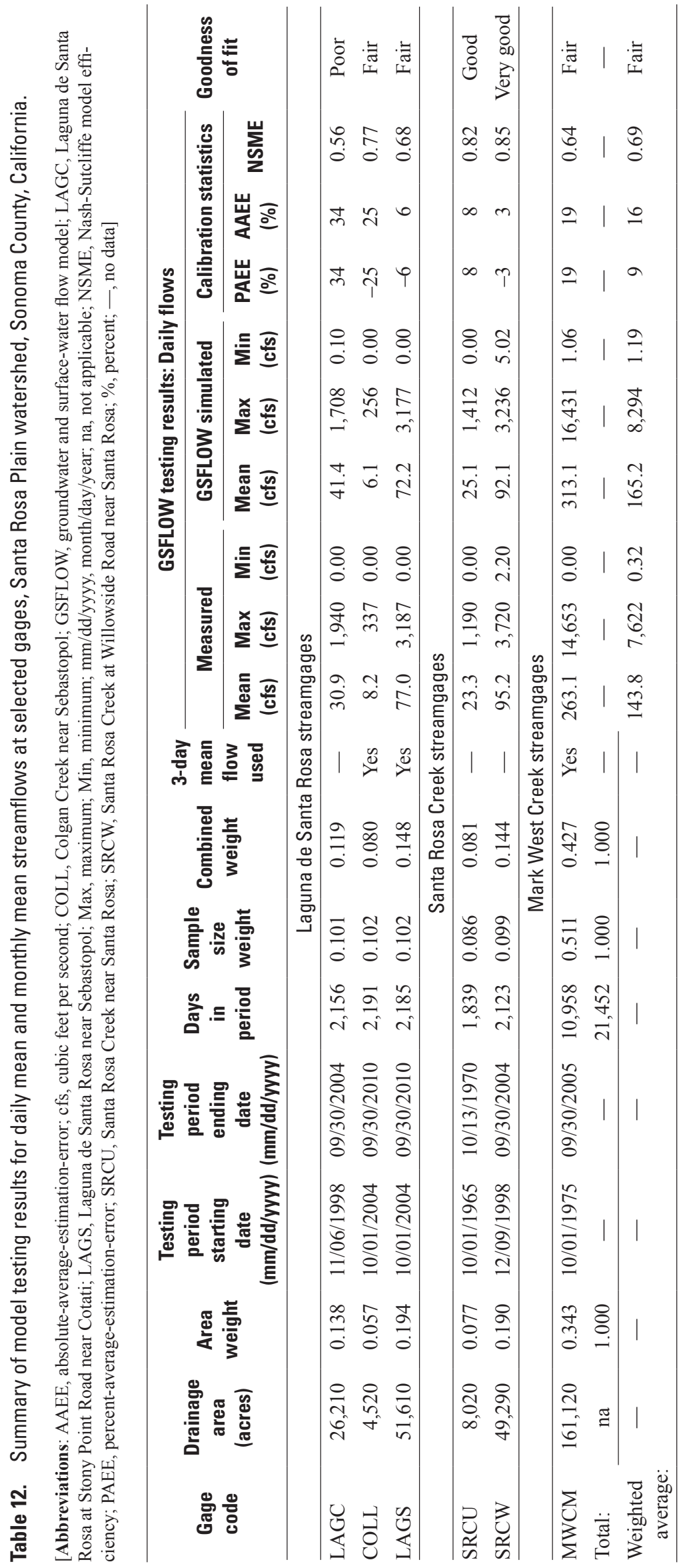




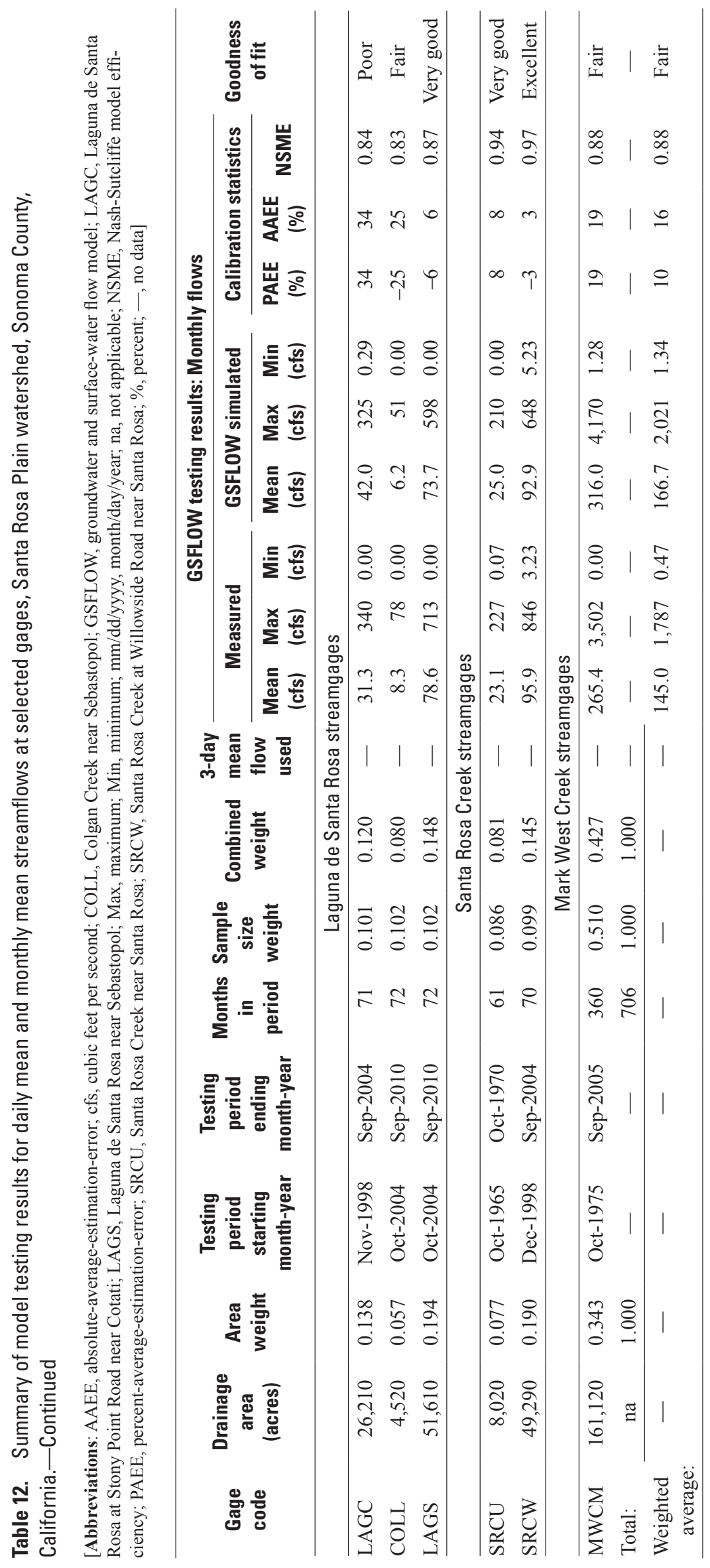



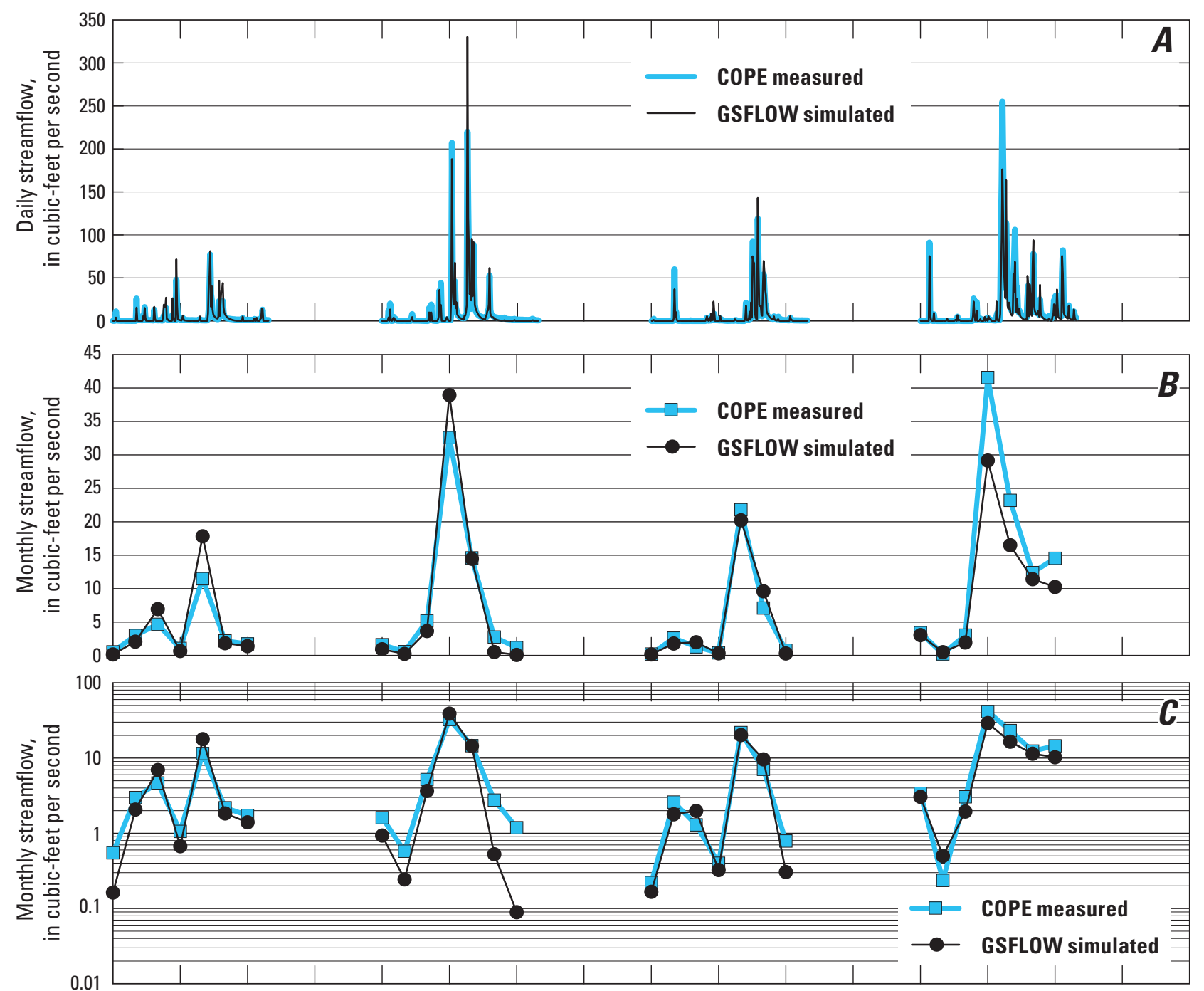

Oct-06 Jan-07 Apr-07 Jul-07 0 0ct-07 Jan-08 Apr-08 Jul-08 0 0ct-08 Jan-09 Apr-09 Jul-09 0 0ct-09 Jan-10 Apr-10 Jul-10 0ct-10

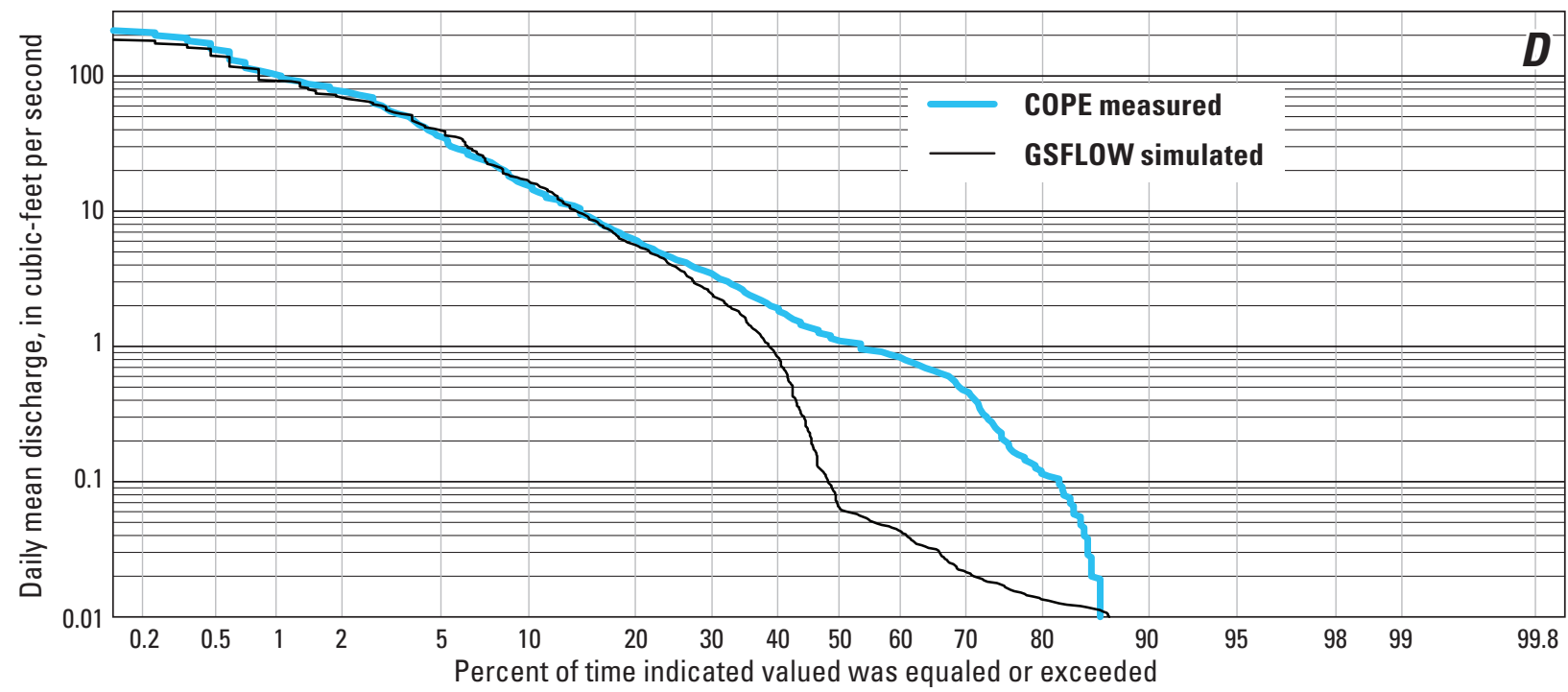

Figure 14. Comparison of simulated and measured streamflow for the calibrated model at the Copeland Creek at Rohnert Park (COPE) streamgage, 11465660, Santa Rosa Plain hydrologic model, Santa Rosa Plain watershed, Sonoma County, California, water years 2007-10: $A$, daily mean; $B$, monthly mean; $C$ monthly mean at logarithmic scale; $D$, flow duration for daily mean streamflow. 

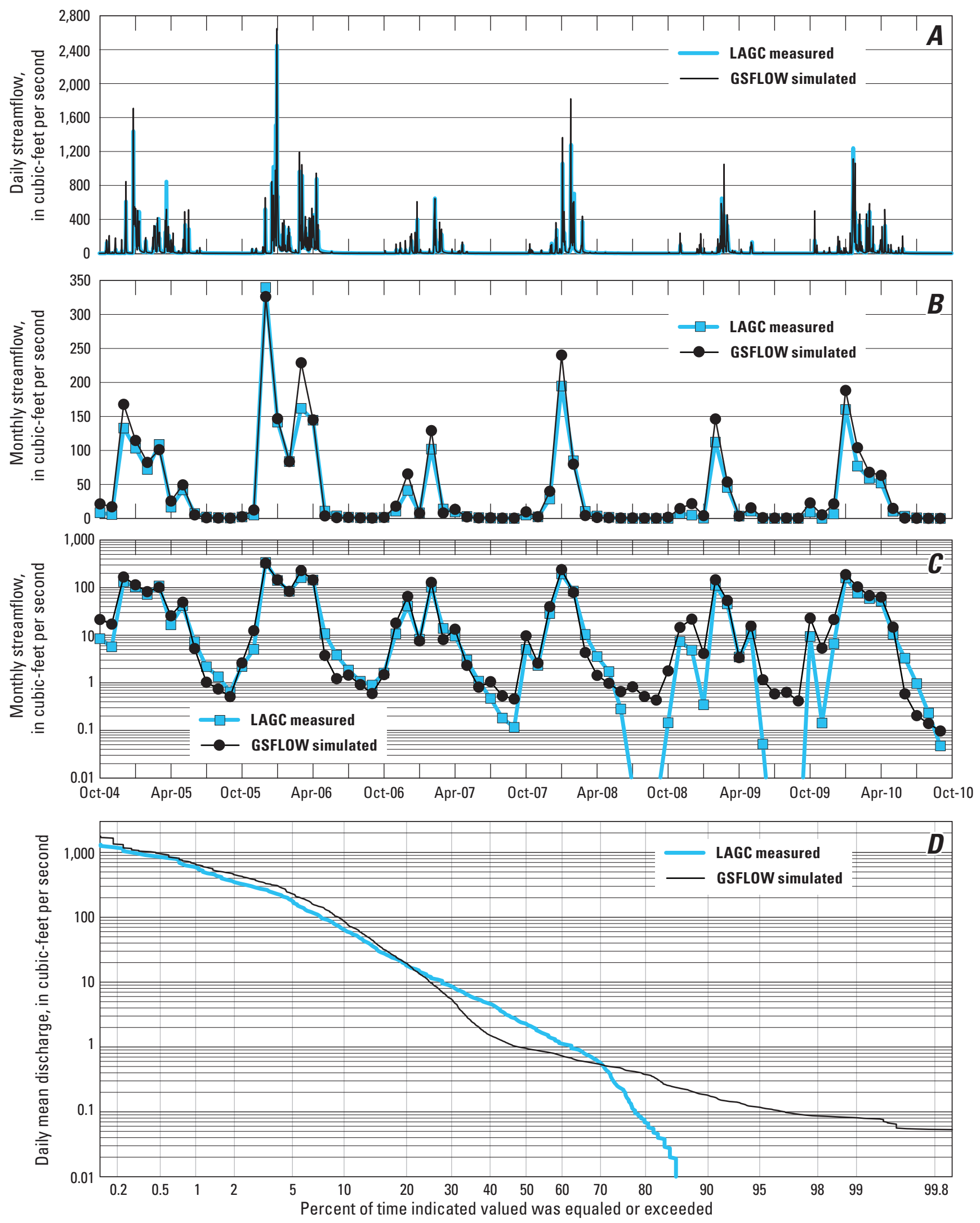

Figure 15. Comparison of simulated and measured streamflow for the calibrated model at the Laguna de Santa Rosa at Stony Point Road near Cotati (LAGC) streamgage, 11465680, Santa Rosa Plain hydrologic model, Santa Rosa watershed, Sonoma County, California, water years 2004-10: $A$, daily mean; $B$, monthly mean; $C$, monthly mean at logarithmic scale; $D$, flow duration for daily mean streamflow 

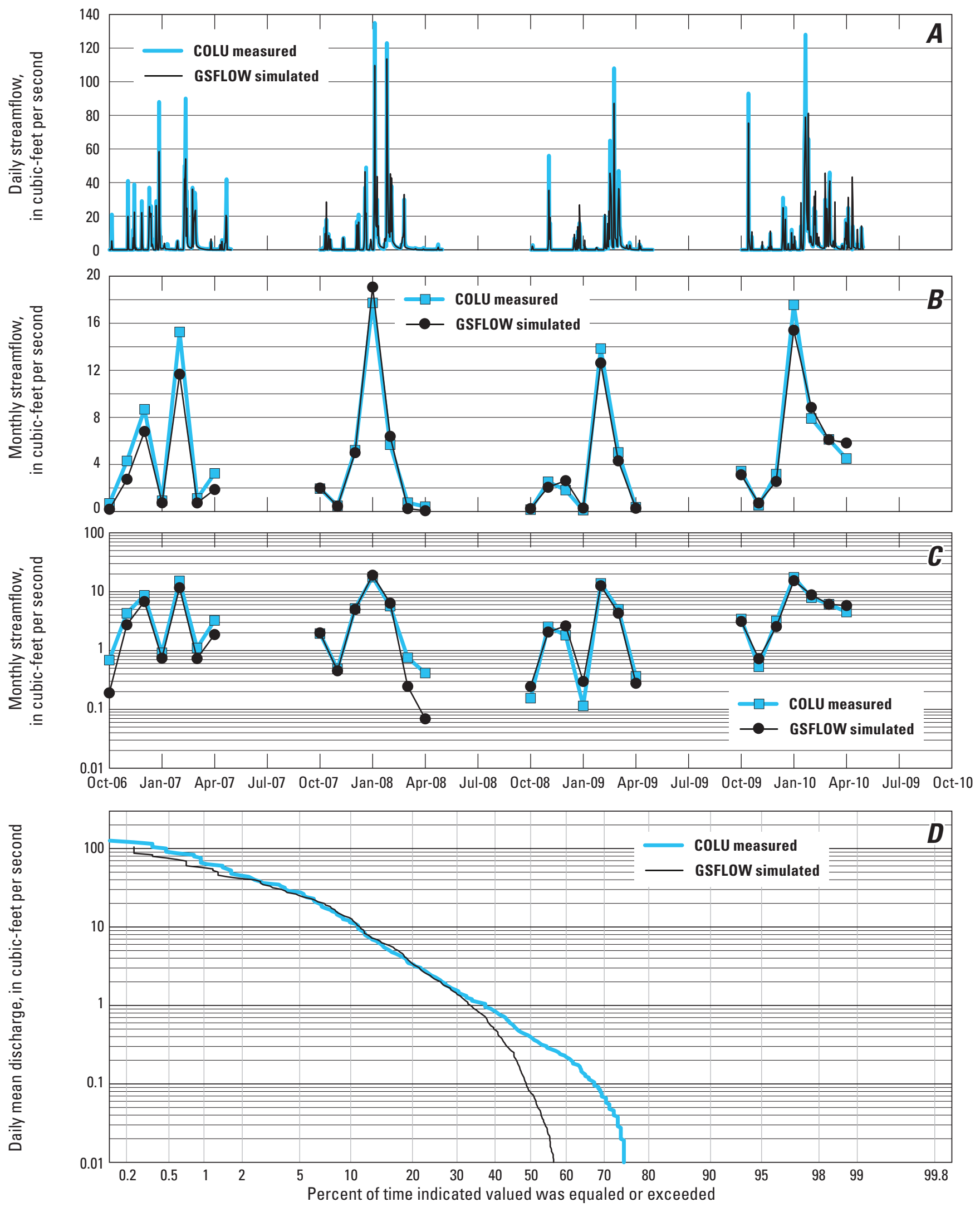

Figure 16. Comparison of simulated and measured streamflow for the calibrated model at the Colgan Creek near Santa Rosa (COLU) streamgage, 11465690, Santa Rosa Plain hydrologic model, Santa Rosa Plain watershed, Sonoma County, California, water years 2007-10: $A$, daily mean; $B$, monthly mean; $C$, monthly mean at logarithmic scale; $D$, flow duration for daily mean streamflow. 

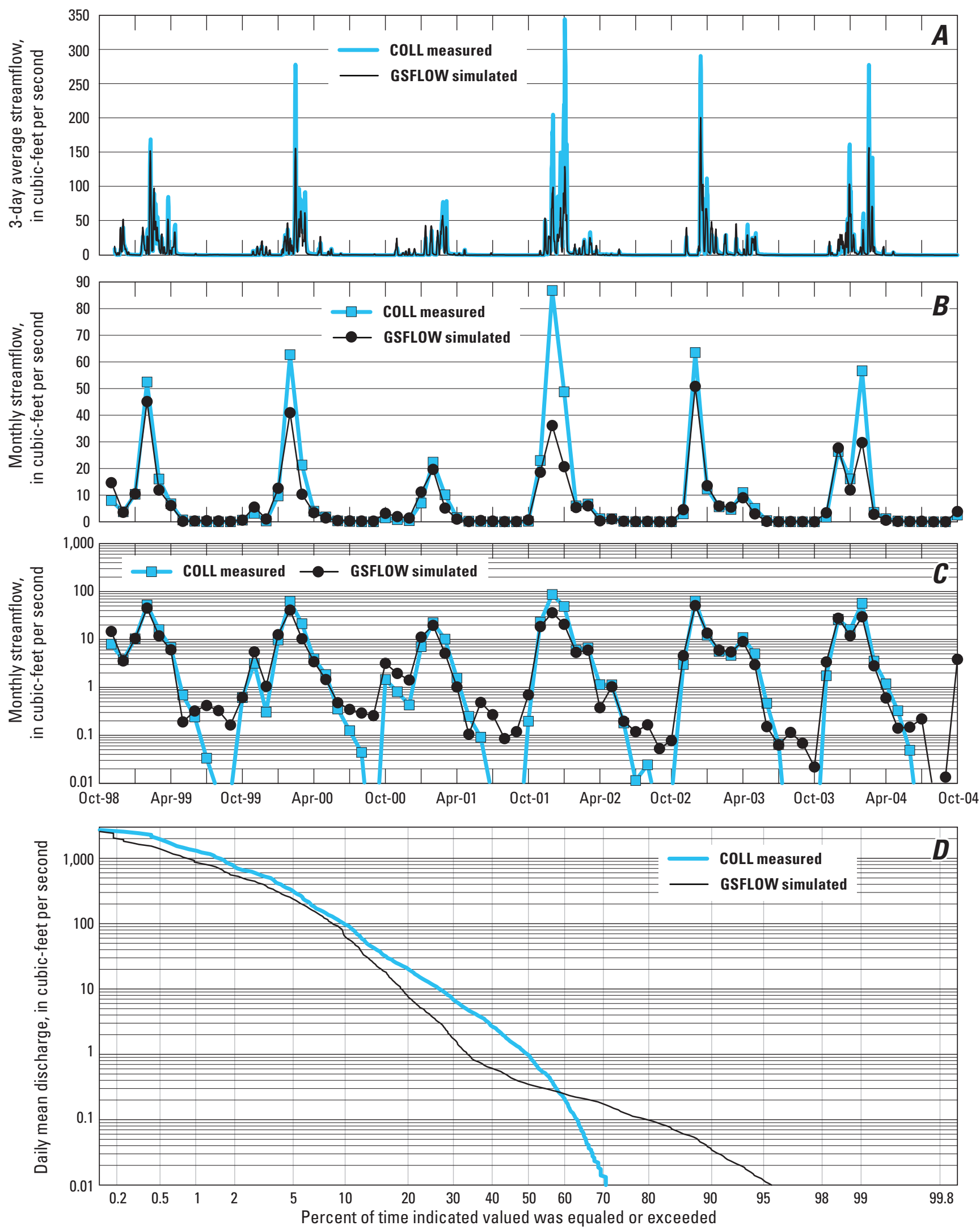

Figure 17. Comparison of simulated and measured streamflow for the calibrated model at the Colgan Creek near Sebastopol (COLL) streamgage, 11465700, Santa Rosa Plain hydrologic model, Santa Rosa Plain watershed, Sonoma County, California, water years 1999-2004: $A$, daily mean; $B$, monthly mean; $C$, monthly mean at logarithmic scale; $D$, flow duration for daily mean streamflow. 

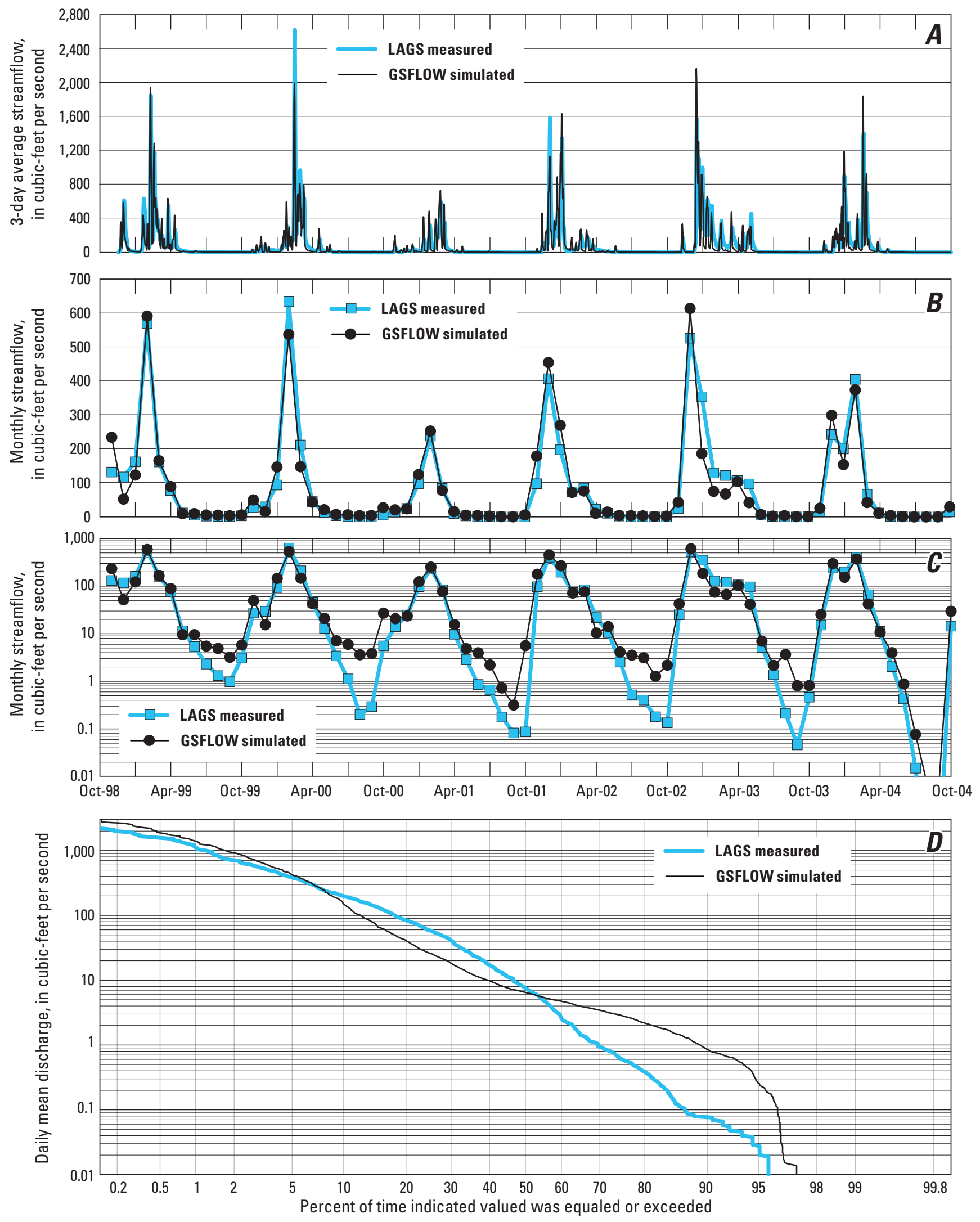

Figure 18. Comparison of simulated and measured streamflow for the calibrated model at the Laguna de Santa Rosa near Sebastopol (LAGS) streamgage, 11466200, Santa Rosa Plain hydrologic model, Santa Rosa Plain watershed, Sonoma County, California, water years 1999-2004: $A$, daily mean; $B$, monthly mean; $C$, monthly mean at logarithmic scale; $D$, flow duration for daily mean streamflows. 


\section{Santa Rosa Creek Subbasin}

The Santa Rosa Creek subbasin contains five USGS streamgages (SRCU, BRSH, MATC, SRCS, and SRCW) that had daily mean streamflow records used for model calibration (table 11; fig. 1A). For a description of the Santa Rosa Creek subbasin streamgages, see Sweetkind and others (2013).

The daily and monthly hydrographs for these streamgages indicated that the SRPHM performed well in terms of matching the timing and frequency of the streamflows (figs. 19-23; table 11). The simulated streamflows reproduced the "flashy" character of the hydrograph, caused by short-duration, high streamflow events, well. Overall, the match between simulated and measured streamflows was generally good at all five gages, except that the measured low streamflows were greater than simulated low streamflows (table 11).

The best calibration results, in terms of the statistics, were obtained for SRCU, MATC, SRCS, and SRCW streamgages for daily mean and monthly mean streamflows (table 11). Calibration results to daily mean and monthly mean streamflows were less favorable for the BRSH streamgage; however, the calibrations were considered fair.

Comparison of the simulated and measured daily mean flow-duration curves at all five gages in the Santa Rosa Creek subbasin indicated that the SRPHM performed well in terms of representing the overall characteristics of streamflow in the subbasin, except for low-flows (figs. 19D, 20D, 21D, 22D, 23D). Streamflows at all streamgages varied by at least three orders of magnitude, and some streamgages had variability of more than four orders of magnitude (figs. 19-23). Although there was some bias in matching the low flows, the intermittent nature of streamflow in this subbasin was represented and is adequate for the appropriate use of the SRPHM (statistically fair to very good for daily streamflows and fair to excellent for monthly streamflows).

The SRPHM results indicated that streamflows of $1 \mathrm{ft}^{3} / \mathrm{s}$ or greater occurred at the SRCU, BRSH, MATC, SRCS, and SRCW gages about $35,60,100,100$, and 100 percent of the time, respectively (figs. $19 D, 20 D, 21 D, 22 D, 23 D$ ). In contrast, the measured records for these streamgages indicated that $1 \mathrm{ft}^{3} / \mathrm{s}$ or greater occurred about $60,55,80,95$, and 97 percent of the time, respectively (figs. $19 D, 20 D, 21 D, 22 D$, 23D).

\section{Mark West Creek Subbasin}

The Mark West Creek subbasin contains two USGS streamgages (MWCW and MWCM) that had daily streamflow records used for model calibration (table 11; fig. 1A). For a description of the Mark West Creek subbasin streamgages, see Sweetkind and others (2013).

The daily and monthly hydrographs for these streamgages indicated that the SRPHM performed well in terms of matching the timing and frequency of the peak streamflows (figs. 24-25; table 11). The simulated flows reproduced the "flashy" character of the hydrograph caused by short-duration peak streamflows. The match between simulated and measured streamflows was generally good at both gages. Overall, the daily mean and monthly mean streamflows were underestimated; the maximum flows were underestimated and the minimum streamflows were overestimated (table 11).

The best calibration results, in terms of the statistics, were obtained for the MWCW streamgage for daily mean streamflows and for both streamgages for monthly mean streamflows (table 11). Calibration results to daily mean streamflows were less favorable for the MWCM streamgage; however, the calibration was considered fair.

The comparison of simulated and measured flow-duration curves at both streamgages in the Mark West Creek subbasin indicated that the SRPHM performs well in terms of representing the overall characteristics of streamflows in the subbasin (figs. 24D, 25D). Streamflows at both streamgages varied by at least three orders of magnitude, and the MWCM streamgage had variability of almost five orders of magnitude. Although the intermediate streamflows (10-100 $\left.\mathrm{ft}^{3} / \mathrm{s}\right)$ were underestimated, the streamflows in this subbasin were represented and are adequate for the appropriate use of the SRPHM (statistically fair to good for daily streamflows and excellent for monthly streamflows).

The simulated results indicated that streamflows of $1 \mathrm{ft}^{3} / \mathrm{s}$ or greater occurred at the MWCW and MWCM streamgages about 95 and 100 percent of the time, respectively (figs. 24D, 25D). In contrast, the measured records for these streamgages indicated that streamflows of $1 \mathrm{ft}^{3} / \mathrm{s}$ or greater occurred about 98 and 92 percent of the time, respectively (figs. 24D, 25D).

\section{Testing Results for Streamflow}

The testing results for streamgages COLL, LAGS, and SRCW were comparable to the calibration results for daily mean and monthly mean streamflows (tables 11, 12). The testing results for the COLL streamgage indicated a slight improvement compared with calibration results for daily and monthly flows; however, results were poorer for daily mean streamflows for streamgages LAGC and SRCU and for monthly mean streamflows for streamgages LAGC and MWCM.

The testing results for streamgage LAGC showed a poorer model fit compared with calibration results for daily mean streamflows and a similar deterioration in fit for monthly mean streamflows, as indicated by an increase in the PAEE value and a decrease in the NMSE value (tables 11, 12). Model testing results for streamgage LAGC showed a good match to the timing of peak streamflows of 800 to $1,900 \mathrm{ft}^{3} / \mathrm{s}$ (fig. 26A) and a good representation of the measured monthly mean streamflows. However, there was a tendency to overestimate the highest 10-percent of streamflows at this location for the testing period, as indicated by the monthly hydrograph and the flow-duration curve (figs. 26B, 26D). The general fit of the SRPHM to streamflows between $50 \mathrm{ft}^{3} / \mathrm{s}$ and $0.4 \mathrm{ft}^{3} / \mathrm{s}$ was considered good; however, the SRPHM overestimated the frequency of streamflows less than $0.7 \mathrm{ft}^{3} / \mathrm{s}$ (fig. 26D). 

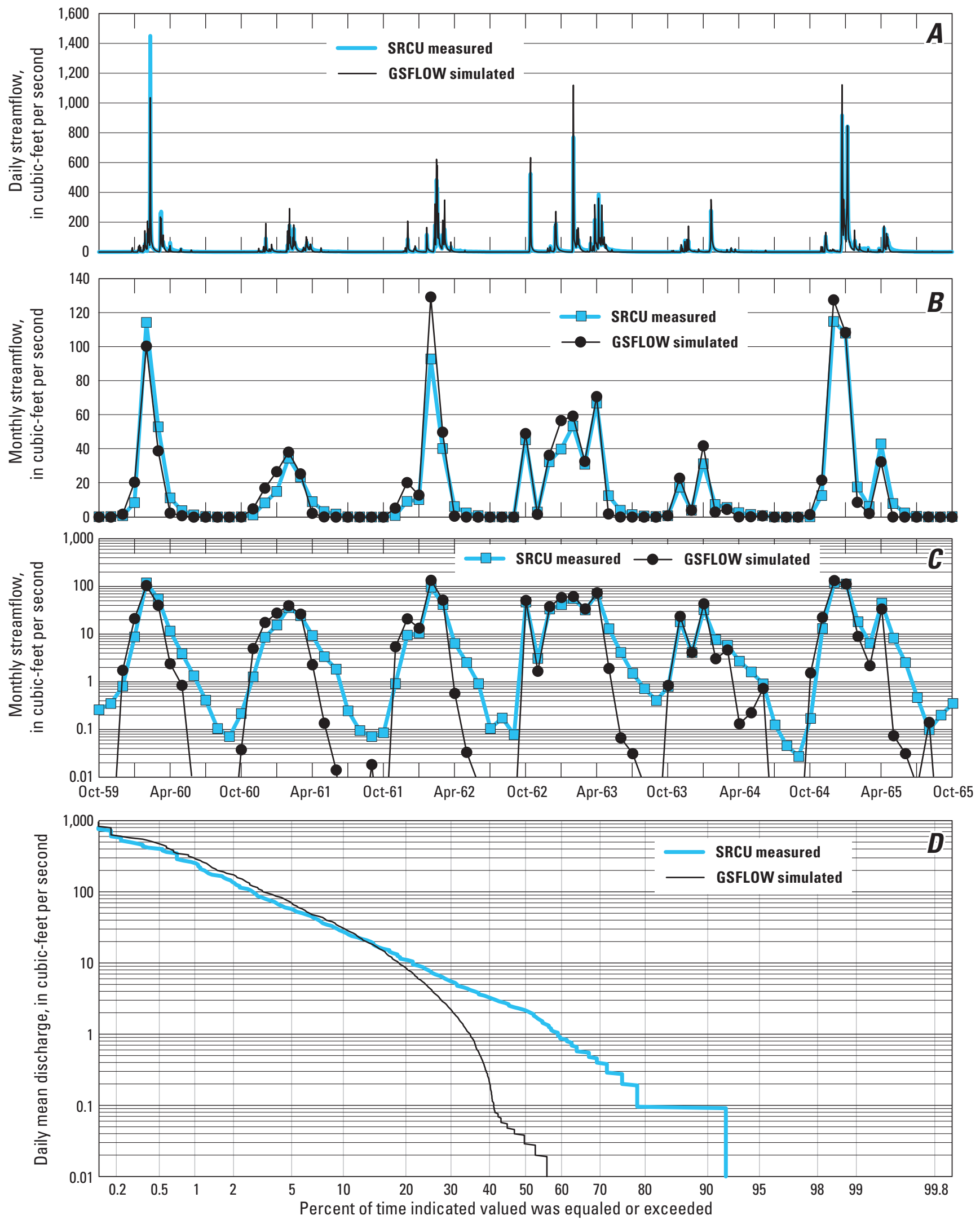

Figure 19. Comparison of simulated and measured streamflows at the Santa Rosa Creek near Santa Rosa (SRCU) streamgage, 11465800, Santa Rosa Plain hydrologic model, Santa Rosa Plain watershed, Sonoma County, California, water years 1959-65: $A$, daily mean; $B$, monthly mean; $C$, monthly mean at logarithmic scale; $D$, flow duration for daily mean streamflow. 

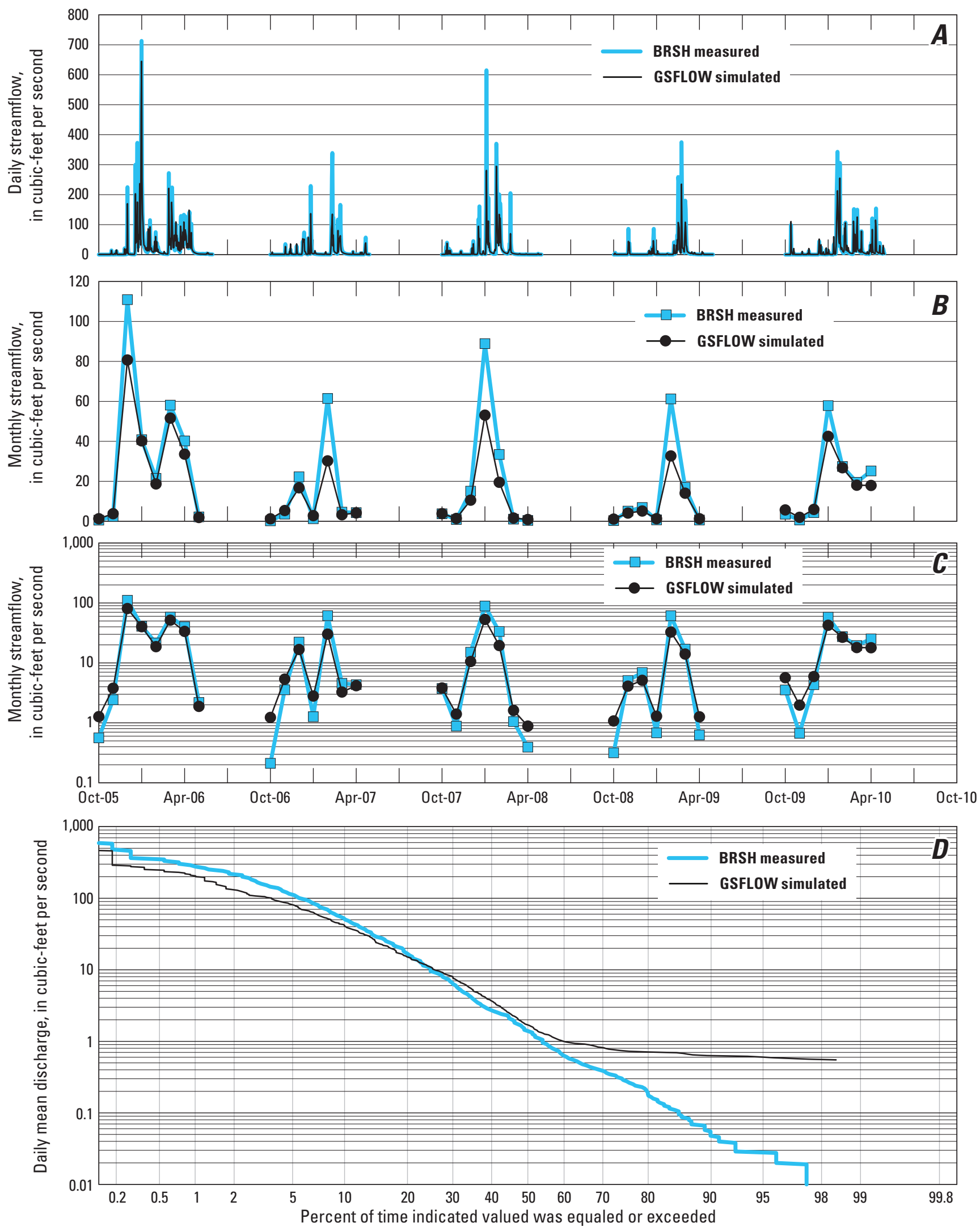

Figure 20. Comparison of simulated and measured streamflows at the Brush Creek near Santa Rosa (BRSH) streamgage, 11466065, Santa Rosa Plain hydrologic model, Santa Rosa Plain watershed, Sonoma County, California, water years 2006-10: $A$, daily mean; $B$, monthly mean; $C$, monthly mean at logarithmic scale; $D$, flow duration for daily mean streamflow. 

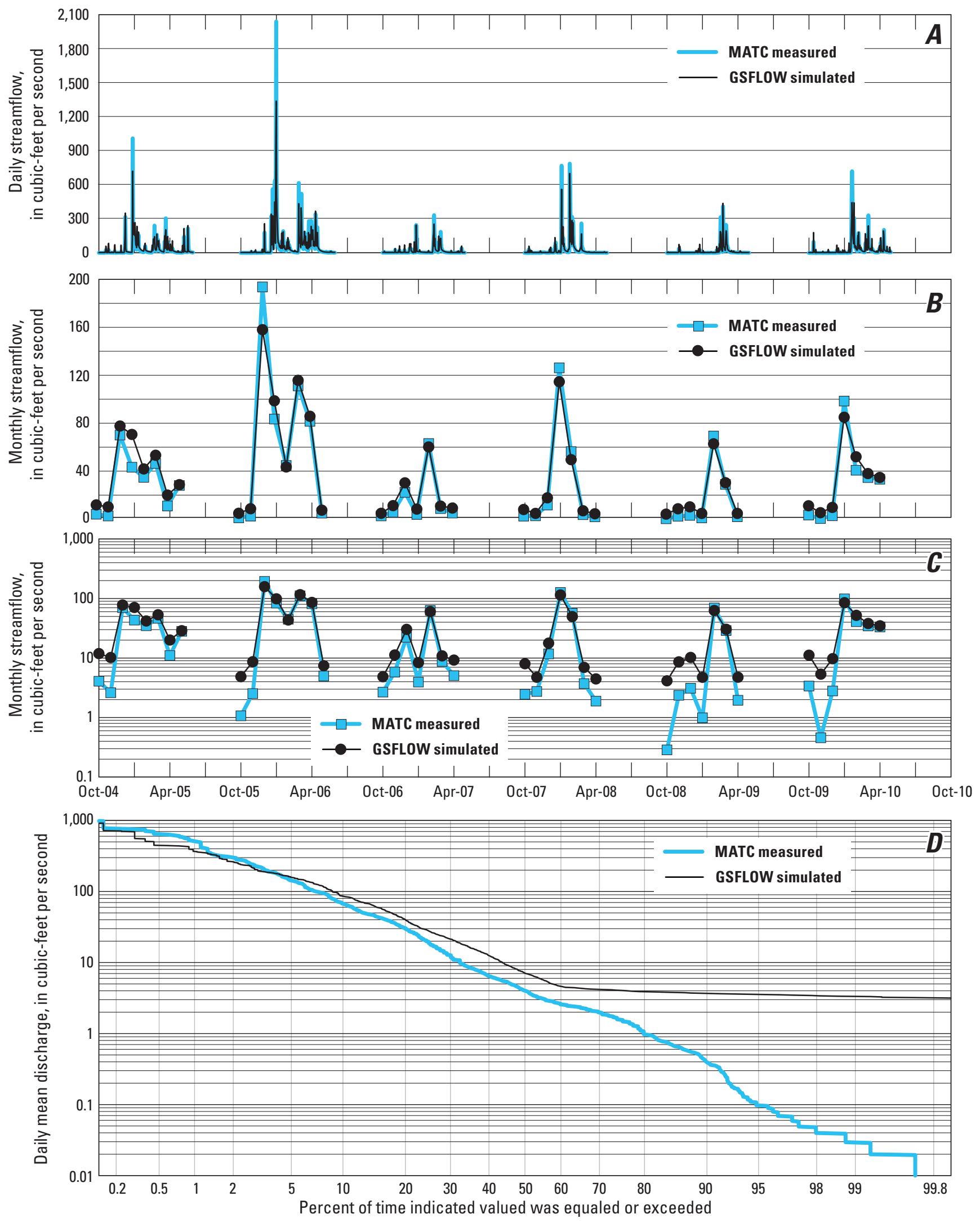

Figure 21. Comparison of simulated and measured streamflows at the Matanzas Creek near Santa Rosa (MATC) streamgage, 11466170, Santa Rosa Plain hydrologic model, Santa Rosa Plain watershed, Sonoma County, California, water years 2005-10: $A$, daily mean; $B$, monthly mean; $C$, monthly mean at logarithmic scale; $D$, flow duration for daily mean streamflow. 

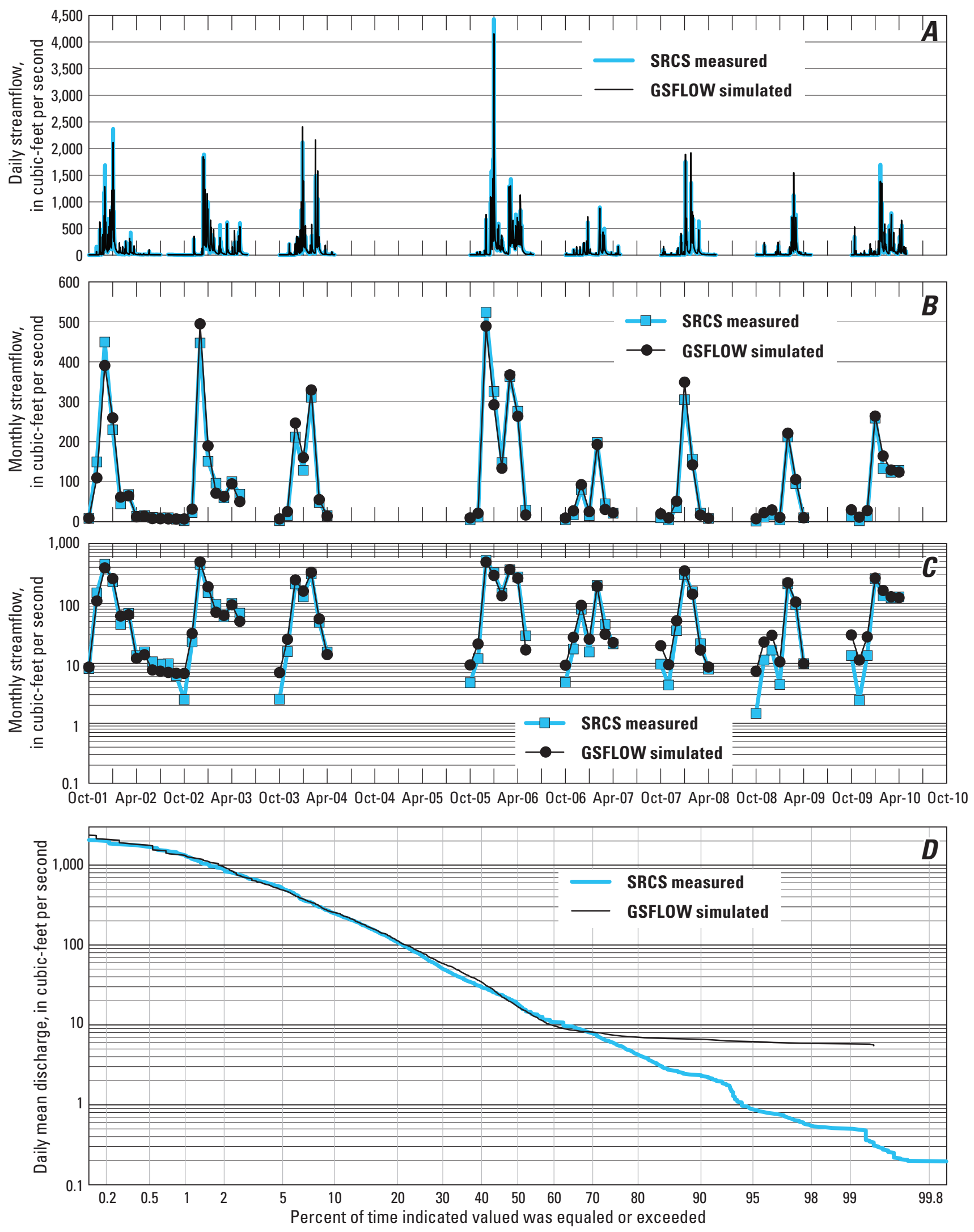

Figure 22. Comparison of simulated and measured streamflows at the Santa Rosa Creek at Santa Rosa (SRCS) streamgage, 11466200, Santa Rosa Plain hydrologic model, Santa Rosa Plain watershed, Sonoma County, California, water years 2002-10: $A$, daily mean; $B$, monthly mean; $C$, monthly mean at logarithmic scale; $D$, flow duration for daily mean streamflow. 

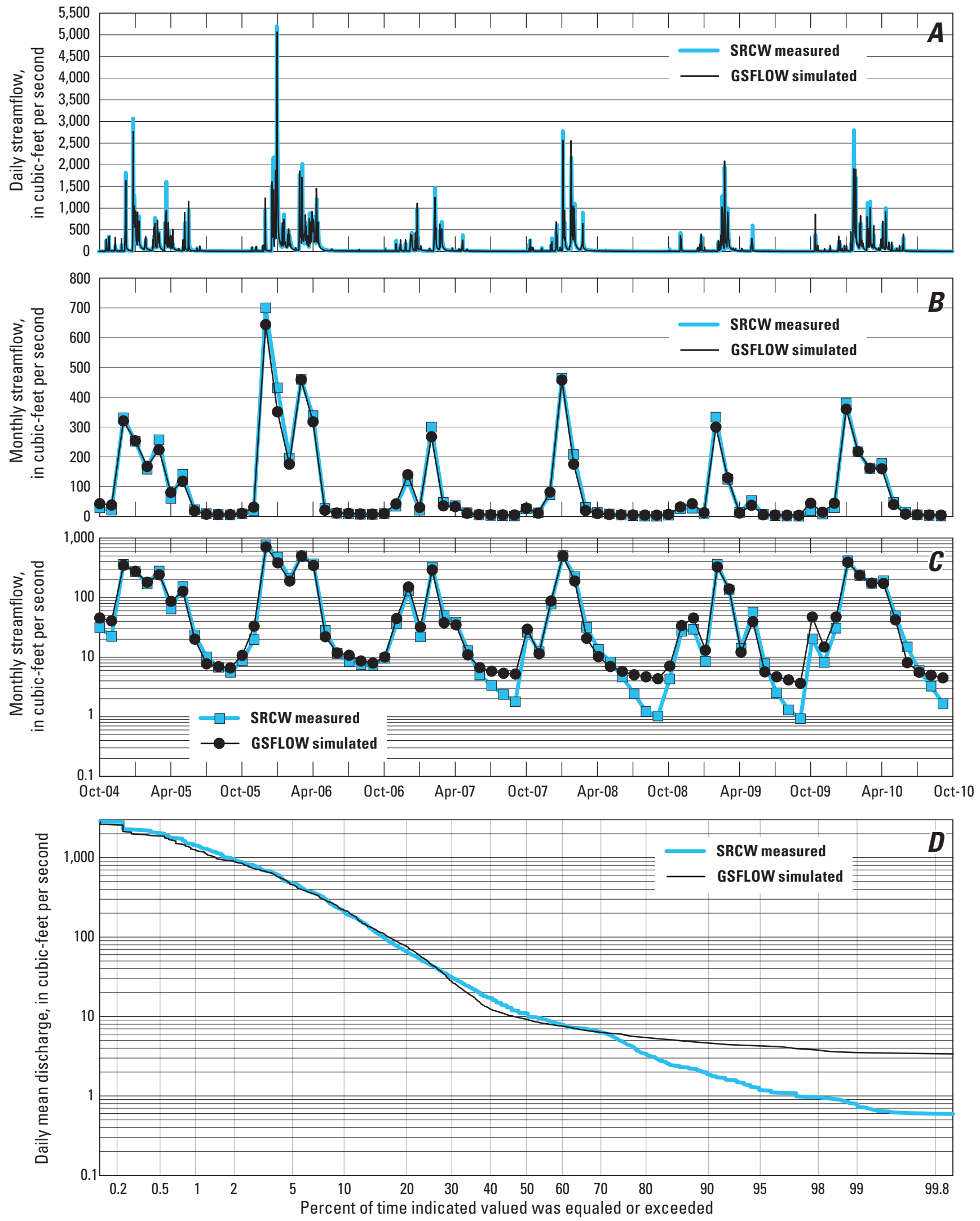

Figure 23. Comparison of simulated and measured streamflows at the Santa Rosa Creek at Willowside Road near Santa Rosa (SRCW) streamgage, 11466320, Santa Rosa Plain hydrologic model, Santa Rosa Plain watershed, Sonoma County, California, water years 2004-10: $A$, daily mean; $B$, monthly mean; $C$, monthly mean at logarithmic scale; $D$, flow duration for daily mean streamflow. 

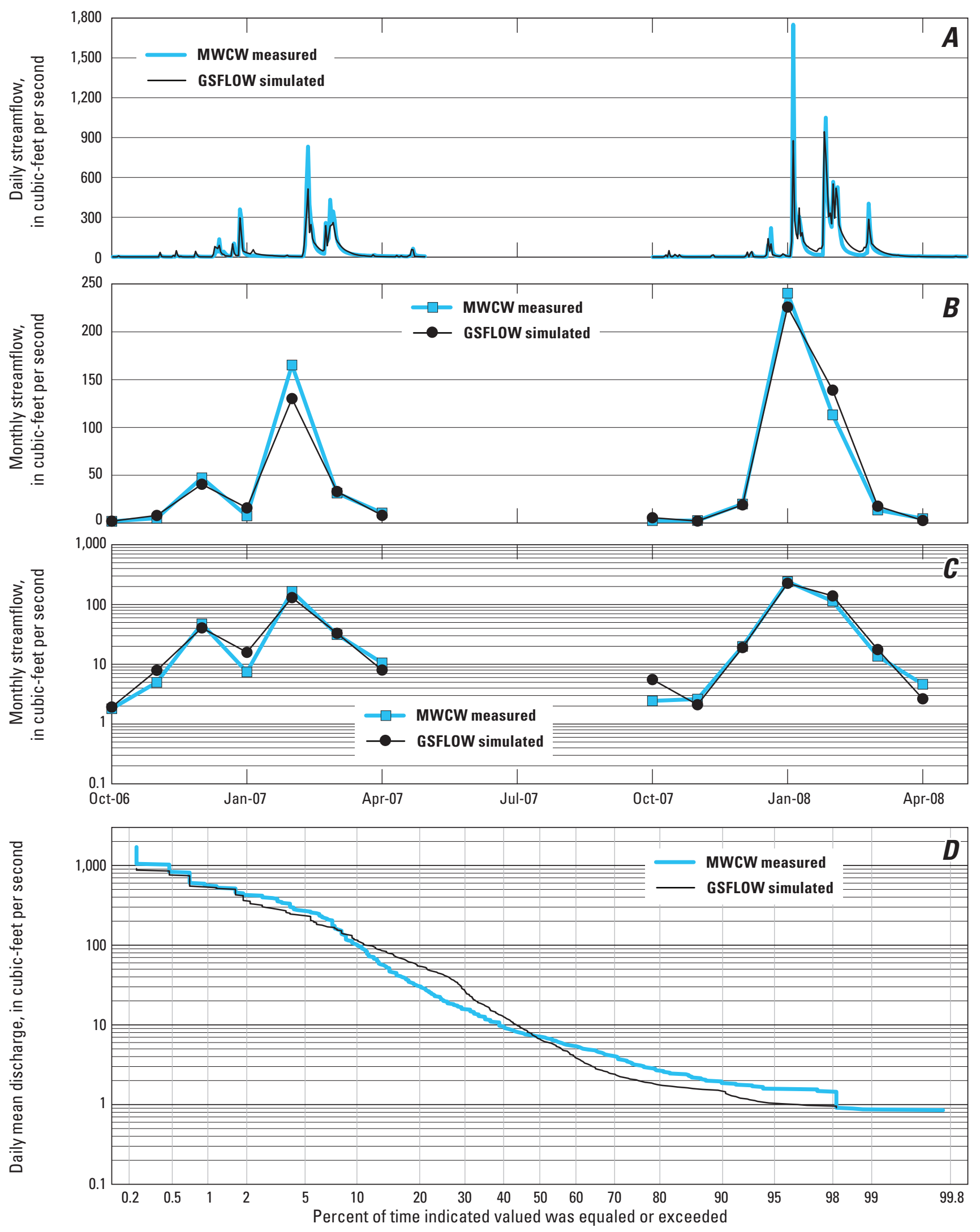

Figure 24. Comparison of simulated and measured streamflows at the Mark West Creek near Windsor (MWCW) streamgage, 11465500, Santa Rosa Plain hydrologic model, Santa Rosa Plain watershed, Sonoma County, California, water years 2006-10: $A$, daily mean; $B$, monthly mean; $C$, monthly mean at logarithmic scale; $D$, flow duration for daily mean streamflow. 

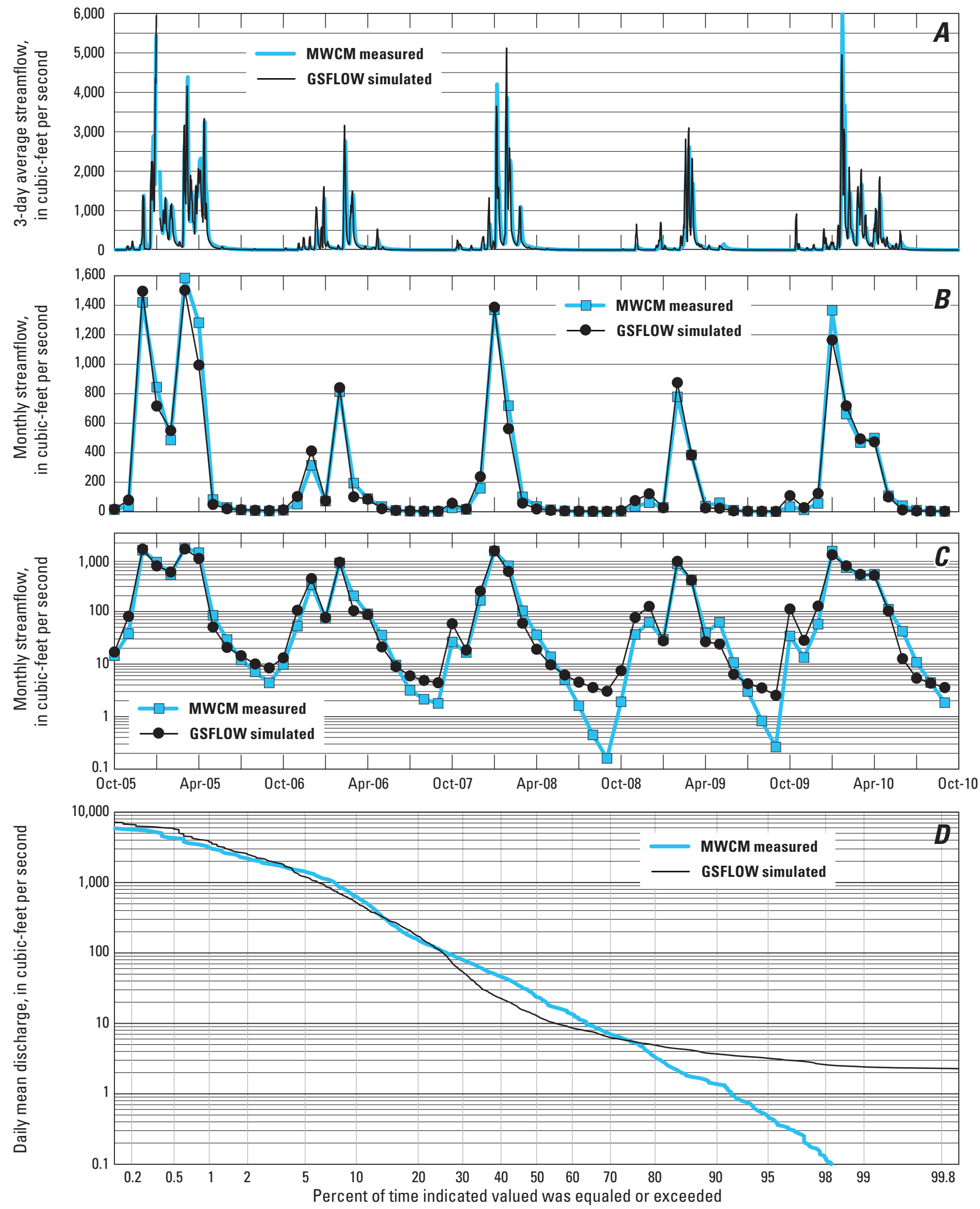

Figure 25. Comparison of simulated and measured streamflows at the Mark West Creek near Mirabel Heights (MWCM) streamgage, 11466800, Santa Rosa Plain hydrologic model, Santa Rosa Plain watershed, Sonoma County, California, water years 2006-10: $A$, daily mean; $B$, monthly mean; $C$, monthly mean at logarithmic scale; $D$, flow duration for daily mean streamflow. 

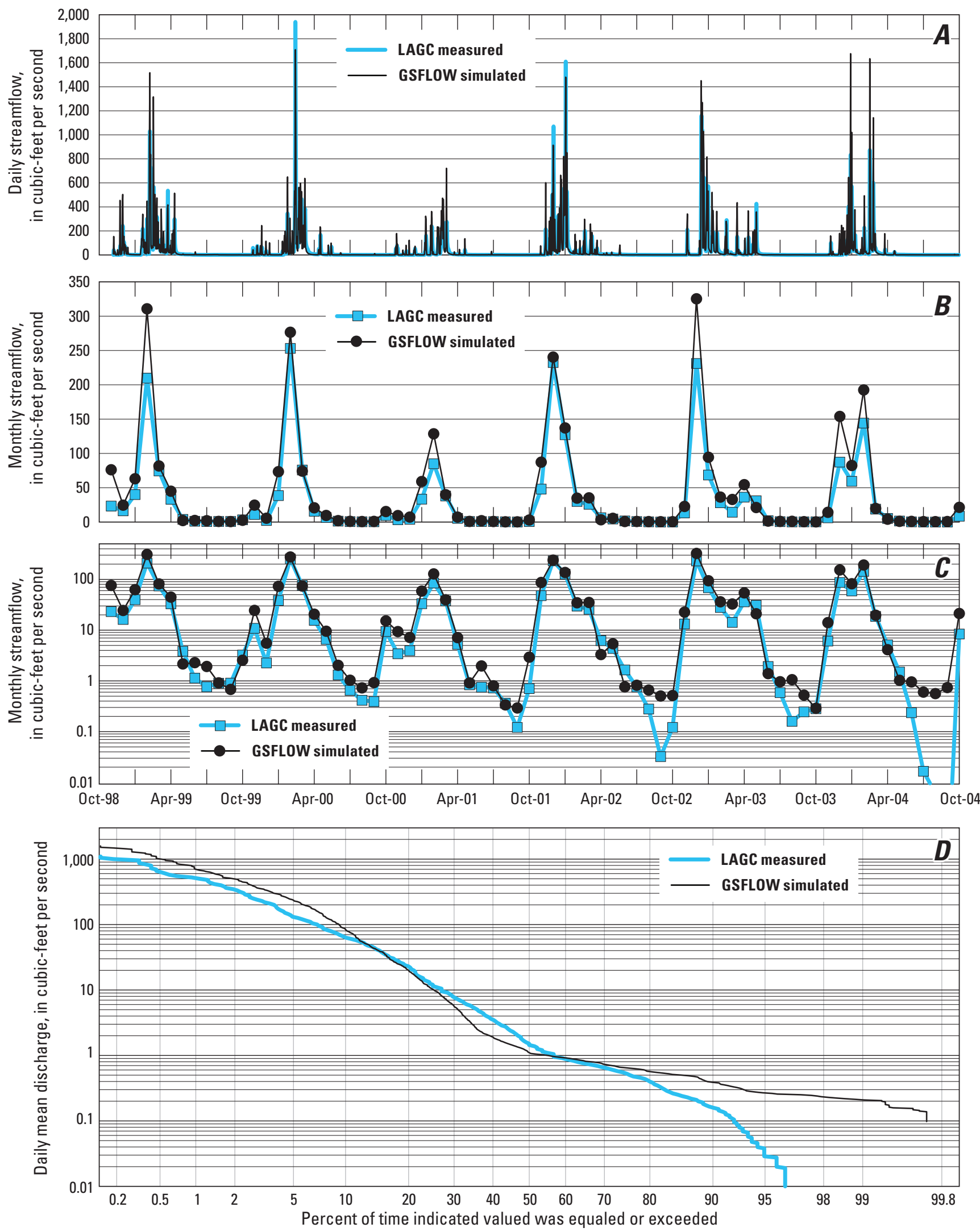

Figure 26. Comparison of simulated and measured streamflows at the Laguna de Santa Rosa at Stony Point Road near Cotati (LAGC) streamgage, 11465680, Santa Rosa Plain hydrologic model, Santa Rosa Plain watershed, Sonoma County, California, water years 1999-2004: $A$, daily mean; $B$, monthly mean; $C$, monthly mean using a logarithmic scale; $D$, flow duration for daily mean streamflow. 
The testing results for the COLL streamgage indicated a slight improvement for daily mean and monthly mean streamflows, with an NMSE value of 0.77 for daily mean streamflows and 0.83 for monthly mean streamflows (table 12) compared with calibration results of 0.73 and 0.77 , respectively (table 11). The fit to the lowest streamflows at streamgage COLL for the testing period was similar to the results obtained for the calibration period, with the SRPHM underestimating most streamflows (fig. 27C). Streamflows less than $0.01 \mathrm{ft}^{3} / \mathrm{s}$ at COLL were reproduced by the SRPHM, with measured and simulated streamflows both indicating streamflows less than $0.01 \mathrm{ft}^{3} / \mathrm{s}$ about 30 percent of the time (fig. 27D).

For the LAGS streamgage, the overall daily streamflow statistic was still fair; the NSME value of 0.68 was slightly greater than it was for the calibration period $(0.64$; tables 11, 12). Although the monthly NSME value and the daily and monthly PAEE values increased slightly from the calibration period, overall, these values still were considered very good (tables 11, 12). Testing results for the LAGS streamgage indicated a good overall model fit to high and low streamflows (fig. 28A-C). The flow-duration curve showed that the frequency and magnitude of high flows were well represented, but there was a tendency to underestimate the low streamflows (fig. 28D). As with the COLL streamgage, the SRPHM simulated the occurrence of zero streamflows well; zero flows were simulated about 3 percent of the time by the SRPHM compared with about 4 percent of the time for measured streamflows (fig. 28D).

The testing results for the SRCU and SRCW streamgages indicated a good or very good model fit to daily mean streamflow and a very good or excellent fit to monthly mean streamflow (table 12). The hydrographs for daily and monthly streamflows for the SRCU streamgage indicated a generally good fit (figs. 29A, 29B); however, the SRPHM underestimated monthly and daily streamflows less than $10 \mathrm{ft}^{3} / \mathrm{s}$ (fig. 29C, 29D). The hydrographs for the SRCW gage showed a good overall fit to daily mean and monthly mean low flows and peak flows (fig. $30 \mathrm{~A}-\mathrm{C}$ ). The testing results showed a good fit for the daily mean and monthly mean streamflows to the measured flows greater than $10 \mathrm{ft}^{3} / \mathrm{s}$; however, flows below $10 \mathrm{ft}^{3} / \mathrm{s}$ were overestimated (fig. 30D).

Testing of the MWCM streamgage showed a slightly poorer fit compared with calibration results, with an overall statistic of fair for both daily mean and monthly mean streamflows (table 11, 12). The testing results for the extended record for the MWCM gage indicated a satisfactory fit, with an NSME of 0.64 for daily mean streamflows and 0.88 for monthly mean streamflows (table 12). The hydrograph of 3-day average of daily mean streamflows indicated a good match of the simulated streamflows to the timing and magnitude of the highest flows in the extended record; however, many of the simulated intermediate high flows overestimate the extended record (fig. 31A). The hydrographs of monthly mean streamflows (figs. $31 \mathrm{~B}, 31 \mathrm{C}$ ) indicated a satisfactory match between the simulated streamflows and extended record, with generally a good match to the low flow and high flow periods. The timing of the four wettest months in the extended record was well represented by the simulated results; however, the SRPHM overestimated the magnitude of the streamflows for these months. The monthly mean streamflows of $10 \mathrm{ft}^{3} / \mathrm{s}$ and less were well represented for the first half of the testing period (water years 1976-89); however, there was a tendency to overestimate the lowest streamflows during the second half of the testing period (fig. 31C). The flow-duration curves indicated a satisfactory match to extended-record daily flows of about $10 \mathrm{ft}^{3} / \mathrm{s}$ and higher, which occurred 70 percent of the time; however, the SRPHM had a tendency to overestimate streamflows less than $6 \mathrm{ft}^{3} / \mathrm{s}$, which occurred about 20 percent of the time at the MWCM streamgage (fig. 31D).

\section{Comparison of Simulated and Measured Annual Streamflow}

Annual mean streamflow hydrographs also were used to compare results between measured and simulated streamflows for both calibration and testing periods (fig. 32). For the LAGC streamgage, the SRPHM had a tendency to overestimate annual-mean measured streamflows, resulting in an increase in estimation bias in the testing period compared with the calibration period (fig. 32A), which could have been caused by differences in land use between the testing period and the calibration period (for example, a change in urbanization).

Results for the COLL streamgage showed a small improvement in the match between simulated and measured annual mean streamflows for the testing period compared with the calibration period (fig. 32B). The simulation results underestimated the measured streamflows for 5 of the 6 water years for both the calibration and testing periods.

Results for the LAGS streamgage generally showed a reasonable match between simulated and measured annual mean streamflows for the calibration and testing periods (fig. 32C); however, the high measured streamflow in water year 2008 was underestimated by the SRPHM.

Results for streamgages SRCW and SRCU showed a good match between measured data and simulated results (fig. 32D, 32E).

For the MWCM streamgage, the SRPHM tended to overestimate the extended-record streamflows (fig. $32 F$ ); however, the difference between simulated and the extendedrecord annual mean streamflows was less in years approaching the calibration period (water years 2003-05). Although the SRPHM overestimated streamflows for most water years prior to water year 2003, there was a good match for the highest and lowest annual mean streamflows. The tendency of the model to overestimate streamflows for the testing period could be explained by the inability of the SRPHM to represent changing watershed characteristics through time. For example, the amount of impervious land area derived from the 2001 landuse data could cause an overestimation of impervious land area for the earlier simulation period, which, in turn, would cause an overestimation of simulated flows for that period. 

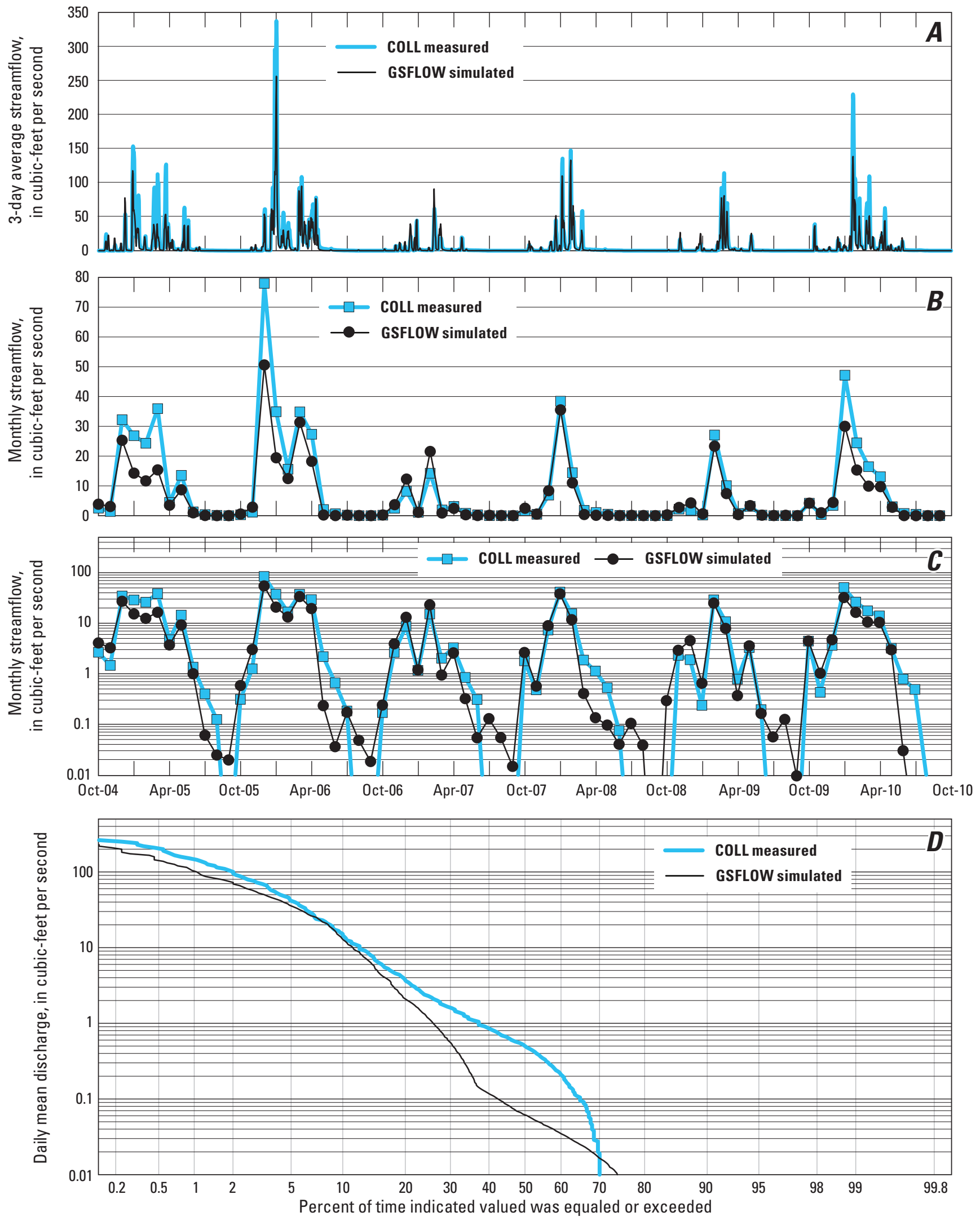

Figure 27. Comparison of simulated and measured streamflows at the Colgan Creek near Santa Rosa (COLL) streamgage, 11465690, Santa Rosa Plain hydrologic model, Santa Rosa Plain watershed, Sonoma County, California, water years 2004-10: $A$, daily mean; $B$, monthly mean; $C$, monthly mean at logarithmic scale; $D$, flow duration for daily mean streamflow. 

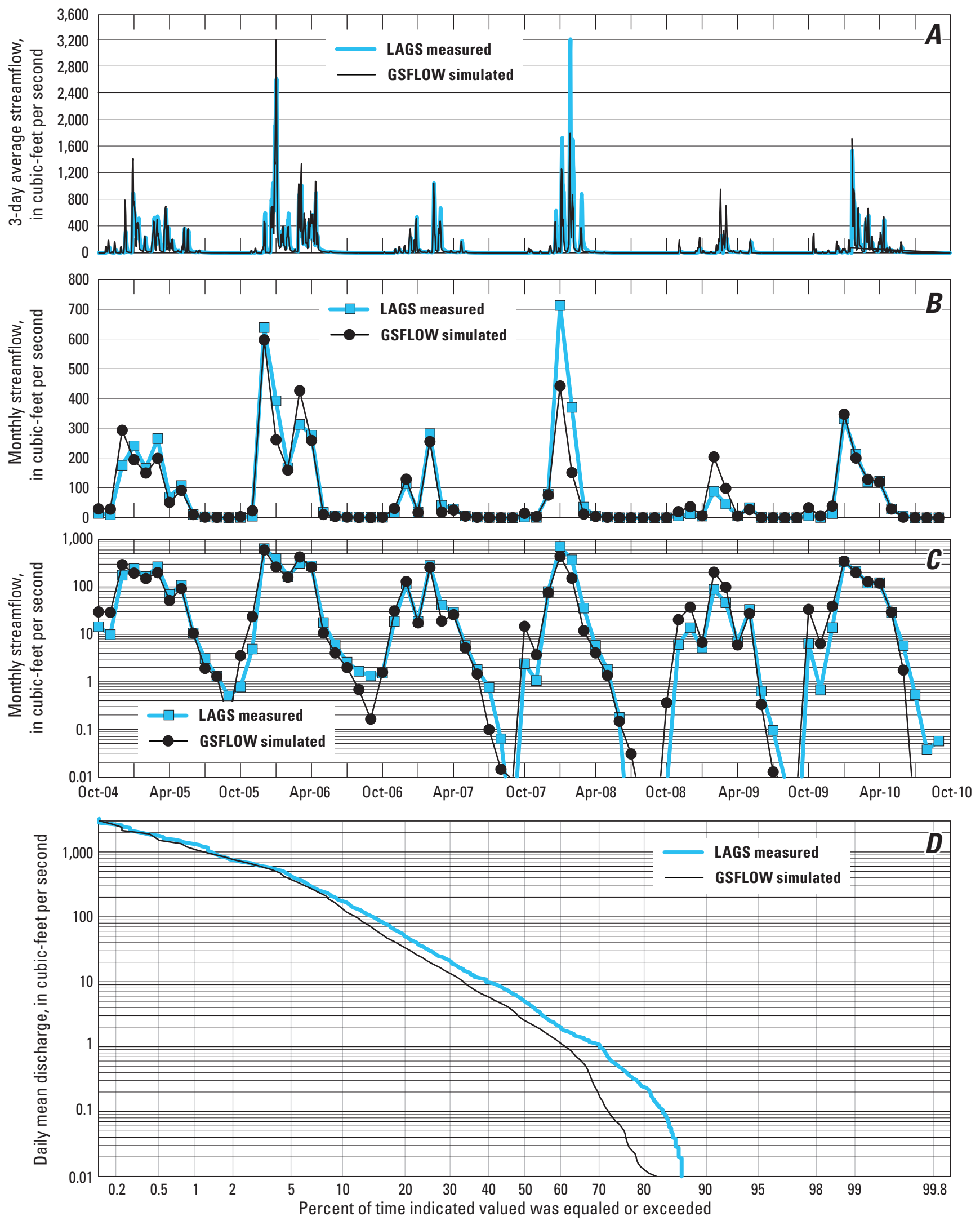

Figure 28. Comparison of simulated and measured streamflows at the Laguna de Santa Rosa near Sebastopol (LAGS) streamgage, 11466200, Santa Rosa Plain hydrologic model, Santa Rosa Plain watershed, Sonoma County, California, water years 2004-10: $A$, daily mean; $B$, monthly mean; $C$, monthly mean at logarithmic scale; $D$, flow duration for daily mean streamflow. 

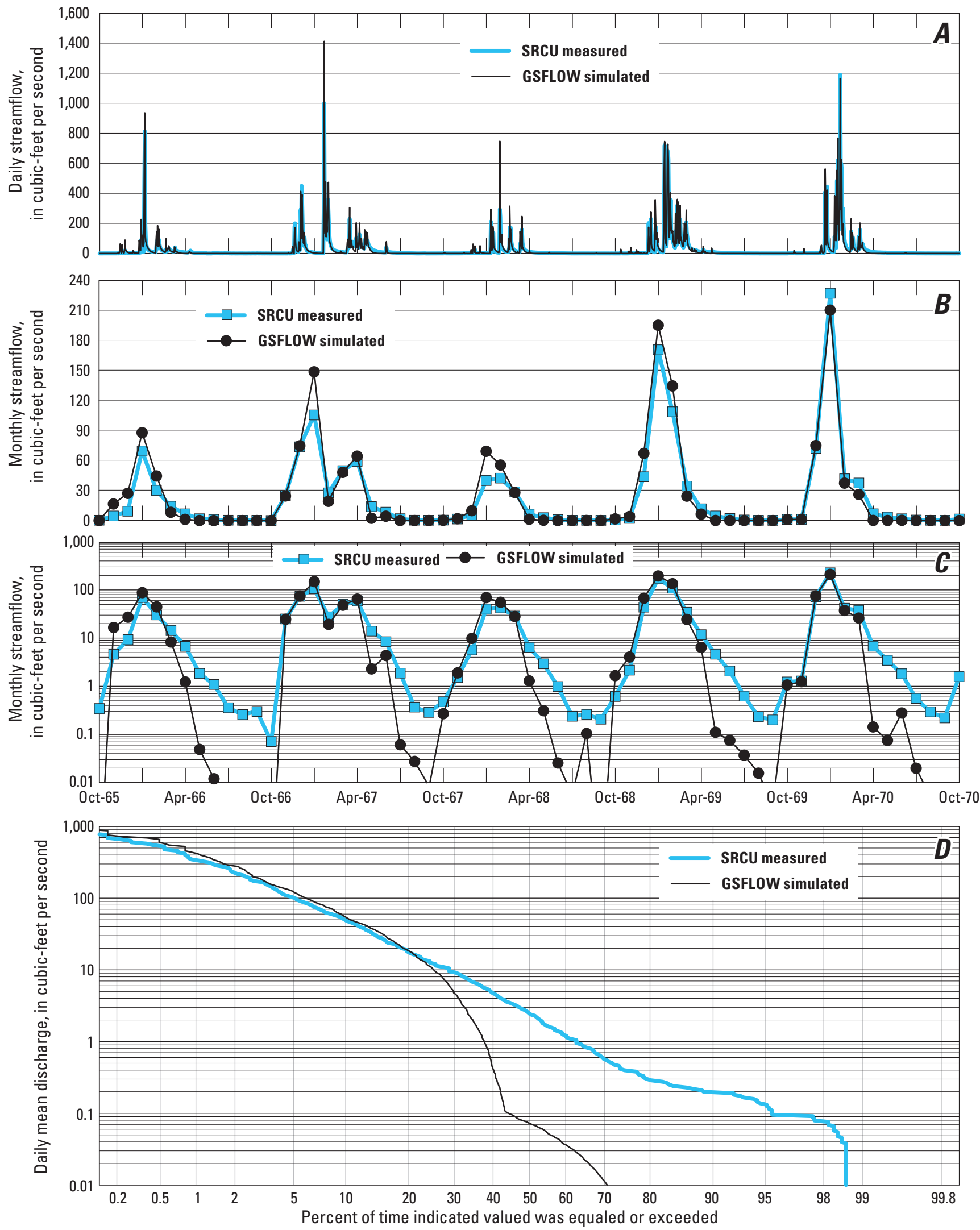

Figure 29. Comparison of simulated and measured streamflows at the Santa Rosa Creek near Santa Rosa (SRCU) streamgage, 11465800, Santa Rosa Plain hydrologic model, Santa Rosa Plain watershed, Sonoma County, California, water years 1966-70: A, daily mean; $B$, monthly mean; $C$, monthly mean at logarithmic scale; $D$, flow duration for daily mean streamflow. 

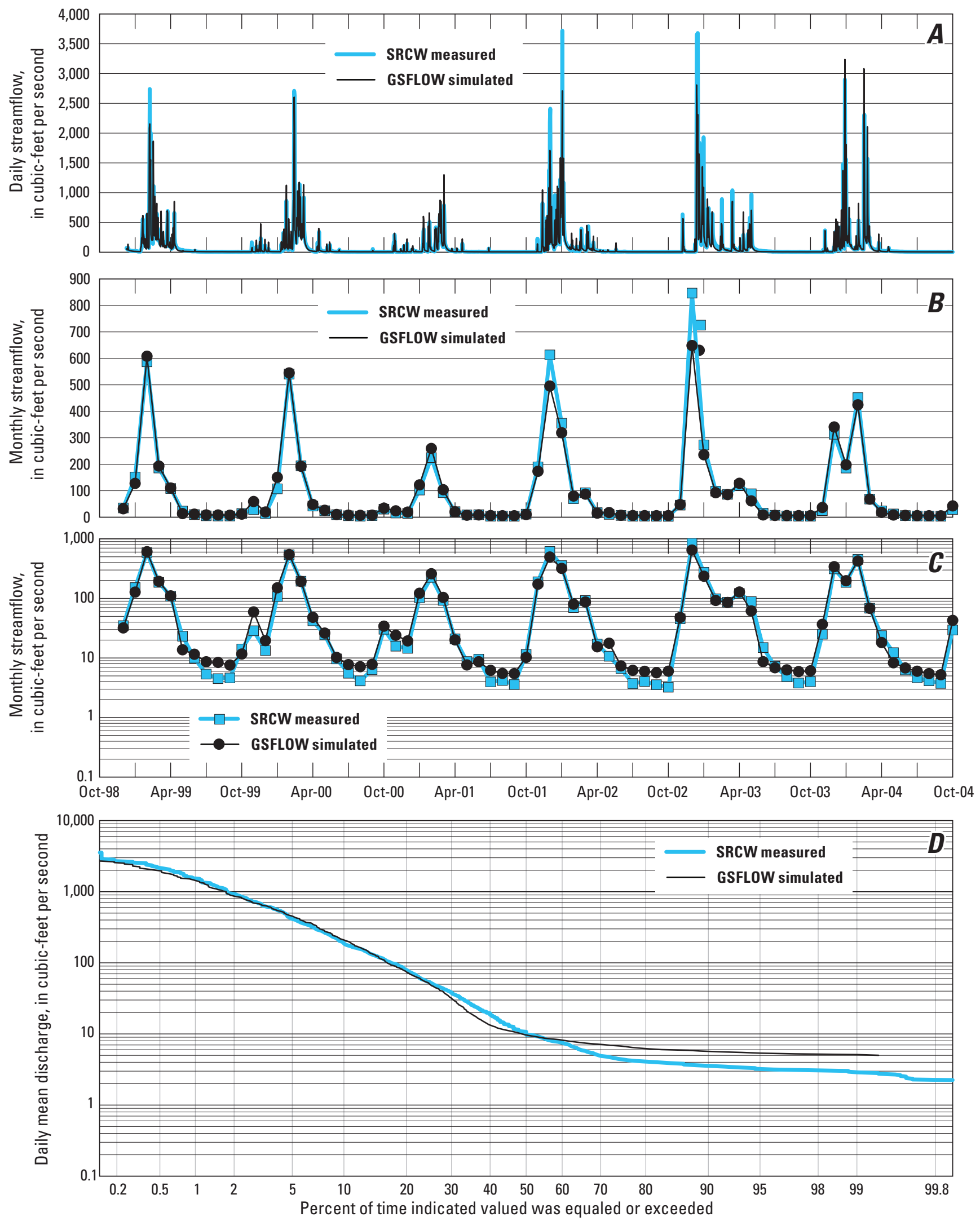

Figure 30. Comparison of simulated and measured streamflows at the Santa Rosa Creek at Willowside Road near Santa Rosa (SRCW) steamgage, 11466320, Santa Rosa Plain hydrologic model, Santa Rosa Plain watershed, Sonoma County, California, water years 1999-2004: $A$, daily mean; $B$, monthly mean; $C$, monthly mean at logarithmic scale; $D$, flow duration for daily mean streamflow. 

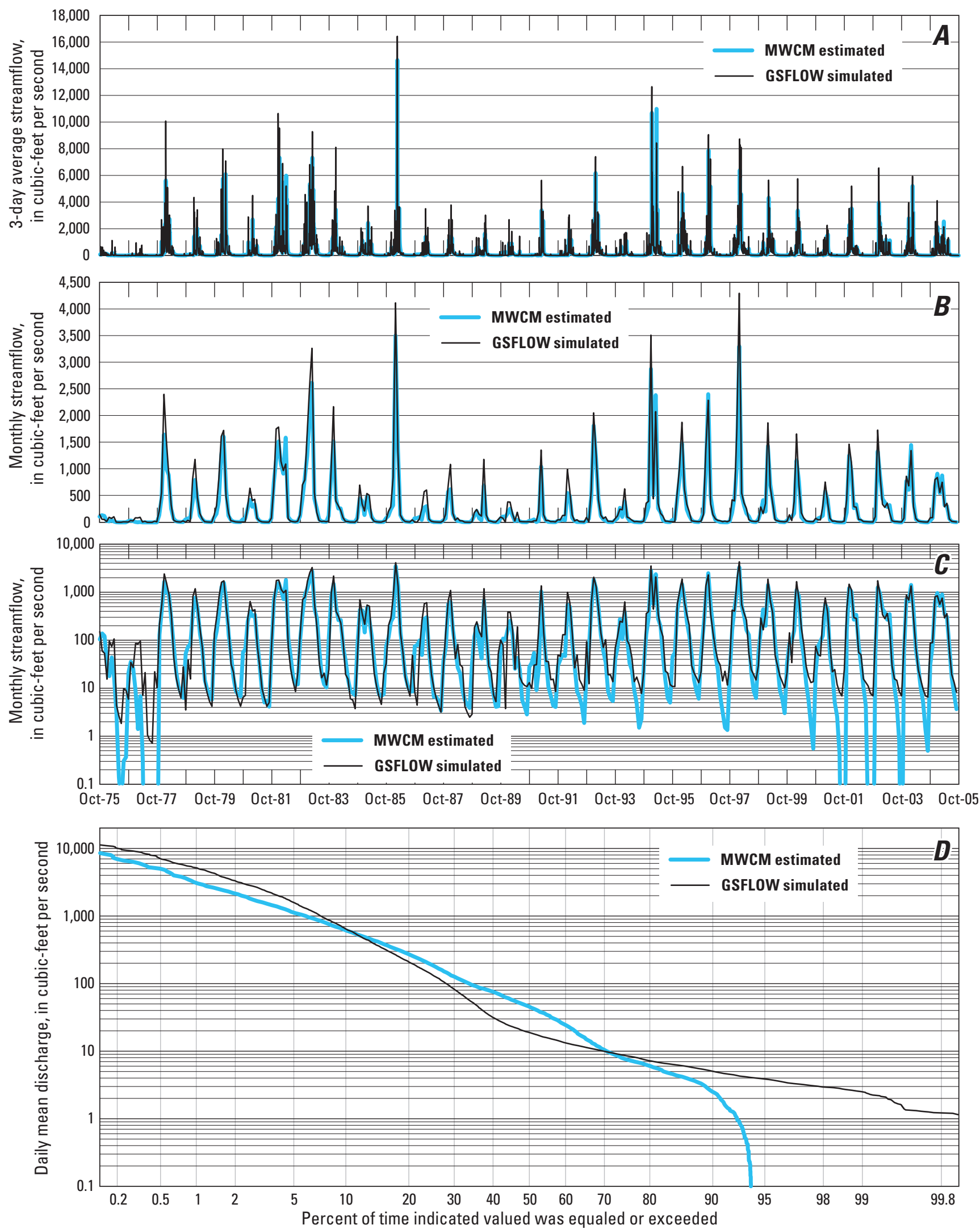

Figure 31. Comparison of simulated and estimated streamflows at the Mark West Creek near Mirabel Heights (MWCM) streamgage, 11466800, Santa Rosa Plain hydrologic model, Santa Rosa Plain watershed, Sonoma County, California, water years 1976-2005: $A$, moving 3-day average; $B$, monthly mean; $C$, monthly mean at logarithmic scale; $D$, flow-duration for daily mean streamflow. 

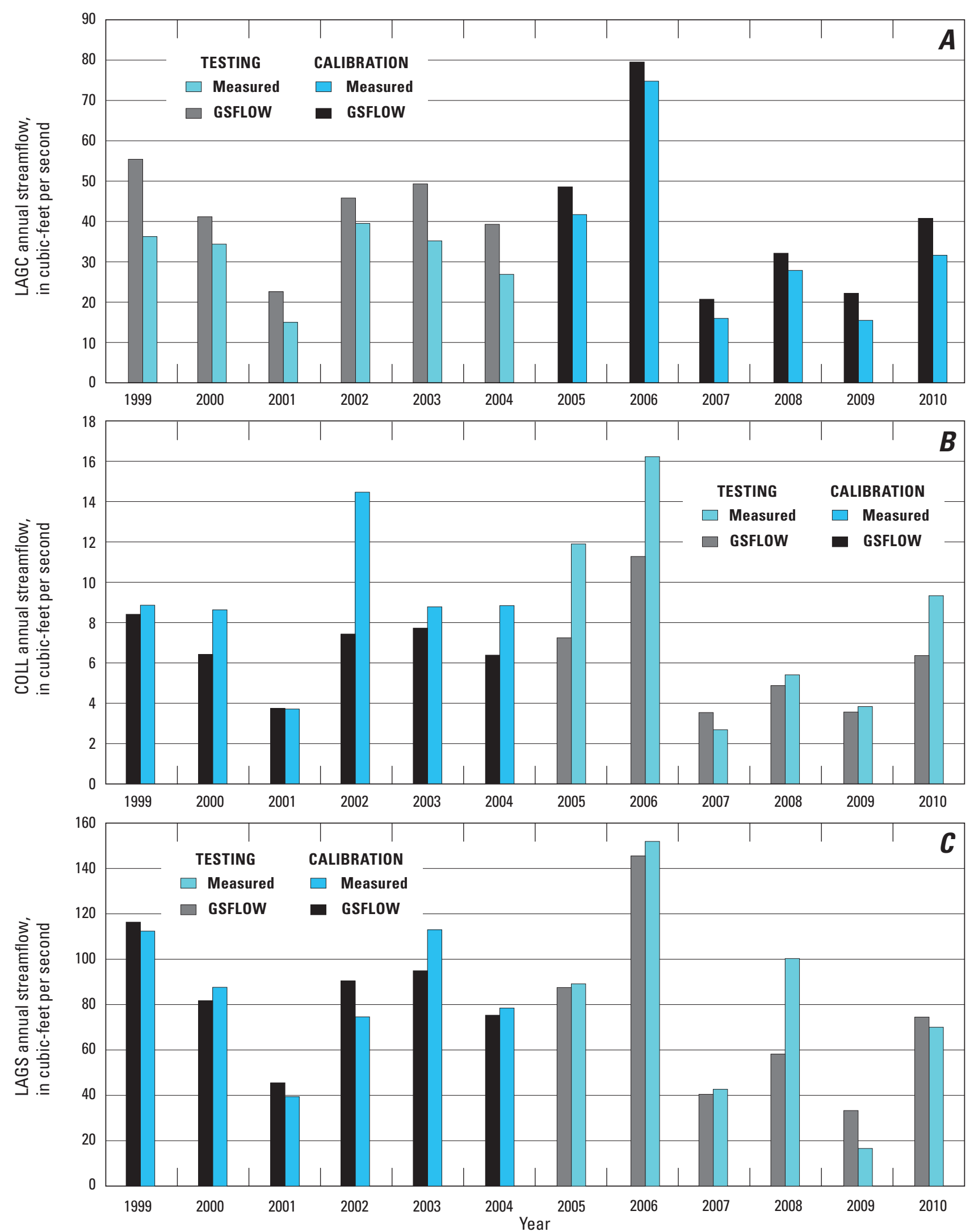

Figure 32. Annual mean streamflows for the calibration and testing periods for the Santa Rosa Plain Hydrologic model, Santa Rosa Plain watershed, Sonoma County, California, for the following streamgages: $A$, Laguna de Santa Rosa at Stony Point Road near Cotati (LAGC); $B$, Colgan Creek near Santa Rosa (COLL); $C$, Laguna de Santa Rosa near Sebastopol (LAGS); D, Santa Rosa Creek near Santa Rosa (SRCU); E, Santa Rosa Creek at Willowside Road near Santa Rosa (SRCW); F, Mark West Creek near Mirabel Heights (MWCM). 

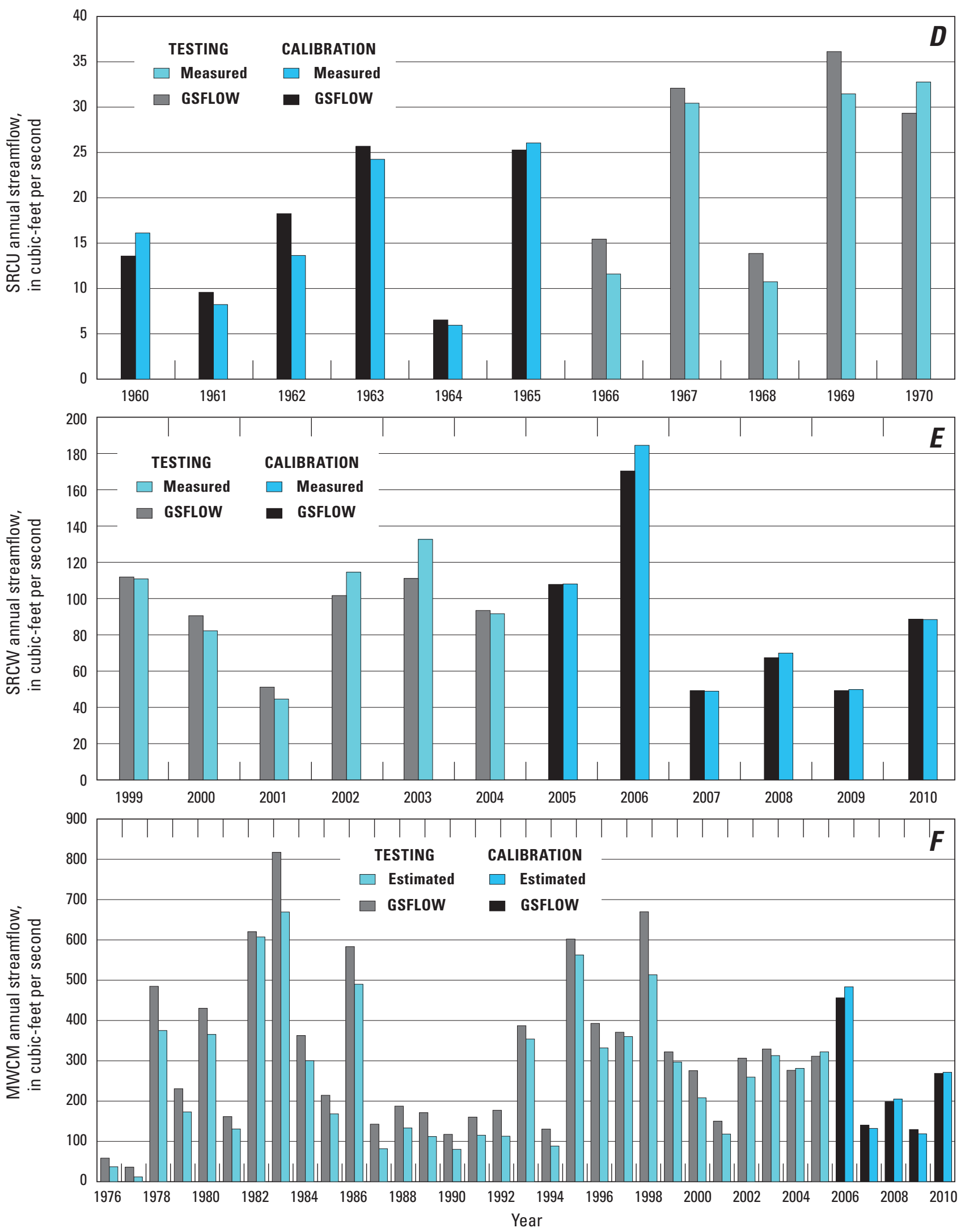

Figure 32. - Continued 


\section{Calibration to Groundwater Levels}

The spatial and temporal variability in the simulated hydraulic heads is dependent on system hydrologic stresses and hydraulic properties. For the SRPHM calibration to measured groundwater levels, simulated hydraulic heads were compared with measured groundwater levels from 83 wells for model-fit statistics; the hydrographs shown for 38 of these wells (locations shown in fig. $1 B$ ) are considered key wells for adequately representing the system spatially and temporally.

Simulated hydraulic heads were compared directly with measured groundwater levels if the wells were perforated in a single model layer. For wells perforated within multiple model layers, MF-NWT calculated a composite, simulatedequivalent hydraulic head by using the hydraulic-head observation (HOB) package (Hill and others, 2000), which is a function of the simulated hydraulic heads and hydraulic properties of the perforated model layers. Measures of model fit for the groundwater component presented herein include the following:

- Model-fit statistics for residuals (the difference between measured groundwater levels and simulated hydraulic heads), including the average, median, minimum, maximum, root mean square error (RMSE), and normalized RMSE (NRMSE).

- Plotting measured groundwater levels against simulated hydraulic heads and residuals against simulated hydraulic heads.

- Spatial distributions of maximum and minimum residuals with measured groundwater-level contours and simulated hydraulic-head distribution for water year 2007.

The NRMSE is calculated by dividing the root mean square error (RMSE) of the residuals by the total range in measured groundwater levels in the groundwater system
(Anderson and Woessner, 1992). The value is expressed as a percentage and previous studies (Drost and others, 1999; Ely and Kahle, 2012) indicated that this should be less than 10 percent to be acceptable. Lesser values of RMSE and NRMSE indicate improved model fit; however, greater RMSE values are considered acceptable where measured groundwater levels fluctuate over a wide range and NRMSE values are low. This is because a simulated head represents an average over the area of the cell, whereas measured water levels represent the head in a well. If the well has a pump in it, or is near a pumped well or other form of hydrologic stress, the response in the well is greater than the average response over the area of a cell containing that well.

When plotting simulated hydraulic heads against measured groundwater levels, all the points would lie on the 1:1 correlation line if the SRPHM results matched the measured data perfectly. Similarly, when plotting the residuals against simulated hydraulic heads, all the points would be at zero if the SRPHM results matched the measured data perfectly.

\section{Comparison of Measured Groundwater Levels and Simulated Hydraulic Heads}

The NRMSE for the SRPHM, calculated by using all 6,361 groundwater-level measurements used for calibration, was 4.4 percent. The RMSE for the Cotati-N MSU was the greatest, but the NRMSE was the smallest (table 13). The greater RMSE was considered acceptable because of the wide range in measured groundwater levels (about $373 \mathrm{ft}$ ) in this MSU. Although the NMRSE values were greater than 10 percent for the Rincon-Kenwood, Windsor, Wilson Grove, and Santa Rosa MSUs, they were reasonably close and were acceptable for the intended use of this model. Although the Bennett Valley-plain MSU had the lowest RMSE value, it had a high NRMSE value influenced by the narrow range in measured groundwater levels (about $25 \mathrm{ft}$ ).

Table 13. Summary of model-fit statistics for model storage units in the Santa Rosa Plain hydrologic model, Santa Rosa Plain watershed, Sonoma County, California.

[Residual: $($ residual $=$ measured water level - simulated head $)]$

\begin{tabular}{|c|c|c|c|c|c|c|c|c|}
\hline $\begin{array}{l}\text { Model } \\
\text { storage } \\
\text { unit }\end{array}$ & $\begin{array}{c}\text { Average } \\
\text { residual } \\
\text { (feet) }\end{array}$ & $\begin{array}{l}\text { Median } \\
\text { residual } \\
\text { (feet) }\end{array}$ & $\begin{array}{c}\text { Minimum } \\
\text { negative } \\
\text { residual } \\
\text { (feet) }\end{array}$ & $\begin{array}{l}\text { Maximum } \\
\text { positive } \\
\text { residual } \\
\text { (feet) }\end{array}$ & $\begin{array}{l}\text { Root mean } \\
\text { square error } \\
\text { (RMSE) } \\
\text { (feet) }\end{array}$ & $\begin{array}{c}\text { Normalized root } \\
\text { mean square } \\
\text { error } \\
\text { (NMRSE) } \\
\text { (percent) }\end{array}$ & $\begin{array}{c}\text { Number } \\
\text { of } \\
\text { wells }\end{array}$ & $\begin{array}{c}\text { Number } \\
\text { of } \\
\text { measurements }\end{array}$ \\
\hline Windsor & -10 & -11 & -61 & 44 & 22 & 13 & 24 & 1,486 \\
\hline Santa Rosa & 4 & 7 & -85 & 45 & 21 & 14 & 24 & 1,387 \\
\hline Cotati-N & -28 & -26 & -160 & 48 & 35 & 9 & 14 & 1,561 \\
\hline Wilson Grove & 16 & 6 & -72 & 136 & 34 & 13 & 10 & 880 \\
\hline Bennett Valley-plain & -5 & -6 & -11 & 4 & 6 & 25 & 3 & 103 \\
\hline Rincon-Kenwood & -6 & -6 & -30 & 49 & 13 & 11 & 2 & 97 \\
\hline $\begin{array}{l}\text { Bennett Valley- } \\
\text { mountains }\end{array}$ & -5 & -2 & -35 & 32 & 20 & 41 & 2 & 75 \\
\hline
\end{tabular}


The composite equivalent simulated hydraulic heads are plotted against the measured groundwater levels in figure $33 \mathrm{~A}$. All but two of these wells are located within the Windsor, Santa Rosa, Cotati-north, Cotati-south, and Sebastopol MSUs. These two wells, 6N/7W-3D1 and 6N/7W-3M1, are located in the Bennett Valley-mountain MSU (fig. 1B) and are the only wells with available data for the uplands. Overall, measured groundwater levels and simulated hydraulic heads above mean sea level (zero on the X-axis) generally followed a 1:1 correlation line (fig. 33A). Groundwater levels below mean sea level were overestimated by the SRPHM, likely because of underestimation of rural pumping in some parts of the SRPW. The SRPHM generally overestimated measured groundwater levels in the Cotati-N, Bennett Valley-plain, and RinconKenwood MSUs and underestimated the measured data in the Cotati-S and Bennett Valley-mountains MSUs. Most measured groundwater levels and simulated hydraulic heads for the Windsor, Santa Rosa, and Wilson Grove MSUs followed the 1:1 correlation line, although some measured groundwater levels were underestimated for the Wilson Grove MSU, and some were overestimated for the Santa Rosa MSU (fig. 33A).

The SRPHM residuals are plotted against the composite simulated groundwater levels in figure $34 B$. If residuals are randomly distributed about zero, there is no bias in the simulated values (Hill, 1998). In general, the plot showed the residuals distributed around zero. The greater number of residuals less than zero, however, indicated the overall tendency of the SRPHM to overestimate measured groundwater levels. The residuals for the simulation period showed that 58 percent of the simulated hydraulic heads were greater than measured groundwater levels by a median residual value of about $-17 \mathrm{ft}$; 42 percent of simulated hydraulic heads were less than measured groundwater levels by a median residual value of about $16 \mathrm{ft}$. For the Windsor, Cotati-N, Bennett Valley-plain, and Rincon-Kenwood MSUs, about 75, 83, 91, and 76 percent, respectively, of the residuals plotted below zero, indicating simulated hydraulic heads were greater than the measured value. Simulated hydraulic heads in these areas, in particular, were high. About 68, 55, and 66 percent of the residuals for the Santa Rosa, Cotati-S, and Wilson Grove MSUs, respectively, plotted above zero (fig. 33B), and simulated hydraulic heads were, on average, less than the measured value. About 52 percent of the residuals for the Bennett Valley-mountains MSU plotted below zero (fig. 33B), indicating the SRPHM slightly overestimated measured groundwater levels. The medians and other model-fit statistics for these MSUs are given in table 13.

The distribution of the maximum and minimum residuals for simulated hydraulic heads and measured groundwater levels in each MSU indicated a general spatial bias in the SRPHM results (fig. 35; table 13). For example, in the Bennett
Valley-plain MSU, the SRPHM slightly overestimated measured groundwater levels, but there was a good fit, as indicated by the comparatively small maximum and minimum residuals for each well. SRPHM overestimated measured groundwater levels predominantly in the Cotati-N and the southern part of the Santa Rosa MSUs (fig. 34B). In the Windsor and northern part of the Santa Rosa MSUs, the SRPHM also overestimated measured groundwater levels, but by a lesser amount. In the Wilson Grove MSU, SRPHM generally underestimated measured groundwater levels (fig. 34A, 34B). In the Cotati-S MSU, the SRPHM both overestimated and underestimated measured groundwater levels in similar proportions (fig. $34 \mathrm{~A}$, $34 B)$.

\section{Spatial Distribution: Water Year 2007}

For simulated hydraulic heads to be acceptable, the distribution of simulated hydraulic heads and gradients are proximate those measured. For this comparison, water-level contours for 2007 from Sweetkind and others (2013) were used. The simulated hydraulic heads for model layer 1 in the SRPW and groundwater-level contours for spring 2007 (Sweetkind and others, 2013) are shown in figure 35.

Contours of the simulated hydraulic heads in layer 1 in the SRP, Bennett Valley, Rincon Valley, and Kenwood Valley for spring 2007 were consistent with the measured groundwater-level contours in most places; the primary directions of groundwater movement were consistent (fig. 35). The simulated hydraulic heads for spring 2007 for model layer 1 ranged from $414 \mathrm{ft}$ in Kenwood Valley to $36 \mathrm{ft}$ in the vicinity of the confluence of Mark West Creek and the Laguna de Santa Rosa. The measured groundwater-levels showed a pumping depression on the east side of the Sebastopol fault in the vicinity of the city of Sebastopol; the simulated hydraulic heads in this area were consistent with depressed groundwater levels; however, the simulated area of the depression indicated by the $60-\mathrm{ft}$ contour was much larger. Uncertainty in location (areally and vertically) and amount of pumpage likely contributed to this discrepancy. In the uplands, the simulated hydraulic heads ranged from 1,830 ft above mean sea level in the Mayacmas Mountains, near the watershed boundary, to $13 \mathrm{ft}$ below mean sea level in the west-central part of the Sonoma Mountains. The lowest values of hydraulic head in the uplands were likely the result of overestimating pumpage from comparatively low-permeability units. The distribution of residuals for simulated hydraulic heads and measured groundwater levels at the 22 wells used for constructing the measured water-level contours (fig. 35) indicated there were eight values between $-5 \mathrm{ft}$ and $5 \mathrm{ft}$ (inclusive). The maximum residual for the 22 wells was $34 \mathrm{ft}$, indicating a reasonable fit of simulated hydraulic heads to measured groundwater-levels, overall, for this period. 

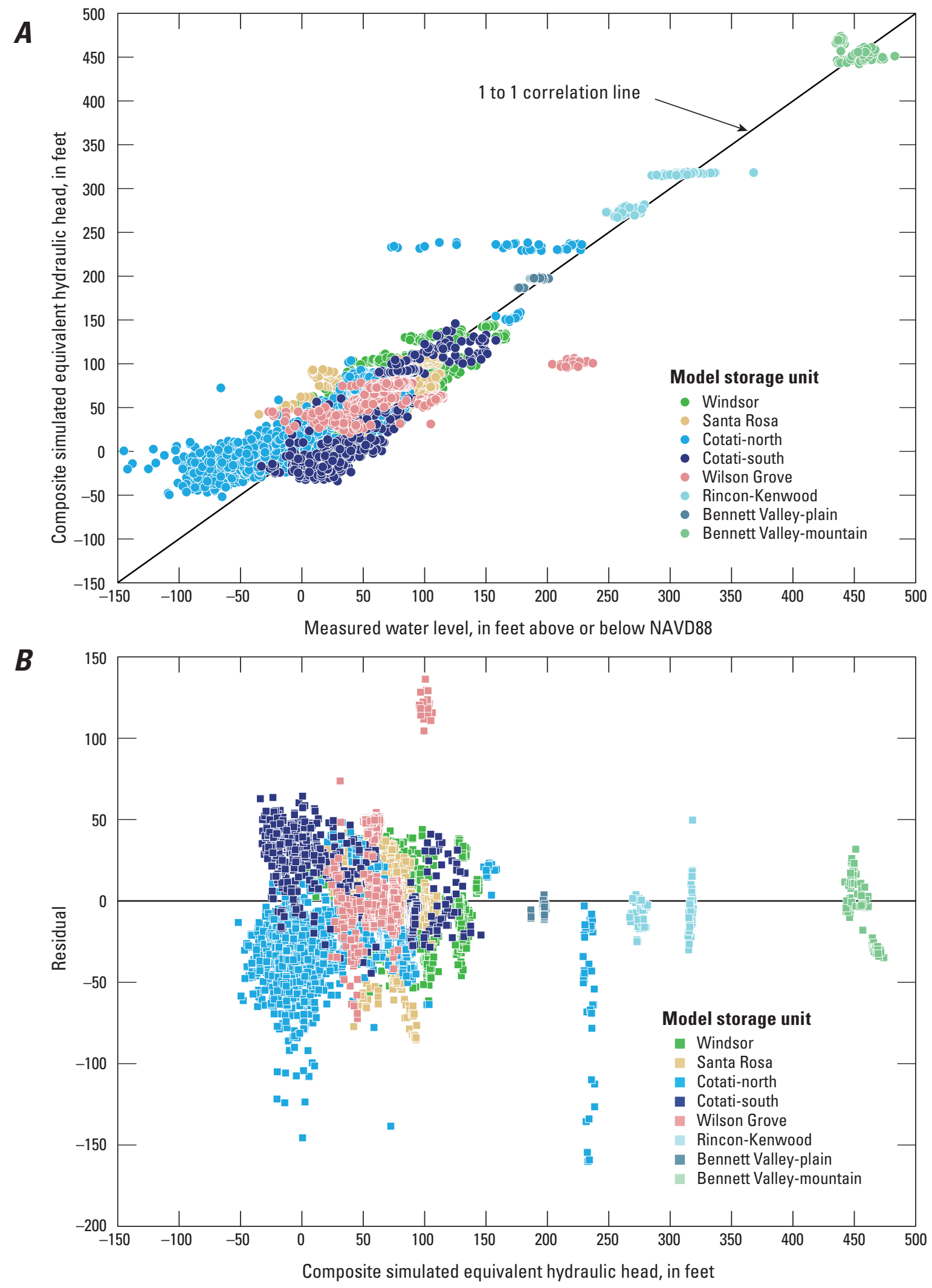

Figure 33. Composite simulated equivalent groundwater levels from the Santa Rosa Plain hydrologic model, Santa Rosa Plain watershed, Sonoma County, California, compared with $A$, measured groundwater levels; and $B$, differences between measured and simulated hydraulic heads (residuals) for transient conditions. 


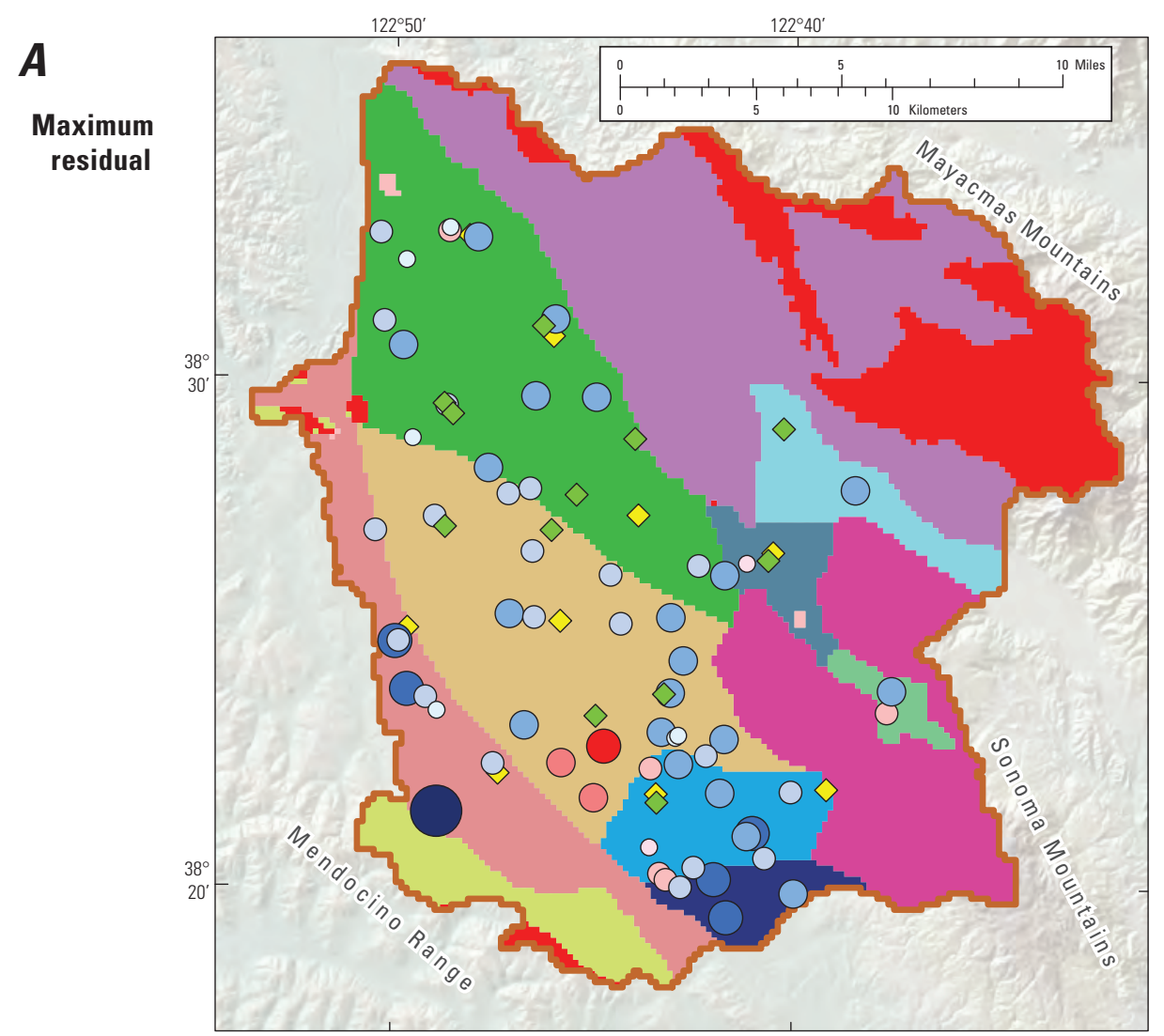

EXPLANATION

Model storage unit

Windsor

Santa Rosa

Cotati-north

Cotati-south

Rincon-Kenwood

Bennett Valley-plain

Wilson Grove

Basement Complex-plain

Mayacmas Mountains

Bennett Valley-mountains

Sonoma Mountains

Wilson Grove-mountains

Basement Complex-mountains

B

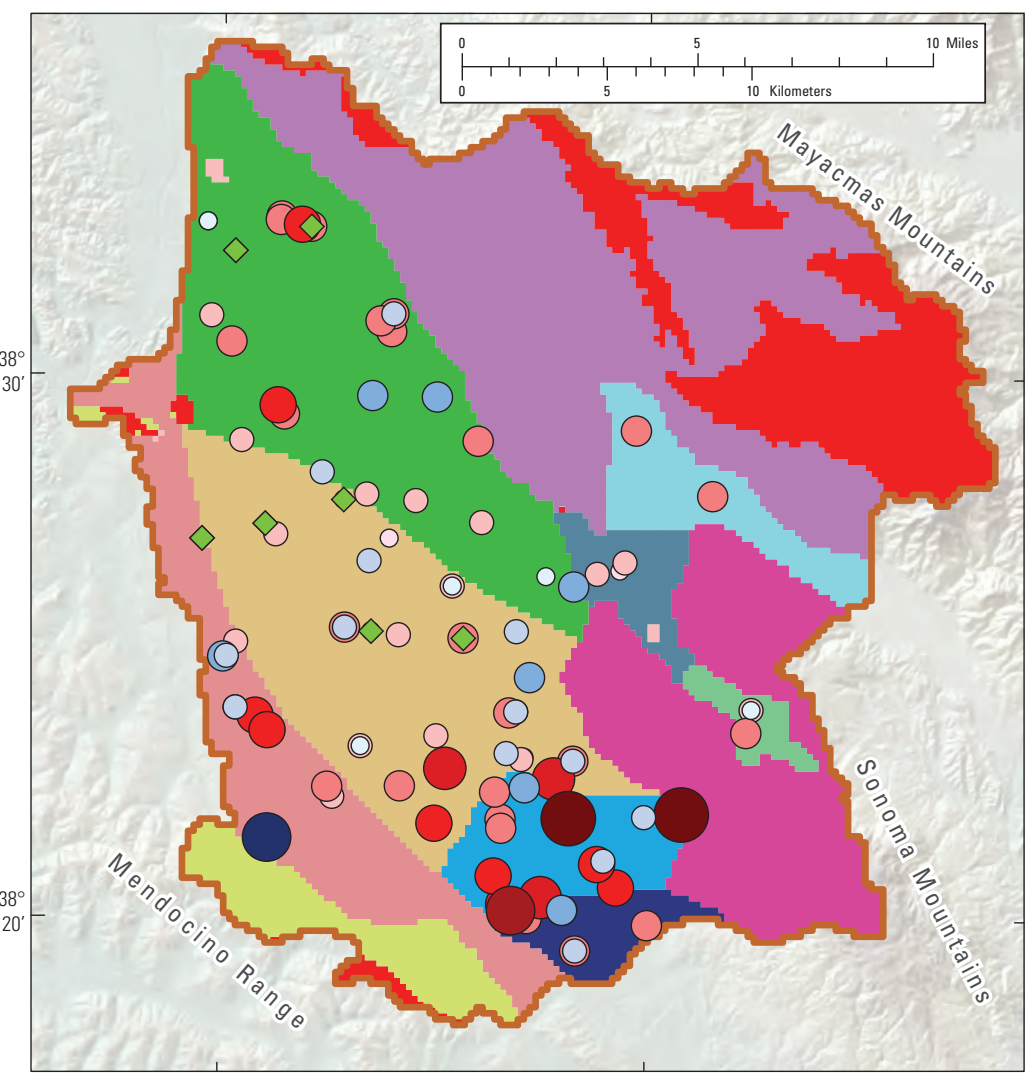

Maximum and minimum, residual, in feet

\begin{tabular}{|c|c|c|}
\hline 0 to 5 & $\diamond$ & -5 to 0 \\
\hline$>5$ to 10 & 0 & $<-10$ to -5 \\
\hline$>10$ to 25 & 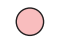 & $<-25$ to -10 \\
\hline$>25$ to 50 & & $<-50$ to -25 \\
\hline$>50$ to 75 & & $<-75$ to -50 \\
\hline$>75$ to 100 & & $<-100$ to -75 \\
\hline$>100$ to 125 & & $<-125$ to -100 \\
\hline$>125$ to 137 & & -160 to -125 \\
\hline
\end{tabular}

Figure 34. Distribution of differences between measured and simulated hydraulic heads (residuals) for the Santa Rosa Plain hydrologic model, Santa Rosa Plain watershed, Sonoma County, California: $A$, maximum differences; and $B$, minimum differences. 


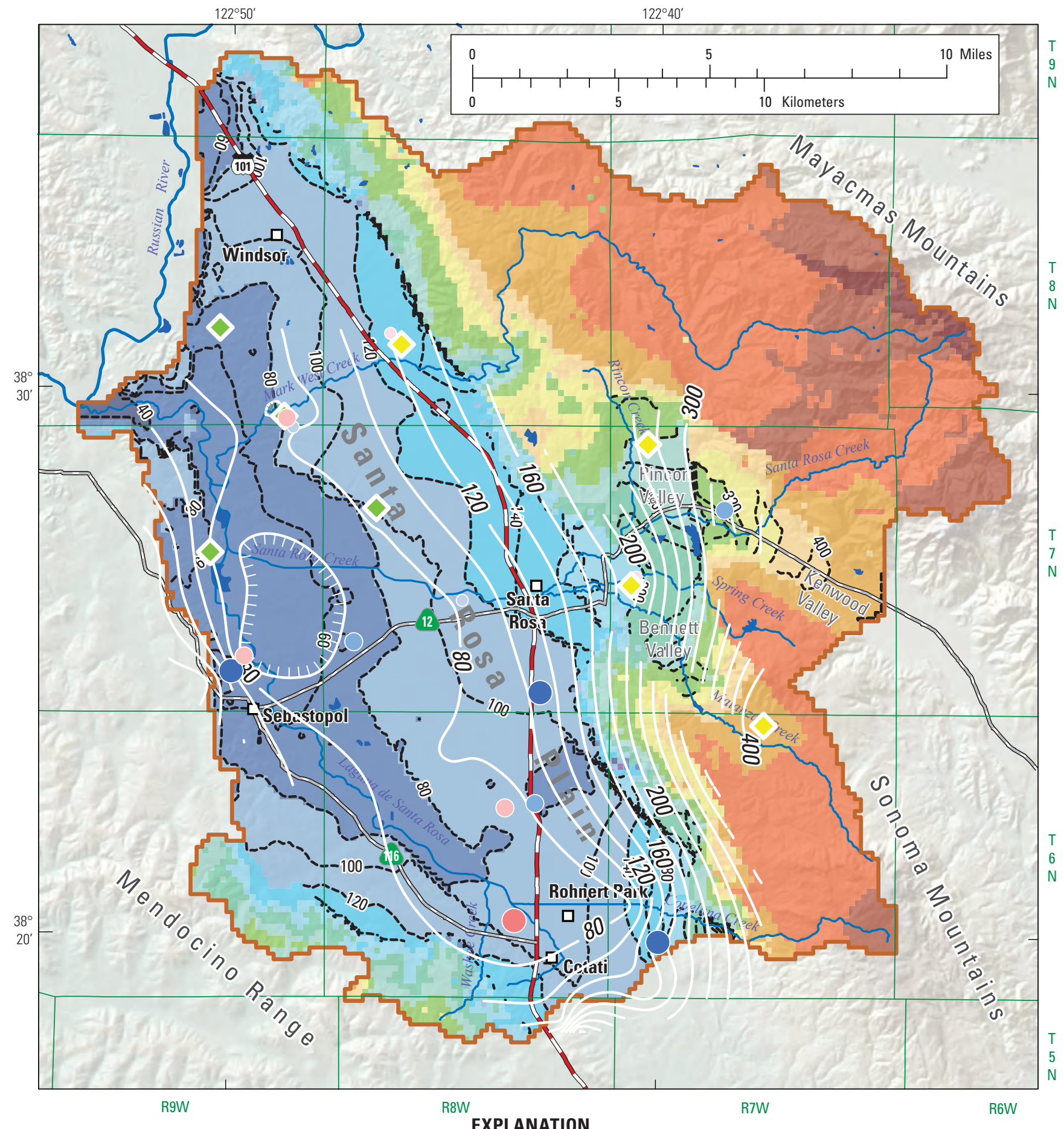

Simulated hydaulic head, in feet

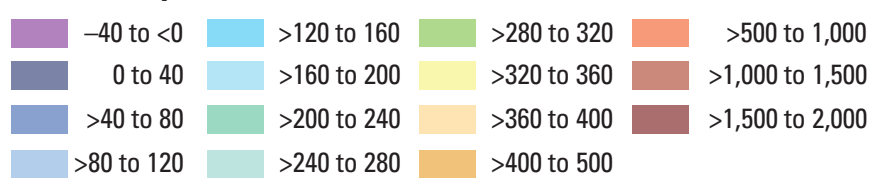

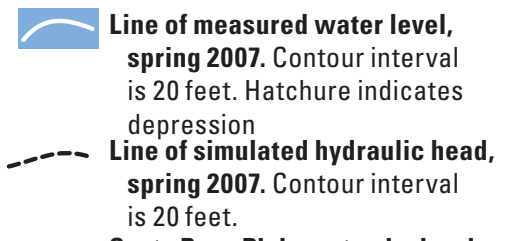

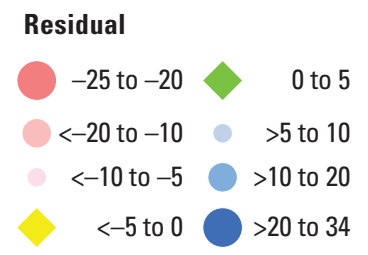

Santa Rosa Plain watershed and hydrologic-model boundary

Figure 35. Simulated hydraulic heads for layer 1, groundwater-level contours from measured data, and residuals for spring 2007, Santa Rosa Plain hydrologic model, Santa Rosa Plain watershed, Sonoma County, California. 


\section{Simulated Hydrographs}

Simulated and measured groundwater levels for selected wells by MSU are shown in figures 36 to 41 . The wells were selected to represent temporal variations (water-level trends that extend through the entire model period, inter-annual variations, and seasonal fluctuations) as well as areal and vertical coverage. Specific aspects are discussed for each hydrograph by MSU in the following sections.

While the SRPHM generally simulated measured water levels reasonably, simulated hydraulic heads were both overestimated and underestimated in the study area. Mismatches between simulated heads and measured water levels can be attributed to overestimation or underestimation of rural pumpage, local variability in hydraulic properties that are not reflected in the model, and uncertainty in the model input used to calculate recharge in the SRPHM (for example, unknown changes in land use and uncertainty in the spatial distribution of precipitation). For the shallower parts of the system, seasonal changes in water levels were more challenging to match because the measured response at a well was compared with the simulated response averaged over the area of a model grid cell.

\section{Windsor Model Storage Unit}

The simulated and measured hydrographs of the Windsor MSU calibration wells are shown in figure 36. Well 8N/9W-13A2 is in the north-central part of the Windsor MSU (fig. $1 B$ ) and is perforated in model-layers 1 and 2. Although the seasonal variations were well simulated, the inter-annual variation in the simulated hydraulic heads in both layers 1 and 2 were less than the measured heads (fig. 36A). The simulated hydraulic heads in layer 2, which has low hydraulic conductivity in this MSU, generally followed the inter-annual variation of the measured groundwater levels and generally tracked the measured data; however, between water years 1986 and 1992, the simulated hydraulic heads showed little change, while the measured groundwater levels tended to increase. Conversely, after water year 1994, the simulated hydraulic heads showed a slight decline, while the measured groundwater levels did not. The trend toward decreasing levels for the simulated hydraulic heads could be the result of overestimation of rural pumpage or underestimation of recharge in this area.

Well 8N/9W-15B1 is in the vicinity of the Russian River general-head boundary (fig. 1B) and is perforated in layer 3 . The simulated hydraulic heads in layer 3 followed the seasonal fluctuations of the measured groundwater levels, although with greater magnitude in some years (fig. 36B). The simulated hydraulic heads were not completely consistent with the interannual variation shown in the measured groundwater levels, which responded to wet years (water years 1983 and 1986) and dry years (water years 1987-1992).
Wells $8 \mathrm{~N} / 8 \mathrm{~W}-29 \mathrm{C} 3$ and 20Q1 are near the boundary between the Windsor and Mayacmas Mountains MSUs (fig. $1 B$ ). Well $29 \mathrm{C} 3$ is perforated in layer, 1 and well $20 \mathrm{Q} 1$ is perforated in layers $1-4$. The simulated hydraulic heads for well 29C3 generally were higher and showed less seasonal fluctuations than the measured groundwater levels, and weakly followed the overall increasing trend of from 1986 to 2010 that is evident in the measured data (fig. 36C). The simulated hydraulic heads in all four layers for well 20Q1 generally followed the inter-annual variation and seasonal fluctuations of the measured groundwater levels (fig. 36D). The measured groundwater levels fell within the range of simulated hydraulic heads in layers $1-4$, indicating a reasonable match (fig. 36D).

Wells $8 \mathrm{~N} / 9 \mathrm{~W}-26 \mathrm{~L} 1$ and $8 \mathrm{~N} / 9 \mathrm{~W}-22 \mathrm{R} 1$ are in the southwestern part of Windsor MSU (fig. 1B). Well 26L1 is perforated in layer 3 , and well 22R1 is perforated in layer 2. Simulated hydraulic heads in both wells generally followed the trend and seasonal fluctuations of the measured groundwater levels (fig. $36 E, 36 F$ ). The simulated seasonal fluctuations for well $8 \mathrm{~N} / 9 \mathrm{~W}-26 \mathrm{~L} 1$ were greater than those in the measured data (fig. 36E). Prior to water year 1997, the simulated hydraulic heads for well $8 \mathrm{~N} / 9 \mathrm{~W}-22 \mathrm{R} 1$ were slightly lower than the measured groundwater levels (fig. 36F).

Well $8 \mathrm{~N} / 8 \mathrm{~W}-32 \mathrm{M} 1$ is in the south-central part of the Windsor MSU (fig. $1 B$ ) and is perforated deep in the system in model layer 4 . The simulated hydraulic heads generally followed the measured groundwater levels. The seasonal highs in the simulated hydraulic heads were about $25 \mathrm{ft}$ lower than the measured groundwater levels, however, and the seasonal fluctuations were greater in magnitude than in the measured data (fig. 36G). This indicates that rural pumpage in the vicinity of this well could have been overestimated, the storage and hydraulic properties were underestimated, or both.

Wells $8 \mathrm{~N} / 9 \mathrm{~W}-36 \mathrm{~N} 1$ and $8 \mathrm{~N} / 9 \mathrm{~W}-36 \mathrm{P} 1$ are in adjacent cells in the western part of the Windsor MSU, just south of Mark West Creek (fig. 1B). Well 36N1 is perforated in the shallow system (layer 1), and well $36 \mathrm{P} 1$ is perforated much deeper in the system (layer 7; figs. 36H, 36I, respectively). The measured data indicated that the shallow system had groundwater levels about $50 \mathrm{ft}$ higher than in the deep system. The SRPHM generally underestimated the vertical gradient between these two wells, particularly prior to water year 1995 (figs. 36H, 36I). The simulated hydraulic heads in well 36N1 were in agreement with measured groundwater levels and followed the seasonal fluctuations (fig. 36H). The simulated hydraulic heads in well 36P1 followed the seasonal fluctuations of the measured groundwater levels, but were higher than the measured data. After water year 1998, the simulated hydraulic heads matched the measured data better because of the reduction in rural pumpage for this period, but were still higher than measured levels (fig. 36I). During water years 1975-98, the simulated hydraulic heads were higher than they were after water year 1998, indicating that the estimated rural pumpage was likely to have been too low for the earlier period in the vicinity of this well. 
$\boldsymbol{A}$

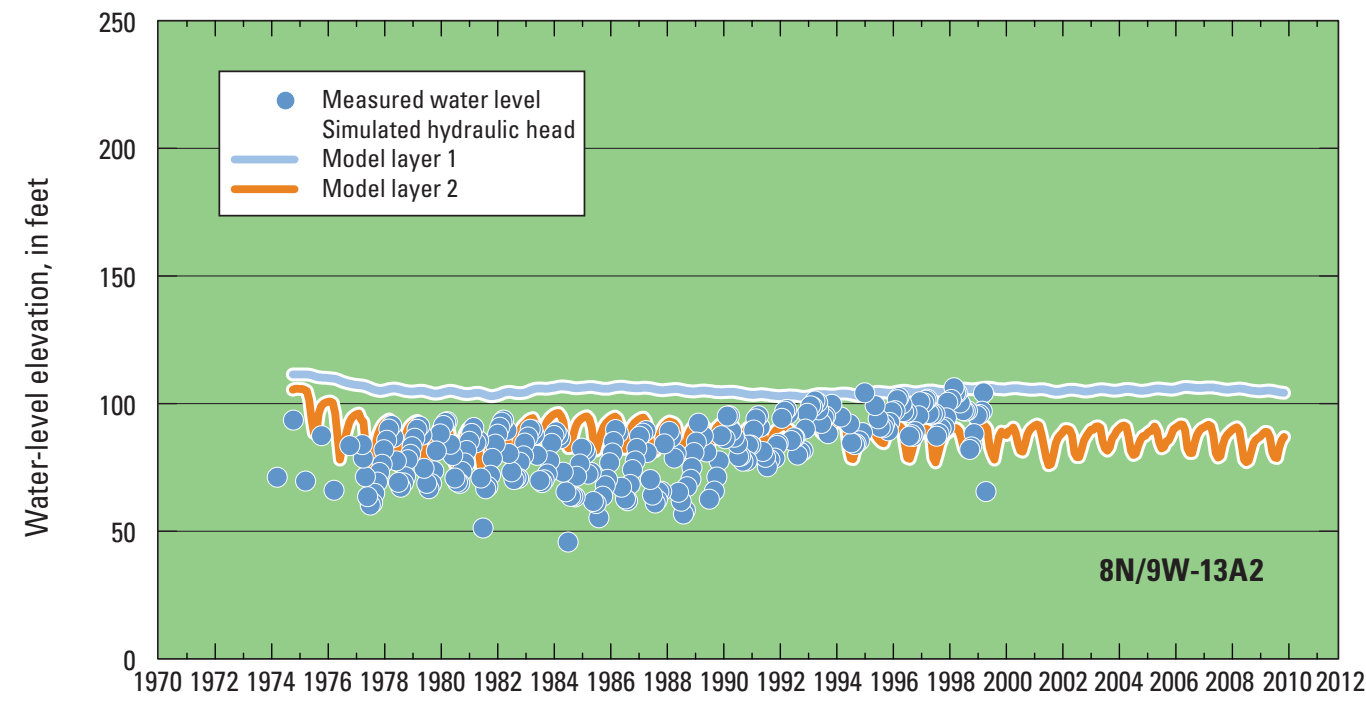

Windsor

B

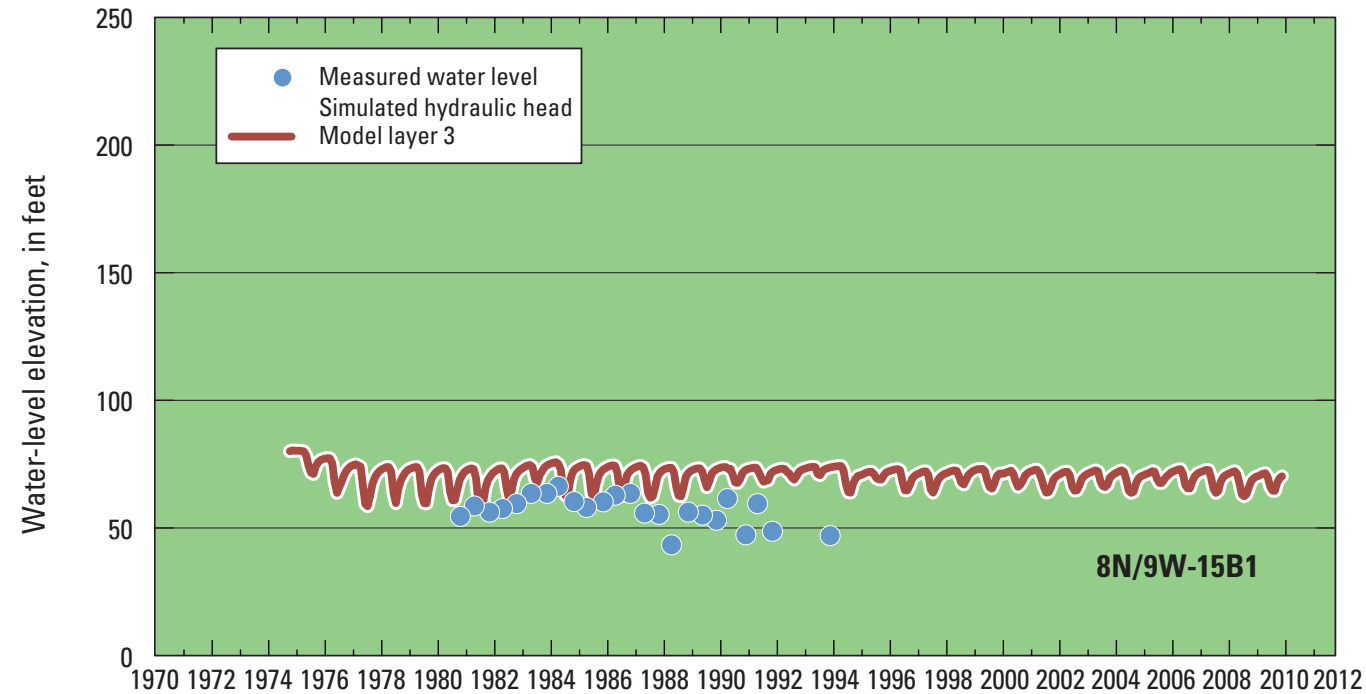

C

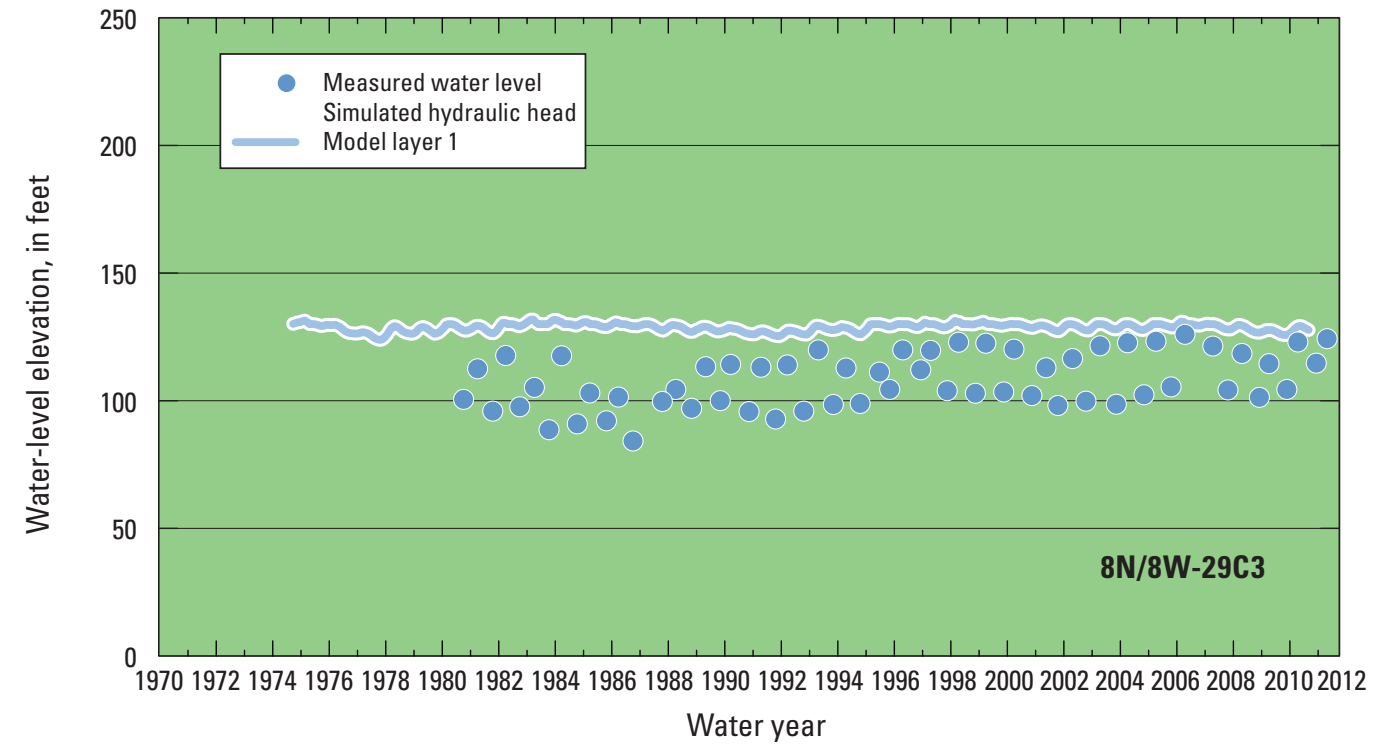

Figure 36. Measured and simulated hydraulic heads for wells in the Windsor model storage unit of the Santa Rosa Plain hydrologic model, Santa Rosa Plain watershed, Sonoma County, California: $A, 8 \mathrm{~N} / 9 \mathrm{~W}-13 \mathrm{~A} 2 ; B, 8 \mathrm{~N} / 9 \mathrm{~W}-15 \mathrm{~B} 1 ; C, 8 \mathrm{~N} / 8 \mathrm{~W}-29 \mathrm{C} 3 ; \mathrm{D}, 8 \mathrm{~N} / 8 \mathrm{~W}-2001 ; E_{\text {, }}$ 8N/9W-26L1; F, 8N/9W-22R1; G, 8N/8W-32M1; H, 8N/9W-36N1; I, 8N/9W-36P1; J, 7N/8W-3L1; K, 7N/8W-24L1; and L, 7N/8W-8M1. 

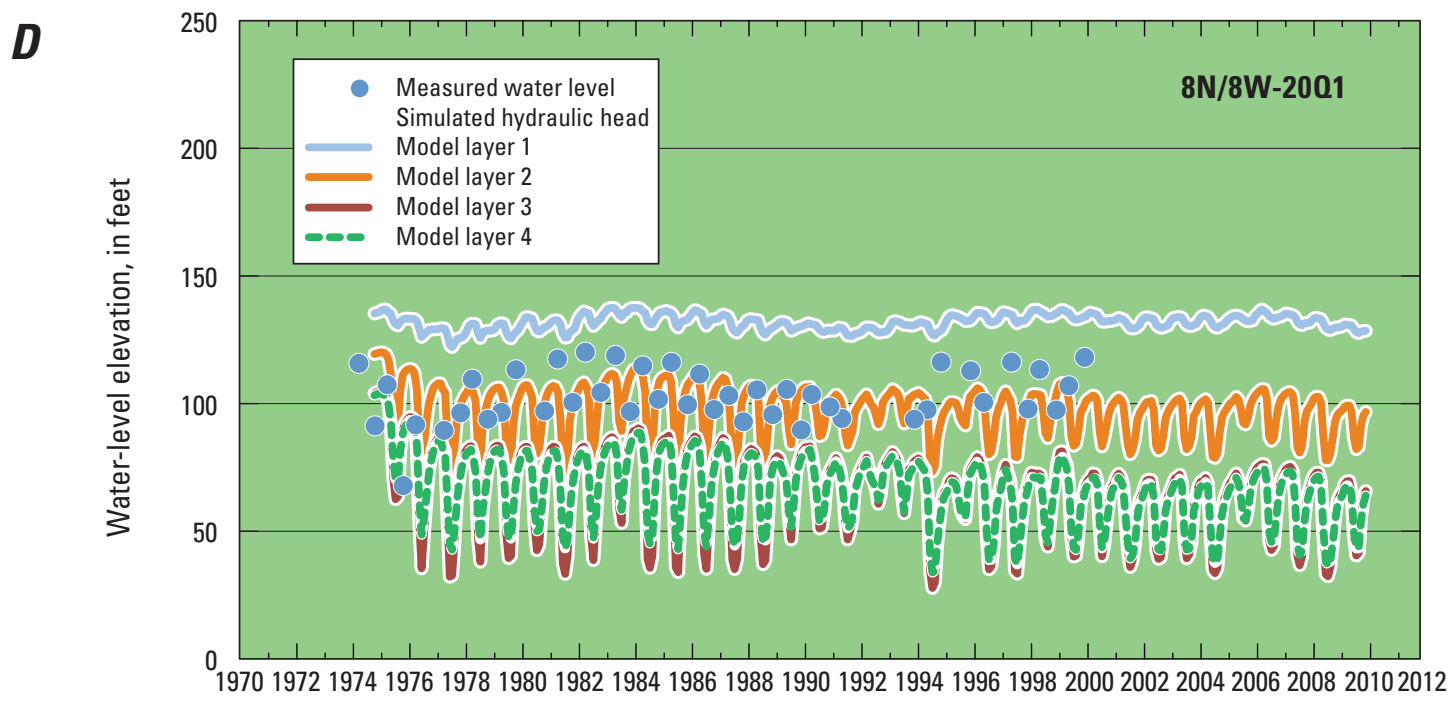

Windsor

$E$

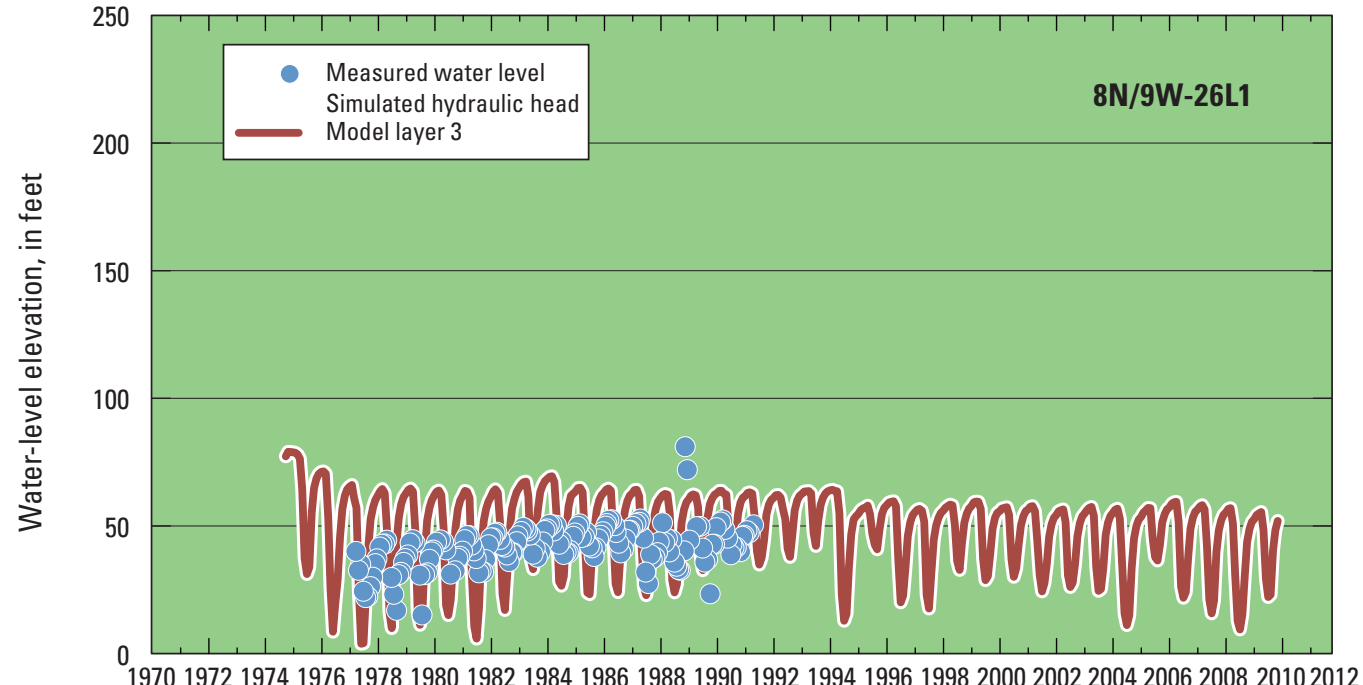

$\boldsymbol{F}$

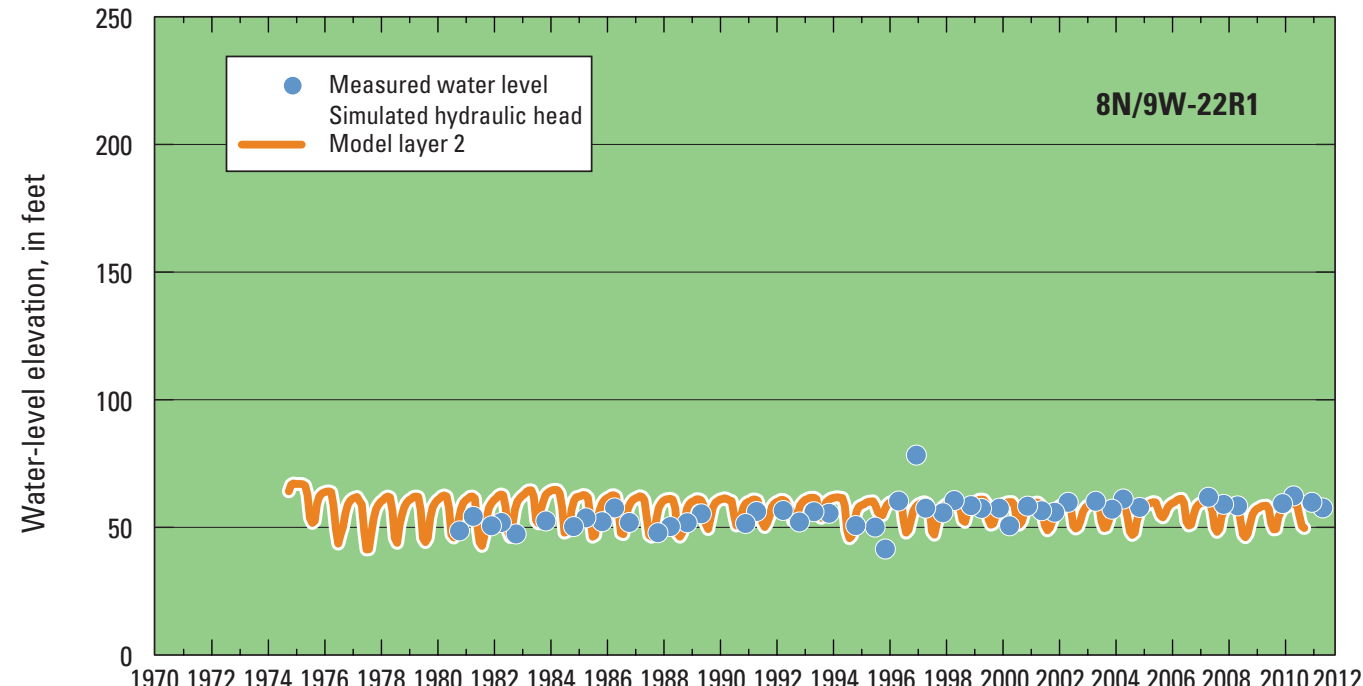

Water year

Figure 36. -Continued 
G

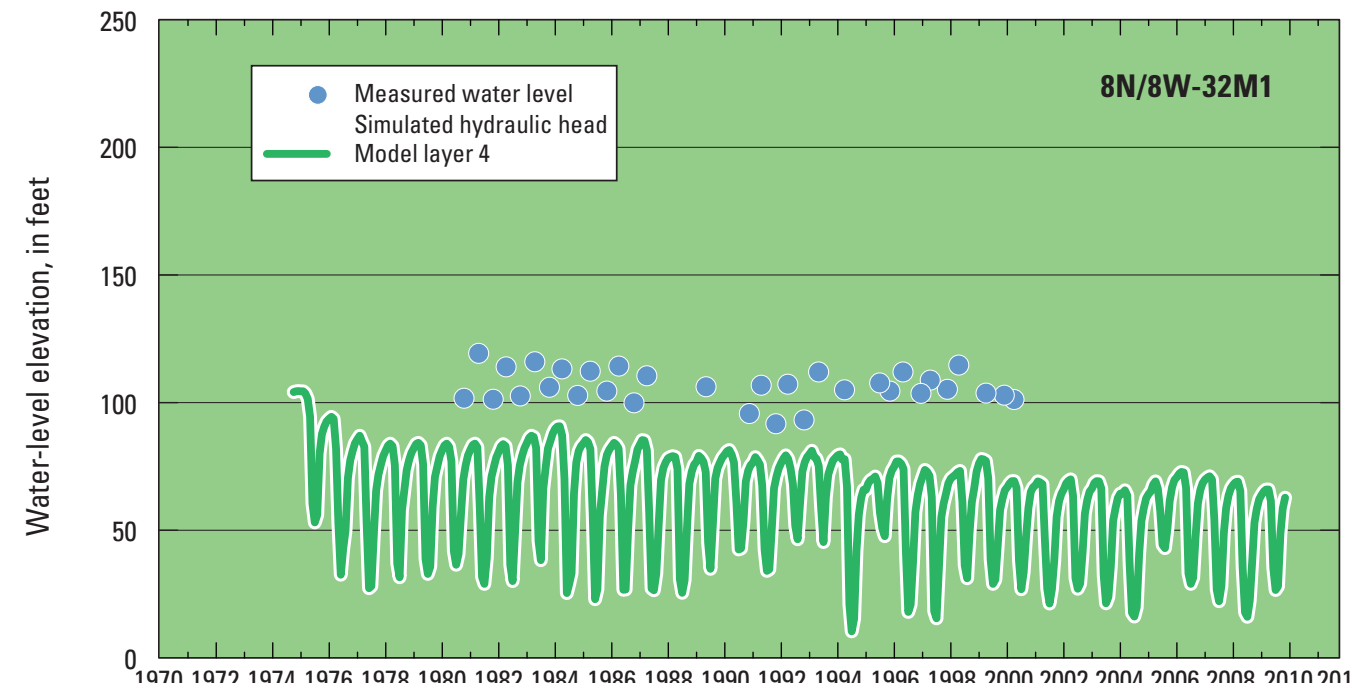

1970197219741976197819801982198419861988199019921994199619982000200220042006200820102012

$\boldsymbol{H}$

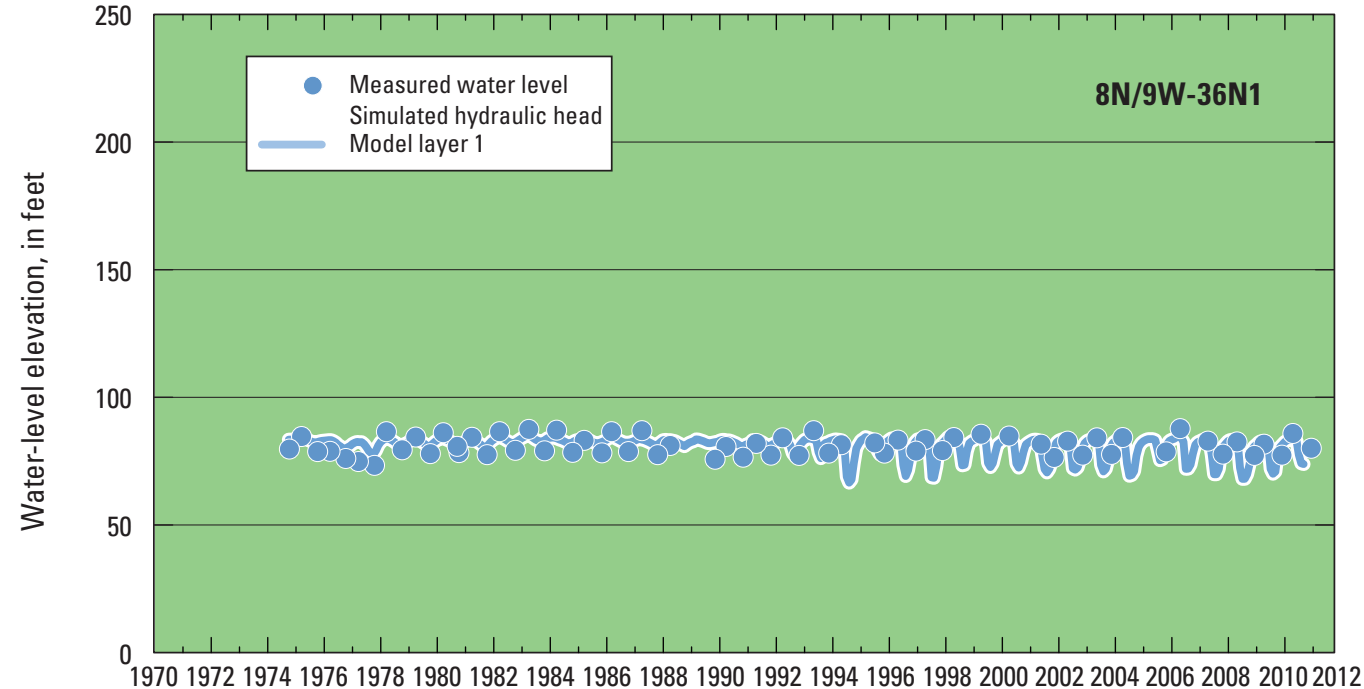

I

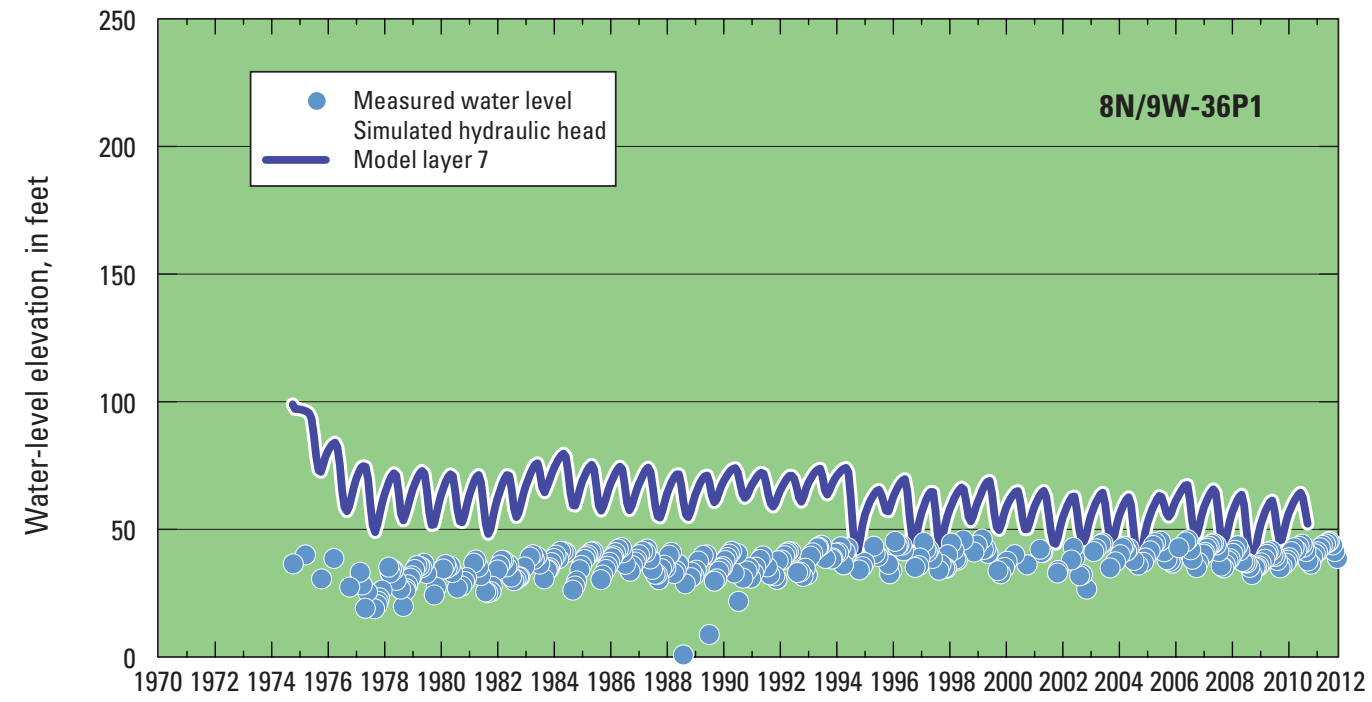

Water year

Figure 36. - Continued 


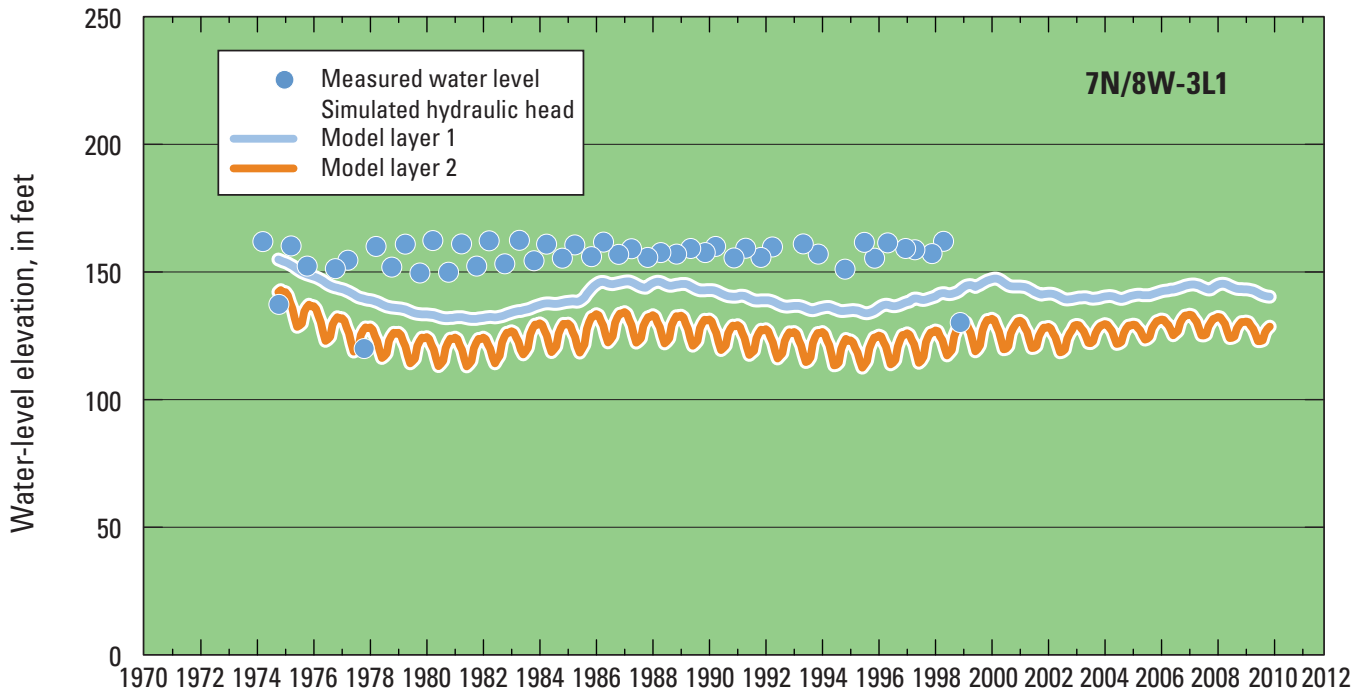

Windsor

$\kappa$

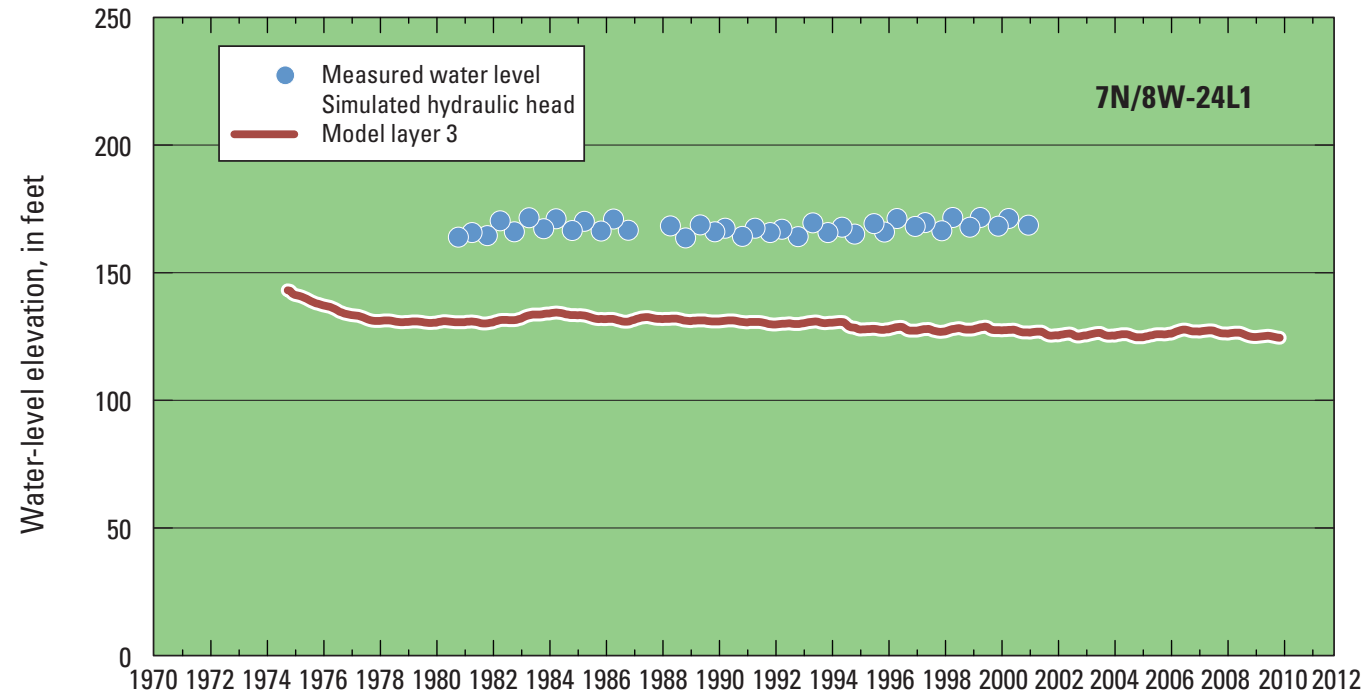

L

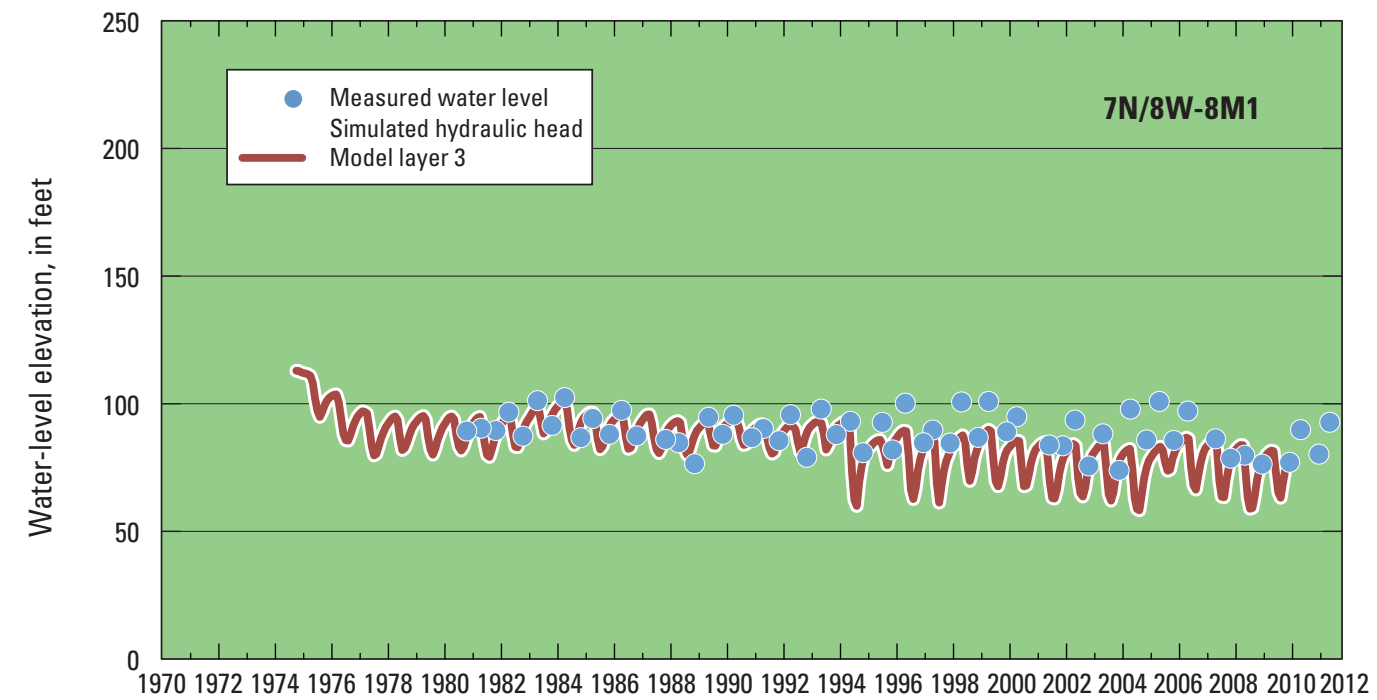

Water year

Figure 36. - Continued 
$\boldsymbol{A}$

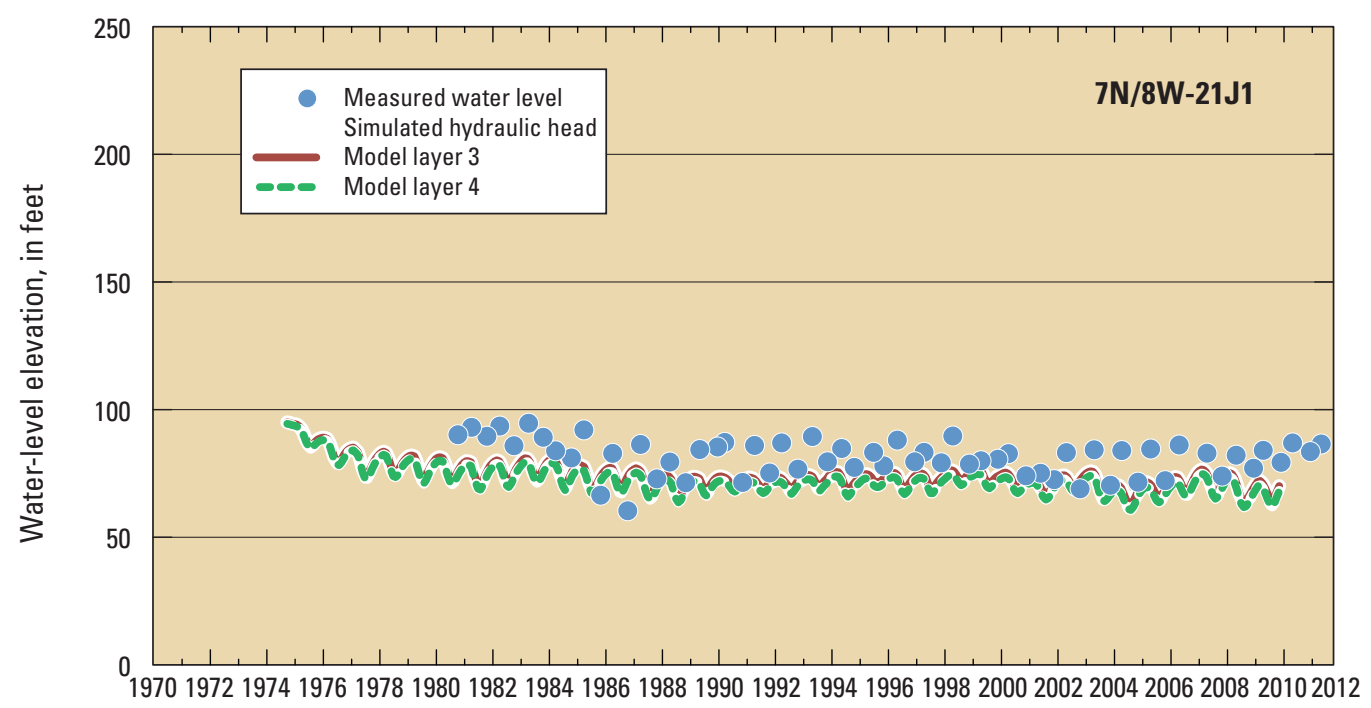

Santa Rosa

$\boldsymbol{B}$

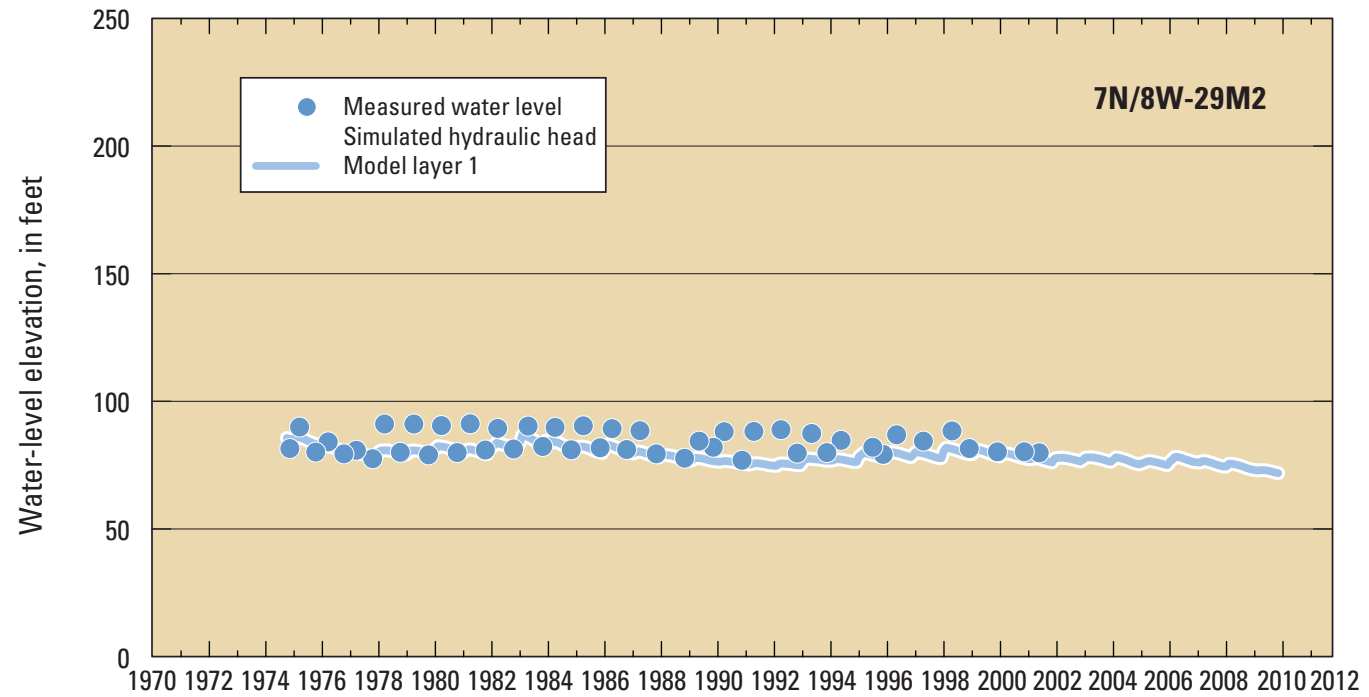

C

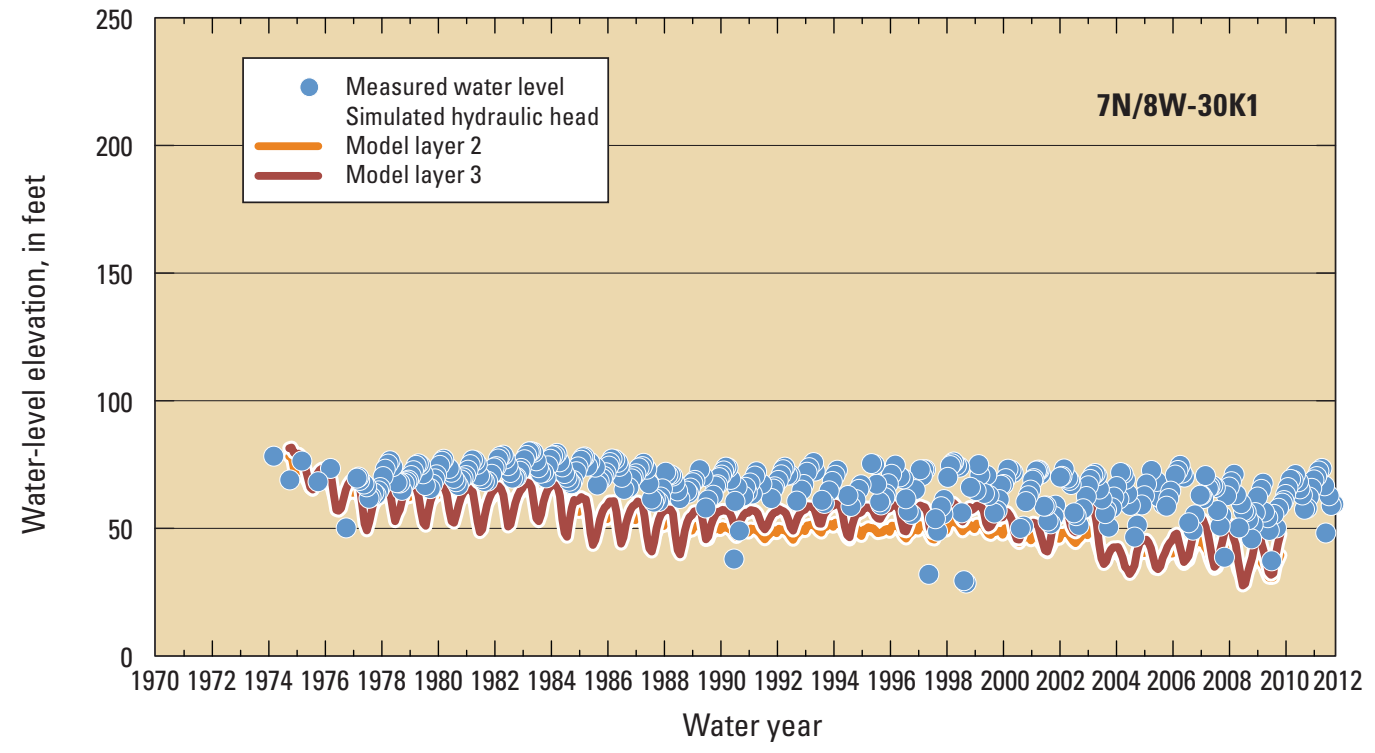

Figure 37. Measured and simulated hydraulic heads for wells in the Santa Rosa model storage unit of the Santa Rosa Plain hydrologic model, Santa Rosa Plain watershed, Sonoma County, California: $A, 7 \mathrm{~N} / 8 \mathrm{~W}-21 \mathrm{~J} 1 ; B, 7 \mathrm{~N} / 8 \mathrm{~W}-29 \mathrm{M} 2 ; C^{2}, 7 \mathrm{~N} / 8 \mathrm{~W}-30 \mathrm{~K} 1 ; D, 7 \mathrm{~N} / 8 \mathrm{~W}-35 \mathrm{~K} 1 ; E_{\text {, }}$ 6N/8W-7A2; and F, 6N/8W-401. 
D

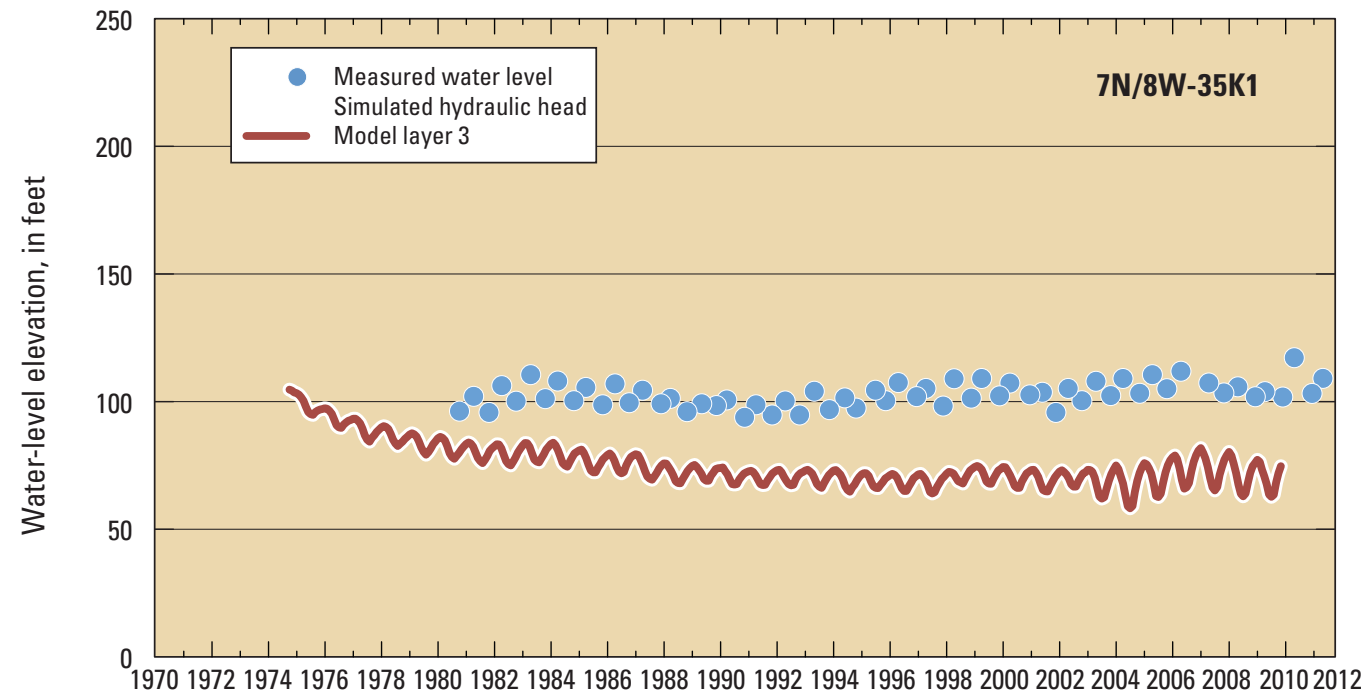

Santa Rosa

E

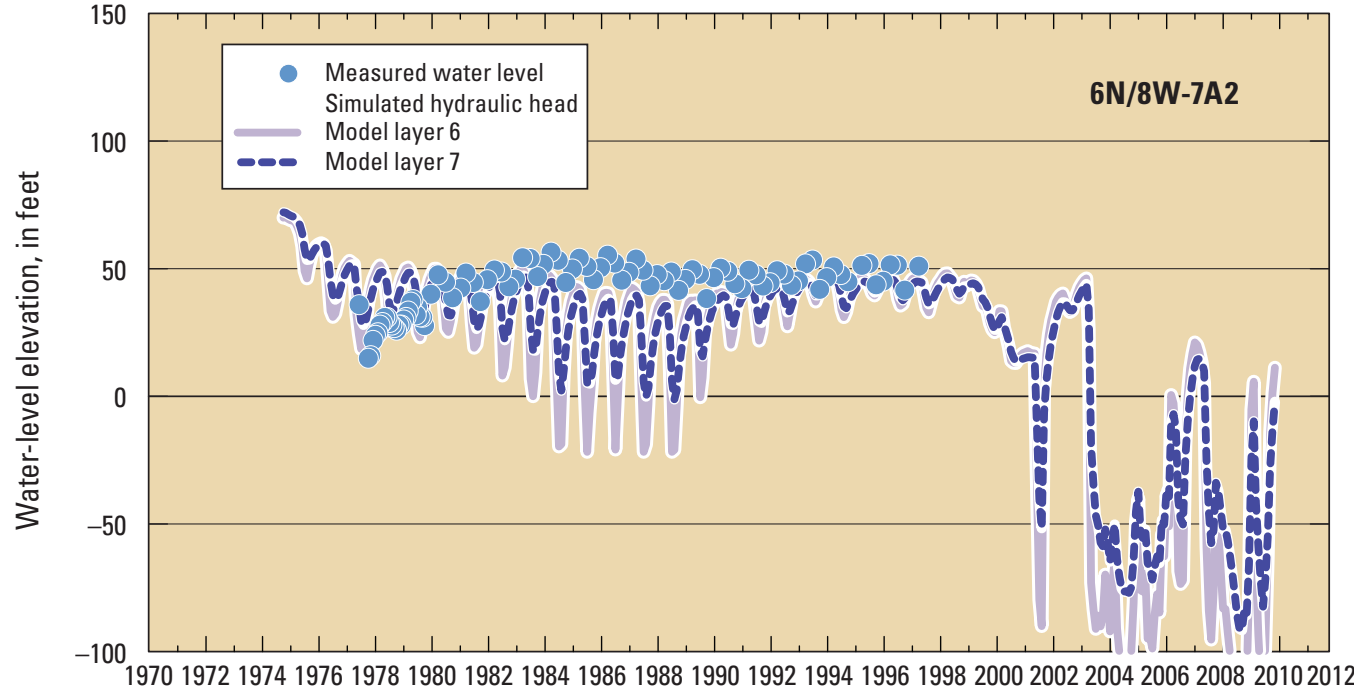

$\boldsymbol{F}$

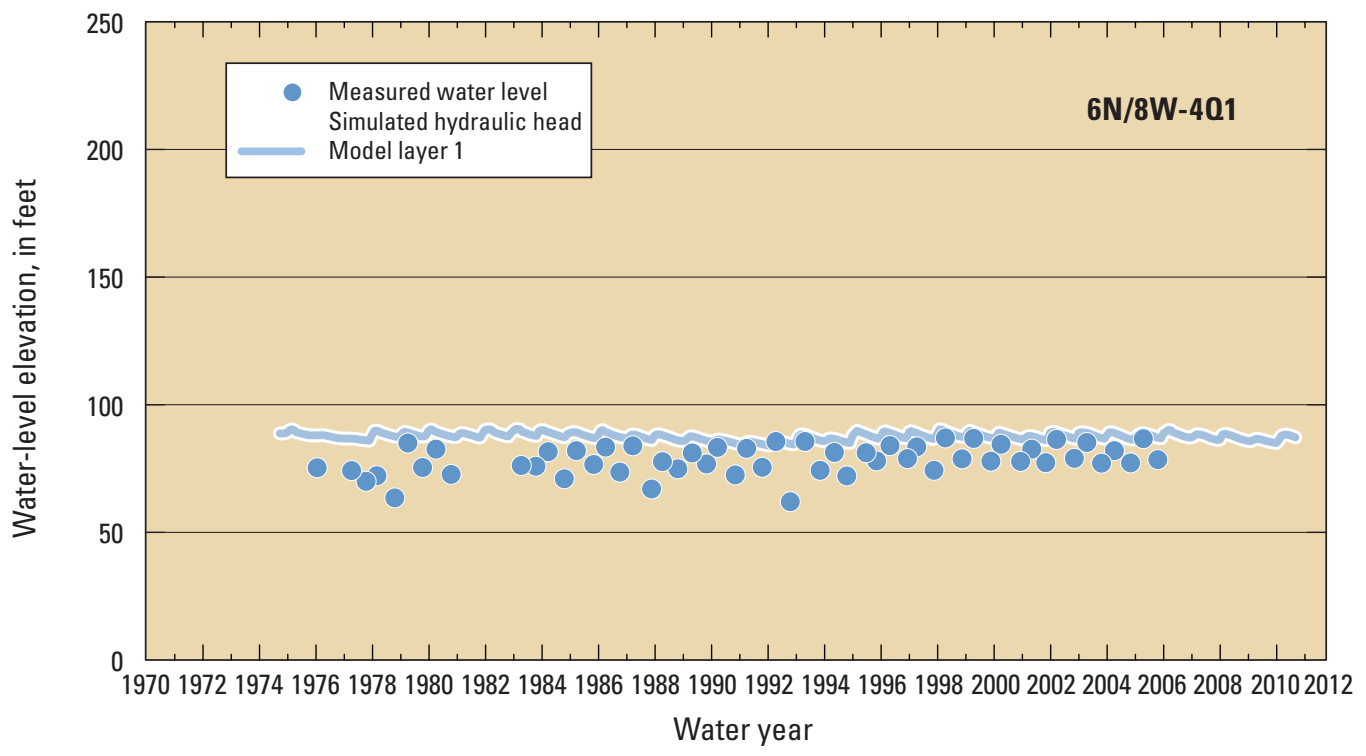

Figure 37. - Continued 
$\boldsymbol{A}$

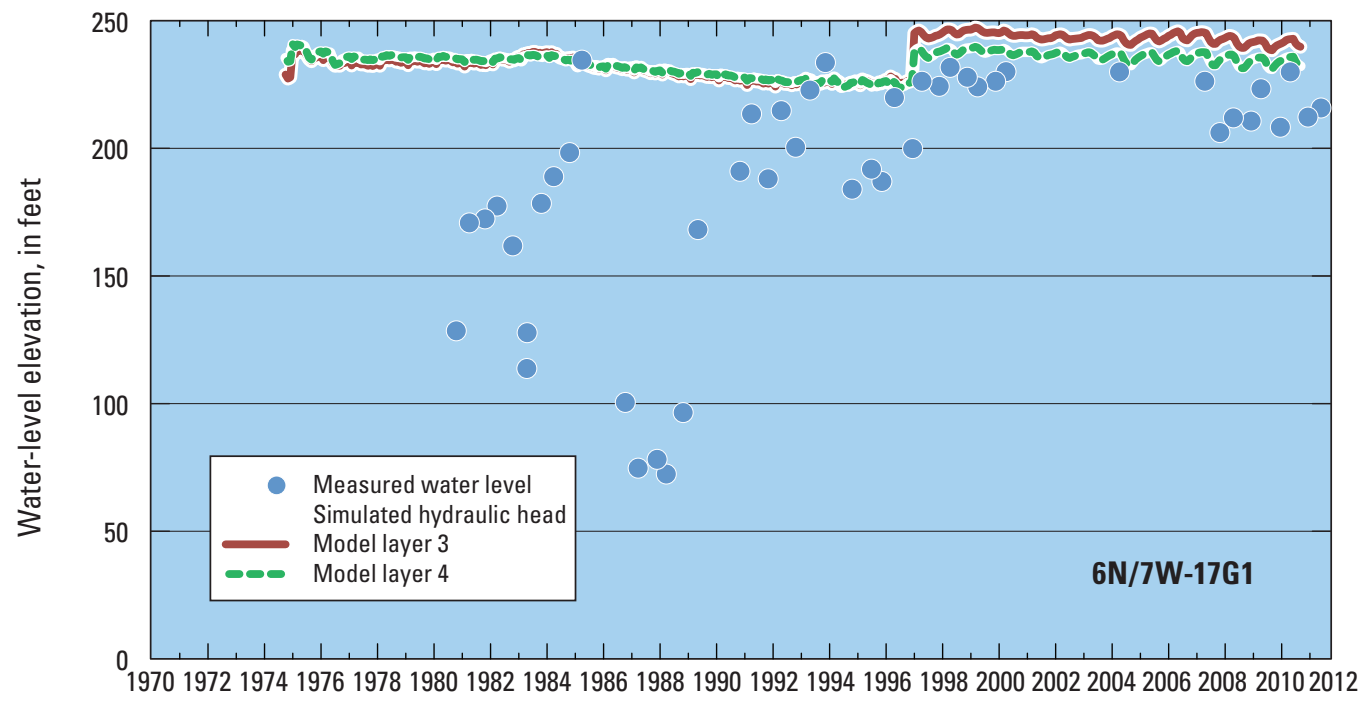

Cotatinorth

$\boldsymbol{B}$

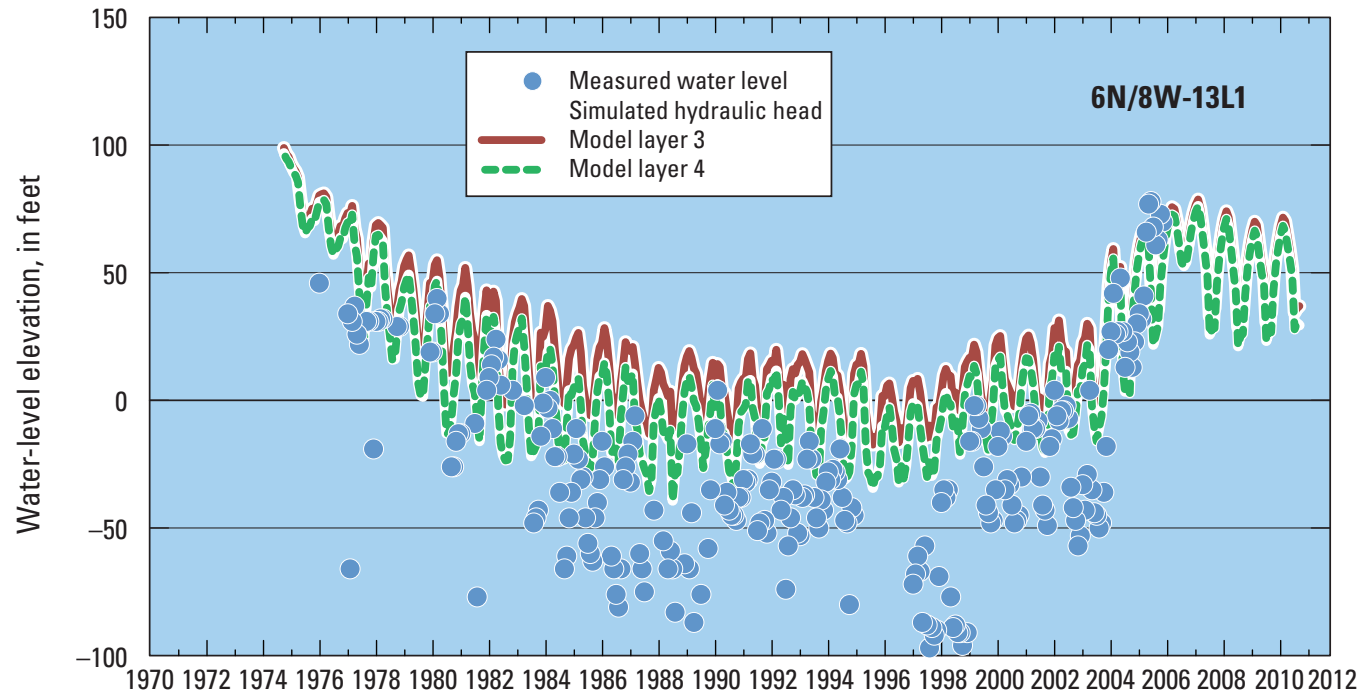

C

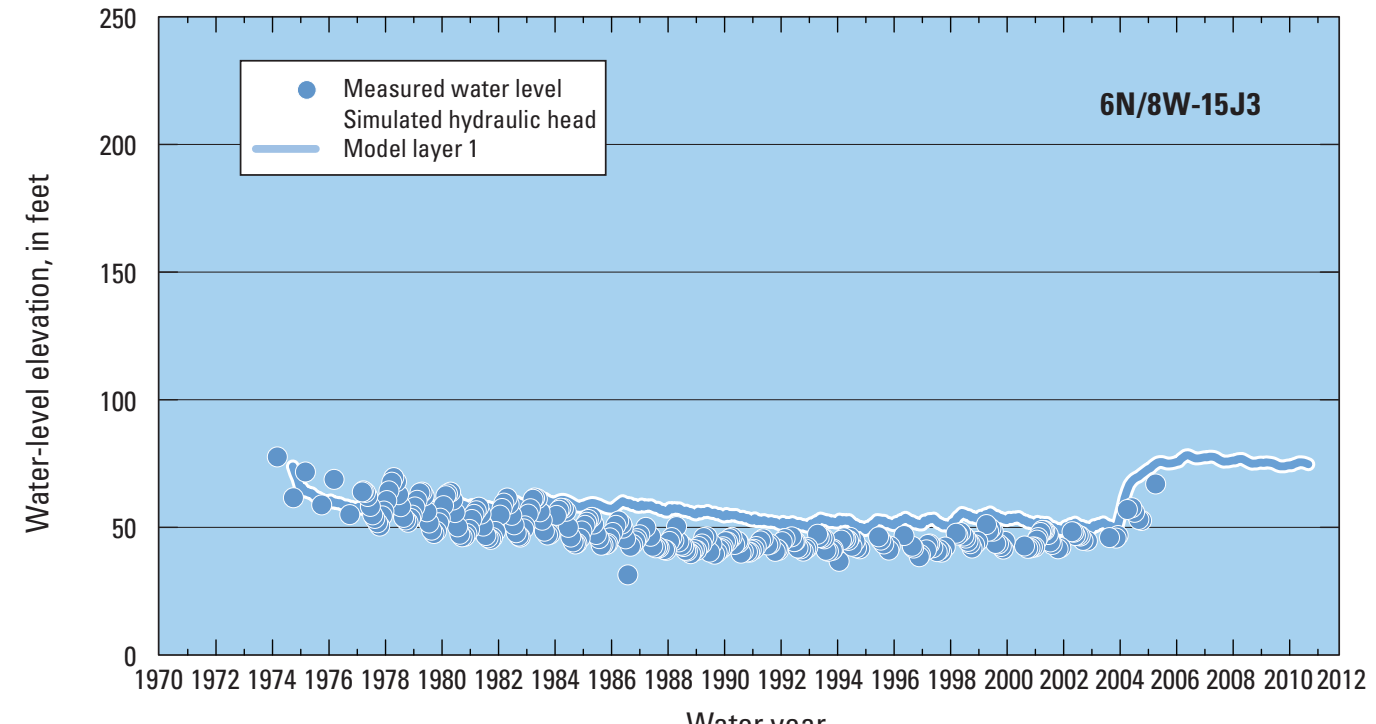

Water year

Figure 38. Measured and simulated hydraulic heads for wells in the Cotati-north model storage unit of the Santa Rosa Plain hydrologic model, Santa Rosa Plain watershed, Sonoma County, California: A, 6N/7W-17G1; B, 6N/8W-13L1; C, 6N/8W-15J3; D, 6N/8W-15R1; E, $6 \mathrm{~N} / 8 \mathrm{~W}-27 \mathrm{H} 1 ; F, 6 \mathrm{~N} / 8 \mathrm{~W}-22 \mathrm{R} 1$; and $G, 6 \mathrm{~N} / 7 \mathrm{~W}-30 \mathrm{C} 1$. 


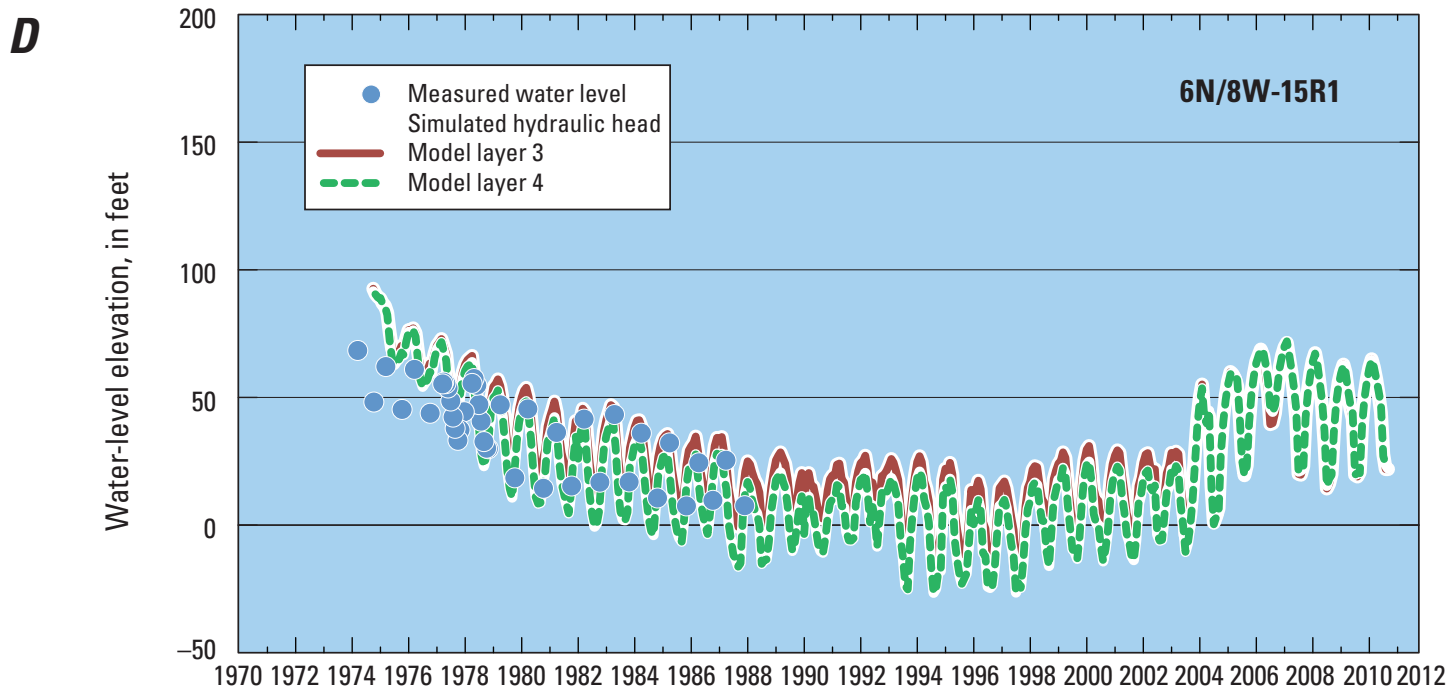

\section{Cotati- north}

E

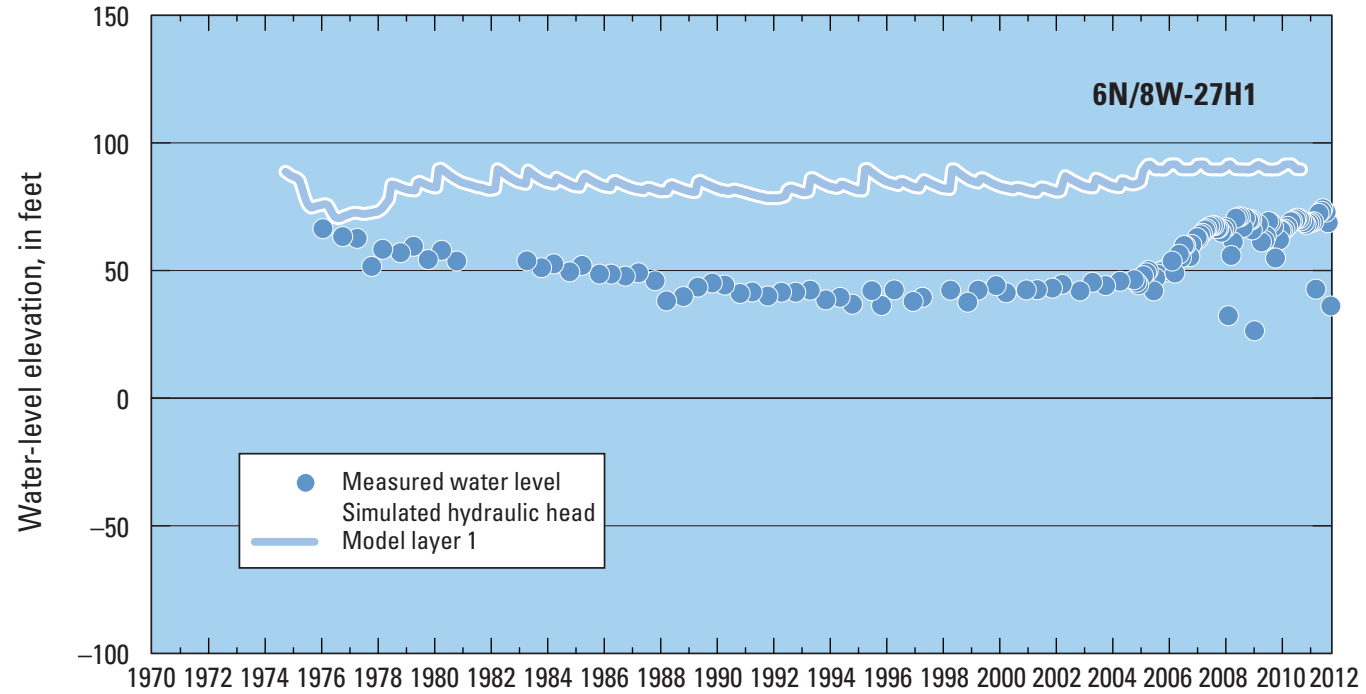

F

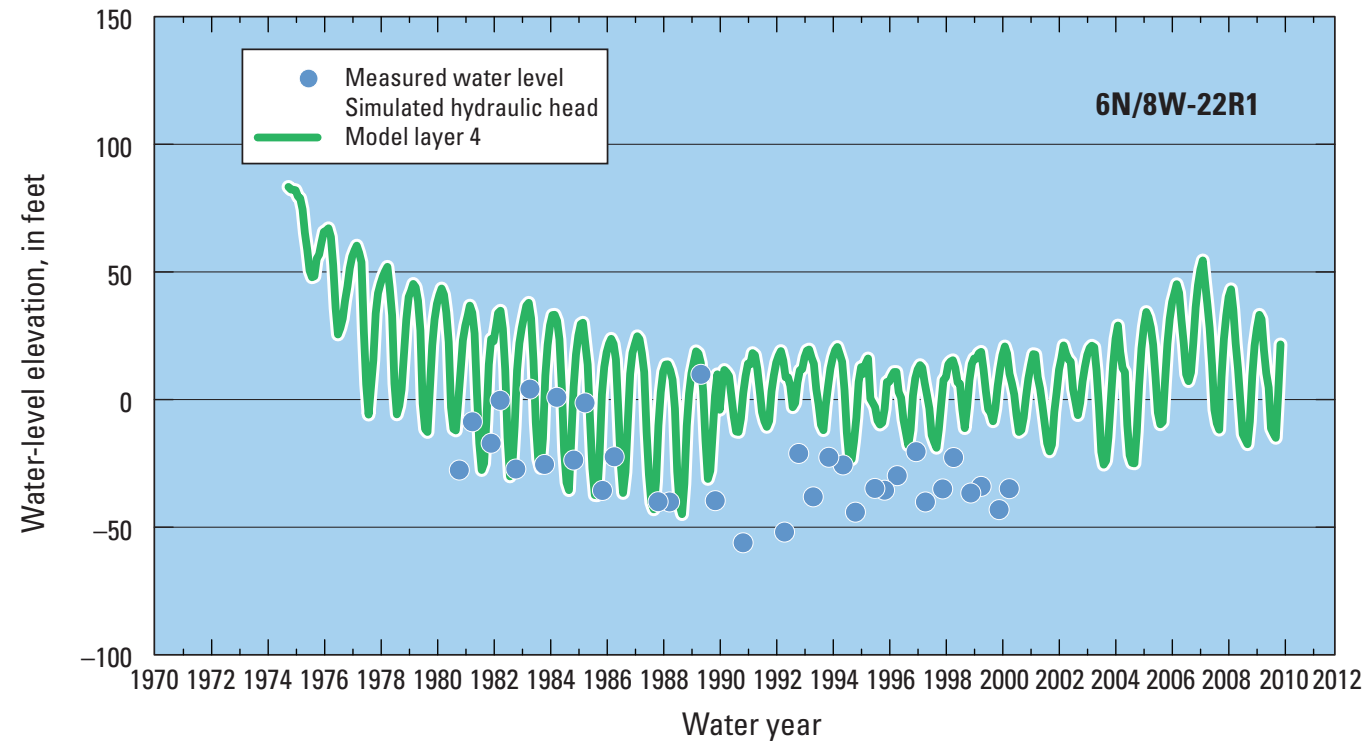

Figure 38. - Continued 


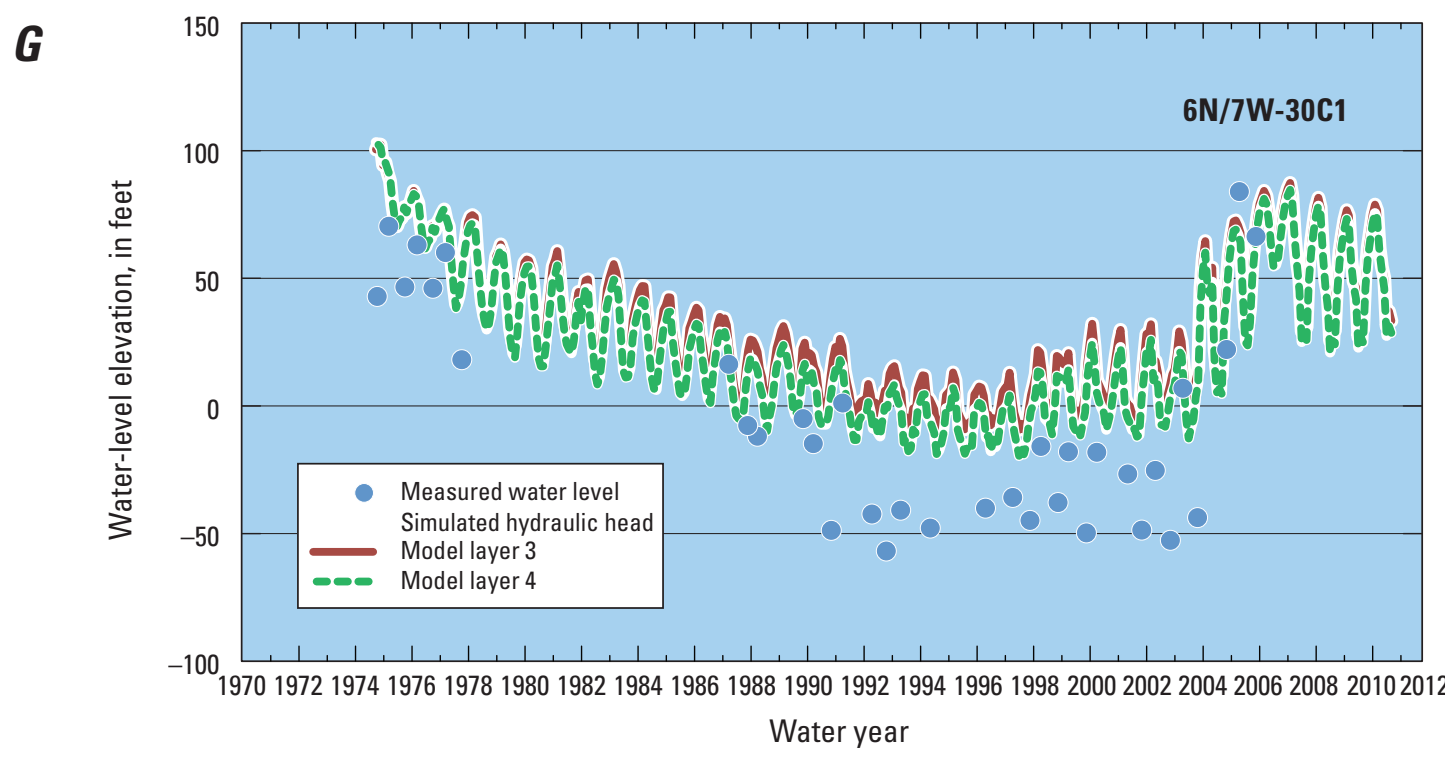

Cotatinorth

Figure 38. - Continued 
$\boldsymbol{A}$

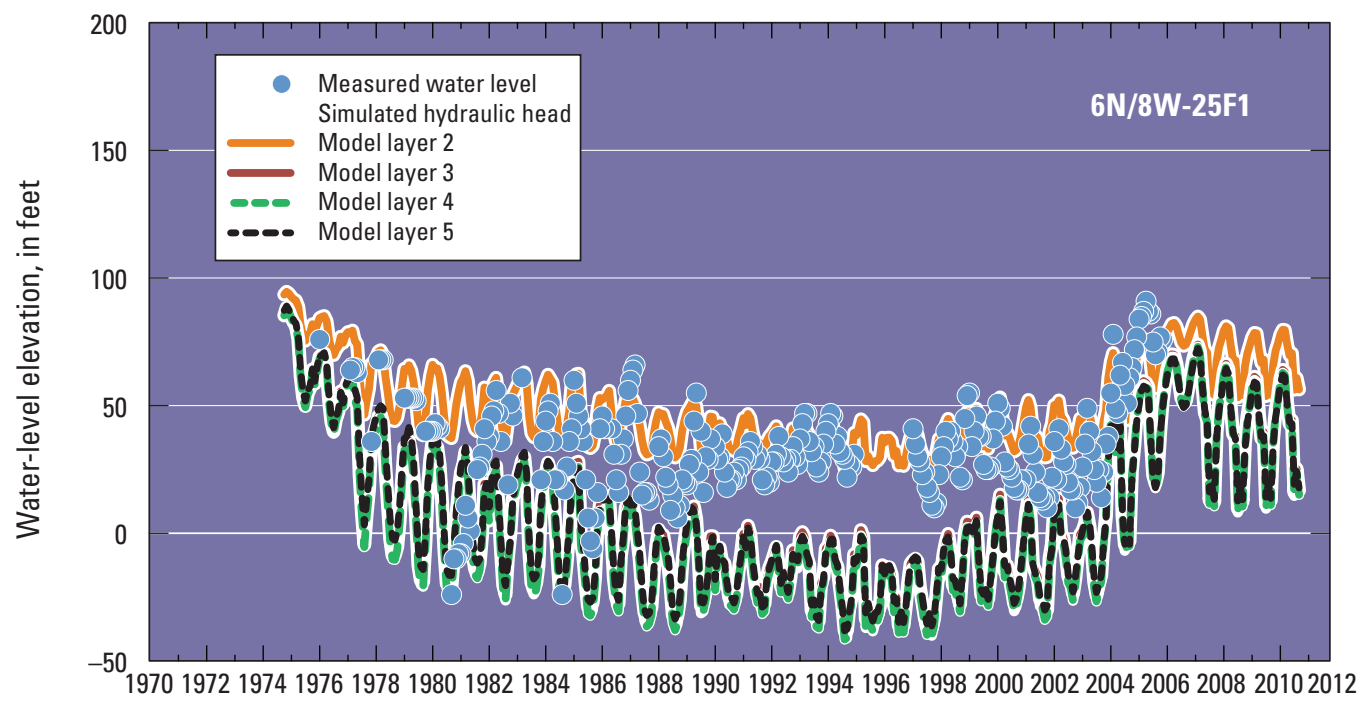

$\boldsymbol{B}$

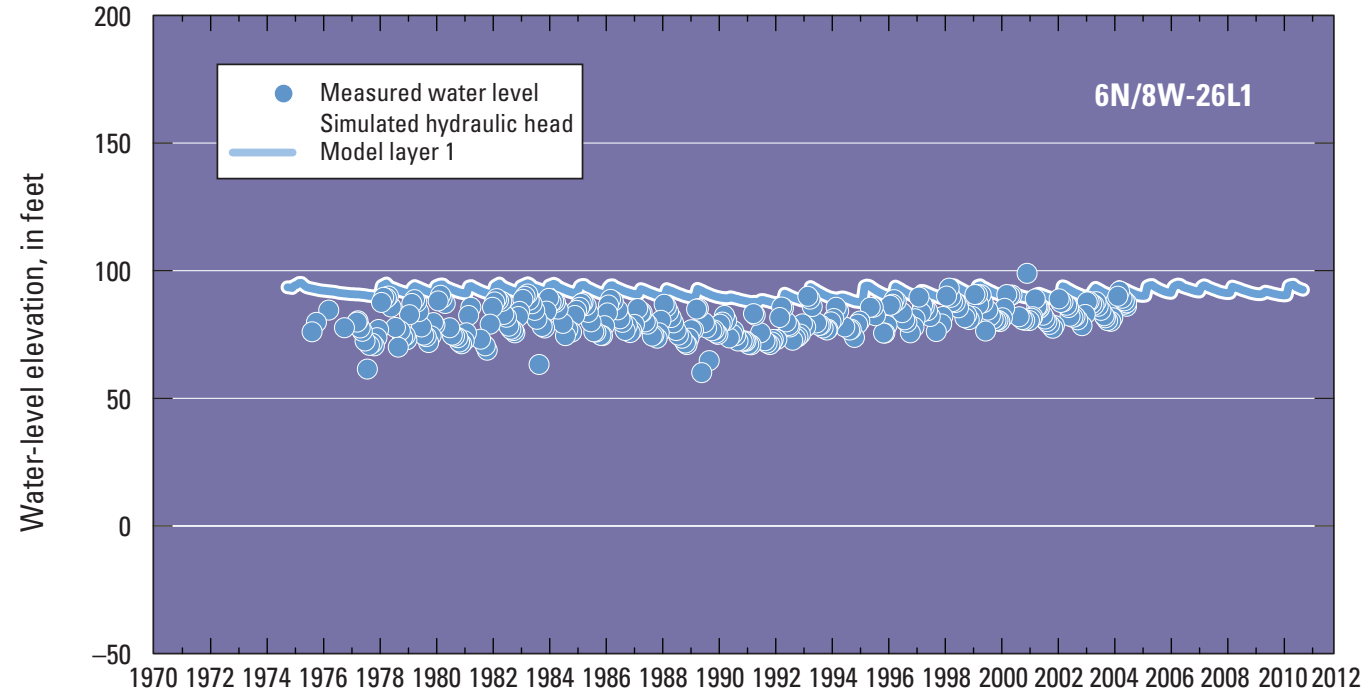

C

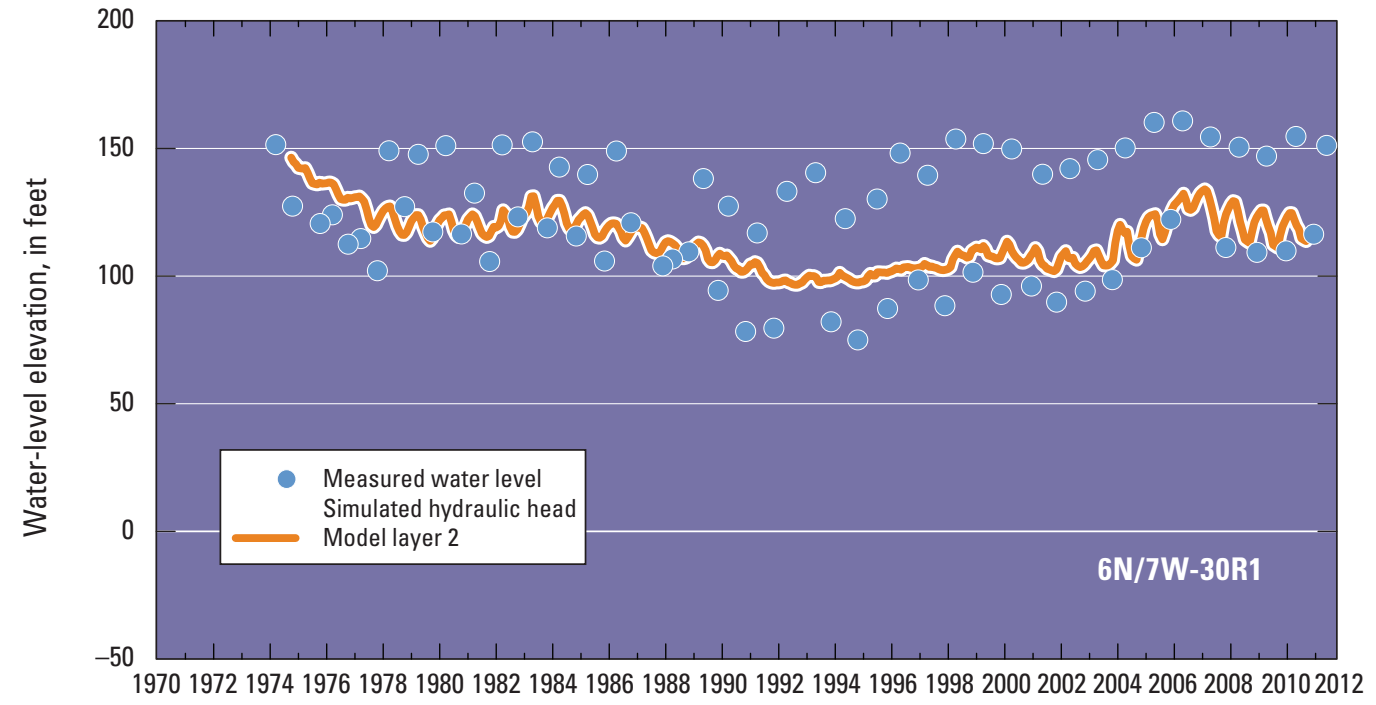

Water year

Figure 39. Measured and simulated hydraulic heads for wells in the Cotati-south model storage unit of the Santa Rosa Plain hydrologic model, Santa Rosa Plain watershed, Sonoma County, California: $A, 6 \mathrm{~N} / 8 \mathrm{~W}-25 \mathrm{F1} ; B, 6 \mathrm{~N} / 8 \mathrm{~W}-26 \mathrm{~L} 1$; and $C, 6 \mathrm{~N} / 7 \mathrm{~W}-30 \mathrm{R} 1$. 


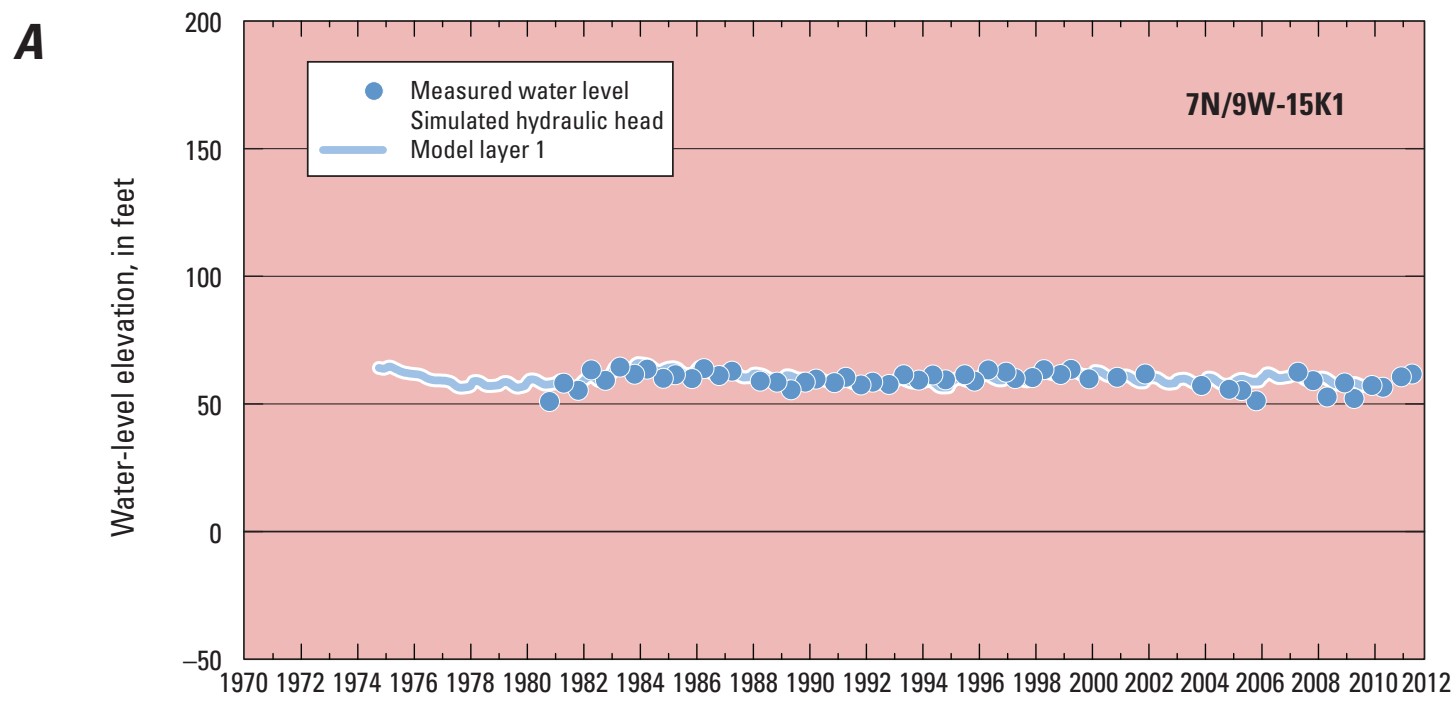

Wilson Grove

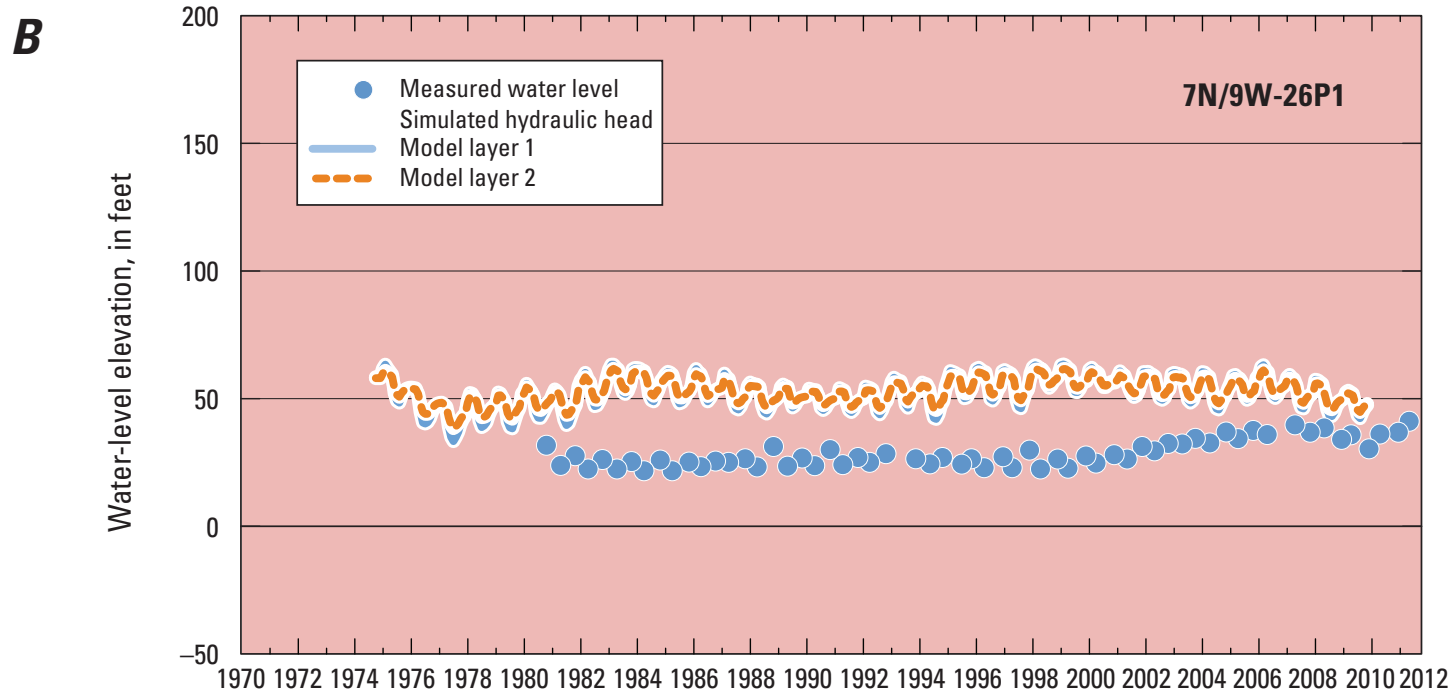

C

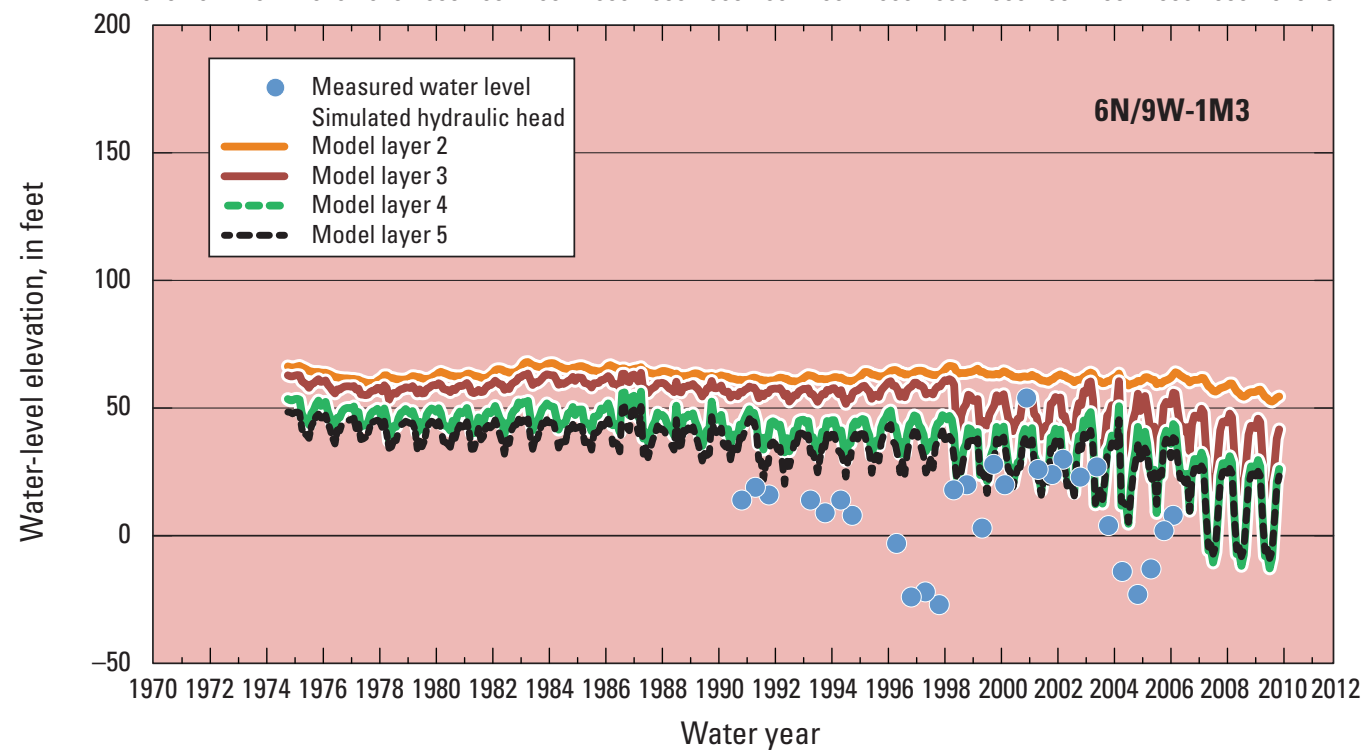

Figure 40. Measured and simulated hydraulic heads for wells in the Wilson Grove model storage unit of the Santa Rosa Plain hydrologic model, Santa Rosa Plain watershed, Sonoma County, California: $A, 7 \mathrm{~N} / 9 \mathrm{~W}-15 \mathrm{~K} 1 ; B, 7 \mathrm{~N} / 9 \mathrm{~W}-26 \mathrm{P} 1 ; C, 6 \mathrm{~N} / 9 \mathrm{~W}-1 \mathrm{M} 3$; $D, 6 \mathrm{~N} / 8 \mathrm{~W}-7 \mathrm{P} 2$; and $E, 6 \mathrm{~N} / 8 \mathrm{~W}-18 \mathrm{C} 1$. 


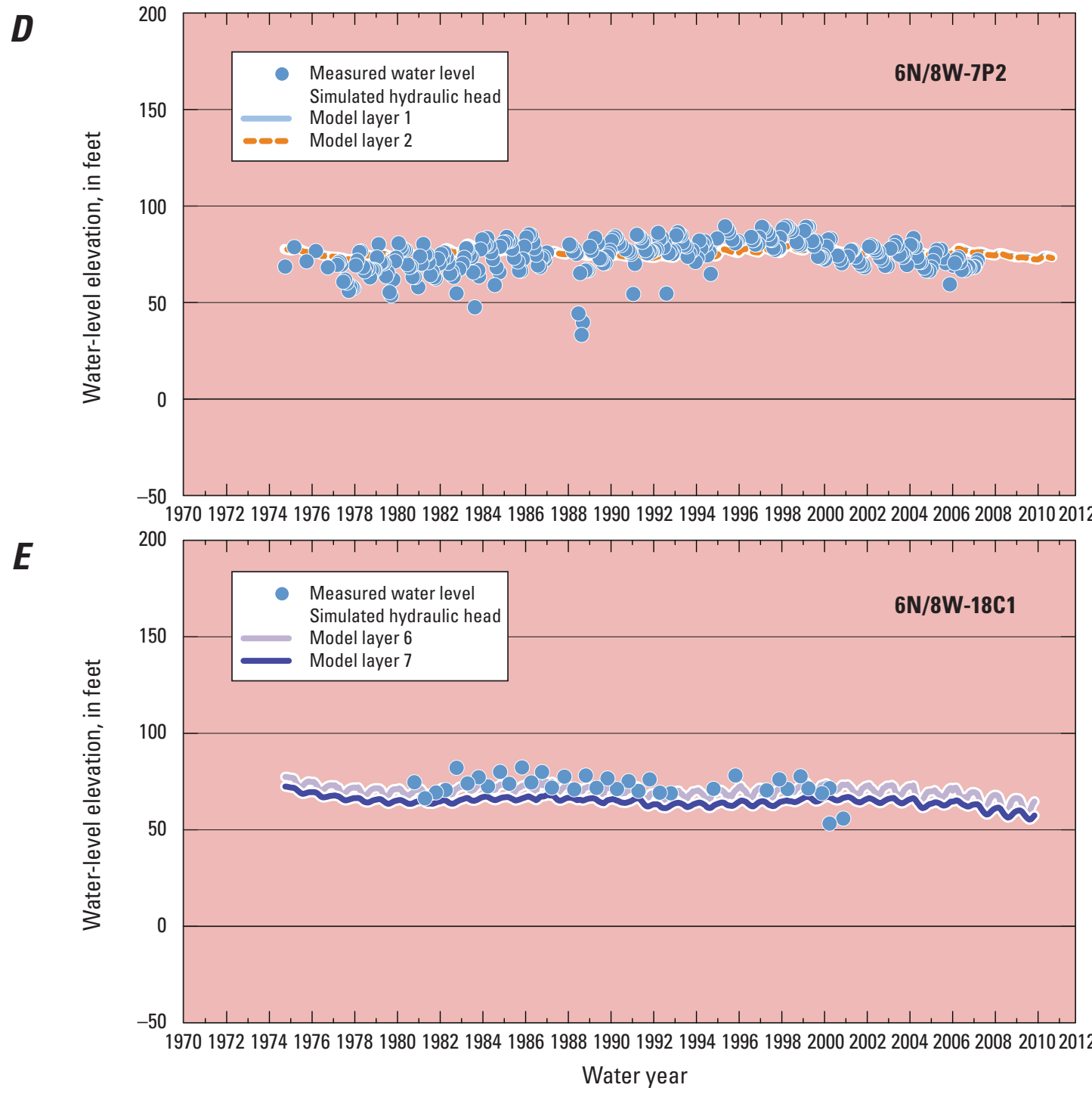

Wilson

Grove

Figure 40. - Continued 
$\boldsymbol{A}$

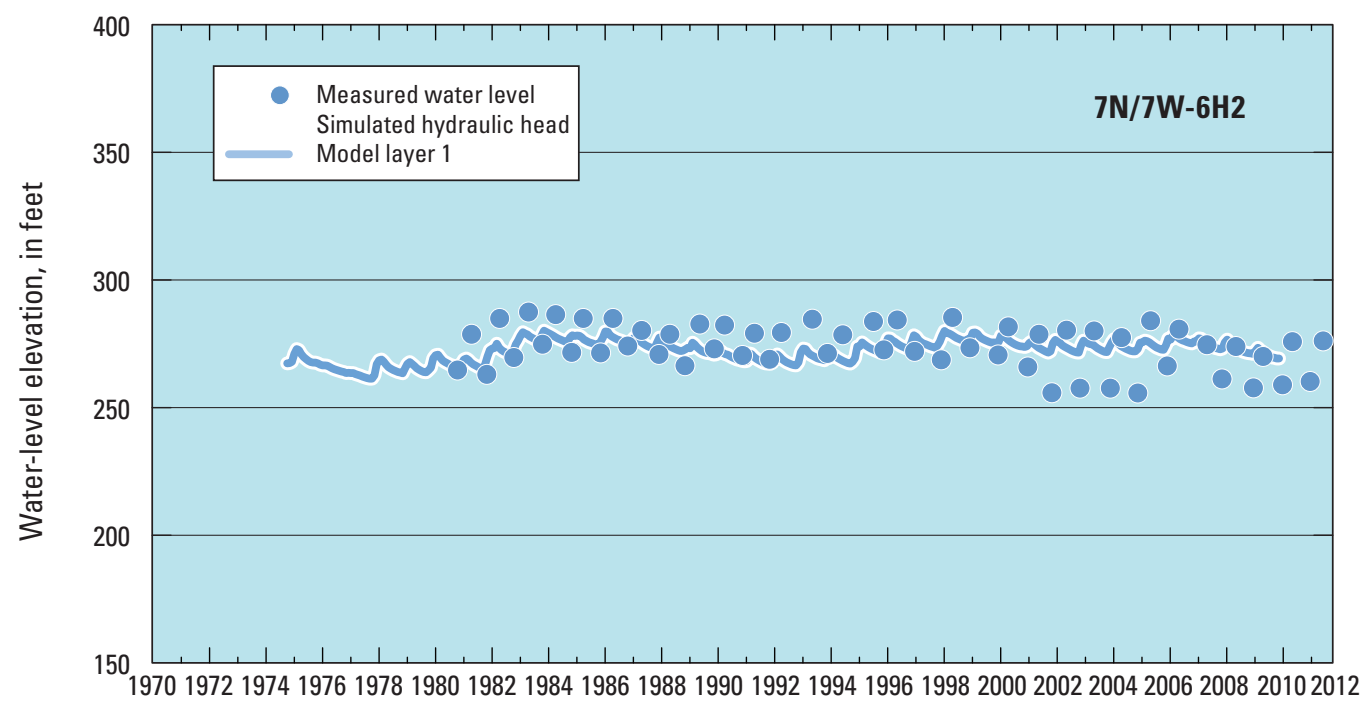

Rincon-

Kenwood

$\boldsymbol{B}$

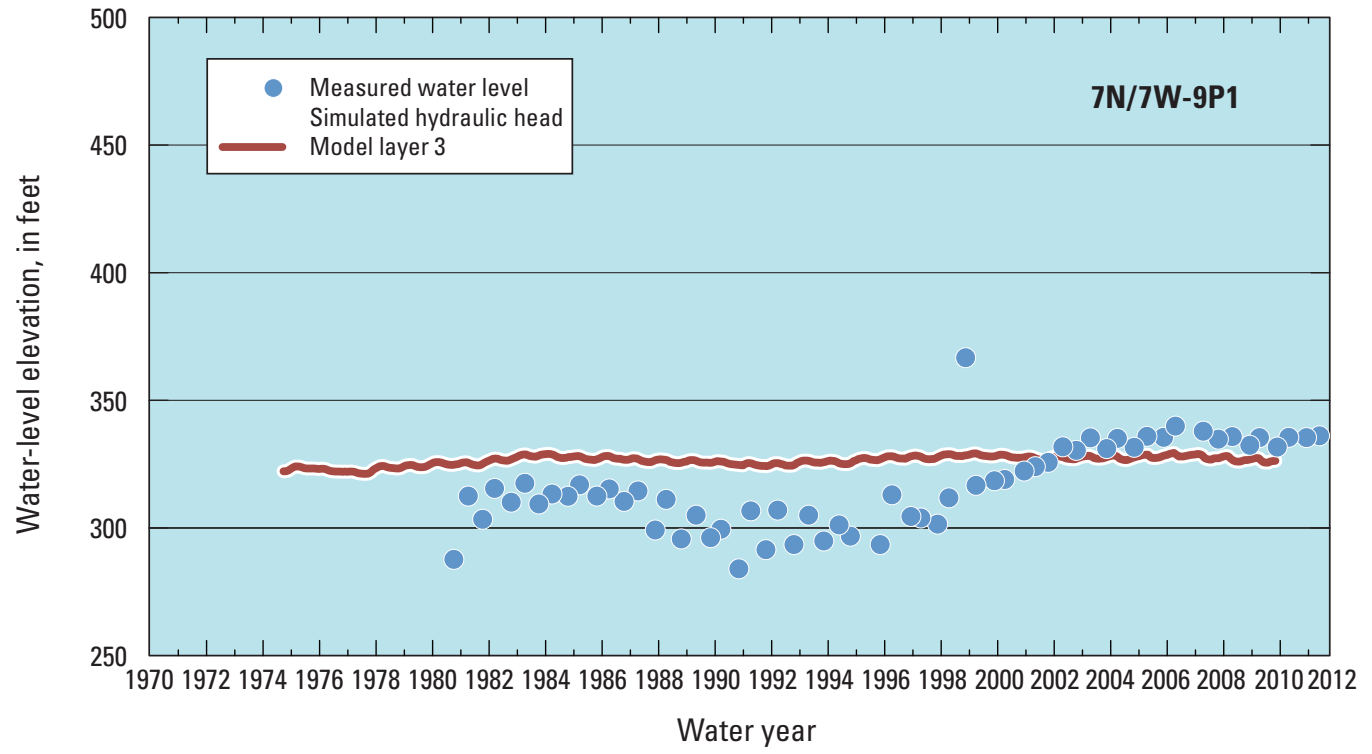

Figure 41. Measured and simulated hydraulic heads for wells used in the Santa Rosa Plain hydrologic model, Santa Rosa Plain watershed, Sonoma County, California: $A, 7 \mathrm{~N} / 7 \mathrm{~W}-6 \mathrm{H} 2$ in the Rincon-Kenwood model storage unit (MSU); $B, 7 \mathrm{~N} / 7 \mathrm{~W}-9 \mathrm{P} 1$ in the RinconKenwood MSU; C, 7N/7W-19B1 in the Bennett Valley-plain MSU; D, 6N/7W-3D1 in the Bennett Valley-mountain MSU; and E, 6N/7W-3M1 in the Bennett Valley-mountain MSU. 
c

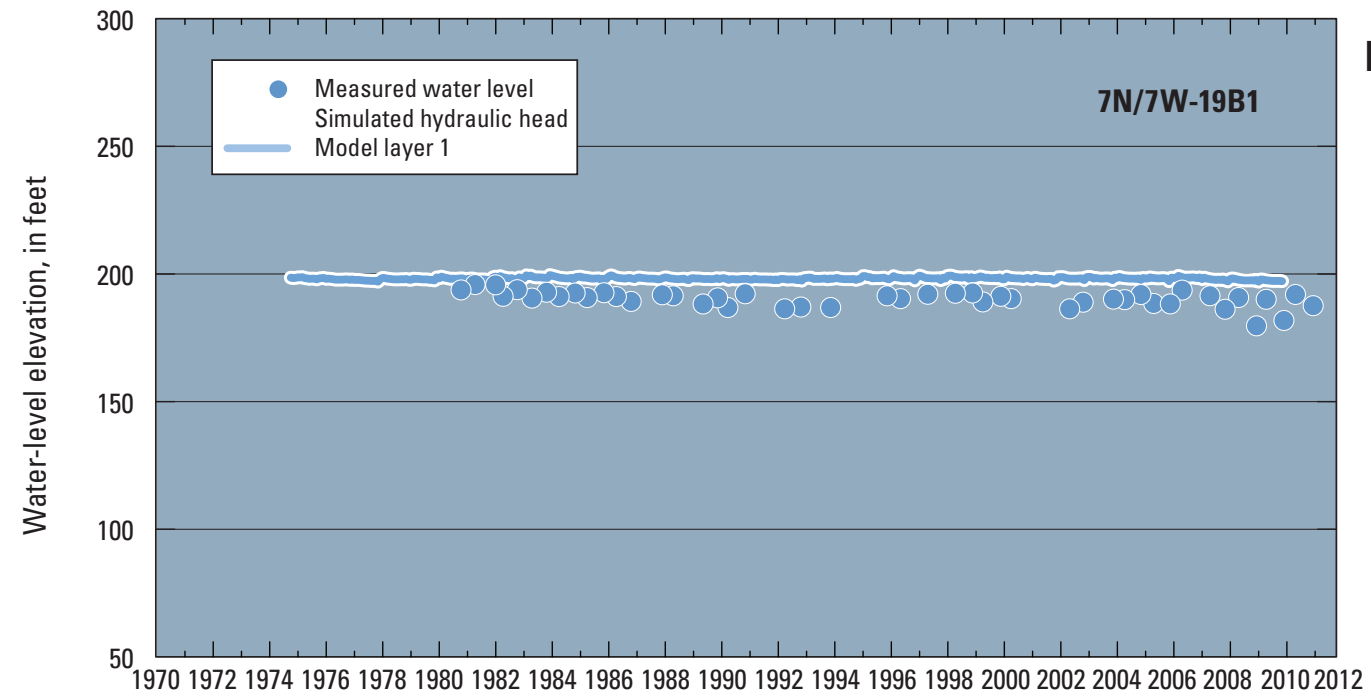

D

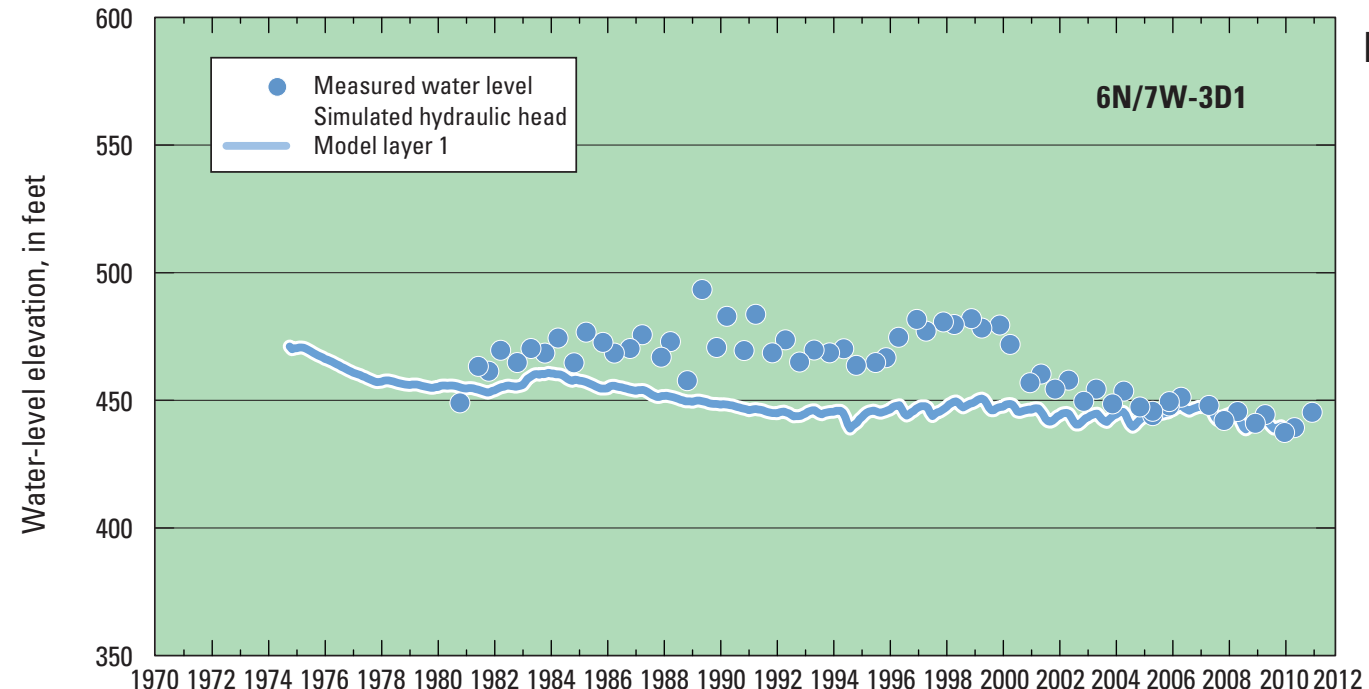

E

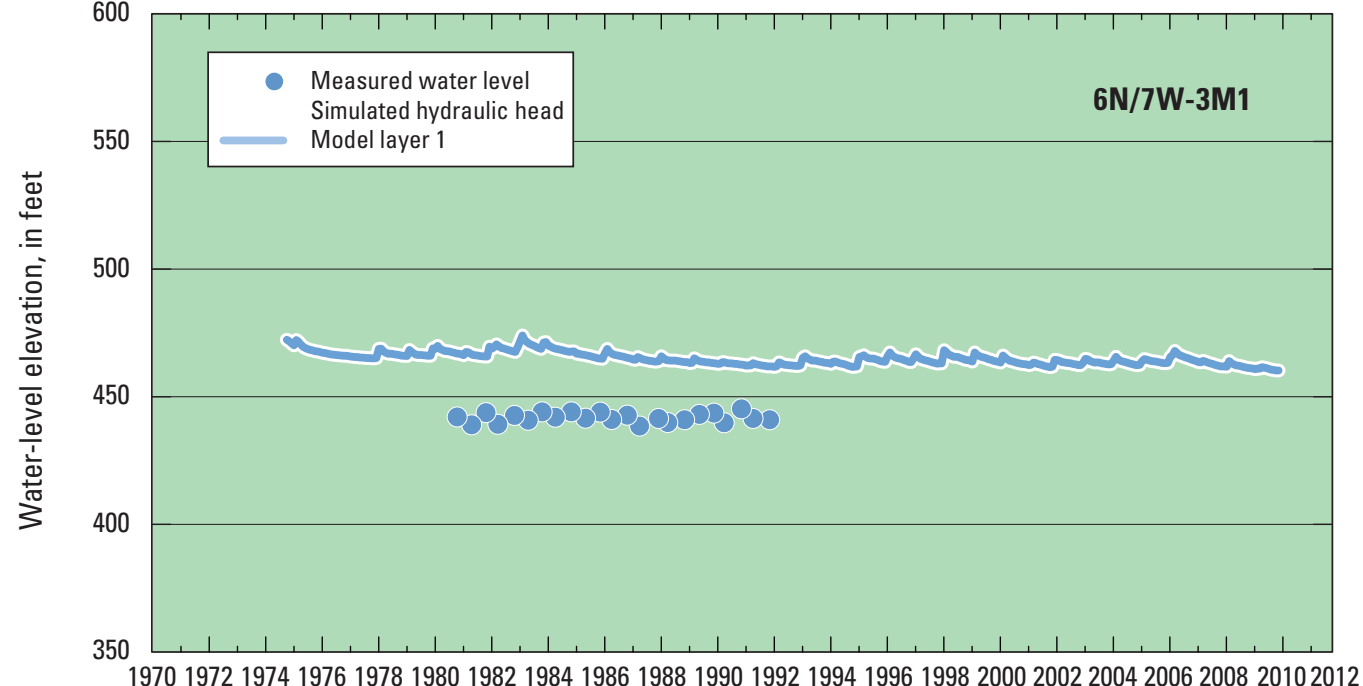

Water year
Bennett Valleyplain

Bennett Valleymountain

Figure 41. - Continued 
Wells 7N/8W-3L1 and 7N/8W-24L1 are in the southeastern part of the Windsor MSU, and well $7 \mathrm{~N} / 8 \mathrm{~W}-8 \mathrm{M} 1$ is in the southwestern part (fig. $1 B$ ). Well 7N/8W-3L1, near the boundary between Windsor and Mayacmas Mountains MSUs, is perforated in model layers 1 and 2 . The simulated hydraulic heads for both layers had inter-annual variation that was not evident in the measured data (fig. 36J). Well 7N/8W-24L1 is near the Rogers Creek fault, where it crosses the Santa Rosa Creek floodplain, and is perforated in model layer 3. The simulated hydraulic heads in this well were about $40 \mathrm{ft}$ lower than the measured groundwater levels and had a slight trend downward not evident in the measurements. The seasonal fluctuations were small for simulated hydraulic heads as well as measured groundwater levels (fig. 36K). Well 7N/8W-8M1 is near the Trenton Ridge fault and is perforated in model layer 3 . The simulated hydraulic heads generally followed the seasonal fluctuations of the measured groundwater levels and their general trend until about 1996. The simulated hydraulic heads declined somewhat more than the measured data after water year 1996 (fig. 36L); however, the overall fit to measured groundwater levels was good.

\section{Santa Rosa Model Storage Unit}

The locations of calibration wells in the Santa Rosa MSU are shown in figure $1 B$, and their hydrographs are shown in figure 37 . Well $7 \mathrm{~N} / 8 \mathrm{~W}-21 \mathrm{~J} 1$ is in the north-central part of the MSU in the vicinity of the Trenton Ridge fault and is perforated in model layer 3 . The simulated hydraulic heads generally followed the inter-annual variation and seasonal fluctuations of the measured groundwater levels until about 2008 (fig. 37A). After 2008, there was a trend for the simulated hydraulic heads to decline slightly, while the measured groundwater levels tended to rise (fig. 37A).

Wells 7N/8W-29M2 and 7N/8W-30K1 are adjacent to each other in the western part of the Santa Rosa MSU (fig. $1 B$ ). Well $7 \mathrm{~N} / 8 \mathrm{~W}-29 \mathrm{M} 2$ is perforated in layer 1 , and well $7 \mathrm{~N} / 8 \mathrm{~W}-30 \mathrm{~K} 1$ is perforated in layers 2 and 3 . The simulated hydraulic heads for well $7 \mathrm{~N} / 8 \mathrm{~W}-29 \mathrm{M} 2$ generally followed the trend and inter-annual variations of the measured groundwater levels; although, the magnitude of the seasonal fluctuations in the simulated hydraulic heads was less than for the measured data (fig. 37B). The seasonal fluctuations and inter-annual variation in the simulated hydraulic heads generally matched the measured data for well 7N/8W-30K1 (fig. 37C). The measured and the simulated hydraulic heads for this well both showed a similar general decline; the rate of decline in the simulated hydraulic heads slightly exceeded the decline observed in the measured data after water year 2003 (fig. 37C).

Well $7 \mathrm{~N} / 8 \mathrm{~W}-35 \mathrm{~K} 1$ is in the eastern part of the Santa Rosa MSU (fig. 1B) and is perforated in layer 3. The seasonal fluctuations and the inter-annual variations from about water year 1990 to about water year 2005 in the simulated hydraulic heads followed the measured groundwater levels; however, overall, the simulated hydraulic heads tended to decrease, but there was no downward trend for the measured groundwater levels (fig. 37D). The simulated hydraulic heads were as much as $40 \mathrm{ft}$ lower than the measured groundwater levels (fig. 37D).

Wells $6 \mathrm{~N} / 8 \mathrm{~W}-7 \mathrm{~A} 2$ and $6 \mathrm{~N} / 8 \mathrm{~W}-4 \mathrm{Q} 1$ are in the westcentral and central parts of the Santa Rosa MSU, respectively (fig. $1 B$ ). Well $6 \mathrm{~N} / 8 \mathrm{~W}-7 \mathrm{~A} 2$ is perforated in layers 6 and 7. It is evident that between water years 1982 and 1990, rural pumpage was overestimated in this area, as indicated by the greater magnitude of seasonal fluctuations and the downward trend not observed in the measured data during this period. Prior to water year 1989, the trend in the measured data was upward, but the simulated hydraulic heads slightly decreased (fig. 37E). The simulated hydraulic heads in well 6N/8W-4Q1 showed similar seasonal fluctuations to the measured data, but generally were slightly above the highest measured groundwater levels (fig. $37 F$ ). The simulated hydraulic heads generally followed the general trend in the measured groundwater levels after water year 1991 (fig. 37F).

\section{Cotati-North Model Storage Unit}

The locations of the Cotati-north MSU calibration wells are shown in figure $1 B$. Well $6 \mathrm{~N} / 7 \mathrm{~W}-17 \mathrm{G} 1$ is in the eastern part of the Cotati-north MSU near the boundary with the Sonoma Mountains MSU (fig. $1 B$ ) and is perforated in layers 3 and 4. Measured groundwater levels were erratic, having a range of about $170 \mathrm{ft}$; the SRPHM matched the highest measured values, but the simulated values showed little seasonal variability (fig. 38A). The abrupt decrease and subsequent increase in measured groundwater levels between water years 1985 and 1989 were the result of local rural pumping. Simulated hydraulic heads did not capture this change; however, the simulated results did reflect the flat trend in the measured data since the mid-1990s. The abrupt change in simulated hydraulic heads in 1997 was the result of an abrupt change in estimated pumpage that was most likely more gradual than depicted by the model.

Well $6 \mathrm{~N} / 8-13 \mathrm{~L} 1$ is in the north-central part of the MSU (fig. $1 B$ ). The magnitude of seasonal fluctuations in the measured data was greater than those in the simulated hydraulic heads. The larger fluctuations in measured groundwater levels indicate that withdrawals were greater than estimated, storage and hydraulic properties were too high, or both. The simulated hydraulic heads approximated the magnitude of the drawdown from water years 1976 to 1990 , the downward trend from the early 1970 s to the mid-1980s, and the recovery of the measured groundwater levels from water years 1999 to 2003 (fig. 38B); however, the simulated hydraulic heads generally were higher than the measured groundwater levels.

Wells $6 \mathrm{~N} / 8 \mathrm{~W}-15 \mathrm{~J} 3$ and $6 \mathrm{~N} / 8 \mathrm{~W}-15 \mathrm{R} 1$ are in the northwestern part of the Cotati-north MSU (fig. $1 B$ ). Well $6 \mathrm{~N} / 8 \mathrm{~W}$ $15 \mathrm{~J} 3$ is perforated in layer 1 , but the perforated interval for 
well $6 \mathrm{~N} / 8 \mathrm{~W}-15 \mathrm{R} 1$ was not reported. However, the total depth of well $6 \mathrm{~N} / 8 \mathrm{~W}-15 \mathrm{R} 1$ is $820 \mathrm{ft}$, and the trend of decline in the measured groundwater levels was consistent with the trend in measured groundwater levels in well $6 \mathrm{~N} / 8 \mathrm{~W}-13 \mathrm{~L} 1$ (fig. 38B), which is perforated in layers 3 and 4; therefore, it was assumed that well $15 \mathrm{R} 1$ is perforated at similar depths. The simulated hydraulic heads in well $6 \mathrm{~N} / 8 \mathrm{~W}-15 \mathrm{~J} 3$ followed the general trend and inter-annual variations of the measured groundwater levels, providing a good fit to the measured data. The simulated hydraulic heads and measured groundwater levels rose sharply after water year 2003 because nearby rural pumping was determined to have stopped for that period (fig. 38C). The simulated heads for well 6N/8W-15R1 followed the general trend and the magnitude of the seasonal fluctuations of the measured groundwater levels (fig. 38D). The trend in the measured groundwater levels for both wells indicated a long-term decline from pumping, followed by recovery after water year 2003. The good fit of the magnitude of the measured groundwater levels for both wells indicated that the SRPHM also simulated the vertical gradient in the vicinity of these two wells.

Wells $6 \mathrm{~N} / 8 \mathrm{~W}-27 \mathrm{H} 1$ and $6 \mathrm{~N} / 8 \mathrm{~W}-22 \mathrm{R} 1$ are in the western part of the Cotati-north MSU, and well $6 \mathrm{~N} / 8 \mathrm{~W}-30 \mathrm{C} 1$ is in the south-central part of the MSU (fig. 1B). Well 27H1 is perforated in layer 1 . The simulated hydraulic heads in well $6 \mathrm{~N} / 8 \mathrm{~W}-27 \mathrm{H} 1$ did not follow the overall downward trend of the measured data between water years 1977 and late 1980s (fig. 38E). The available land-use data (California Department of Water Resources, 1974, 1979, 1986) did not indicate irrigated agriculture in the vicinity of well $6 \mathrm{~N} / 8 \mathrm{~W}-27 \mathrm{H} 1$ after 1977; therefore, the domestic pumpage that could account for the decline in measured groundwater levels could have been underestimated in this area.

Well $6 \mathrm{~N} / 8 \mathrm{~W}-22 \mathrm{R} 1$ is perforated in layer 4 . The simulated hydraulic heads generally matched the general trend, interannual variations, and magnitude of seasonal fluctuations of the limited measured data; however, the simulated hydraulic heads were about $30 \mathrm{ft}$ higher than the measured groundwater levels (fig. $38 F$ ).

Well $6 \mathrm{~N} / 8 \mathrm{~W}-30 \mathrm{C} 1$ is perforated in layers 3 and 4 . The general trend, inter-annual variations, and seasonal fluctuations of the simulated hydraulic heads followed the measured groundwater levels; however, the simulated hydraulic heads generally were higher, except during the recovery period after water year 2004 (fig. 38G).

\section{Cotati-South Model Storage Unit}

The locations of the Cotati-south MSU calibration wells are shown in figure $1 B$. Well $6 \mathrm{~N} / 8 \mathrm{~W}-25 \mathrm{~F} 1$ is in the western part of the Cotati-south MSU and is perforated in layers 2-5. The simulated hydraulic heads in well $6 \mathrm{~N} / 8 \mathrm{~W}-25 \mathrm{~F} 1$ showed a good fit to the measured data by generally following the trend, inter-annual variations, and magnitude of the measured data (fig. 39A).
Well $6 \mathrm{~N} / 8 \mathrm{~W}-26 \mathrm{~L} 1$ is in the western part of the Cotatisouth MSU and is perforated in layer 1. The simulated hydraulic heads in well $26 \mathrm{~L} 1$ generally were consistent with the highest measured groundwater levels; the inter-annual variation and seasonal fluctuations had a lesser magnitude than observed in the measured data (fig 39B).

Well 6N/8W-30R1 is in the southeastern part of the MSU and is perforated in layer 2 . The simulated hydraulic heads in well $6 \mathrm{~N} / 8 \mathrm{~W}-30 \mathrm{R} 1$ showed a reasonable fit to the measured data, generally following the trend and inter-annual variations of the measured data; however, the seasonal fluctuations in the simulated hydraulic heads were considerably smaller than those in the measured groundwater levels (fig. 39C).

\section{Wilson Grove Model Storage Unit}

The locations of the Wilson Grove MSU calibration wells are shown in figure $1 B$. Well $7 \mathrm{~N} / 8 \mathrm{~W}-15 \mathrm{~K} 1$ is in the northern part of the MSU and is perforated in layer 1. The overall trend, inter-annual variations, and seasonal fluctuations of the simulated hydraulic heads were in agreement with the measured data (fig. 40A).

Well 7N/8W-26P1 is in the central part of the MSU and is perforated in layers 1 and 2 . The flat trend for the simulated hydraulic heads in both layers generally followed the trend for the measured groundwater levels (fig. 40B). Despite the match in trend, the simulated hydraulic heads were approximately $25 \mathrm{ft}$ higher than measured.

Well $6 \mathrm{~N} / 9 \mathrm{~W}-1 \mathrm{M} 3$ is in the south-central part of the MSU (fig. $1 B$ ) and is perforated in layers $2-5$. The general trend in the simulated hydraulic heads for all layers generally followed the trend in measured groundwater levels (fig. 40C). The measured data showed greater drawdown in some periods (for example, water years 1997-98 and 2005) than the simulated results, indicating that there could have been additional pumpage nearby that was not included in the SRPHM.

Well $6 \mathrm{~N} / 8 \mathrm{~W}-7 \mathrm{P} 2$ is in the vicinity of well $6 \mathrm{~N} / 8 \mathrm{~W}-18 \mathrm{C} 1$, and both wells are in the southern part of the Wilson Grove MSU. Well $6 \mathrm{~N} / 8 \mathrm{~W}-7 \mathrm{P} 2$ is perforated in layers 2 and 3, and well $6 \mathrm{~N} / 8 \mathrm{~W}-18 \mathrm{C} 1$ is perforated in layers 6 and 7 . The measured groundwater-level elevations in both wells were similar, indicating that there is very little vertical gradient between the shallower and deeper parts of the system at this location. The SRPHM generally simulated the vertical gradient, the general trend, and the inter-annual variation in measured groundwater levels for these wells, indicating a good fit to the measured data (fig. $40 D, 40 E$ ). The magnitude of seasonal variation is underestimated in the upper part of the system (well 6N/8W-7P2), indicating that local pumpage is underestimated or that the storage or hydraulic properties are too high for this region. 


\section{Rincon-Kenwood, Bennett Valley-Plain, And Bennett Valley-Mountains Model Storage Units}

The locations of the Rincon-Kenwood, Bennett Valleyplain, and Bennett Valley-mountains MSU calibration wells are shown in figure $1 B$. Wells $7 \mathrm{~N} / 7 \mathrm{~W}-6 \mathrm{H} 2$ and $7 \mathrm{~N} / 7 \mathrm{~W}-9 \mathrm{P} 1$ are in the Rincon-Kenwood MSU. Well $7 \mathrm{~N} / 7 \mathrm{~W}-6 \mathrm{H} 2$ is in the Rincon Valley and is perforated in layer 1 . The simulated hydraulic heads in $7 \mathrm{~N} / 7 \mathrm{~W}-6 \mathrm{H} 2$ followed the general trend and inter-annual variations of the measured groundwater levels (fig. 41A); the seasonal fluctuations were underestimated. Despite the smaller seasonal fluctuations, the simulated hydraulic heads generally were consistent with the measured groundwater levels, indicating a good model fit for this well (fig. 41A).

Well 7N/7W-9P1 is in the Kenwood Valley (fig. $1 B$ ) and is perforated in layer 3 . The measured inter-annual variations and seasonal fluctuations were much greater than those simulated (fig. $41 B$ ). The general trend of the measured data was upward, which also was not reflected by the simulated hydraulic heads (fig. 41B). After water year 2001, SRPHM slightly underestimated measured groundwater levels.

Well 7N/7W-19B1 is in the Bennett Valley-plain MSU (fig. 1B) and is perforated in layer 1. The simulated hydraulic heads were slightly higher than the measured groundwater levels, but the overall fit to the measured data was good (fig. 41C). There was little seasonal variation in the simulated hydraulic heads or measured groundwater levels.

Wells 6N/7W-3D1 and 6N/7W-3M1 are in the Bennett Valley-mountains MSU (fig. $1 B$ ). Both wells are perforated in layer 1. Both the simulated hydraulic heads and measured groundwater levels showed a downward trend for well $6 \mathrm{~N} / 7 \mathrm{~W}-3 \mathrm{D} 1$; however, the magnitude of the interannual variations between water years 1980 and 2001 was greater in the measured data than in the simulated hydraulic heads (fig. 41D). After water year 2001, the hydraulic heads generally were consistent with the measured groundwater levels (fig. 41D). The simulated hydraulic heads for well $6 \mathrm{~N} / 7 \mathrm{~W}-3 \mathrm{M} 1$ showed a slight downward trend, compared with the flat trend in the limited, measured groundwater levels. The simulated hydraulic heads were about 20-25 ft higher than measured groundwater levels (fig. $41 E$ ). These wells are the only wells in the uplands with available data; hydraulic heads were not simulated accurately for either well. Improved hydrogeologic information is needed in these uplands to constrain SRPHM.

\section{Sensitivity Analysis}

Sensitivity analysis is a procedure for evaluating the sensitivity of the model results to variations in the input parameters. The sensitivity of parameters in the SRPHM was determined qualitatively throughout the trial-and-error calibration process. The SRPHM generally was sensitive to several parameters, including the hydraulic characteristic of horizontal-flow barriers, horizontal and vertical hydraulic conductivity, streambed conductance, and general-head boundary conductance. The SRPHM also was sensitive to the quantity and distribution of pumping. The SRPHM was less sensitive to the saturated vertical hydraulic conductivity of the unsaturated zone, specific yield, specific storage, and ET extinction depth.

Simulated hydraulic heads in the Windsor and Santa Rosa MSUs were sensitive to the hydraulic characteristic of the Trenton Ridge fault, and simulated hydraulic heads in the Santa Rosa and Wilson Grove MSUs were sensitive to hydraulic characteristic of Sebastopol fault. Simulated hydraulic heads in the SRP were somewhat sensitive to the hydraulic characteristic of the Rogers Creek fault; however, simulated hydraulic heads in the uplands east of the fault were comparatively insensitive to the hydraulic characteristics. Simulated hydraulic heads in the mountains were comparatively insensitive to the hydraulic characteristic of the faults. Simulated hydraulic heads were sensitive to horizontal hydraulic conductivity as well as vertical anisotropy in most layers. For example, model layer 2 is the low-conductivity layer in the Windsor, Santa Rosa, Cotati-north, and Cotati-south MSUs; reducing the vertical hydraulic conductivity of layer 2 during model calibration decreased simulated hydraulic heads appreciably in underlying layers.

The seasonal fluctuations in simulated hydraulic heads in layer 1 were somewhat sensitive to specific yield; however, the simulated hydraulic heads in all layers were comparatively insensitive to the specific storage. Simulated hydraulic heads, particularly in layer 1 , were somewhat sensitive to the value and distribution of vertical hydraulic conductivity in the unsaturated zone (intra-channel and underlying streams) and the properties of the soil zone, which influences the distribution and quantity of recharge.

Simulated hydraulic heads in the vicinity of streams, particularly in layer 1, were sensitive to streambed conductance. The ET extinction depth is another parameter that can influence the quantity and distribution of recharge in the vicinity of streams; however, the SRPHM was comparatively insensitive to this parameter.

Simulated hydraulic heads in the vicinity of generalhead boundaries were sensitive to the conductance of these boundaries. For example, the conductance for segments of the general-head boundary in the vicinity of wells 7N/9W-26P1 and $6 \mathrm{~N} / 9 \mathrm{~W}-1 \mathrm{M} 3$ in the Wilson Grove MSU (fig. $1 B$ ) was adjusted higher than for other segments of this boundary to improve the match of simulated hydraulic heads to measured groundwater levels in these wells.

The trend in simulated hydraulic heads was influenced strongly by groundwater pumping, which was mostly estimated. During model calibration, simulated hydraulic heads in some wells showed a downward trend after about 1995, compared with measured groundwater levels which had a flat or slightly upward trend. The simulated hydraulic heads matched the measured groundwater levels better after reducing rural pumpage by as much as 33 percent. 


\section{Appropriate Use of the Santa Rosa Plain Hydrologic Model}

The SRPHM synthesizes current data and understanding of the SRPW. The overall fit of the SRPHM to measured data (streamflows and groundwater levels) was reasonable. The purpose for developing the SRPHM was to provide a tool to help assess potential effects of climate change in the future and to evaluate water-management strategies. When applied carefully, the SRPHM can be used for simulating hydrologic responses to various changes in stresses to the groundwater and surface-water flow systems. The potential hydrologic response to changes in stresses can be assessed by evaluating simulated results from management scenarios together with the simulated results from the calibrated SRPHM.

Development of the SRPHM also was useful for identifying key data gaps. Improvement in estimates of the amount and distribution of groundwater pumping and collection of additional land-use, streamflow, and depth-dependent groundwater-level data, particularly in the SRP, could improve the accuracy of the results and reduce uncertainty in simulating future water-resource management scenarios.

In the future, the SRPHM also could be used as a platform to connect the simulation of hydrologic processes with water allocation/optimization models. The SRPHM could be used to evaluate sub-regional water resources issues such as proposed importation or exportation of water to or from the hydrologic system. The relatively detailed database on lithology coupled with water-level altitudes may make SRPHM particularly useful for assessing artificial-recharge sites.

\section{References Cited}

Anderson, M.R., and Woessner, W.W., 1992, Applied groundwater modeling simulation of flow and advective transport: San Diego, Calif., Academic Press, 381 p.

California Department of Water Resources, 1974, 1974 Sonoma County land use survey data: unpublished data located at Division of Integrated Regional Water Management, North-Central Region, West Sacramento, California, scale 1:24,000.

California Department of Water Resources, 1979, 1979 Sonoma County land use survey data: unpublished data located at Division of Integrated Regional Water Management, North-Central Region, West Sacramento, California, scale $1: 24,000$.
California Department of Water Resources, 1986, 1986 Sonoma County land use survey data: unpublished data located at Division of Integrated Regional Water Management, North-Central Region, West Sacramento, California, scale $1: 24,000$.

Chow, V.T., 1959, Open channel hydraulics: New York, McGraw-Hill, $350 \mathrm{p}$.

Doherty, John, 2005, PEST-Model-independent parameter estimation, user manual (5th ed.): Brisbane, Queensland, Australia, Watermark Numerical Computing, 336 p.

Doherty, John, 2010, PEST-Model-independent parameter estimation: Brisbane, Queensland, Australia, Watermark Numerical Compututing, www.pesthomepage.org.

Doherty, J.E., Hunt, R. J., and Tonkin, M. J., 2010, Approaches to highly parameterized inversion: A guide to using PEST for model-parameter and predictive-uncertainty analysis: U.S. Geological Survey Scientific Investigations Report 2010-5211, 71 p.

Donigian, A.S., Jr., Imhoff, J. C., Bicknell, B.R., and Kittle, J.L., Jr., 1984, Application guide for hydrological simulation program-FORTRAN (HSPF): Athens, Ga., U.S. Environmental Protection Agency, Environmental Research Laboratory, EPA-600/3-84-065, 177 p.

Drost, B.W., Ely, D.M., and Lum, W.E., 1999, Conceptual model and numerical simulation of the ground-water flow system in the unconsolidated sediments of Thurston County, Washington: U.S. Geological Survey Water-Resources Investigations Report 99-4165, 106 p.

Ely, D.M., and Kahle, S.C., 2012, Simulation of groundwater and surface-water resources and evaluation of watermanagement alternatives for the Chamokane Creek basin, Stevens County, Washington: U.S. Geological Survey Scientific Investigations Report 2012-5224, 74 p.

Harbaugh, A.W., 2005, MODFLOW-2005, the U.S. Geological Survey modular ground-water model - the ground-water flow process: U.S. Geological Survey Techniques and Methods 6-A16, variously paged.

Hay, L.E., and Umemoto, Makiko, 2006, Multiple-objective stepwise calibration using Luca: U.S. Geological Survey Open-File Report 2006-1323, 25 p.

Hevesi, J.A., Istok, J.D., and Flint, A.L., 1992, Precipitation estimation in mountainous terrain using multivariate geostatistics. Part I: structural analysis: Journal of Applied Meteorology, vol. 31, no. 7, p. 661-676. 
Hill, M.C., 1998, Methods and guidelines for effective model calibration: U.S. Geological Survey Water-Resources Investigations Report, 98-4005, 90 p.

Hill, M.C., and Tiedeman, C.R., 2007, Effective groundwater model calibration: with analysis of data, sensitivities, predictions, and uncertainty: Hoboken, N.J., John Wiley and Sons, $455 \mathrm{p}$.

Hill, M.C., Banta, E.R., Harbaugh, A.W., and Anderman, E.R., 2000, MODFLOW-2000, the U.S. Geological Survey modular ground-water model-User guide to the observation, sensitivity, and parameter-estimation processes and three post-processing programs: U.S. Geological Survey Open-File Report 00-184, 210 p.

Hsieh, P.A., and Freckleton, J.R., 1993, Documentation of a computer program to simulate horizontal-flow barriers using the U.S. Geological Survey's modular three-dimensional finite-difference ground-water flow model: U.S. Geological Survey Open File Report 92-477, 32 p.

Kadir, T.N., and McGuire, R.A., 1987, Santa Rosa Plain ground water model: Sacramento, Calif., California Department of Water Resources, Central District, 318 p.

Krause, Paul, Boyle, D.P., and Base, Frank, 2005, Comparison of different efficiency criteria for hydrological model assessment: Advances in Geosciences, v. 5, p. 89-97.

Linsley, R.K., Kohler, M.A., Paulhus, J.L.H., 1982, Hydrology for engineers: New York, McGraw-Hill, 508 p.

Maidment, D.R., 1993, Handbook of hydrology: New York, McGraw-Hill, 148 p.

Markstrom, S.L. Niswonger, R.L., Regan, R.S., Prudic, D.E., and Barlow, P.A., 2008, GSFLOW-coupled groundwater and surface-water FLOW Model based on the integration of the precipitation-runoff modeling system (PRMS) and the modular groundwater flow model (MODFLOW-2005): U.S. Geological Survey Techniques and Methods 6-D1, 240 p.

Nishikawa, Tracy, Hevesi, J.A., Sweetkind, D.S., and Martin, Peter, 2013, Conceptual model of Santa Rosa Plain watershed hydrologic system, chap. D of Nishikawa, Tracy, ed., Hydrologic and geochemical characterization of the Santa Rosa Plain watershed, Sonoma County, California: U.S. Geological Survey Scientific Investigations Report 20135118, p. 167-177.

Niswonger, R.G., and Prudic, D.E., 2006, Documentation of the streamflow routing (SFR2) package to include unsaturated flow beneath streams-A modification to SFR1: U.S. Geological Survey Techniques and Methods 6-A13, 48 p.

Niswonger, R.G., Panday, Sorab, and Ibaraki, Motomu, 2011, MODLOW-NWT, A Newton formulation for MODFLOW-2005: U.S. Geological Survey Techniques and Methods 6-A37, $44 \mathrm{p}$.
Poeter, E.P., Hill, M.C., Banta, E.R., Mehl, Steffen, and Christensen, Steen, 2008, UCODE_2005 and six other computer codes for universal sensitivity analysis, calibration, and uncertainty evaluation: U.S. Geological Survey Techniques and Methods 6-A11, 283 p.

Sweetkind, D.S., Taylor, E.M., McCabe, C.A., Langenheim, V.E., and McLaughlin, R.J., 2010, Three-dimensional geologic modeling of the Santa Rosa Plain, California: Geosphere, v. 6, p. 237-274.

Sweetkind, D.S., Hevesi, J.A., Nishikawa, Tracy, Martin, Peter, and Farrar, C.D., 2013, Hydrology of the Santa Rosa Plain watershed, Sonoma County, California, chap. B of Nishikawa, Tracy, ed., Hydrologic and geochemical characterization of the Santa Rosa Plain watershed, Sonoma County, California: U.S. Geological Survey Scientific Investigations Report 2013-5118, p. 27-112. 


\section{Chapter E. Santa Rosa Plain Hydrologic Model Results}

\author{
By Linda R. Woolfenden and Joseph A. Hevesi
}

\section{Introduction}

The Santa Rosa Plain hydrologic model (SRPHM) was used to derive components of the hydrologic budgets for water years 1976-2010, with particular attention given to a recent period (water years 2004-11), a dry water year (2009), and a wet water year (2006). The SRPHM also was used to evaluate simulated distributions of streamflow and net flux at the water table and to assess the effects of pumping on selected hydrologic and groundwater-budget components. Model results without pumping were compared with results with pumping to determine the effects of pumping on components of the hydrologic budgets. Although the simulation period was water years 1975-2010, the first year (water year 1975) was considered a "spin-up" period to allow the model to stabilize and, therefore, was omitted in the evaluation of model results.

\section{Simulated Hydrologic Budgets}

The simulated annual hydrologic-budget components for the SRPHM for water years 1976-2010 are presented in figure 1 and table 1. Total evapotranspiration (ET), shown in figure 1 and table 1, is the sum of ET from the soil, unsaturated and saturated zones, evaporation from impervious surfaces (for example, highways and parking lots), and interception evaporation from the tree canopy and low-lying vegetation. Total streamflow is the sum of runoff, interflow, and groundwater discharge to streams (commonly known as baseflow). Total storage change is the sum of storage change in the soil zone, unsaturated zone, and saturated zone and is defined as total inflows minus total outflows.

On average, pumpage was about an order of magnitude less than either total ET or total streamflow (fig. 1A, table 1). Precipitation was the greatest source of inflow to the Santa Rosa Plain watershed (SRPW), while total ET and total streamflow were the greatest outflows (fig. 1). As described in chapter $B$ of this report, reclaimed water was added to precipitation to account for its use on irrigated agriculture starting in calendar year 1990. Therefore, in this report, precipitation represents a combination of precipitation and reclaimed water. Net boundary flows (not shown in fig. 1) were more than an order of magnitude less than pumpage and were not an important component of the hydrologic budget.
Table 1. Average annual hydrologic budgets simulated with and without pumping for the Santa Rosa Plain hydrologic model, Santa Rosa Plain watershed, Sonoma County, California, water years 1976-2010.

\begin{tabular}{|c|c|c|}
\hline $\begin{array}{c}\text { Inflows and } \\
\text { outflows }\end{array}$ & $\begin{array}{c}\text { Average water } \\
\text { years 1976-2010 } \\
\text { with pumping } \\
\text { (acre-feet per } \\
\text { year) }\end{array}$ & $\begin{array}{c}\text { Average water } \\
\text { years 1976-2010 } \\
\text { without pumping } \\
\text { (acre-feet per } \\
\text { year) }\end{array}$ \\
\hline \multicolumn{3}{|c|}{ Inflows } \\
\hline Precipitation $^{1}$ & 531,000 & 531,000 \\
\hline Total inflows & 531,000 & 531,000 \\
\hline \multicolumn{3}{|c|}{ Outflows } \\
\hline Evapotranspiration & 262,000 & 271,000 \\
\hline Streamflow & 230,000 & 249,000 \\
\hline Net groundwater boundary flow & 700 & 3,600 \\
\hline Pumpage & 35,600 & 0 \\
\hline Total outflows & 528,600 & 523,600 \\
\hline $\begin{array}{l}\text { Change in total storage } \\
\text { (total inflow - total outflow) }\end{array}$ & 2,700 & 7,400 \\
\hline
\end{tabular}

${ }^{1}$ Includes reclaimed water.

The temporal change in the simulated hydrologic budget over a range of climatic conditions indicated that, during most of the transient simulation period (1976-2010), precipitation exceeded simulated total ET; however, during the driest year in the simulation period (water year 1977), almost all the precipitation was evapotranspired (as indicated by the nearequal values of total precipitation and total ET; fig. $1 A$ ), which left a comparatively small amount of precipitation to recharge the groundwater system. Total ET and total streamflow both followed the annual variation and general multi-year trend of precipitation for the period, although the variation and trends in total ET were damped, comparatively. The budget also indicated that pumpage generally (except for wet years) showed an upward trend from water years 1976 to 2010 and was a small percentage of the overall hydrologic budget (fig. 1). The difference between simulated total streamflow with and without pumping indicated that, on average, pumping reduced total streamflow by about 19,000 acre-ft/yr (table 1).

\section{Annual Variations in Evapotranspiration and Streamflow}

GSFLOW allows for a detailed analysis of hydrologicbudget components, such as ET and streamflow. Figure $2 \mathrm{~A}$ shows annual precipitation, average air temperature, and potential evapotranspiration (PET). Figures $2 B-D$ show components of total ET, components of total streamflow, and streambed inflows and outflows, respectively. The difference between streambed inflow and outflow is the net gain or loss through the streambed, which is shown in figure $2 D$. 

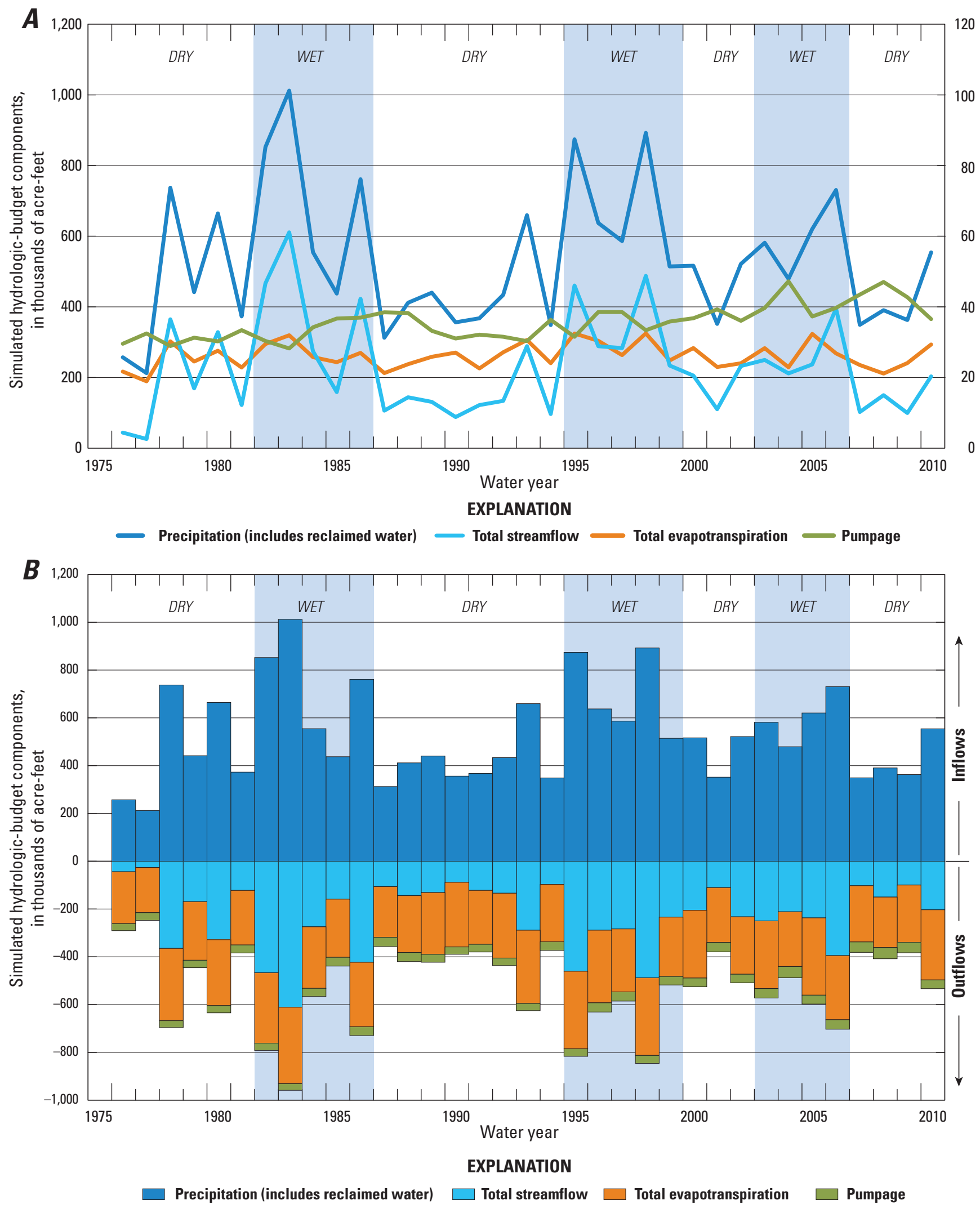

Figure 1. Simulated annual hydrologic-budget components for the Santa Rosa Plain hydrologic model, Santa Rosa Plain watershed, Sonoma County, California, 1976-2010, shown by $A$, line graph; $B$, bar chart. 


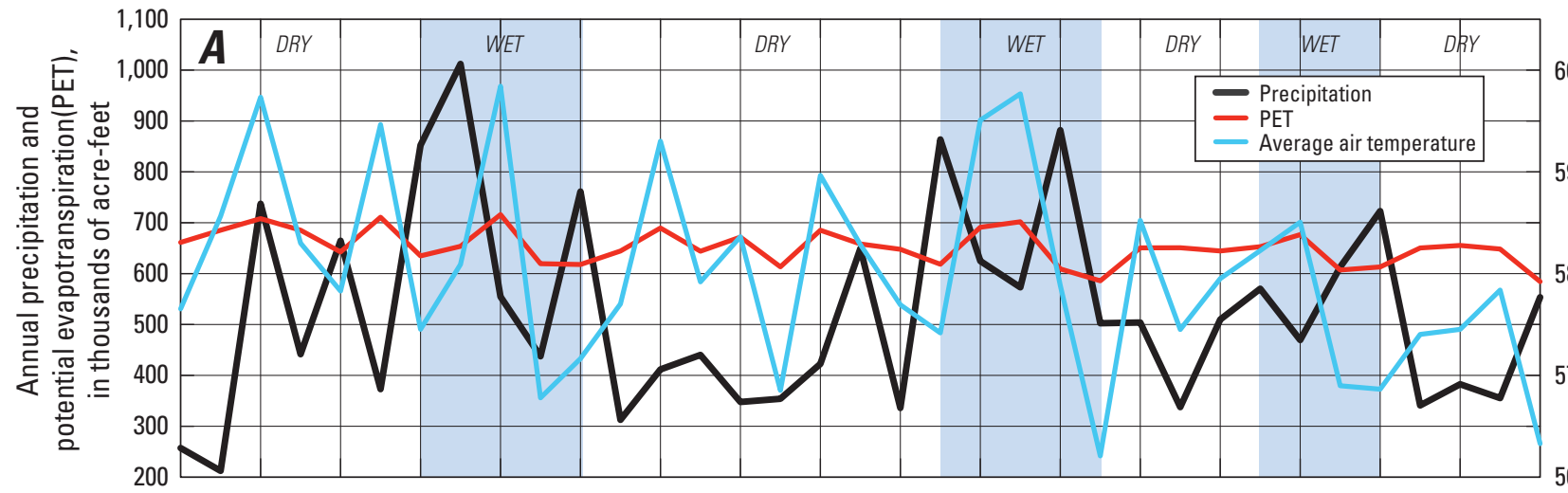
60

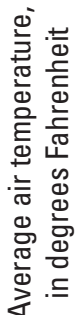
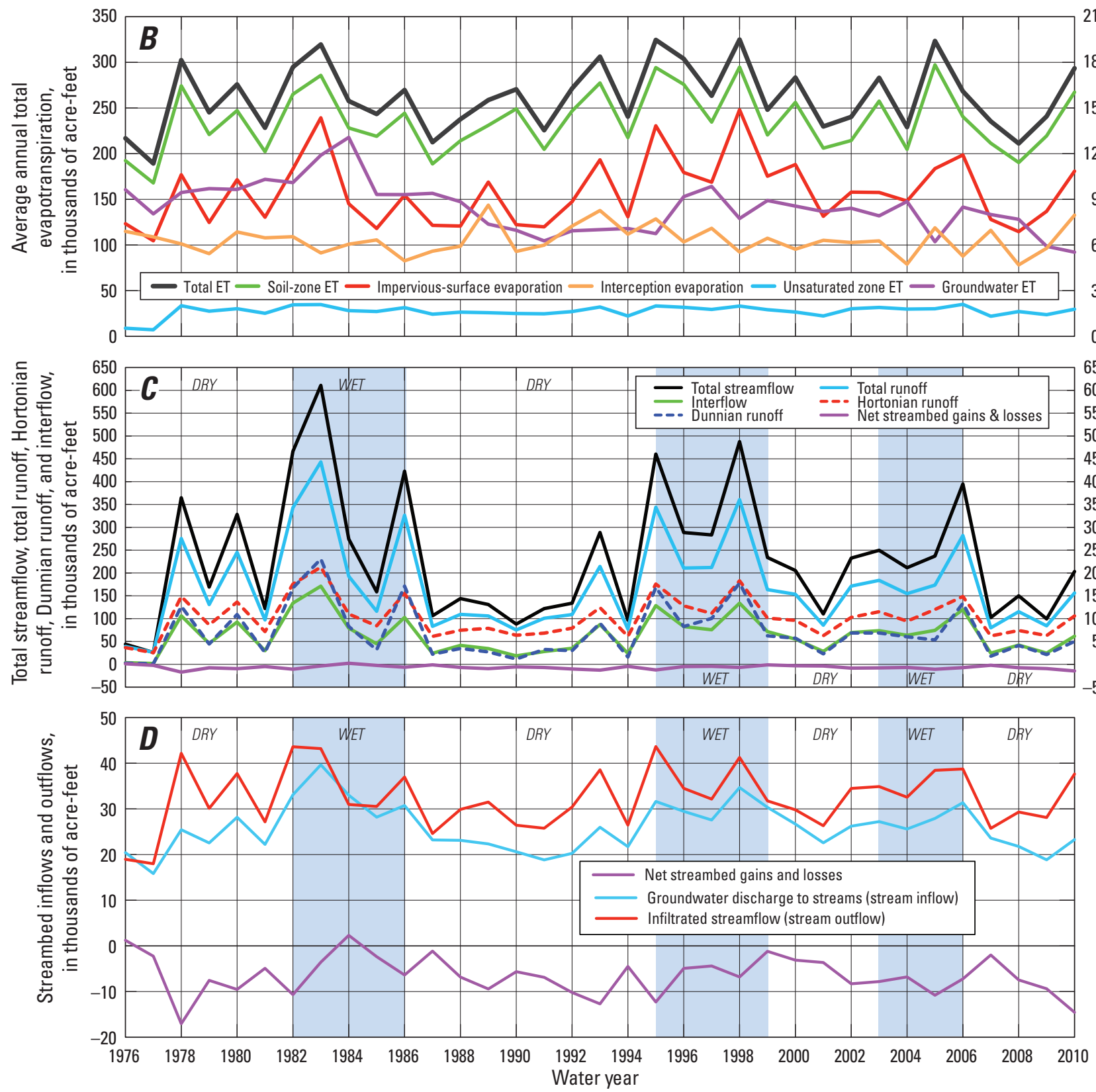

Figure 2. Annual values of hydrologic-budget components in the Santa Rosa Plain hydrologic model, Santa Rosa Plain watershed, Sonoma County, California, water years 1976-2010: $A$, precipitation, average air temperature, and potential evapotranspiration (PET); $B$, components of total evapotranspiration (ET); $C$, components of total streamflow; and $D$, streambed inflows and outflows. 


\section{Evapotranspiration}

Potential evapotranspiration (PET) is the limit of total ET possible. Simulated annual PET, which was directly correlated with variations in air temperature and precipitation, ranged from a maximum of 716,000 acre-ft for water year 1984 to a minimum of 584,000 acre-ft for water year 2010 (fig. 2A). Higher air temperature caused PET to increase, whereas more precipitation caused PET to decrease because lower temperatures were associated with the more frequent cloud cover and greater humidity was associated with the wetter periods. Average annual air temperature ranged from a maximum of about $59.8^{\circ} \mathrm{F}$ in water year 1984 to a minimum of about $56.2^{\circ} \mathrm{F}$ in water year 1999 (fig. 2A).

Simulated total ET ranged from a maximum of about 325,000 acre-ft for water year 1998, the second wettest water year in the simulation period, to a minimum of 175,000 acre-ft for water year 1977, the driest water year in the period (fig. 2B). Differences in the timing and distribution of precipitation throughout the year also affected variations in total ET-during winter, less frequent, but large storms resulted in more streamflow and less ET, whereas more frequent, but smaller storms extending into the spring months resulted in more ET. For example, there was considerably less precipitation in water years 1993 and 2005 than in water years 1983, 1995, and 1998, but total ET for 1993 and 2005 was similar to the wetter water years (greater than 300,000 acre-ft).

Components of total ET are shown in figure $2 B$. Soilzone ET was the largest component of total ET, averaging $236,000 \mathrm{acre}-\mathrm{ft} / \mathrm{yr}$ for the simulation period, with a maximum of 297,000 acre-ft for water year 2005 and a minimum of 168,000 acre-ft for water year 1977 (fig. 2B). Soil-zone ET was also comparatively low (less than 200,000 acre-ft) for water years 1987 and 2008 because there was very little precipitation during the warmer spring months in these drier-thanaverage water years.

Similar to soil-zone ET, impervious-surface evaporation was correlated to annual precipitation, averaging $9,500 \mathrm{acre}-\mathrm{ft} / \mathrm{yr}$ for the simulation period, with a maximum of about 15,000 acre-ft for water year 1998 and a minimum of 6,300 acre-ft for water year 1977 (fig. 2B). Interception evaporation averaged $6,300 \mathrm{acre}-\mathrm{ft} / \mathrm{yr}$, reached a maximum of 8,600 acre-ft in water year 1989, and was at its minimum of 4,700 acre-ft in water year 2008 (fig. 2B). Unlike soil-zone ET and impervious-surface evaporation, interception evaporation did not correlate to annual precipitation.

Saturated-zone ET (commonly known as groundwater ET) averaged 8,500 acre-ft/yr for the simulation period, with a maximum of 13,000 acre-ft in water year 1984 and a minimum of 5,500 acre-ft in water year 2010 (fig. 2B). Groundwater ET was not directly dependent on the availability of water from precipitation, but rather on the simulated groundwatertable elevation and residual PET, where residual PET was calculated after soil-zone ET had taken place. The maximum groundwater ET of 13,000 acre-ft was simulated in water year 1984 because the water table was high following a very wet period during water years 1982 and 1983 (figs. $2 A, B$ ) and because residual PET was comparatively high. A minimum groundwater ET of 5,500 acre-ft was simulated for water year 2010 because the water table was low as a result of pumping and there was comparatively low residual PET.

Unsaturated-zone ET was the smallest component of total ET, averaging 1,600 acre-ft/yr for the simulation period, with a maximum of 2,100 acre-ft for water year 2006 and a minimum of 432 acre-ft for water year 1977 (fig. 2B). In contrast to groundwater ET, unsaturated-zone ET was loosely correlated to annual precipitation.

\section{Streamflow}

Total streamflow leaving the SRPW varied from a maximum of about 611,000 acre-ft for the wettest water year (1983) to a minimum of about 26,000 acre-ft for the driest water year (1977) (fig. 2C). Despite the variation in streamflow discharge from the SRPW, the relative contributions of surface runoff (overland sheet flow and focused surface flow toward stream channels) and interflow (shallow subsurface flow in the soil zone) to streamflow were, on average, similar for most years; the average total surface runoff, which includes Hortonian (when the precipitation rate exceeds the infiltration capacity of the soil) and Dunnian (when the soil is fully saturated and precipitation cannot infiltrate) runoff rates, was $173,000 \mathrm{acre}-\mathrm{ft} / \mathrm{yr}$, and the average interflow rate was 64,000 acre-ft/yr (fig. 2C).

Groundwater discharge to streams (baseflow) was small relative to surface runoff and interflow, averaging 26,000 acre-ft/yr for water years 1976-2010 (fig. 2D). The maximum and minimum annual groundwater discharge to streams of 40,000 and 16,000 acre-ft occurred in water years 1983 and 1977, respectively. In wetter than average periods, such as water years 1983-87, groundwater discharge to streams was about 7 percent less than infiltrated streamflow (fig. 2D). In contrast, during drier-than-normal periods, such as water years 1989-93, groundwater discharge to streams was about 29 percent less than infiltrated streamflow (figs. $2 A, D$ ). Infiltrated streamflow almost always exceeded groundwater discharge to streams, as indicated by the mostly negative net streambed gains and losses (fig. 2D).

\section{Monthly Variations in Evapotranspiration and Streamflow}

The SRPHM also was used to evaluate the average monthly components of total ET (figs. $3 A, B$ ) and total streamflow (figs. $3 C, D$ ). ET components that were evaluated included interception evaporation, impervious-surface evaporation, soil-zone ET, unsaturated-zone ET, and groundwater ET (unsaturated-zone and groundwater ET are defined only for the stream channels in the SRPHM). Components of total streamflow that were evaluated included average monthly distributions of surface runoff, interflow, and groundwater 


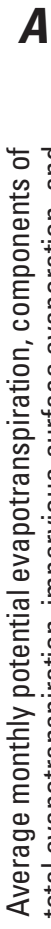

A
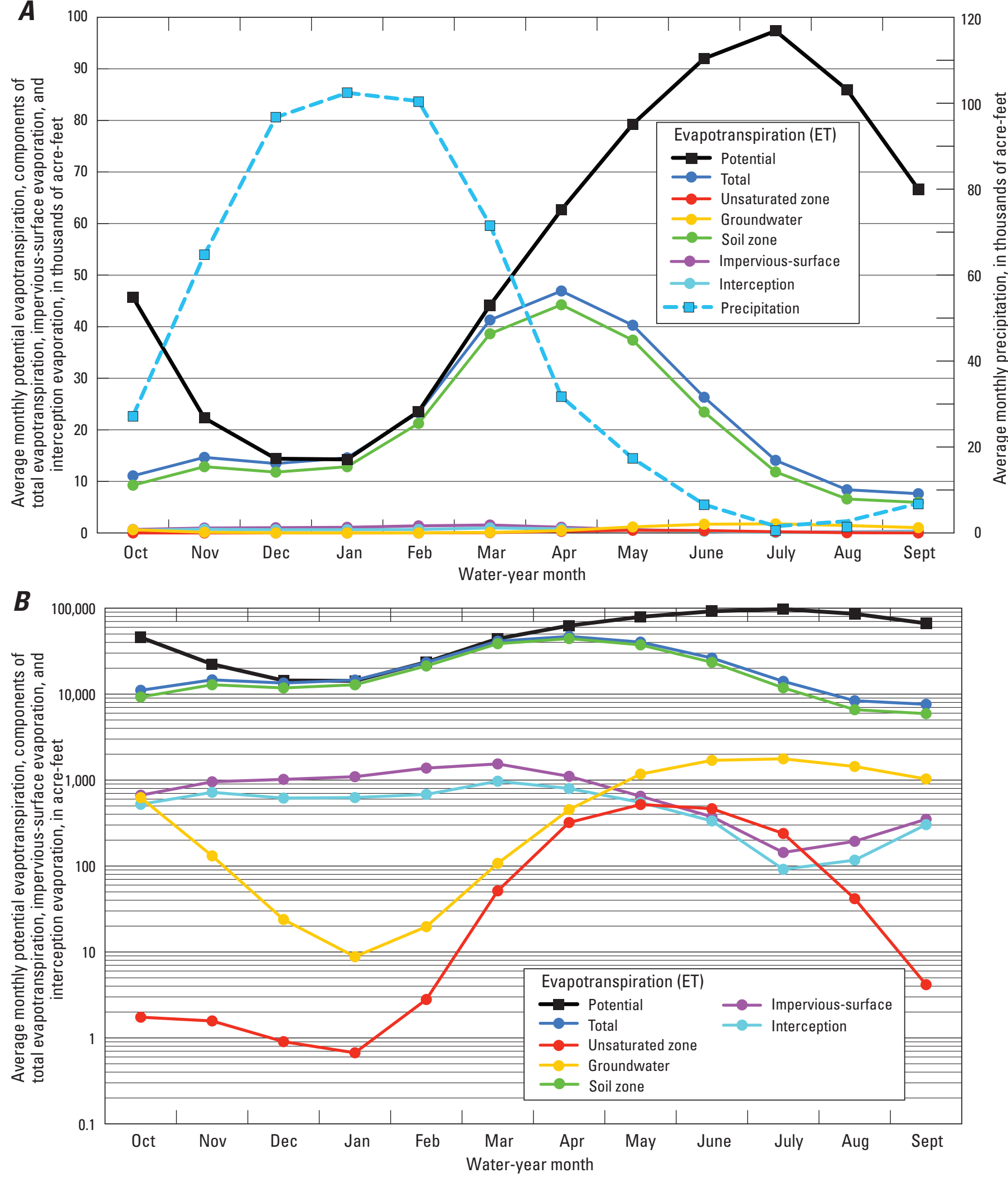

Figure 3. Average monthly results for simulated components of the Santa Rosa Plain hydrologic model, Santa Rosa Plain watershed, Sonoma County, California, water years 1976-2010: $A$, evapotranspiration at arithmetic scale; $B$, evapotranspiration at logarithmic scale; $C$, streamflow at arithmetic scale; $D$, streamflow at logarithmic scale. 

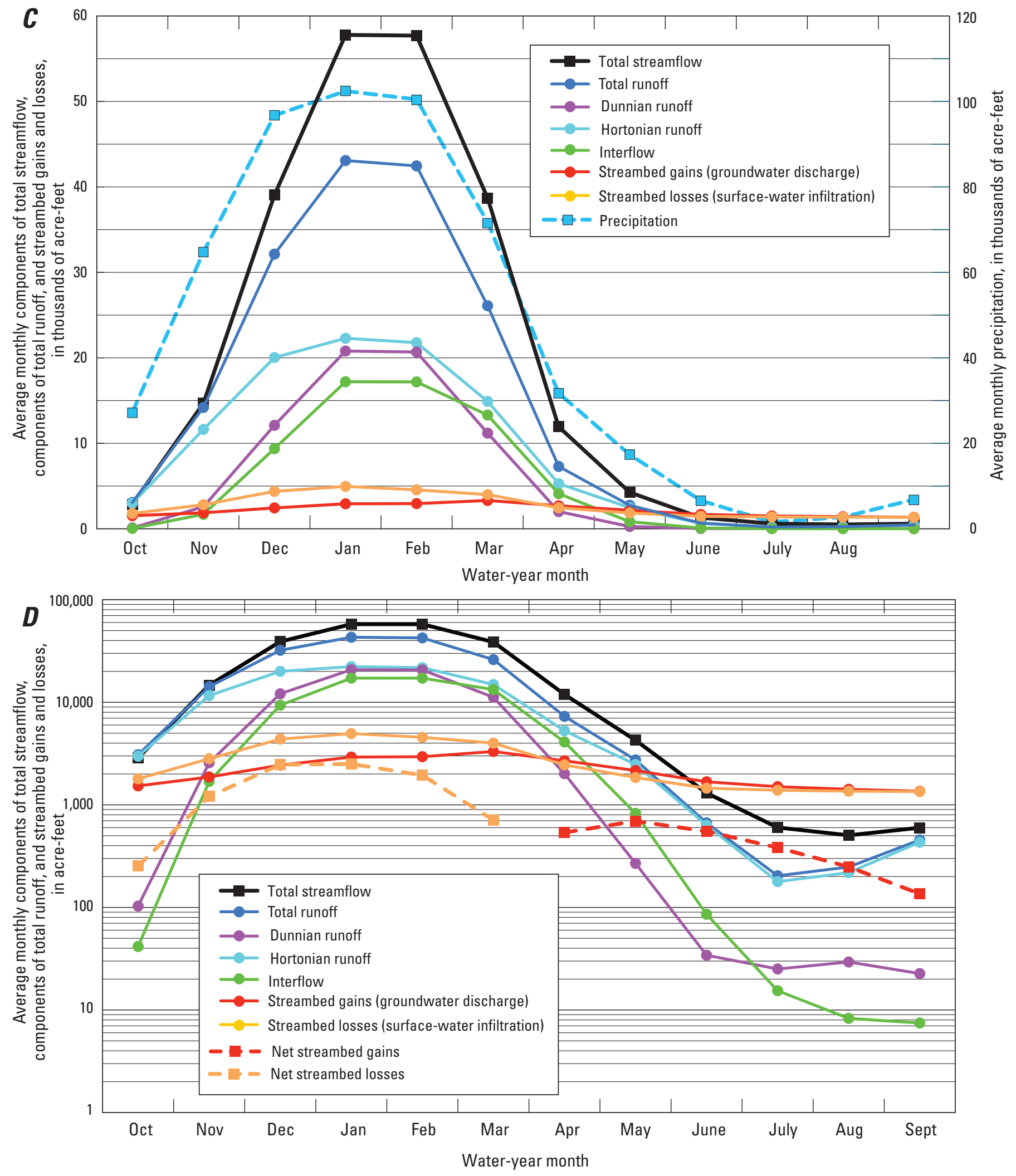

Figure 3. - Continued 
discharge to streams. Surface runoff is overland flow resulting from either high intensity rainfall or over-saturation of the soil zone. In addition to surface runoff, interflow and groundwater discharge to streams also contribute to total streamflow.

In general, the monthly results indicated strongly seasonal variations in the simulated total ET, with the highest average rates during March-May (figs. 3A, $B$ ). Soil-zone ET was the primary component of total ET, reaching an average maximum of about 44,000 acre-ft in April (figs. 3A, B). Average monthly groundwater ET reached a maximum of about 1,800 acre- $\mathrm{ft}$ in July and a minimum of 9 acre- $\mathrm{ft}$ in January. Unsaturated-zone ET was less than groundwater ET because it was limited by availability of moisture from infiltrated streamflow, whereas groundwater ET takes place as long as the groundwater table is above the ET extinction depth. Impervious-surface and interception-storage evaporation were shown to be small components of the water budget, with maximum values in March and minimum values in July.

The monthly results for total streamflow also showed strong seasonality, with the highest streamflows during December-March (figs. 3C, D). Total surface runoff (Hortonian and Dunnian runoff combined) was the dominant streamflow component during November-April (figs. $3 C, D$ ). Interflow also was an important component of total streamflow. Interflow was similar in magnitude to Hortonian and Dunnian runoff in January-April because the soil zone saturation levels were high as a result of winter precipitation; after April, precipitation decreases cause the surface-water runoff component of streamflow to decrease. In May, interflow decreases rapidly as the soil zone becomes dry, and PET increases (fig. $3 A$ ), allowing for groundwater discharge to streams to become the dominant component of streamflow from May through October. Groundwater discharge to streams is fairly constant throughout the year (figs. $3 C, D$ ).

\section{Groundwater Budgets}

The simulated average groundwater (saturated-zone) budgets were examined for the long-term (water years 1976-2010, referred to here as the long-term average), the recent short-term conditions (water years 2004-10, referred to here as the short-term average), a dry water year with less-than-average precipitation (water year 2009; table 2), and a wet year with greater-than-average precipitation (water year 2006; table 2). The groundwater budget for the longterm average (table 2) was used as a basis for comparison. The short-term average budget and wet and dry years demonstrated the hydrologic variability in the SRPW. Simulated long-term average groundwater budgets also were examined for selected subareas in the SRPW.

\section{Basin-Wide Groundwater Budgets}

The long-term average indicated that recharge from streams (losing streams) was about 26 percent greater than groundwater discharge to streams (baseflow; table 2). Average groundwater-storage depletion (inflow minus outflow) was about 3,300 acre-ft/year, indicating that about 9 percent of pumpage was supplied by groundwater storage depletion.

Table 2. Average precipitation and simulated groundwater budgets for the long-term (water years 1976-2010), the recent short-term (water years 2004-10), a wet year (water year 2006), and a dry year (water year 2009) for the Santa Rosa Plain hydrologic model, Santa Rosa Plain watershed, Sonoma County, California.

\begin{tabular}{lcccr}
\hline & $\begin{array}{c}\text { Long-term average } \\
\text { 1976-2010 water years } \\
\text { (acre-feet per year) }\end{array}$ & $\begin{array}{c}\text { Short-term average } \\
\text { 2004-10 water years } \\
\text { (acre-feet per year) }\end{array}$ & $\begin{array}{c}\text { Dry water year } \\
\text { (2009) } \\
\text { (acre-feet) }\end{array}$ & $\begin{array}{c}\text { Wet water year } \\
\text { (2006) } \\
\text { (acre-feet) }\end{array}$ \\
\hline Precipitation $^{1}$ & 525,000 & 491,000 & 355,000 & 723,000 \\
\hline Boundary flows & INFLOWS & & & 7,000 \\
Extra-channel recharge & 7,200 & 7,200 & 7,300 & 69,700 \\
Recharge from streams & 41,000 & 41,700 & 21,500 & 38,700 \\
Total inflow & 32,400 & 32,900 & 28,100 & 115,400 \\
\hline & 80,600 & 81,800 & 56,900 & 39,700 \\
\hline Pumpage & OUTFLOWS & \multicolumn{3}{c}{8,300} \\
Boundary flows & 35,600 & 42,000 & 42,700 & 8,500 \\
Groundwater evapotranspiration (ET) & 7,900 & 7,600 & 7,100 & 8,100 \\
Surface leakage & 8,500 & 7,200 & 5,900 & 31,400 \\
Groundwater discharge to streams & 6,100 & 5,200 & 3,100 & 96,000 \\
Total outflow & 25,800 & 24,600 & 18,900 & 19,400 \\
Storage change (total inflow - total outflow) & 83,900 & 86,600 & 77,700 & \\
\hline
\end{tabular}

${ }^{1}$ Does not include reclaimed water. 
For the short-term average, recharge from streams was about 34 percent greater than groundwater discharge to streams. Recharge from streams was about 2 percent greater than simulated long-term average conditions; groundwater discharge to streams (baseflow) was about 5 percent less (table 2). The groundwater contribution to streamflow was less for the short-term period because increases in extrachannel recharge and recharge from streams were insufficient to compensate for the increase in pumpage, causing groundwater levels to decline. Groundwater-storage depletion was about 45 percent greater for water years 2004-10 than for the simulated long-term average results, indicating that about 11 percent of pumpage was supplied by groundwater-storage depletion for the short term.

Total annual inflow for the dry and wet years was about 56,900 acre- $\mathrm{ft}$ and 115,400 acre-ft, respectively, and total outflow for these years was about 77,700 acre-ft and 96,000 acre-ft, respectively (table 2 ). The reduction in groundwater storage for the dry year (about 20,800 acre-ft) was about six times that of the long-term average and more than four times that of the short-term average conditions. For the wet year, total extra-channel recharge and recharge from streams were more than twice the total of the dry year and about 48 and 45 percent greater than the long- and short-term average periods, respectively. About 19,400 acre-ft was added to groundwater storage during the wet water year (table 2).

The overall trend in the cumulative change in groundwater storage and net stream leakage (the difference between recharge from streams and groundwater discharge to streams) for water years 1976-2010 indicated that as pumping increases, net stream leakage increases, and groundwater storage decreases (figs. $4 A, B$ ). The simulated net stream leakage varied slightly between wet and dry periods, but, overall, there was an upward trend and a cumulative net stream leakage of about 230,000 acre-ft for water years 1976-2010 (fig. 4B).

The simulated change in groundwater storage differed for wet and dry years (fig. $4 B$ ). Simulation results indicated that it is possible for the loss of groundwater storage in drier-thanaverage years to offset the increases in recharge during wetterthan-average years. Overall, however, there was a cumulative groundwater-storage depletion of about 120,000 acre- $\mathrm{ft}$ for water years 1976-2010. The drought during water years 1976-77 had the lowest average precipitation for the simulation period (fig. 1), causing an increase in groundwater pumpage (fig. 4) and a decrease in groundwater levels. Although simulated pumpage for these 2 years was less than average for the simulation period (about 35,600 acre- $\mathrm{ft} / \mathrm{yr}$ ), the depletion in groundwater storage was greater than for any other year in the period (fig. $4 B$ ). During the wet period of water years 1982-86, pumpage increased during water years 1984-86 because of increases in irrigated acreage and population.
However, pumpage declined for water years 1982 and 1983, and groundwater storage increased by nearly the same amount as was removed from groundwater storage during the 1976-77 drought (fig. 4B). The cumulative groundwater storage generally increased for subsequent wet periods, but recharge during those periods was insufficient for groundwater storage to recover from pumping and reduced recharge during the dry periods (fig. $4 B$ ).

\section{Groundwater Budgets for Subareas}

The SRPHM can be used to generate groundwater budgets on a scale smaller than the entire watershed. The model results are reported for subareas that correspond to selected model storage units (MSUs), except for the Cotati-north and Cotati-south MSUs, which were combined for simplicity (fig. 5, table 3). The average groundwater budgets for longterm conditions are given in table 3 . These results could be useful for assessing local groundwater-management strategies.

During the simulation period, the primary inflows were extra-channel recharge and recharge from streams for the Windsor, Santa Rosa, and Cotati subareas, but were extrachannel recharge and boundary flows in the Wilson Grove subarea. On average, streams were a net groundwater source (losing stream reaches) in the Windsor, Santa Rosa, and Cotati subareas and a net groundwater sink in the Wilson Grove subarea (gaining stream reaches). The primary outflow from the Windsor, Santa Rosa, and Cotati subareas was pumping. For the Windsor, Santa Rosa, and the Cotati subareas, groundwater ET and recharge from streams also were important outflows. Boundary flows and pumpage were the largest outflows for the Wilson Grove subarea (table 3). During the long-term simulation of the Windsor, Santa Rosa, and Wilson Grove subareas, on average, groundwater storage was depleted. For the Cotati subarea, inflows to and outflows from the groundwater-flow system were balanced.

Flow between subareas can be induced by pumping or influenced by natural flow patterns. Generally, flow between subareas was small; however, the contribution to inflow from the Santa Rosa subarea was about 10 percent of total outflow for the Cotati subarea (table 3). Natural flow patterns in the Cotati subarea generally were from east to west; hence, pumping from public-supply and rural wells in the subarea likely induces some flow from the Santa Rosa subarea to the Cotati subarea. For the Wilson Grove subarea, the contribution to inflow from the Wilson Grove mountains subarea was about 5 percent of total inflow (table 3). There are more than 50 rural wells in the southern part of the Wilson Grove subarea; it is likely that inflow from the Wilson Grove mountains subarea results from a combination of natural flow patterns and induced flow from pumping. 
$\boldsymbol{A}$

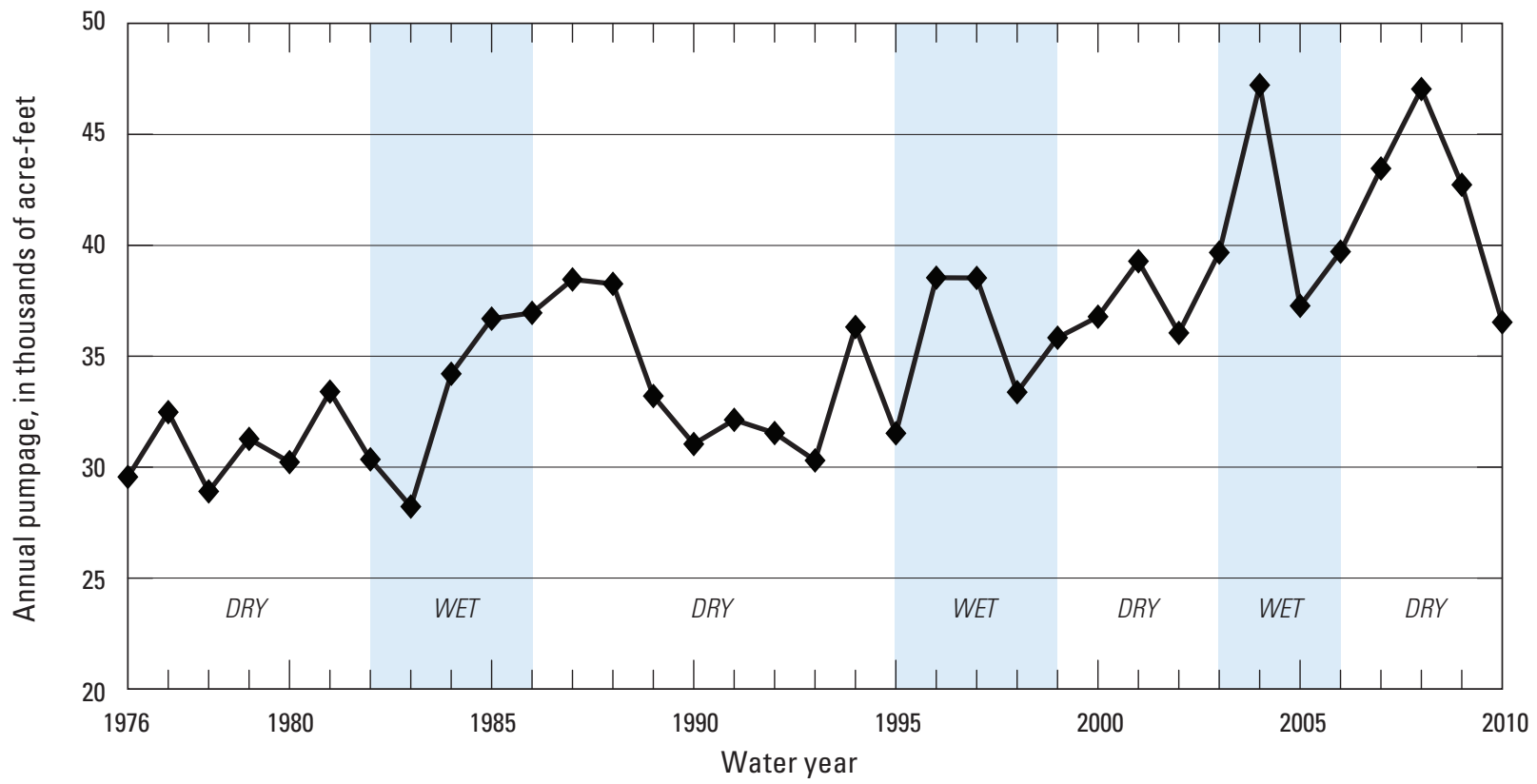

EXPLANATION

\section{B}

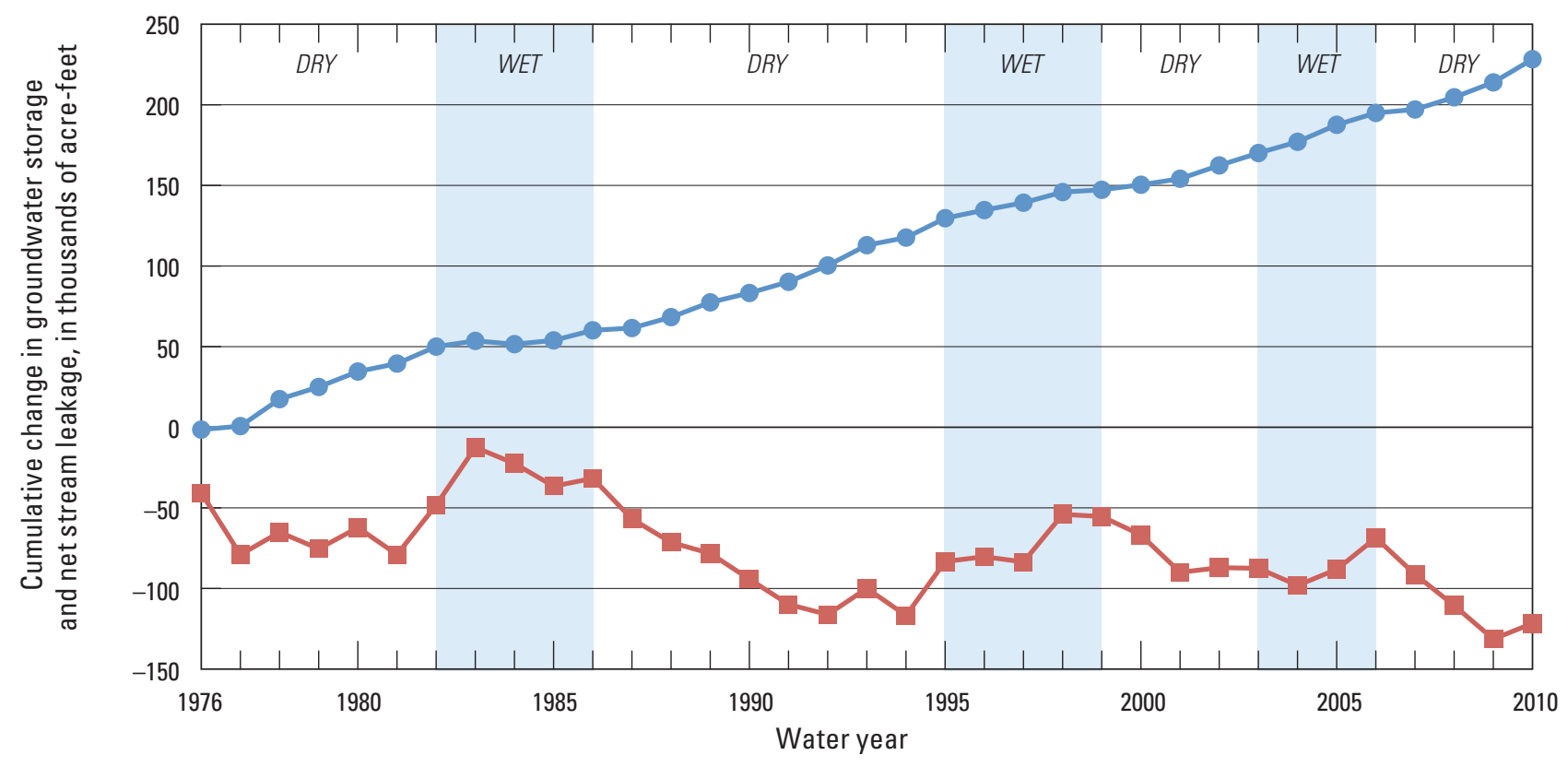

\section{EXPLANATION}

- Net stream leakage

Groundwater-storage change

Figure 4. Simulated values for water years 1976-2010 for the Santa Rosa Plain hydrologic model, Santa Rosa Plain watershed, Sonoma County, California, for $A$, annual pumpage; $B$, cumulative change in groundwater storage and net stream leakage. 


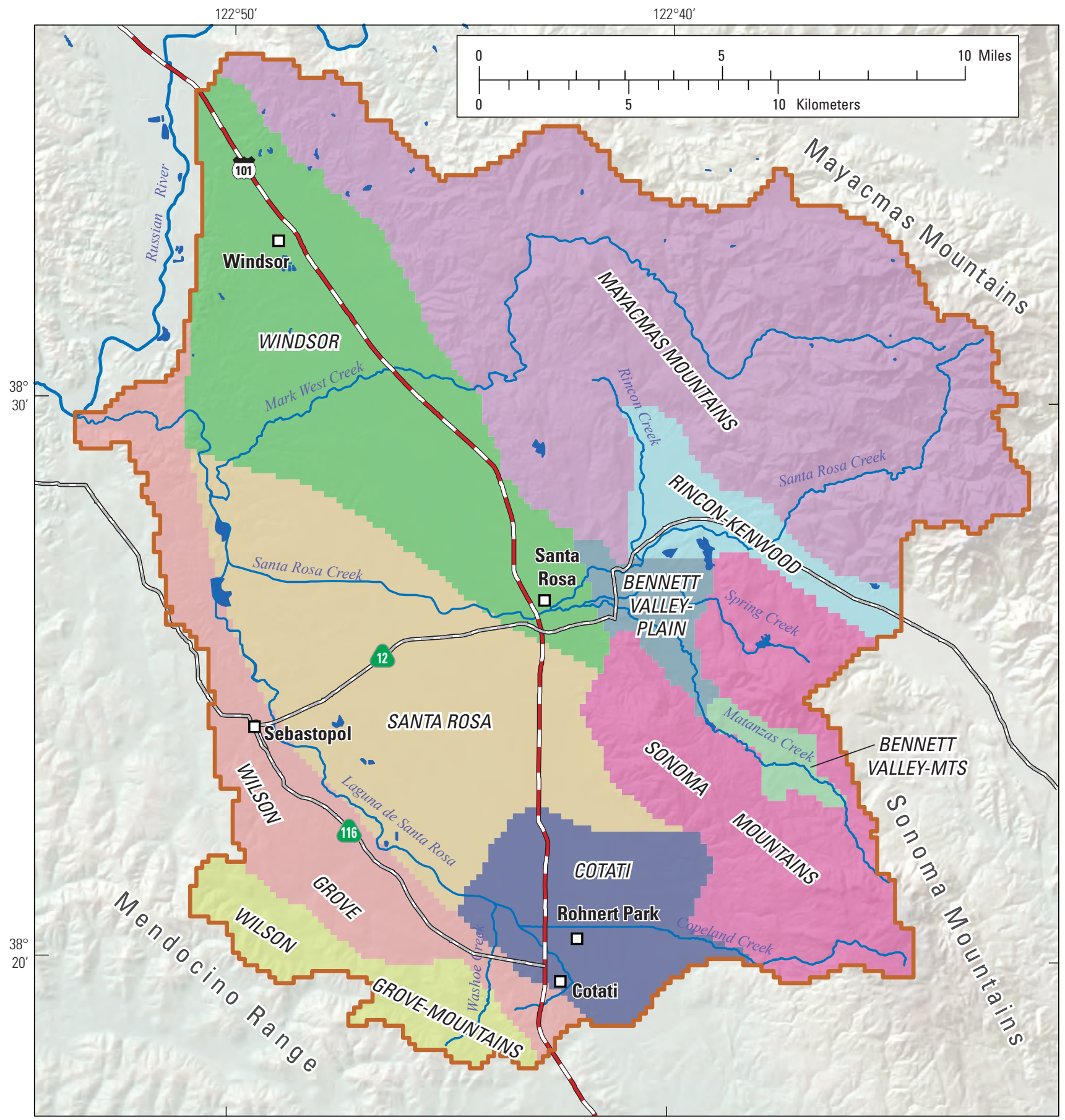

\section{EXPLANATION}

Subarea

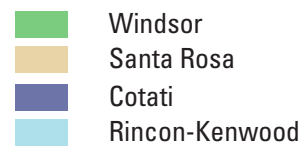

Bennett Valley-plain Wilson Grove

Mayacmas Mountains

Bennett Valley-mountains
Sonoma Mountains

Wilson Grove-mountains

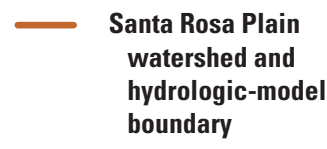

Figure 5. Subareas in the Santa Rosa Plain hydrologic model, Santa Rosa Plain watershed, Sonoma County, California. 
Table 3. Simulated groundwater budgets for long-term average conditions for selected subareas in the Santa Rosa Plain hydrologic model, Santa Rosa Plain watershed, Sonoma County, California.

[Abbreviation: - , not applicable]

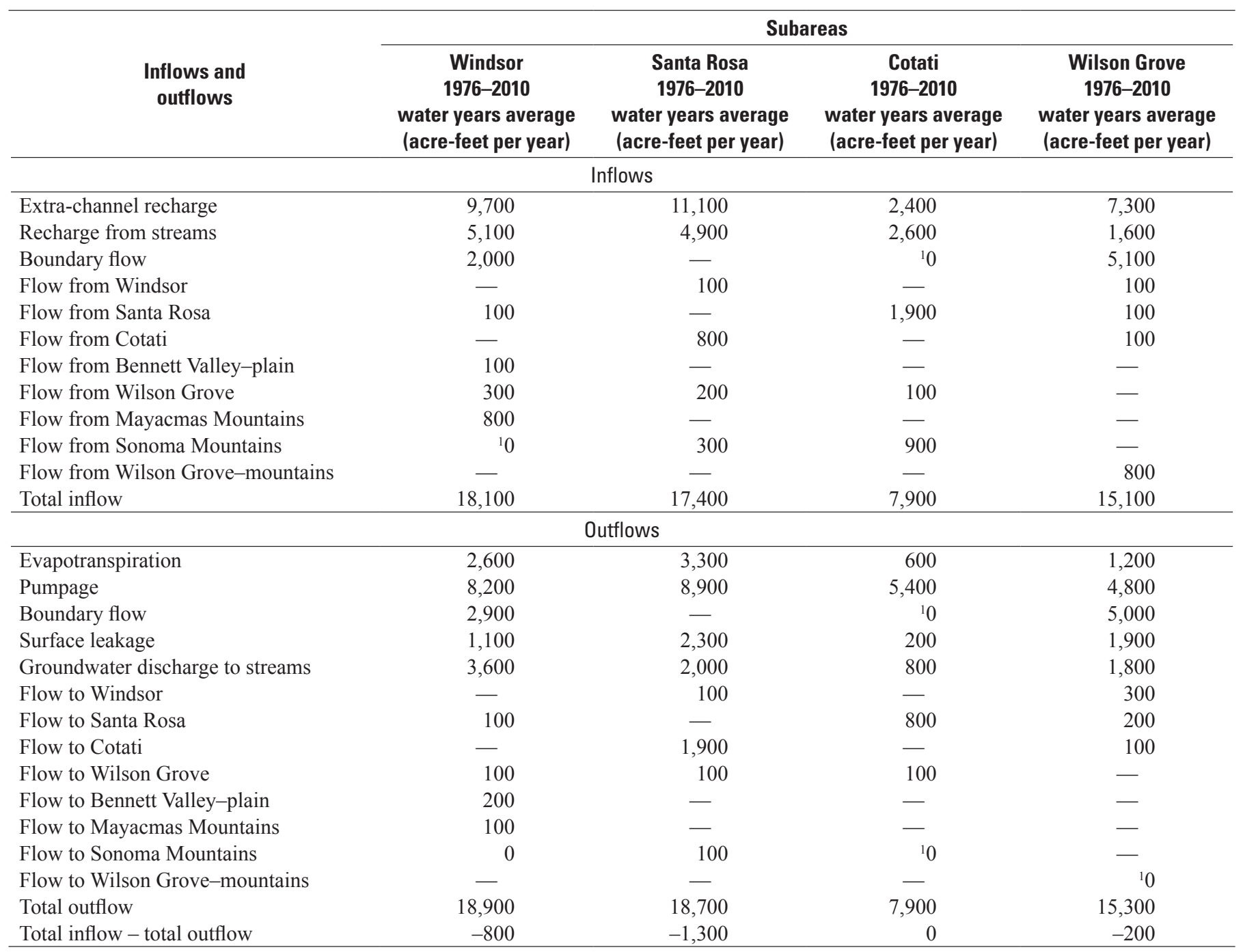

${ }^{1}$ Value is less than 50 acre-feet. 


\section{Spatially Distributed Streamflow and Net Groundwater Flux}

\section{Streamflow}

Simulated average annual streamflows for water years 1976-2010 ranged from a maximum of $310 \mathrm{ft}^{3} / \mathrm{s}$ at the mouth of Mark West Creek to near zero for HRUs located on drainage divides (these HRUs do not receive inflows from upstream areas; fig. $6 A$ ). The highest average annual streamflows of 110 to $310 \mathrm{ft}^{3} / \mathrm{s}(79,690$ to $224,766 \mathrm{acre}-\mathrm{ft} / \mathrm{yr})$ were simulated for the stream segments in the lower section of Mark West Creek, the lowermost sections of Santa Rosa Creek, and the Laguna de Santa Rosa. Simulated maximum daily streamflows ranged from 2.3 to $27,000 \mathrm{ft}^{3} / \mathrm{s}$, and the greatest streamflows were in the lowermost sections of Mark West Creek, Santa Rosa Creek, and the Laguna de Santa Rosa (fig. 6B). Simulated minimum daily streamflows ranged from 0 to $4.6 \mathrm{ft}^{3} / \mathrm{s}$, with the lowest streamflows in the stream tributaries (fig. 6C). Unlike the average annual and maximum simulated streamflows, where the maximum streamflows were in the lower reaches, the highest minimum streamflow was in a middle segment of Santa Rosa Creek (fig. 6C).

\section{Net Groundwater Flux}

The net groundwater flux (recharge or discharge) calculated by the SRPHM is the sum of all inflows (recharge from the unsaturated zone and net stream seepage) and outflows (groundwater ET and groundwater discharge to the soil zone or land surface) at the surface of the water table (Richard G. Niswonger, U.S. Geological Survey, written commun., August $31,2011)$. The distributions of net groundwater flux for longterm average conditions, a dry year (water year 2009), and a wet year (water year 2006) are presented in figure 7. Positive numbers indicate recharge and negative numbers indicate discharge. Areas without coloration indicate zero or near zero net groundwater flux. That is, although there could be recharge to the saturated zone, it was balanced by groundwater ET and surface discharge.

For long-term average conditions, about 93 percent of net groundwater discharge was to the stream channels, and about 72 percent of net discharge in the stream channels was in the Santa Rosa Plain (SRP). Although the spatial distribution indicated widespread net groundwater recharge in the extra-channel areas of the SRP (fig. 7A), about 54 percent of net recharge took place in the stream channels throughout the SRPW. About 62 percent of the net recharge in the stream channels was in the SRP. The long-term average net groundwater flux (recharge) over the SRPW was about 33,200 acre-ft/yr (fig. 7A).

The simulated net groundwater-flux distribution for the dry water year indicated that 94 percent of net groundwater discharge was in the stream channels, with about 68 percent of this in the SRP. This discharge was about 22 percent less than for simulated long-term average conditions because of a reduction in groundwater discharge to streams from declining water levels due to the combination of reduced recharge and increased pumping. Similar to the long-term average, the spatial distribution of net groundwater recharge was widespread in the extra-channel areas of the SRP; however, about 64 percent of the net recharge took place in the stream channels, with about 68 percent of this in the SRP. The net recharge over the watershed was about 22,200 acre-ft, or 33 percent less than for the simulated long-term average conditions (fig. $7 B$ ).

The simulated net groundwater-flux distribution for the wet water year indicated that 93 percent of net groundwater discharge was in the stream channels, with about 55 percent of this in the SRP. Similar to the simulated long-term average and dry year conditions, the spatial distribution of net groundwater recharge was widespread in the extra-channel areas of the SRP; however, about 64 percent of the quantity of net recharge took place in the stream channels, with about 68 percent of this in the SRP. The net recharge over the watershed was about 48,300 acre-ft, 45 percent more than for the simulated longterm average conditions and 54 percent more than for dry-year conditions (fig. 7C).

\section{Effects of Pumping on the Hydrologic System}

The SRPHM was used to simulate the variability in average hydrologic conditions with and without pumping during water years 1976-2010 (long-term) to determine the effects of pumping on components of the hydrologic budget (table 1). As previously stated, total storage includes storage from the soil and the unsaturated and saturated zones. With pumping simulated, an average of about 2,700 acre-ft/yr was added to total storage during water years 1976-2010. This means that about 6,000 acre- $\mathrm{ft}$ was added to storage in the soil and unsaturated zones, on average, to compensate for the 3,300 acre- $\mathrm{ft}$ loss in saturated-zone (groundwater) storage (table 2). With no pumping simulated, an average of almost 7,400 acre-ft/yr was added to total storage (table 1). This was a result of a decrease in pumpage from almost 36,000 acre- $\mathrm{ft} / \mathrm{yr}$ to none.

Comparison of the long-term average results with and without pumping can be made by calculating the difference between the hydrologic-budget component with and without pumping as a percentage of pumpage. These results indicated that about 53 percent of the total quantity of groundwater pumped from the SRPW was derived from a reduction in total streamflow, about 25 percent from a reduction in total ET, about 13 percent from a reduction in water augmenting total storage, and about 8 percent from changes in net boundary flows (fig. 8). Values do not add to 100 percent because of rounding of large numbers. 


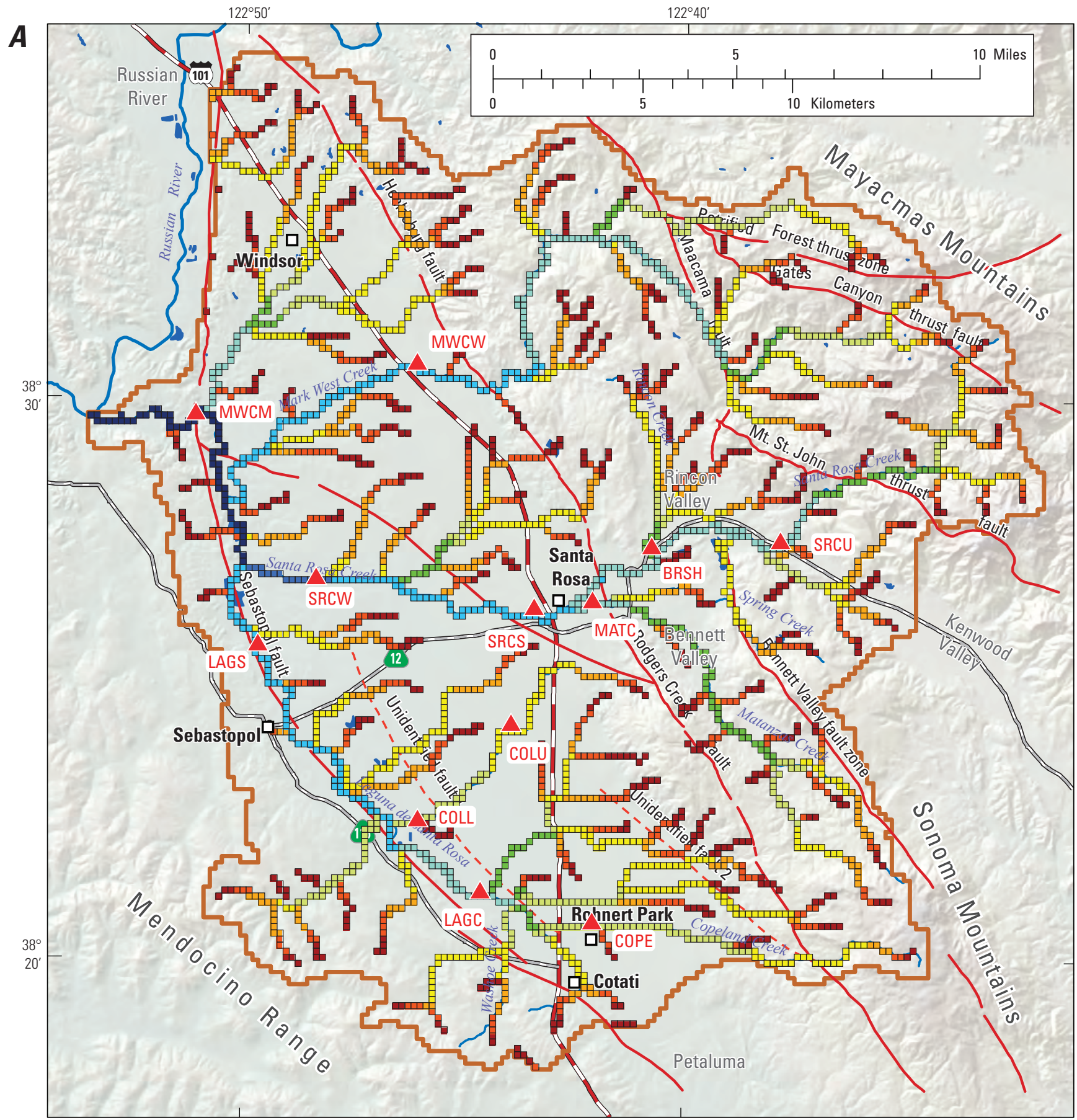

EXPLANATION

Simulated average water-year streamflow, in cubic-feet per second, 1976-2010

- 0.029 to $0.50 \square 1.1$ to $2.0 \square 5.1$ to $10 \square 21$ to $50 \square 101$ to 200

घ $\quad 0.51$ to $1.0 \square 2.1$ to $5.0 \square 11$ to $20 \square 51$ to $100 \quad 201$ to 310

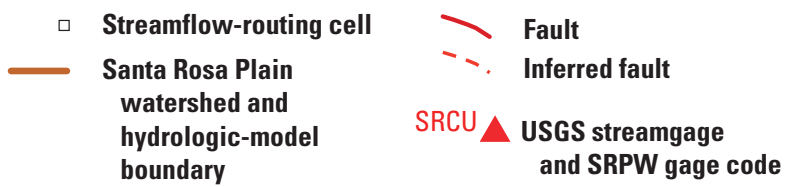

Figure 6. Simulated streamflow for water years 1976-2010, Santa Rosa Plain hydrologic model, Santa Rosa Plain watershed, Sonoma County, California: $A$, average; $B$, maximum; $C$, minimum. 


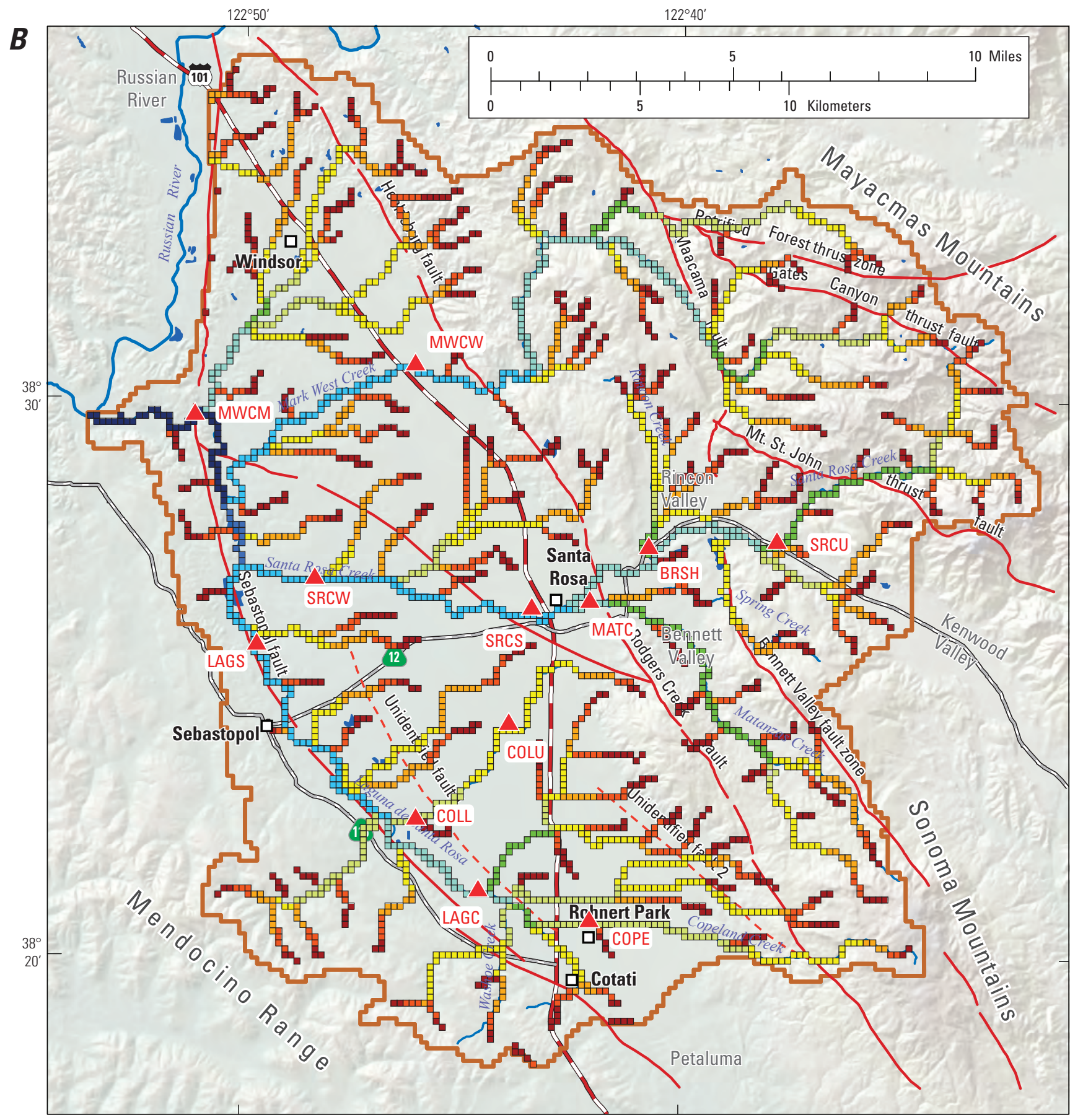

EXPLANATION

\section{Simulated maximum daily streamflow, in cubic-feet per second, 1976-2010}

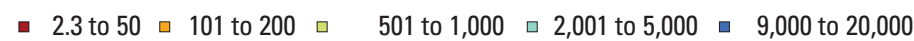

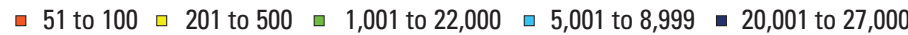

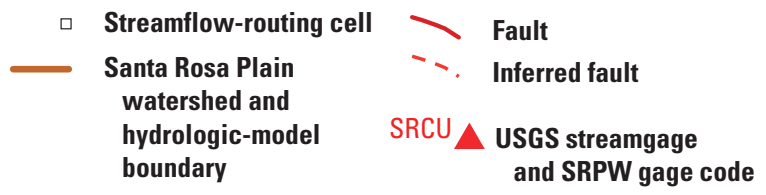

Figure 6. - Continued 


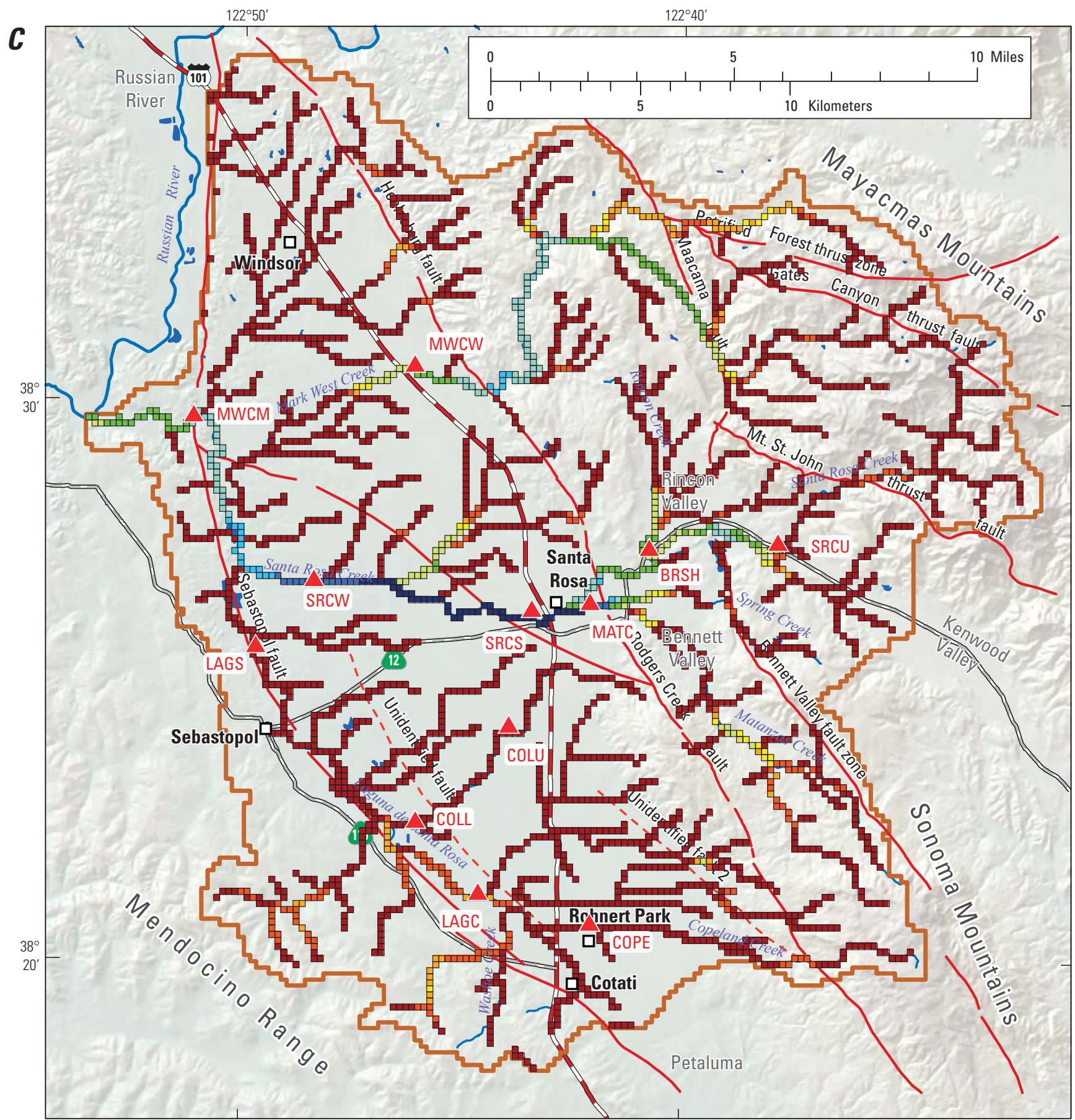

EXPLANATION

Simulated minimum daily streamflow, in cubic-feet per second, 1976-2010

- $\quad 0$ to $0.010 \square 0.051$ to $0.10 \square 0.21$ to $0.50 \square 1.1$ to $1.5 \square 2.1$ to 3.0

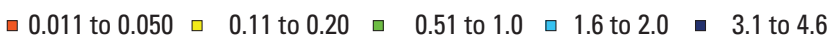

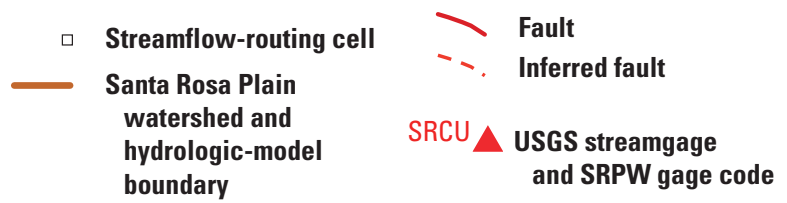

Figure 6. - Continued 


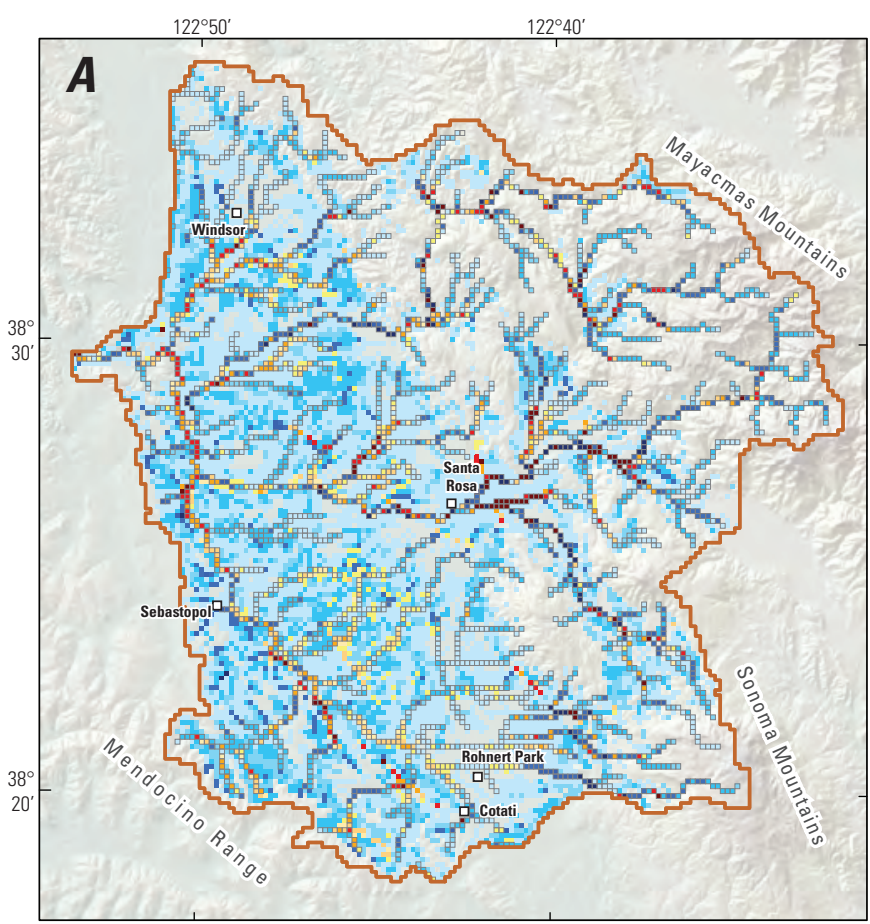

1976-2010

Average net flux (recharge) $=33,200$ acre-feet per year

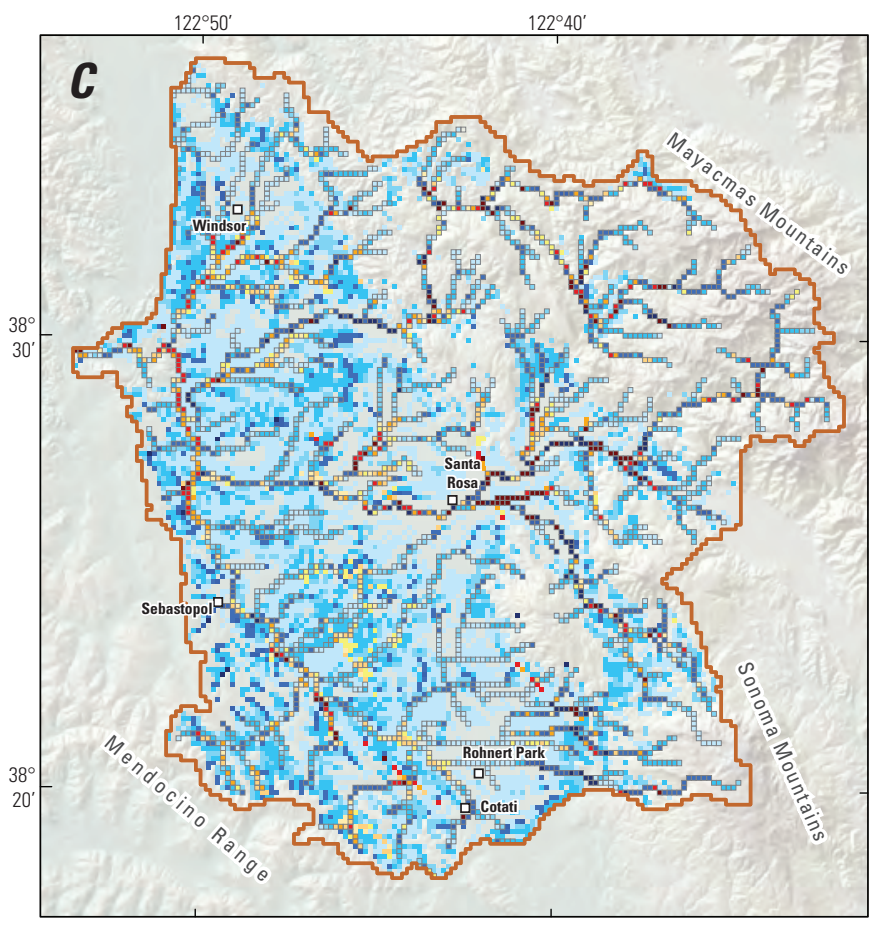

Wet Year 2006

Average net flux (recharge) $=48,300$ acre-feet

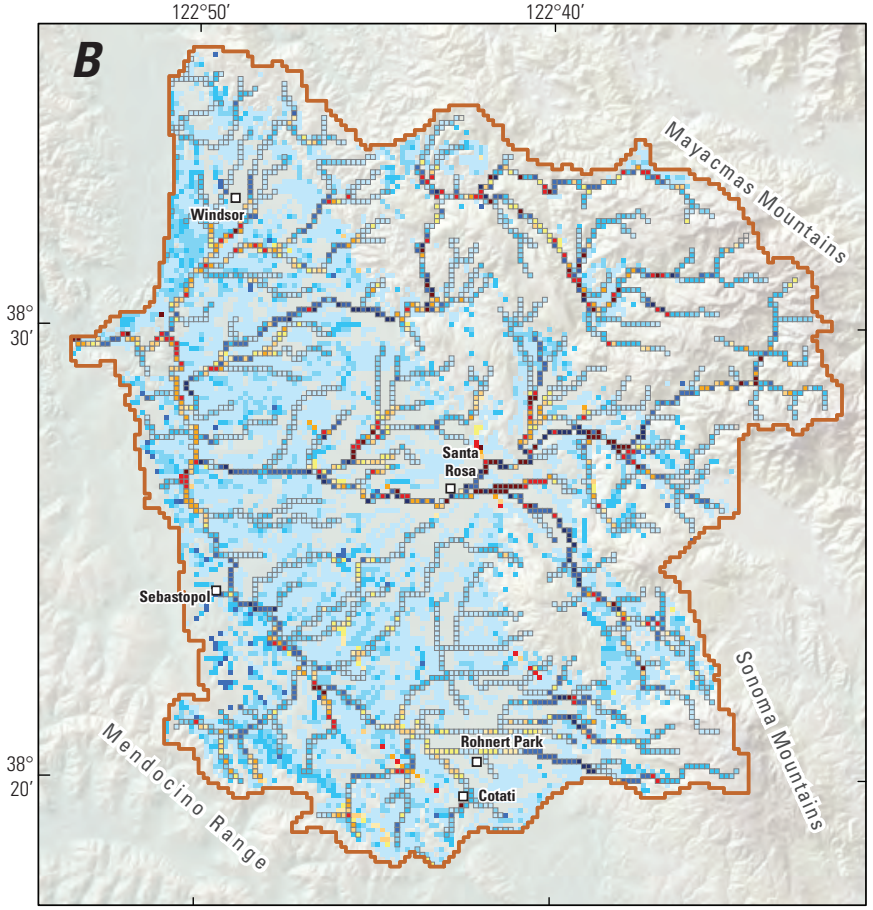

Dry Year 2009

Average net flux (recharge) $=22,200$ acre-feet

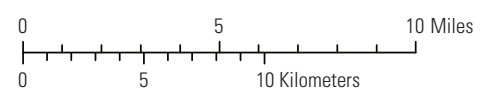

EXPLANATION

Net flux, in inches per year

\begin{tabular}{|r|r|r|r|}
\hline-668 to -100 & -9 to -5 & 6 to 10 \\
-99 to -50 & -4 to 0 & 11 to 25 \\
-49 to -25 & No color & 0 & 26 to 50 \\
-24 to -10 & 1 to 5 & 51 to 100 \\
& & 101 to 507 \\
\hline
\end{tabular}

Streamflow-routing cell

Santa Rosa Plain watershed and hydrologic-model boundary

Figure 7. Simulated net groundwater-flux distribution from the Santa Rosa Plain hydrologic model, Santa Rosa Plain watershed, Sonoma County, California: $A$, long-term average conditions (1976-2010); $B$, a dry water year (2009); $C$, a wet water year (2006). 


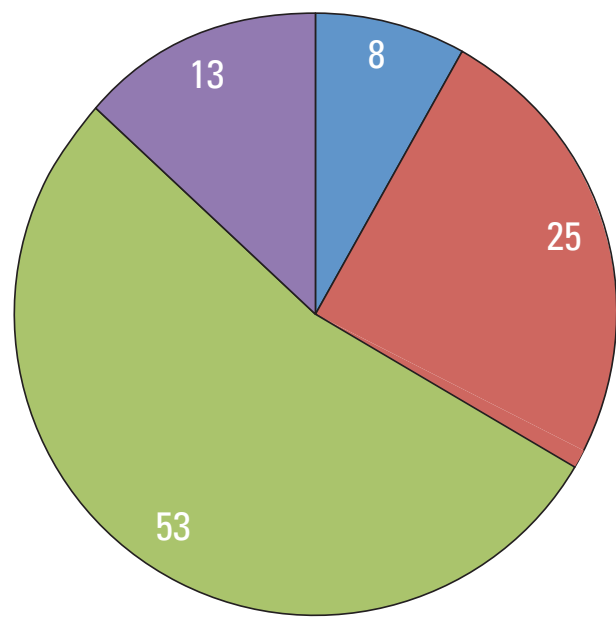

\section{EXPLANATION}

Net general-head boundary flows

Total evapotranspiration

Total streamflow

Total storage change

Number is percentage of total; Values do not sum to 100 percent as a result of rounding of large numbers.

Figure 8. Annual average simulated hydrologic-budget components affected by pumping for water years 1976-2010, Santa Rosa Plain hydrologic model, Santa Rosa Plain watershed, Sonoma County, California.

\section{Simulated Streamflow}

Pumping from wells in the vicinity of streams can have a strong effect on streamflow. For example, a lowering of the groundwater table in response to pumping can decrease groundwater discharge to streams, decrease riparian ET, and increase streamflow contributions to recharge (Barlow and Leake, 2012). The SRPHM can be used to assess the effects of pumping on the surface-water system. The effect of pumping on total streamflow in the SRPW was evaluated by comparing streamflow simulated with and without pumping. The comparison used average simulated results for water years 1976-2010 (long-term average) for basin-wide simulation results (fig. 9). The results obtained at three streamgages used for calibration and testing - COPE (11465660, Copeland Creek at Rohnert Park, Calif.), LAGS (11465750, Laguna de Santa Rosa near Sebastopol), and MWCM (11466800, Mark West Creek near Mirabel Heights) - are highlighted because they are spatially representative of the entire surface-water system, and total streamflow at these streamgages was among the most affected by pumping (table 4 ).

\section{Basin-Wide Streamflow}

Pumping resulted in an overall decrease in streamflow for most stream segments in the SRPW (fig. 9). Maximum differences in average annual streamflow as a result of pumping (calculated as the difference between simulated streamflow without pumping minus simulated streamflow with pumping) were 16 to $26 \mathrm{ft}^{3} / \mathrm{s}$ and took place in the lower sections of the Laguna de Santa Rosa and Mark West Creek (fig. 9A). Reductions in streamflow ranged from 2.1 to $15 \mathrm{ft}^{3} / \mathrm{s}$ for the middle sections of Mark West Creek and Santa Rosa Creek, the upper section of Laguna de Santa Rosa, and the lower section of Matanzas Creek. Although the absolute decreases in streamflow were small (less than $1 \mathrm{ft}^{3} / \mathrm{s}$ ) for most locations, the percent decrease in streamflow for the with-pumping simulation was more than 10 percent for many locations, particularly for streams in Bennett Valley and the Santa Rosa Plain (fig. 9B). For example, the difference in average streamflow of 1.1 to $1.5 \mathrm{ft}^{3} / \mathrm{s}$ at the Copeland Creek gage was a decrease in streamflow of more than 16 percent.

Simulated results showed that the streamflow was reduced with time and that the relative change in total streamflow generally increased with time, corresponding to a general trend of increased pumpage. The long-term average reduction in total streamflow was about 8 percent (from about 249,000 acre-ft/yr without pumping to about 230,000 acre-ft/yr with pumping, table 1). Average pumpage was about 35,600 acre-ft/yr for this period.

Comparison of average annual total streamflow with and without pumping indicated that the relative reduction in total streamflow was greater for the drier years because groundwater discharge to streams was reduced with pumping and was a greater percentage of total streamflow during those years. There were reductions in total streamflow of more than 16 percent during water years 1977, 1990, 2007, and 2009, all of which were relatively dry years (fig. 10A).

The comparison of average monthly streamflow for simulations with and without pumping indicated that there were greater relative changes in streamflow during the summer months (fig. 10B), when groundwater discharge to streams was reduced by pumping. An increase in pumpage during the summer months resulted in lower groundwater levels that caused a reduction in groundwater discharge to streams and increased recharge from streams (more losing stream reaches). The runoff and interflow components of total streamflow during the summer months were not affected by pumping. Comparison of August streamflows indicated that the reduction in the average total streamflow in response to pumping was about $600 \mathrm{acre}-\mathrm{ft} / \mathrm{yr}$ (fig. 10C). Although the effect of pumping on August streamflow was pronounced, the annual variability in streamflow for scenarios with and without pumping was caused primarily by variability in precipitation rather than in pumpage. 


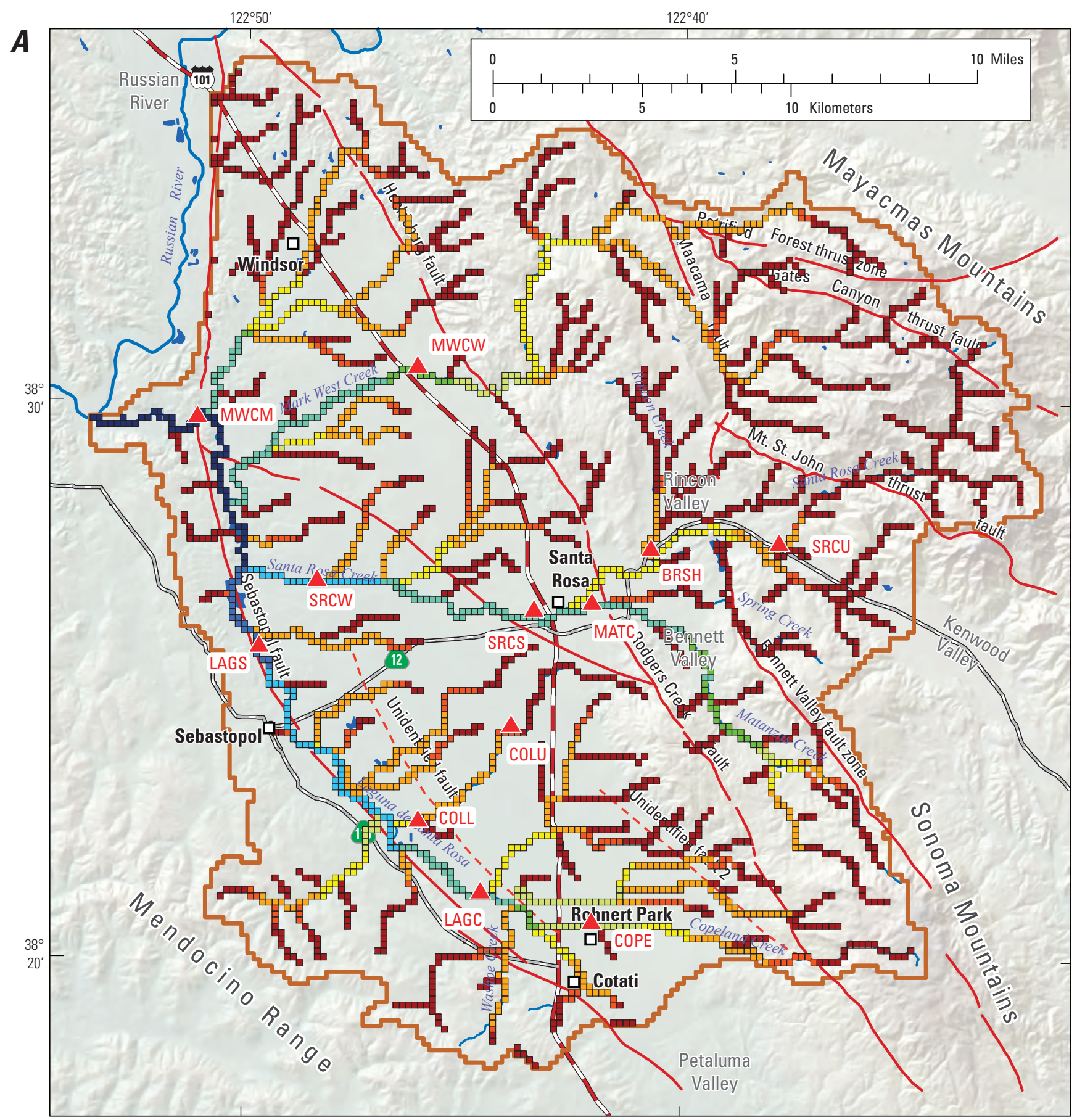

EXPLANATION

Difference in average annual streamflow (without pumping minus with pumping), in cubic-feet per second

घ 0 to $0.050 \square 0.11$ to $0.50 \square 1.1$ to $1.5 \square 2.1$ to $5.0 \square 11$ to 15

$\square 0.051$ to $0.10 \square 0.51$ to $1.0 \square 1.6$ to $2.0 \square 5.1$ to $10 \square 16$ to 26

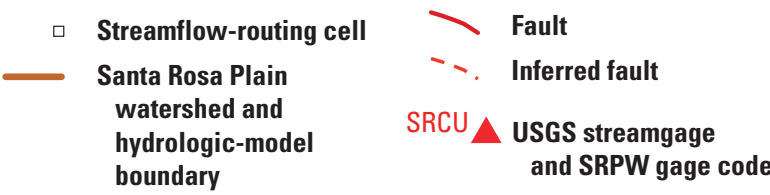

Figure 9. Spatial distribution of changes in streamflow with and without pumping, water years 1976-2010, Santa Rosa Plain hydrologic model, Santa Rosa Plain watershed, Sonoma County, California: $A$, difference in average streamflow; $B$, percentage decrease in streamflow without pumping. 


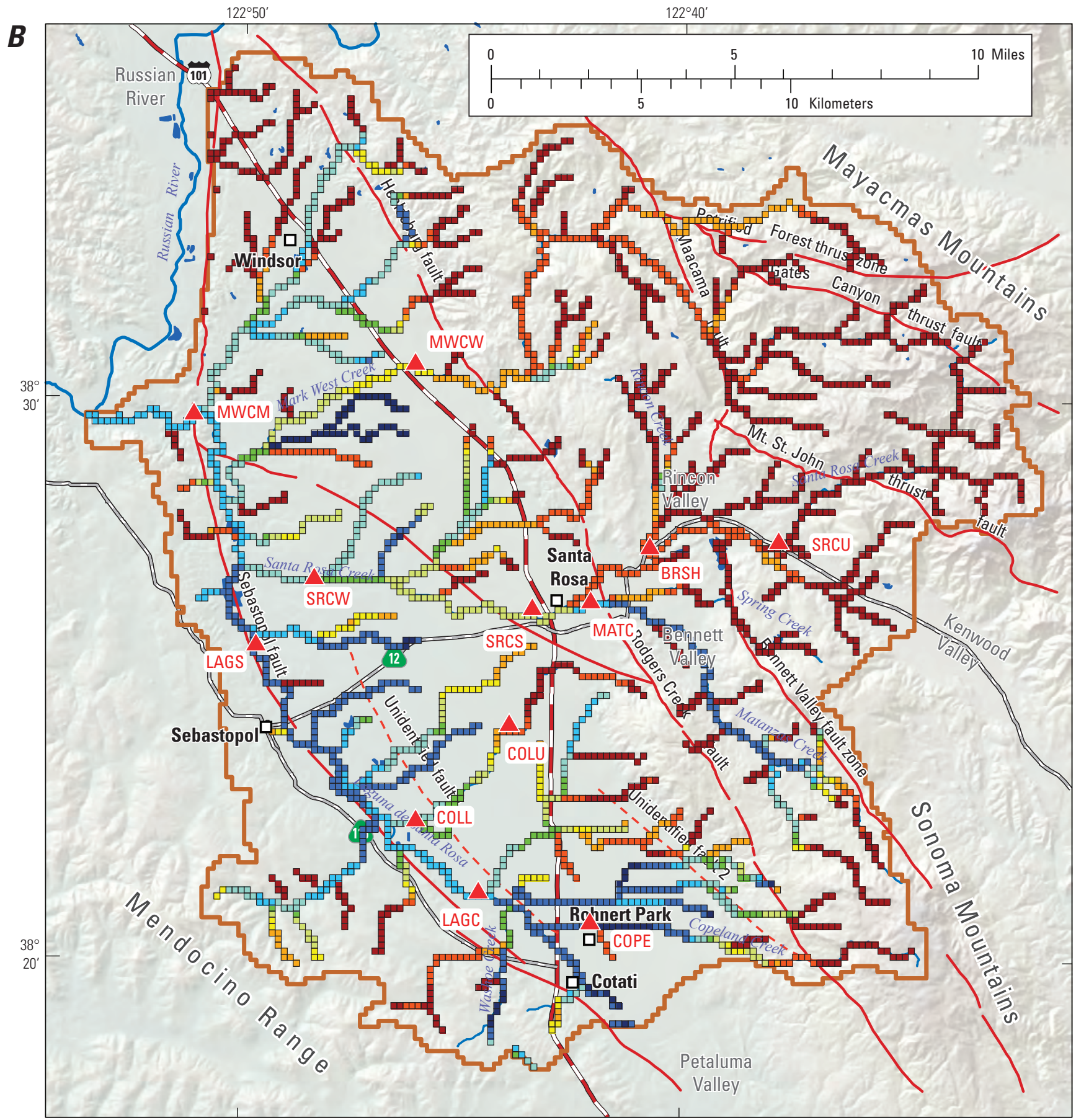

EXPLANATION

Percentage decrease in average streamflow [(without pumping minus with pumping/without pumping) $x$ 100]

$\square \quad<1.0 \square 2.1$ to $3.0 \square 4.1$ to $5.0 \square 6.1$ to $8.0 \square 11$ to 15

- 1.1 to $2.0 \square 3.1$ to $4.0 \square 5.1$ to $6.0 \square 8.1$ to $10 \quad 16$ to 56

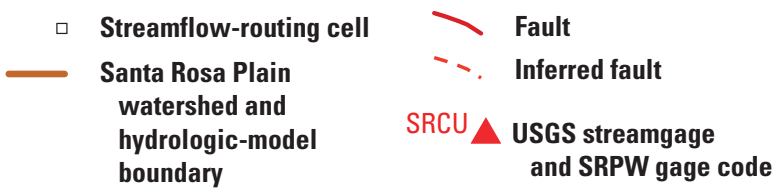

Figure 9. - Continued 


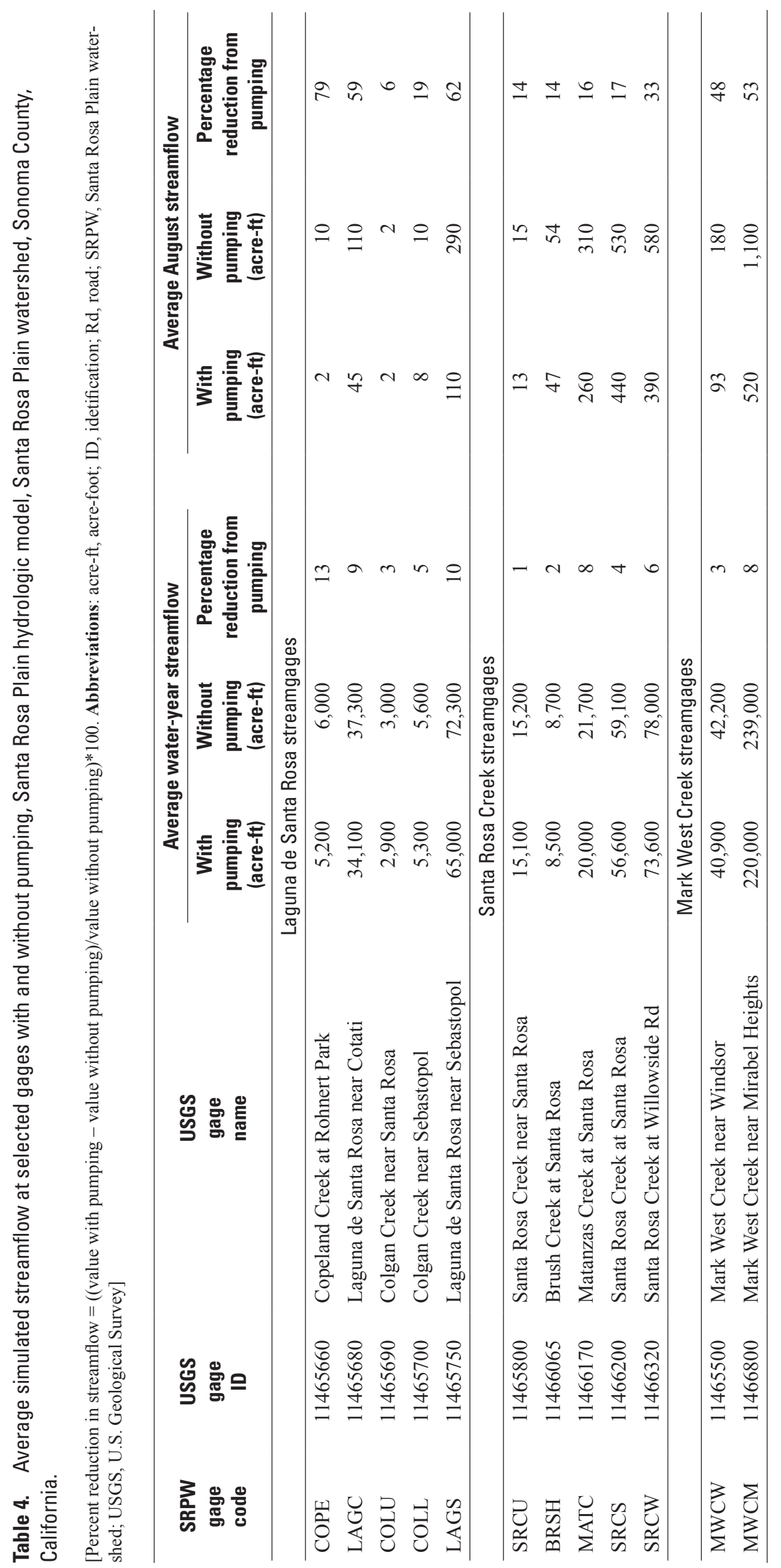



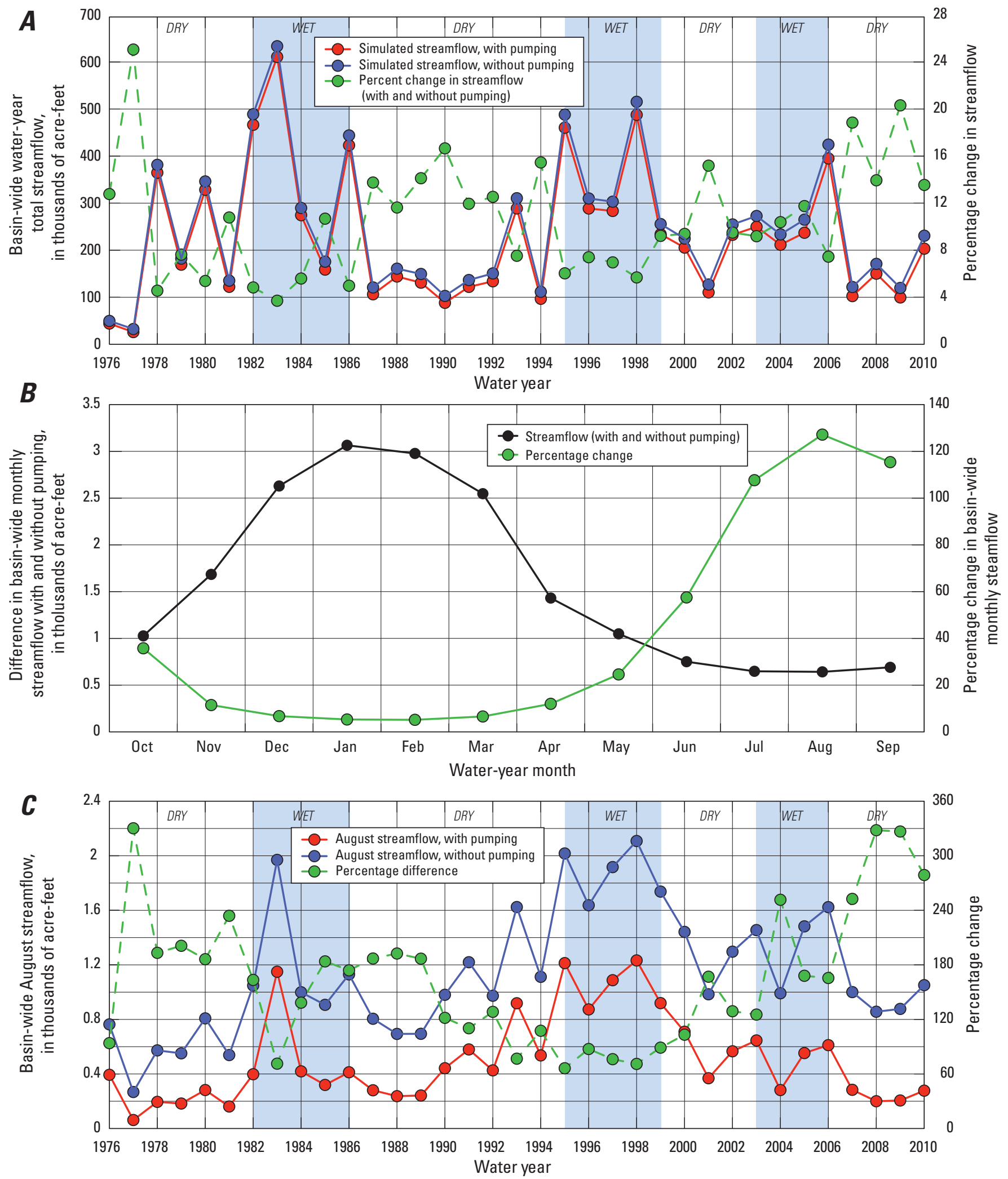

Figure 10. Comparison of basin-wide total streamflow simulated with and without pumping for water years 1976-2010, Santa Rosa Plain hydrologic model, Santa Rosa Plain watershed, Sonoma County, California: $A$, annual total streamflow; $B$, average monthly streamflow; $C$, average August streamflow. 


\section{Streamflow at Selected Gages}

In general, pumping had the greatest effect on simulated streamflow of the Laguna de Santa Rosa, the lower-most sections of the Mark West Creek, and Santa Rosa Creek subbasins (fig. 9A). Therefore, simulated results with and without pumping are presented for the COPE, LAGS, and MWCM gages.

At all three gages, the greatest relative reductions in total streamflow were during the months of July, August, and September (figs. $11 A, 12 A, 13 A$ ). Annual variability in the average simulated August streamflow for the three gages is shown in figures $11 B, 12 B, 13 B$. The upward trend in August streamflow during water years 1990-98 for the LAGS and MWCM streamgages, both with and without pumping, likely was a combined result of the introduction of reclaimed water for agricultural irrigation (which started in 1990) and greater-than-average precipitation that caused the water table to rise and groundwater discharge to streams to increase (fig. 12B, 13B). After water year 1998, drier-than-average conditions predominated; after water year 2001, application of reclaimed water for irrigation decreased, causing groundwater discharge to streams to decrease. The downward shift in the flow-duration curves for the three gages for the simulation with pumping compared with the simulation without pumping indicated a reduction in all flows, but the most pronounced relative change in streamflow was for flows less than $10 \mathrm{ft}^{3} / \mathrm{s}$ (figs. 11C, 12C, 13C).

At the COPE gage, the largest absolute reduction in average monthly streamflow from pumping was 145 acre-ft in January (fig. 11A). The largest relative reduction in average monthly streamflow (about 80 percent) was in August, although the absolute reduction in streamflow (from about $10 \mathrm{acre}-\mathrm{ft} / \mathrm{yr}$ without pumping to about 2 acre-ft/yr with pumping) was small (table 4, fig. 11A). The average annual streamflow at the COPE gage was reduced by about 13 percent, from 6,000 to 5,200 acre-ft/yr (table 4). Pumping resulted in zero flows (flows less than $0.01 \mathrm{ft}^{3} / \mathrm{s}$ ) about 25 percent of the time (fig. 11C). Peak streamflows occurred about 0.5 percent of the time and were relatively unaffected by pumping (fig. 11C).

At the LAGS gage, the largest absolute reduction in average monthly streamflow from pumping was 1,354 acre-ft in February (fig. 12A). The largest relative reduction in average monthly streamflow (about 62 percent) was in August, although the absolute reduction in streamflow (from about 290 acre-ft/yr without pumping to about 110 acre- $\mathrm{ft} / \mathrm{yr}$ with pumping) was small (table 4 , fig. 12A). The average annual streamflow at the LAGS gage was reduced by about 10 percent, from about 72,300 acre-ft/yr to 65,000 acre-ft/ yr (table 4). For the simulation with pumping, streamflow less than $0.01 \mathrm{ft}^{3} / \mathrm{s}$ occurred approximately 15 percent of the time at the LAGS gages, whereas streamflow was greater than $0.01 \mathrm{ft}^{3} / \mathrm{s}$ for the simulation without pumping more than 99 percent of the time (fig. 12C). Peak streamflows occurred about 0.5 percent of the time and were relatively unaffected by pumping (fig. 12C).
At the MWCM gage, largest absolute reduction in average monthly streamflow from pumping was 2,992 acre- $\mathrm{ft}$ in January (fig. 13A). The largest relative reduction in average monthly streamflow (about 53 percent) was in August, although the absolute reduction in streamflow (from about 1,100 acre-ft/yr without pumping to about $520 \mathrm{acre}-\mathrm{ft} / \mathrm{yr}$ with pumping) comparatively was small (table 4, fig. 13A). The average annual streamflow at the MWCM gage was reduced by about 8 percent, from about 239,000 acre-ft/yr to about 220,000 acre-ft/yr (table 4). The simulations showed no streamflows less than $0.01 \mathrm{ft}^{3} / \mathrm{s}$ (fig. 13C). Peak streamflows occurred about 0.5 percent of the time and were relatively unaffected by pumping (fig. 13C).

\section{Simulated Groundwater-Budget Components}

The SRPHM was used to estimate the effects of pumping on selected groundwater-budget components (figs. 14-16). The differences in figures $14 C, 15 C$, and $16 C$ were calculated by subtracting the component simulated without pumping from the component simulated with pumping. Therefore, negative differences indicated a reduction with pumping. For storage change, the differences greater than zero indicated greater groundwater storage change with pumping than without pumping. The results indicated that, overall, pumping primarily was associated with a decrease in groundwater discharge to streams (baseflow; fig. 14) and groundwater ET (fig. 15), and from a loss in groundwater storage (fig. 16). The inter-annual variations and multi-year trends are discussed along with a summary of the monthly variations.

\section{Annual Variations}

A decrease in groundwater levels, in response to pumping, caused a reduction in groundwater discharge to the streams (figs. 14B, C), a reduction in groundwater ET (figs. $15 B, C$ ), an increase in storage depletion (figs. $16 B, C$ ), and an increase in recharge from streams (stream leakage into the groundwater system from losing-stream reaches; figs. $17 B, C)$. The reduction in groundwater discharge to streams with pumping for water years 1976-2010 ranged from about 3,300 acre-ft/yr to about 12,000 acre-ft/yr, and averaged about 8,600 acre-ft/yr (figs. 14B, C). For groundwater ET, the annual reduction with pumping ranged from about 3,500 acre-ft to about 8,000 acre- $\mathrm{ft}$, and averaged about 6,000 acre-ft (figs. 15B, C). The cumulative reductions in groundwater discharge to streams and groundwater ET associated with pumping were about 300,000 acre-ft (fig. 14C) and 211,000 acre-ft (fig. 15C), respectively. The cumulative reduction in groundwater storage in response to pumping was about 204,000 acre-ft (fig. 16C); this included the reduction in storage of about 120,000 acre-ft with pumping and the storage accretion of about 84,000 acre-ft without pumping. The cumulative increase in recharge from streams was about 189,000 acre-ft (fig. 17C). 

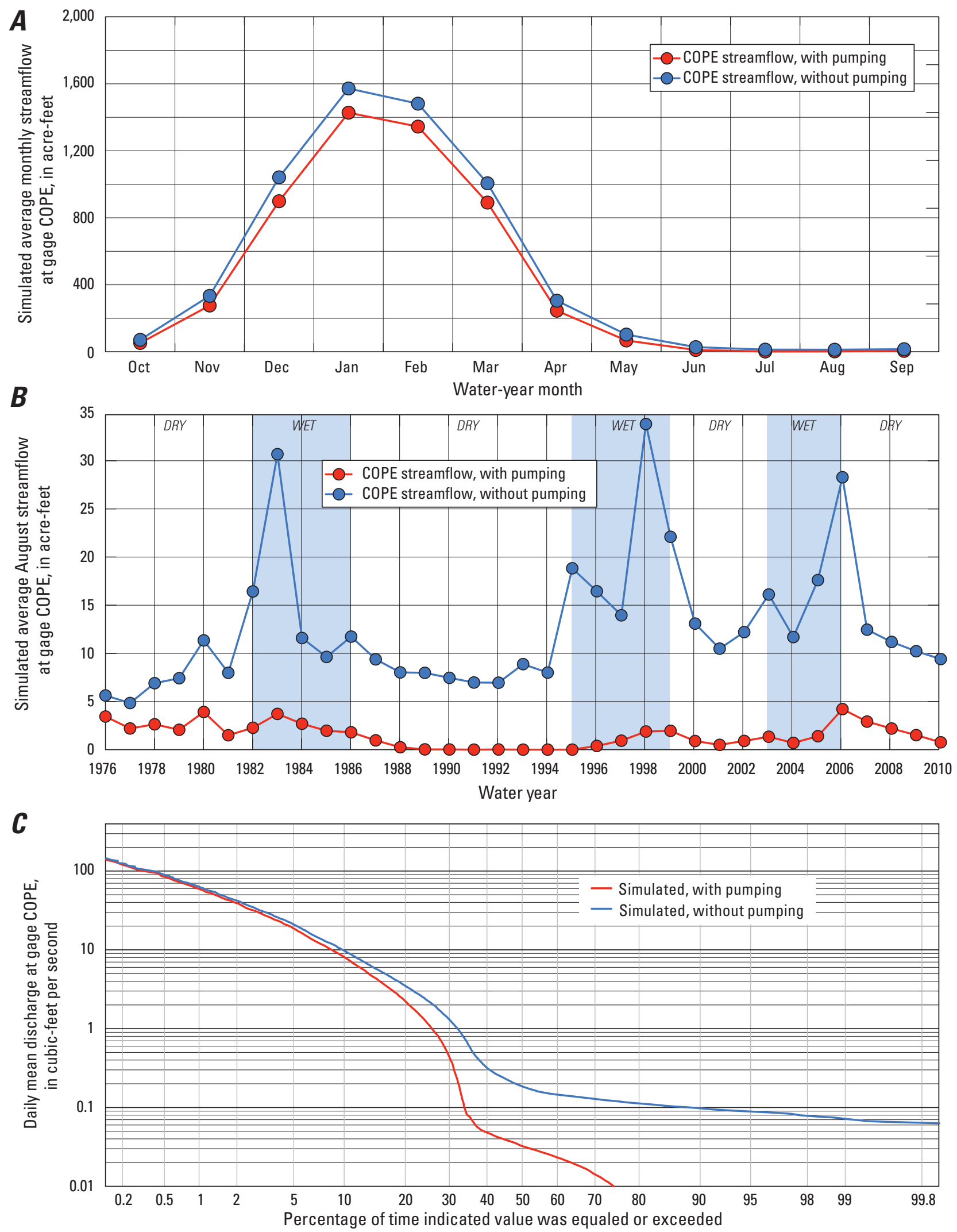

Figure 11. Comparison of streamflow simulated with and without pumping at the Copeland Creek at Rohnert Park (COPE) gage, water years 1976-2010, Santa Rosa Plain hydrologic model, Santa Rosa Plain watershed, Sonoma County, California: A, average monthly streamflow; $B$, average August streamflow; $C$, flow-duration curve for daily mean discharge. 

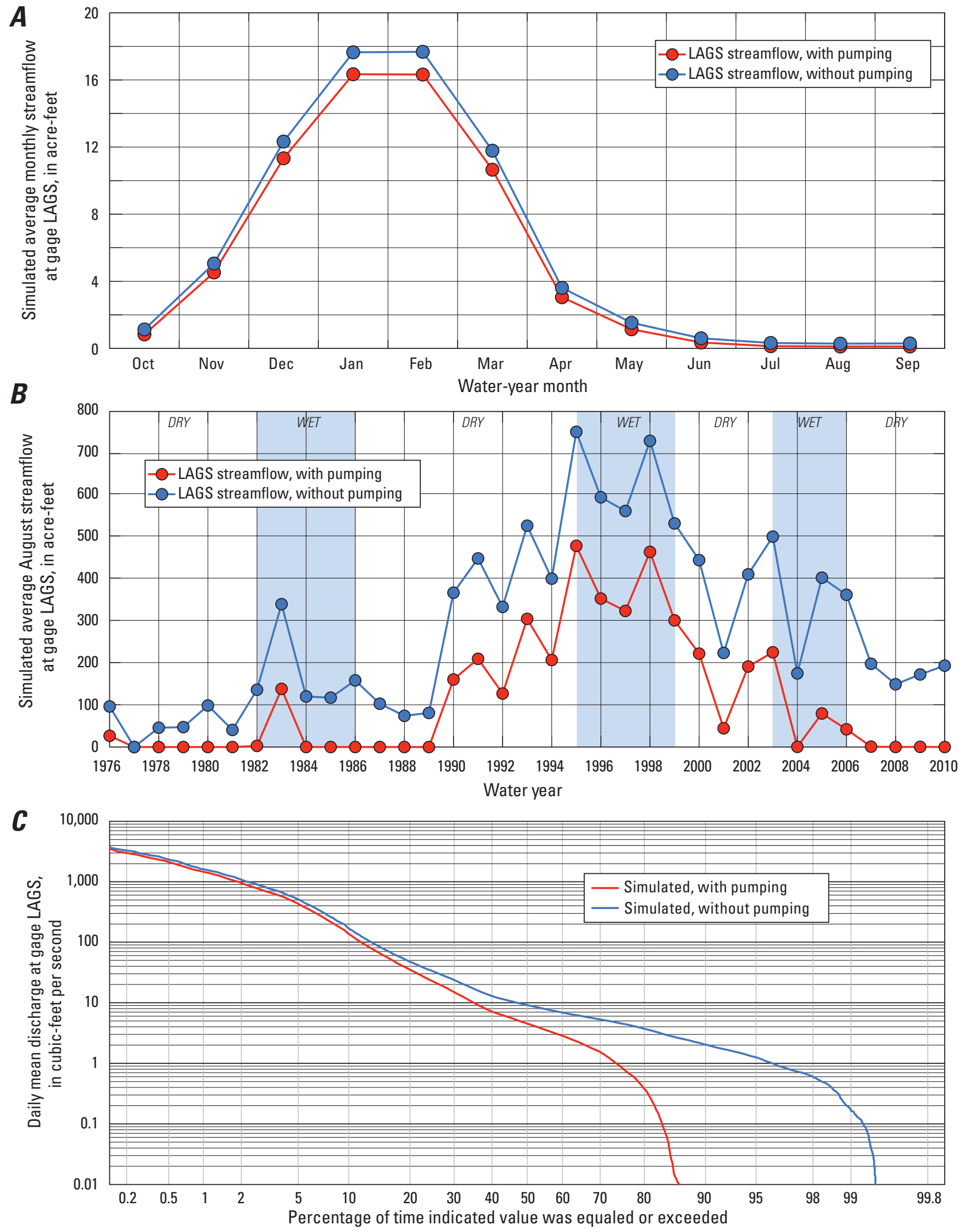

Figure 12. Comparison of streamflow simulated with and without pumping at the Laguna de Santa Rosa near Sebastopol (LAGS) gage, water years 1976-2010, Santa Rosa Plain hydrologic model, Santa Rosa Plain watershed, Sonoma County, California: A, average monthly streamflow; $B$, average August streamflow; $C$, flow-duration curve for daily mean discharge. 

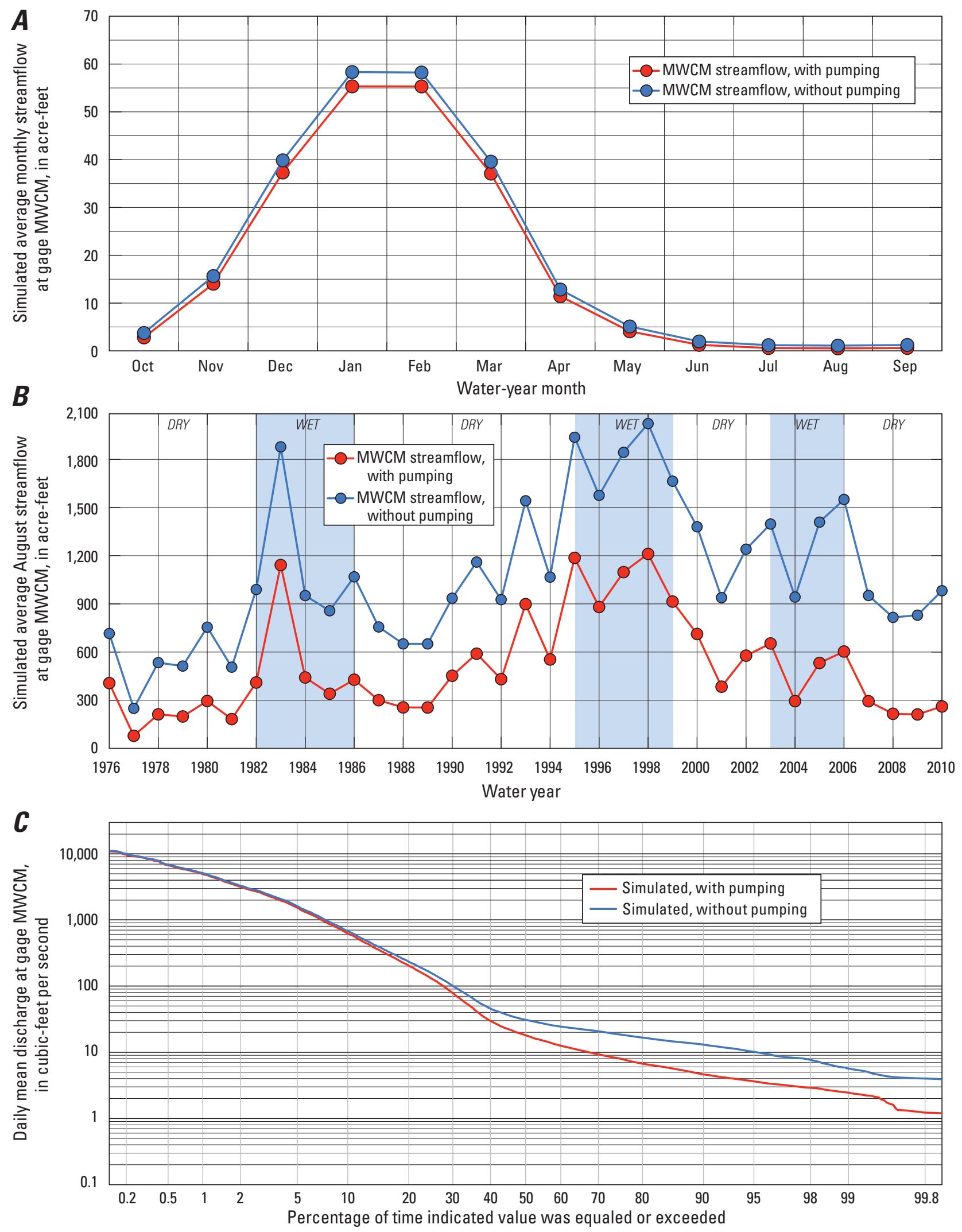

Figure 13. Comparison of streamflow simulated with and without pumping at gage Mark West Creek near Mirabel Heights (MWCM), water years 1976-2010, Santa Rosa Plain hydrologic model, Santa Rosa Plain watershed, Sonoma County, California: $A$, average monthly streamflow; $B$, average August streamflow; $C$, flow-duration curve for daily mean discharge. 
A

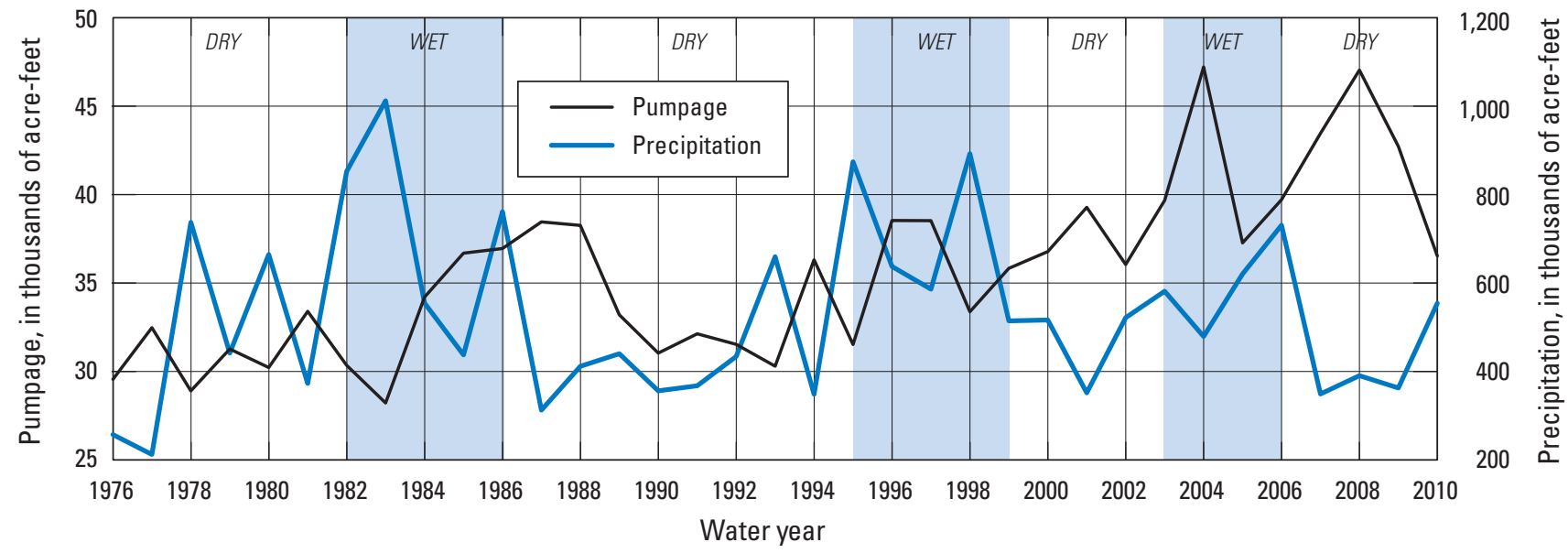

$B$

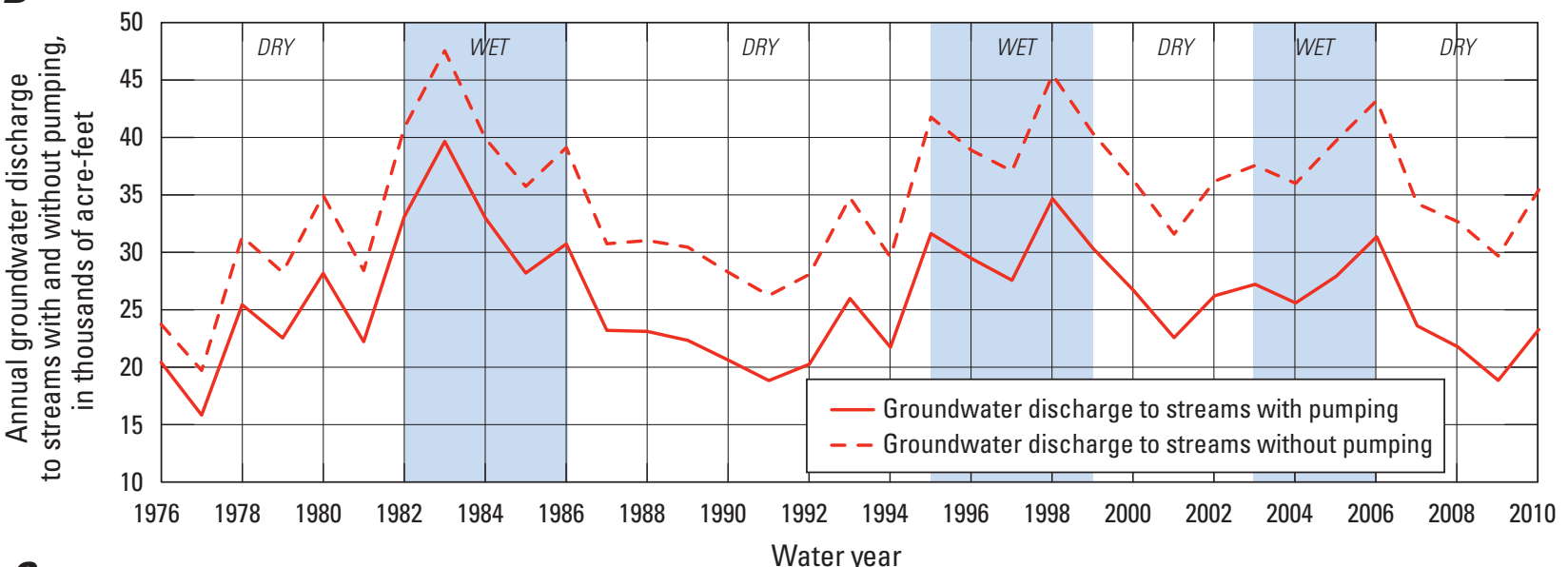

C

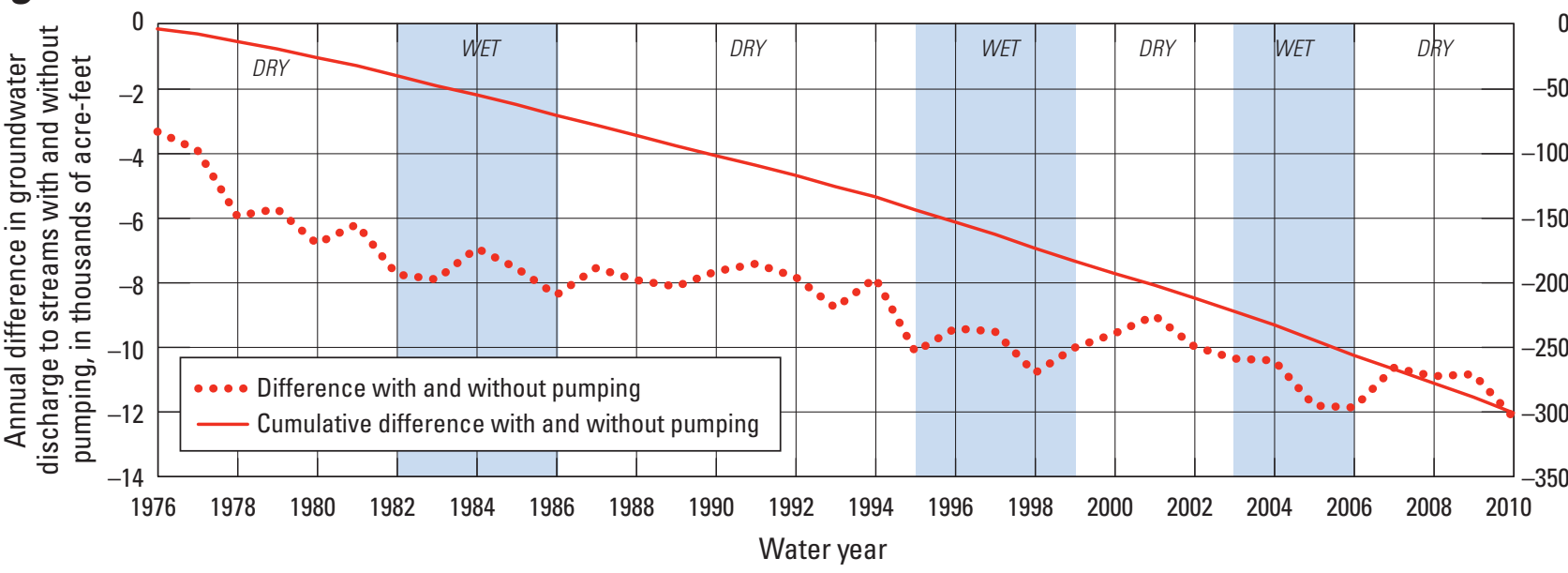

Figure 14. Values for components of the Santa Rosa Plain hydrologic model, Santa Rosa Plain watershed, Sonoma County, California, for water years 1976-2010, demonstrating the effects of pumping on simulated groundwater discharge to streams: $A$, annual precipitation and groundwater pumpage; $B$, annual groundwater discharge to streams simulated with and without pumping; $C$, annual and cumulative differences in groundwater discharge to streams simulated with and without pumping. 
$\boldsymbol{A}$

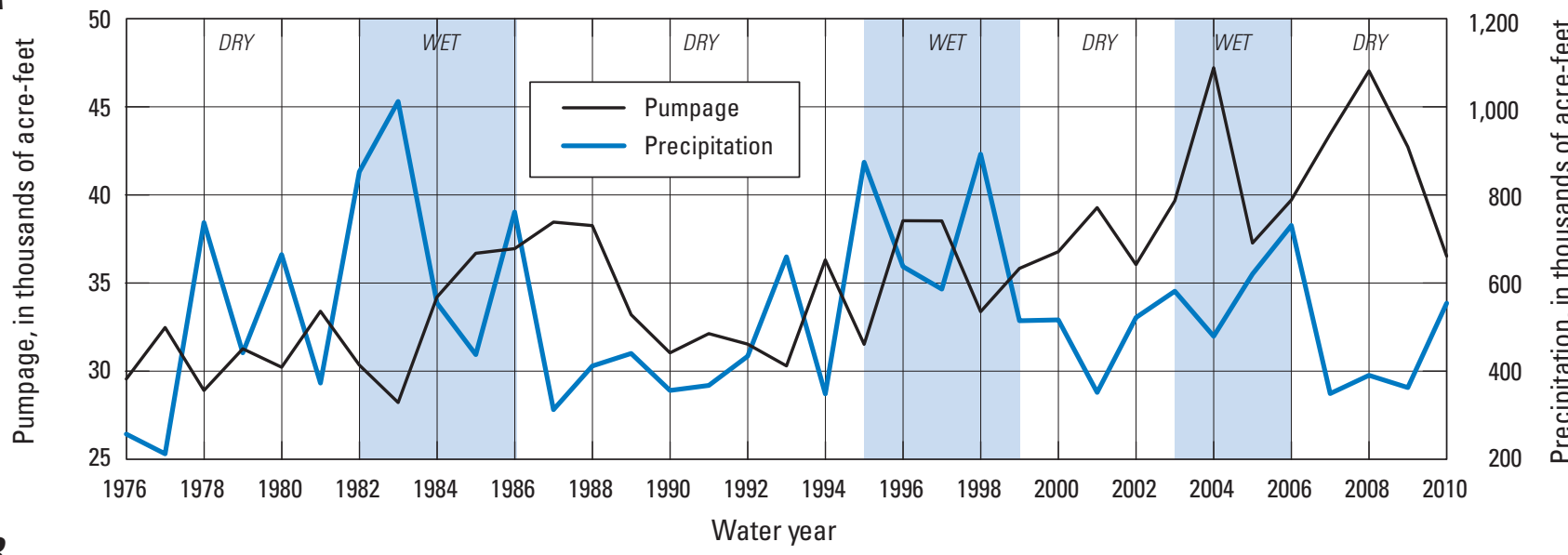

B

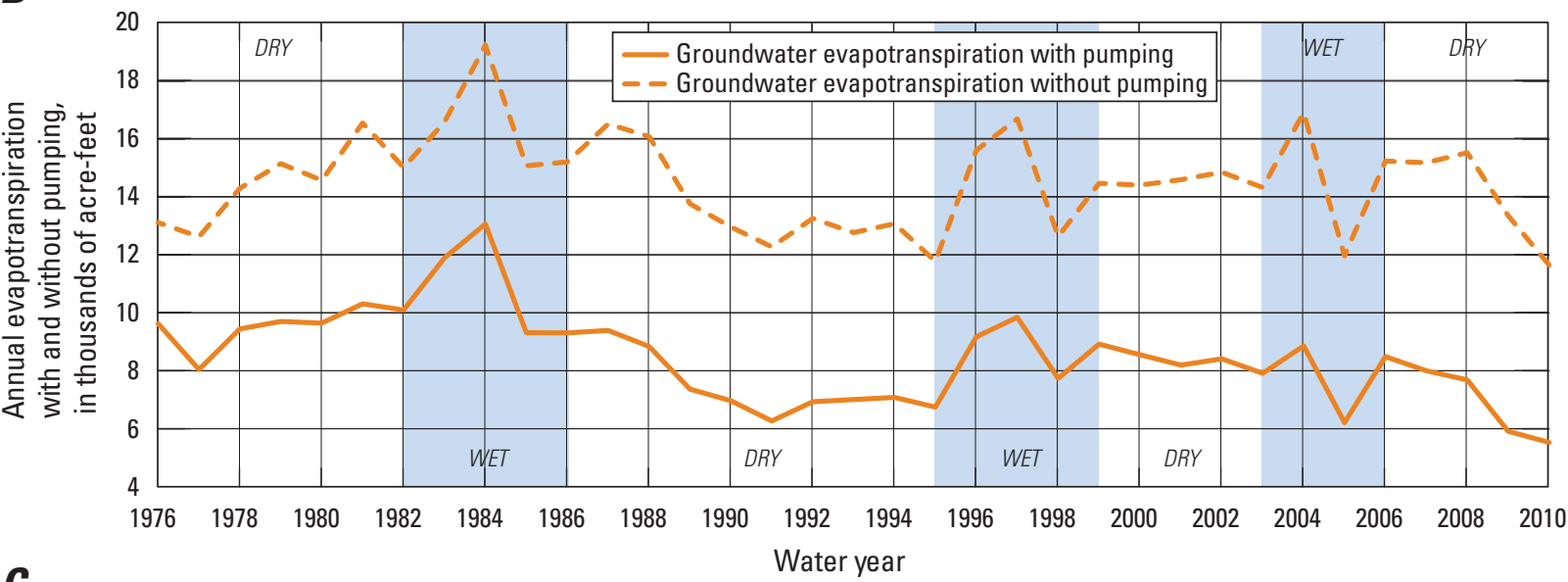

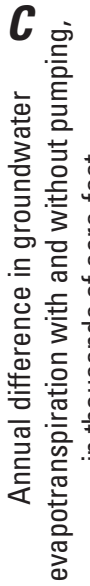

Water year

Figure 15. Values for components of the Santa Rosa Plain hydrologic model, Santa Rosa Plain watershed, Sonoma County, California, for water years 1976-2010: $A$, annual precipitation and groundwater pumpage; $B$, annual groundwater evapotranspiration simulated with and without pumping; $C$, annual and cumulative differences in groundwater evapotranspiration simulated with and without pumping. 
$\boldsymbol{A}$

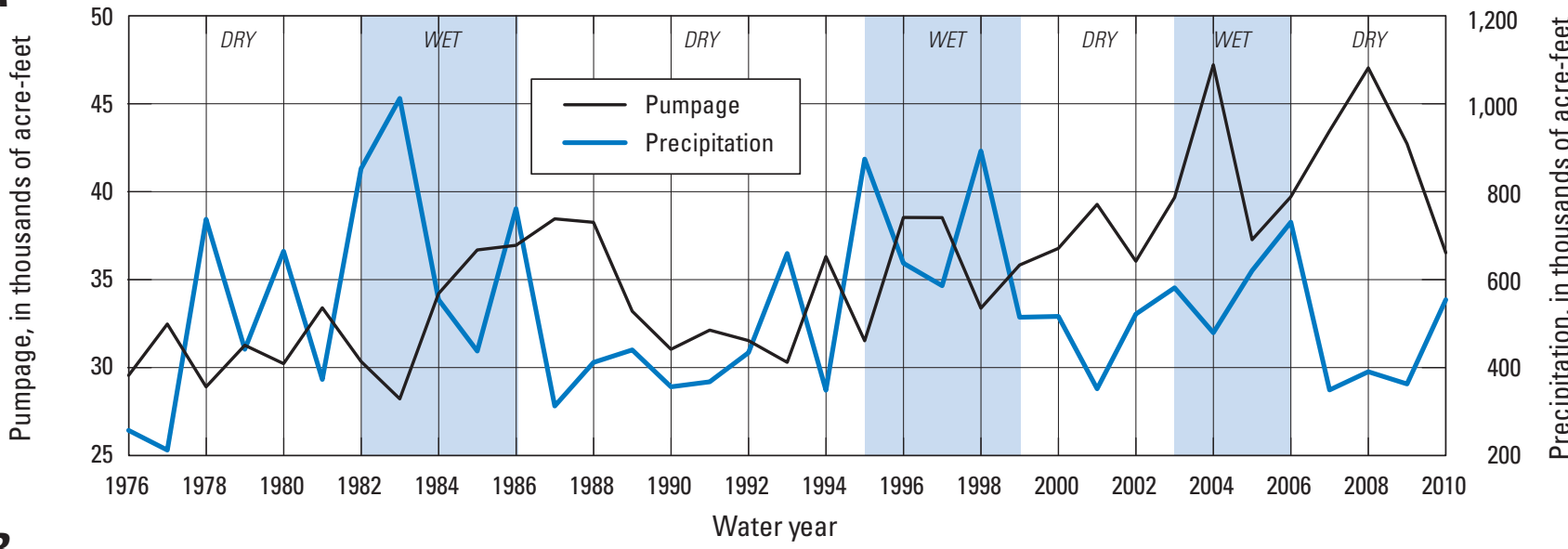

$\boldsymbol{B}$

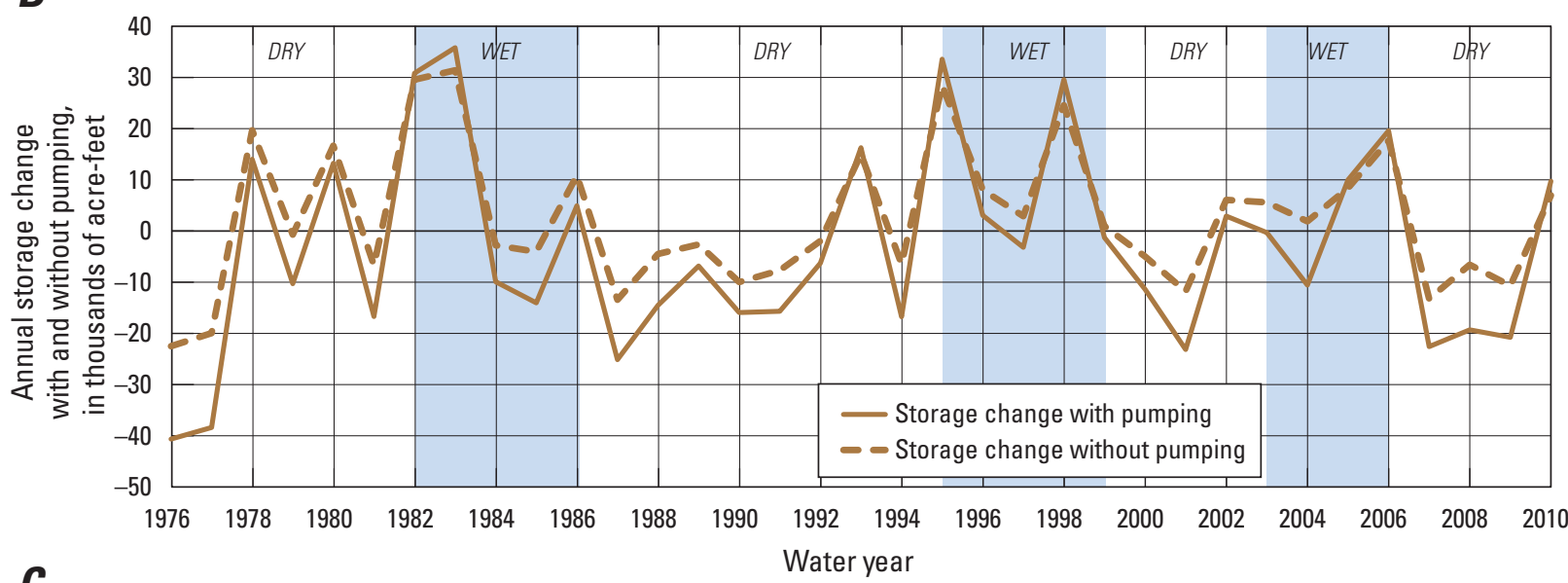

C

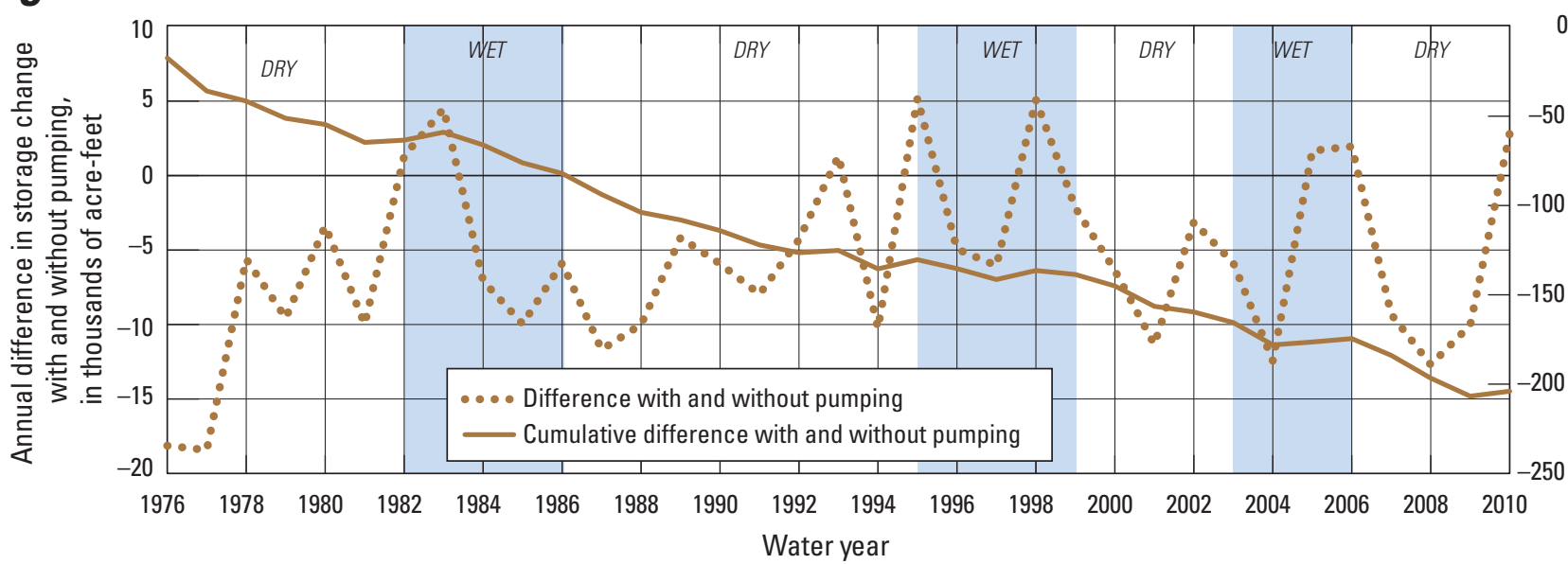

Figure 16. Values for components of the Santa Rosa Plain hydrologic model, Santa Rosa Plain watershed, Sonoma County, California, for water years 1976-2010: $A$, annual precipitation and groundwater pumpage; $B$, annual groundwater storage change simulated with and without pumping; $C$, annual and cumulative differences in groundwater storage change simulated with and without pumping. 
$\boldsymbol{A}$

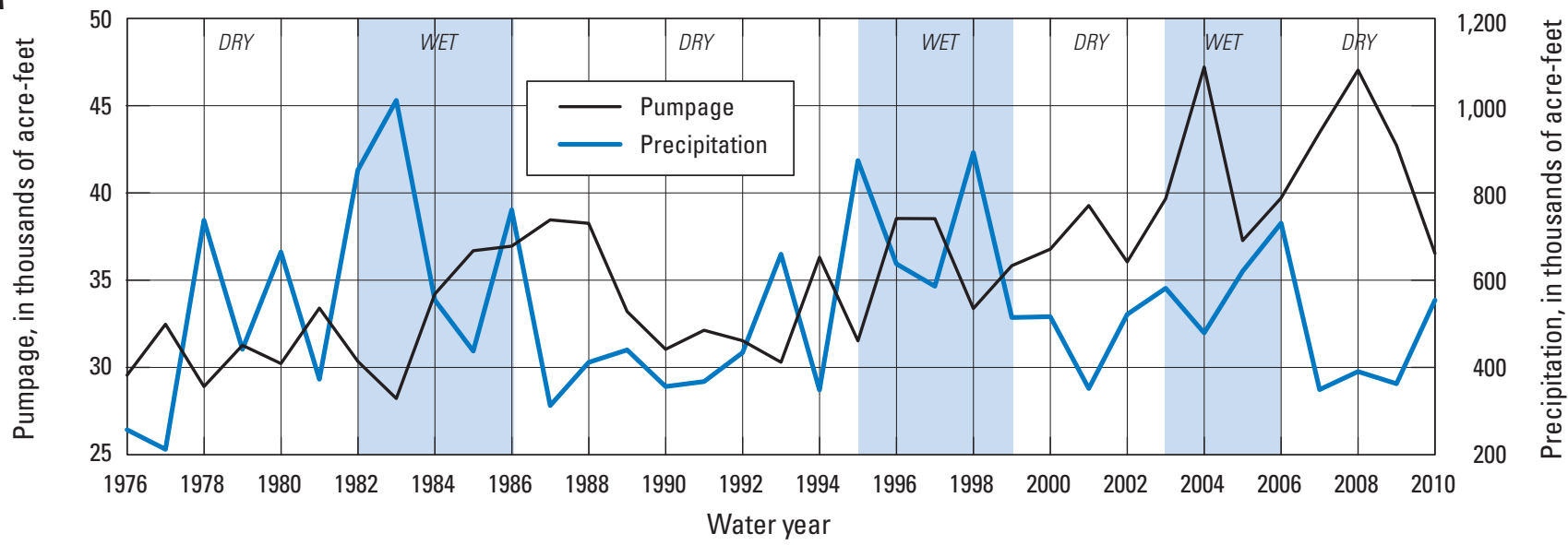

$\boldsymbol{B}$
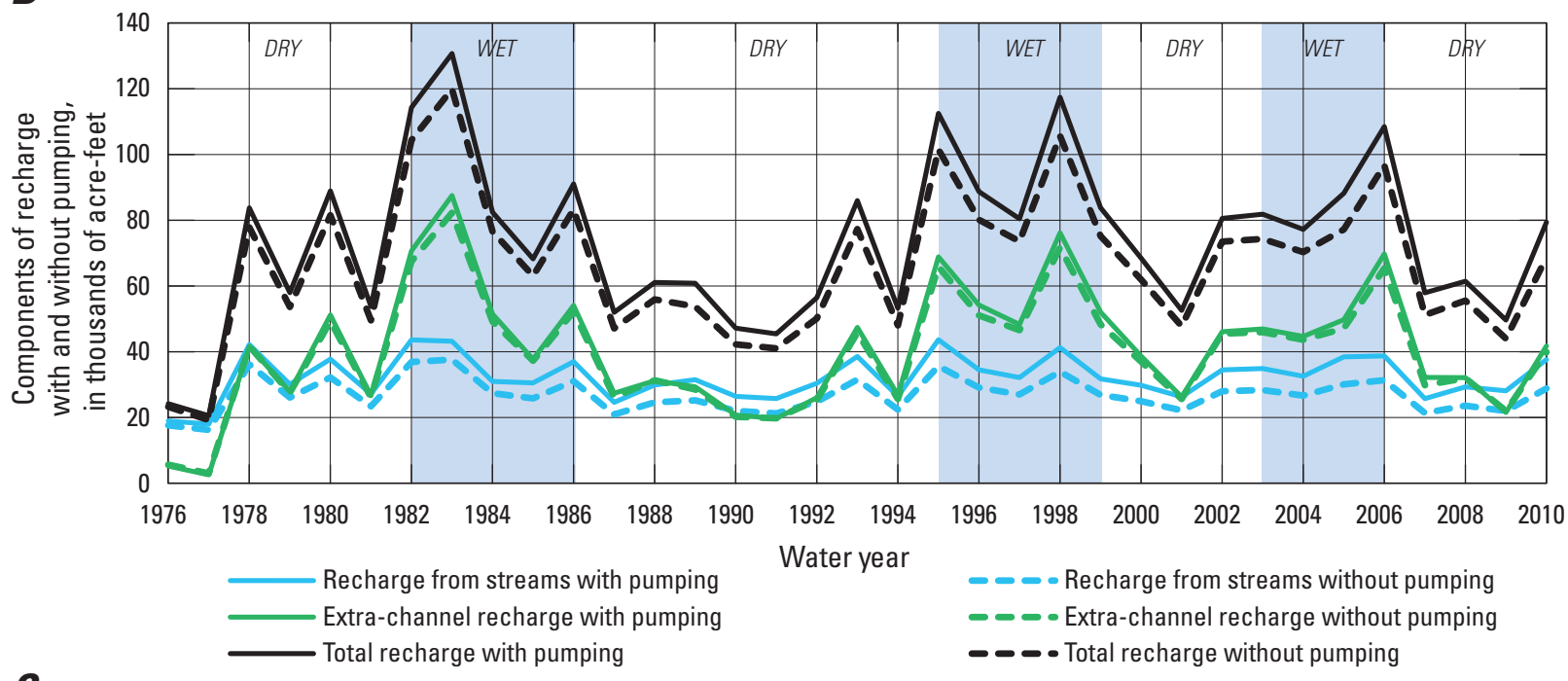

C

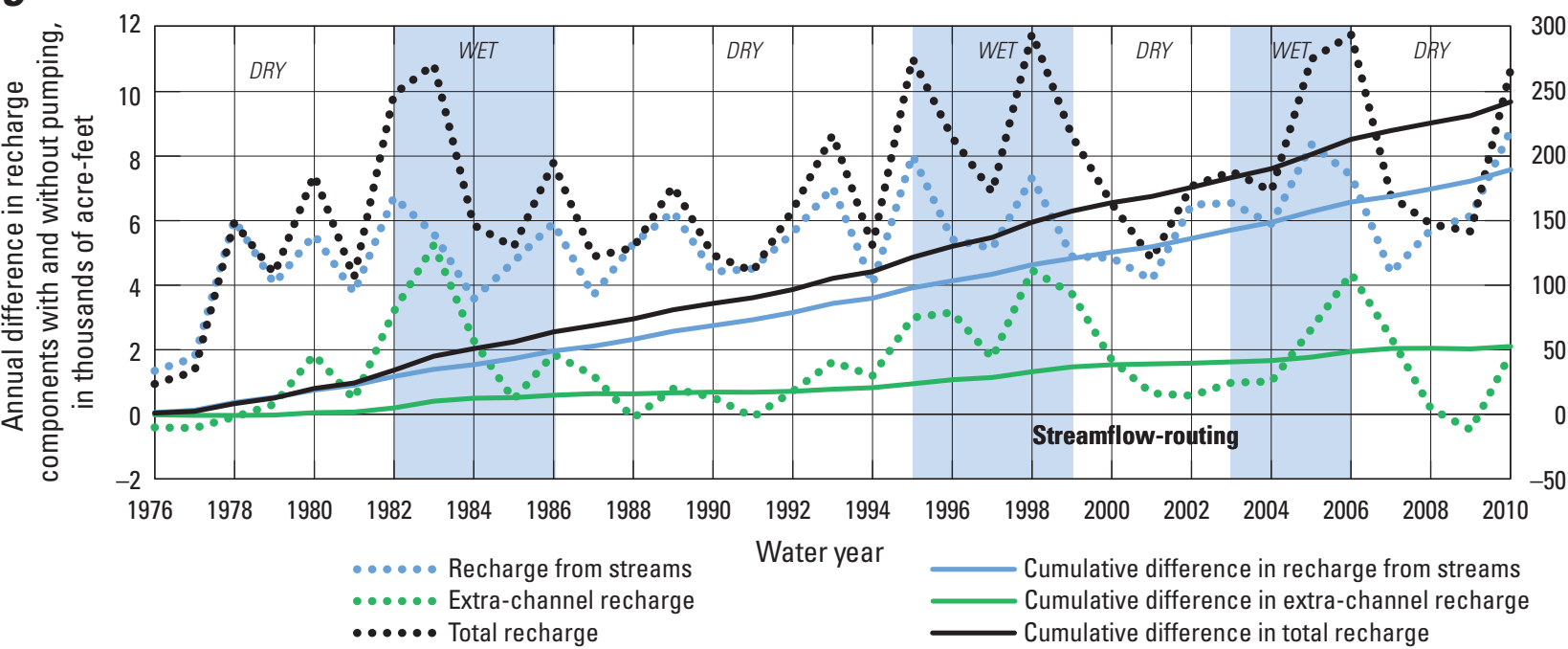

Figure 17. Values for components of the Santa Rosa Plain hydrologic model, Santa Rosa Plain watershed, Sonoma County, California for water years 1976-2010: A, annual precipitation and groundwater pumpage; B, annual total recharge, extra-channel recharge, and recharge from streams simulated with and without pumping; $C$, annual and cumulative differences in total recharge, extra-channel recharge, and recharge from streams simulated with and without pumping. 
The inter-annual variation in storage change with and without pumping generally followed the variation in precipitation (figs. 16A, B). After water year 1998, the multi-year trend in storage change with pumping was inverse to that of pumpage (fig. 16B). For most years during the simulation period, more groundwater was depleted from storage with pumping (more negative values) than without pumping (fig. 16B). There were some years (water years 1982, 1983, 1993, 1995, 1998, 2005,2006 , and 2010), however, when groundwater storage increased more with pumping than without pumping. These years followed dry periods, when a decline in water levels with pumping created more storage capacity than without pumping, thereby allowing greater recharge during subsequent wet years.

Simulated recharge, including extra-channel and recharge from streams, was compared for simulations with and without pumping. Recharge in this context differs from net recharge described in the "Net Flux" section of this chapter in that it is not reduced by outflows at the surface of the water table. Extra-channel recharge was the greatest component of total recharge, and the simulated results indicated that total recharge and extra-channel recharge primarily varied with annual precipitation (figs. 17A, $B$ ). Average extra-channel recharge was about 1,500 acre-ft/yr greater with pumping than without pumping (fig. 17C). Extra-channel recharge was slightly greater without pumping for water years 1976-1978, 1988, 1991, and 2009 (fig. 17B). All these water years, except water year 1978, had less-than-average precipitation. Water year 1978 was preceded by a 2-year drought, and recharge from increased precipitation in water year 1978 was insufficient to compensate for the prior decline in water levels.

The difference between recharge from streams with and without pumping ranged from 1,300 acre-ft for water year 1976 to about 8,800 acre-ft for water year 2010, and averaged about 5,400 acre-ft/yr more with pumping than without pumping for water years 1976-2010 (fig. 17B, 17C). The generally upward multi-year trend for both pumpage and the difference in recharge from streams with and without pumping (figs. $17 \mathrm{~A}, 17 \mathrm{C}$ ) reflect that recharge from streams is induced by pumping. The cumulative difference in recharge from streams indicated that pumping increased recharge from streams by about 190,000 acre-ft (fig. 17C).

\section{Monthly Variations}

The monthly variation in precipitation and pumpage affected groundwater discharge to streams, groundwater $\mathrm{ET}$, the amount of water in storage, and the components of recharge (fig. 18). As mentioned previously, total streamflow was primarily composed of groundwater discharge to streams in the summer months, and the relative reduction from pumpage was greater in summer than in the winter months (fig. 10B). Although a greater percentage of groundwater discharge to streams was reduced by pumping during the summer months (fig. 10B), the absolute reduction in groundwater discharge to streams with pumping was greater during the winter months (January, February, and March; fig. 18B). Pumping caused an average decrease in groundwater discharge to streams of about 900 acre-feet per month (acre-ft/mo) during the winter months compared with about $530 \mathrm{acre}-\mathrm{ft} / \mathrm{mo}$ during the summer months (July, August, and September; figs. 18B). Groundwater discharge to streams with pumping was greater in the winter months than in the summer months because groundwater levels were higher in the winter months.

Results for simulated groundwater ET indicated the greatest effect of pumping was during the summer months, when monthly reductions in ET averaged about 1,200 acre-ft/mo, compared with about 400 acre-ft/mo during the winter months (figs. 18C). The higher ET in summer primarily reflected higher PET compared with the winter months. Although the absolute reduction in groundwater ET was less during the winter months, a greater percentage of ET was reduced with pumping during these months.

As would be expected, the amount of groundwater in storage increased during the winter and decreased during the summer (fig. 18D). Comparison of the average monthly results for storage change with and without pumping indicated that during the winter months, there was a greater increase in storage with pumping than without pumping (figs. 18D) due to greater recharge and more available storage capacity from summer and fall pumping. During the summer months, storage was more depleted with pumping than without pumping (fig. 18D). Pumping resulted in an average increase in groundwater storage of about 1,000 acre-ft/mo during the winter months compared with an average decrease of about 2,800 acre-ft/mo during the summer months (figs. 18D).

Simulated results indicated that pumping affected recharge from streams the greatest during the winter months, causing an average increase of about $850 \mathrm{acre}-\mathrm{ft} / \mathrm{mo}$ compared with an average of about $100 \mathrm{acre}-\mathrm{ft} / \mathrm{mo}$ during the summer months. (fig. 18E). The greater recharge from streams in the winter months likely was the result of higher precipitation and streamflow for these months in conjunction with a general lowering of the water table associated with pumping (figs. $18 A, D$ ), which creates more losing stream reaches than were present without pumping. The peak recharge from streams occurred in January, while the peak for the extra-channel recharge occurred in March with and without pumping (fig. 18E), indicating that more time was required for extra-channel recharge to reach the water table than for recharge from streams. 
$\boldsymbol{A}$

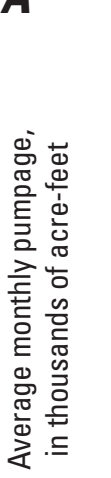

6

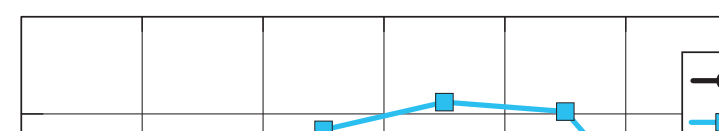

5

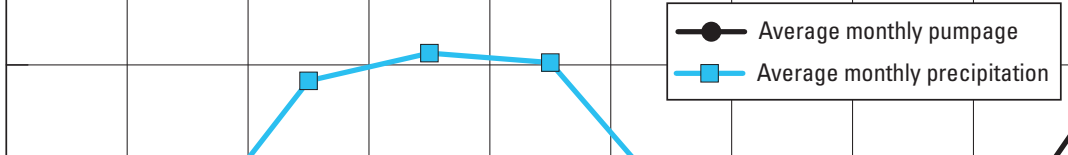

4

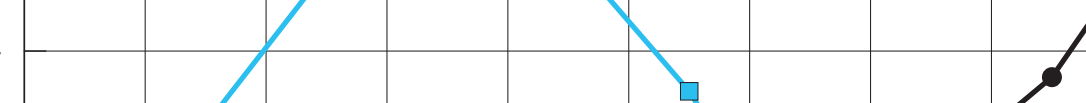

3

3

2

9

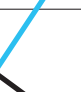

?

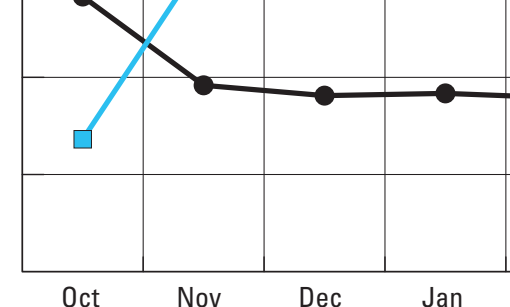

0

Nov

Water-year month

B

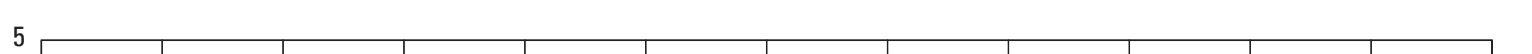

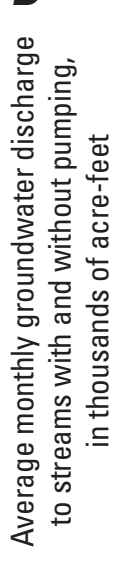

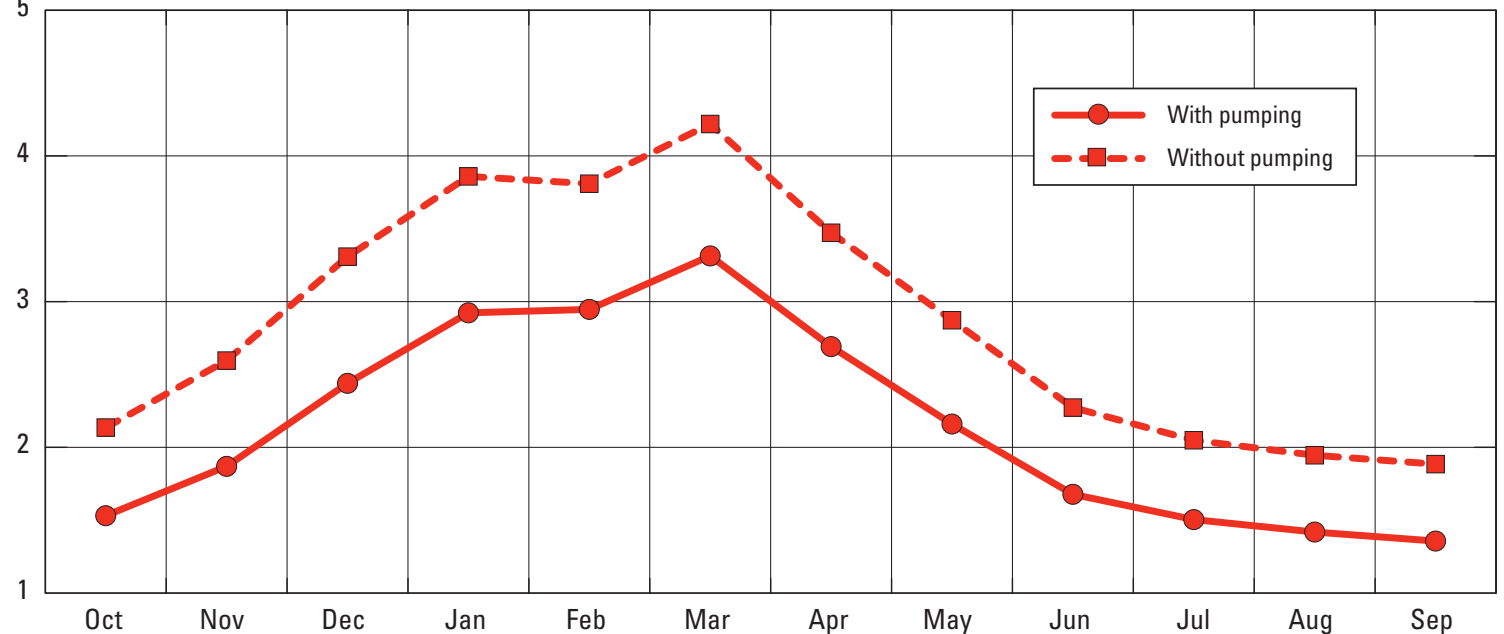

C

Water-year month

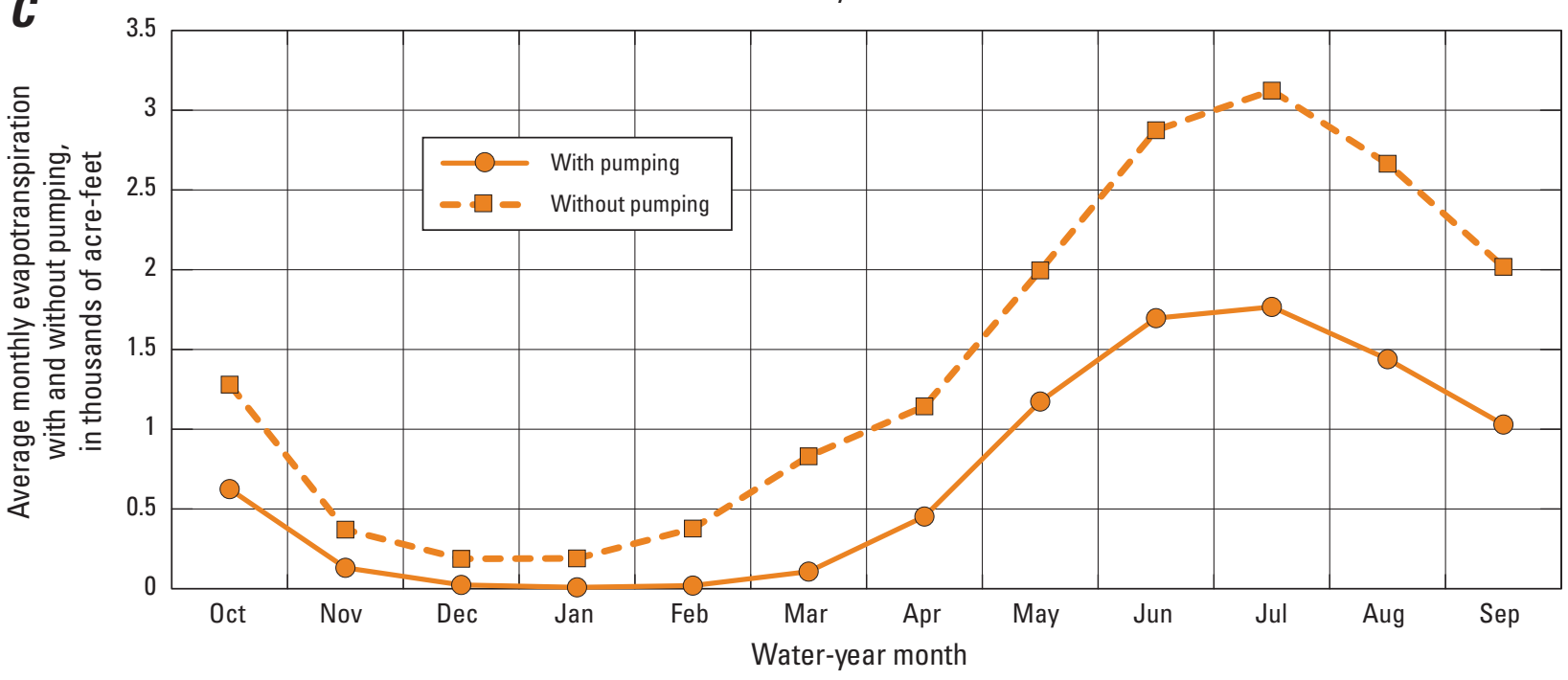

Figure 18. Average monthly values and results of simulations with and without pumping for the Santa Rosa Plain hydrologic model, Santa Rosa Plain watershed, Sonoma County, California, water years 1976-2010, for $A$, pumping and precipitation; $B$, groundwater discharge to streams; $C$, groundwater evapotranspiration; $D$, groundwater-storage change; $E$, recharge components. 

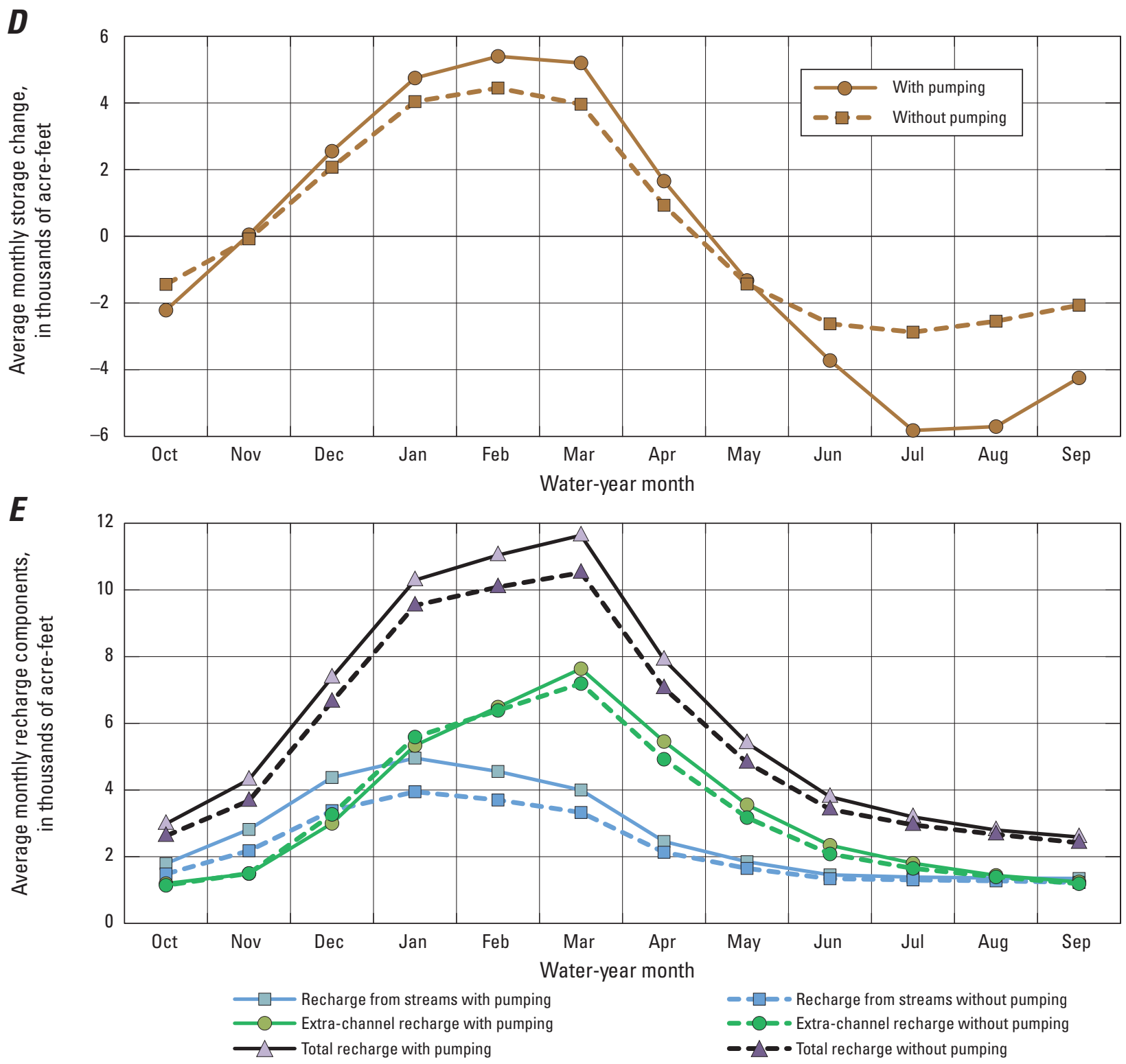

Figure 18. -Continued 


\section{Simulated Groundwater Flow Between Model Layers}

Comparison of the SRPHM results with and without pumping can be used to assess the effect of pumping on flow between model layers in the SRPHM. These results can quantify, for example, the amount of downward vertical flow from shallow depths that was induced by deeper pumping, which could reduce groundwater discharge to streams by pumping near streams or reduce the production capacity of wells if water levels drop into or below shallow perforated intervals. Figure 19 shows average annual pumpage in model layers 2-8 and groundwater flow from model layer 1 to underlying layers with and without pumping. The general trend for downward vertical flow between the layers was flat without pumping and showed little inter-annual variation, indicating that changes in climatic conditions had little effect on flow between layer 1 and underlying layers and that the low-conductivity of layer 2 effectively impeded flow between layer 1 and the underlying layers. An upward trend with pumping indicated that, as pumping in layers 2-8 increased, downward vertical flow from layer 1 to the underlying layers increased (fig. 19). With pumping, inter-annual variation in quantities of flow from layer 1 to underlying layers generally followed inter-annual variation and multi-year trend in pumpage, with some attenuation (fig. 19). The flow from layer 1 to underlying layers with pumping averaged about 11,400 acre-ft/yr and ranged from about 7,000 acre-ft in water year 1976 to about 15,200 acre-ft in water year 2004. In comparison, the flow from layer 1 to the underlying layers without pumping averaged about $1,700 \mathrm{acre}-\mathrm{ft} / \mathrm{yr}$ and ranged from 1,600 acre-ft for water year 1977 to about 2,000 acre-ft in water year 1983.

\section{References Cited}

Barlow, P.M., and Leake, S.A., 2012, Streamflow depletion by wells - Understanding and managing the effects of groundwater pumping on streamflow: U.S. Geological Survey Circular 1376, 84 p., http://pubs.usgs.gov/circ/1376/.

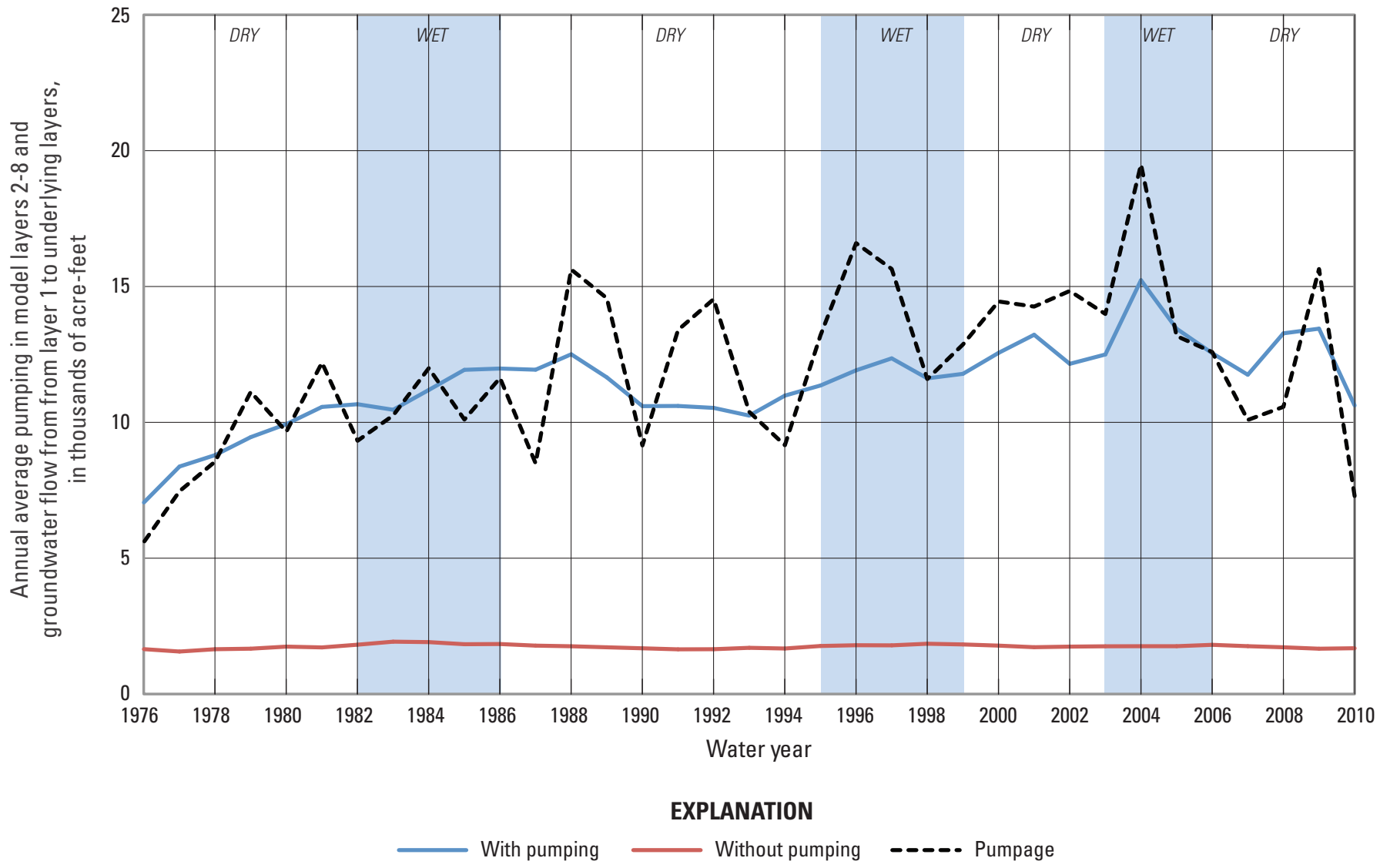

Figure 19. Effect of pumping in model layers 2-8 on flow from model layer 1 to the underlying layers of the Santa Rosa Plain hydrologic model, Santa Rosa Plain watershed, Sonoma County, California. 
This page intentionally left blank. 


\section{Chapter F. Santa Rosa Plain Hydrologic Model Scenarios}

\author{
By Joseph A. Hevesi and Linda R. Woolfenden
}

\section{Introduction}

The climate has been changing in California at a rapid pace for at least a decade (2000-10) in comparison to the previous 50 years (Flint and Flint, 2012). An important objective for developing the Santa Rosa Plain hydrologic model (SRPHM) was to simulate the response of the hydrologic system to potential changes in climate. Climate change could result in long-term changes in precipitation and temperature, which, in turn, would affect water demand, potential evapotranspiration (PET), and runoff patterns. The net effect can be a change in demand for groundwater; therefore, the SRPHM was used to assess the potential combined hydrologic effects of projected pumping and climate change. This was done by comparing simulations that included different climate change scenarios used in future climate projections to a simulated historical-climate baseline period. The historical-climate baseline period was water years 1981-2010. This 30-year period was selected to match the 30 -year periods used to analyze the simulated future-climate results.

The hydrologic effects of climate change were evaluated by comparing SRPHM-simulated annual and monthly water-budget results for the future-climate scenarios without pumping to those for the historical-climate baseline period. In addition, simulated water-budget components and groundwater levels for the future-climate scenarios for three 30-year periods (water years 2011-40, 2041-70, and 2070-99) were compared with results for the historical-climate baseline period.

The SRPHM was applied to evaluate the potential effects of four potential future-climate scenarios on the Santa Rosa Plain watershed (SRPW) hydrologic system; these scenarios are discussed in the next section of this chapter. The model was run continuously from water year 2005 through water year 2099 for the future-climate scenarios. Water years 2005-10 were used as a "spin-up" period for the futureclimate simulations and are not included in the analysis of results. In addition, the estimates of projected public-supply, agricultural, and domestic pumpage were combined with the future-climate scenarios to simulate possible future hydrologic conditions during water years 2011-40.

\section{Future-Climate Scenarios}

Global-climate models (GCMs) incorporate projections of greenhouse-gas emissions to simulate changes in climate-manifested properties, such as air temperature and precipitation (Flint and Flint, 2012). The results from four GCM scenarios, in the form of projected air temperature and precipitation records, were used to develop alternate 100-year projections of future climate. These scenarios included potential trends in climate as well as climate variability and cycles superimposed on the long-term climate changes. The futureclimate scenarios used in this study were 100 -year projections of daily precipitation and daily maximum and minimum air temperature simulated by two GCMs.

\section{Selection of Scenarios}

On the basis of previous studies and background information presented in Flint and Flint (2012), four future-climate scenarios, developed by using two GCMs and two greenhouse-gas emission scenarios, were selected for use in this study. The two GCMs are (1) the National Oceanic and Atmospheric Administration (NOAA) Geophysical Fluid Dynamics Laboratory (GFDL) GCM and (2) the Parallel Circulation Model (PCM) GCM (Flint and Flint, 2012). The two greenhouse gas-emission scenarios are (1) A2, a mediumhigh emission scenario, and (2) B1, a low-emission scenario (Flint and Flint, 2012). The combination of GCMs and carbon dioxide $\left(\mathrm{CO}_{2}\right)$ emission scenarios provided the following four future-climate scenarios: (1) the GFDL A2 scenario (referred to as GA2), (2) the GFDL B1 scenario (referred to as GB1), (3) the PCM A2 scenario (referred to as PA2), and (4) the PCM B1 scenario (referred to as PB1). For additional information regarding the GCMs and the greenhouse gas emission scenarios, see Flint and Flint (2012).

\section{Downscaling and Bias Correction to Study Area}

Results for the GA2, GB1, PA2, and PB1 future-climate scenarios, consisting of daily precipitation and maximum and minimum daily air temperature, are available on a 2-degree spatial scale, which is approximately 250 -kilometers $(\mathrm{km})$ in northern California (Flint and Flint, 2012). Results on the 2-degree spatial scale generally do not provide a good representation of climate conditions on the more local scale of watersheds, such as the SRPW. Downscaling of GCM results to the watershed scale was done to represent local-scale variability in climate better, which was especially important in an area like the SRPW, where topography and proximity to the coast strongly affect climate. Downscaling refers to statistical techniques that convert model output with coarse spatial scales (hundreds of kilometers or miles) to much finer scales (hundreds of meters or feet; Flint and Flint, 2012). 
The methodology presented by Flint and Flint (2012) was used to downscale daily precipitation and maximum and minimum daily air temperature from the 2-degree GCM output to the 660 -foot (ft) grid scale of the SRPHM; the downscaling was completed in three steps. The first step consisted of using the constructed analogs method of Hidalgo and others (2008) to downscale the GCM output to a $12-\mathrm{km}$ grid scale for the United States. The second step consisted of downscaling from the $12-\mathrm{km}$ grid to a 270 -meter $(\mathrm{m})$ grid by using a spatial gradient and inverse-distance-squared interpolation model developed by Nalder and Wein (1998), allowing for the incorporation of monthly Parameter Regression on Independent Slopes Model (PRISM) data (Daly and others, 2004) at a 4-km grid scale in order to represent local-scale variability in climate better relative to topography (Flint and Flint, 2012). The third step in the downscaling process consisted of mapping the results for the 270-m (886-ft) grid to the 660-ft grid of the SRPHM by using inverse-distance-squared interpolation.

The GCM results were not calibrated to match the current climate. Rather, the results from GCMs needed to be adjusted, or "bias-corrected," so that the projected future trend in climate begins with conditions representative of the current climate for the area of interest (Flint and Flint, 2012). The bias correction was done following the methodology presented in Flint and Flint (2012), where the monthly PRISM grids were used with the 1950-2000 baseline-climate output available for the GCMs. The bias correction was done as part of the downscaling procedure using the intermediate, 4-km grid scale of the PRISM grids and required adjustment of the 12-km GCM output so that baseline GCM results matched the mean and standard deviation of the historical data (Flint and Flint, 2012). For each climate scenario, the combined downscaling and bias-correction processing of the GCM output resulted in a unique continuous daily time series of precipitation and maximum and minimum air temperatures for water years 2005-99 mapped to each hydrologic response unit (HRU) of the SRPHM. Downscaling and bias-correction processes may add uncertainty in the future-climate scenarios; therefore, application of the SRPHM using these future-climate scenarios is useful for evaluating long-term trends, annual variability and cycles, seasonal variability, and daily variability rather than the magnitude of hydrologic response. A summary of climate inputs to the SRPHM for this period is given in table 1.

\section{Future-Climate Precipitation}

The time series of total annual precipitation for the future-climate scenarios, spatially averaged over the area of the SRPW, showed many characteristics similar to the historical-climate baseline (water years 1981 to 2010) for all four scenarios, but also showed some differences that could have important consequences for the SRPW (fig. 1). The GA2 future-climate scenario was characterized by a relatively flat trend in precipitation followed by a trend of decreasing precipitation from water years 2062-95, as indicated by the 10 -year moving average (fig. $1 A$ ). The 10 -year moving average for scenario GA2 also was drier than any 10 -year average in the historical-climate baseline as well as the other futureclimate scenarios. Of the four future-climate scenarios, the GA2 had the lowest 95-year average precipitation (table 1) and was drier than the historical-climate baseline of water years 1981-2010 (table 1).

For the previous and upcoming discussions, the 10-year moving average used in this work is calculated as described by Manning (1987). Some know this as an "endpoint" moving average or a "simple" moving average.

The GB1 future-climate scenario displayed a weak trend of decreasing precipitation, as indicated by the 10 -year moving average (fig. $1 B$ ). There was, however, a period of high precipitation from water years 2018-22 (fig. 1B). Despite this period of higher precipitation, the 95-year average precipitation rate for the GB1 scenario was less than the average precipitation for the baseline period, similar to the GA2 scenario (table 1). Annual precipitation for the GB1 scenario was more variable than the historical-climate baseline, especially during the early part of the 95 -year period (fig. $1 B$ ), as indicated by a higher standard deviation for the 95-year simulation period and for the first two 30-year periods (table 1).

The PA2 and PB1 future-climate scenarios also showed increased variability in precipitation compared with the historical-climate baseline (fig. 1; table 1). The 95-year average annual precipitation for the PA2 scenario was the same as the historical-climate baseline; however, the scenario had a greater standard deviation (table 1), indicating greater variability. The 10-year moving average indicated a weak upward trend in annual precipitation after water year 2075 (fig. 1C). The PB1 scenario was the wettest and showed the greatest variability in annual precipitation of the four futureclimate scenarios, with a mean of 41.8 inches (in.) and a standard deviation of 15.9 in. compared with a mean of 38.9 in. and standard deviation of $11.8 \mathrm{in}$. for historical-climate baseline (table 1; fig. 1D).

\section{Future Maximum Daily Air Temperature}

Maximum daily air temperature showed a distinct trend of increasing temperatures for all future-climate scenarios in response to the projected greenhouse-gas emissions included in the GCMs (fig. 2). The GA2 scenario showed the greatest increase in maximum daily air temperature (fig. $2 A$ and table 1). The PB1 scenario showed the weakest trend of increasing air temperatures (fig. $2 D$ and table 1). All futureclimate scenarios began with a distinct shift of about 2-4 degrees Fahrenheit $\left({ }^{\circ} \mathrm{F}\right)$ increased temperature relative to the historical-climate baseline, as indicated by the 10 -year moving averages (fig. 2). The temperatures shifted upward because the future-climate scenarios were not calibrated to match actual climate records during the spin-up period, water years 2005-10, when the historical-climate baseline and the futureclimate scenarios overlap. As discussed earlier in this chapter, the bias correction was done for the water years 1950-2000 baseline period, which is prior to the period of overlap shown in figure 2. 
Table 1. Summary of precipitation and air temperature for future-climate scenarios, Santa Rosa Plain watershed, Sonoma County, California, for water years 2005-99; 2011-40; 2041-70; and 2070-99.

[Abbreviations: acre-ft; acre-foot; acre-ft/yr; acre-foot per year; deg F, degree Fahrenheit; GCM, global-climate model; in., inch; in./yr, inch per year; na, not available]

\begin{tabular}{|c|c|c|c|c|c|}
\hline Scenario & $\begin{array}{l}\text { Historical-climate } \\
\text { baseline }\end{array}$ & GA2 & GB1 & PA2 & PB1 \\
\hline GCM model & na & GFDL & GFDL & PCM & PCM \\
\hline Climate period (water years) & $1981-2010$ & 2005-99 & 2005-99 & 2005-99 & 2005-99 \\
\hline \multicolumn{6}{|c|}{ Precipitation } \\
\hline Minimum annual (in.) & 15.2 & 8.6 & 7.5 & 8.0 & 13.0 \\
\hline Standard deviation (in.) & 11.8 & 12.1 & 14.4 & 14.3 & 15.9 \\
\hline \multicolumn{6}{|c|}{ Maximum daily air temperature } \\
\hline Average (deg F) & 70.3 & 75.5 & 74.5 & 75.2 & 74.3 \\
\hline \multicolumn{6}{|c|}{ Minimum daily air temperature } \\
\hline Average (deg F) & 45.4 & 47.8 & 46.6 & 46.4 & 45.4 \\
\hline Maximum annual average (deg F) & 47.5 & 53.6 & 50.1 & 50.0 & 48.0 \\
\hline Minimum annual average (deg F) & 43.5 & 43.5 & 42.9 & 41.9 & 42.4 \\
\hline Standard deviation (deg F) & 1.2 & 2.6 & 1.5 & 1.8 & 1.1 \\
\hline \multicolumn{6}{|c|}{ Average daily air temperature } \\
\hline Average (deg F) & 57.9 & 61.6 & 60.5 & 60.8 & 59.9 \\
\hline Maximum annual average (deg F) & 60.0 & 67.3 & 63.9 & 65.0 & 62.7 \\
\hline Minimum annual average (deg F) & 55.5 & 57.1 & 57.3 & 56.6 & 56.8 \\
\hline
\end{tabular}


Table 1. Summary of precipitation and air temperature for future-climate scenarios, Santa Rosa Plain watershed, Sonoma County, California, for water years 2005-99; 2011-40; 2041-70; and 2070-99._Continued

[Abbreviations: acre-ft; acre-foot; acre-ft/yr; acre-foot per year; deg F, degree Fahrenheit; GCM, global-climate model; in., inch; in./yr, inch per year; na, not available]

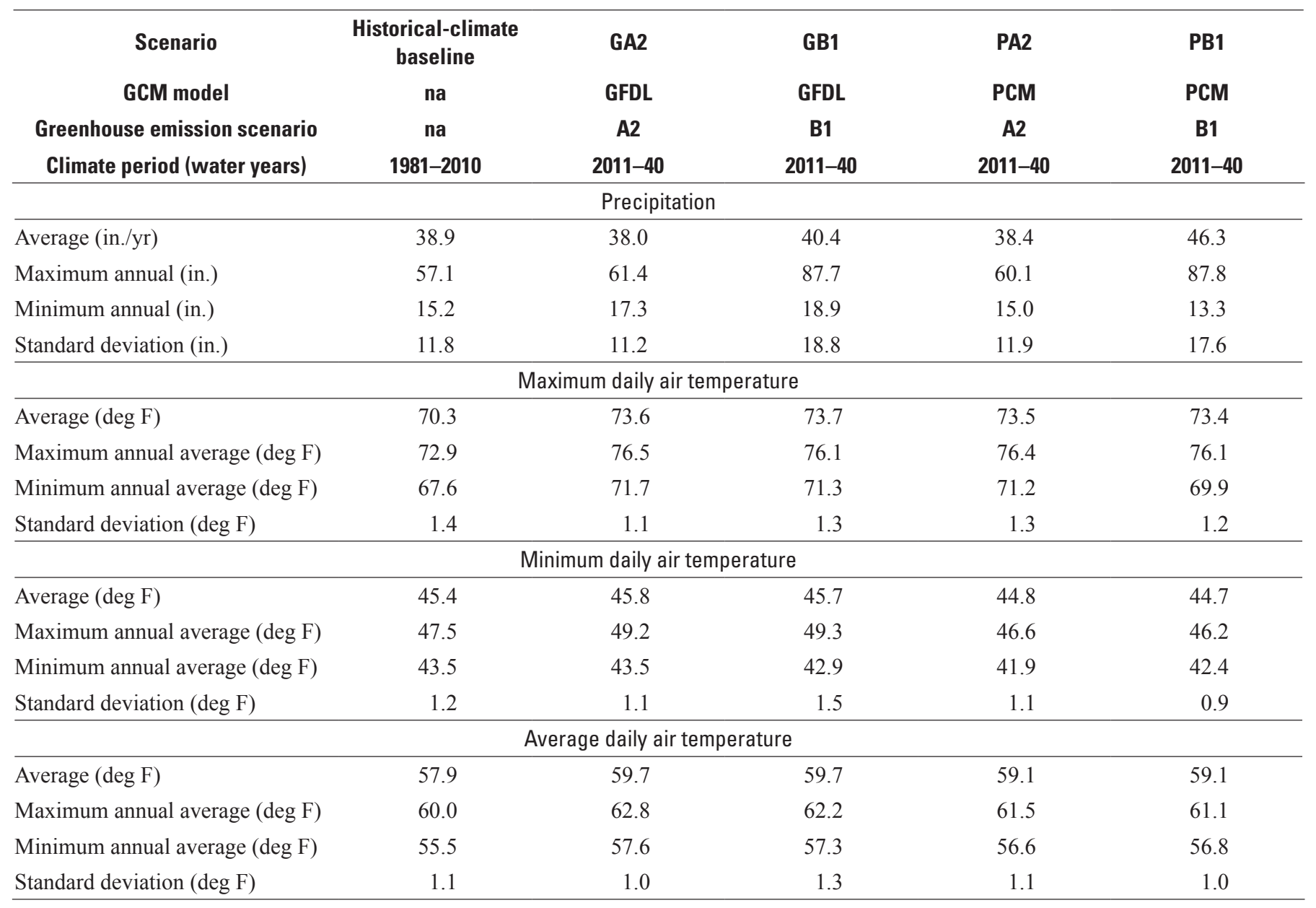


Table 1. Summary of precipitation and air temperature for future-climate scenarios, Santa Rosa Plain watershed, Sonoma County, California, for water years 2005-99; 2011-40; 2041-70; and 2070-99.-Continued

[Abbreviations: acre-ft; acre-foot; acre-ft/yr; acre-foot per year; deg F, degree Fahrenheit; GCM, global-climate model; in., inch; in./yr, inch per year; na, not available]

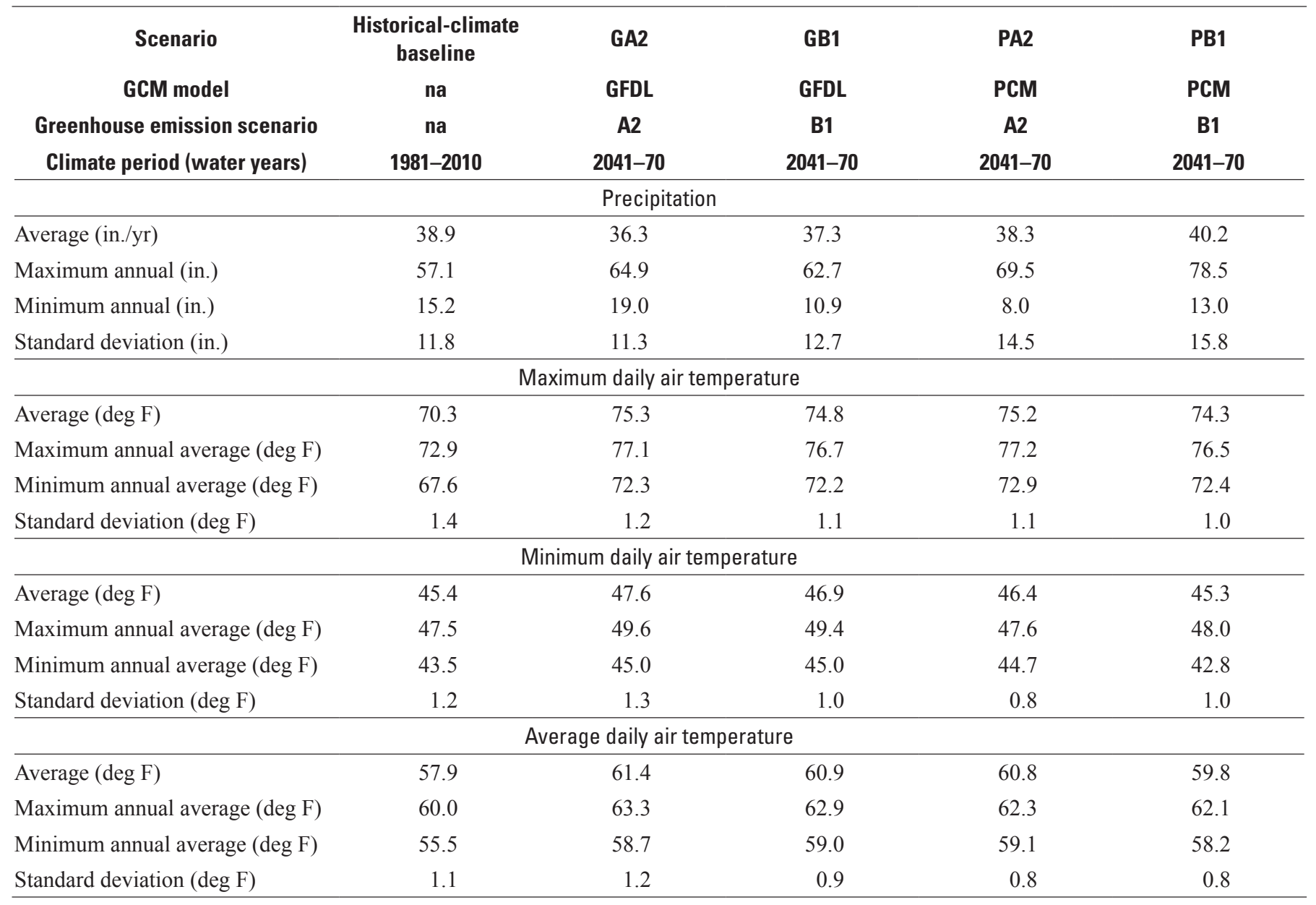


Table 1. Summary of precipitation and air temperature for future-climate scenarios, Santa Rosa Plain watershed, Sonoma County, California, for water years 2005-99; 2011-40; 2041-70; and 2070-99.

[Abbreviations: acre-ft; acre-foot; acre-ft/yr; acre-foot per year; deg F, degree Fahrenheit; GCM, global-climate model; in., inch; in./yr, inch per year; na, not available]

\begin{tabular}{|c|c|c|c|c|c|}
\hline Scenario & $\begin{array}{c}\text { Historical-climate } \\
\text { baseline }\end{array}$ & GA2 & GB1 & PA2 & PB1 \\
\hline GCM model & na & GFDL & GFDL & PCM & PCM \\
\hline Climate period (water years) & $1981-2010$ & 2070-99 & 2070-99 & 2070-99 & $2070-99$ \\
\hline \multicolumn{6}{|c|}{ Precipitation } \\
\hline Minimum annual (in.) & 15.2 & 8.6 & 7.5 & 16.3 & 13.6 \\
\hline Standard deviation (in.) & 11.8 & 12.4 & 11.4 & 16.8 & 16.3 \\
\hline \multicolumn{6}{|c|}{ Maximum daily air temperature } \\
\hline Average (deg F) & 70.3 & 78.4 & 75.6 & 77.2 & 75.6 \\
\hline \multicolumn{6}{|c|}{ Minimum daily air temperature } \\
\hline Average (deg F) & 45.4 & 50.7 & 47.6 & 48.5 & 46.4 \\
\hline Maximum annual average (deg F) & 47.5 & 53.5 & 50.1 & 50.0 & 47.9 \\
\hline Minimum annual average (deg F) & 43.5 & 48.0 & 46.0 & 46.8 & 44.8 \\
\hline Standard deviation (deg F) & 1.2 & 1.4 & 1.0 & 1.0 & 0.8 \\
\hline \multicolumn{6}{|c|}{ Average daily air temperature } \\
\hline Average (deg F) & 57.9 & 64.6 & 61.6 & 62.9 & 61.0 \\
\hline Maximum annual average (deg F) & 60.0 & 66.7 & 63.9 & 65.0 & 62.7 \\
\hline Minimum annual average (deg F) & 55.5 & 62.5 & 59.7 & 61.1 & 59.5 \\
\hline
\end{tabular}



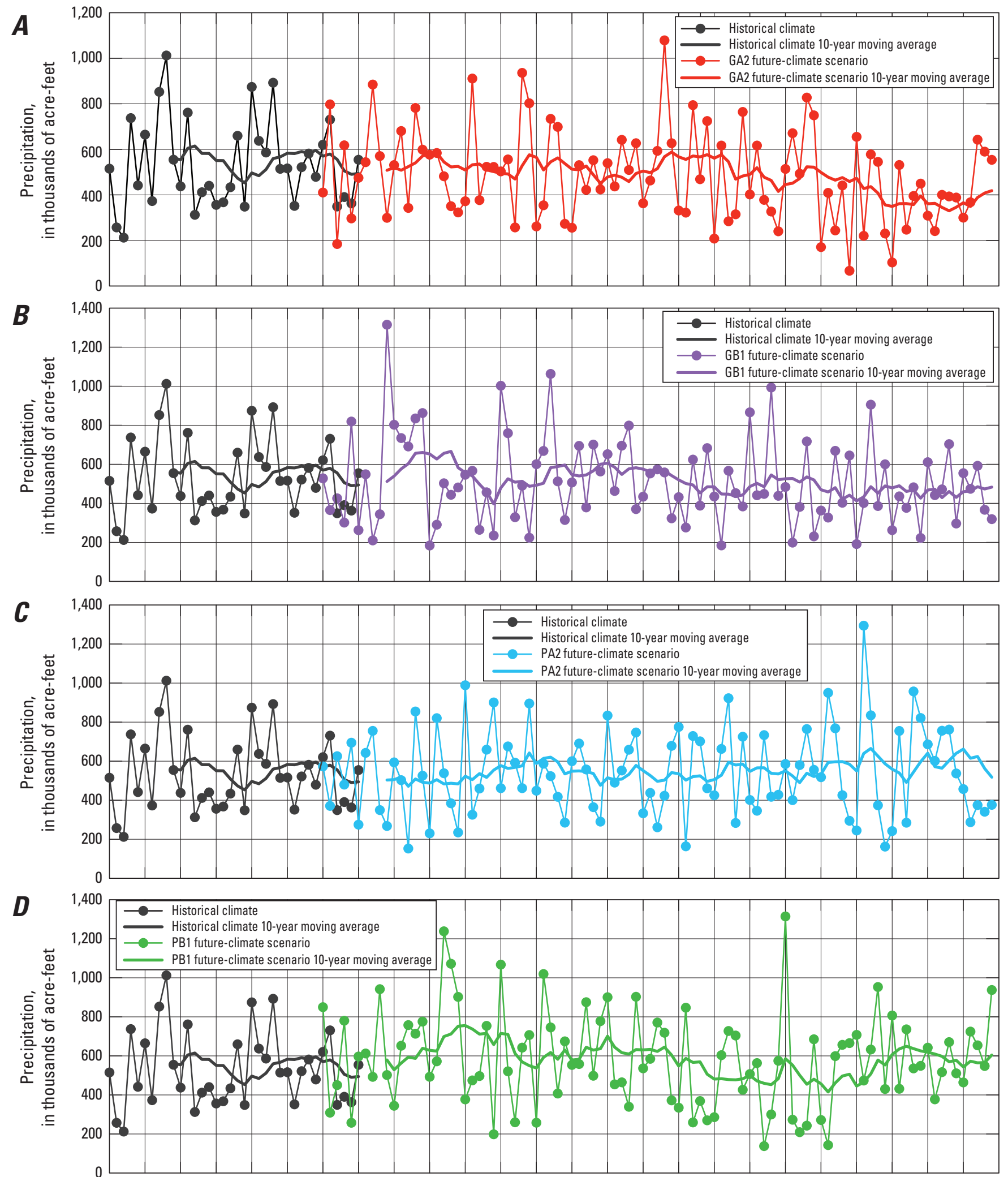

19751980198519901995200020052010201520202025203020352040204520502055206020652070207520802085209020952100 Water year

Figure 1. Water year precipitation for the historical-climate baseline and the following future-climate scenarios for the Santa Rosa Plain Watershed, Sonoma County, California: $A, \mathrm{GA} 2 ; B, \mathrm{~GB} 1 ; C, \mathrm{PA2}$; , PB1. 

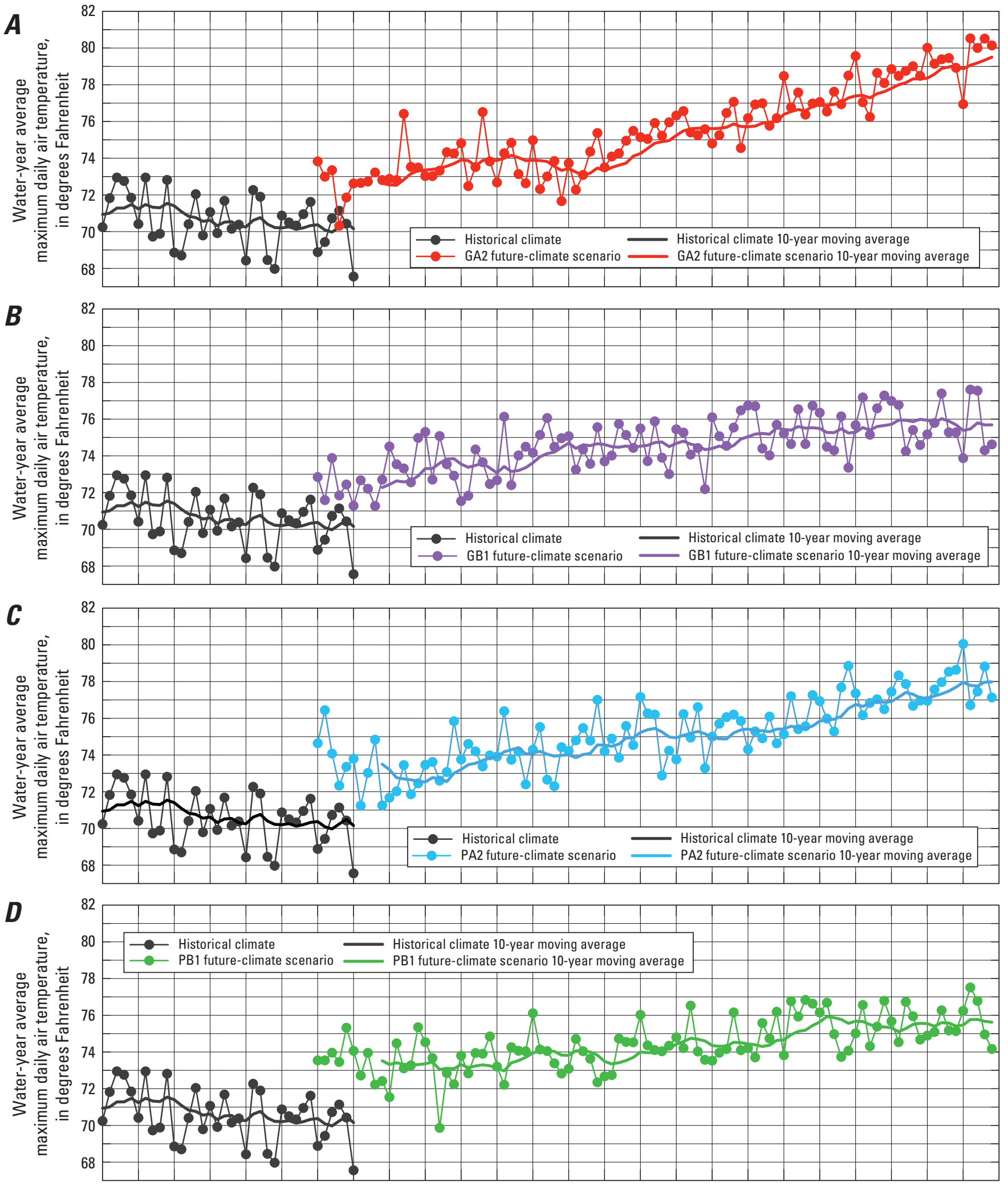

19751980198519901995200020052010201520202025203020352040204520502055206020652070207520802085209020952100 Water year

Figure 2. Maximum daily air temperatures for historical-climate baseline and the following future-climate scenarios, Santa Rosa Plain watershed, Sonoma County, California: $A, \mathrm{GA} 2 ; B, \mathrm{~GB} 1 ; C, \mathrm{PA} 2 ; D, \mathrm{~PB} 1$. 


\section{Future Minimum Daily Air Temperature}

Minimum daily air temperature also showed a trend of increasing temperatures for all future-climate scenarios in response to the projected greenhouse-gas emissions simulated by the GCMs (fig. 3); however, the 95-year averages were in agreement with the historical-climate baseline average (table 1). There was a small, but distinct, shift of temperature relative to historical-climate baseline (fig. 3).

\section{Future Average Air Temperature}

Comparison of the 10-year moving average of mean daily air temperature in all four future-climate scenarios indicated a trend of increasing air temperature (fig. 4). This trend was clearest in the GA2 scenario compared with the others. Overall, the GA2 climate was the warmest future-climate scenario; however, it also had the greatest standard deviation (fig. 4, table 1). The PB1 future-climate scenario was the coolest scenario and had the lowest standard deviation (table 1). Similar to the maximum daily air temperature, all future-climate scenarios begin with a distinct shift of about $1-2{ }^{\circ} \mathrm{F}$ increased average temperature relative to the historical-climate baseline (fig. 4).

\section{Model Application: Future-Climate Scenarios without Pumping}

Initially, the future-climate scenarios were used in the SRPHM without including pumping, in order to evaluate the hydrologic response of the SRPW to changes and variability in climate only. The simulation results for the future-climate scenarios without pumping were compared with the simulation results for the historical-climate baseline period without pumping. The historical-climate baseline period (water years 1981-2010) was used in comparison to three 30-year periods (water years 2011-40, 2041-70, and 2070-99) from the future-climate scenarios (table 1).

\section{Annual Results}

The annual time series of simulated total streamflow, total recharge, groundwater discharge to streams, and groundwater evapotranspiration (ET) for water years 2011-99 were analyzed for the four future-climate scenarios. The characteristics of the time series for the historical-climate baseline were compared with those for the future-climate scenarios to evaluate changes in the hydrologic system in response to the future-climate scenarios. The comparisons indicated similarities as well as differences in the hydrologic responses, but overall, the application of each future-climate scenario showed a unique hydrologic response.

\section{Average Annual Streamflow}

A visual comparison of the simulated results for the future-climate scenarios without pumping to the simulated results for the historical-climate baseline period without pumping indicated the average annual total streamflows (referred to as annual streamflows) for all future-climate scenarios varied more than during the historical-climate baseline period (fig. 5). Overall, annual streamflows were well correlated with annual precipitation for all future-climate scenarios (figs. 1, 5). Relatively low annual streamflows (less than 100,000 acre-ft) occurred with greater frequency in all the future-climate scenarios compared with the historical-climate baseline period (fig. 5). All future-climate scenarios had at least 1 year with very high annual streamflows (greater than 700,000 acre-ft), whereas the maximum annual streamflows for the historicalclimate baseline period was 620,000 acre-ft.

The annual streamflows for the simulations using the GA2, GB1, PA2, and PB1 scenarios showed differences compared with the historical-climate baseline period. Compared with the other three scenarios, the results for the GA2 scenario had the lowest average precipitation and had a drier-than average period during water years 2075 through 2096 (fig. 1). As a result, the SRPHM simulated a relatively greater number of annual streamflows less than 100,000 acre-ft, particularly during this later period (fig. $5 \mathrm{~A}$ ).

The simulation using the GB1 scenario began with a period (water years 2014-19) that had more annual streamflows greater than 400,000 acre-ft compared with the historical-climate baseline period (fig. $5 B$ ). During water years 2030-60, annual streamflows were comparable to the historical-climate baseline period (fig. 5B). After water year 2060, the GB1 scenario was drier than the historical-climate baseline period and had a 10 -year moving average close to 200,000 acre-ft/yr for annual streamflows (fig. 5B).

The simulation using the PA2 scenario showed streamflows similar to that for the historical-climate baseline period during water years 2011-80. After water year 2080, there were more annual streamflows exceeding 400,000 acre-ft. This was particularly evident in water year 2081, which had a streamflow of about 890,000 acre-ft, compared with the baseline annual flow of about 250,000 acre-ft and a maximum flow of about 630,000 acre-ft.

The simulation using the PB1 scenario had three water years with annual streamflows greater than 700,000 acre-ft, which were greater than the streamflows for any year during the historical-climate baseline period. The first two high streamflow water years were during a period that was wetter than the baseline period (water years 2013-36), and the third high streamflow water year (2070) was during a dry period (water years 2057-76). Although the results for the PB1 scenario had high streamflows for these three water years, many periods showed less variability in annual streamflows compared with the historical-climate baseline period as well as the other three future-climate scenarios (figs. $5 A-D$ ). 

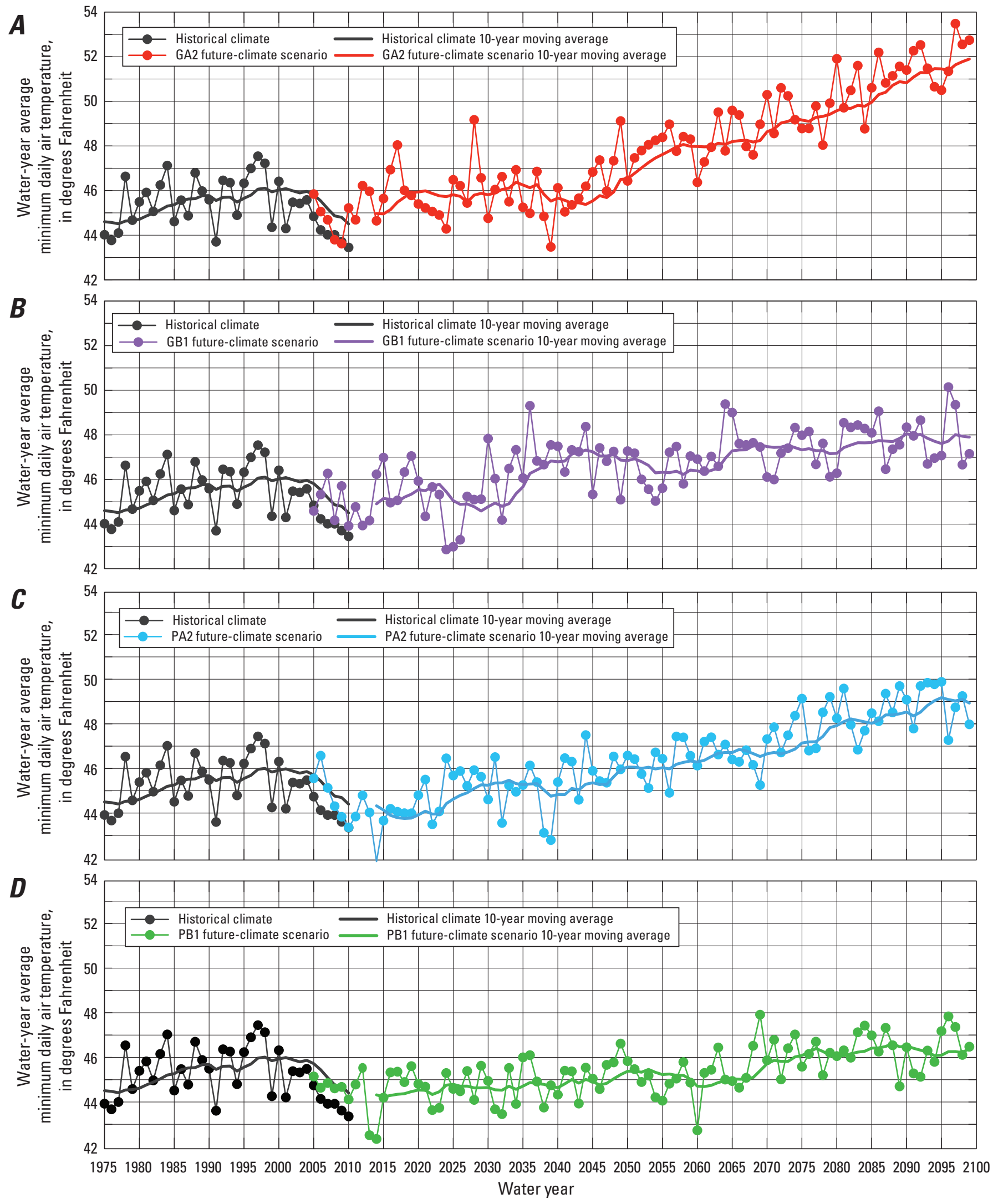

Figure 3. Minimum daily air temperatures for the historical-climate baseline and the following future-climate scenarios, Santa Rosa Plain watershed, Sonoma County, California: $A, \mathrm{GA2}$;, $\mathrm{GB} 1 ; C, \mathrm{PA} 2$; D, PB1. 


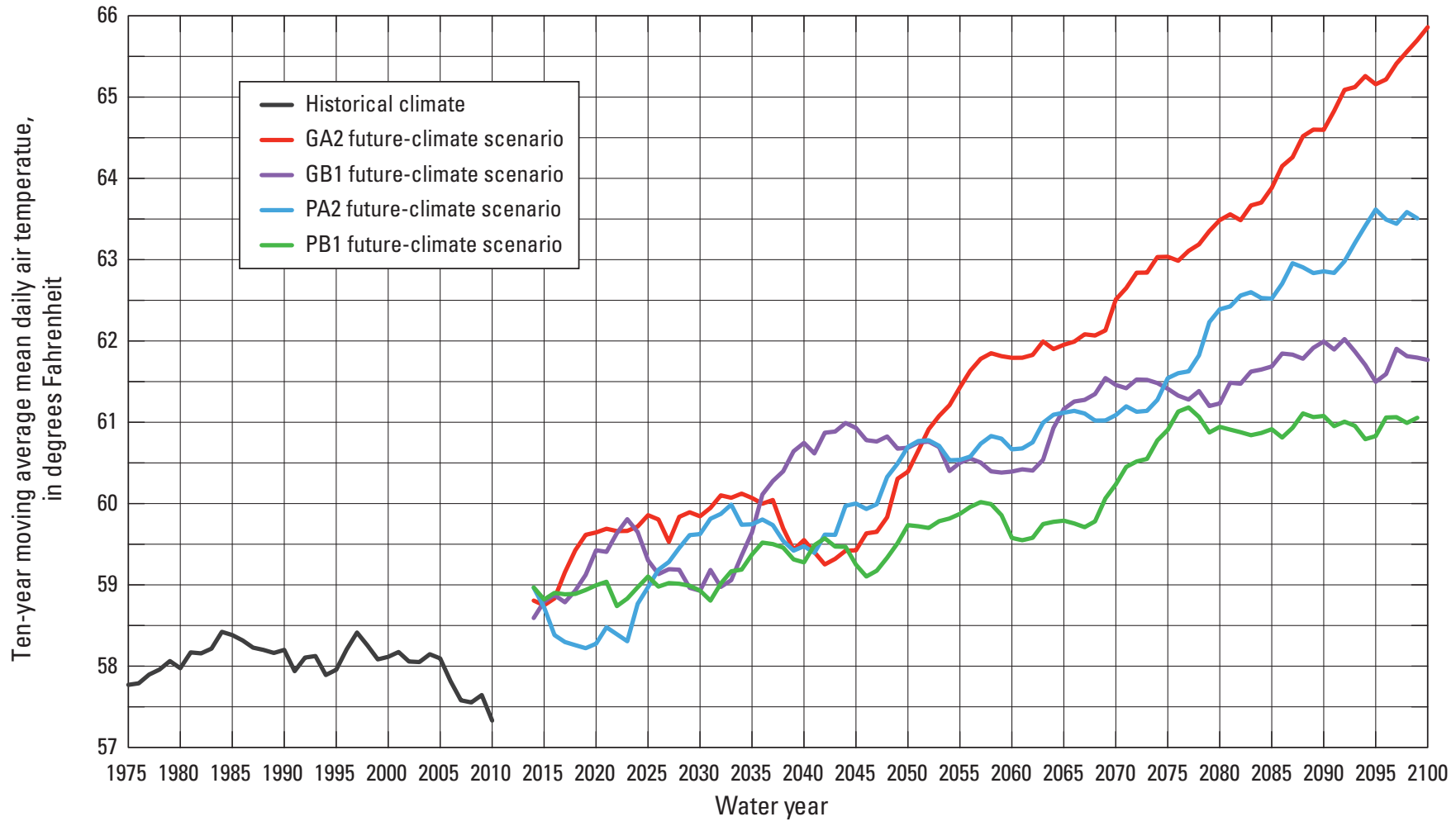

Figure 4. Comparison of the 10-year moving average of average daily air temperature for the historical-climate baseline and futureclimate scenarios, Santa Rosa Plain watershed, Sonoma County, California. 


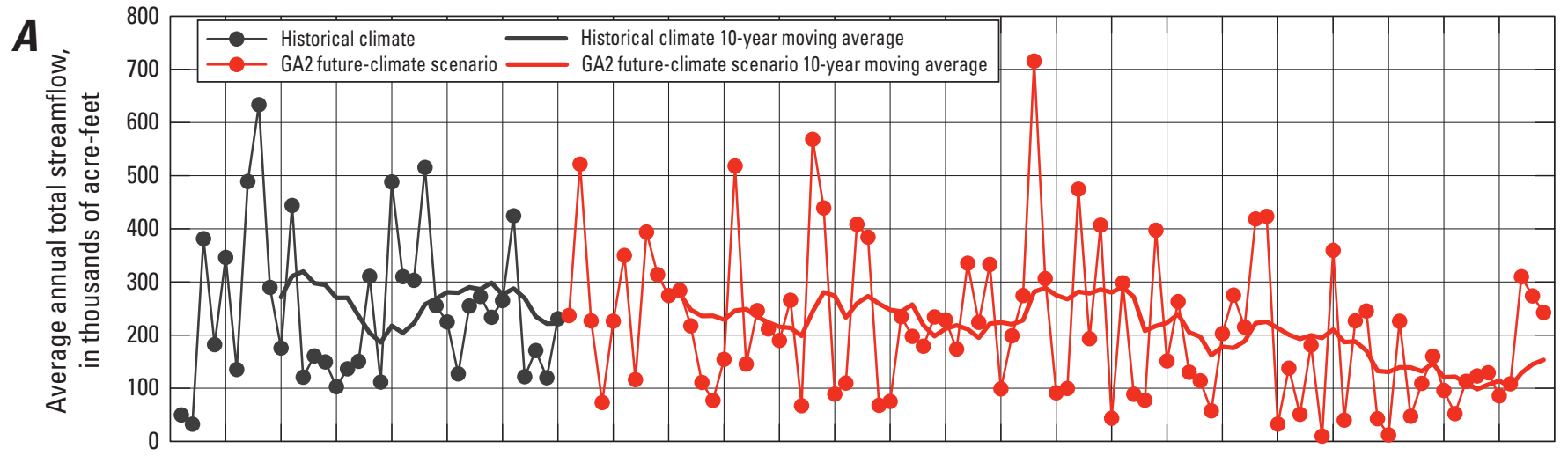

$\boldsymbol{B}$

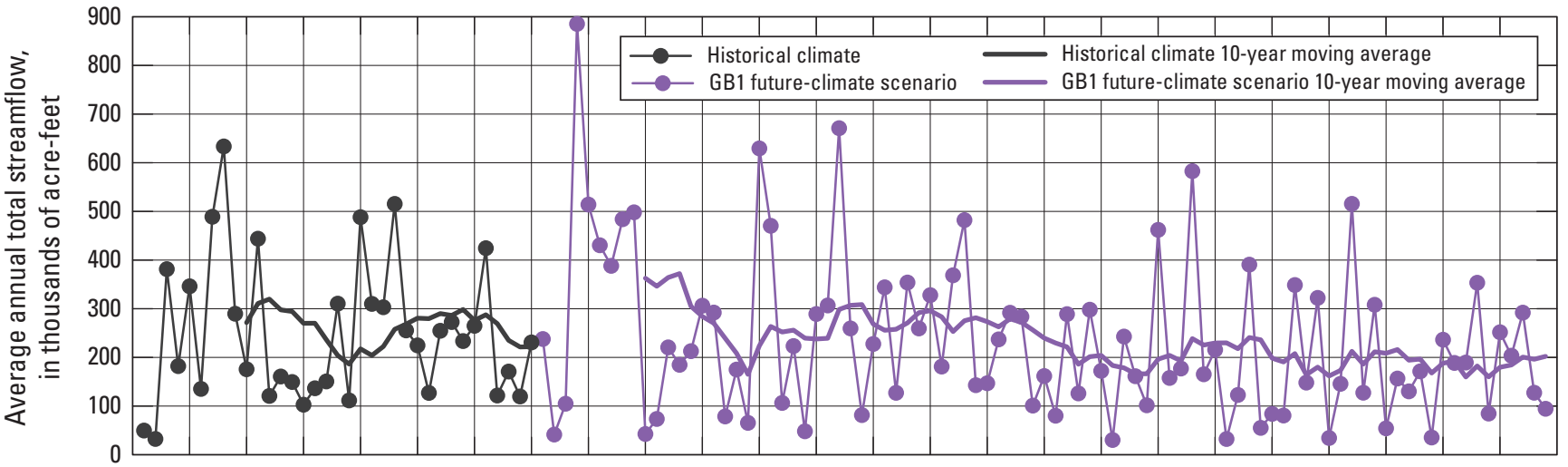

C

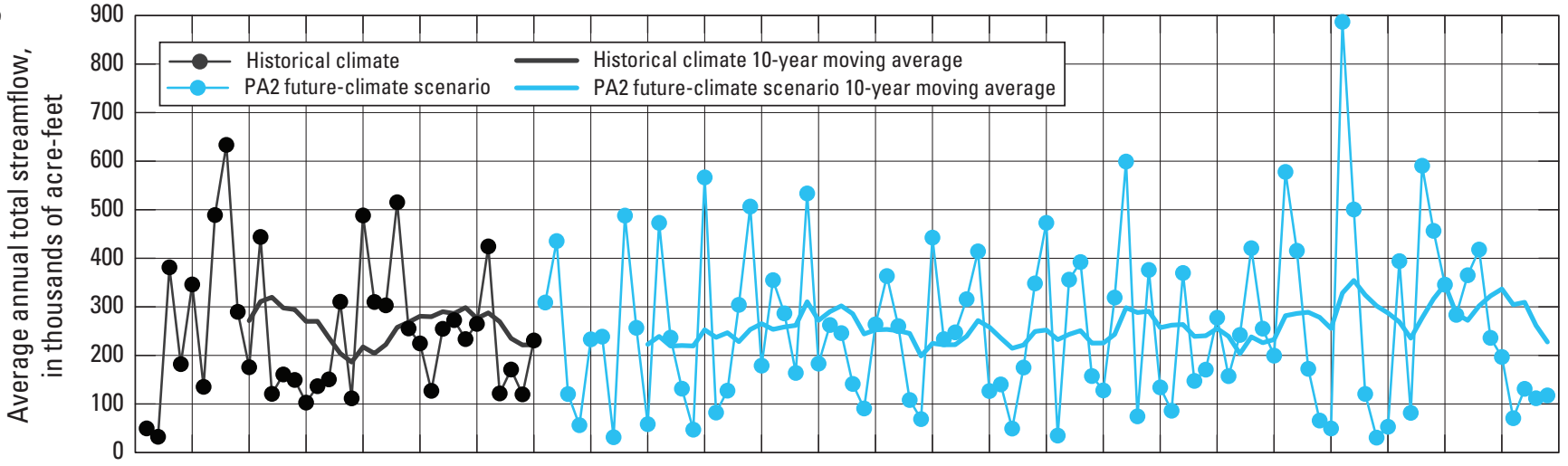

D

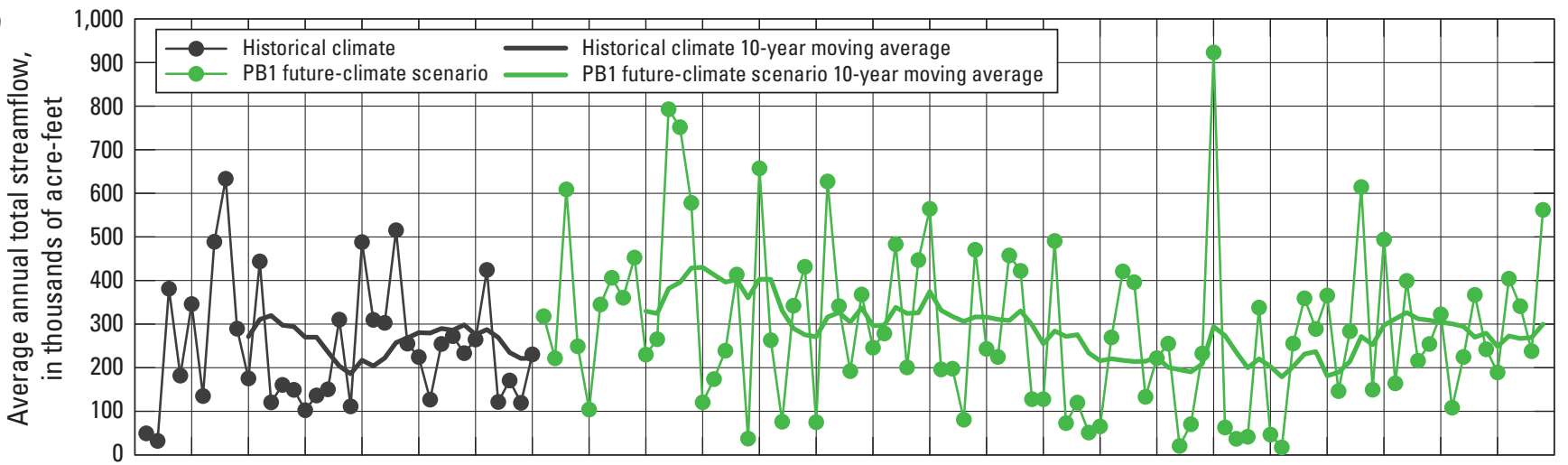

19751980198519901995200020052010201520202025203020352040204520502055206020652070207520802085209020952100 Water year

Figure 5. Average annual total streamflows and 10-year moving average of streamflows, simulated without pumping for water years 1976-2099, by using the historical-climate baseline and the following future-climate scenarios, Santa Rosa Plain hydrologic model, Santa Rosa Plain watershed, Sonoma County, California: $A, \mathrm{GA} 2 ; B, \mathrm{~GB} 1 ; C, \mathrm{PA} 2 ; D, \mathrm{~PB} 1$. 


\section{Average Annual Recharge}

Similar to annual streamflows, the average annual recharge, which includes extra-channel recharge and recharge from streams (referred to as annual recharge), was correlated to annual precipitation for all four future-climate scenarios (figs. 1, 6). In general, however, the variability in annual recharge for the future-climate scenarios was similar to that of the historical-climate baseline period (fig. 6). Simulated results for all four future-climate scenarios showed an increased number of water years with annual recharge less than 30,000 acre-ft due to the combination of lower precipitation and higher air temperatures compared with the historicalbaseline period.

The GA2 scenario had very dry conditions after water year 2075 (fig. 1A), and annual recharge was often less than 30,000 acre-ft; after water year 2085, the 10-year moving average was less than 40,000 acre-ft (fig. $6 A$ ). In the simulated results for the GA2 scenario, a downward trend in the 10-year moving average recharge after water year 2062 was correlated with a trend of increasing air temperature during the same time (fig. 4), along with a corresponding increase in PET.

Similar to the simulated results for the GA2 scenario, the simulated results for the GB1 scenario often had low annual recharge; however, compared with the other scenarios, the GB1 scenario results also often had annual recharge greater than 70,000 acre-ft, including a maximum recharge near 120,000 acre-ft for water year 2014 (fig. 6B). The 10-year moving average for recharge in the GB1 scenario results showed a slightly downward trend, particularly after water year 2055, when there was a general shift to annual recharge of about 50,000 acre-ft.

The simulated results for the PA2 scenario had the most variability in annual recharge; however, the 10-year moving average showed less variability than the other scenarios (fig. 6C). The simulated results for the PB1 scenario was the only scenario that had annual recharge greater than 100,000 acre- $f t$ for three water years (fig. 6D). The 10-year moving average for recharge did not show a downward trend in the PA2 and PB1 scenarios results because increases in PET were offset by the greater precipitation in these scenarios.

\section{Average Annual Groundwater Discharge to Streams}

Groundwater discharge to streams (baseflow) is one component of total discharge, which also includes groundwater ET, surface leakage, boundary flows, and pumpage. The pattern of inter-annual variability and multi-year trends in average annual total groundwater discharge to streams (referred to as annual discharge to streams), generally, was similar to the variability and trends in average annual recharge (figs. 6,7). Annual discharge to streams was more sensitive to variations and trends in future climates than annual recharge, however.
The annual discharge to streams declined more rapidly than annual recharge in the simulated results for the GA2 scenario (figs. 6A, 7A). Furthermore, during water years 2080-99 in the GA2 scenario results (fig. $7 A$ ) and water years 2076-96 in the GB1 scenario results (fig. $7 B$ ), annual discharge to streams was low compared with the historical-climate baseline period. Only the 10-year moving average in the PA2 scenario results was similar to the baseline 10 -year moving average (fig. 7C). In the simulated results for the PB1 scenario, there were periods with more (water years 2022-58 and water years 2086-99) and less (water years 2074-82) annual discharge to streams compared with the historical-climate baseline period (fig. 7D). In the PB1 scenario results, fluctuations in the 10 -year moving average of annual discharge to streams were more pronounced than those for total recharge (figs. $6 \mathrm{D}, 7 D$ ) because of the temporal lag associated with extra-channel recharge moving through the unsaturated zone to the water table.

\section{Average Annual Groundwater Evapotranspiration}

Average annual groundwater ET (referred to as annual groundwater ET) is another component of groundwater discharge. In all four future-climate scenarios, the increase in air temperature corresponded to increased PET. Groundwater ET can increase with PET during wet periods when the water table is higher; however, groundwater ET can decrease, even though PET increases, when the availability of groundwater is limited by less-than-average precipitation. The annual groundwater ET generally was higher in all future-climate scenarios compared with the historical-climate baseline period (fig. 8). The simulated results for all four future-climate scenarios had a maximum annual groundwater ET greater than 19,500 acre-ft, which was greater than the maximum for the historical-climate baseline period (fig. 8). Furthermore, for all four future-climate scenarios, the simulated results showed some similarity among multi-year cycles of annual groundwater discharge to streams and of annual groundwater ET (figs. 7, 8).

Annual groundwater ET in the GA2 scenario results followed a trend that reflected increasing temperatures; however, annual groundwater ET decreased during water years 2086-96 (fig. 8A) because a decrease in recharge (fig. 6A) during this period lowered the water table to below the ET extinction depth. In the GB1 scenario results, SRPHM simulations showed higher annual groundwater ET for water years 2015-60 compared with the historical-climate baseline period because of higher air temperatures and greater precipitation for that period. For water years 2061-99, the 10-year moving average of annual groundwater ET in the GB1 scenario results varied above and below the maximum 10-year moving average of annual groundwater ET for the historical-climate baseline period (16,000 acre-ft; fig. $8 B$ ). At the beginning of the 


\section{$\boldsymbol{A}$}

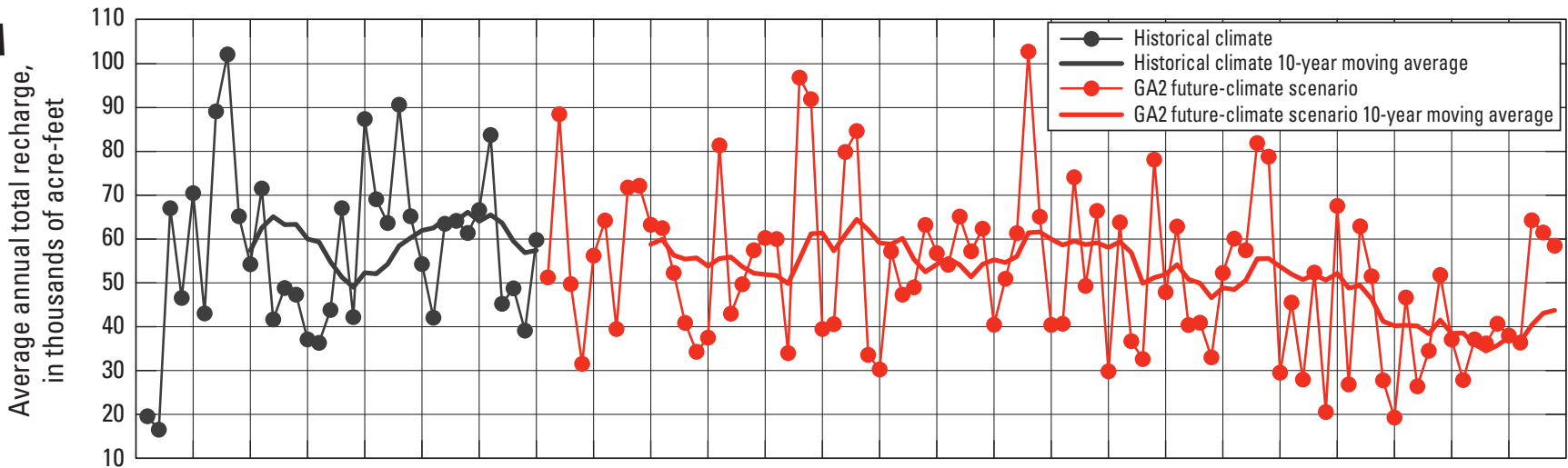

$\boldsymbol{B}$

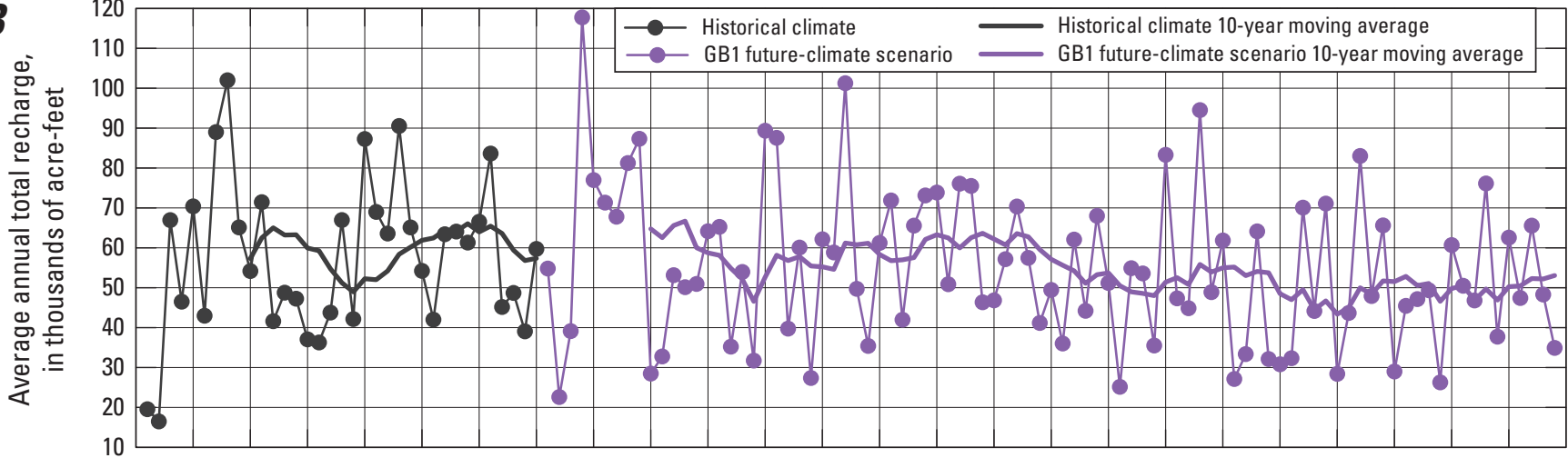

$c$

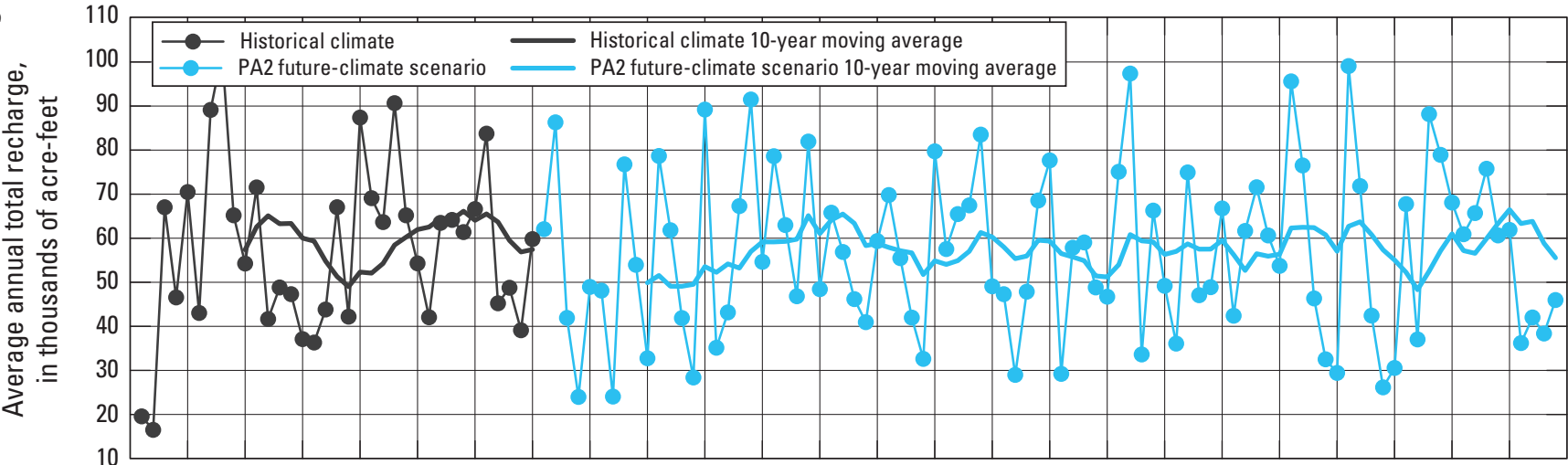

D

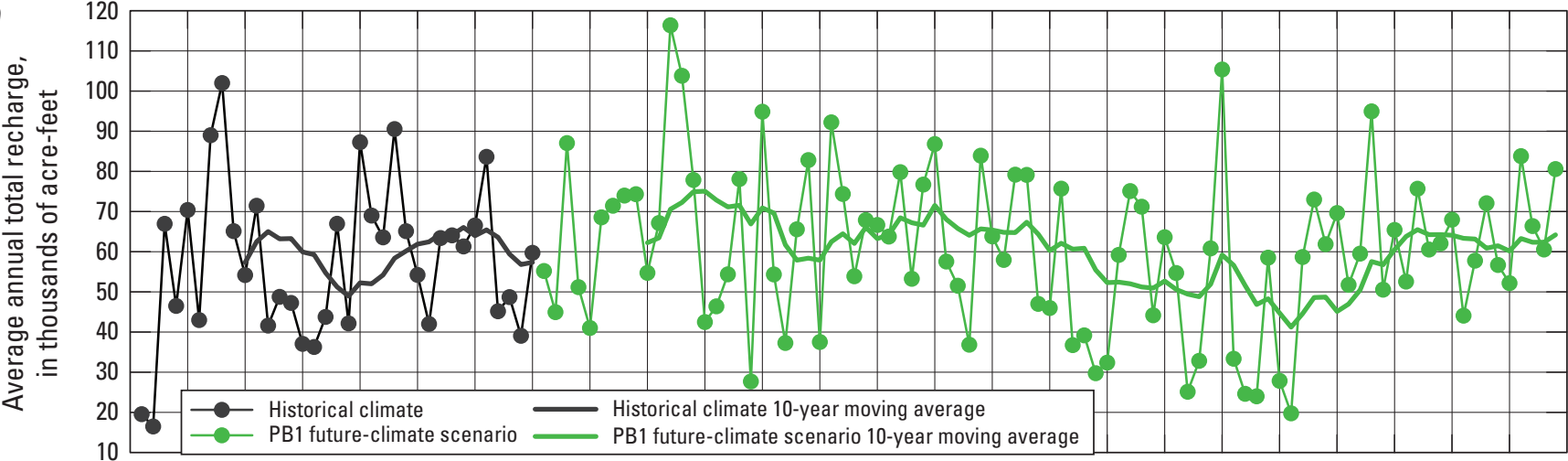

19751980198519901995200020052010201520202025203020352040204520502055206020652070207520802085209020952100 Water year

Figure 6. Average annual total recharge and 10-year moving average of streamflow simulated without pumping for water years 1976-2099 using the historical-climate baseline and thefollowing future-climate scenarios, Santa Rosa Plain hydrologic model, Santa Rosa Plain watershed, Sonoma County, California: $A, \mathrm{GA} 2 ; B, \mathrm{~GB} 1 ; C, \mathrm{PA2}$;, $\mathrm{PB} 1$. 

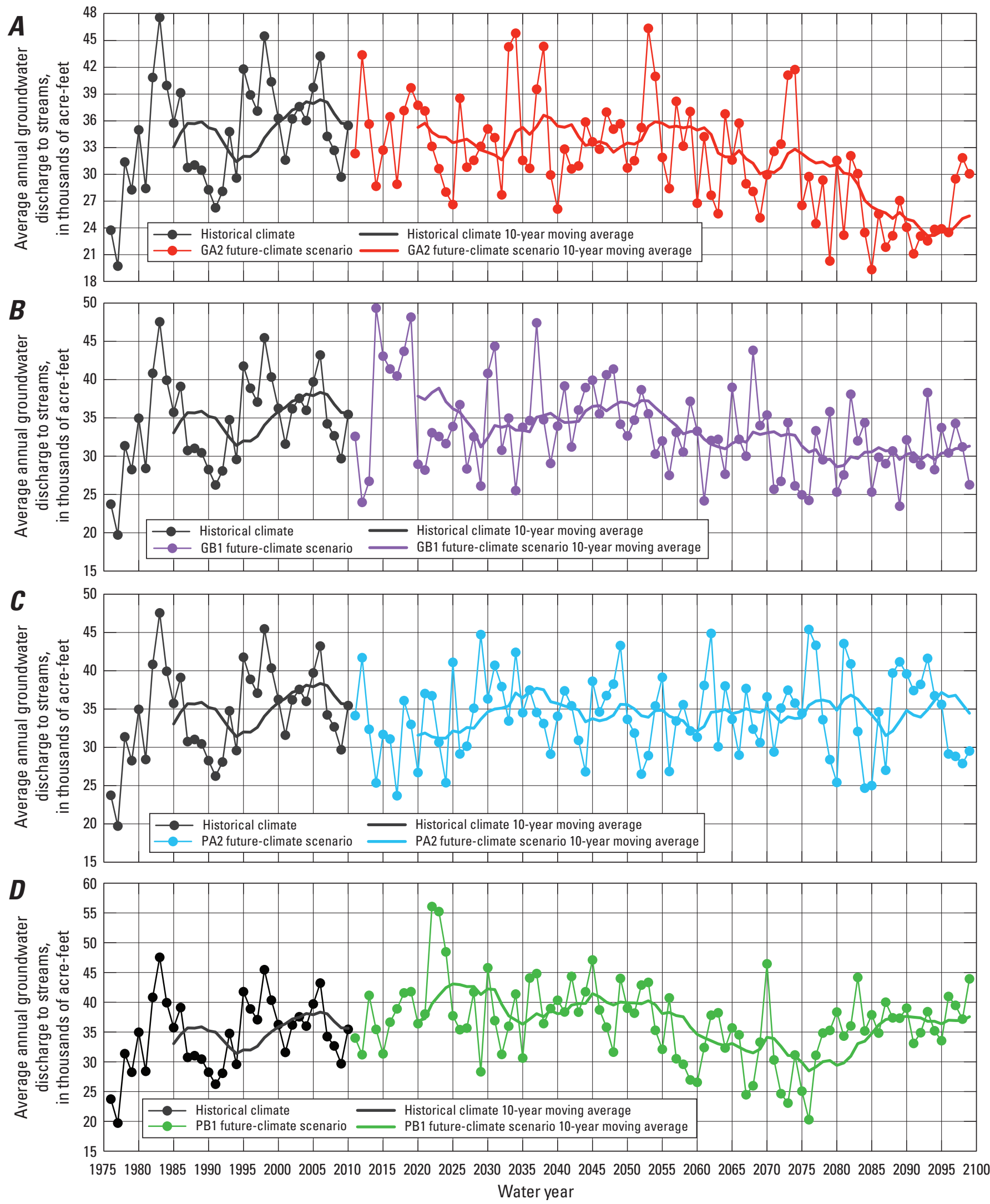

Figure 7. Average annual groundwater discharge to streams and 10 -year moving average of total discharge simulated without pumping for water years 1976-2099 using the historical-climate baseline and the following future-climate scenarios, Santa Rosa Plain hydrologic model, Santa Rosa Plain watershed, Sonoma County, California: A, GA2; $B, \mathrm{~GB} 1$; $C$, PA2; D, PB1. 

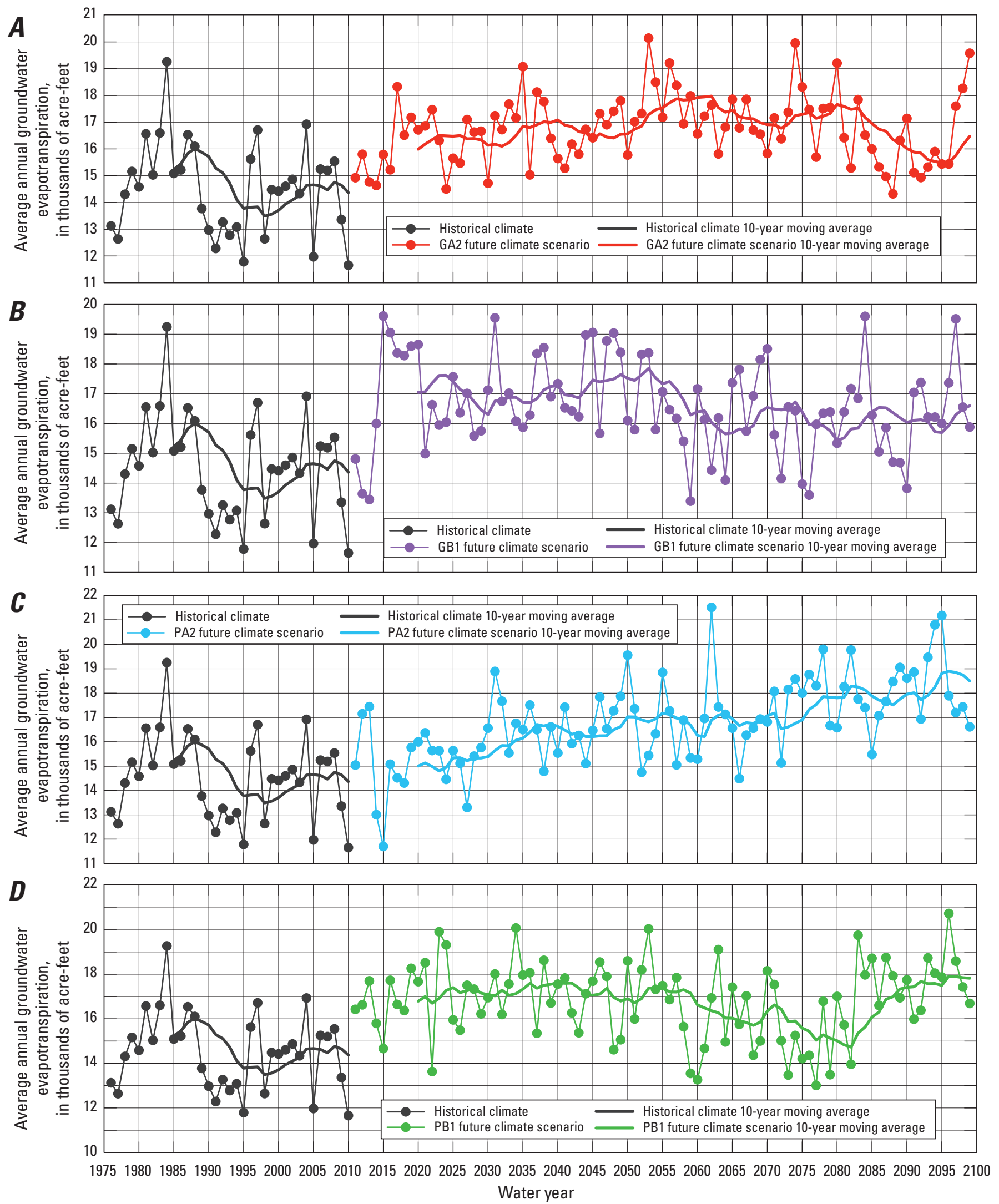

Figure 8. Average annual groundwater evapotranspiration and the 10-year moving average of groundwater evapotranspiration, simulated without pumping for water years 1976-2099 using the historical-climate baseline and the following future-climate scenarios, Santa Rosa Plain hydrologic model, Santa Rosa Plain watershed, Sonoma County, California: $A$, GA2; B, GB1; C, PA2; D, PB1. 
future-climate period, annual groundwater ET in the PA2 scenario results was similar to that of the historic baseline; then, it steadily increased as PET and precipitation increased (fig. 8C). Results for the PB1 scenario indicated that precipitation had a greater influence on groundwater ET than did PET, because this scenario generally had greater precipitation (fig. 1D), but less increased PET, which is correlated to the average air temperature (fig. 4), compared with the other future-climate scenarios and the historical-climate baseline period. In addition, annual groundwater ET increased in the PB1 scenario results during water years 2011-57 and decreased during water years 2058-82 (fig. 8D). The decrease was a result of a decrease in annual recharge during this period (fig. $6 D$ ), which caused water levels to be below the ET extinction depth.

\section{Monthly Results, Water Years 1981-2099}

Changes in the values of water-budget components simulated by applying the future-climate scenarios in the model also were evaluated by comparing average monthly results from three different 30-year periods (water years 2011-40, 2041-70, and 2070-99) to those from the historical-climate baseline simulation. Like the annual comparisons, the average monthly results of four selected water-budget components were compared: (1) streamflow, (2) recharge, (3) groundwater discharge to streams, and (4) groundwater ET.

Similar to the results from annual comparisons, these monthly water-budget components were influenced strongly by precipitation (fig. 9); however, the future-climate scenarios also were characterized by noticeable differences in the monthly distribution of precipitation relative to the historicalclimate baseline period and among the 30 -year periods in the scenarios. For reference, although the exact month varied among the historical-climate baseline and all future-climate scenarios, precipitation showed a low during the summer that gradually increased to a winter high. Despite a similar pattern, the future-climate scenarios generally had relatively less precipitation in December and relatively more precipitation in February compared with the historical-climate baseline period (fig. 9).

\section{Average Monthly Streamflow}

The SRPHM simulated average monthly total streamflows showed clear shifts in the temporal distribution of total streamflows relative to the historical-climate baseline (figs. 10, 11). For all four future-climate scenarios, there were decreases in December streamflows and increases in February streamflows during at least two of the three 30 -year periods examined that paralleled the reduced precipitation in December and increased precipitation in February (fig. 9). Simulated average monthly streamflows for the months of May through July in all four future-climate scenarios were low-less than 10,000 acre- $\mathrm{ft}$ - compared with the historical-climate baseline period (fig. 11A-D).
Overall, the SRPHM simulations showed that variability in the future climate could affect the SRPW hydrologic system substantially. Results from the GA2 scenario showed the greatest decrease in low flows relative to the historical-climate baseline period (fig. 10A, 11A). Except during the spring and summer, results for the GB1 scenario generally bracketed flows in the historical-climate baseline period (figs. 10B, 11B). The most consistent difference, relative to the historicalclimate baseline streamflows, was in the PA2 scenario results, which had decreased streamflows in December and increased streamflows in February for all three 30-year periods (figs. $10 C, 11 C$ ). In contrast to the other three scenarios, for these same months the PB1 scenario results were similar to the historical-climate baseline (figs. 10D, 11D). Results from the PB1 scenario indicated the greatest overall difference in streamflows relative to the historical-climate baseline was in February during water years 2011-40 and in January during water years 2041-99 (fig. 10D).

\section{Average Monthly Recharge}

In all future-climate scenarios, the distribution of simulated average monthly recharge was generally similar to that of the historical-climate baseline simulation, where there was maximum recharge in March and minimum recharge from August through October (fig. 12). There were decreases in total recharge, relative to the historical-climate baseline, for all months during water years 2070-99 in the results for the GA2 and GB1 scenarios (figs. 12A, $B$ ). The consistent decreases in average monthly recharge were caused by the increases in air temperature and the corresponding increase in simulated PET during the latter part of the 100-year future-climate scenarios (fig. 4). In addition, in the GA2 and GB1 scenarios, PET increased in conjunction with decreased precipitation during water years 2070-99 (table 1), resulting in the greatest relative decrease for each month. Overall, results for the PA2 scenario showed the least amount of change in the amount and timing of total recharge relative to the historical-climate baseline (fig. 12C). In the PB1 scenario, there was a great increase in total recharge, relative to the historical-climate baseline, from February through May during water years 2011-40 (fig. 12D). The increased recharge in the PB1 scenario results corresponded to a period of higher-than-average monthly precipitation during water years 2011-40 (fig. 9).

\section{Average Monthly Groundwater Discharge to Streams}

The comparison of simulated average monthly groundwater discharge to streams with the historical-climate baseline (fig. 13) showed changes in the monthly distributions that were similar to the results for annual recharge (fig. 12). For all future-climate scenarios and the historical-climate baseline, the greatest groundwater discharge to streams was in March. The most notable change from the historical-climate 

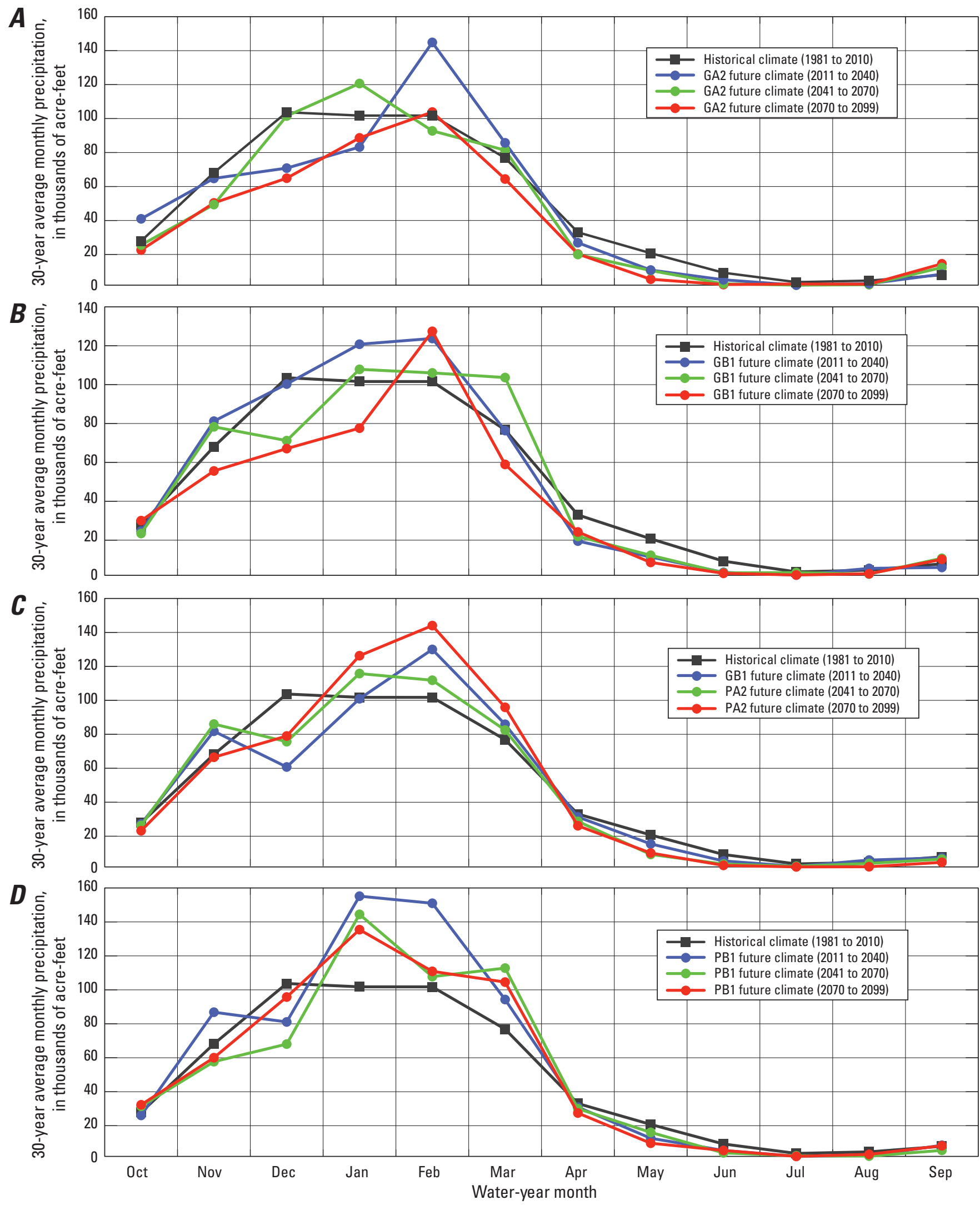

Figure 9. Comparison of 30-year monthly average precipitation using the historical-climate baseline and the following future-climate scenarios, Santa Rosa Plain hydrologic model, Santa Rosa Plain watershed, Sonoma County, California: $A, \mathrm{GA2} B, \mathrm{~GB} 1$; $C$, PA2; $D, \mathrm{~PB} 1$. 

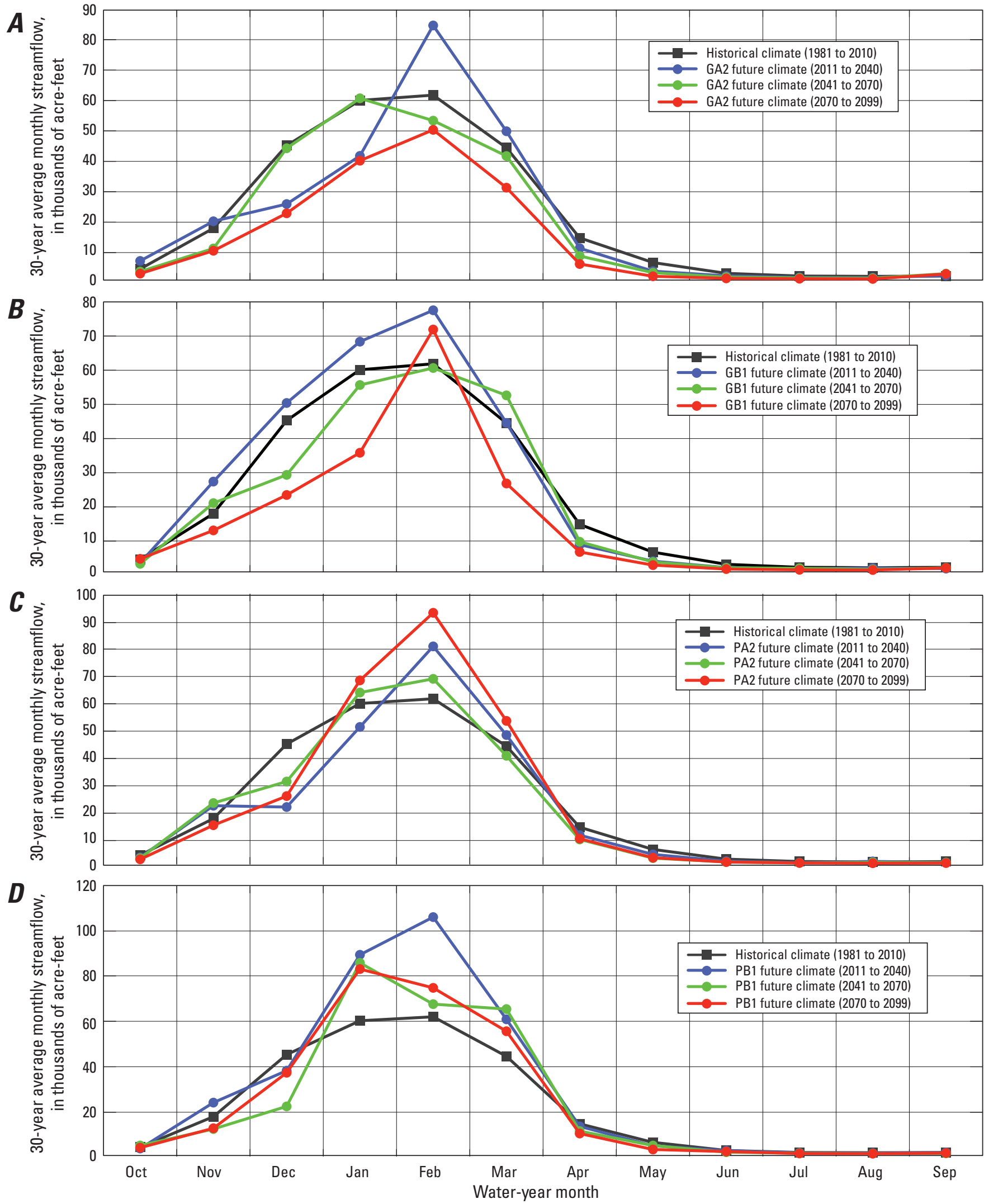

Figure 10. Comparison of 30-year monthly average total streamflow, simulated without pumping, using the historical-climate baseline and the following future-climate scenarios, Santa Rosa Plain hydrologic model, Santa Rosa Plain watershed, Sonoma County, California: $A, \mathrm{GA} 2 ; B, \mathrm{~GB} 1 ; C, \mathrm{PA} 2 ; D, \mathrm{~PB} 1$. 

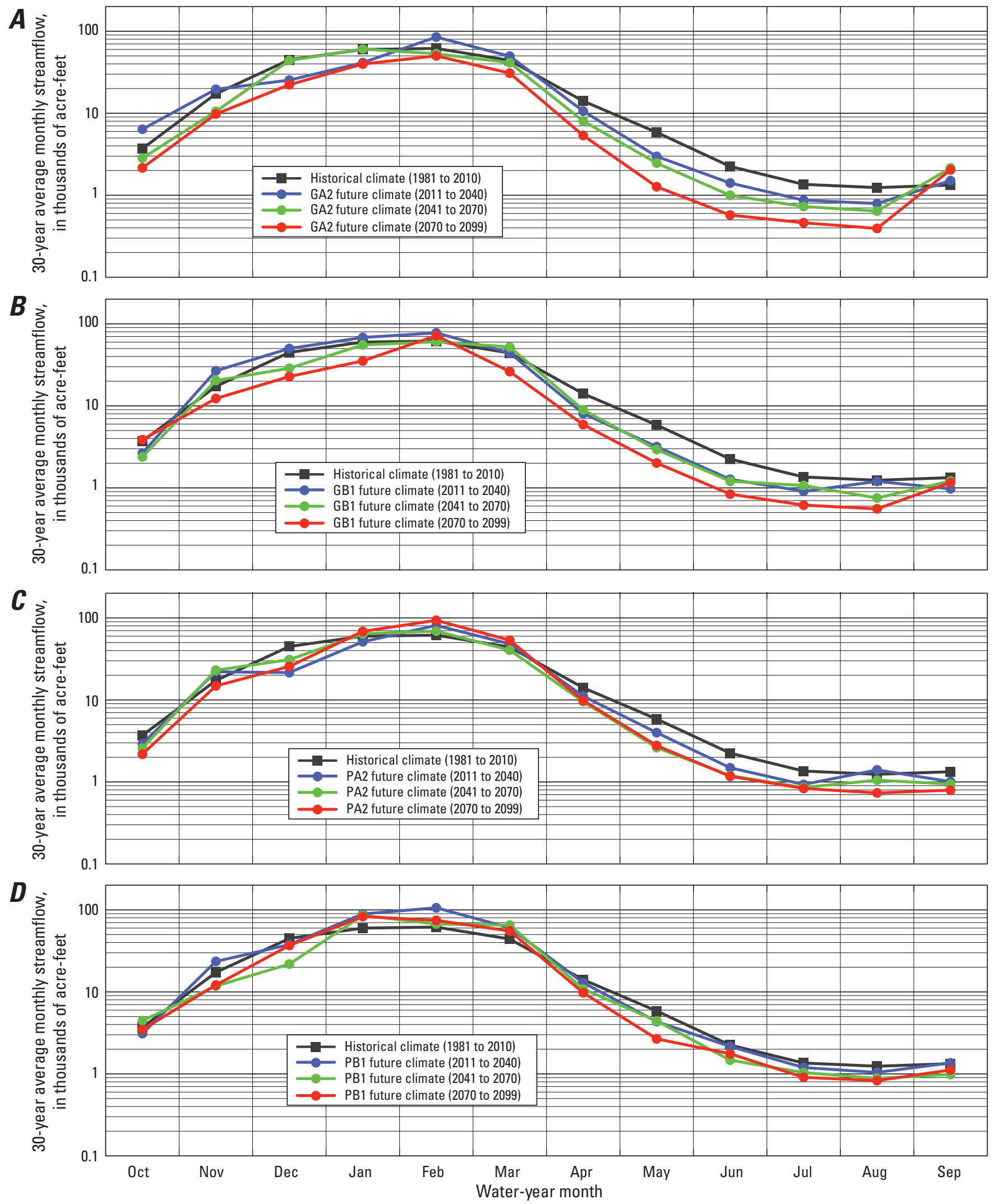

Figure 11. Comparison of 30-year monthly average total streamflows, on a logarithmic scale, simulated without pumping using the historical-climate baseline and the following future-climate scenarios, Santa Rosa Plain hydrologic model, Santa Rosa Plain watershed, Sonoma County, California: $A, \mathrm{GA} 2 ; B, \mathrm{~GB} 1 ; C, \mathrm{PA} 2 ; D, \mathrm{~PB} 1$. 

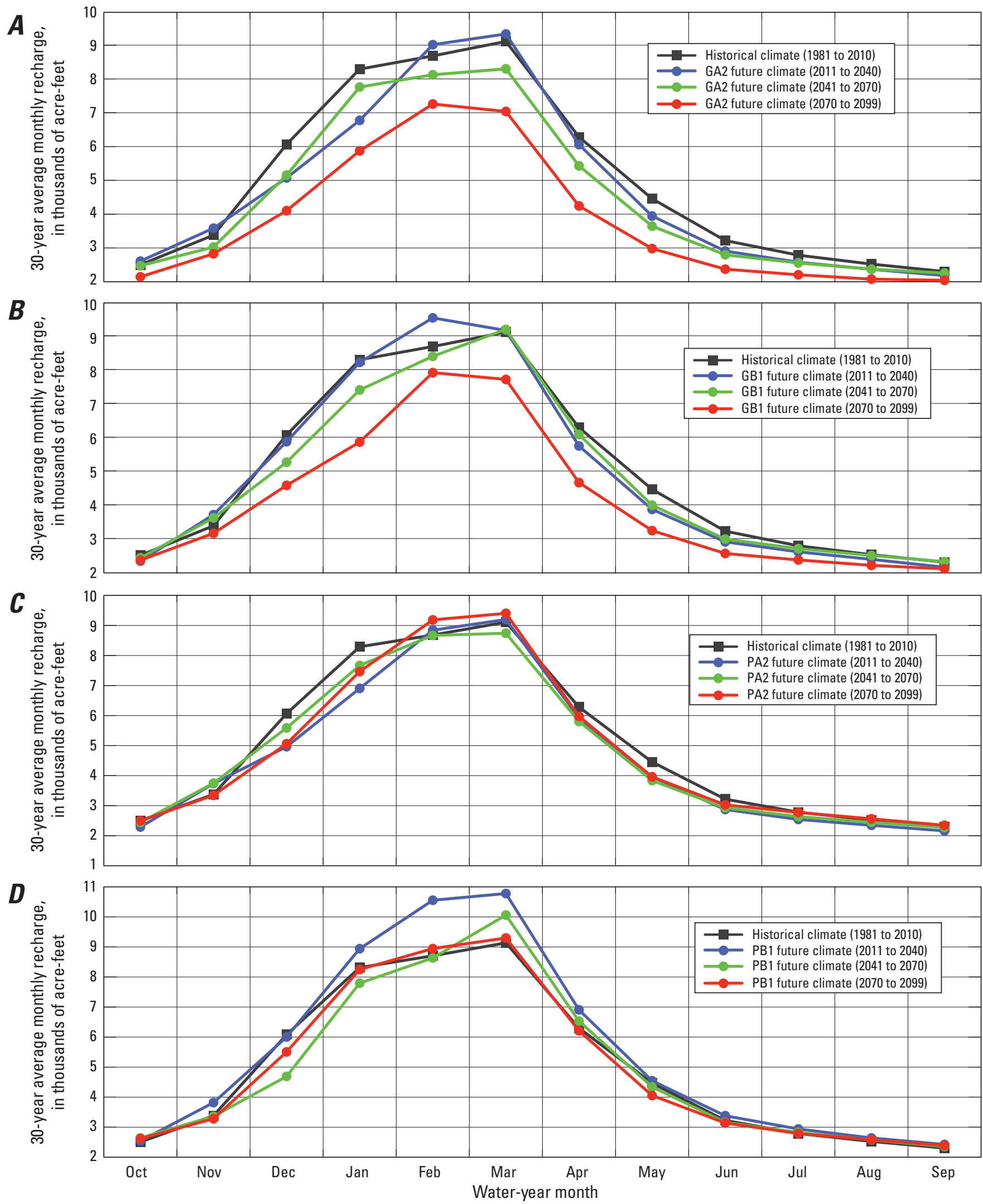

Figure 12. Comparison of 30-year monthly averages of total recharge simulated without pumping using the historical-climate baseline and the following future-climate scenarios, Santa Rosa Plain hydrologic model, Santa Rosa Plain watershed, Sonoma County, California: $A, \mathrm{GA} 2 ; B, \mathrm{~GB} 1 ; C, \mathrm{PA} 2 ; D, \mathrm{~PB} 1$. 

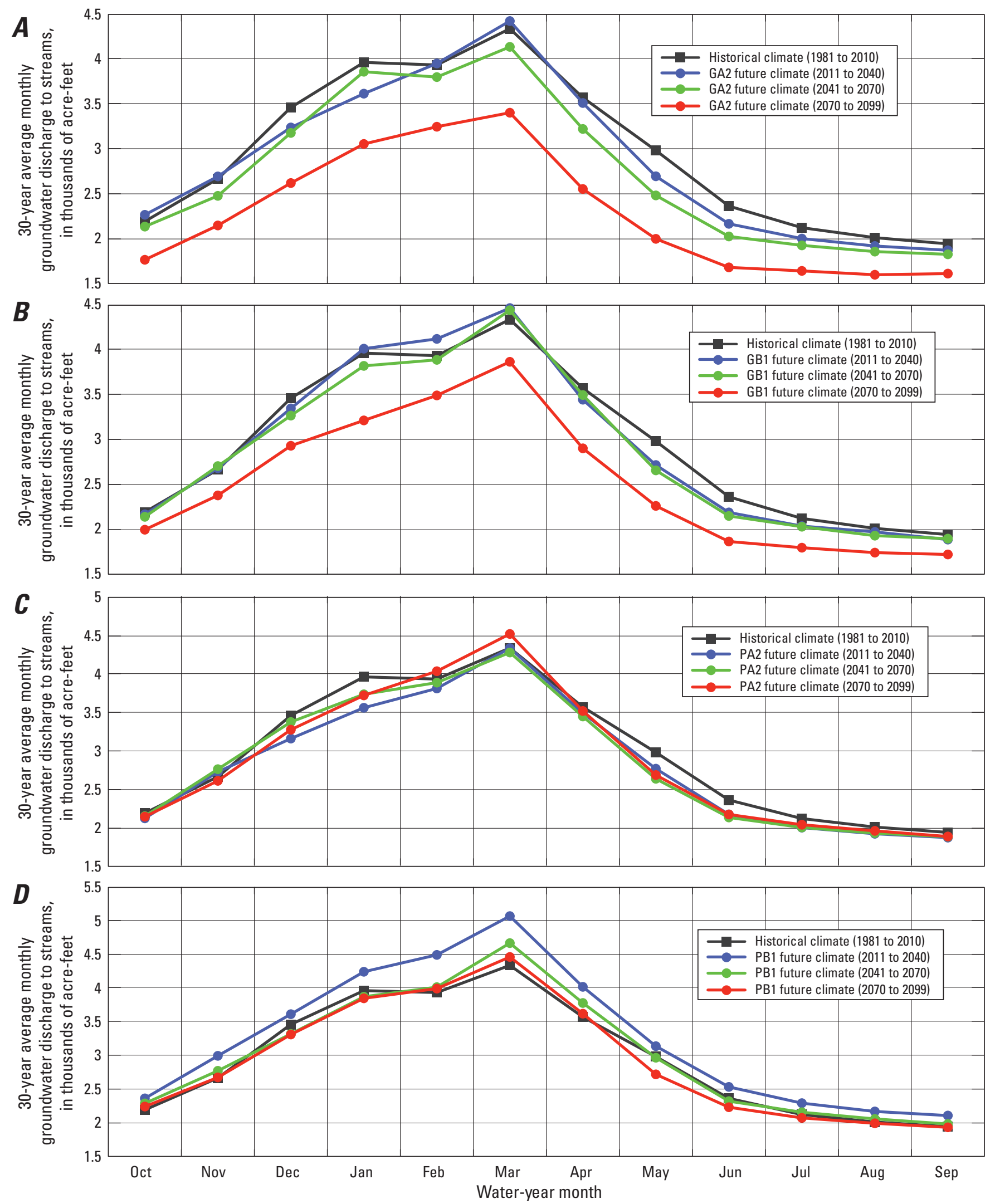

Figure 13. Comparison of 30-year monthly average groundwater discharge to streams simulated without pumping for the following future-climate scenarios, Santa Rosa Plain hydrologic model, Santa Rosa Plain watershed, Sonoma County, California: $A$, GA2; $B$, GB1; $C$, PA2; D, PB1. 
baseline period was in the results for the GA2 and GB1 scenarios during water years $2070-99$, when there was a pronounced decrease in groundwater discharge to streams for all months (figs. 13A, $B$ ). Groundwater discharge to streams was most like the historical-climate baseline in the PA2 climate scenario results (fig. 13C). For water years 2011-40, the PB1 scenario results differed noticeably from the historical-climate baseline by showing a large increase in groundwater discharge to streams during February, March, and April (fig. 13D).

\section{Average Monthly Groundwater Evapotranspiration}

The comparison of simulated average monthly results for simulated groundwater ET with the historical-climate baseline showed that for all future-climate scenarios, groundwater ET was higher for most months (fig. 14). This increase correlated to increasing air temperatures in the future-climate scenarios, which resulted in higher PET. For all the future-climate scenarios, the months of May, June, and July had the greatest increase in groundwater ET relative to the historical-climate baseline period.

Simulations using the GA2 and GB1 scenarios showed that, for water years 2011-40 and 2041-70, groundwater ET was higher from April through September than it was in the historical-climate baseline period (figs. 14A, $B$ ). For water years 2070-99, groundwater ET was less than the historicalclimate baseline period during July and August (figs. 14A, B) as a result of a decrease in recharge (figs. $12 A, B$ ) that caused water levels to decline below the ET extinction depths.

In contrast to the results from the simulations for the GA2 and GB1 scenarios, those for the PA2 and PB1 scenarios showed that for all 30-year periods for April through September groundwater ET was higher than for the historical-climate baseline period (figs. $14 C, D$ ). This increase resulted from an increase in recharge for these scenarios (figs. $12 C, D$ ).

\section{Effects of Future-Climate on the Spatial Distribution of Recharge}

Differences in the rate and location of recharge resulted from differences in the rate and distribution of precipitation among the future-climate scenarios in conjunction with differences in temperature, and associated PET, relative to historical-climate baseline. The differences in rates are discussed in detail in the "Average Annual Recharge" section of this chapter (fig. 6), but generalities in these differences are reviewed here. The spatial distribution of average annual simulated total recharge for the four future-climate scenarios, using the three 30 -year averaging periods used in the previous analyses, were compared with the 30 -year average recharge for the historical-climate baseline, both without pumping. The comparisons were done by calculating the areal difference, by model cell, between the average 30-year recharge for the future-climate scenarios and the historical-climate baseline period (future-climate recharge minus historical-climate baseline recharge). Hence, negative numbers in figures 15, 16, and 17 indicate a decrease in recharge and positive numbers indicate an increase for the future-climate scenarios. Recharge can be more sensitive to the distribution and timing of precipitation than to the increased PET from higher temperatures, resulting in greater recharge in some areas of the SRPW for the future-climate scenarios than for the historical-climate baseline period.

For water years 2011-40, the differences between average annual simulated recharge distribution for the four future-climate scenarios and the historical-climate baseline varied spatially among the scenarios (fig. 15). In general, recharge increased in the northeastern part of the SRPW (fig. 15). Conversely, recharge decreased in the western and southeastern parts of the SRPW in the results for the GA2 and PAC scenarios, in the southwestern and southeastern parts of the SRPW in the GB1 scenario results, and in the southwestern part of the SRPW in the PB1 scenario results (fig. 15). On a local scale, differences in recharge (both negative and positive) were greater in response to changes in runoff and interflow along cascades, which route both surface and subsurface flow across land areas. In the stream channels, decreased groundwater levels caused more recharge from streams and less groundwater discharge to streams. Extra-channel recharge increased the most compared with historical-climate conditions in the PB1 scenario results (fig. 15D).

Comparison of recharge simulated without pumping for water years 2041-70 with the historical-climate baseline recharge indicated an overall decrease in recharge in the results for all four future-climate scenarios (fig. 6 and figs. $16 A-D$ ). Recharge decreased the most along the southwestern part of the SRPW and in isolated upland areas, primarily where inflows from cascades were most affected by climatic differences.

Comparison of recharge simulated without pumping for water years 2070-99 with the historical-climate baseline recharge indicated that the greatest relative decreases in basinwide recharge in the results for the GA2 and GB1 scenarios were along the southwestern part of the SRPW (figs. 17A, $B$ ). Even with the substantial decreases in basin-wide recharge in the results for the GA2 and GB1 scenarios, there were areas of increased recharge as a result of changes in the spatial distribution of precipitation and air temperature and of decreasing groundwater levels, which decreased the likelihood of rejected recharge. In the results for the PA2 and PB1 scenarios, there were large areas of increased recharge in the central and northern parts of the SRPW (figs. 17C, D). 

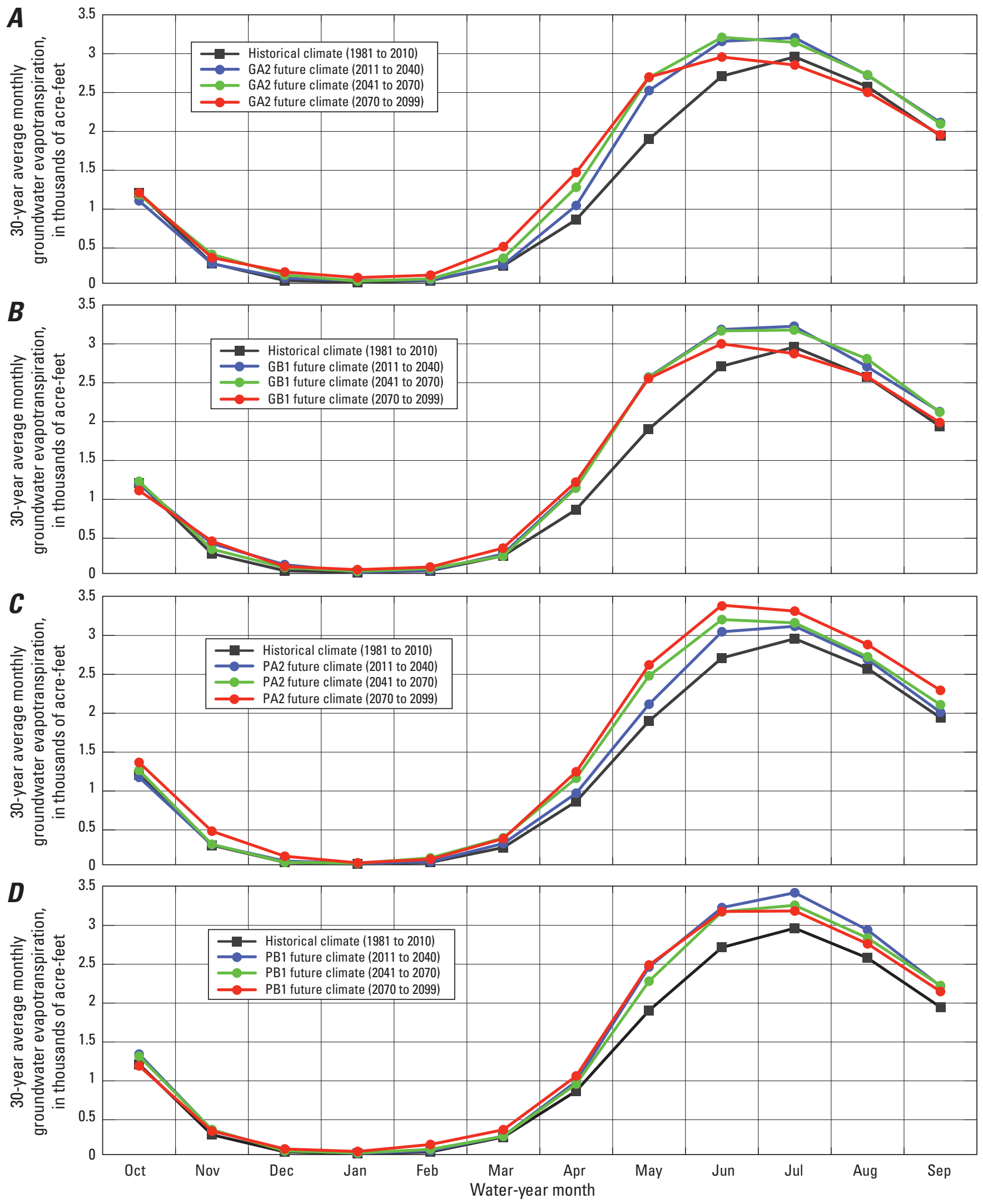

Figure 14. Comparison of 30-year monthly average groundwater evapotranspiration simulated without pumping for the following future-climate scenarios, Santa Rosa Plain hydrologic model, Santa Rosa Plain watershed, Sonoma County, California: $A, \mathrm{GA2}$; $B$, GB1; $C$, PA2; D, PB1. 

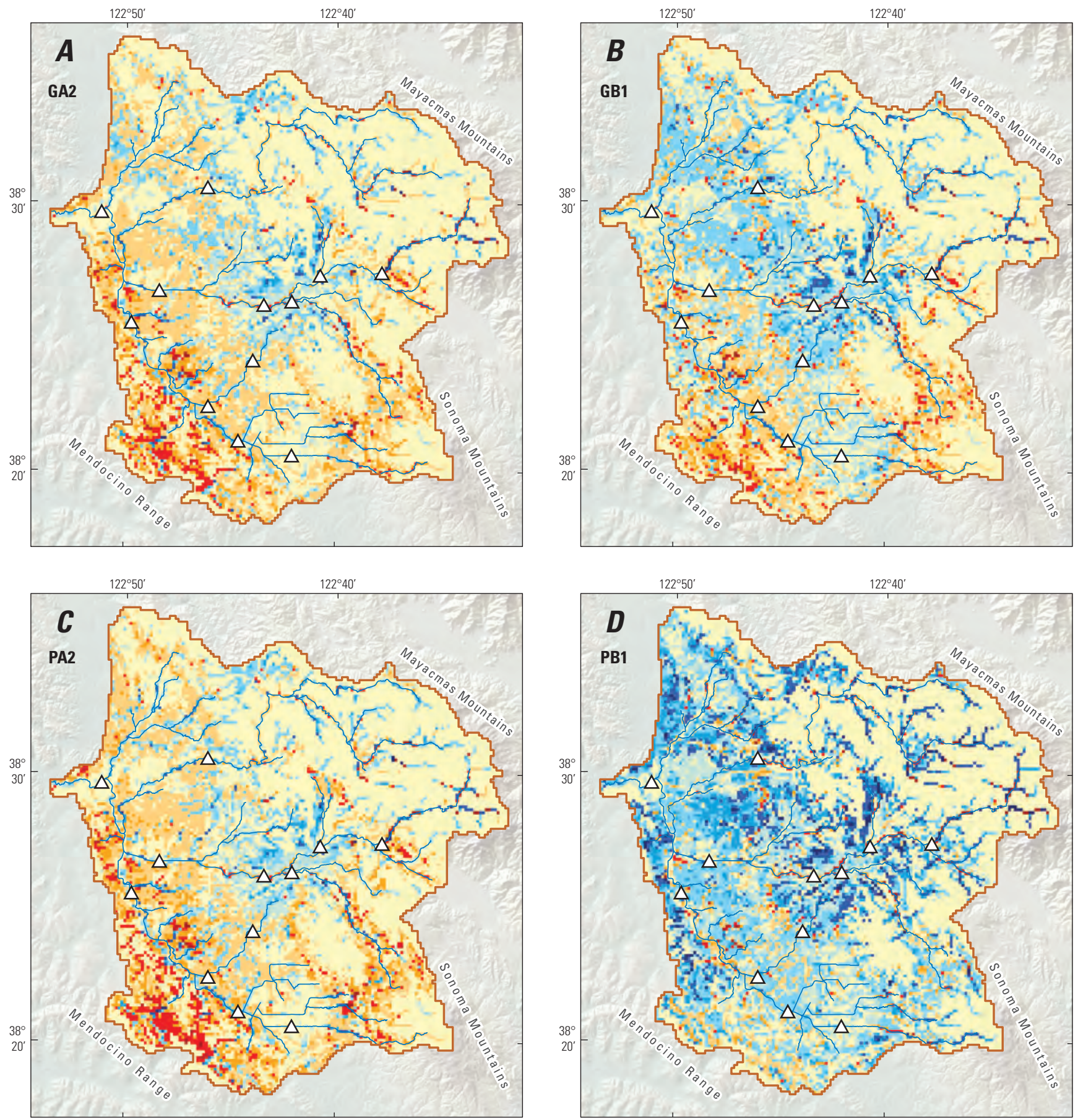

\section{EXPLANATION}

Difference in 30-year average recharge, in inches per year, without pumping, for future-climate scenarios (2011-2040) minus historic climate (1981-2010)

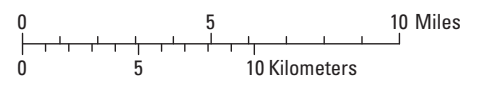

\begin{tabular}{|r|r|r|r|r|}
\hline-47 to -5 & -1.9 to -1 & -0.09 to 0 & 0.11 to 1 & 2.1 to 5 \\
-4.9 to -2 & -0.9 to -0.1 & 0.01 to 0.1 & 1.1 to 2 & 5.1 to 76
\end{tabular}

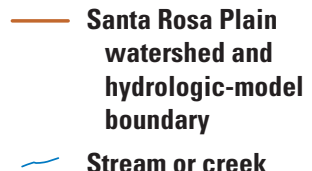

$\triangle$ USGS streamgage

Figure 15. Difference between 30-year average recharge simulated without pumping for water years 2011-40 and historical-climate baseline conditions (water years 1981-2010), using the following future-climate scenarios, Santa Rosa Plain hydrologic model, Santa Rosa Plain watershed, Sonoma County, California: $A, \mathrm{GA} 2 ; B, \mathrm{~GB} 1 ; C, \mathrm{PA} 2 ; \mathrm{D}, \mathrm{PB} 1$. 

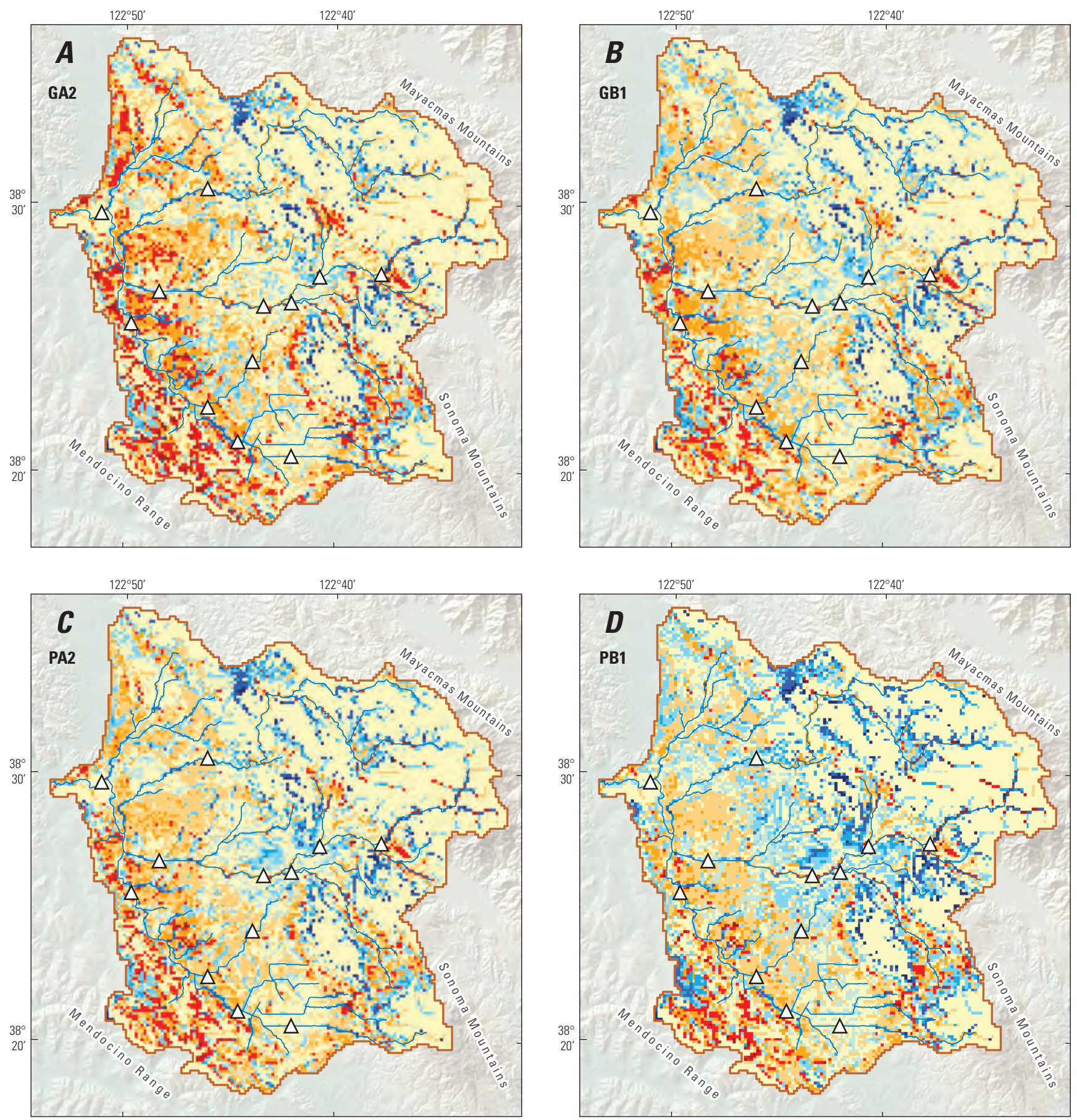

\section{EXPLANATION}

Difference in 30-year average recharge, in inches per year, without pumping, for future-climate scenarios (2041-2070) minus historic climate (1981-2010)

\begin{tabular}{|r|r|r|r|r|}
\hline-54 to -5 & -1.9 to -1 & -0.09 to 0 & 0.11 to 1 & 2.1 to 5 \\
-4.9 to -2 & -0.9 to -0.1 & 0.01 to 0.1 & 1.1 to 2 & 5.1 to 36
\end{tabular}
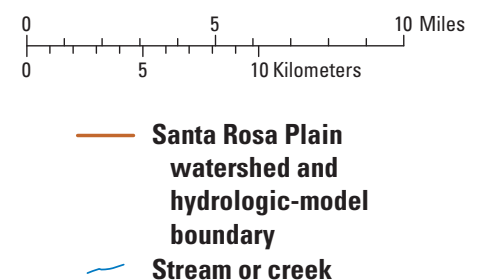

$\triangle$ USGS streamgage

Figure 16. Difference between 30-year average recharge simulated without pumping for water years 2041-70 and 30-year average recharge for historical-climate baseline conditions (water years 1981-2010) using the following future-climate scenarios, Santa Rosa Plain hydrologic model, Santa Rosa Plain watershed, Sonoma County, California: A, GA2; B, GB1; C, PA2; D, PB1. 

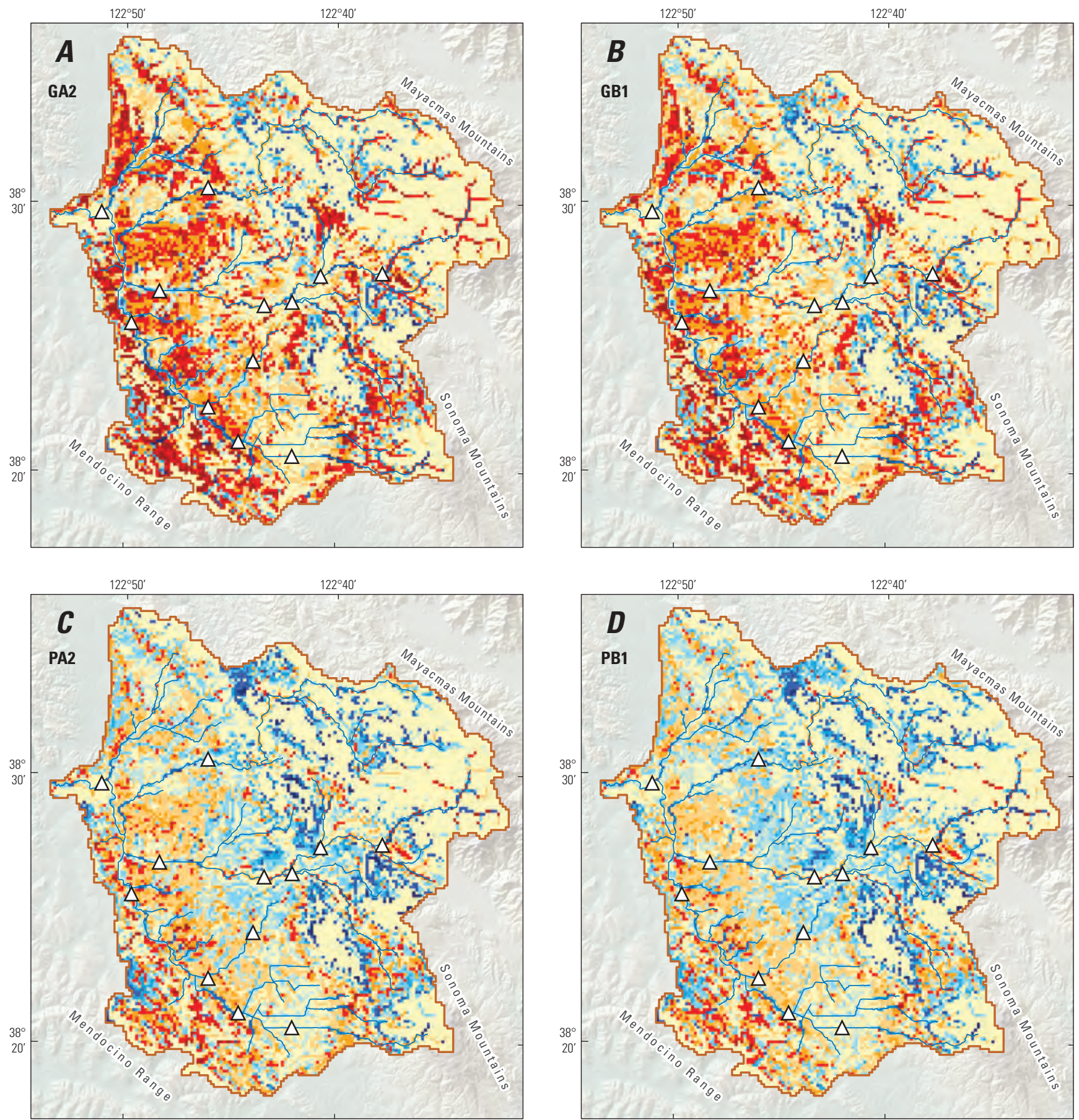

\section{EXPLANATION}

Difference in 30-year average recharge, in inches per year, without pumping, for future-climate scenarios (2070-2099) minus historic climate (1981-2010)
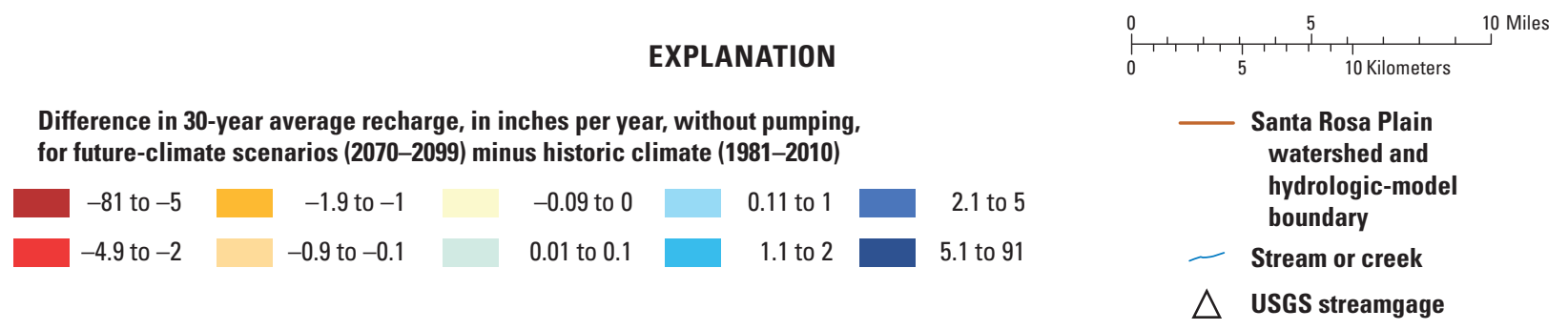

Figure 17. Difference between 30-year average recharge simulated without pumping for water years 2070-99 historical-climate baseline conditions (water years 1981-2010) using the following future-climate scenarios, Santa Rosa Plain hydrologic model, Santa Rosa Plain watershed, Sonoma County, California: $A, \mathrm{GA} 2 ; B, \mathrm{~GB} 1 ; C, \mathrm{PA} 2 ; D, \mathrm{~PB} 1$. 


\section{Effects of Future Climate on the Spatial Distribution of Streamflow}

For simplicity, to assess the effects of future climate on the spatial distribution of streamflow, 30-year windows from two of the future-climate extremes were examined. The simulated streamflow for water years 2070-99 in the GA2 scenario and 2011-40 in the PB1 scenario were compared with simulated streamflow in the 30 -year historical-climate baseline period (figs. 5, 18). Comparisons were made using average annual streamflow and average monthly streamflow for February, May, and August. The GA2 scenario was drier and the PB1 scenario was wetter than the other scenarios for water years 2011-99 (table 1).

The average streamflow for the historical-climate baseline period indicated that for the main stream channels, average streamflow generally was greater than $40 \mathrm{ft}^{3} / \mathrm{s}$, while average streamflow in most tributaries was comparatively low, ranging from about $5 \mathrm{ft}^{3} / \mathrm{s}$ to less than $1 \mathrm{ft}^{3} / \mathrm{s}$ (fig. 18A). Simulated average monthly streamflow was highest for February and lowest for August, with many streams going dry in August (figs. 18B, D). Simulated streamflow for August indicated sections of streams where the upstream flows were higher than the downstream flows because the streams were losing and recharging the groundwater system (figs. 18B, D). For example, the highest average August streamflow was 2-5 $\mathrm{ft}^{3} / \mathrm{s}$ (about 1,450-3,600 acre-ft/yr), simulated upstream from the Matanzas Creek at Santa Rosa (MATC) streamgage, whereas streamflow downstream from this streamgage was only $0.5-1 \mathrm{ft}^{3} / \mathrm{s}$ (about 360-720 acre-ft/yr; fig. 18D). Average streamflow in May was comparatively high in the main stream channels, averaging 10-15 $\mathrm{ft}^{3} / \mathrm{s}$ at the Mark West Creek near Mirabel Heights (MWCM) streamgage and $20-50 \mathrm{ft}^{3} / \mathrm{s}$ at the SRCW and Laguna de Santa Rosa near Sebastopol (LAGS) streamgages; however, streamflows were comparatively low in the smaller tributaries. For example, streamflows at the Copeland Creek at Rohnert Park (COPE) streamgage were only $1-2 \mathrm{ft}^{3} / \mathrm{s}$ (fig. 18C).

As previously stated, the GA2 future-climate scenario was the driest overall (table 1). Specifically, the GA2 scenario was driest during water years 2070-99, with an average precipitation rate of 30 inches per year (in/yr) (table 1). Average simulated streamflow for water years 2070-99 using the GA2 scenario indicated a reduction in the annual and monthly streamflows relative to simulated streamflow for the historical-climate baseline simulation (figs. 5, 19). Average annual streamflow throughout the central part of the Laguna de Santa Rosa ranged from 40 to $80 \mathrm{ft}^{3} / \mathrm{s}$ (about 29,000-58,000 acre-ft/yr) compared with an average annual streamflow of $80-160 \mathrm{ft}^{3} / \mathrm{s}$ (about 58,000-116,000 acre-ft/yr) for the historical-climate baseline period (figs. 18A, 19A). Streamflow for February in the Laguna de Santa Rosa, upstream from the LAGS streamgage, ranged from 160 to $320 \mathrm{ft}^{3} / \mathrm{s}$ (about 116,000-232,000 acre-ft/yr) and was similar to the streamflow in the historical-climate baseline period (figs. 18B, 19B). Streamflow for May in the Laguna de Santa Rosa ranged from 2 to $5 \mathrm{ft}^{3} / \mathrm{s}$ (about 1,500-3,600 acre-ft/yr) compared with an average monthly rate of $20-50 \mathrm{ft}^{3} / \mathrm{s}$ (about 14,000-36,000 acre-ft/yr) for the historical-climate baseline period (figs. 18C, 19C). Streamflow for August in the Laguna de Santa Rosa was less than $1 \mathrm{ft}^{3} / \mathrm{s}$ (about 700 acre-ft/yr) for water years 2070-99 compared with an average monthly rate of $2-5 \mathrm{ft}^{3} / \mathrm{s}$ (about 1,500-3,600 acre-ft/yr) for the historicalclimate baseline period (figs. 18D, 19D). Many of the stream segments that maintained minimum streamflows during May and August in the historical-climate baseline simulation became dry during May and August in the GA2 scenario results during water years 2070-99 (figs. 19C, D).

The PB1 future-climate scenario was the wettest scenario overall (table 1). Specifically, the PB1 scenario had high precipitation rates during water years $2011-40$ with an average precipitation rate of $46.3 \mathrm{in} / \mathrm{yr}$ (table 1). In the PB1 scenario, the high precipitation during water years 2011-40 resulted in increased streamflow relative to the historicalclimate baseline period (figs. 5, 20). Average annual streamflow for the middle upper Mark West Creek ranged from 80 to $160 \mathrm{ft}^{3} / \mathrm{s}(58,000-116,000$ acre-ft/yr) compared with an average annual rate of 40-80 ft³ $/ \mathrm{s}(29,000-58,000$ acre-ft/yr) during the historical-climate baseline period (figs. 18A, 20A). The most pronounced change was the increase in streamflow during February in the PB1 scenario results; average monthly streamflow increased to at least $321 \mathrm{ft}^{3} / \mathrm{s}$ (about 232,000 acre-ft/yr) for the middle sections of Mark West Creek, Santa Rosa Creek, and the Laguna de Santa Rosa compared with average streamflow of $161-320 \mathrm{ft}^{3} / \mathrm{s}$ (about 117,000-232,000 acre-ft/yr) during the historical-climate baseline period (figs. 18B, 20B). May streamflow decreased relative to the historical-climate baseline in the PB1 scenario (figs. 18C, 20C), whereas August streamflow increased for Mark West Creek, but decreased in smaller tributaries (figs. 18D, 20D). These differences reflected a shift of the runoff and interflow components of streamflow to January and February because the most precipitation fell in these months in the PB1 scenario, whereas precipitation was distributed more evenly from December through March during the historicalclimate period (fig. 9).

\section{Model Application: Future-Climate Scenarios with Projected Pumpage}

Estimated future pumpage was included with the futureclimate scenarios to assess the hydrologic response to the combination of these stresses. The future-climate simulations with pumping were used to develop the groundwater budget for water years 2011-40. Estimates of groundwater pumpage, which is composed of public-supply and rural (domestic and agricultural combined) pumpage, were projected through 2040. Comparisons were made to the historical-climate baseline simulation with pumpage to evaluate changes in selected components of the groundwater budget. For simplicity, reclaimed water, which was applied to agricultural irrigation as added precipitation in the historical-baseline period, was not used for the future-climate scenarios. 


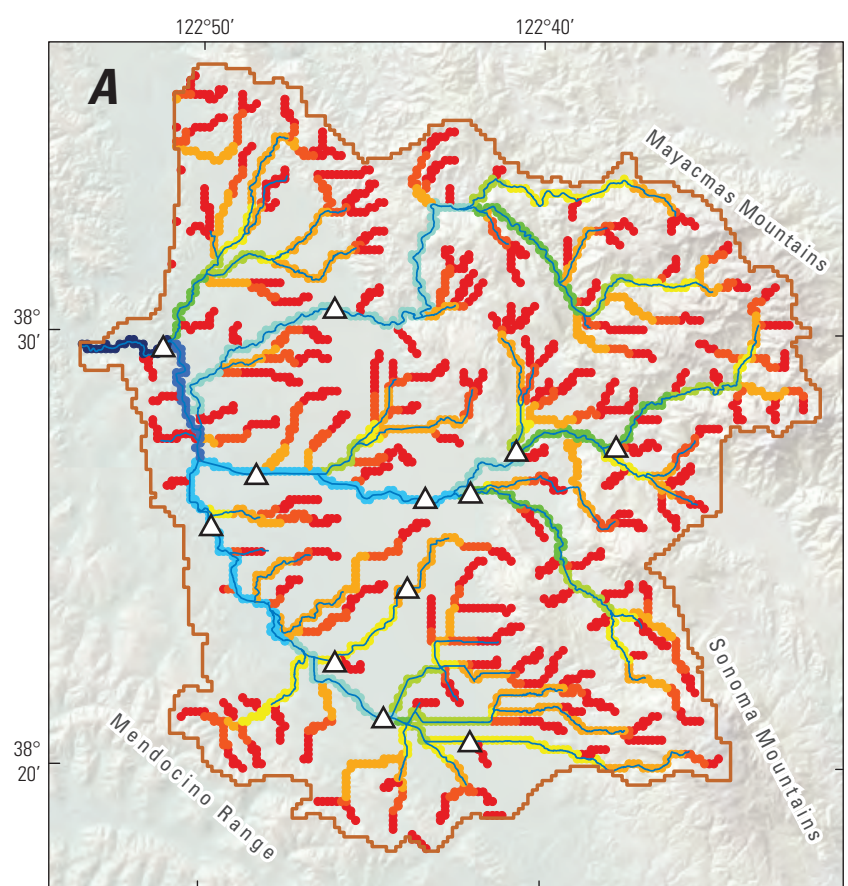

Average annual streamflow, in cubic-feet per second, without pumping, water years 1981-2010

- 0.03 to $1 \quad 2.01$ to $5 \quad 10.1$ to $20 \quad 40.1$ to $80 \quad-161$ to 320

- 1.01 to $2 \quad 5.01$ to $10 \quad 20.1$ to $40 \quad 80.1$ to 160 - 321 to 346

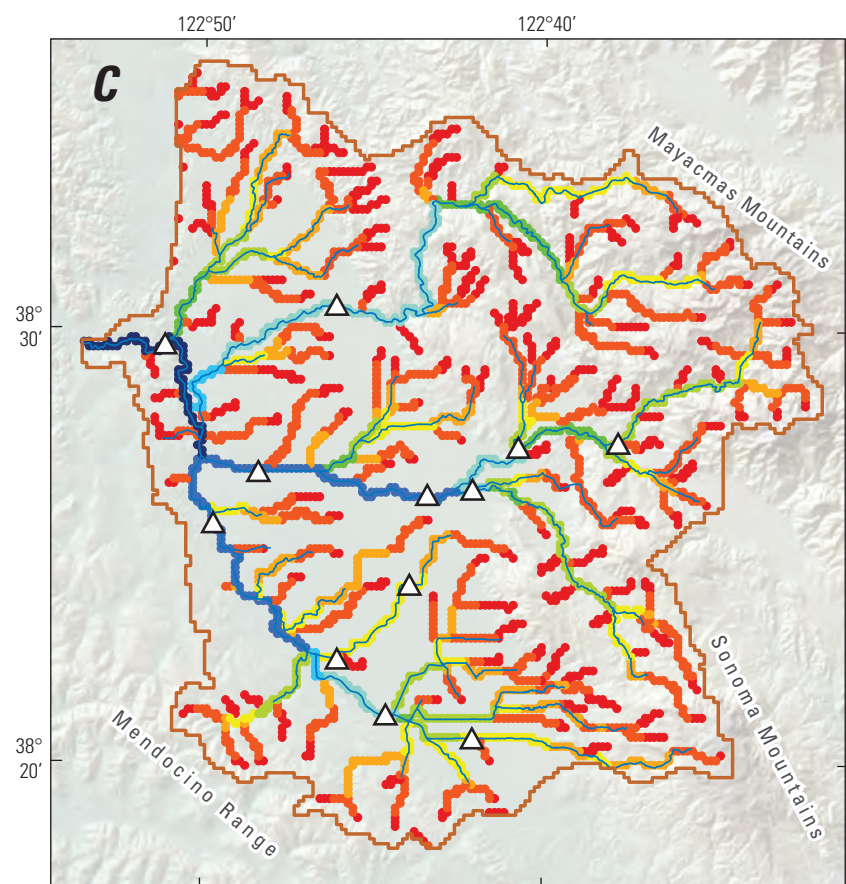

Average May streamflow, in cubic-feet per second, without pumping, water years 1981-2010

- 0.005 to $0.1 \cdot 0.501$ to $1 \quad 2.01$ to $5 \quad 10.1$ to $15 \quad 20.1$ to 50

- 0.101 to $0.5 \quad 1.01$ to $2 \quad 5.01$ to 10 - 15.1 to 20 - 50.1 to 93.8

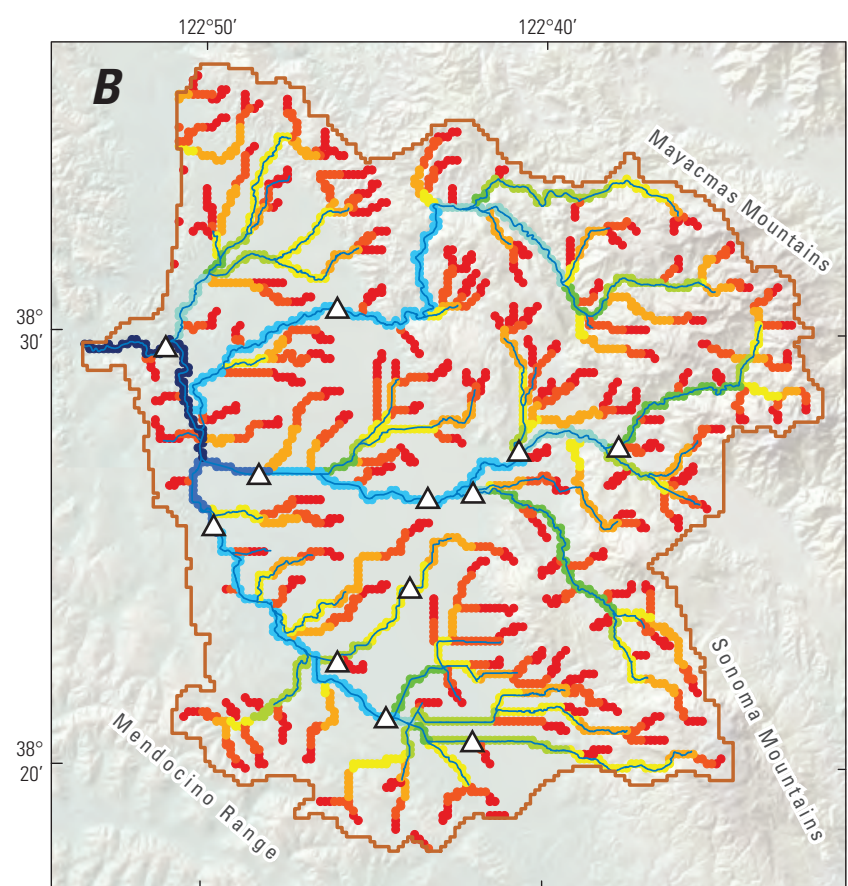

Average February streamflow, in cubic-feet per second, without pumping, water years 1981-2010

- 0.09 to $2 \quad 5.01$ to $10 * 20.1$ to $40 * 80.1$ to $160 * 321$ to 640

- 2.01 to $5 \quad 10.1$ to $20 \quad 40.1$ to $80 \quad 161$ to $320 \quad 641$ to 1,070

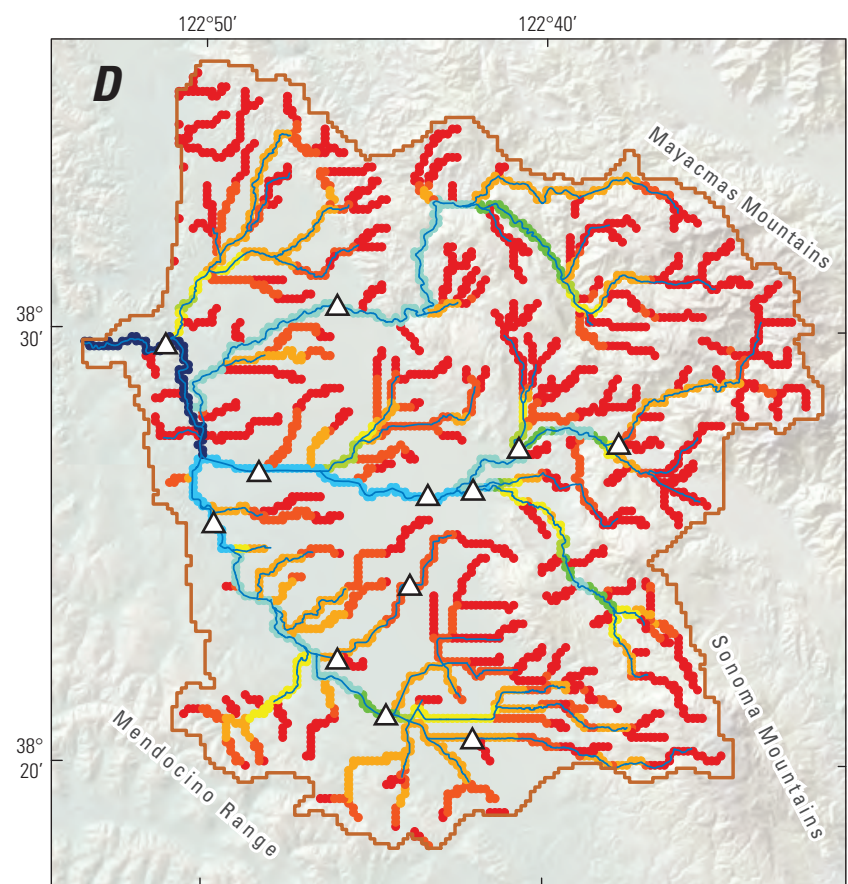

Average August streamflow, in cubic-feet per second, without pumping, water years 1981-2010

- 0 to $0.01 \quad 0.101$ to $0.5-1.01$ to $1.50-2.01$ to $5 \quad 10.1$ to 15

0.0101 to $0.1 \quad 0.501$ to 1 - 1.51 to 2 - 5.01 to 10 - 15.1 to 20.1

\section{EXPLANATION}

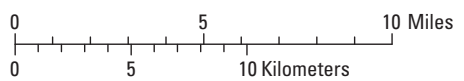

_ Santa Rosa Plain watershed and hydrologic-model boundary

- Stream or creek $\triangle$ USGS streamgage

Figure 18. 30-year average streamflow simulated without pumping for historical-climate baseline conditions (water years 1981-2010), Santa Rosa Plain hydrologic model, Santa Rosa Plain watershed, Sonoma County, California: $A$, annual; $B$, February; $C$, May; $D$, August 


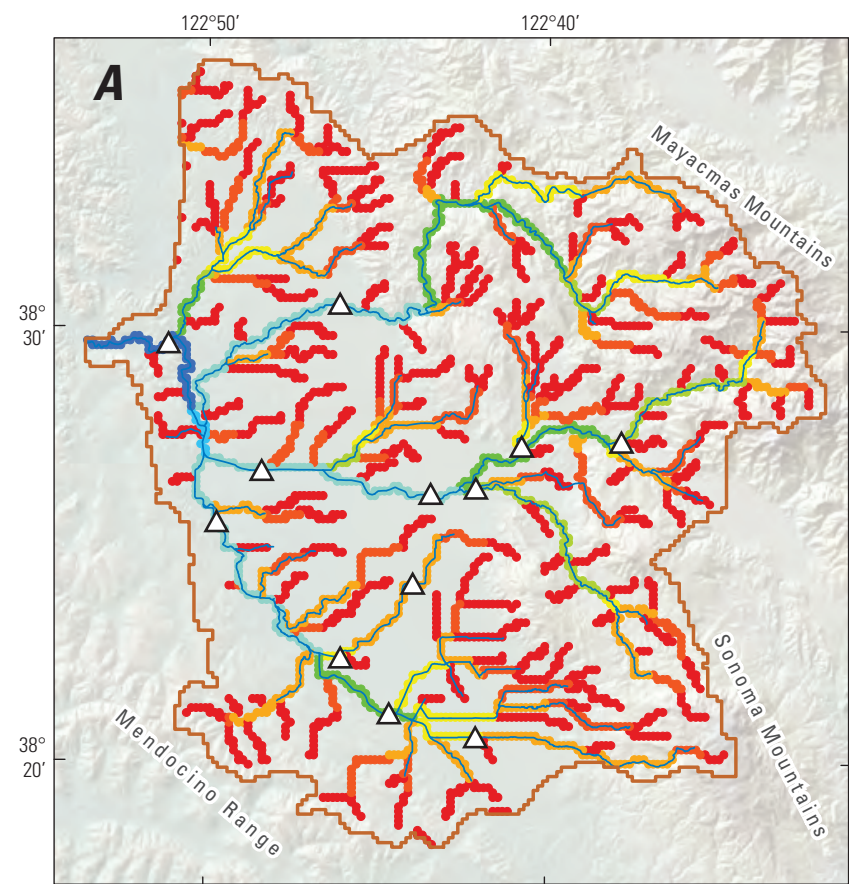

Average annual streamflow, in cubic-feet per second, without pumping, water years 2070-2099

- 0.02 to $1-2.01$ to 5 - 10.1 to $20 \quad 40.1$ to $80 \quad 161$ to 320

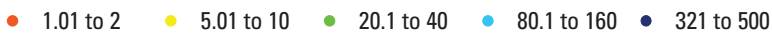

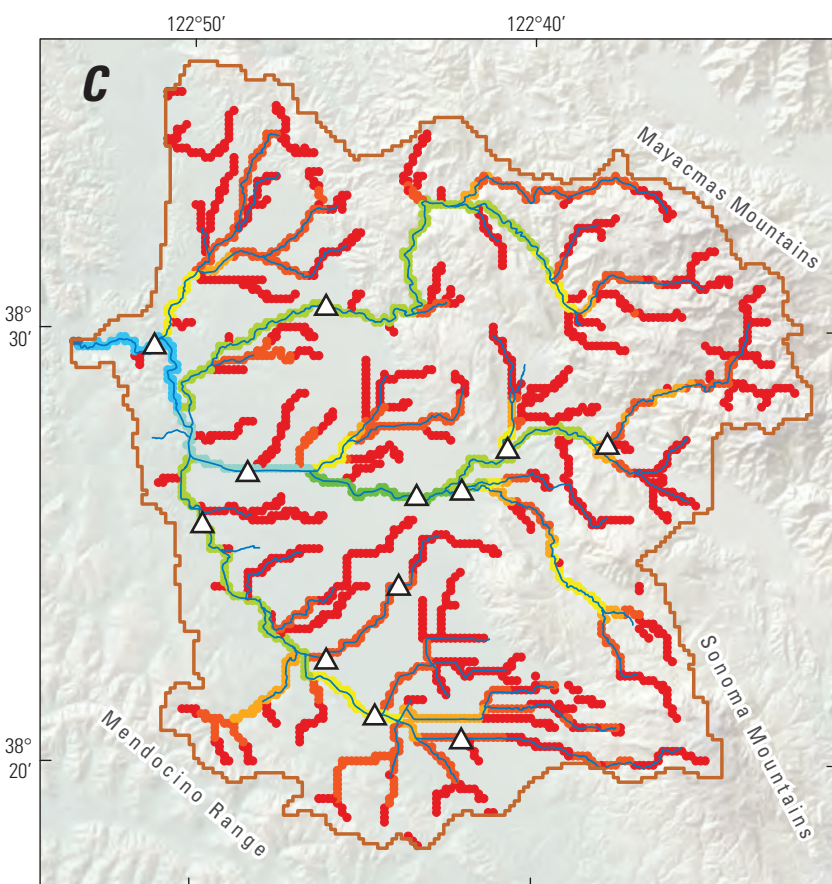

Average May streamflow, in cubic-feet per second, without pumping, water years 2070-2099

- 0 to $0.1 \quad 0.501$ to $1-2.01$ to $5 \quad 10.1$ to $15 \quad 20.1$ to 50

- 0.101 to $0.5 \quad 1.01$ to $2 \quad 5.01$ to $10 * 15.1$ to 20 - 50.1 to 93.8

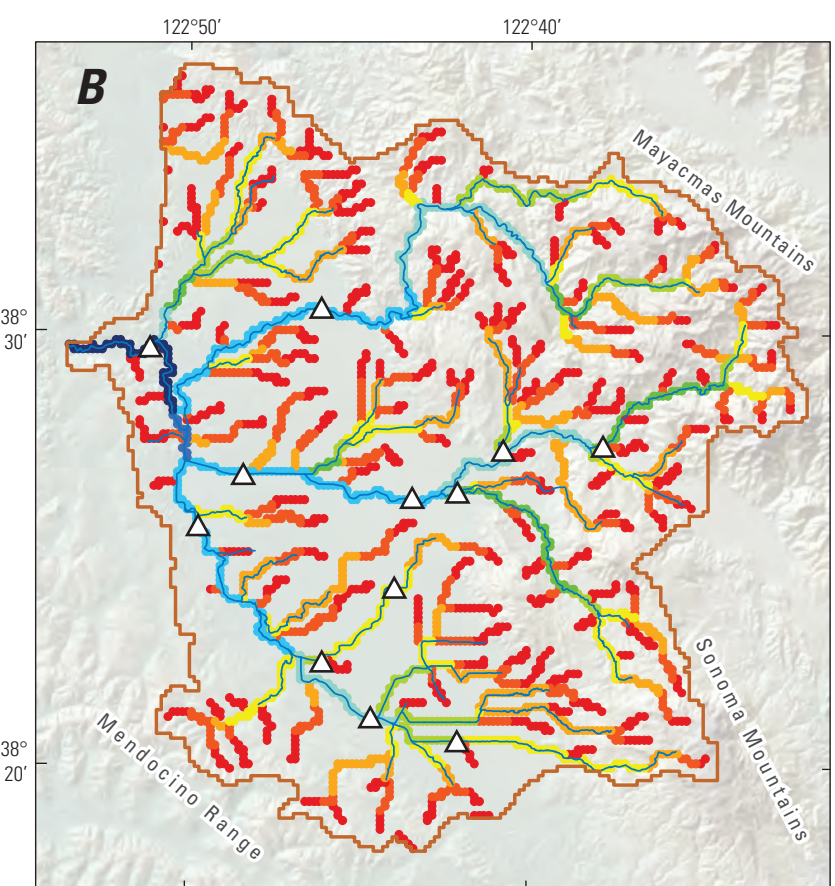

Average February streamflow, in cubic-feet per second, without pumping, water years 2070-2099

- 0.08 to $2 \quad 5.01$ to $10 \quad 20.1$ to $40 \quad 80.1$ to $160 \quad 321$ to 640

- 2.01 to $5 \quad 10.1$ to $20 \quad 40.1$ to $80 \quad 161$ to $320 \quad 641$ to 870

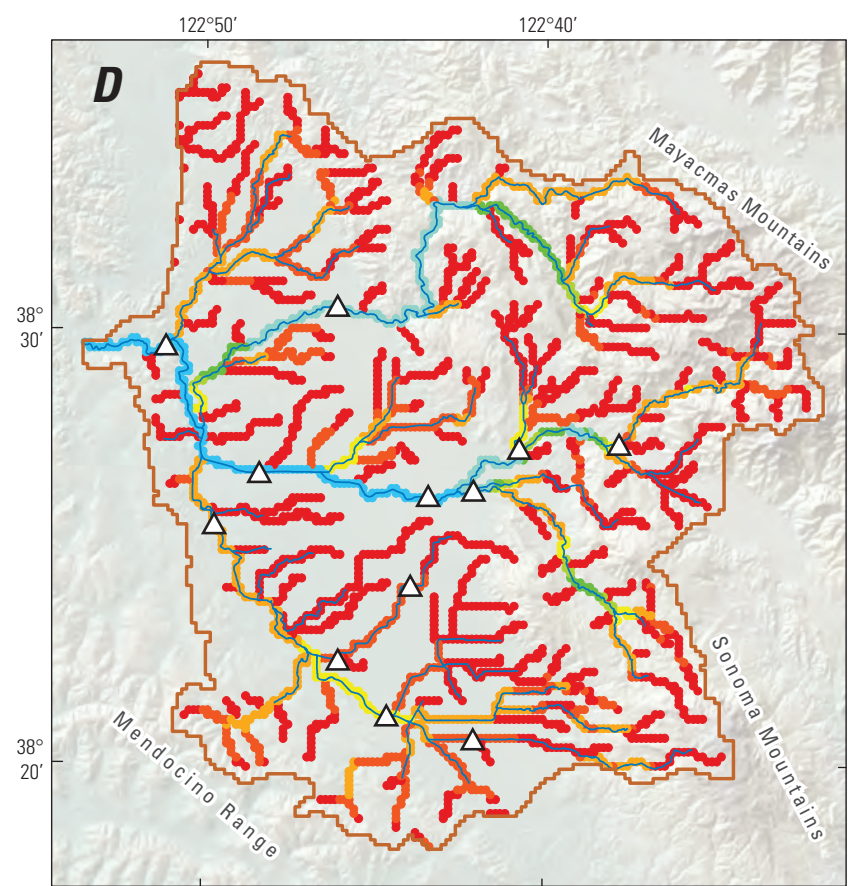

Average August streamflow, in cubic-feet per second, without pumping, water years 2070-2099

-0 to $0.01 \quad 0.101$ to $0.5 \cdot 1.01$ to $1.50 \bullet 2.01$ to $5 \cdot 10.1$ to 15

0.0101 to $0.1 \quad 0.501$ to 1 - 1.51 to 2 - 5.01 to 10 - 15.1 to 20.1

\section{EXPLANATION}

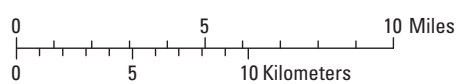

— Santa Rosa Plain watershed and hydrologic-model boundary

- Stream or creek $\triangle$ USGS streamgage

Figure 19. 30-year average streamflow simulated without pumping for water years 2070-99 in the GA2 future-climate scenario, Santa Rosa Plain hydrologic model, Santa Rosa Plain watershed, Sonoma County, California: $A$, annual; $B$, February; $C$, May; $D$, August. 


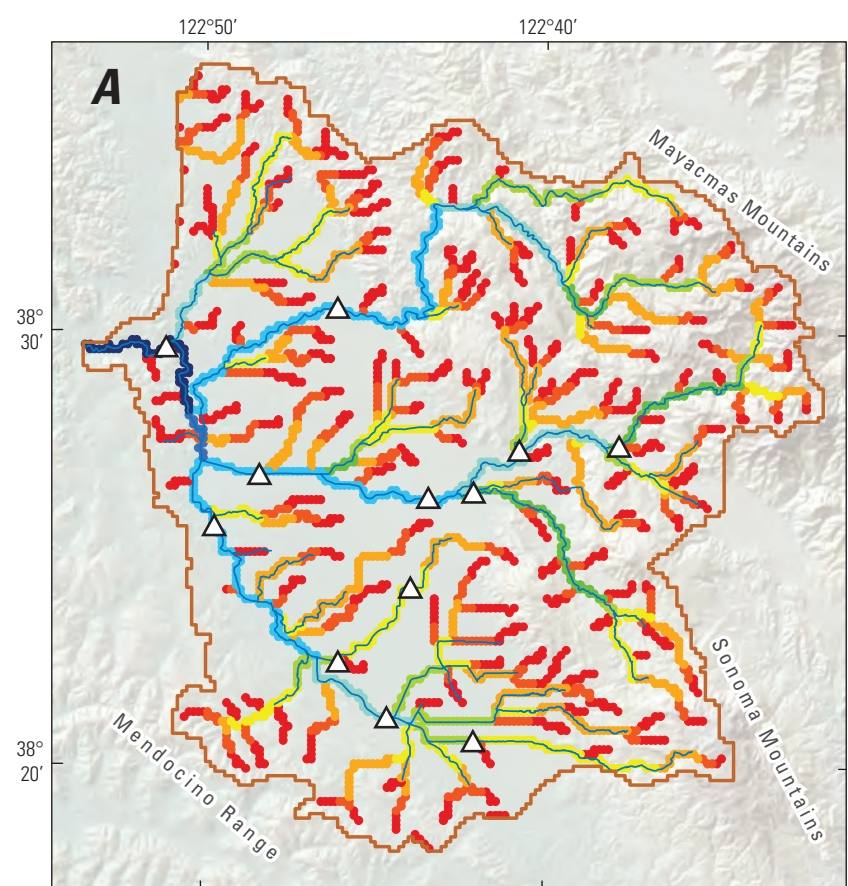

Average annual streamflow, in cubic-feet per second, without pumping, water years 2011-2040

- 0.04 to $1 \quad 2.01$ to $5 \quad 10.1$ to $20 \quad 40.1$ to $80 \quad-161$ to 320

- 1.01 to $2 \quad 5.01$ to $10 \quad 20.1$ to $40 \cdot 80.1$ to 160 - 321 to 461

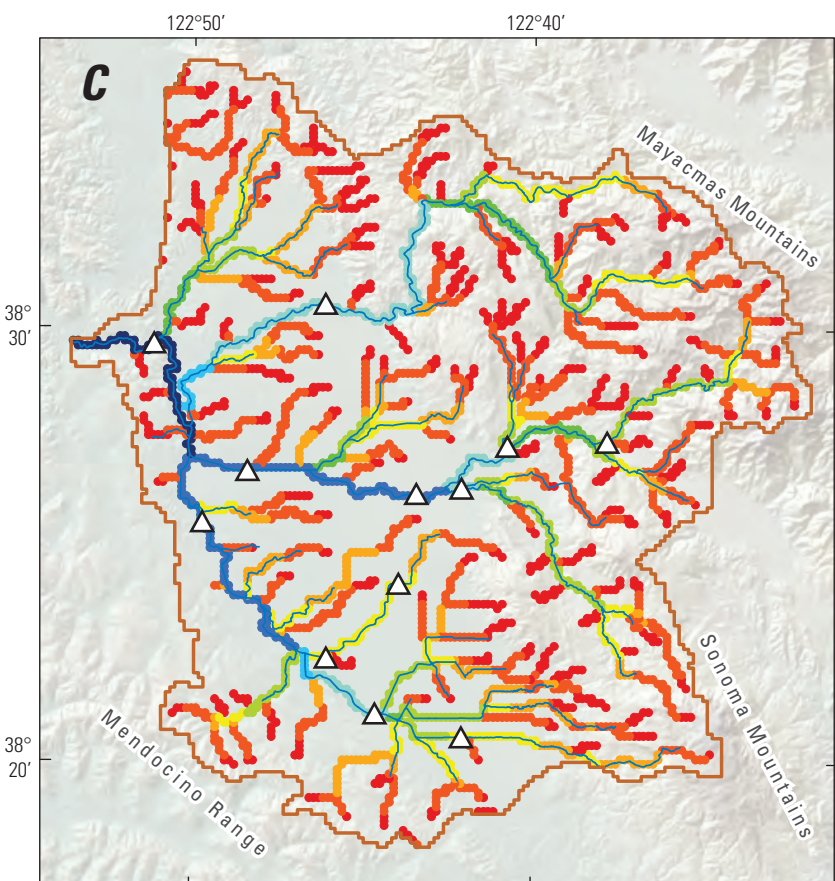

Average May streamflow, in cubic-feet per second, without pumping, water years 2011-2040

- 0.005 to $0.1 \cdot 0.501$ to $1 \quad 2.01$ to $5 \quad 10.1$ to $15 \quad 20.1$ to 50

- 0.101 to $0.5 \quad 1.01$ to 2 - 5.01 to 10 - 15.1 to 20 - 50.1 to 93.8

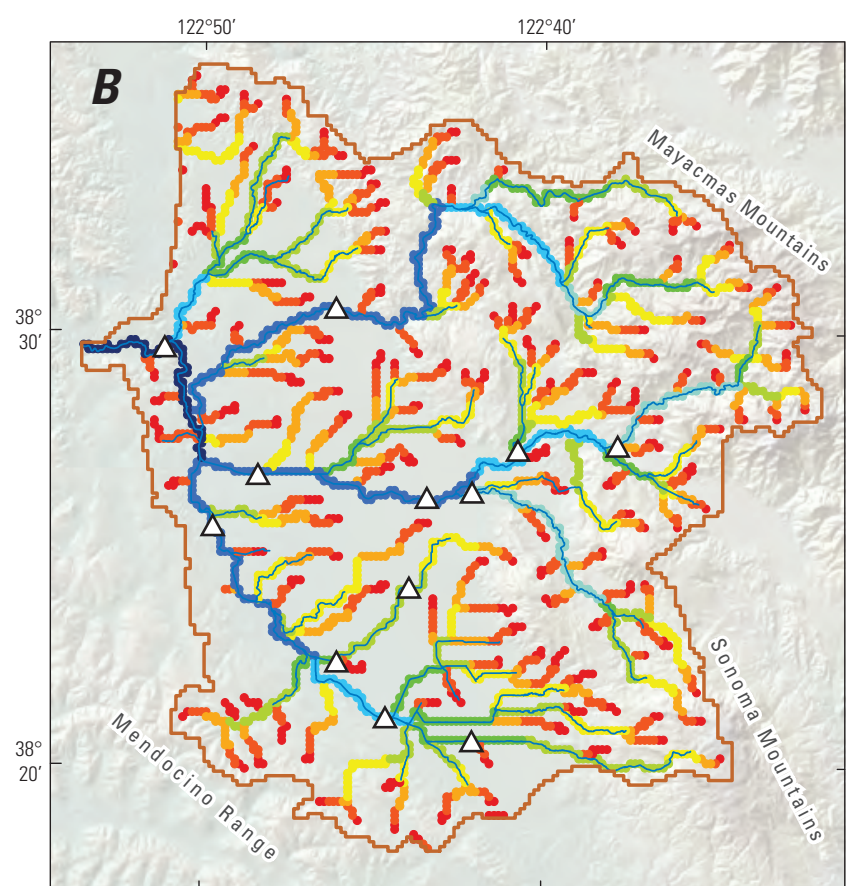

Average February streamflow, in cubic-feet per second, without pumping, water years 2011-2040

- 0.0939 to $2 * 5.01$ to $10 * 20.1$ to $40 * 80.1$ to 160 - 321 to 640

- 2.01 to $5 \quad 10.1$ to $20 \quad 40.1$ to $80 \quad 161$ to $320 \quad 641$ to 2,000

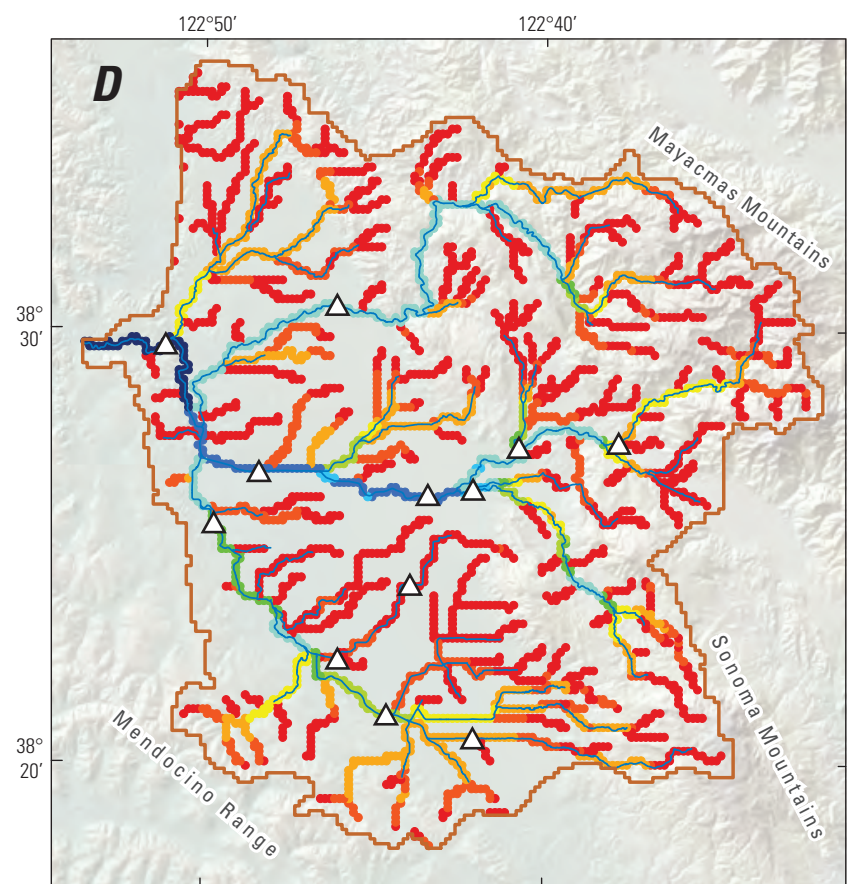

Average August streamflow, in cubic-feet per second, without pumping, water years 2011-2040

- 0 to $0.01 \quad 0.101$ to $0.5-1.01$ to $1.50 \bullet 2.01$ to $5 \quad 10.1$ to 15

0.0101 to $0.1 \quad 0.501$ to 1 - 1.51 to 2 - 5.01 to 10 - 15.1 to 20.1

\section{EXPLANATION}

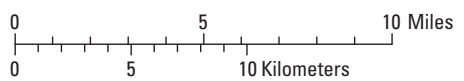

_ Santa Rosa Plain watershed and hydrologic-model boundary

- Stream or creek $\triangle$ USGS streamgage

Figure 20. 30-year average streamflow simulated without pumping for water years $2011-40$ in the PB1 future-climate scenario, Santa Rosa Plain hydrologic model, Santa Rosa Plain watershed, Sonoma County, California: $A$, annual; $B$, February; $C$, May; $D$, August. 


\section{Groundwater Pumpage}

Groundwater use in the SRPW is predominantly for public supply and rural uses. Public-supply pumpage was estimated by Sonoma County Water Agency (Marcus Trotta, Sonoma County Water Agency, written commun., July 24, 2012). Domestic pumpage for water years 2011-40 was estimated on the basis of a projected 12-percent increase in the number of households in unincorporated areas of Sonoma County (Association of Bay Area Governments, 2013). This was prorated over the 30 -year period to be about 0.4 percent per year. The monthly pumpage for a given water year was determined by multiplying the pumpage for each month in the preceding water year by a factor of 1.004 . Note that this simplified calculation resulted in a total growth of 12.7 percent because of monthly compounding. Public-supply and domestic pumpage were assumed not to be influenced by climate, and the same estimates were used for all future-climate scenarios.

Estimates of agricultural pumpage were developed for the four future-climate scenarios using the 2008 land-use map (Appendix 1, fig. 2E) and the methods discussed in Appendix 1 of this report. The spatial distribution of irrigated crop types was the same as the 2008 land-use map, held constant throughout the 30-year future climate scenarios; therefore, variations in irrigation estimates were in response only to the variability and trends in the future-climate scenarios, not to the changes in land use.

The 30-year projection of agricultural pumping indicated an increase in pumpage relative to historical-climate baseline period for all future-climate scenarios (fig. 21). There was a trend of increasing agricultural pumping in the GA2 and GB1 future-climate scenarios in response to the trends of increasing air temperature and lower precipitation, which, in turn, resulted in higher PET, drier soils, and greater crop-water demand. In contrast, although agricultural pumpage generally increased from the historical baseline period in the PA2 and PB1 scenarios, it showed little change with time.

\section{Simulated Groundwater Results for the Future- Climate Scenarios, Water Years 2011-40}

The SRPHM was used to analyze groundwater conditions for the four future-climate scenarios relative to the historicalclimate baseline period (water years 1981-2010). This analysis is presented in three sections: (1) a discussion of selected average annual surface-water components and groundwater budgets for the historical-climate baseline period and projected average annual groundwater budgets for the four futureclimate scenarios; (2) a discussion of how variations in pumpage and precipitation affect net stream leakage (the difference between recharge from streams and groundwater discharge to streams), groundwater ET, and groundwater-storage change for the four future-climate scenarios compared with the historical-climate baseline period; and (3) a discussion of changes in groundwater levels in model layer 1 between spring 2010 (using pumping for the historical-climate baseline period) and spring 2040 (using projected pumping). The simulated average annual surface-water components and groundwater budgets for the historical-climate baseline period and the four future-climate scenarios are presented in table 2 . The temporal variation in pumpage and precipitation; the cumulative net stream leakage, groundwater ET, and groundwater-storage change for the historical-climate baseline period; and the four future-climate scenarios for 2011-40 are shown in figure 22.

\section{Selected Surface-Water Components and Groundwater Budgets}

In order to analyze changes in selected simulated average surface-water components and simulated average groundwater budgets for water years 2010-2040, including groundwater pumpage, for the four future-climate scenarios, the average annual conditions for the historical-climate baseline period and the four future-climate scenarios were calculated (table 2). Total streamflow for the GA2 and PA2 scenarios during water years 2010-2040 was about 9 and 8 percent, respectively, less than for the historical-climate baseline period. For the wetter GB1 and PB1 scenarios, total streamflow was about 9 and 32 percent, respectively, greater than the historical-climate baseline period. Runoff, which is the largest component of total streamflow, was directly related to the amount of precipitation; hence, less precipitation resulted in less runoff. Interflow was higher for all four scenarios; however, it was not sufficient to offset the reduced runoff in the GA2 and PA2 scenarios. Net stream leakage reduced total streamflow because, overall, there were more losing stream reaches than gaining stream reaches.

In general, the groundwater-inflow budgets simulated for the future-climate scenarios were similar to those for of baseline period (table 2). In the GA2, GB1, and PA2 scenarios, extra-channel recharge was about $1-9$ percent less than in the historical-climate baseline period, but was about 17 percent greater than historical-climate baseline period in the PB1 scenario. Although the average precipitation for the GA2, GB1, and PA2 future-climate scenarios was about equal to the historical-climate baseline period (table 1), the higher average and maximum temperatures for these three future-climate scenarios (table 1) resulted in increased ET of infiltrating precipitation in the soil zone, which resulted in reduced extra-channel recharge. Net boundary flows changed from a small outflow (800 acre-ft/yr) for the historical-climate baseline period to a small inflow (200-1,000 acre-ft/yr) for the four scenarios. Net stream leakage into the groundwater system for all four scenarios was about 75-141 percent greater than the historicalclimate baseline period (table 2). In summary, except for the PB1 scenario, increased pumpage and reduced extra-channel recharge resulted in lower groundwater levels, thereby slightly increasing boundary inflows and greatly increasing net stream leakage to the groundwater system. 

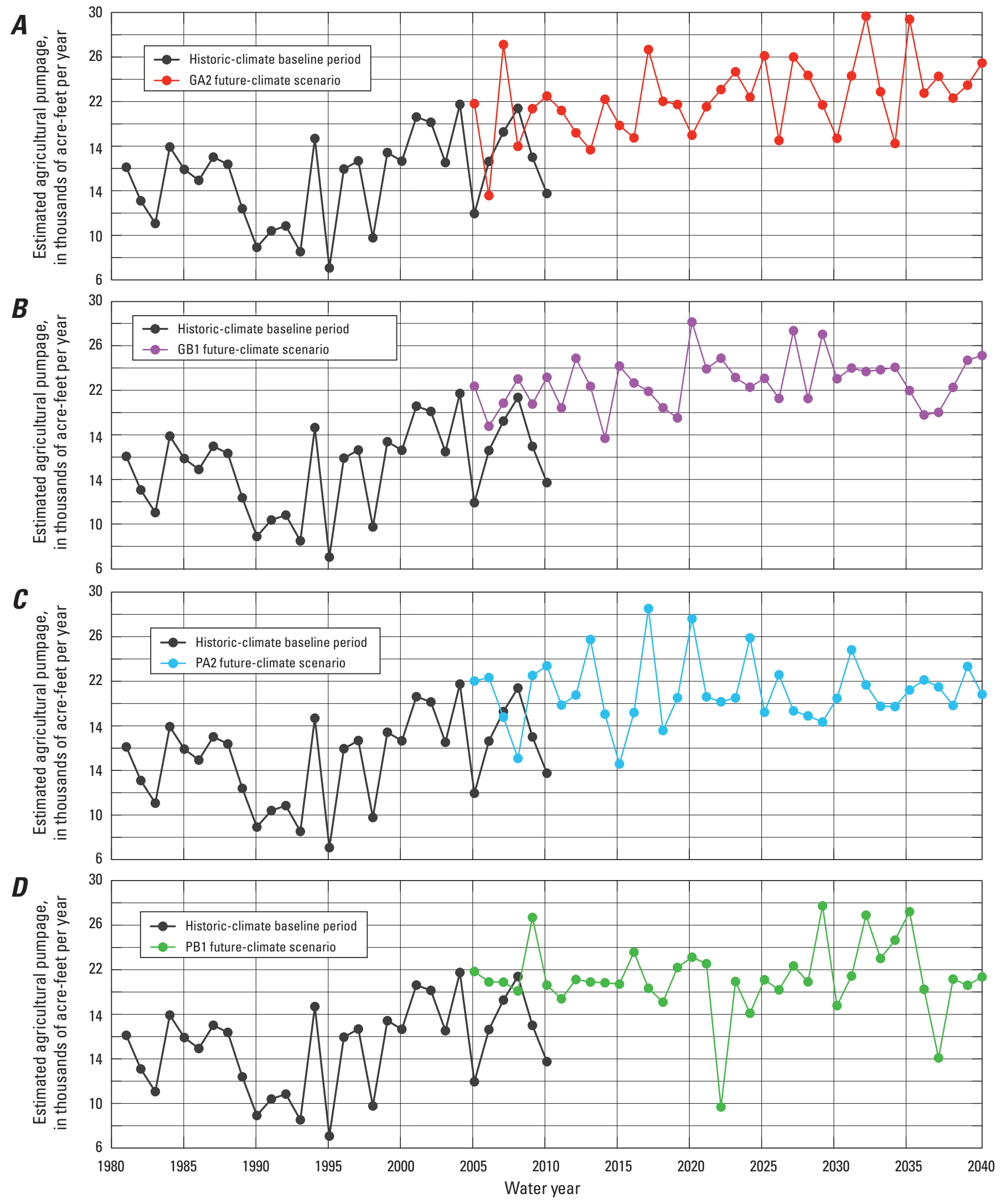

Figure 21. Estimated agricultural pumpage for the historical-climate baseline period during water years 1981-2010 and the following future-climate scenarios, Santa Rosa Plain hydrologic model, Santa Rosa Plain watershed, Sonoma County, California: $A, \mathrm{GA2}$; $B$, GB1; $C$, PA2; D, PB1 during water years 2011-40. 
Table 2. Average annual results for selected surface-water components and simulated groundwater budgets for the 1981-2010 historical-climate period, and projected average annual results for 2011-40 for future-climate scenarios GA2, GB1, PA2, and PB1, Santa Rosa Plain hydrologic model, Santa Rosa Plain watershed, Sonoma County, California.

[Precipitation for the historical-climate baseline includes reclaimed water; total streamflow is the sum of runoff and interflow minus net stream leakage]

\begin{tabular}{|c|c|c|c|c|c|}
\hline $\begin{array}{l}\text { Selected surface-water } \\
\text { components }\end{array}$ & $\begin{array}{c}\text { Historical-climate } \\
\text { baseline } \\
\text { 1981-2010 } \\
\text { water years, } \\
\text { (acre-feet } \\
\text { per year) }\end{array}$ & $\begin{array}{c}\text { GA2 } \\
\text { 2011-40 } \\
\text { water years, } \\
\text { (acre-feet } \\
\text { per year) }\end{array}$ & $\begin{array}{c}\text { GB1 } \\
\text { 2011-40 } \\
\text { water years, } \\
\text { (acre-feet } \\
\text { per year) }\end{array}$ & $\begin{array}{c}\text { PA2 } \\
\text { 2011-40 } \\
\text { water years, } \\
\text { (acre-feet } \\
\text { per year) }\end{array}$ & $\begin{array}{c}\text { PB1 } \\
\text { 2011-40 } \\
\text { water years, } \\
\text { (acre-feet } \\
\text { per year) }\end{array}$ \\
\hline Precipitation & 543,000 & 530,000 & 559,000 & 538,000 & 641,000 \\
\hline Interflow & 66,200 & 67,400 & 78,000 & 68,900 & 96,000 \\
\hline Net stream leakage & 6,400 & 14,800 & 14,600 & 15,400 & 11,200 \\
\hline \multicolumn{6}{|c|}{ Groundwater inflows } \\
\hline Boundary flows & 7,200 & 7,500 & 7,500 & 7,500 & 7,300 \\
\hline Extra-channel recharge & 43,500 & 40,900 & 43,200 & 39,400 & 50,900 \\
\hline Pumping & 36,500 & 47,300 & 47,600 & 45,900 & 46,300 \\
\hline Boundary Flows & 8,000 & 6,500 & 6,600 & 6,500 & 7,100 \\
\hline Groundwater evapotranspiration (ET) & 8,300 & 7,000 & 7,200 & 6,700 & 8,400 \\
\hline Surface leakage & 6,300 & 3,400 & 3,800 & 3,400 & 5,400 \\
\hline Groundwater discharge to streams & 26,400 & 21,100 & 21,700 & 20,900 & 25,500 \\
\hline Total outflow & 85,500 & 85,300 & 86,900 & 83,400 & 92,700 \\
\hline Storage change (total inflow-total outflow) & $-2,000$ & $-1,000$ & 100 & -200 & 2,200 \\
\hline
\end{tabular}



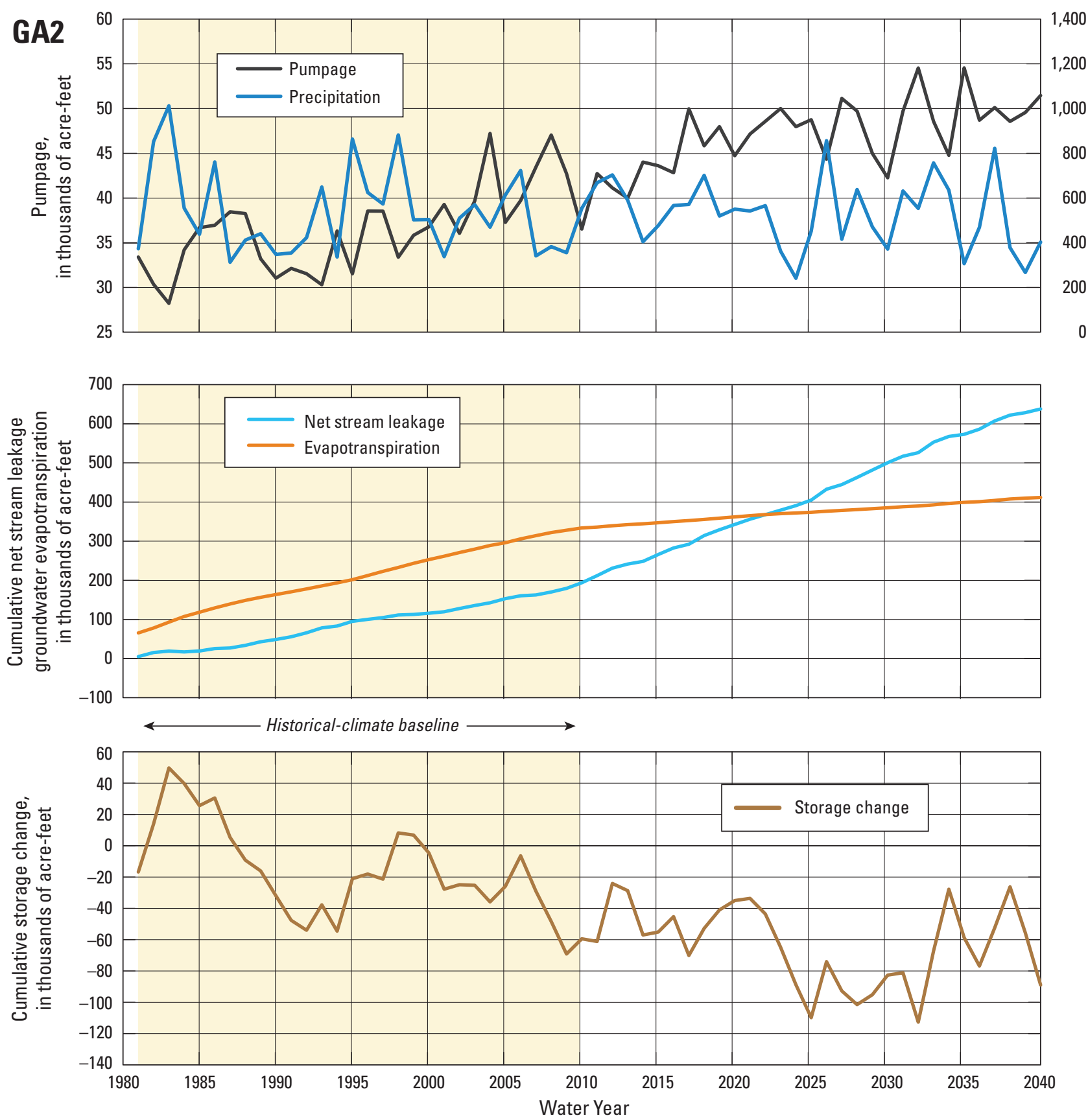

Figure 22. Annual pumpage and precipitation, cumulative groundwater-budget net steam leakage, groundwater evapotranspiration, and groundwater storage change for water years 1981-2010 for the historical-climate baseline period and for water years 2011-40 for the following future-climate scenarios, Santa Rosa Plain hydrologic model, Santa Rosa Plain watershed, Sonoma County, California: $A$, $\mathrm{GA} 2 ; B, \mathrm{~GB} 1 ; C, \mathrm{PA} 2 ; D, \mathrm{~PB} 1$. 

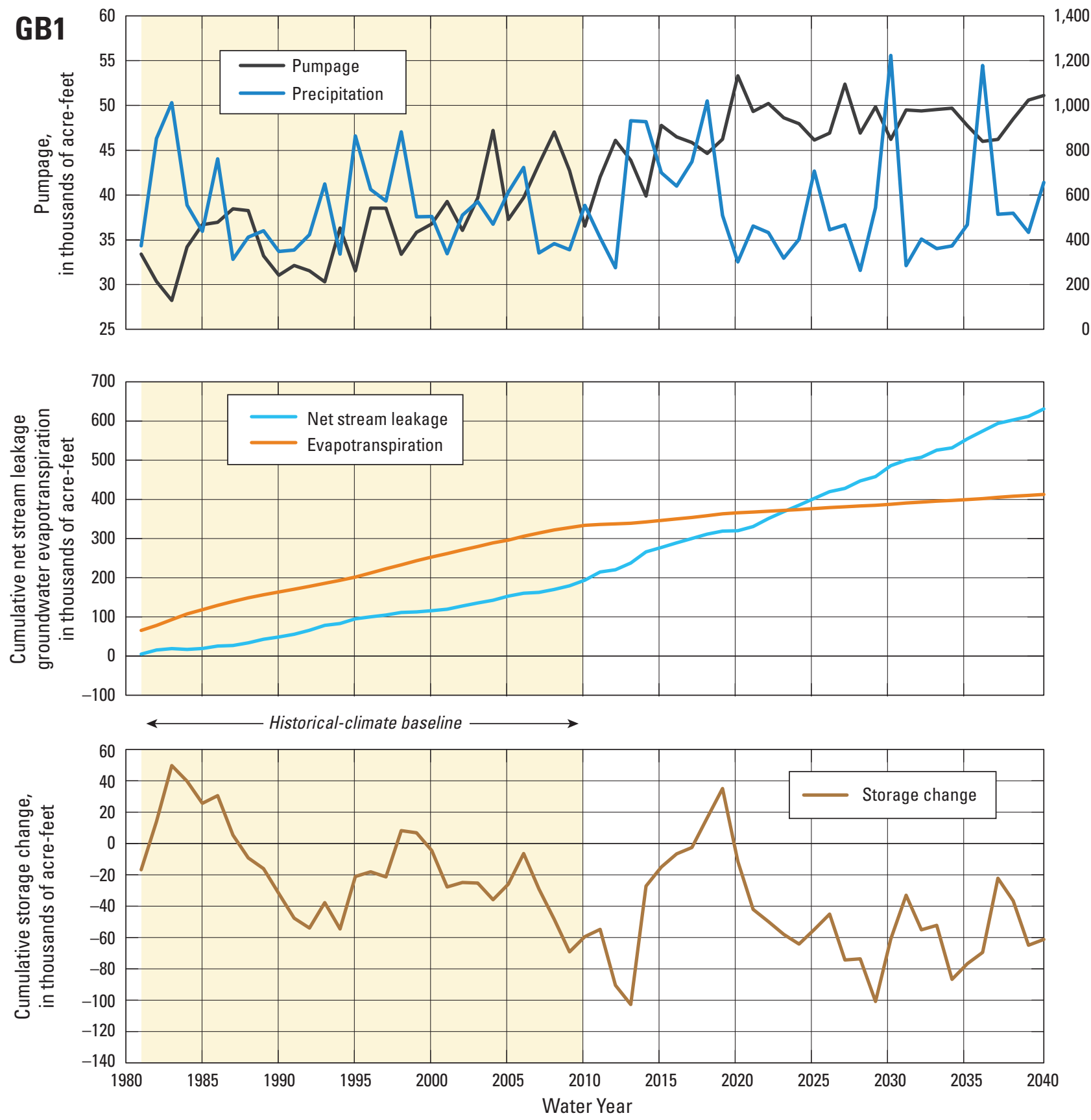

Figure 22. - Continued 

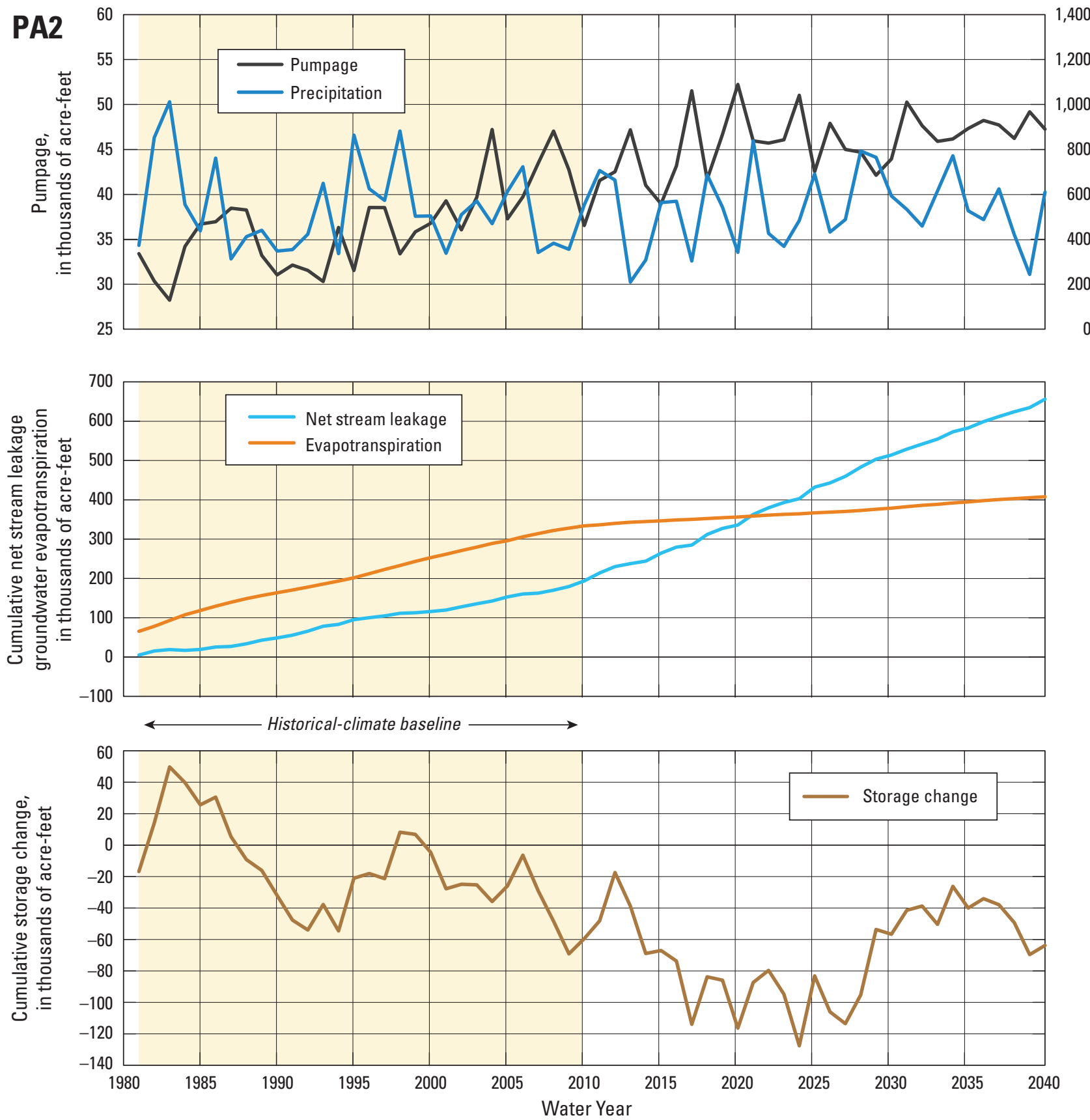

Figure 22. -Continued 

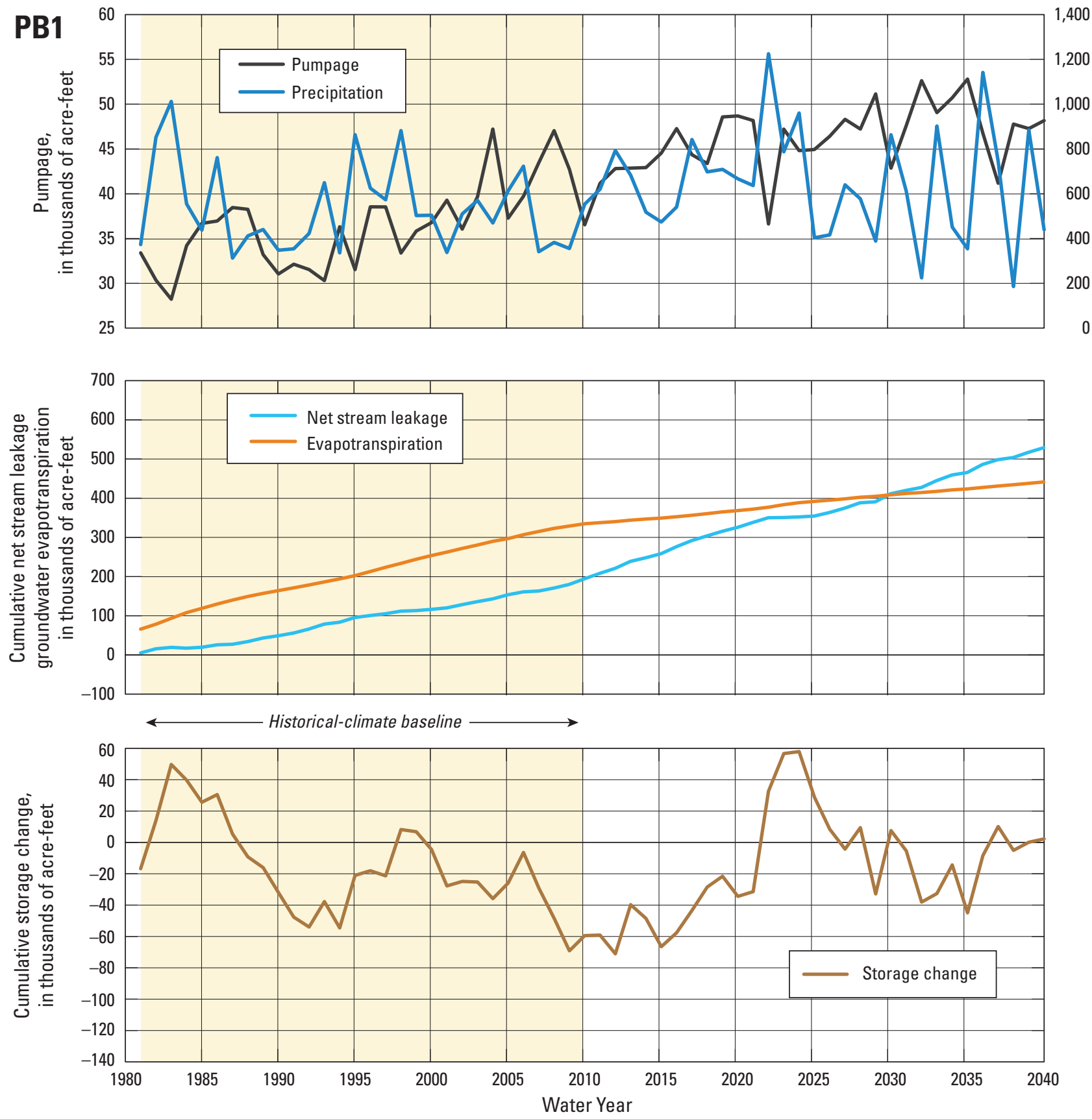

Figure 22. - Continued 
In contrast to inflows, except for the specified pumpage, groundwater outflows simulated for all four future-climate scenarios generally were lower than the historical-climate baseline period (table 2), indicating groundwater pumping reduced other outflows from the groundwater system. Specifically, increased groundwater pumping was partially offset by the increase in recharge from streams and net boundary flow and the decrease in groundwater discharge to streams and groundwater ET (table 2). Increased pumpage lowered the water table, thereby reducing the simulated groundwater ET, surface leakage, and groundwater discharge to streams. Simulated groundwater ET was 13-19 percent less in the GA2, GB1, and PA2 future-climate scenarios and 1 percent greater in the PB1 scenario, and surface leakage (groundwater that leaves the groundwater system into either the soil zone or land surface) was 14-46 percent less, in the four future-climate scenarios compared with the historical-climate baseline period (table 2). Similarly, simulated groundwater discharge to streams, or baseflow, in the four scenarios was about 3-21 percent less than it was in the historical-climate baseline period (table 2). Note that groundwater discharge to streams decreased for the wettest future-climate scenario (PB1) where the wetter conditions did not mitigate the reduction in groundwater discharge to streams associated with increased pumpage because most of the precipitation fell during the winter months, when demand was low.

The groundwater budgets showed that, on average, increased groundwater pumping was partially offset by increases in recharge from streams and decreases in groundwater discharge to streams, net boundary flows, and groundwater ET (table 2). However, the reduction in groundwater storage was less for the GA2 and PA2 scenarios and there was storage accretion for the GB1 and PB1 scenarios compared with the historical-climate baseline period. In the GA2 scenario, the reduction in groundwater storage was about half of that of the historical-climate baseline period of about 2,000 acre-ft/yr; in the GB1 scenario, there was an accretion in groundwater storage of about $100 \mathrm{acre-ft} / \mathrm{yr}$; and in the PA2 scenario, there was a reduction in groundwater storage of about $200 \mathrm{acre}-\mathrm{ft} / \mathrm{yr}$. The primary reason for this difference in groundwater storage, compared with the historic-baseline period, was the higher net stream leakage into the aquifer system, or streamflow depletion, which partially offsets the higher pumpage for the future-climate scenarios. In contrast, in the PB1 scenario, higher extra-channel recharge from increased precipitation mitigated the effects of pumping, so groundwater storage was increased in this scenario compared with the historical-climate baseline period.

In summary, the primary reason for the difference in average groundwater storage change between the historicalclimate baseline period and the future-climate scenarios is the sum of the outflows, less the pumpages, were lower than for the historical-climate baseline period. Although, in general, the total recharge was slightly greater than or about the same for the future-climate scenarios, the outflows other than pumpage ranged from about 5 to 23 percent lower than for the historical-climate baseline period. The lower water table from the higher pumpage in the future-climate scenarios resulted in the reduction of groundwater discharge to streams, groundwater ET, and surface leakage, and created more losing stream reaches with greater potential for infiltration of available streamflow. For the GA2 and PA2 scenarios the potential for infiltration of streamflow was limited by runoff values that were lower than for the historical-climate baseline period and the GB1 and PB1 scenarios.

In general, the average precipitation and air temperatures for the future-climate scenarios from 2011-2040 are somewhat different than the historical-baseline climate (table 1). However, the differences are greater as time progresses after water year 2040, particularly lower precipitation for the GA2, GB1, and PA2 scenarios and greater air temperature for all the scenarios (table 1). Greater agricultural pumpage resulting from the changing climate coupled with increasing population will result in greater total groundwater pumpage. This higher pumpage may result in a further lowering of the water table, resulting in greater losses of groundwater storage than was simulated for 2011-2040. There may be a time after water year 2040 when surface-water resources can no longer offset the effects of drier conditions and higher pumpage, and the reduction of groundwater storage may happen at a more rapid rate.

\section{Annual Variations in Future-Climate Scenarios}

The values and rates of change for cumulative groundwater-budget components in the future-climate scenarios differed considerably from the historical-climate baseline conditions (fig. 22). Overall, rates of groundwater ET were greater during the historical-climate baseline period than during all four future-climate scenarios. In contrast, rates of net stream leakage increased sharply from the historical-climate baseline period in all the future-climate scenarios. As a result, the cumulative volume of net stream leakage was greater than that of groundwater ET at the end of the 30-year simulation for all four future-climate scenarios (fig. 22).

Variability in the patterns of cumulative groundwaterstorage change in the four future-climate scenarios reflected variability in the projected precipitation for each scenario. The rates of groundwater ET for all the future-climate scenarios were lower than the historic-climate baseline rates, such that cumulative net stream leakage outpaced ET earlier in the simulations of the GA2, GB1, and PA2 scenarios than in the PB1 scenario (fig. 22) because wetter conditions in the PB1 scenario resulted in higher groundwater levels that caused increased groundwater ET and groundwater discharge to streams. In contrast, the GA2, GB1, and PA2 scenarios were relatively dry, resulting in lower groundwater levels and decreased groundwater discharge to streams; therefore, cumulative net stream leakage was greater with time in these three scenarios compared with the wetter PB1 scenario (fig. 22). 
In the GA2 scenario, which had the lowest average precipitation (table 1), the cumulative groundwater-storage change decreased from the historical-climate baseline period (fig. 22A). In the GB1 scenario, cumulative groundwaterstorage change was similar to that of the historical-climate baseline period in that the declines and increases generally were balanced; however, overall, groundwater-storage change was less in the GB1 scenario (fig. 22B). Similar to the GB1 scenario, the cumulative groundwater-storage change for the PA2 scenario was less, overall, than during the historicalbaseline period. The decline during water years 2011-27, and subsequent increase due to wetter-than-average conditions after water year 2027 (figs. 1C, 22C), balanced groundwaterstorage change in the PA2 scenario. In the PB1 scenario, which had the highest average precipitation, there was an increase in groundwater storage (fig. 22D).

Although the changes in average annual groundwater storage were small, as discussed in the "Selected SurfaceWater Components and Groundwater Budgets" section, it should be noted that there were periods where there were large decreases in groundwater storage. The largest cumulative storage loss for the GA2 scenario (76,000 acre-ft) was during water years 2021-2025, for an average loss of about $15,200 \mathrm{acre}-\mathrm{ft} / \mathrm{yr}$. The largest cumulative storage loss for the GB1 scenario (136,000 acre-ft) was during 2019-2029, for an average loss of about 12,400 acre-ft/yr. The largest cumulative storage loss for the PA2 scenario $(110,000$ acre-ft) was during 2012-2024, for an average loss of about 8,500 acre-ft/yr. The largest cumulative storage loss for the PB1 scenario (103,000 acre-ft) was during water years 2024-2035, for an average loss of about 8,600 acre-ft/yr.

\section{Water-Level Change}

The spatial distribution of the change in groundwater levels between spring 2010 and spring 2040 provides a visual example of the change in groundwater levels in model layer 1, which generally correlates with the change in groundwater storage. Negative numbers in figure 23 indicate that simulated hydraulic heads in model layer 1 were lower in water year 2040 than in water year 2010, and positive numbers indicate the opposite. Groundwater levels in the GA2, GB1, and PA2 future-climate scenarios generally declined (figs. 23A-C), resulting in a reduction in baseflow, an increase in losing stream reaches, and a reduction in riparian ET. In the PB1 scenario, an increase in water levels throughout most of the SRPW (fig. 23D) was mitigated by the increase in riparian ET in some stream channels that reduced the leakage from these streams. This is illustrated by the attenuated increase in water levels in the vicinity of these stream channels in figure $23 D$.

Overall, simulated hydraulic heads were between 5 and $25 \mathrm{ft}$ lower in spring 2040 than in spring 2010 in the GA2, $\mathrm{GB} 1$, and PA2 future-climate scenarios (figs. 23A-C). The groundwater-level declines in these three scenarios generally were less in the vicinity of the major drainages than in the extra-channel areas. In the SRPHM, streams are simulated as head-dependent boundaries that minimize the decline in heads from both gaining and losing reaches; however, because the net stream leakage into the groundwater system increased from the historical-climate baseline period in all future-climate scenarios (fig. 22), stream-aquifer interaction was the primary component mitigating the decline in groundwater levels.

Simulated hydraulic heads were as much as $10 \mathrm{ft}$ higher in spring 2040 than in spring 2010 in the GA2, GB1, and PA2 scenarios in the Santa Rosa area, in the vicinity of some streams throughout the SRP, and in the vicinity of the southern boundary of the SRPW (figs. 23A-C). In water year 2040, about 66 percent of the SRPW showed a decrease in simulated hydraulic heads of $1 \mathrm{ft}$ or more in the GA2 scenario, about 53 percent in the GB1 scenario, about 56 percent in the PA2 scenario, and about 24 percent in the PB1 scenario. In water year 2040, about 14 percent of the SRPW showed an increase in simulated hydraulic heads of $1 \mathrm{ft}$ or more in the GA2 and GB1 scenarios, about 13 percent in the PA2 scenario, and about 46 percent in the PB1 scenario. The SRPHM simulations showed that the groundwater-level decline was more widespread in the GA2 scenario than in the other scenarios. Because of the warmer temperatures, the GA2 agricultural component of rural pumpage for spring 2040 was about 6, 57, and 40 percent greater than in the GB1, PA2, and PB1, respectively, which could have contributed to the groundwater-level decline over a larger area in this scenario (fig. 23A).

The greatest (more than $25 \mathrm{ft}$ ) decline in simulated hydraulic heads between spring 2010 and spring 2040 was in the Mayacmas and Sonoma Mountains in all four futureclimate scenarios. Recharge occurred in these areas during the historical-climate baseline period; however, in the futureclimate scenarios, average recharge declined to zero over much of these areas for water years 2011-40. Ironically, the greatest increase in simulated hydraulic heads also was in the Mayacmas Mountains, particularly where the basement complex crops out (figs. $23 A-D$ ).

The higher precipitation, and, hence, greater recharge, in the PB1 scenario lessened the effect of pumpage on simulated hydraulic heads. Because of higher average annual precipitation in the PB1 scenario compared with the historical-climate baseline and other scenarios, the PB1 scenario had a much smaller average decline in groundwater levels in the southwestern part of the SRPW (fig. 23D). In fact, simulated hydraulic heads in a large part of the SRP, including the extra-channel areas and in the vicinity of the streams, were 1 to $10 \mathrm{ft}$ higher in spring 2040 (fig. 23D) than in spring 2010 . Conversely, groundwater levels in the parts of the upland areas were at least $25 \mathrm{ft}$ lower in spring 2040; however, the extent of this decline was less than for the other three future-climate scenarios. 

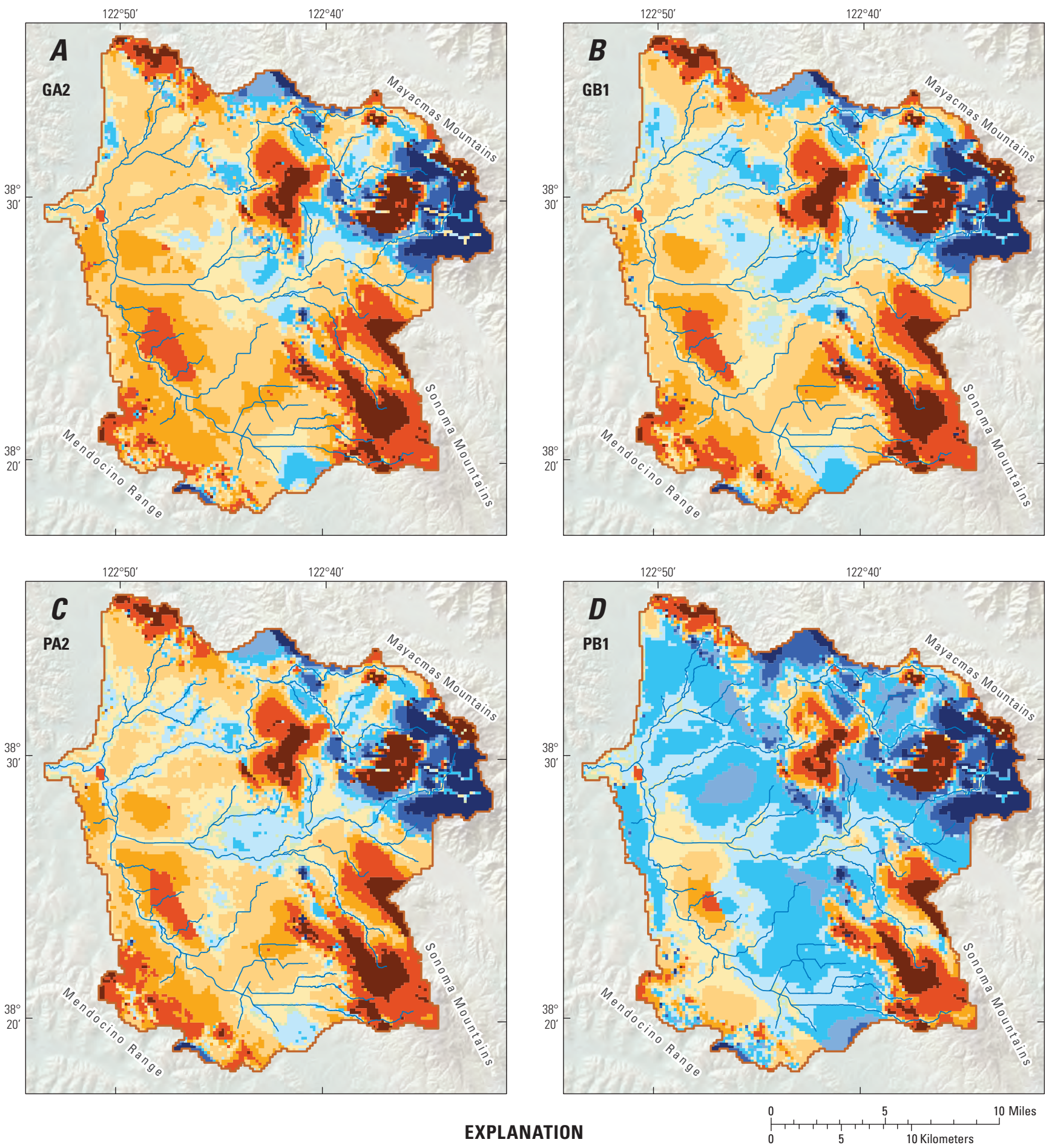

Difference in hydraulic head, spring 2040 minus spring 2010, in feet

\begin{tabular}{r|r|r|r|r|r|r|r|}
$<-25$ & -5 to $<-1$ & 0 to 1 & $>10$ to 25 \\
-25 to $<-10$ & -1 to 0 & $>1$ to 5 & $>25$ \\
-10 to $<-5$ & 0 & $>5$ to 10 &
\end{tabular}

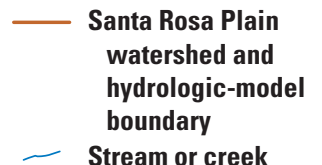

Figure 23. Differences in simulated hydraulic heads in model layer 1 between spring 2010 and spring 2040 for the following futureclimate scenarios, Santa Rosa Plain hydrologic model, Santa Rosa Plain watershed, Sonoma County, California: $A, G A 2 ; B, G B 1 ; C$, PA2; D, PB1. 


\section{References Cited}

Association of Bay Area Governments, 2012, Appendices for the draft forecast for 2010-2040 for the Jobs-Housing Connections Strategy: San Francisco, Calif., OneBayArea, 45 p., http://onebayarea.org/pdf/JHCS/May_2012_Jobs Housing_Connection_Strategy_Appendices_Low_Res.pdf

Daly, Christopher, Gibson, W.P., Doggett, Matthew, Smith, Joseph, and Taylor, George, 2004, Up-to-date monthly climate maps for the conterminous United States: American Meteorological Society Conference on Applied Climatology, 14th, Seattle, Wash., 2004, January 13-16, 2004 , Proceedings, Paper P5.1, http://www.prism.oregonstate. edu/pub/prism/docs/appclim04-uptodate_monthly_climate_ maps-daly.pdf.

Flint, L.E., and Flint, A.L., 2012, Simulation of climate change in San Francisco Bay Basins, California: Case studies in the Russian River Valley and Santa Cruz Mountains: U.S. Geological Survey Scientific Investigations Report 2012-5132, $55 \mathrm{p}$.

Hidalgo, Hugo, Dettinger, M.D., and Cayan, D.R., 2008, Downscaling with constructed analogues: Daily precipitation and temperature fields over the United States: California Energy Commission Report No. CEC-500-2007-123, 48 p., http://meteora.ucsd.edu/cap/pdffiles/analog_pier_report. $p d f$.

Manning, J.C., 1987, Applied principles of hydrology: Columbus, Ohio, Merrill, 278 p.

Nalder, I.A., and Wein, R.W., 1998, Spatial interpolation of climatic normals: Test of a new method in the Canadian boreal forest: Agricultural and Forest Meteorology, v. 92, no. 4, p. 211-225. 


\section{Chapter G. Summary, Model Limitations, and Conclusions}

\author{
By Joseph A. Hevesi and Linda R. Woolfenden
}

This report, which documents the development and application of the SRPHM, comprises seven chapters, including this one. Chapter $A$ summarizes the purpose and scope of the study, provides a description of the study area, presents an overview of previous work, and presents an overview of the SRPW conceptual and numerical models. Chapter $B$ provides a detailed description of the development of the watershedmodel component of the SRPHM. Chapter $C$ provides a detailed description of the development of the groundwatermodel component of the SRPHM. Chapter D presents the calibration of the SRPHM. Chapter E presents the simulation results from the SRPHM. Chapter F presents the simulated results of four possible future climate scenarios and projected pumping. Chapter $G$ (this chapter) presents the summary, model limitations, and conclusions of the report. Appendix 1 describes the development, example input and output, and application of a crop water-demand model (CWDM) that was used to estimate agricultural pumpage.

\section{Summary}

The Santa Rosa Plain hydrologic model (SRPHM) was developed to help better understand the hydrology of the Santa Rosa Plain watershed (SRPW) and to provide a new method for evaluating the hydrologic response of the SRPW to different management and climate-change scenarios (chapter A, figs. 1 and 2). The SRPHM uses the coupled surface-water-groundwater flow modeling program (GSFLOW; Markstrom and others, 2008), which consists of two integrated model components: (1) a watershed-component model developed using Precipitation Runoff Modeling System (PRMS), and (2) a groundwater-component model developed using Modular Groundwater Flow Model (MODFLOWNWT). The watershed-component model is used to simulate the hydrology of the land surface, vegetation, and soil zone. The groundwater-component model is used to simulate the properties and processes of the subsurface, including the unsaturated zone, saturated zone, the major streams, and the interaction between surface water and groundwater.

\section{Model Description}

The watershed-component model consists of 16,741 hydrologic response units (HRUs); each HRU is a cell within a grid of square cells, each $660 \mathrm{foot}$ (ft) by $660 \mathrm{ft}$ (10 acre) in size, discretized to match the grid of the underlying groundwater-component model. The grid-based HRUs are connected by using a network of cascades and stream segments. Surface-water runoff and interflow are routed by the cascades to the stream segments; the stream segments route streamflow to ten outflow points on the boundary of the SRPHM, and Mark West Creek, at the confluence with the Russian River (chapter A, fig. 2), is the main outflow point.

The watershed-component model distributes the dailyclimate input used in the transient GSFLOW simulation to all the HRUs, accounting for spatial variability in precipitation and air temperature. The spatially distributed climate input was developed by using precipitation and air-temperature records from a regional network of climate stations centered on the area of the SRPW, including eight climate stations in the SRPW. The average monthly precipitation and the maximum and minimum monthly air temperatures for 1971-2000 were used to spatially distribute the climate inputs (Daly and others, 2004). The resulting climate data set consists of a time series of daily precipitation and maximum and minimum daily air temperatures for water years 1918 through 2010. Because of the uncertainty in the estimated climate data prior to water year 1948, records for water years 1948 through 2010 of daily precipitation, estimated from 36 climate stations, and maximum and minimum air temperatures, estimated from 16 climate stations, were used as input to the model.

The groundwater-component model consists of 8 layers on a finite-difference grid of 168 rows and 157 columns, and uniform, square model cells with a dimension of $660 \mathrm{ft}$ on each side (chapters $A, D$ ). All model layers are convertible and can switch between confined and unconfined flow conditions; however, generally only the top layer is unconfined. Hydraulic conductivity is spatially defined by hydrogeologic units. Hydrogeologic units were defined by stratigraphic units and textural properties and were the basis for distributing horizontal hydraulic conductivity, vertical anisotropy, specific storage, and specific yield values to the cells in the model grid. Lateralboundary conditions, which govern the interaction between the SRPW and adjacent areas, include no-flow and headdependent flow boundaries. Major faults and two unidentified minor faults are simulated in the model as partial barriers to groundwater flow. The SRPW was divided into model storage units (MSUs) to aid in the calibration of the aquifer properties and boundary conditions. 
Sources of inflow to the groundwater system include extra-channel recharge, recharge from streams, infiltration of treated wastewater, and subsurface inflow from adjacent basins. Groundwater outflow from the SRPW includes pumping, groundwater discharge to streams, riparian evapotranspiration (ET), groundwater discharge to the unsaturated zone or land surface, and subsurface flow to adjacent groundwater basins. Reported municipal pumpage were used in the SRPHM. Agricultural pumpage was estimated by using the calibrated watershed-component model and a daily CWDM (Appendix 1). Domestic pumpage was estimated on the basis of population data for the non-urban areas and a per-capita consumptive-use factor of 0.19 acre-foot per year (acre-ft/yr; California Department of Water Resources, 1994). Recharge from streams, groundwater discharge to streams, extra-channel recharge, boundary flows, and ET were calculated by the SRPHM as part of this study.

\section{Model Calibration}

Initial calibration of the SRPHM was done in decoupled mode where the watershed and groundwater-components were calibrated separately. Once calibrated, the components were then coupled and recalibrated.

Calibration of the SRPHM using coupled-GSFLOW simulations for transient conditions during water years 1975-2010 was completed by using an iterative trial-and-error approach of adjusting model parameters to achieve a reasonable fit between (1) simulated and measured streamflow, and (2) simulated hydraulic heads and measured groundwater levels. The calibration process for the SRPHM included adjusting the initial estimates of the land-surface properties, soil-zone properties, stream-channel properties, aquifer properties, general-head boundary heads and conductances, and fault characteristics. The SRPHM was calibrated by using measured groundwater levels at 83 wells and published spring 2007 groundwater-level contours as calibration targets. The watershed-component model was calibrated by using monthly streamflow records at 12 streamgages in the SRPW as calibration targets. In addition, transmissivity estimates for six wells were used to constrain horizontal hydraulic conductivity for selected model layers. Model parameters controlling simulated streamflow were manually adjusted until a reasonable fit was obtained.

The SRPHM simulated monthly streamflow best at the Mark West Creek near Mirabel Heights, Mark West Creek near Windsor, Santa Rosa Creek at Santa Rosa, and Santa Rosa Creek at Willowside road streamgages. Simulated streamflow at the Laguna de Santa Rosa near Cotati, Brush Creek at Santa Rosa, and Colgan Creek near Santa Rosa gages had a poorer fit to the measured data (chapter D, table 11).
The normalized root mean square error (NRMSE) for the match between simulated heads and measured groundwater levels was within 10 percent, indicating that the overall fit of the groundwater-component model to measured data was reasonable (chapter $D$ ). The normalized root-mean-square error was within 10 percent for the Cotati-N MSU and slightly greater than 10 percent for the Rincon-Kenwood, Wilson Grove, and Santa Rosa MSUs, which were acceptable for the intended use of this model (chapter D, table 13).

\section{Model Results}

The SRPHM was used to derive components of the hydrologic budget for water years 1976-2010 (chapter E). Figure 1 summarizes the simulated inflows and outflows of the coupled surface-water and groundwater systems. Although the simulation period was water years 1975-2010, the first year (water year 1975) was considered a "spin-up" period to allow the transient model to stabilize with respect to the specified initial conditions; therefore, those results were omitted in the evaluation of the model results.

Precipitation was the largest inflow to the SRPW, averaging about 531,000 acre-feet per year (acre-ft/yr) for water years 1976-2010. The largest outflows, on average, from the SRPW were total streamflow, at about 230,000 acre-ft/yr, and total ET, at about 262,000 acre-ft/yr. Pumpage was about an order of magnitude less, averaging about 35,600 acre-ft/yr (fig. 1). During water years 1976-2010, an average of about $2,700 \mathrm{acre}-\mathrm{ft} / \mathrm{yr}$ was added to total storage. Total storage calculated by GSFLOW is the sum of surface, soil-zone, unsaturated-zone, and groundwater storage. Unsaturated-zone and groundwater storage losses averaged 10,000 acre-ft/yr, and surface and soil-zone storage gained 12,700 acre-ft/yr (fig. 1). Simulation results indicated that about 54 percent of the total quantity of groundwater pumped from the SRPW was provided by a reduction in total streamflow, about 24 percent from a reduction in total $\mathrm{ET}$, about 14 percent from a reduction in total storage, and about 8 percent from changes in boundary flows.

The SRPHM also was used to estimate groundwater budgets for the SRPW. For water years 1976-2010, average extrachannel recharge and recharge from streams accounted for 51 and 40 percent, respectively, of total groundwater inflow. Pumpage and groundwater discharge to streams were the major outflows on average, accounting for 42 and 31 percent, respectively, of total outflow. Net stream leakage was about $6,600 \mathrm{acre}-\mathrm{ft} / \mathrm{yr}$, indicating that, overall, streams were a source of water to the groundwater system. Groundwater-storage depletion was about 3,300 acre-ft/yr on average (fig. 1). 


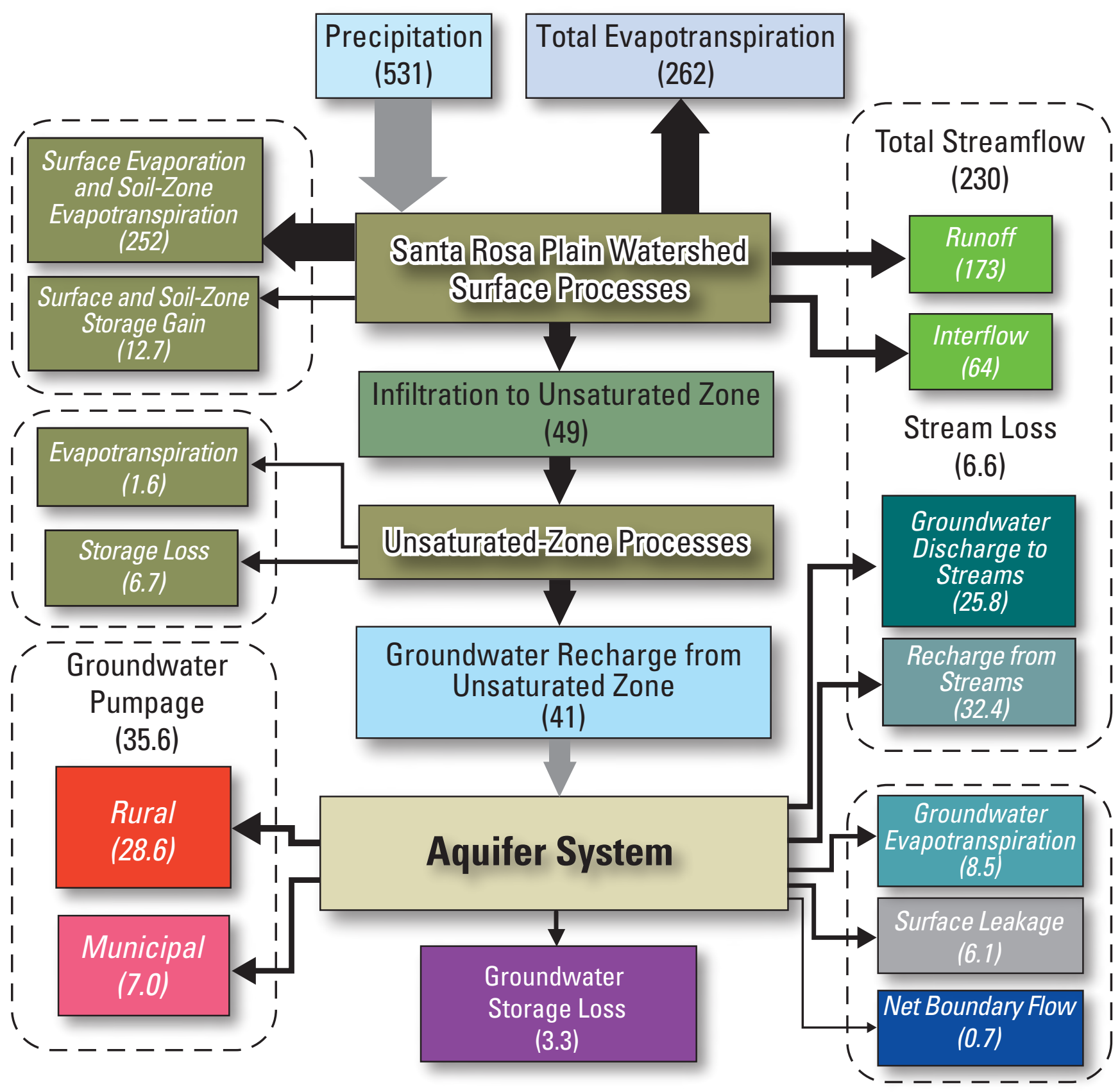

Values in thousands of acre-feet per year.

The sum of runoff, interflow, and stream loss should equal total streamflow, however, the value differs as a result of rounding.

The sum of surface evaporation and soil-zone evapotranspiration, unsaturared zone evapotranspiration, and evapotranspiration from aquifer system should equal total evaporation; however the value differs as a result of rounding

Figure 1. Diagram showing average water budget for water years 1976-2010, Santa Rosa Plain hydrologic model, Santa Rosa Plain watershed, Sonoma County, California. 
The groundwater budget for short-term (water years 2004-10) average conditions were evaluated to focus on the effects of the most recent estimates of rural-pumpage. Results indicated that pumpage was about 18 percent greater than the long-term average, and about 45 percent more groundwater was removed from storage compared with the long-term average results.

Model results for a dry water year (water year 2009) indicated that extra-channel recharge was about 48 percent less than for the long-term average, while pumpage was about 20 percent greater. Groundwater discharge to streams and ET were about 27 and 30 percent, respectively, less than for the long-term average results. About 20,800 acre-ft was removed from groundwater storage in water year 2009.

For a wet water year (water year 2006), extra-channel recharge was about 70 percent greater than for the long-term average. Groundwater discharge to streams and surface leakage were about 22 and 33 percent, respectively, greater than the long-term average results. About 19,400 acre-ft was added to groundwater storage in water year 2006.

The SRPHM was used to estimate groundwater budgets for selected subareas and to estimate flow from layer 1 to underlying layers. The largest inflow for the Windsor, Santa Rosa, and Wilson Grove subareas was extra-channel recharge, whereas the largest inflow to the Cotati subarea was recharge from streams. The largest outflow for the Windsor, Santa Rosa, and Cotati subareas was pumping. For the Wilson Grove subarea, pumping and boundary flows were the largest outflows. Groundwater storage was reduced in the Windsor, Santa Rosa, Wilson Grove, and Cotati subareas. Pumping induced an average of nearly 10,000 acre-ft/yr of groundwater flow from layer 1 to underlying layers in the Windsor, Santa Rosa, and Cotati subareas.

The distribution of net flux across the water table for long-term average conditions for water years 1976-2010, dryyear conditions for water year 2009, and wet-year conditions for water year 2006 indicated that the highest recharge rates were in stream channels with permeable streambeds. The longterm average net recharge was about 33,000 acre- $\mathrm{ft} / \mathrm{yr}$. For the dry-water year in 2009, the net recharge was about 33 percent less than the long-term average results. For the wet-water year in 2006, net recharge was about 45 percent greater than for the long-term average results.

\section{Model Application}

The calibrated SRPHM was used to assess the effects of climate change and variability as estimated using four possible future-climate scenarios on the SRPW water resources over 30-year periods during water years 2011-99 (chapter F). The simulations were done for water years 2005-99, including a 5-year model "spin-up" period. Climate change was represented by using future-climate scenarios consisting of daily precipitation and maximum and minimum daily air temperature simulated by global-climate models (GCMs) for water years 2000-2100. On the basis of previous studies and background information presented in Flint and Flint (2012), four different climate scenarios, developed by using two GCMs and two greenhouse gas (carbon dioxide) emission scenarios, were selected for application with the SRPHM. The results from the GCMs were downscaled and bias-corrected to the SRPW by using methods described in Flint and Flint (2012). These climate scenarios are referred to as the GA2, GB1, PA2, and PB1 scenarios. The application of four different future-climate scenarios was done to represent uncertainty in the future-climate simulations.

To evaluate the effect of climate alone on the SRPW hydrologic system, the SRPHM was applied using the four future-climate scenarios without pumping for water years 2005-99. The time series of annual simulation results for water years 2011-99 were compared with results for water years 1981-2010 (historical-climate baseline period) by using the historical-climate baseline simulation without pumping. Comparison of simulation results between future-climate scenarios and the historic-climate baseline also was done by using average monthly results for 30 -year periods.

Results from the SRPHM for the four future-climate scenarios without pumping were analyzed to assess the effects of the changes and variability in climate on total streamflow, total recharge, groundwater discharge to streams, and groundwater ET. The frequency of very low total streamflow (less than 100,000 acre-ft) increased for all four scenarios relative to the baseline period. The annual variability in total streamflow in the GA2 scenario, which was the driest and warmest, overall, was similar to that of the historical climate; however, the minimum total streamflow was more frequent than it was in the historical climate. All future-climate scenarios had at least one year with very high annual streamflow (greater than 700,000 acre-ft), whereas the maximum annual streamflow for the historical-baseline climate period was 620,000 acre-ft.

Results for all four future-climate scenarios showed an increase in the number of water years with annual recharge less than 30,000 acre-ft; this was due to a combination of lower precipitation (GA2 and GB1 scenarios) or higher air temperatures (all four scenarios), or both, than for the historical-baseline climate period. The GA2 and GB1 scenarios had periods of low recharge relative to the baseline period, where the 10-year moving average recharge was less than 50,000 acre-ft/yr. The PA2 scenario had the most variability in annual recharge; however, the 10-year moving average showed less variability than the other scenarios. The PB1 scenario had periods where the average recharge was high relative to the historical-baseline climate period, including a very wet period (10-year moving average greater than 70,000 acre-ft/yr) during water years 2022-30.

Groundwater discharge to streams showed more sensitivity to multi-year trends and inter-annual variations in future climates than recharge. The inter-annual variability in groundwater discharge to streams in all four future-climate scenarios was similar to the variability of the historical-climate baseline period. Results for the GA2 scenario had the lowest average and absolute values for groundwater discharge to streams 
for water years 2080-99 compared with results for all years for the other future-climate scenarios and historical-climate baseline. This reflected the low precipitation and high air temperatures of the GA2 scenario for that period. The PB1 scenario was characterized by a wet period from water years 2022-30 and had the highest groundwater discharge to streams during this period compared with the other scenarios and the historical-climate baseline period. The PA2 scenario had the least overall variability in groundwater discharge to streams. The GB1 was similar to the GA2 scenario by showing an overall downward trend for groundwater discharge to streams.

Groundwater ET showed the most sensitivity to increasing air temperatures in all four future-climate scenarios. Results for all four scenarios showed an increase in groundwater ET compared with the historical-climate baseline period. Results for the GA2 and PA2 scenarios indicated a trend of increasing groundwater ET during water years 2011-80; however, the trend turned downward in the GA2 scenario after water year 2080 because of very dry conditions. Results for all four scenarios showed that the minimum annual groundwater ET was much greater than the minimum for the historical-climate baseline period.

The SRPHM also was applied by using the four futureclimate scenarios with projections of future pumpage for water years 2011-40. Agricultural pumpage was estimated by using the characteristics of the climate scenarios in combination with the calibrated watershed-component model and CWDM. The CWDM was applied by using the crop distributions defined by the 2008 land-use map. Public-supply pumpage was projected on the basis of estimates provided by water purveyors in the SRPW through 2040. Domestic pumpage was projected for water years 2011-40 on the basis of a measured increase in pumpage in unincorporated areas of Sonoma County.

Results from the SRPHM with pumping for water years 2011-40 were compared with the historical-climate baseline period of water years 1981-2010 to determine the effect of projected pumpage and future climate on the groundwaterflow system in the SRPW for a typical 30-yr water-management plan timeframe. Pumpage ranged from about 22 percent more in the PA2 scenario to about 26 percent more in the GB1 scenario compared with the historical-climate baseline period. In the GA2, GB1, and PA2 future-climate scenarios, extrachannel recharge was less than was simulated in the historicalclimate baseline period, while in the comparatively wetter PB1 scenario, extra-channel recharge was more. Recharge from streams to the groundwater system was greater than the historical-climate baseline average in all four future-climate scenarios. The results also indicated an overall reduction in groundwater discharge to streams in all four future-climate scenarios. Groundwater storage was reduced in the GA2 and PA2 scenarios, but by much less than it was during the historical-climate baseline period. In the GB1 and PB1 scenario, groundwater storage increased.
The values of cumulative groundwater-budget components in the future-climate scenarios differed considerably from the cumulative change during historical-climate baseline conditions. Overall, cumulative groundwater ET volumes were greater during the historical-climate baseline period, and cumulative net stream leakage was greater during all four future-climate scenarios. As a result, the cumulative volume of net stream leakage was greater than that of groundwater ET at the end of the 30-year simulation for all four future-climate scenarios. The overall cumulative groundwater storage change for the GA2, GB1, and PA2 scenarios was about the same as, or less than, the decrease in cumulative groundwater storage during historical-climate baseline period. In the PB1 scenario, there was an overall increase in groundwater storage.

The difference in simulated hydraulic heads in model layer 1 between spring 2010 and spring 2040 indicated that, on average, simulated groundwater levels were between 5 and $25 \mathrm{ft}$ lower in spring 2040 in the GA2, GB1, and PA2 futureclimate scenarios (chapter $F$, fig. $23 A-C$ ). The groundwaterlevel declines in these three scenarios generally were less in the vicinity of the major drainages than in the extra-channel areas. The decline was most pronounced in the comparatively drier GA2 scenario, where the simulated groundwater levels decreased over a larger area in the SRP than in the other three scenarios. Simulated groundwater levels in a large part of the SRP, including the extra-channel areas and in the vicinity of the streams, were 1 to $10 \mathrm{ft}$ higher in spring 2040 (chapter F, fig. 23D) than in spring 2010 in the PB1 scenario. The greatest decrease in heads (greater than $25 \mathrm{ft}$ ) was in the uplands in all four future-climate scenarios.

\section{Model Limitations}

Though the development of the SRPHM used some of the latest modeling methods available at the time of the study, the use of numerical models to simulation hydrologic systems still has inherent limitations. Limitations of the modeling software, data limitations, assumptions made during model development, conceptual model error (Bredehoeft, 2005), and results of model calibration and sensitivity analysis are all factors that constrain the appropriate use of hydrologic models, including the SRPHM. Differences between simulated and actual hydrologic conditions arise from a number of sources and are known collectively as model error (Walter and Whealan, 2005).

One component of model error relates to discretization. For example, the MODFLOW and PRMS spatial discretizations are 660 by $660 \mathrm{ft}$. The conditions in the grid division (groundwater level, groundwater flow, ET rate, and soil moisture), thus, are reduced to one average value for the entire cell or HRU. Therefore, the model may not be suitable for many local-scale or local-headwater problems or issues without additional spatial refinement. 
Similarly, temporal simplifications were needed to develop tractable models used for this work. Models were constructed using daily time increments; therefore, partial-day ("continuous" or "storm-mode") simulations of individual storm events were not in the scope of this work. Actual flood peaks in the SRPW caused by intense rainfall on the partialday timescale are not reflected on the daily timestep by this modeling.

A model is a highly idealized approximation of the actual system that is based on average and estimated conditions. The capability of the SRPHM to reliably reproduce hydrologic responses is related to the accuracy of the input data and conceptual model and is inversely related to the magnitude of the proposed changes in the hydrologic stress being applied to the model as well as to the length of the simulation period. There were important data limitations for the study area that affected the estimates of pumpage used in the model. Pumpage data were available only for the public-supply wells; agricultural and domestic pumpage rates were not reported and, therefore, were estimated by using a CWDM (Appendix 1) for agricultural and census data with an assumed consumption rate (Nishikawa and others, 2013) for domestic pumpage. In addition, the lack of information on the locations of agricultural and domestic wells added uncertainty to the distribution of pumpage, potentially resulting in excess or insufficient pumpage in some locations. Given the general lack of information, agricultural and domestic pumpage were combined and defined as rural pumpage. There is uncertainty associated with the assumptions made in the estimation of rural pumping, and in adjustments made during model calibration. These factors are likely to contribute to the inaccuracy of the simulated heads compared with the measured groundwater levels for some observation wells.

The complexity of the hydrogeologic system was represented by a hydrologic-framework model developed based on lithologic information from drillers' logs from the many wells in the SRPW. There were few, if any, borehole-geophysical data with which to better understand the hydrogeology. These data would contribute to a better estimation of hydrologic properties.

Streamflow and groundwater-level data are needed to accurately calibrate the SRPHM. Although streamflow data were available for various periods of record for the 12 gaging stations used in model calibration, continuous long-term records would improve the accuracy of both the watershed and groundwater components of the SRPHM. Depth-dependent groundwater-level data are necessary to accurately constrain the groundwater-component model. Although there are many wells in the SRPW, there are only three multiple-completion well sites, and they are all in the same area. Unfortunately, these also have comparatively short-term groundwater-level records. Three well pairs in other parts of the SRPW that were perforated at a shallow depth and a deeper depth with longerterm records were used for model calibration; however, a more complete distribution of multiple-completion well sites would improve the accuracy of the model.
Although there are many wells at higher elevations in the mountains, most of these wells are located along drainages. The lithology from these wells was extrapolated over large areas lacking data; thus, the hydrogeology in these areas is uncertain. In addition, temporal groundwater-level data were not available in the mountains (except in Bennett Valley); therefore, the model was not as well calibrated in the mountains, and conclusions should be limited to general groundwater-flow directions and relative magnitudes.

As simplifications to the model, lakes were not simulated and the Laguna de Santa Rosa was simulated as a stream rather than as a floodplain, because, for the majority of the time, the Laguna de Santa Rosa has characteristics more like a stream channel rather than a large water body. Although the surface-water groundwater interactions along the main channel were correctly represented the majority of the time by using this approach, flooding in the Laguna de Santa Rosa was not represented by the model; therefore, model uncertainty in this region is greater during periods of flooding.

An important source of uncertainty in the SRPHM watershed-component model was that associated with the spatially distributed daily precipitation input. The average monthly spatial interpolation of daily inputs for the SRPHM provided a reasonable representation of the average monthly distribution of precipitation, but potentially did not accurately represent the true distribution of precipitation for a given storm or for a given month. Although the precipitation data used in the SRPHM honored the available records for climate stations in the SRPW, many data gaps existed in the available records, and many locations in the SRPW were not well represented.

Irrigation was included as an inflow to the SRPHM by adding estimates of daily irrigation to the precipitation-input time series developed for each HRU (irrigation was zero for non-irrigated HRUs). Although this method accounted for spatial and temporal variations in crop types and climate-related crop water demand, it did not account for changes in irrigation practices (for example, changing from spray irrigation to drip irrigation). It also was assumed that recharge from irrigation in excess of crop requirements was negligible, which is a potential source of error that could lead to underestimates of pumping and recharge. Landscape irrigation in urban areas and water application for other purposes, such as frost protection, were not included as inflows.

Application of the SRPHM using future-climate scenarios included additional limitations. The GCM results are not intended as forecasts of climate, but rather as representations of the characteristics of potential future climates, including long-term trends, annual variability and cycles, seasonal variability, and daily variability. The future-climate scenarios are useful for evaluating potential hydrologic responses to climate variability and long-term climate trends, but cannot be used to predict actual climate conditions for a specific future time. The spatial distribution of precipitation and air temperature in the SRPW was estimated as part of the downscaling and biascorrection processes, and is an additional source of uncertainty in the future climate simulations. 
Estimates of future agricultural irrigation, used to define agricultural pumping for water years 2005 through 2040 for each future-climate scenario, were associated with a great degree of uncertainty and were developed using many simplifying assumptions. An important assumption used to estimate future agricultural irrigation was that the distribution of irrigated crops defined for water year 2008 can be applied validly to water years 2005 through 2040, and that groundwater continues to be used as the primary source of irrigation water for crops.

Other changes in the characteristics of land cover were not addressed in the future-climate scenarios as well. The percentage of impervious cover, as defined for calendar year 2001, was used directly as input for the 1976-2010 calibration simulation and also was applied to the futureclimate simulations for water years 2005-99. As with the historical-climate baseline simulation, urban-area landscape irrigation and associated return flows were not included in the application of the SRPHM using the future-climate scenarios. In addition, other return flows, such as septic-tank effluent and leaking water pipes, were assumed to be negligible.

Potential evapotranspiration (PET) was simulated by using the Jensen-Haise method (Markstrom and others, 2008). Changes in air temperature projected by the future climate scenarios have a direct effect on PET; the trend of increasing air temperature caused by greenhouse-gas forcing resulted in a corresponding increase in PET for all four future climate scenarios considered in this study. However, the Jensen Haise method does not account for changes in humidity and other factors, such as changes in atmospheric turbidity, that also can occur with climate change. Decreases in PET related to cloud cover are empirically represented in the PET simulation during periods of precipitation, but increases in cloud cover during periods without precipitation are not represented by the PET simulation; therefore, the effect of increasing cloud cover on PET potential is not well represented in the future-climate scenarios. These combined factors increase the uncertainty of simulated PET in the future-climate scenarios.

\section{Conclusions}

The SRPHM was developed for the SRPW and synthesized the current data and understanding of the hydrologic system. It provides a tool to assess potential effects of futureclimate change and to evaluate the relative effectiveness of alternative water-management strategies. Development of the model also has been useful for identifying key data gaps. When applied carefully, the SRPHM can be useful for simulating hydrologic responses to various changes in hydrologic stresses to the groundwater and surface-water flow systems.
Model results for water years 1976-2010 using historical climate data, reported municipal pumpage, and estimates of rural pumpage indicated that only a small percentage of groundwater was removed from groundwater storage relative to the total volume of groundwater stored and the long-term average recharge rate. However, noticeable shifts in the balance between natural recharge, changes in groundwater storage, streamflow, and pumpage were simulated by the SRPHM. For example, large decreases in groundwater storage and streamflow resulted from drier-than-average periods. The loss of groundwater storage during dry periods was largely offset by increased recharge during wetter-than-average periods. Increased pumping lowered groundwater levels, causing increased recharge and reduced groundwater ET along stream channels, which partially mitigated the loss of groundwater storage, but the lower groundwater levels resulted in decreased baseflow, especially during late spring and summer.

Application of the SRPHM to determine the effects of projected pumping and four future-climate scenarios for water years 2011-40 simulated an increase in recharge from streams and a reduction in groundwater discharge to streams. The simulation also showed that the number of losing stream reaches increased, while the number of gaining reaches decreased. In the wettest scenario, the projected pumpage was offset by greater extra-channel recharge compared with the other three scenarios, resulting in an increase in hydraulic heads over a comparatively large area of the SRP. In the driest scenario, projected pumping resulted in head declines over a wider area. Compared with the baseline period, the reduction in groundwater ET, baseflow, and boundary flows out of the SRPW for water years 2011-40 mitigated the reduction in extra-channel recharge, resulting in less groundwater-storage depletion.

\section{References Cited}

Bredehoeft, John, 2005, The conceptualization model problem-surprise: Hydrogeology Journal, v. 13, p. 37-46.

California Department of Water Resources, 1994, California water plan update: Bulletin 160-93, October 1994, v. 2: Sacramento, Calif., California Department of Water Resources, $315 \mathrm{p}$.

Daly, Christopher, Gibson, W.P., Doggett, Matthew, Smith, Joseph, and Taylor, George, 2004, Up-to-date monthly climate maps for the conterminous United States: American Meteorological Society Conference on Applied Climatology, 14th, Seattle, Wash., 2004, January 13-16, 2004, Proceedings, Paper P5.1, http://www.prism.oregonstate. edu/pub/prism/docs/appclim04-uptodate_monthly_climate_ maps-daly.pdf. 
Flint, L.E., and Flint, A.L., 2012, Simulation of climate change in San Francisco Bay Basins, California: Case studies in the Russian River Valley and Santa Cruz Mountains: U.S. Geological Survey Scientific Investigations Report 2012-5132, $55 \mathrm{p}$.

Markstrom, S.L. Niswonger, R.L., Regan, R.S., Prudic, D.E., and Barlow, P.A., 2008, GSFLOW-coupled groundwater and surface-water FLOW model based on the integration of the precipitation-runoff modeling system (PRMS) and the modular groundwater flow model (MODFLOW-2005): U.S. Geological Survey Techniques and Methods 6-D1, 240 p.

Nishikawa, Tracy, Hevesi, J.A., Sweetkind, D.S., and Martin, Peter, 2013, Conceptual model of Santa Rosa Plain watershed hydrologic system, chap. D of Nishikawa, Tracy, ed., Hydrogeologic and geochemical characterization of the Santa Rosa Plain watershed, Sonoma County, California: U.S. Geological Survey Scientific Investigations Report 2013-5118, p. 167-177.

Walter, D.A., and Whealan, A.T., 2005, Simulated water sources and effects of pumping on surface and ground water, Sagamore and Monomoy flow lenses, Cape Cod, Massachusetts: U.S. Geological Survey Scientific Investigations Report 2004-5181, 85 p. 


\title{
Appendix 1. Supplemental Information: Documentation of the Crop Water Demand Model Used to Estimate Agricultural Irrigation
}

\author{
By Joseph A. Hevesi
}

\section{Introduction}

Groundwater is the primary source of water for irrigating crops in the Santa Rosa Plain watershed (SRPW). Although agricultural pumpage was a large component of the water budget for the period of this study (water years 1975-2010), it was unreported in the SRPW; Kadir and McGuire (1987) estimated agricultural pumpage for 1974-84, however. To develop estimates of agricultural pumpage for this study, watershedcomponent model simulations (decoupled precipitation runoff modeling system, or PRMS-only, simulations made by using the groundwater and surface-water flow model, or GSFLOW; Markstrom and others, 2008) were used in conjunction with a daily crop water-demand model (CWDM) to estimate the unmet crop water demand. This unmet demand is equal to the crop demand after accounting for effective precipitation and reclaimed-water application (Hevesi and others, 2011). The CWDM uses a root-zone water balance approach similar to previous studies by Brush and others (2004), Schmid and Hanson (2009), California Department of Water Resources (CDWR; 2013a), and California Department of Water Resources (2013b). The CWDM differs from the approach used in these studies in that it assumes that the source of all water for crop transpiration is rainfall and irrigation. For simplification, transpiration of groundwater from the saturated zone was excluded from the CWDM.

In the CWDM application used in this study, it was assumed that all of the unmet crop water demand was satisfied by irrigation supplied by groundwater pumpage. This is a reasonable assumption because diversions of surface water for irrigation are negligible in the SRPW (Donald Seymour, Sonoma County Water Agency, written commun., 2010). In addition, all pumpage was assumed to meet unmet demand with no losses. In other words, the CWDM assumes 100-percent irrigation efficiency. In general, these assumptions tend to underestimate pumpage.

The CWDM calculated monthly estimates of the unmet demand for all irrigated hydrologic response units (HRUs). This unmet demand was assigned to agricultural wells linked to the HRUs. The primary output from the CWDM was the average monthly pumping rate for each agricultural well. The secondary output generated by the CWDM was daily irrigation for each irrigated HRU.

\section{Calculations}

The CWDM calculated the unmet crop water demand (on a daily basis) for each HRU on the basis of (1) crop type; (2) crop coefficients (representing factors such as growing season and crop water demand); (3) available potential evapotranspiration (APET), calculated as potential evapotranspiration (PET) minus evapotranspiration (ET); and (4) soil moisture. The simulated soil moisture accounts for antecedent conditions as well as rapidly draining soils. Precipitation increases soil moisture, resulting in a reduced crop water deficit, but a permeable soil drains relatively quickly, which increases the unmet crop water demand. Conditions resulting in high crop water demand include (1) high APET, (2) low soil moisture, and (3) a high crop-coefficient value (values close to 1.0 usually represent the peak of the growing season). Conditions resulting in a low crop water demand include (1) low APET, (2) high soil moisture, and (3) crop-coefficient value of zero or close to zero (periods outside of the crop growing season).

The CWDM calculations were done on a daily basis for all irrigated HRUs. The first step was to calculate the APET:

$$
\boldsymbol{A P E T}_{i}=\boldsymbol{P E T}_{i}-\boldsymbol{E T}_{i}
$$

where

$\boldsymbol{P E T}$ and $\boldsymbol{E T}$ are the potential and actual ET (in inches), respectively, for HRU $\boldsymbol{i}$.

In the SRPHM, these values were calculated in the PRMSonly simulation. In other words, the energy available for transpiration in the CWDM takes into account the ET that has already occurred. In the second step of the CWDM, the change in soil moisture (DSM) was calculated for all HRUs:

$$
\operatorname{DSM}_{i}=\boldsymbol{S M}_{i}-\text { SMold }_{i}
$$

where
$\boldsymbol{S M}_{i} \quad$ is the soil moisture (in inches) for the current day for HRU $i$, and

SMold is the soil moisture for the previous day (in inches) for HRU $\boldsymbol{i}$. 
The third step calculated the potential crop water demand (PCWD):

$$
\boldsymbol{P C W D}_{i}=\text { APET }_{i}-\mathrm{DSM}_{i}
$$

If the value of the $\boldsymbol{P C W D}$ was negative (for example, this can result if an increase in the HRU soil moisture caused by precipitation, surface-water inflow, or both were greater than $\boldsymbol{A P E T}$ ), then $\boldsymbol{P C W D}$ was set to zero. If the $\boldsymbol{S M}$ was less than it was the previous day (as a result of a combination of ET and deep percolation), the $\boldsymbol{P C} \boldsymbol{W D}$ would be greater than the APET value, assuming that a target soil moisture was being maintained for irrigated crops. It was assumed that all of the applied water was used by crops, and no water remained to add to the soil moisture the next day. This assumed that the crops were irrigated every day. For example, for rapidly draining soils (sandy soils), the $\boldsymbol{P C W D}$ value would tend to be greater than for poorly draining soils (clay-rich soils). The fourth step was an adjustment of the PCWD based on the crop coefficient:

$$
A C W D_{i}=C C_{j k} * P C W D_{i}
$$

where

$\boldsymbol{A C W D _ { i }}$ is the adjusted crop water demand for HRU $\boldsymbol{i}$, and

$\boldsymbol{C C}_{j k} \quad$ is the crop coefficient for crop type $\boldsymbol{j}$ and month $\boldsymbol{k}$.

The crop coefficients were equivalent to the crop coefficients generally used in crop water-demand calculations (Brush and others, 2004; California Irrigation Management Information System (CIMIS), 2005; Schmid and Hanson, 2009) and were used to represent crop water demand on the basis of growing season and crop type.

In the fifth step, the $\boldsymbol{A C W D}$ was further adjusted by using an additional crop coefficient that defined the maximum soil moisture, SMmax, as a function of the estimated soil field capacity and crop type. If the soil moisture was greater than the defined maximum soil moisture, the final crop water demand, $\boldsymbol{C} \boldsymbol{W} \boldsymbol{D}_{i}$, was set to zero:

$$
\begin{gathered}
C W D_{i}=A C W D_{i} \\
\text { If } S M_{i}>S M \max _{i}, C W D_{i}=0 \\
\operatorname{SMmax}_{i}=F C_{i} * S M C_{j k}(5)
\end{gathered}
$$

where

$\boldsymbol{F C}_{i}$ is the estimated soil field capacity for HRU $\boldsymbol{i}$ (in inches), and

$\boldsymbol{S M C}_{j k}$ is the monthly soil moisture crop coefficient for crop type $\boldsymbol{j}$ and month $\boldsymbol{k}$.

The final crop water demand ( $\boldsymbol{C} \boldsymbol{W D})$ defined the amount of irrigation (in inches) applied to each HRU.

\section{Factors Affecting the Crop Water Demand Model}

There are several important factors affecting the CWDM and its estimates. The CWDM did not account for changing crop types and crop distributions. The CWDM used a constant spatial distribution of irrigated crop types as defined by a single land-use map representing the year 1974, 1979, 1986, 1999, or 2008.

Antecedent conditions affecting crop water demand were accounted for in three different ways. First, equation 1 reduced the crop water demand on the basis of the amount of ET. If there was precipitation on or prior to the day for which crop water demand was calculated, the soil was wetter, ET was higher, and this decreased the crop water demand because the residual PET was less. Second, equation 3 caused a further decrease in the crop water demand if there was an increase in soil moisture compared to the previous day. Third, equation 5 set the crop water demand to zero if the soil moisture was greater than the upper limit defined by the field capacity (FC), which generally was the case if the preceding period experienced significant precipitation.

The CWDM accounts for deep percolation as well as ET from the soil profile in the calculation of the crop water demand. For irrigated HRUs with rapidly draining soils, the $\boldsymbol{D S} \boldsymbol{M}$ value can be negative, which, in turn, increases $\boldsymbol{P C W D}$. In other words, for two HRUs with identical crop types, PET, and ET, the HRU with the more permeable soil would be likely to have a greater decrease in the soil water content (if no precipitation has occurred), which results in greater crop water demand.

\section{Santa Rosa Plain Crop Water-Demand Model Setup}

For the Santa Rosa Plain hydrologic model (SRPHM), the CWDM was used to estimate the unmet crop water demand and, ultimately, to develop estimates of agricultural pumpage. For these estimates, the watershed-component (referred to here as PRMS) model provided daily inputs to the CWDM. This was done for irrigated HRUs only, which were identified on the basis of land-use maps. Although the CWDM could be modified to apply to other studies, the description in this appendix is specific to the SRPHM.

For each simulation period, adjustments were made to the PRMS parameters to represent better the differences in vegetation types defined by the land-use period being simulated. The PRMS simulation provided daily inputs of PET, ET, and soil moisture to the CWDM. Additional inputs to the CWDM included the crop type defined for each HRU and monthly crop coefficients for each crop type to represent factors such as growing season and crop water use. The CWDM calculated 
the unmet daily crop water demand for each HRU on the basis of (1) the crop type, (2) the monthly crop coefficients specified for the crop type, (3) the residual PET (calculated as PRMSsimulated PET minus PRMS-simulated ET), and (4) PRMSsimulated soil moisture.

The CWDM was applied separately to five different simulation periods spanning water years 1975-2010; each period was associated with a unique land-use map that was representative of the crop distribution during that period. The most prevalent crop type and land use were assigned to each HRU; HRUs with mostly non-irrigated land uses or crop types were defined as non-irrigated HRUs. The CWDM was applied separately to each of the five land-use periods, and the results were combined into a continuous time series of daily irrigation and monthly agricultural pumpage.

\section{Inputs}

The CWDM inputs consisted of four groups: (1) HRU properties, (2) daily water-balance components, (3) monthly coefficients, and (4) the assignment of an agricultural well to each HRU. The CWDM inputs defining the HRU properties were developed from land-use and soils maps. Daily waterbalance components were developed as outputs from the PRMS simulations. The monthly coefficients were included as part of the CWDM control file, which also defined the simulation period and the names of input and output files. Initial values for the monthly crop coefficients were estimated and then adjusted as part of the CWDM calibration. There are two types of input files: the control file and the input-data files. The control file defined the CWDM simulation period; the input file named the four input-data groups and all output file names (fig. 1-1).

\section{Hydrologic Response Unit Properties}

Two HRU properties were used as input by the CWDM: (1) crop type and (2) estimated $\boldsymbol{F C}$. The crop type was defined by using four land-use maps from the California Department of Water Resources (CDWR; 1974, 1979, 1986, 1999) and a more recent land-use map provided by the Sonoma County Water Agency (Sonoma County Water Agency, written commun., 2008). These land-use maps were used to define five irrigation periods. The irrigation periods defined from the CDWR land-use maps for 1974 and 1979 were used for calibrating the crop coefficients by comparison of the CWDM total estimated water-year irrigation to published estimates from Kadir and McGuire (1987). As indicated in figure 1-2, the various crop types defined by the five land-use maps were grouped into seven generalized crop types used by the CWDM: (1) orchard, (2) field crop, (3) grain, (4) pasture, (5) truck crop, (6) vineyards, and (7) turf. The most prevalent crop type within each HRU was identified; a value of zero was assigned to non-irrigated HRUs. If an HRU was less than 50 percent irrigated, the crop type was assigned a value of 0 . The total irrigated crop area for the SRPW ranged from 6,700 acres in 1974 to 24,140 acres in 2008. Pasture and vineyards were the most prevalent irrigated crop types for all five land-use maps.

The $\boldsymbol{F C}$ (fig. 1-3) was estimated for each land-use period by using Natural Resources Conservation Service, Soil Survey Geographic (SSURGO) soils data (U.S. Department of Agriculture, 2007) and estimated average crop root depths for the seven crop types. Specifically, the available watercapacity (AWC) values in the SSURGO database were used to define field capacities according to their relative saturation (volumetric water contents). The AWC values were multiplied by the estimated root depth (in inches) for each crop type to calculate the $\boldsymbol{F C}$ for each HRU and each land-use period. The calculated $\boldsymbol{F} \boldsymbol{C}$ values were the same values used to define the soil_moist_max parameter in PRMS (see chapters $B$ and $D$ ). The estimated root depths were based on published values (Brush and others, 2004; Schmid and Hanson, 2009) and ranged from 1 to 10 feet (ft). The calculated $\boldsymbol{F} \boldsymbol{C}$ values for HRUs with irrigated crops ranged from about 0.5 to 11 inches (in.; fig. 1-3).

\section{Daily Water-Balance Components}

The PRMS model was used to simulate daily waterbalance components (PET, ET, and SM) that were used as input to the CWDM for all irrigated and non-irrigated HRUs. In addition to the PRMS-simulated components, the daily precipitation input used for the PRMS simulation was included as input for the CWDM.

For the PRMS model, reclaimed wastewater was added to the spatially distributed daily precipitation input for those HRUs where reclaimed water was used for irrigation. The modified or "effective" precipitation input that included the reclaimed wastewater used for irrigation was developed as a pre-processing step (see chapter $B$ ) and, then, was used in the PRMS-only simulations to generate the inputs for the CWDM. The inclusion of reclaimed water resulted in greater soilmoisture values simulated by PRMS for those HRUs where reclaimed wastewater was applied, which, in turn, resulted in a decrease in the simulated crop water demand compared to results obtained by using the unmodified precipitation input. This decreased demand was assumed to be realistic, and the "effective" precipitation was used as input.

\section{Monthly Coefficients}

Two different monthly coefficients are assigned to each crop type: (1) monthly crop coefficients $(\boldsymbol{C} \boldsymbol{C})$ and (2) monthly soil-moisture coefficients $(\boldsymbol{S M C})$. The $\boldsymbol{C} \boldsymbol{C}$ s are used to estimate crop water demand by using combined energy and water balance methods (Brush and others, 2004; California Irrigation Management Information System, 2005). The $\boldsymbol{S M C}$ s were used to account for the effect of differences in soil properties 


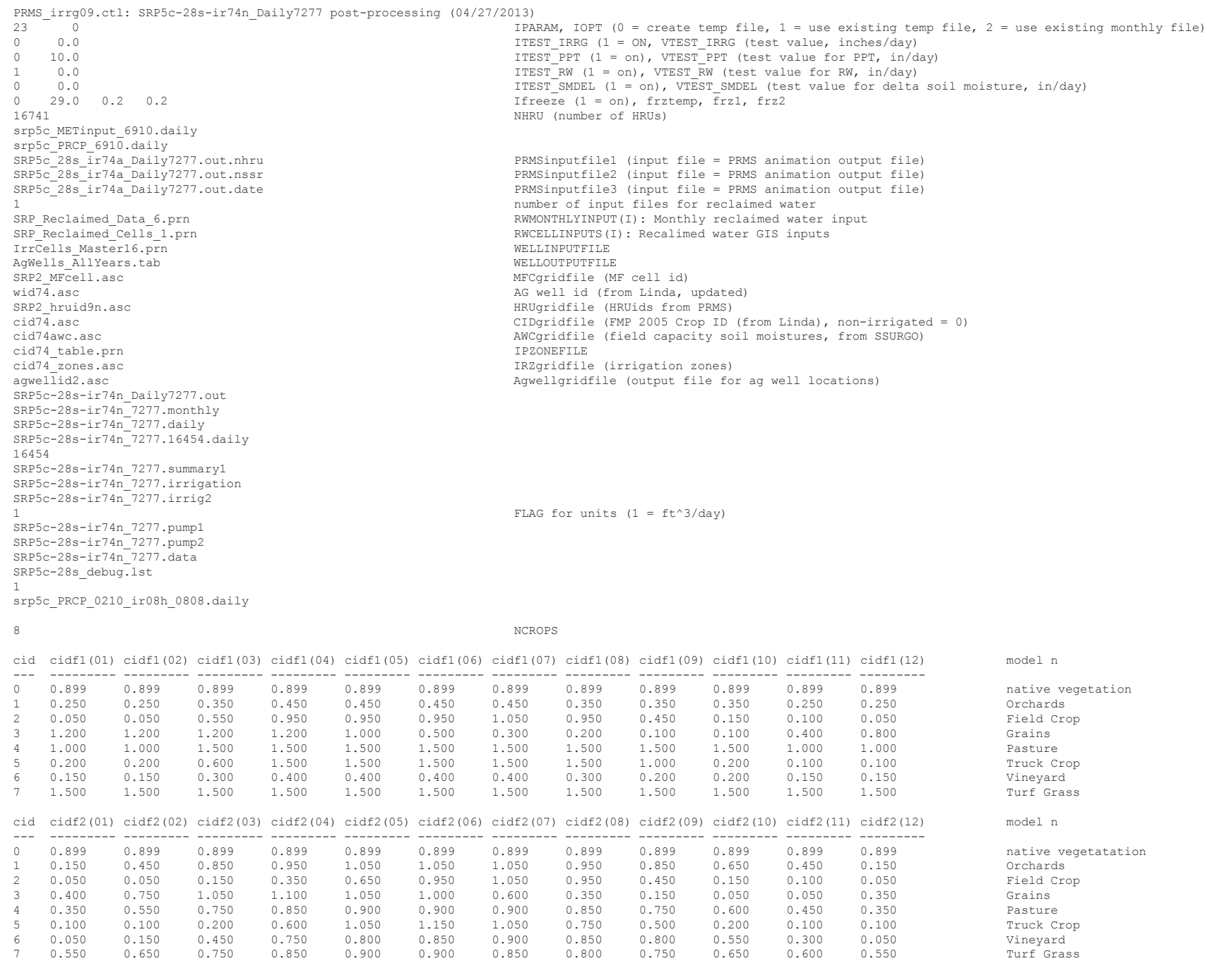

Figure 1-1. Example input file: CWDM control file, Santa Rosa Plain watershed, Sonoma County, California. 


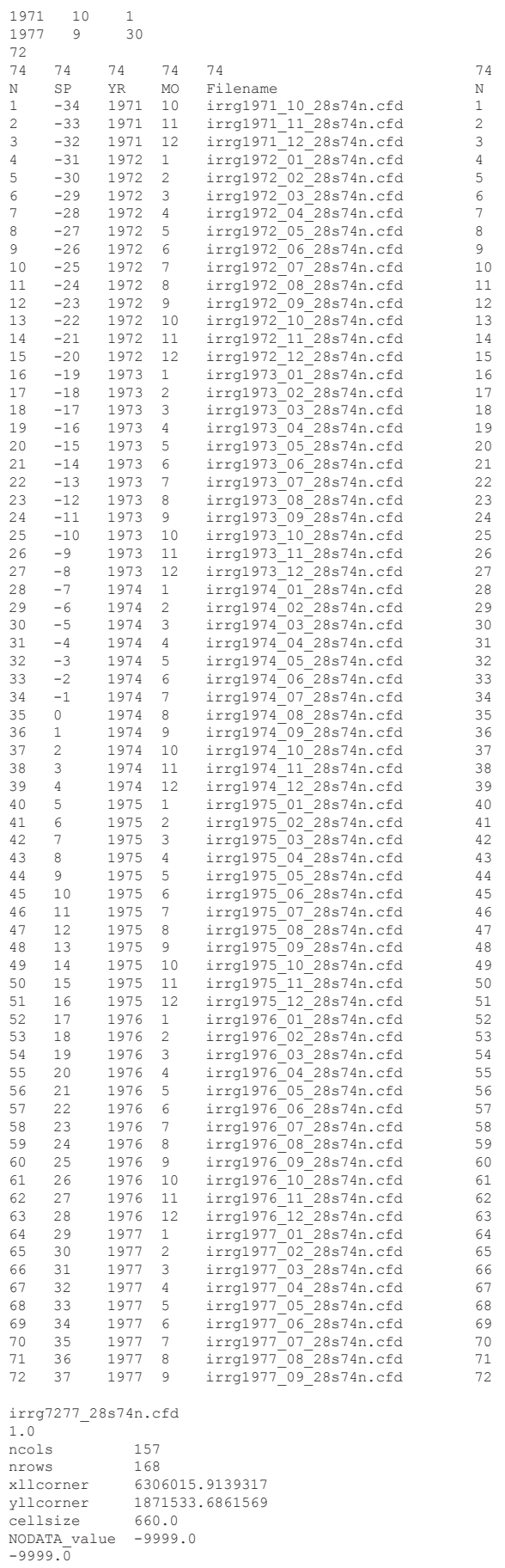

Figure 1-1. - - Continued 


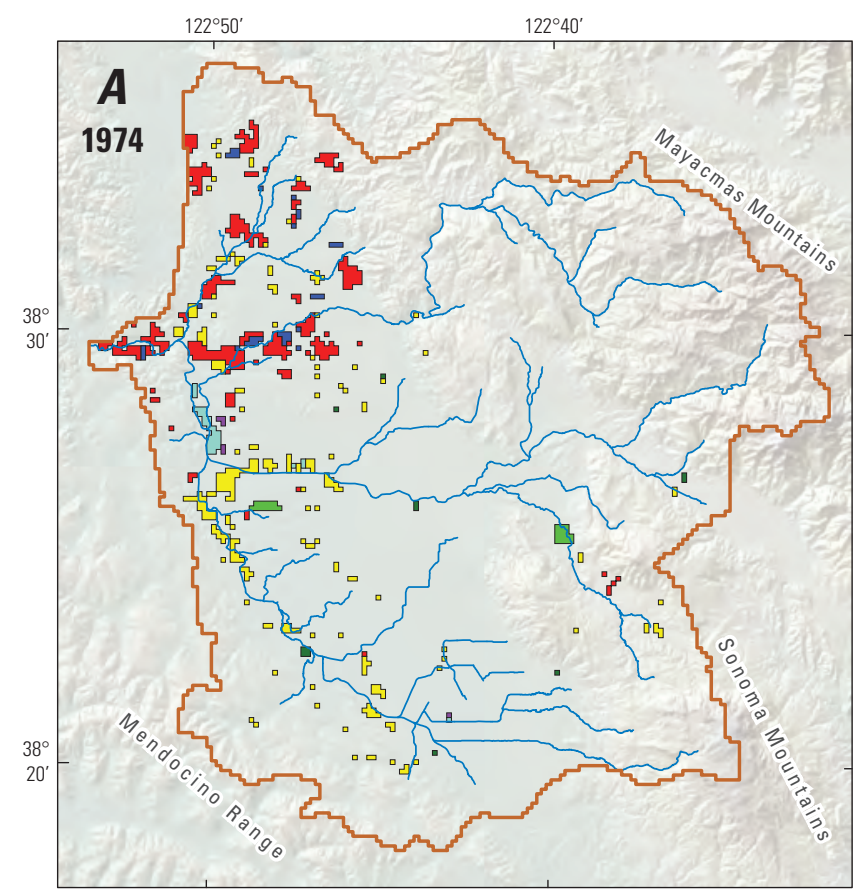

1974 Irrigated crop types $(6,700$ total acres)
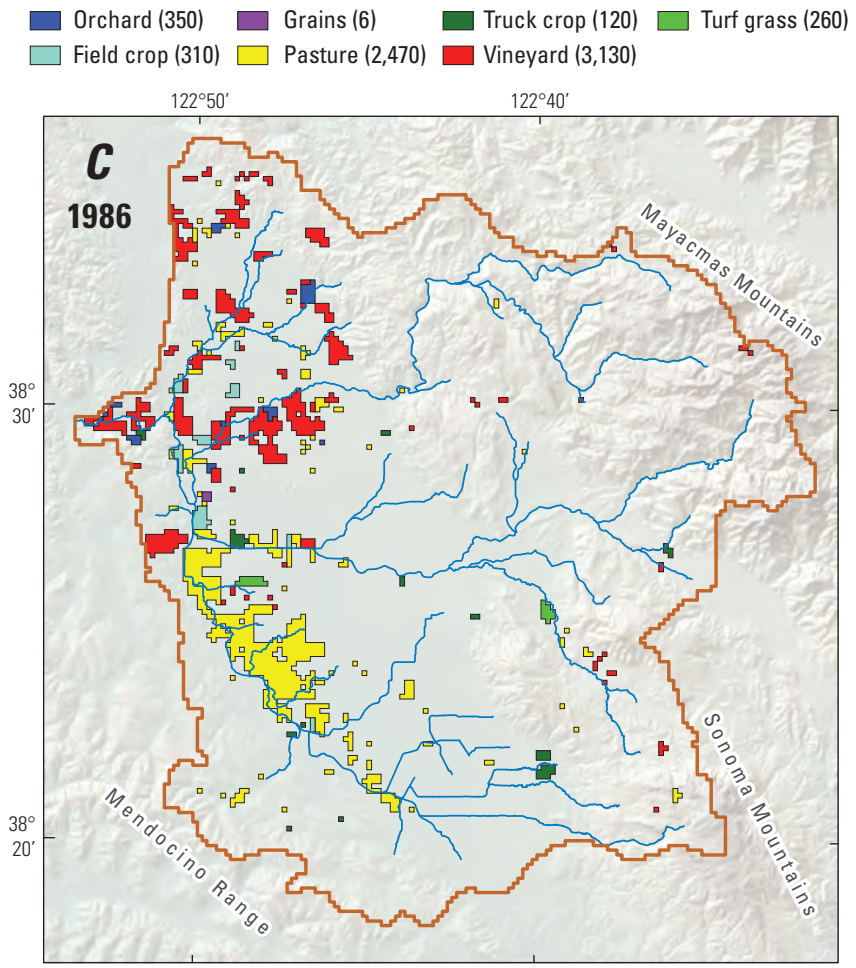

1986 Irrigated crop types $(6,700$ total acres)

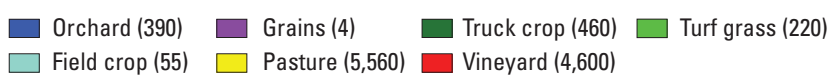

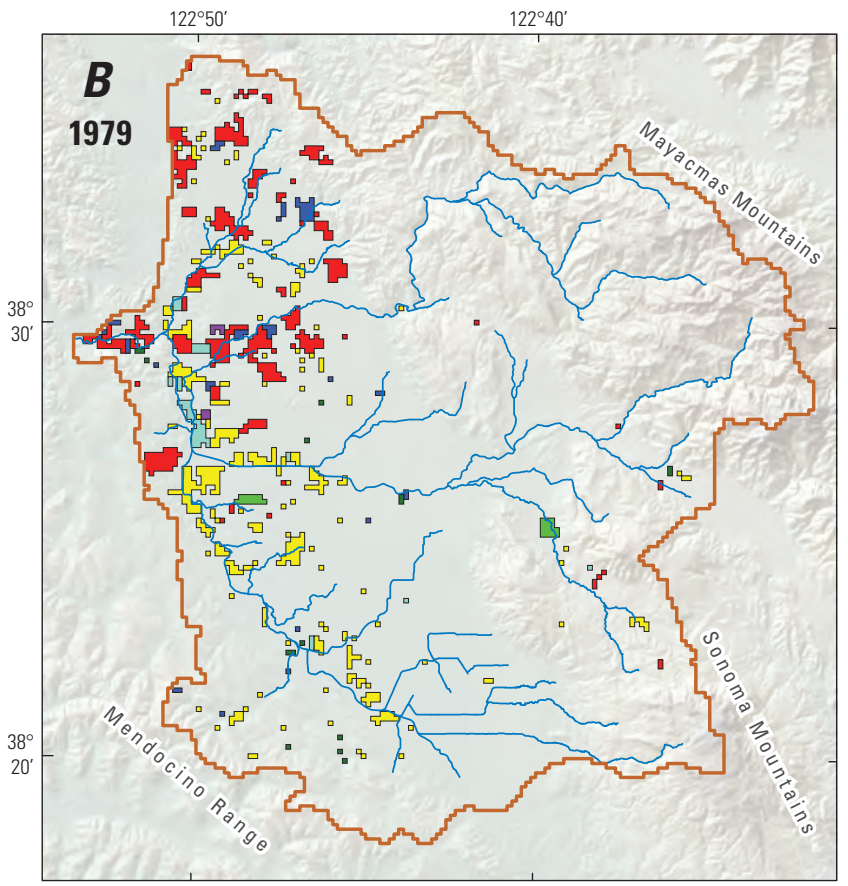

1979 Irrigated crop types $(9,410$ total acres)

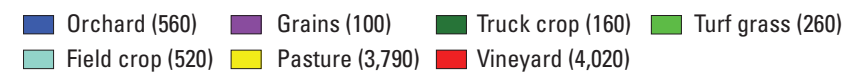

Field crop (520) $\square$ Pasture $(3,790) \square$ Vineyard $(4,020)$

\section{EXPLANATION}

_ Santa Rosa Plain watershed and hydrologic-model boundary

- Stream or creek

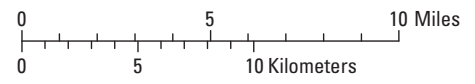

Figure 1-2. Generalized crop types used as input for the crop water-demand model, Santa Rosa Plain watershed, Sonoma County, California, based on land-use maps for $A, 1974 ; B, 1979 ; C, 1986 ; D, 1999$; and $E, 2008$. 

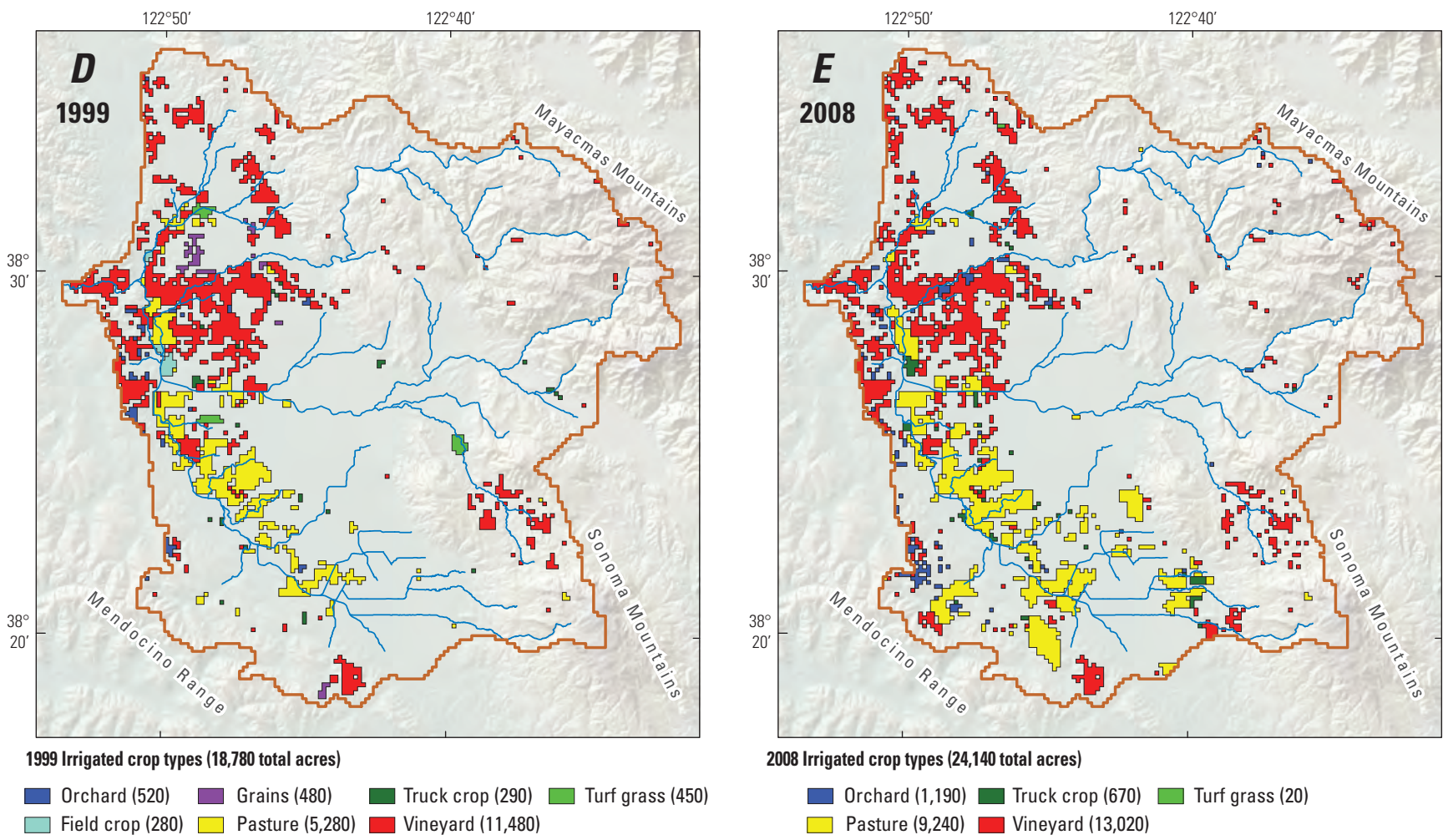

2008 Irrigated crop types (24,140 total acres)

$\square$ Orchard $(1,190) \square$ Truck crop $(670) \quad \square$ Turf grass (20)

$\square$ Pasture $(9,240) \square$ Vineyard $(13,020)$

\section{EXPLANATION}

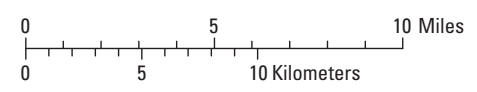

_ Santa Rosa Plain watershed and hydrologic-model boundary

Stream or creek

Figure 1-2. - Continued 


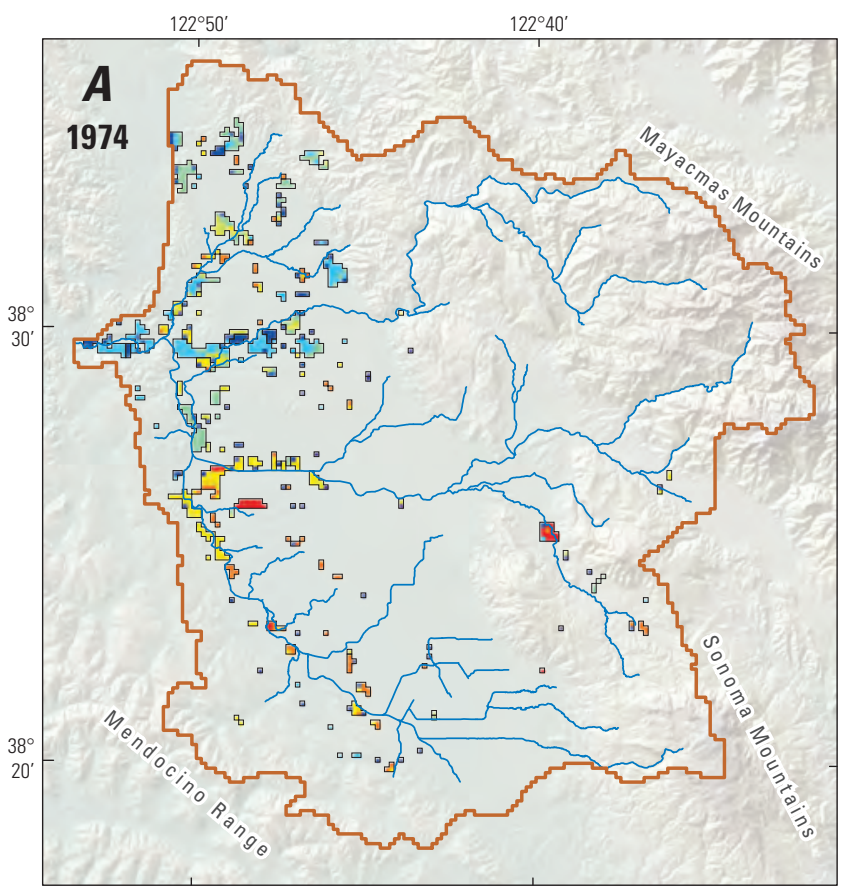

1974 Soil field capacity, in inches, irrigated crop areas

$\begin{array}{llll}0.5 \text { to } 1 & 1.6 \text { to } 2 \square & 3.1 \text { to } 4 \square & 6.1 \text { to } 8\end{array}$

\begin{tabular}{l|l|l|l} 
& 1.1 to 1.5 & 2.1 to 3 & 4.1 to 6 \\
$\square$ & 8.1 to 11
\end{tabular}

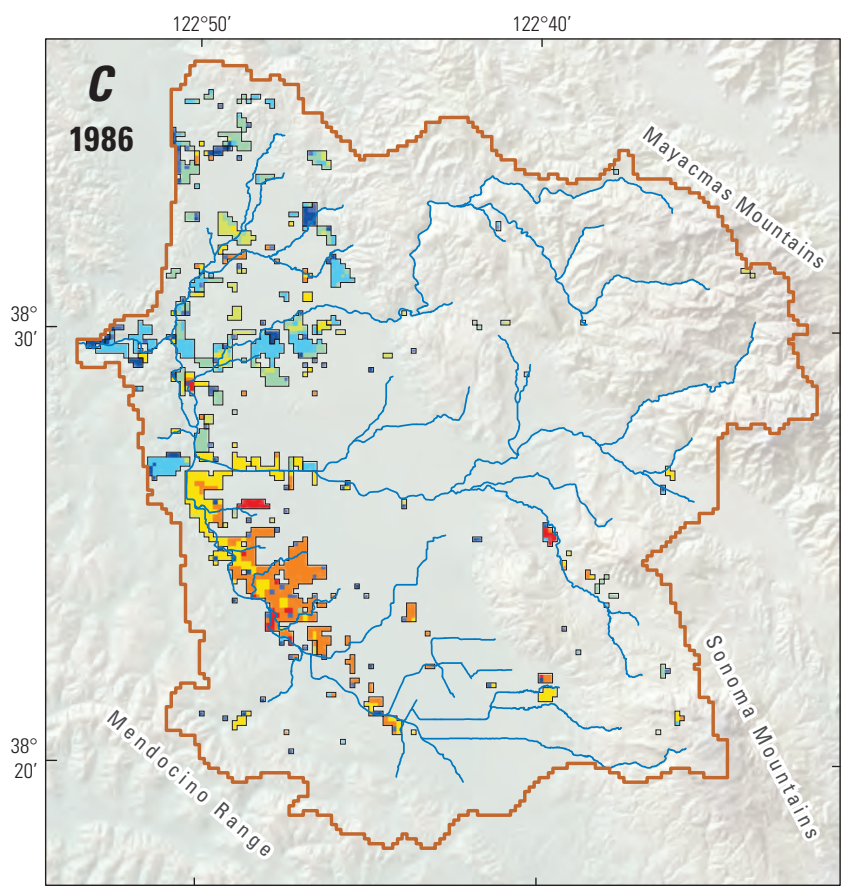

1986 Soil field capacity, in inches, irrigated crop areas

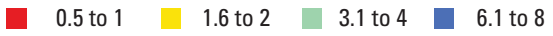

\begin{tabular}{l|l}
1.1 to 1.5 & 2.1 to 3 \\
\hline
\end{tabular}

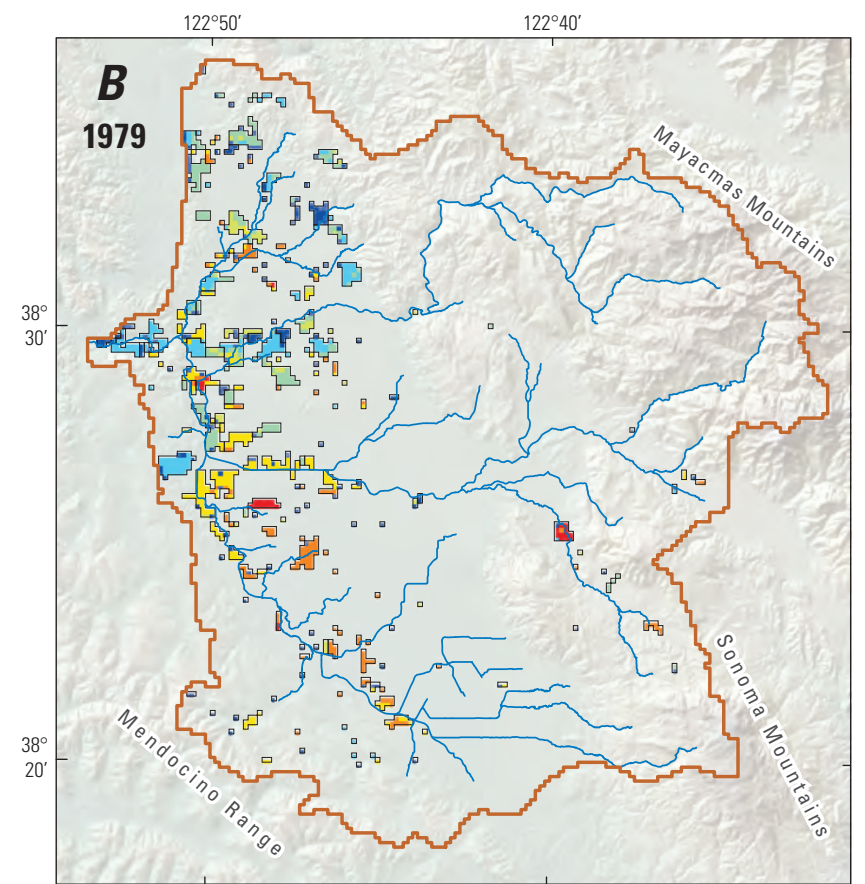

1979 Soil field capacity, in inches, irrigated crop areas

$\begin{array}{lll}0.5 \text { to } 1 \square & 1.6 \text { to } 2 \square 3.1 \text { to } 4 \square 6.1 \text { to } 8\end{array}$

\begin{tabular}{l|l|l|l} 
& 1.1 to 1.5 & 2.1 to 3 & 4.1 to 6 \\
\hline & 8.1 to 11
\end{tabular}

\section{EXPLANATION}

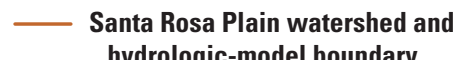
hydrologic-model boundary

_ Stream or creek

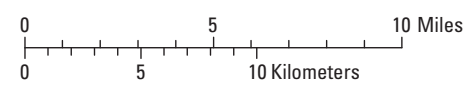

Figure 1-3. Calculated field-capacity values used as input for the crop water-demand model, Santa Rosa Plain watershed, Sonoma County, California, based on Natural Resources Conservation Service, Soil Survey Geographic (SSURGO) soils data, reported crop root depths, and land-use maps for $A, 1974 ; B, 1979 ; C, 1986 ; D, 1999$; and $E, 2008$. 


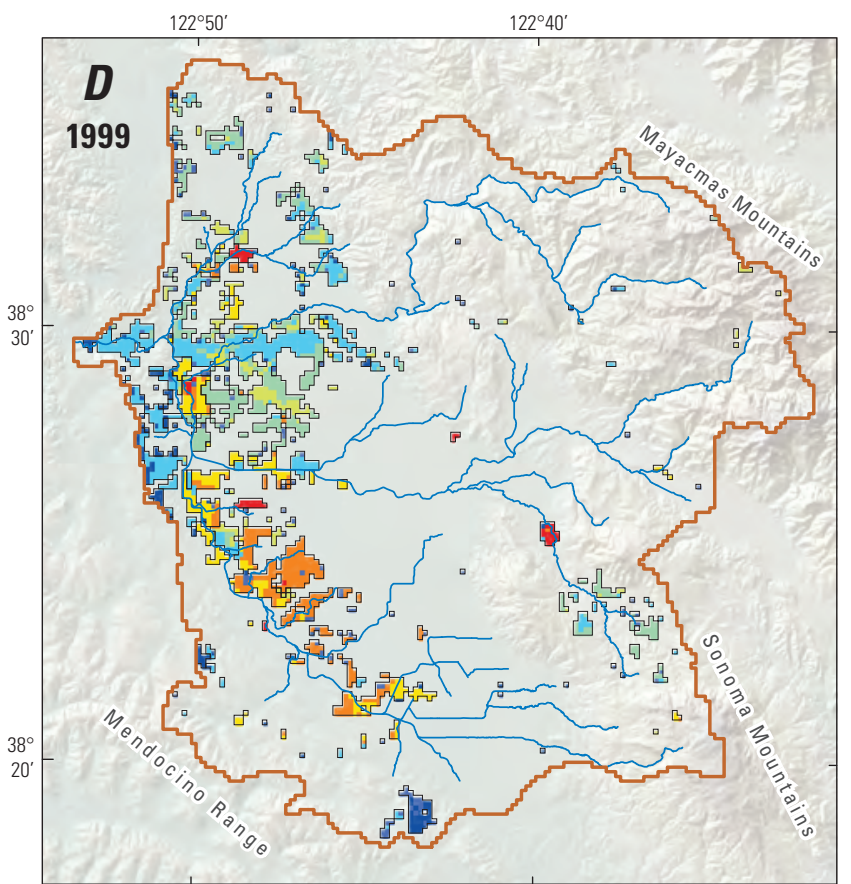

1999 Soil field capacity, in inches, irrigated crop areas

\begin{tabular}{lll|l}
0.5 to 1 & 1.6 to 2 & 3.1 to 4 & 6.1 to 8
\end{tabular}

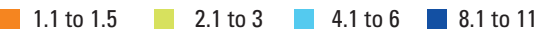

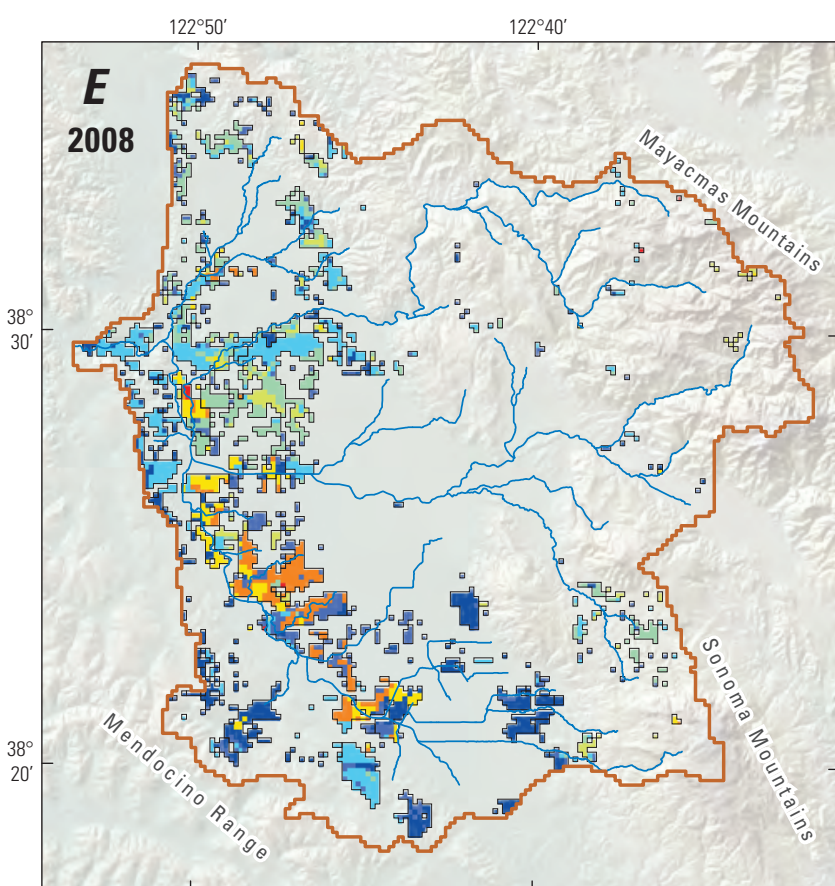

2008 Soil field capacity, in inches, irrigated crop areas

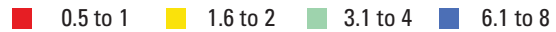

\begin{tabular}{l|l|l|l}
1.1 to 1.5 & 2.1 to 3 & 4.1 to 6 &
\end{tabular}

EXPLANATION

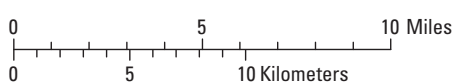

Figure 1-3. -Continued on transpiration and to set a lower limit for soil moisture. Specifically, if the soil moisture was greater than the $\boldsymbol{S M C}$, then the crop water demand was set to zero (equation 5), and no irrigation was needed because the soil-saturation level was sufficient to meet the demand.

Initial estimates of monthly crop coefficients were made on the basis of reported values (Pittenger and Shaw, 2003; Faunt, 2009; Schmid and Hanson, 2009; Chris Delaney, Sonoma County Water Agency, written commun., 2010). Because these values were estimates and varied widely with planting conditions, crop variety, and location, the monthly crop coefficients were adjusted for each crop type as part of the CWDM calibration. The initial and calibrated $\boldsymbol{C} C$ values are given in table 1-1.

The $\boldsymbol{S M C s}$ for each crop type and month were given an initial value of 1.0. These values were adjusted (by crop type) as part of the calibration. Calibrated $\boldsymbol{S M C}$ values are given in table 1-2. Note that it was assumed that the $\boldsymbol{S M C}$ values varied according to crop type and month and did not vary according to soil type. For simplification, it was assumed that crops were planted in suitable soils. Both sets of monthly coefficients were included as input parameters in the CWDM control file (fig. 1-1).

\section{Agricultural-Well Assignment}

The CWDM simulated unmet crop water demand for all irrigated HRUs and, then, calculated (1) average monthly demand and (2) the total estimated monthly agricultural pumpage, in cubic-feet per day $\left(\mathrm{ft}^{3} / \mathrm{d}\right)$, for all agricultural wells. The pumpage was assigned to agricultural wells, and each irrigated HRU was linked to one well. A single well can be linked to multiple HRUs. The agricultural well parameters identified the connections between irrigated HRUs and wells for each irrigation period (fig. 1-4). In the example input file shown in figure 1-4, the first well (WID 1) irrigated seven HRUs, all with a crop-type value of 6 (vineyard), in the 1974 irrigation period (see "Time Series of Application and Results" section in this appendix). The location of the well was indicated by the WellRow and WellCol parameters, and the location of the seven HRUs was indicated by the IrrRow and IrrCol parameters. In this example, the configuration of irrigated HRUs and the corresponding crop-type value remained constant for the first three irrigation periods (1974, 1979, and 1986). For the 1999 irrigation period, only four HRUs were irrigated by WID 1. For the 2008 irrigation period, seven HRUs, again, were irrigated. 
Table 1-1. Monthly crop coefficients for seven crop types used as input for the calibrated crop water-demand model (CWDM), Santa Rosa Plain watershed, Sonoma County, California.

[Abbreviations: Apr, April; Aug, August; CVHM, Central Valley hydrologic model (Faunt, 2009); CWDM, crop water demand model; Dec, December; Feb, February; FMP, farm process (Schmid and Hanson, 2009); Jan, January; Jul, July; Jun, June; Mar, March; Nov, November; Oct, October; Sep, September; SEBAL, surface energy balance algorithm for land (Chris Delaney, Sonoma County Water Agency, written commun., 2010); UCCE, University of California Cooperative Extension (Pittenger and Shaw, 2003); - , none]

\begin{tabular}{|c|c|c|c|c|c|c|c|c|c|c|c|c|c|}
\hline $\begin{array}{l}\text { Crop } \\
\text { type }\end{array}$ & $\begin{array}{l}\text { CWDM / } \\
\text { reference }\end{array}$ & Jan & Feb & Mar & Apr & May & Jun & Jul & Aug & Sep & Oct & Nov & Dec \\
\hline Orchards & CWDM & 0.150 & 0.450 & 0.850 & 0.950 & 1.050 & 1.050 & 1.050 & 0.950 & 0.850 & 0.650 & 0.450 & 0.150 \\
\hline Orchards & FMP & 0.105 & 0.520 & 0.586 & 0.722 & 0.856 & 0.910 & 0.910 & 0.910 & 0.910 & 0.826 & 0.060 & 0.060 \\
\hline Orchards & SEBAL & - & 0.320 & 1.170 & 0.760 & 0.930 & 0.760 & 1.500 & 0.680 & 0.780 & 0.550 & - & - \\
\hline Field crop & CWDM & 0.050 & 0.050 & 0.150 & 0.350 & 0.650 & 0.950 & 1.050 & 0.950 & 0.450 & 0.150 & 0.100 & 0.050 \\
\hline Field crop & FMP & 0.027 & 0.027 & 0.027 & 0.066 & 0.369 & 0.909 & 1.090 & 0.876 & 0.027 & 0.027 & 0.027 & 0.027 \\
\hline Field crop & CVHM & 0.100 & 0.100 & 0.100 & 0.100 & 0.390 & 0.900 & 1.100 & 0.900 & 0.100 & 0.100 & 0.100 & 0.100 \\
\hline Grains & CWDM & 0.400 & 0.750 & 1.050 & 1.100 & 1.050 & 1.000 & 0.600 & 0.350 & 0.150 & 0.050 & 0.050 & 0.350 \\
\hline Grains & FMP & 0.533 & 1.017 & 1.170 & 1.170 & 0.900 & 0.010 & 0.001 & 0.001 & 0.001 & 0.001 & 0.001 & 0.232 \\
\hline Grains & CVHM & 0.970 & 1.200 & 1.200 & 1.200 & 0.500 & 0.000 & 0.000 & 0.000 & 0.000 & 0.000 & 0.220 & 0.350 \\
\hline Pasture & CWDM & 0.350 & 0.550 & 0.750 & 0.850 & 0.900 & 0.900 & 0.900 & 0.850 & 0.750 & 0.600 & 0.450 & 0.350 \\
\hline Pasture & FMP & 0.975 & 0.975 & 0.975 & 0.975 & 0.975 & 0.975 & 0.975 & 0.975 & 0.975 & 0.975 & 0.975 & 0.945 \\
\hline Pasture & SEBAL & - & 0.380 & 0.985 & 0.880 & 0.975 & 0.840 & 1.100 & 0.780 & 0.775 & 0.605 & - & - \\
\hline Pasture & CVHM & 0.600 & 0.750 & 0.950 & 1.100 & 1.100 & 1.100 & 1.100 & 1.100 & 1.100 & 0.750 & 0.280 & 0.280 \\
\hline Truck crop & CWDM & 0.100 & 0.100 & 0.200 & 0.600 & 1.050 & 1.150 & 1.050 & 0.750 & 0.500 & 0.200 & 0.100 & 0.100 \\
\hline Truck crop & FMP & 0.065 & 0.065 & 0.254 & 0.581 & 0.952 & 1.041 & 0.736 & 0.065 & 0.065 & 0.065 & 0.065 & 0.065 \\
\hline Truck crop & CVHM & 1.100 & 0.700 & 0.150 & 0.400 & 0.780 & 1.100 & 1.100 & 0.700 & 0.170 & 0.400 & 0.790 & 1.090 \\
\hline Vineyard & CWDM & 0.050 & 0.150 & 0.450 & 0.750 & 0.800 & 0.850 & 0.900 & 0.850 & 0.800 & 0.550 & 0.300 & 0.050 \\
\hline Vineyard & FMP & 0.060 & 0.250 & 0.264 & 0.458 & 0.704 & 0.800 & 0.800 & 0.800 & 0.800 & 0.694 & 0.250 & 0.060 \\
\hline Vineyard & SEBAL & - & 0.315 & 0.960 & 0.695 & 0.770 & 0.680 & 1.290 & 0.750 & 0.945 & 0.540 & - & - \\
\hline Vineyard & CVHM & 0.100 & 0.100 & 0.280 & 0.450 & 0.650 & 0.800 & 0.800 & 0.800 & 0.800 & 0.750 & 0.600 & 0.390 \\
\hline Turf & CWDM & 0.550 & 0.650 & 0.750 & 0.850 & 0.900 & 0.900 & 0.850 & 0.800 & 0.750 & 0.650 & 0.600 & 0.550 \\
\hline Turf & UCCE & 0.580 & 0.590 & 0.755 & 0.880 & 0.870 & 0.780 & 0.825 & 0.785 & 0.680 & 0.645 & 0.635 & 0.575 \\
\hline
\end{tabular}

Table 1-2. Monthly soil moisture crop coefficients for seven crop types used as input for the calibrated crop water-demand model, Santa Rosa Plain watershed, Sonoma County, California.

[Abbreviations: Apr, April; Aug, August; Dec, December; Feb, February; Jan, January; Jul, July; Jun, June; Mar, March; Nov, November; Oct, October; Sep, September]

\begin{tabular}{lccccccccccccc}
\hline \multicolumn{1}{c}{ Crop type } & Jan & Feb & Mar & Apr & May & Jun & Jul & Aug & Sep & Oct & Nov & Dec \\
\hline Orchards & 0.250 & 0.250 & 0.350 & 0.450 & 0.450 & 0.450 & 0.450 & 0.350 & 0.350 & 0.350 & 0.250 & 0.250 \\
Field crop & 0.050 & 0.050 & 0.550 & 0.950 & 0.950 & 0.950 & 1.050 & 0.950 & 0.450 & 0.150 & 0.100 & 0.050 \\
Grains & 1.200 & 1.200 & 1.200 & 1.200 & 1.000 & 0.500 & 0.300 & 0.200 & 0.100 & 0.100 & 0.400 & 0.800 \\
Pasture & 1.000 & 1.000 & 1.500 & 1.500 & 1.500 & 1.500 & 1.500 & 1.500 & 1.500 & 1.500 & 1.000 & 1.000 \\
Truck crop & 0.200 & 0.200 & 0.600 & 1.500 & 1.500 & 1.500 & 1.500 & 1.500 & 1.000 & 0.200 & 0.100 & 0.100 \\
Vineyard & 0.150 & 0.150 & 0.300 & 0.400 & 0.400 & 0.400 & 0.400 & 0.300 & 0.200 & 0.200 & 0.150 & 0.150 \\
Turf & 1.500 & 1.500 & 1.500 & 1.500 & 1.500 & 1.500 & 1.500 & 1.500 & 1.500 & 1.500 & 1.500 & 1.500 \\
\hline
\end{tabular}



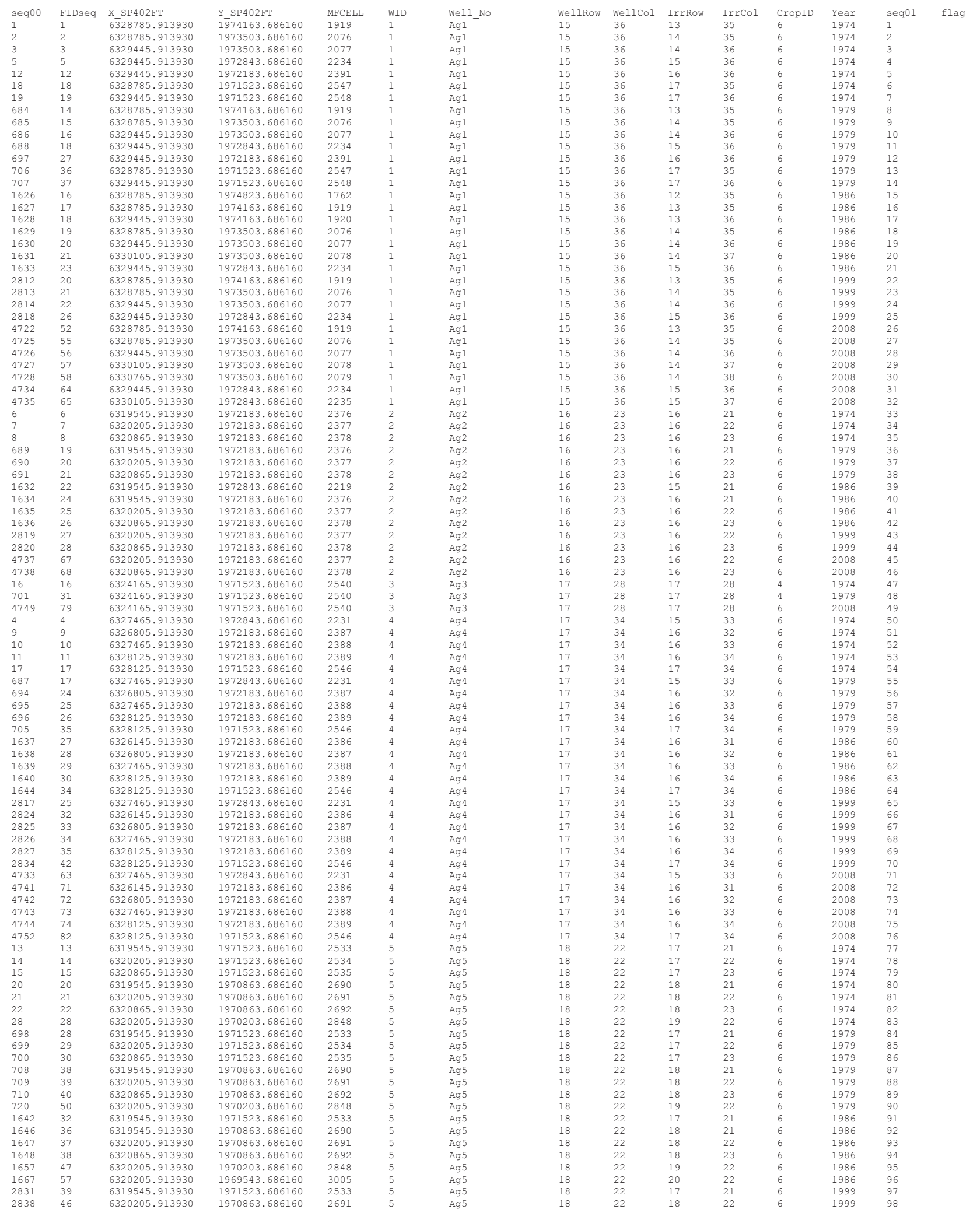

Figure 1-4. Example input file: agricultural-well parameters, Santa Rosa Plain crop water-demand model, Santa Rosa Plain watershed, Sonoma County, California. 


\section{Output Files}

The CWDM generated several output files. The primary output file was the simulated monthly pumpage for all agricultural wells for the period of the simulation (fig. 1-5). All wells for all land-use periods were included in the output; however, if a well was inactive during the simulated irrigation period, the monthly pumpage was set to zero.

Additional output files included monthly irrigation for all crop types (fig. 1-6), daily irrigation for all crop types (fig. 1-7), the "effective" daily precipitation input used by the SRPHM, daily water-budget results (including irrigation) for specified HRUs (fig. 1-7), and two-dimensional arrays (grids) of annual and monthly irrigation.

\section{Calibration}

The CWDM was calibrated by using previous estimates of irrigation for the SRPW (Kadir and McGuire, 1987). Kadir and McGuire (1987) estimated annual agricultural pumpage for water years 1974-84 by calculating crop water demand (based on land use and crop water demand) and subtracting the part of the demand supplied by the small amount of surfacewater deliveries.

Water year 1974 was used for the model-initialization (or "spin up") period and was excluded from the calibration period. Calibration was done qualitatively by trial-and-error adjustment of monthly $\boldsymbol{C} \boldsymbol{C}$ s and $\boldsymbol{S M C}$ s until a satisfactory fit was obtained between estimated and simulated irrigation values. Comparison of the time series of total water-year simulated and estimated irrigation indicated a reasonable match (fig. 1-8). The CWDM-simulated irrigation indicated greater year-to-year variability than the estimates by Kadir and McGuire (1987), with a minimum of 9,100 acre-feet per year (acre-ft/yr) simulated for water year 1975 and a maximum of $18,000 \mathrm{acre}-\mathrm{ft} / \mathrm{yr}$ simulated for water year 1984 by the CWDM (fig. 1-8). The 10-year average irrigation rate simulated by the CWDM was 13,500 acre-ft/yr, compared to 14,500 acre-ft/yr estimated by Kadir and McGuire (1987).

\section{Sample Results}

The CWDM daily simulation results for HRU 16,454 provided a sample of the effect of antecedent conditions on simulated crop water demand (in this case, the crop type is vineyard) for water years 1975 and 1976 (fig. 1-9). As mentioned earlier, the $\boldsymbol{C W D}$ is the simulated daily crop water demand that determines the amount of irrigation applied to each HRU. Precipitation was greater for water year 1975 compared to water year 1976 (fig. 1-9A). The drier, antecedent conditions for water year 1976 caused an earlier initiation of simulated irrigation; simulated irrigation began on July 1 in water year 1975 in contrast to May 20 in water year 1976 (fig. 1-9A). There were large increases in PRMSsimulated soil moisture in response to infiltrating precipitation (fig. 1-9A). Although not directly shown on figure 1-9A, there were smaller, but more continuous, decreases in soil moisture in response to ET and deep percolation. The PRMSsimulated ET matched PET during periods of relatively high precipitation, so soil moisture was not a factor in limiting ET (fig. 1-9B). From November through April for both water years, zero irrigation was simulated by the CWDM because of the combination of available soil moisture, less PET during the winter months, and smaller crop coefficients for the winter months (fig. 1-9B). During most days when non-zero irrigation was simulated, the simulated irrigation was less than the available PET because the crop coefficients for vineyards were less than 1.0 for all months (table 1-1). Most of July in water year 1975 was an exception; simulated irrigation was slightly greater than available PET because deep percolation caused additional drying of the soil profile. The PRMS-simulated soil moisture indicated a large difference in the water available for ET between water years 1975 and 1976; soil moisture reached a maximum of about $9.4 \mathrm{in}$. in water year 1975 compared to a maximum of 4.9 in. in water year 1976 (fig. 1-9C). The $\boldsymbol{S M C}$ for vineyards limited irrigation to periods when the soil moisture was less than about $1.5 \mathrm{in}$. This primary factor controlling the onset of irrigation is a function of antecedent conditions. Following equation 5, the final crop water demand (or $\boldsymbol{C W D}$ ) equaled the adjusted crop water demand (or $\boldsymbol{A C W D}$ ) only for those days when soil moisture was below the limiting condition (fig. 1-9D). 


\begin{tabular}{|c|c|c|c|c|c|c|c|c|c|c|c|}
\hline $\mathrm{r}$ & Mon & ND & HRUID & MFcell & Row & $\mathrm{Col}$ & CID & Well-ID & Well name & Irrigation(in) & Pumpage $\left(f t^{\wedge} 3 / d\right)$ \\
\hline 1971 & 10 & 31 & 2594 & 8391 & 54 & 70 & 4 & 63 & Ag63 & $0.1771515 \mathrm{E}+01$ & $0.2074387 \mathrm{E}+04$ \\
\hline 1971 & 10 & 31 & 2652 & 9649 & 62 & 72 & 4 & 104 & Ag104 & $0.1904793 \mathrm{E}+01$ & $0.2230451 \mathrm{E}+04$ \\
\hline 1971 & 10 & 31 & 2767 & 8526 & 55 & 48 & 6 & 64 & $\mathrm{Ag} 64$ & $0.1600048 \mathrm{E}+01$ & $0.1873604 \mathrm{E}+04$ \\
\hline 1971 & 10 & 31 & 2781 & 8682 & 56 & 47 & 6 & 64 & Ag64 & $0.1631116 \mathrm{E}+01$ & $0.1909984 \mathrm{E}+04$ \\
\hline 1971 & 10 & 31 & 2783 & 8681 & 56 & 46 & 6 & 70 & Ag70 & $0.1626202 \mathrm{E}+01$ & $0.1904230 \mathrm{E}+04$ \\
\hline 1971 & 10 & 31 & 2788 & 8991 & 58 & 42 & 1 & 79 & Ag79 & $0.1913581 \mathrm{E}+01$ & $0.2240742 \mathrm{E}+04$ \\
\hline 1971 & 10 & 31 & 2789 & 8986 & 58 & 37 & 6 & 73 & Ag73 & $0.1642439 \mathrm{E}+01$ & $0.1923243 \mathrm{E}+04$ \\
\hline 1971 & 10 & 31 & 2790 & 8990 & 58 & 41 & 1 & 79 & Ag79 & $0.1894952 \mathrm{E}+01$ & $0.2218927 \mathrm{E}+04$ \\
\hline 1971 & 10 & 31 & 2791 & 8985 & 58 & 36 & 6 & 73 & Ag73 & $0.1625164 \mathrm{E}+01$ & $0.1903015 \mathrm{E}+04$ \\
\hline 1971 & 10 & 31 & 2792 & 9147 & 59 & 41 & 6 & 74 & Ag74 & $0.1631130 \mathrm{E}+01$ & $0.1910001 \mathrm{E}+04$ \\
\hline 1971 & 10 & 31 & 2793 & 9146 & 59 & 40 & 6 & 74 & $\mathrm{Ag} 74$ & $0.1613708 \mathrm{E}+01$ & $0.1889600 \mathrm{E}+04$ \\
\hline 1971 & 10 & 31 & 2794 & 9303 & 60 & 40 & 6 & 74 & $\operatorname{Ag} 74$ & $0.1629643 \mathrm{E}+01$ & $0.1908259 \mathrm{E}+04$ \\
\hline 1971 & 10 & 31 & 2796 & 9458 & 61 & 38 & 6 & 83 & Ag83 & $0.1606127 \mathrm{E}+01$ & $0.1880723 \mathrm{E}+04$ \\
\hline 1971 & 10 & 31 & 2798 & 9298 & 60 & 35 & 1 & 78 & $\mathrm{Ag} 78$ & $0.1917219 \mathrm{E}+01$ & $0.2245002 \mathrm{E}+04$ \\
\hline 1971 & 10 & 31 & 2805 & 9143 & 59 & 37 & 1 & 78 & Ag78 & $0.1944131 \mathrm{E}+01$ & $0.2276515 \mathrm{E}+04$ \\
\hline 1971 & 10 & 31 & 2806 & 9302 & 60 & 39 & 6 & 83 & Ag8 3 & $0.1610819 \mathrm{E}+01$ & $0.1886217 \mathrm{E}+04$ \\
\hline 1971 & 10 & 31 & 2807 & 9142 & 59 & 36 & 1 & 78 & Ag78 & $0.1935200 \mathrm{E}+01$ & $0.2266056 \mathrm{E}+04$ \\
\hline 1971 & 10 & 31 & 2808 & 8675 & 56 & 40 & 4 & 66 & Ag66 & $0.1813476 \mathrm{E}+01$ & $0.2123522 \mathrm{E}+04$ \\
\hline 1971 & 10 & 31 & 2815 & 8370 & 54 & 49 & 4 & 62 & Ag62 & $0.1756600 \mathrm{E}+01$ & $0.2056922 \mathrm{E}+04$ \\
\hline 1971 & 10 & 31 & 2816 & 8369 & 54 & 48 & 6 & 64 & Ag6 4 & $0.1608427 \mathrm{E}+01$ & $0.1883416 \mathrm{E}+04$ \\
\hline 1971 & 10 & 31 & 2818 & 8525 & 55 & 47 & 6 & 64 & Ag6 4 & $0.1603364 \mathrm{E}+01$ & $0.1877488 \mathrm{E}+04$ \\
\hline 1971 & 10 & 31 & 2821 & 8680 & 56 & 45 & 6 & 70 & Ag70 & $0.1619327 \mathrm{E}+01$ & $0.1896179 \mathrm{E}+04$ \\
\hline 1971 & 10 & 31 & 2828 & 8989 & 58 & 40 & 6 & 74 & $\mathrm{Ag} 74$ & $0.1607467 \mathrm{E}+01$ & $0.1882292 \mathrm{E}+04$ \\
\hline 1971 & 10 & 31 & 2833 & 9299 & 60 & 36 & 1 & 78 & Ag78 & $0.1912806 \mathrm{E}+01$ & $0.2239834 \mathrm{E}+04$ \\
\hline 1971 & 10 & 31 & 2855 & 8983 & 58 & 34 & 6 & 73 & Ag73 & $0.1645723 \mathrm{E}+01$ & $0.1927088 E+04$ \\
\hline 1971 & 10 & 31 & 2856 & 9141 & 59 & 35 & 1 & 78 & Ag78 & $0.1930990 \mathrm{E}+01$ & $0.2261127 \mathrm{E}+04$ \\
\hline 1971 & 10 & 31 & 2869 & 8984 & 58 & 35 & 6 & 73 & Ag73 & $0.1612066 \mathrm{E}+01$ & $0.1887678 \mathrm{E}+04$ \\
\hline 1971 & 10 & 31 & 2875 & 9139 & 59 & 33 & 6 & 73 & Ag73 & $0.1623018 \mathrm{E}+01$ & $0.1900501 \mathrm{E}+04$ \\
\hline 1971 & 10 & 31 & 2876 & 9140 & 59 & 34 & 6 & 73 & Ag73 & $0.1622875 \mathrm{E}+01$ & $0.1900334 \mathrm{E}+04$ \\
\hline 1971 & 10 & 31 & 2877 & 9297 & 60 & 34 & 1 & 78 & Ag78 & $0.1920707 \mathrm{E}+01$ & $0.2249086 \mathrm{E}+04$ \\
\hline 1971 & 10 & 31 & 2879 & 9296 & 60 & 33 & 6 & 73 & Ag73 & $0.1644709 \mathrm{E}+01$ & $0.1925901 \mathrm{E}+04$ \\
\hline 1971 & 10 & 31 & 2882 & 9451 & 61 & 31 & 6 & 93 & Ag93 & $0.1632342 \mathrm{E}+01$ & $0.1911420 \mathrm{E}+04$ \\
\hline 1971 & 10 & 31 & 2883 & 9610 & 62 & 33 & 6 & 102 & Ag102 & $0.1606214 \mathrm{E}+01$ & $0.1880825 \mathrm{E}+04$ \\
\hline 1971 & 10 & 31 & 2884 & 9767 & 63 & 33 & 6 & 102 & Ag102 & $0.1629017 \mathrm{E}+01$ & $0.1907527 \mathrm{E}+04$ \\
\hline 1971 & 10 & 31 & 2885 & 9608 & 62 & 31 & 6 & 93 & Ag93 & $0.1614446 \mathrm{E}+01$ & $0.1890464 \mathrm{E}+04$ \\
\hline 1971 & 10 & 31 & 2886 & 9607 & 62 & 30 & 6 & 101 & Ag101 & $0.1609655 \mathrm{E}+01$ & $0.1884854 \mathrm{E}+04$ \\
\hline 1971 & 10 & 31 & 2887 & 9923 & 64 & 32 & 6 & 102 & Ag102 & $0.1615014 \mathrm{E}+01$ & $0.1891130 \mathrm{E}+04$ \\
\hline 1971 & 10 & 31 & 2888 & 9764 & 63 & 30 & 6 & 101 & Ag101 & $0.1607184 \mathrm{E}+01$ & $0.1881960 \mathrm{E}+04$ \\
\hline 1971 & 10 & 31 & 2889 & 9921 & 64 & 30 & 6 & 93 & Ag93 & $0.1612371 \mathrm{E}+01$ & $0.1888034 \mathrm{E}+04$ \\
\hline 1971 & 10 & 31 & 2890 & 9766 & 63 & 32 & 6 & 102 & Ag102 & $0.1618891 \mathrm{E}+01$ & $0.1895670 \mathrm{E}+04$ \\
\hline 1971 & 10 & 31 & 2893 & 9452 & 61 & 32 & 1 & 94 & $\mathrm{Ag} 94$ & $0.1921171 \mathrm{E}+01$ & $0.2249629 \mathrm{E}+04$ \\
\hline 1971 & 10 & 31 & 2894 & 9609 & 62 & 32 & 6 & 102 & $\mathrm{Ag} 102$ & $0.1607339 \mathrm{E}+01$ & $0.1882142 \mathrm{E}+04$ \\
\hline 1971 & 10 & 31 & 2895 & 9765 & 63 & 31 & 6 & 93 & Ag93 & $0.1331885 \mathrm{E}+01$ & $0.1559594 \mathrm{E}+04$ \\
\hline 1971 & 10 & 31 & 2896 & 9922 & 64 & 31 & 6 & 102 & Ag102 & $0.1331294 \mathrm{E}+01$ & $0.1558902 \mathrm{E}+04$ \\
\hline 1971 & 10 & 31 & 2911 & 9321 & 60 & 58 & 6 & 87 & Ag87 & $0.1623837 \mathrm{E}+01$ & $0.1901461 \mathrm{E}+04$ \\
\hline 1971 & 10 & 31 & 2925 & 9155 & 59 & 49 & 6 & 86 & Ag86 & $0.1631667 \mathrm{E}+01$ & $0.1910629 \mathrm{E}+04$ \\
\hline 1971 & 10 & 31 & 2927 & 8683 & 56 & 48 & 6 & 64 & Ag64 & $0.1646747 \mathrm{E}+01$ & $0.1928287 \mathrm{E}+04$ \\
\hline 1971 & 10 & 31 & 2929 & 9311 & 60 & 48 & 6 & 86 & Ag86 & $0.1619199 \mathrm{E}+01$ & $0.1896030 \mathrm{E}+04$ \\
\hline 1971 & 10 & 31 & 2930 & 8996 & 58 & 47 & 6 & 75 & Ag75 & $0.1627385 \mathrm{E}+01$ & $0.1905615 \mathrm{E}+04$ \\
\hline 1971 & 10 & 31 & 2931 & 8995 & 58 & 46 & 6 & 75 & Ag75 & $0.1625888 \mathrm{E}+01$ & $0.1903862 \mathrm{E}+04$ \\
\hline 1971 & 10 & 31 & 2932 & 8992 & 58 & 43 & 1 & 79 & Ag79 & $0.1935172 \mathrm{E}+01$ & $0.2266024 \mathrm{E}+04$ \\
\hline 1971 & 10 & 31 & 2934 & 9148 & 59 & 42 & 1 & 79 & Ag79 & $0.1942628 \mathrm{E}+01$ & $0.2274754 \mathrm{E}+04$ \\
\hline 1971 & 10 & 31 & 2937 & 9304 & 60 & 41 & 6 & 84 & Ag8 4 & $0.1639118 \mathrm{E}+01$ & $0.1919355 \mathrm{E}+04$ \\
\hline 1971 & 10 & 31 & 2938 & 9619 & 62 & 42 & 6 & 85 & Ag85 & $0.1628629 \mathrm{E}+01$ & $0.1907072 \mathrm{E}+04$ \\
\hline 1971 & 10 & 31 & 2939 & 9460 & 61 & 40 & 6 & 84 & Ag8 4 & $0.1634435 \mathrm{E}+01$ & $0.1913870 \mathrm{E}+04$ \\
\hline 1971 & 10 & 31 & 2940 & 9461 & 61 & 41 & 6 & 84 & Ag84 & $0.1633369 \mathrm{E}+01$ & $0.1912622 \mathrm{E}+04$ \\
\hline 1971 & 10 & 31 & 2993 & 9000 & 58 & 51 & 6 & 76 & Ag76 & $0.1638480 \mathrm{E}+01$ & $0.1918607 \mathrm{E}+04$ \\
\hline 1971 & 10 & 31 & 2997 & 8840 & 57 & 48 & 6 & 70 & Ag70 & $0.1633919 \mathrm{E}+01$ & $0.1913267 \mathrm{E}+04$ \\
\hline 1971 & 10 & 31 & 2998 & 8839 & 57 & 47 & 6 & 70 & Ag70 & $0.1638372 \mathrm{E}+01$ & $0.1918481 \mathrm{E}+04$ \\
\hline 1971 & 10 & 31 & 2999 & 8838 & 57 & 46 & 6 & 70 & Ag70 & $0.1627725 \mathrm{E}+01$ & $0.1906014 \mathrm{E}+04$ \\
\hline 1971 & 10 & 31 & 3000 & 8837 & 57 & 45 & 1 & 69 & Ag69 & $0.1902967 \mathrm{E}+01$ & $0.2228314 \mathrm{E}+04$ \\
\hline 1971 & 10 & 31 & 3003 & 9149 & 59 & 43 & 1 & 79 & Ag79 & $0.1935178 \mathrm{E}+01$ & $0.2266031 \mathrm{E}+04$ \\
\hline
\end{tabular}

Flgure 1-5. Example output file: simulated monthly irrigation and pumping for agricultural wells, Santa Rosa Plain crop water-demand model, Santa Rosa Plain watershed, Sonoma County, California. 

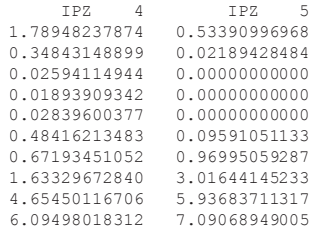

$\begin{array}{cccc}\text { IPZ } 6 & \text { IPZ } 7\end{array}$

$\begin{array}{ll}1.65503190570 & 1.97681960975 \\ 0.18572794432 & 0.42035095933\end{array}$

$0.00000000000 \quad 0.02216977971$

$0.00000000000 \quad 0.03202067142$

$0.00000000000 \quad 0.06628881531$

$\begin{array}{ll}0.00070281520 & 0.22627983552\end{array}$

$\begin{array}{ll}0.04673471260 & 0.26780774563 \\ 0.53409795817 & 0.55015332819\end{array}$

$\begin{array}{ll}0.53409795817 & 0.55015332819 \\ 2.81962359466 & 1.71022935177\end{array}$

$\begin{array}{ll}2.81962359466 & 1.71022935177 \\ 5.94627170564 & 4.03314358300\end{array}$

$\begin{array}{ll}5.94627170564 & 4.03314358300 \\ 4.98178965615 & 3.90534110016\end{array}$

$\begin{array}{ll}2.92090722317 & 2.84111553800 \\ 0.22640893373 & 0.46168149598\end{array}$

$\begin{array}{ll}0.22640893373 & 0.46168149598 \\ 0.00000000000 & 0.04043681973\end{array}$

$0.00000000000 \quad 0.02110871400$

$\begin{array}{ll}0.000000000000 & 0.02110871400 \\ 0.00000000000 & 0.02463920833\end{array}$

$0.00000000000 \quad 0.05001405150$

$\begin{array}{ll}0.00000000000 & 0.05001405150 \\ 0.01832558484 & 0.14525557423 \\ 0.500182187268796\end{array}$

$\begin{array}{ll}0.01832558484 & 0.34807268796 \\ 0.50018211872 & 0.65155348904\end{array}$

$3.22052854298 \quad 1.70441103581$

$\begin{array}{ll}3.03429659955 & 2.57778026524 \\ 6.79011615700 & 3.36968956620\end{array}$

$\begin{array}{ll}4.79011615700 & 3.36968956620\end{array}$

$2.48993630269 \quad 2.45270341689$

$\begin{array}{lll}0.18063896889 & 0.42344671237\end{array}$

$0.00000000000 \quad 0.01907950462$

$0.00000000000 \quad 0.03306519002$

$\begin{array}{ll}0.000000000000 & 0.02836904569 \\ 0.00000000000 & 0.06196158300\end{array}$

$0.00000000000 \quad 0.12860067404$

$0.00000000000 \quad 0.28036633238$

$\begin{array}{lll}0.20657568198 & 0.50888718623\end{array}$

$\begin{array}{ll}1.38184992713 & 0.92803267427\end{array}$

$\begin{array}{ll}1.63383675828 & 0.85973380221 \\ 2.26395096424 & 1.3807536868\end{array}$

$\begin{array}{ll}1.63383675828 & 0.85973380221 \\ 2.46395096424 & 1.38075368688\end{array}$

$\begin{array}{ll}2.46597429322 & 1.60189607385 \\ 1.49703916166 & 1.62709210527\end{array}$

$1.49703916166 \quad 1.62709218527$

0.00000000000 .03980601312

$0.00000000000 \quad 0.03880865704$

$0.00000000000 \quad 0.05486925775$

$0.00000000000 \quad 0.10447644000$

$\begin{array}{ll}0.01043905508 & 0.53691640338\end{array}$

$\begin{array}{ll}0.21043905508 & 0.53691640338 \\ 1.20768580391 & 0.86494089060\end{array}$

$\begin{array}{ll}1.20768580391 & 0.836494089060 \\ 4.46393418660 & 1.99643693925\end{array}$

$\begin{array}{ll}4.483934127300 & 1.99643693925 \\ 4.48465127302542265421\end{array}$

$3.42361253793 \quad 2.83934072490$

$0.41972097863 \quad 0.57279939408$

$0.00000000000 \quad 0.06267401160$

$0.00000000000 \quad 0.04748596452$

$0.00000000000 \quad 0.05566021448$

$\begin{array}{ll}0.00000000000 & 0.05566021448 \\ 0.01295757694 & 0.05953141750 \\ 0.16600742927 & 0.19587278712\end{array}$

$\begin{array}{ll}0.16600742927 & 0.26548520479\end{array}$

$\begin{array}{ll}1.88112014597 & 1.07029628758\end{array}$

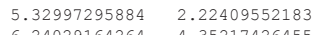

$\begin{array}{ll}6.24029164264 & 4.35217426455\end{array}$

$\begin{array}{ll}3.80267924026 & 3.54130921893\end{array}$

$\begin{array}{ll}2.33177219264 & 2.66317038032\end{array}$

$\begin{array}{ll}0.46893720712 & 0.75681849993 \\ 0.04818461240 & 0.33193277705\end{array}$

$0.04818461240 \quad 0.33193277705$

0.00000000000 .06113005870

$0.00000000000 \quad 0.08820148154$

$0.00625882176 \quad 0.17485050517$

$0.49669930409 \quad 0.37598050065$

$4.66878519531-1.93310879776$

$\begin{array}{ll}4.66878519531 & 1.93310879776 \\ 6.35600982577 & 4.45793196889\end{array}$

$\begin{array}{ll}6.35600982577 & 4.45793196889 \\ 5.25779495634 & 4.69834742598\end{array}$

$\begin{array}{ll}5.07660254322 & 2.13110575497\end{array}$

Flgure 1-6. Example output file: simulated monthly irrigation by crop type, Santa Rosa Plain crop water-demand model, Santa Rosa Plain watershed, Sonoma County, California. 


\begin{tabular}{|c|c|c|c|c|c|c|c|c|c|c|}
\hline Year & Mon Day & Irrigation & IPZ & IPZ & IPZ & IPZ & IPZ & IPZ & & \\
\hline & 101 & & 0000000 & 72824597 & 0161439 & $0053682 \mathrm{Cl}$ & & & & \\
\hline 71 & 10 & & & & & & & & & $\begin{array}{l}0.07275727250 \\
0.08195612550\end{array}$ \\
\hline & & & & & & & & & & \\
\hline & 10 & & & & & 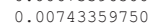 & 52246 & (202 & 9 & 3250 \\
\hline & 10 & 349309209 & & 040548822 & 2338411742 & 0775319833 & 09464755142 & 3211563. & 08815728 & 0415163500 \\
\hline & 10 & 0324626481 & & 962045500 & D2232951194 & 0736309083 & \$8843052170 & 29357105 & 8168098200 & 0 \\
\hline & 10 & 328192296 & 0000 & 975835472 & 2176502081 & 0724537833 & 88916702729 & 087221833 & 8249851658 & \\
\hline & 10 & 00311776133 & 30000 & 9254064857 & 02110624113 & 0699148583 & 08483099538 & 2867783667 & 43520304 & 10 \\
\hline 7. & 109 & 00281468536 & & 8415479243 & & 19658667 & & & 97484 & \\
\hline 71 & $10 \quad 10$ & 1 & & 6 & 06 & 17 & 92 & 33 & 63 & \\
\hline 71 & $\begin{array}{ll}10 & 11 \\
10 & 12\end{array}$ & 5 & 0.000000 & 838 & 77 & 1060 & 775161 & 26181 & 70849 & 50 \\
\hline & $\begin{array}{ll}10 & 12 \\
10 & 13\end{array}$ & 42 & 0.000000 & $\begin{array}{l}095233114529 \\
0949317157\end{array}$ & $\begin{array}{r}.2117186565 \\
02175892016\end{array}$ & 00703035417 & $\begin{array}{l}08637719320 \\
08726960308\end{array}$ & $\begin{array}{l}02960287000 \\
02950710833\end{array}$ & $\begin{array}{l}0.08061613930 \\
0.08047195759\end{array}$ & 9.9750 \\
\hline & $\begin{array}{ll}10 & 13 \\
10 & 14\end{array}$ & 00287064760 & $\begin{array}{l}0.000 \\
0.000\end{array}$ & $\begin{array}{l}0949231157 \\
08504012029\end{array}$ & $\begin{array}{l}0.0217589216 \\
0.01953484790\end{array}$ & 0645724667 & $\begin{array}{r}07826960308 \\
0782454381\end{array}$ & $\begin{array}{r}029507118333 \\
026377667\end{array}$ & $\begin{array}{l}0804719459 \\
07211044799\end{array}$ & $\begin{array}{l}9578971250 \\
8570090750\end{array}$ \\
\hline 71 & $10 \quad 15$ & 00231701436 & 00 & 06797820157 & 01607492806 & 529596667 & 6365409748 & 213468 & 5773403768 & 50 \\
\hline 971 & 10 & 72 & & 684 & 3345094 & & 9 & & & \\
\hline & & & & & & & & & & \\
\hline & $10 \quad 18$ & & & & & & & & & \\
\hline & 10 & & & & & & & & & 27 \\
\hline & 10 & 000074350 & & 000000 & 00000000 & 0000 & 0003908341 & 0023277 & 00000000 & 00000 \\
\hline & 10 & 175308814 & & $0=40$ & 199941718 & 043 & 4773126928 & 28 & 4475221780 & 68388 \\
\hline & 10 & 470721 & & 4924698994 & 27326259 & 0137556195 & 4790581116 & 001262 & 83314 & 49935 \\
\hline 71 & 10 & 00000 & & & & & 000000 & & & \\
\hline 71 & 10 & & & & 82 & 51 & 13 & & 25 & \\
\hline${ }_{71}^{71}$ & $\begin{array}{ll}10 & 25 \\
10 & 26\end{array}$ & 14 & $\begin{array}{l}0.0 \\
0.0\end{array}$ & $\begin{array}{l}50513950070 \\
5477336913\end{array}$ & 670 & 556 & $\begin{array}{r}.04728565587 \\
0.05007576594\end{array}$ & $\begin{array}{l}00596150987 \\
000708838535\end{array}$ & $\begin{array}{l}0.04346793951 \\
0.04568919014\end{array}$ & 19293 \\
\hline 71 & $\begin{array}{ll}10 & 26 \\
10 & 27\end{array}$ & $\begin{array}{l}168136899 \\
1681369\end{array}$ & & $\begin{array}{l}54773366913 \\
5045918529\end{array}$ & $\begin{array}{l}.01132669710 \\
.01057257820\end{array}$ & $\begin{array}{l}00098 \\
00652\end{array}$ & $\begin{array}{l}050007076594 \\
.04640761797\end{array}$ & $\begin{array}{l}0007088383555 \\
00649191132\end{array}$ & $\begin{array}{l}0.04569819014 \\
0.04214164391\end{array}$ & $\begin{array}{l}05474741165 \\
05073619783\end{array}$ \\
\hline 971 & 10 & 30319 & & 891 & 8265065 & 045518551 & 3313045830 & 0472055988 & 3061919185 & 38243 \\
\hline 1971 & 10 & 1946412 & & 07020 & 49 & 132 & 62 & 7 & & \\
\hline 71 & 10 & & & & & & & & & \\
\hline & & & & & & & & & & \\
\hline & 11 & & & & & & & & & \\
\hline & 11 & & & & & & & 8 & & \\
\hline & 11 & & & & & & & & & \\
\hline & 11 & & & & & & & & & 2 \\
\hline & 11 & & & 345 & 89 & 258 & 30 & 46 & 28 & 38184 \\
\hline & 11 & & & & & & & & & \\
\hline & 11 & & & & & & & & & \\
\hline $717+3$ & 11 & & & & & & & & & \\
\hline 97 & 11 & & & & & & & & & 59 \\
\hline $\begin{array}{l}1971 \\
1971\end{array}$ & $\begin{array}{ll}11 & 10 \\
11 & 11\end{array}$ & 90 & $\begin{array}{l}10 \\
10\end{array}$ & $\begin{array}{l}833 \\
000\end{array}$ & $\begin{array}{l}0.06 \\
0.08\end{array}$ & $\begin{array}{l}671 \\
000\end{array}$ & $\begin{array}{l}2855447032 \\
000000000\end{array}$ & 002158 & $\begin{array}{l}1797601463 \\
000000000\end{array}$ & 338 \\
\hline 11 & $\begin{array}{ll}11 & 11 \\
11 & 12\end{array}$ & 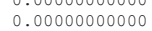 & & $\begin{array}{l}000 \\
000\end{array}$ & 000 & $\begin{array}{l}0000000 \\
000000\end{array}$ & 0000 & 000 & 000 & 0000 \\
\hline & $\begin{array}{ll}11 & 13 \\
11\end{array}$ & 10 & & & & & & & & \\
\hline 971 & $11 \quad 14$ & & & 27640 & $0.0 \quad$ a & 00 & 03 & & & 154 \\
\hline & $\begin{array}{ll}11 & 15\end{array}$ & & & & & & & & & \\
\hline & $\begin{array}{ll}11 & 16\end{array}$ & & & & & & & & & \\
\hline & $\begin{array}{ll}11 & 17\end{array}$ & & & & & & & & & \\
\hline & $11 \quad 18$ & & & & & & & & & \\
\hline & 11 & & & & & & & & & \\
\hline 971 & 11 & & & & & & & & & \\
\hline 971 & 11 & & & & & & & & & \\
\hline 71 & 11 & & & & & & & & & \\
\hline 971 & ${ }_{11}^{11}$ & & & & & & & & & \\
\hline 971 & $\begin{array}{ll}11 & 24 \\
11 & 24\end{array}$ & 0000 & & & & & & & & \\
\hline 71 & $\begin{array}{ll}11 & 25 \\
11 & 26\end{array}$ & $\begin{array}{l}2 \\
0\end{array}$ & 000 & 30 & $\begin{array}{l}0.0000 \\
0.0000\end{array}$ & $\begin{array}{l}75 \\
00\end{array}$ & $\begin{array}{l}444 \\
00\end{array}$ & $\begin{array}{l}00 \\
00 \\
00\end{array}$ & $\begin{array}{l}00 \\
00 \\
00\end{array}$ & $\begin{array}{l}9008 \\
000\end{array}$ \\
\hline & $\begin{array}{ll}11 & 20 \\
11 & \end{array}$ & 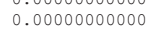 & 0 & 0 & 00 & & & 00 & & \\
\hline & 1128 & & & 00 & & & 00 & & & 200 \\
\hline & 11 & & & & & & & & & \\
\hline & 11 & & & & & & & & & \\
\hline & 12 & & & & & & & & & \\
\hline & 12 & & & & & & & & & \\
\hline & 12 & & & & & & & & & \\
\hline 197 & 12 & & & & & & & & & \\
\hline 1971 & 12 & & & & & & & & & \\
\hline 971 & 12 & & & & & & & & & \\
\hline 71 & $\begin{array}{l}12 \\
12\end{array}$ & $\begin{array}{l}5 \\
4 \\
\end{array}$ & & & & & & & & \\
\hline 971 & $\begin{array}{l}12 \\
12\end{array}$ & $\begin{array}{l}4 \\
0\end{array}$ & $\begin{array}{l}0.00 \\
0.00\end{array}$ & & 00 & & & & & 40 \\
\hline & 12 & & .0u & & $\begin{array}{l}10 \\
0 \\
0\end{array}$ & $\begin{array}{l}00 \\
00 \\
00\end{array}$ & 00 & & & 00000 \\
\hline 1971 & $\begin{array}{ll}12 & 11\end{array}$ & & & & & & & & & \\
\hline 1971 & 12 & & & & & & & & & \\
\hline 771 & $\begin{array}{ll}12 & 13 \\
12\end{array}$ & 4 & $\begin{array}{l}0.00 \\
0.00\end{array}$ & 0. & $\begin{array}{l}0 \\
0 \\
0\end{array}$ & & & & & \\
\hline 971 & 12 & & & & & & & & & \\
\hline & 12 & & & & & & & & & \\
\hline & 12 & & & & & & & & & \\
\hline & 12 & & & & & & & & & \\
\hline 71 & 12 & & & & & & & & & \\
\hline & 12 & & & & & & & & & \\
\hline 97. & $\begin{array}{l}12 \\
12\end{array}$ & & & & & & & & & \\
\hline & $\begin{array}{l}12 \\
12\end{array}$ & & & & & & & & & \\
\hline & 12 & & & & & & & & & \\
\hline & 12 & & & & & & & & & \\
\hline 971 & 12 & & & & & & & & & \\
\hline & 12 & & & & & & & & & \\
\hline & 22 & & & & & & & & & \\
\hline & $2+2+3$ & & & & & & & & & \\
\hline & 12 & & & & & & & & & \\
\hline & & & & & & & & & & \\
\hline
\end{tabular}

Figure 1-7. Example output file: simulated daily irrigation by crop type, Santa Rosa Plain crop water-demand model, Santa Rosa Plain watershed, Sonoma County, California. 


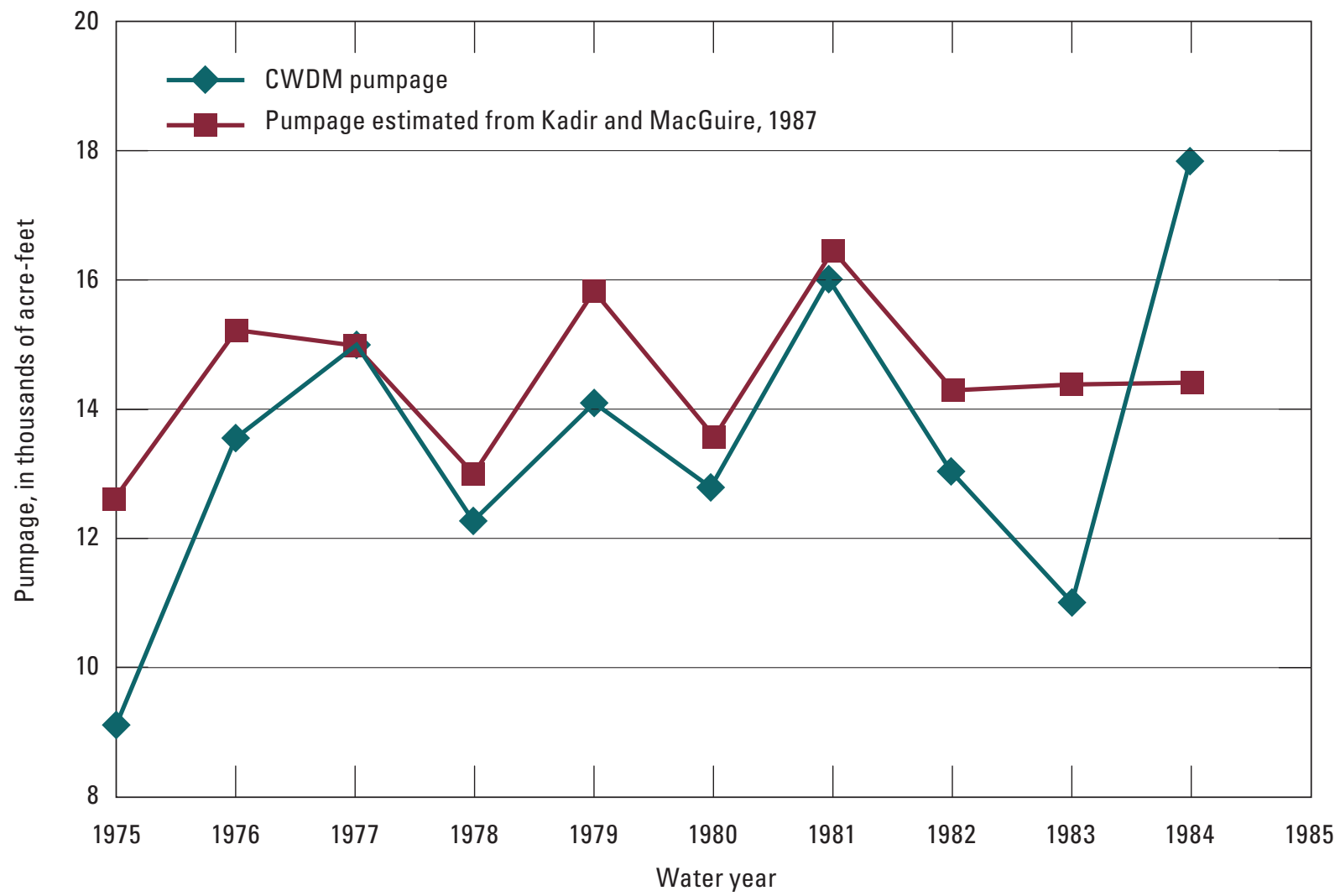

Figure 1-8. Crop water-demand model (CWDM) calibration results, water years 1975-84, annual (water year) time-series comparison to previous estimates by Kadir and McGuire (1987), Santa Rosa Plain watershed, Sonoma County, California. 

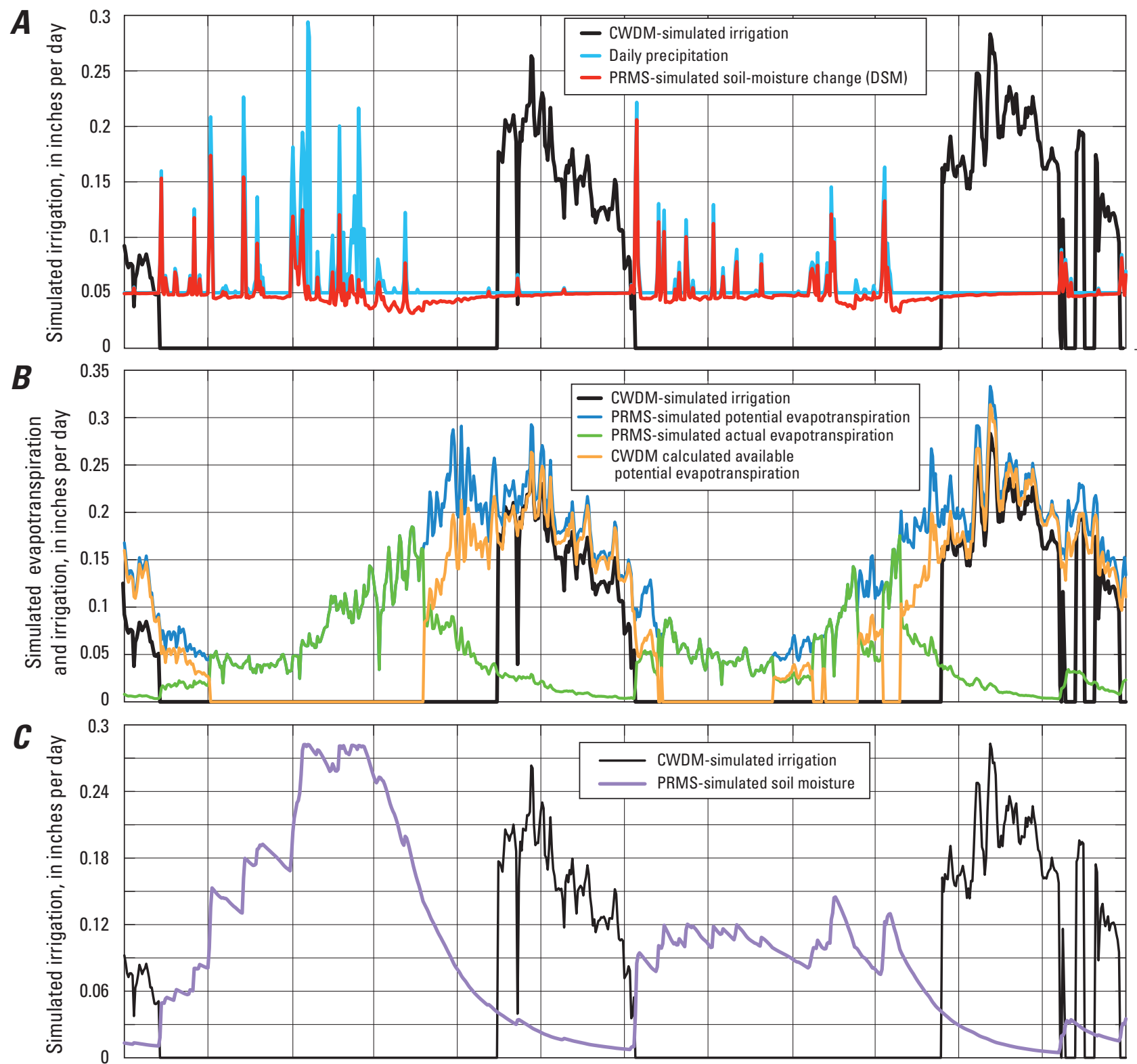

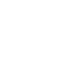




\section{Time Series of Application and Results}

Five irrigation periods were defined for the CWDM application (fig. 1-10). Results from separate CWDM and PRMS-only simulations for monthly irrigation and agricultural pumpage were combined into a continuous monthly time series of estimated irrigation and agricultural pumpage for the simulation period. The irrigation periods were defined on the basis of the years represented by the five land-use maps (figs. 1-2, 1-10). The irrigation periods overlapped in time by 2 years, and each irrigation period followed a 1-year model spin-up period (fig. 1-10). Results from the two overlapping irrigation periods were averaged in order to develop a smoother transition from one period to the next (for example, see water years 2003 and 2004 in fig. 1-11).

Examples of averaged spatially distributed results simulated by the CWDM are shown in figure 1-12 for six random periods that span land-use periods (water years 1972-77, 1975-83, 1981-88, 1987-93, 1997-2004, and 2002-10). The results indicated differences in the spatial distribution of irrigation demand caused by (1) changes in the spatial coverage and distribution of crop types; (2) the distribution of precipitation, including reclaimed wastewater; (3) spatial differences in soil properties; and (4) spatial differences in PET. Comparison of the average estimated irrigation for the last four periods (water years 1981-88, 1987-93, 1997-2004, and 2002-10) showed an increase in the total area irrigated, a reduction in agricultural irrigation in the Laguna de Santa Rosa in response to the application of reclaimed water, and an increase in water use for pasture compared to vineyards. Maximum irrigation rates of 24 to 38 inches per year (in/yr) were estimated for the pasture areas not receiving reclaimed water for the 2002-10 land-use period. Intermediate irrigation rates of 12 to $20 \mathrm{in} / \mathrm{yr}$ were estimated for most the vineyards; however, some vineyards had comparatively high irrigation rates of 31-38 in/yr because more water was required to maintain an adequate soil moisture in coarser soils that drained more rapidly.

There was high seasonal variability in the simulated irrigation, with a minimum monthly irrigation of zero during winter and a maximum monthly irrigation of more than 2,000 acre-feet (acre-ft) during spring and summer (fig. 1-13A). The estimated maximum monthly irrigation increased from about 4,000 acre-ft, or more, during 1976-88 to more than 10,000 acre-ft for the 2008 land-use period. Estimated water-year irrigation ranged from about 7,000 to 19,000 acre-ft prior to water year 1995 and from about 10,000 to 43,000 acre-ft after water year 1995 (fig. 1-13B). Within a given land-use period, estimated irrigation was the lowest for the wettest water years (for example, 1983, 1993, and 1995 ) and the highest for the driest water years (for example, 1977, 1994, 2004, and 2008). The CWDM did not account for changes in crop management, such as fallowing to reduce water demand during drought periods, and, therefore, the model could overestimate irrigation during dry years. 


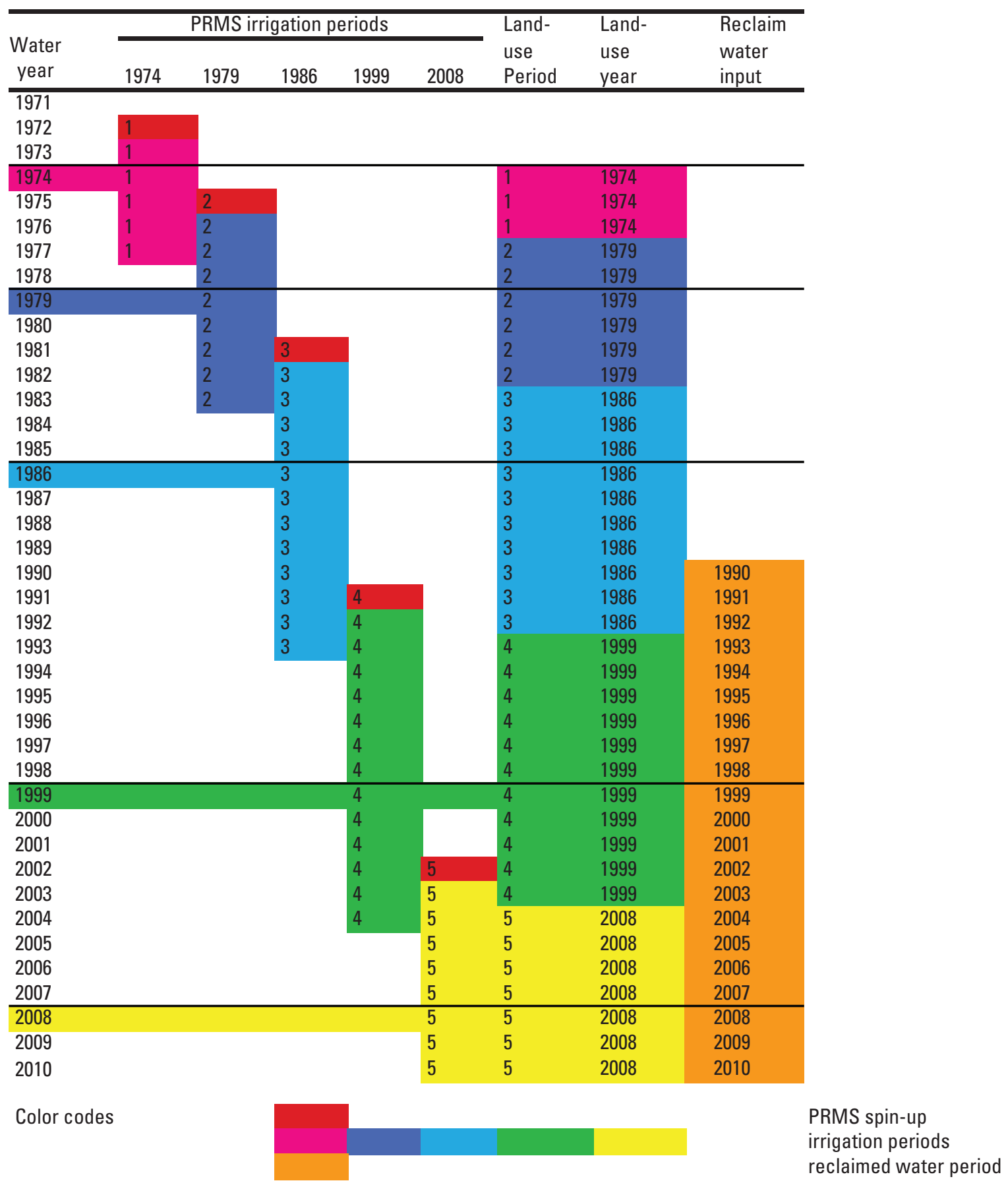

Figure 1-10. Irrigation periods and period of reclaimed water input used in the crop water-demand model, Santa Rosa Plain watershed, Sonoma County, California. 


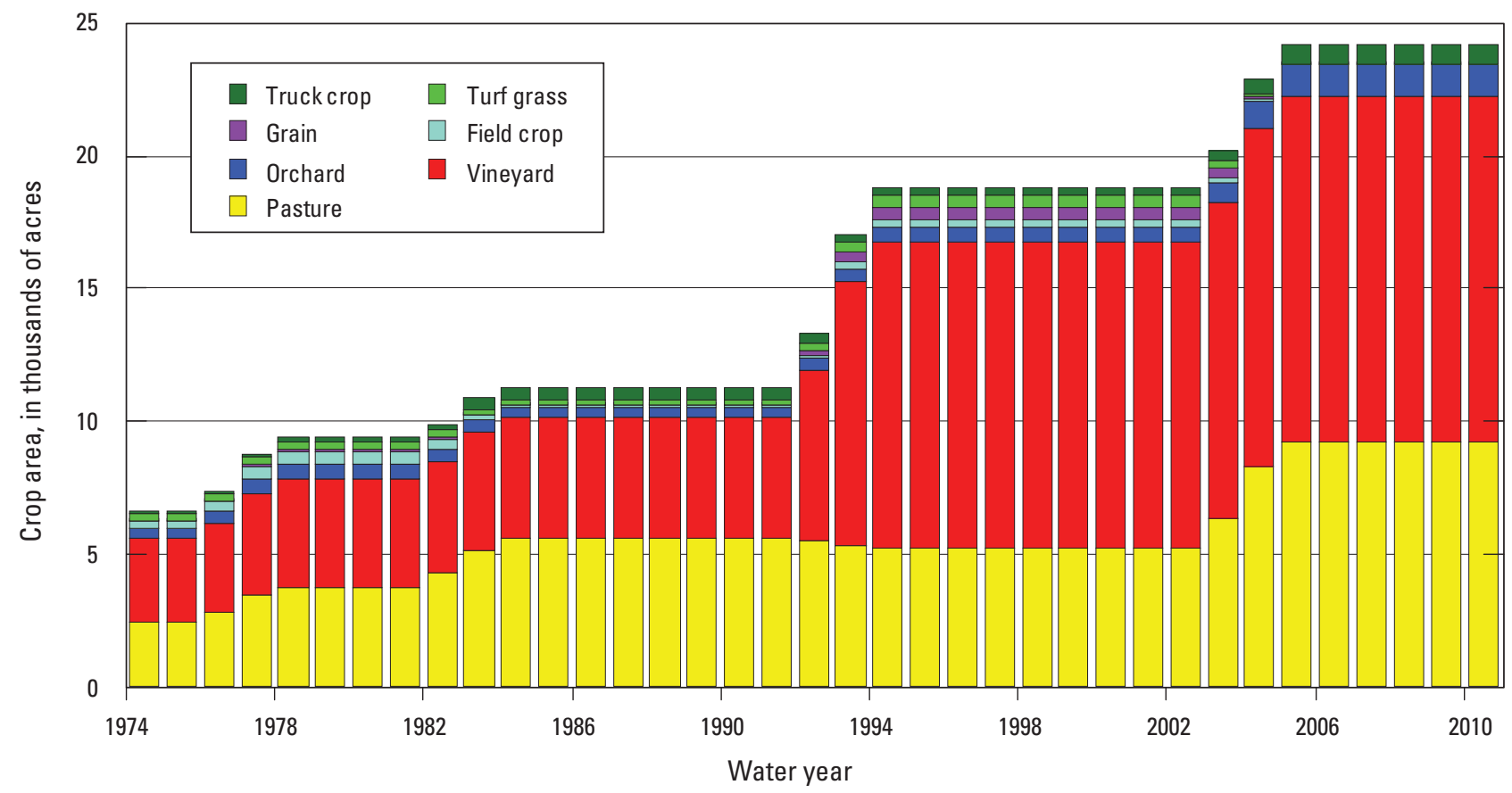

Figure 1-11. Annual variation of crop types used in the crop water-demand model, Santa Rosa Plain watershed, Sonoma County, California. 


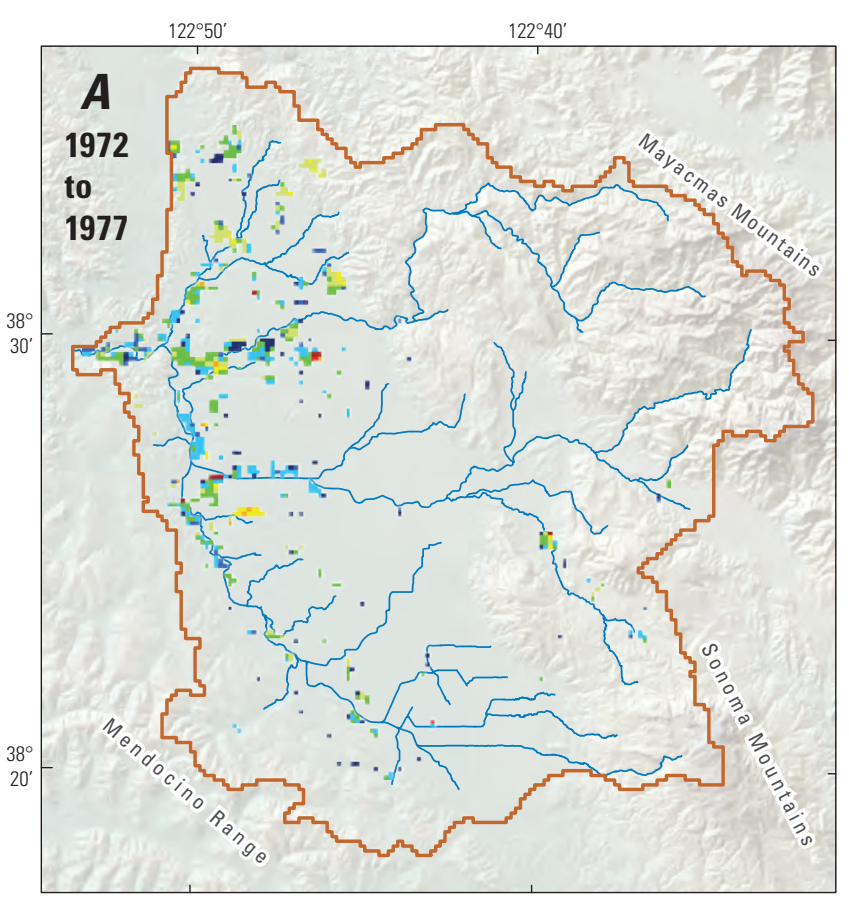

Estimated average annual irrigation, in inches per year, water years 1972 to 1977 \begin{tabular}{ll|l|l|l|l|}
\hline & 0 to 0.001 & 1.1 to 2 & 5.1 to 10 & 16 to 20 &
\end{tabular} \begin{tabular}{l|l|l|l|l|l|l|l|}
0.0011 to 1 & 2.1 to 5 & 11 to 15 & 21 to 25 & & 31 to 38
\end{tabular}

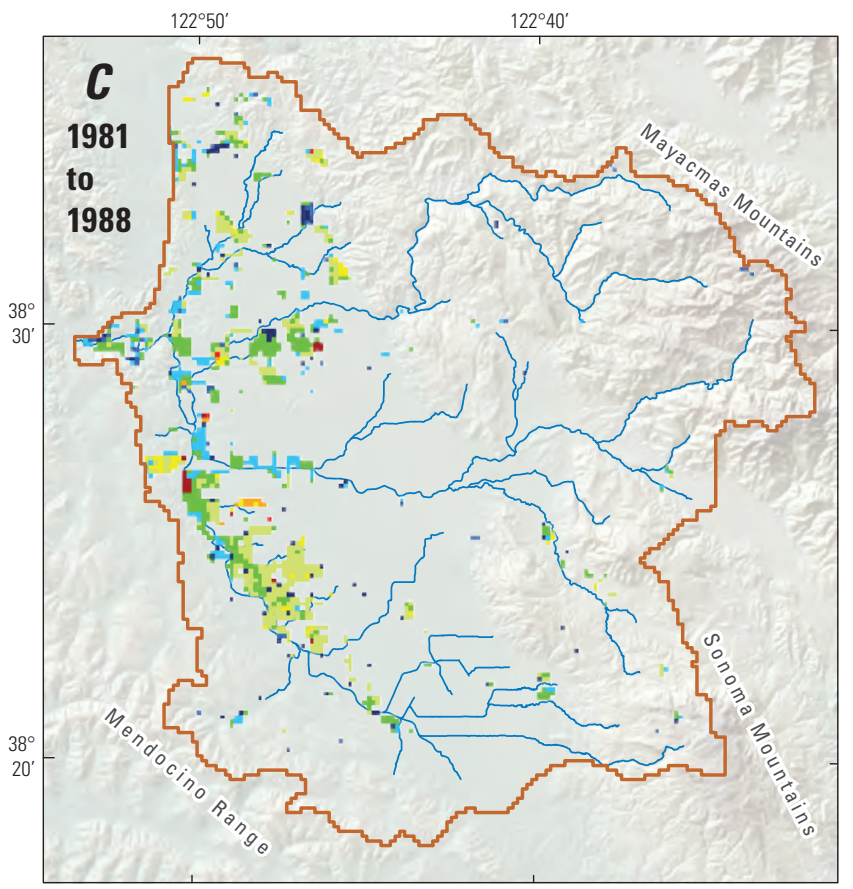

Estimated average annual irrigation, in inches per year, water years 1981 to 1988

\begin{tabular}{|l|l|l|l|l|l|l}
\hline & 0 to 0.001 & 1.1 to 2 & 5.1 to 10 & 16 to 20 & 26 to 30
\end{tabular} \begin{tabular}{l|l|l|l|l|l}
0.0011 to 1 & 2.1 to 5 & 11 to 15 & 21 to 25 & 31 to 38
\end{tabular}

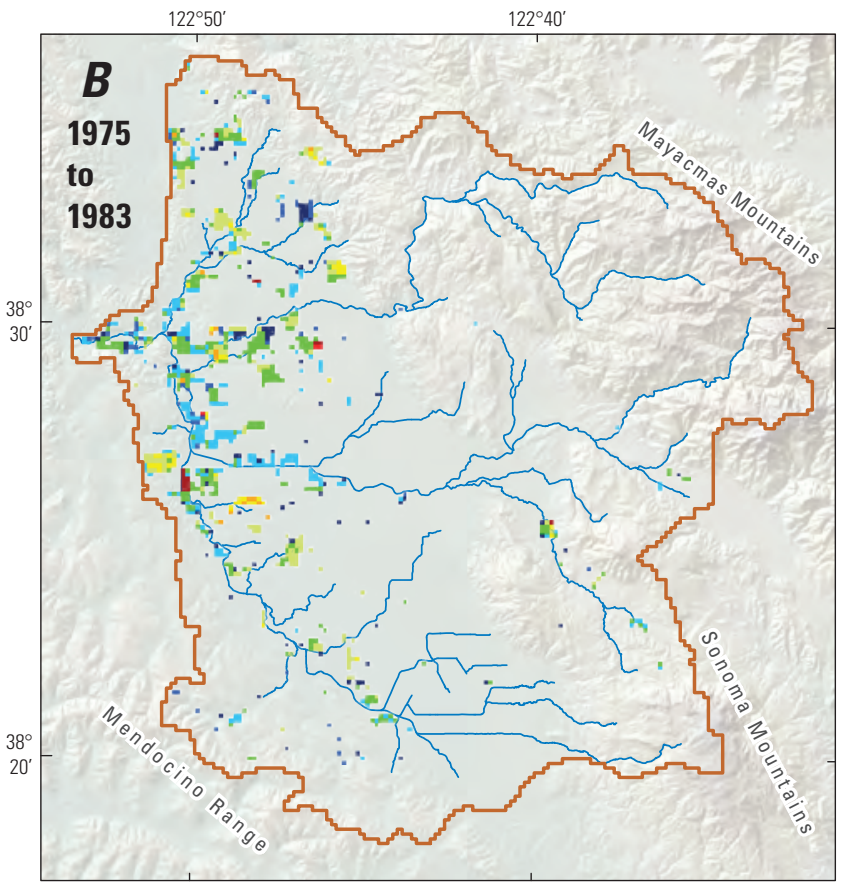

Estimated average annual irrigation, in inches per year, water years 1975 to 1983

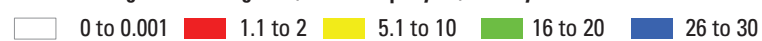

\begin{tabular}{l|l|l|l|l|l}
0.0011 to 1 & 2.1 to 5 & 11 to 15 & 21 to 25 &
\end{tabular}

\section{EXPLANATION}

_ Santa Rosa Plain watershed and hydrologic-model boundary

_ Stream or creek

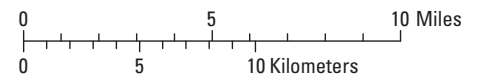

Figure 1-12. Spatially distributed agricultural irrigation estimates simulated using the crop water-demand model (CWDM) Santa Rosa Plain watershed, Sonoma County, California, for water years A, 1972-77; B, 1975-83; C, 1981-88; D, 1987-93; E, 1997-2004; and F, $2002-10$. 


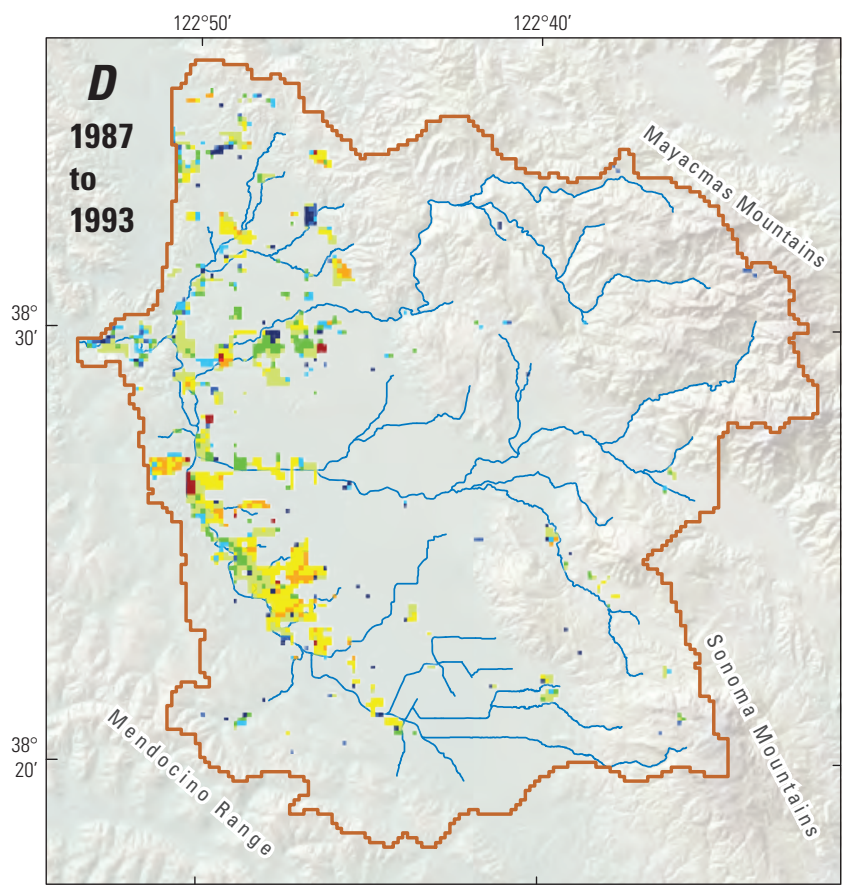

Estimated average annual irrigation, in inches per year, water years 1987 to 1993

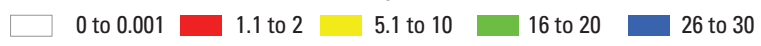

\begin{tabular}{ll|l|l|l|l|l}
0.0011 to 1 & 2.1 to 5 & 11 to 15 & 21 to 25 & 31 to 38
\end{tabular}

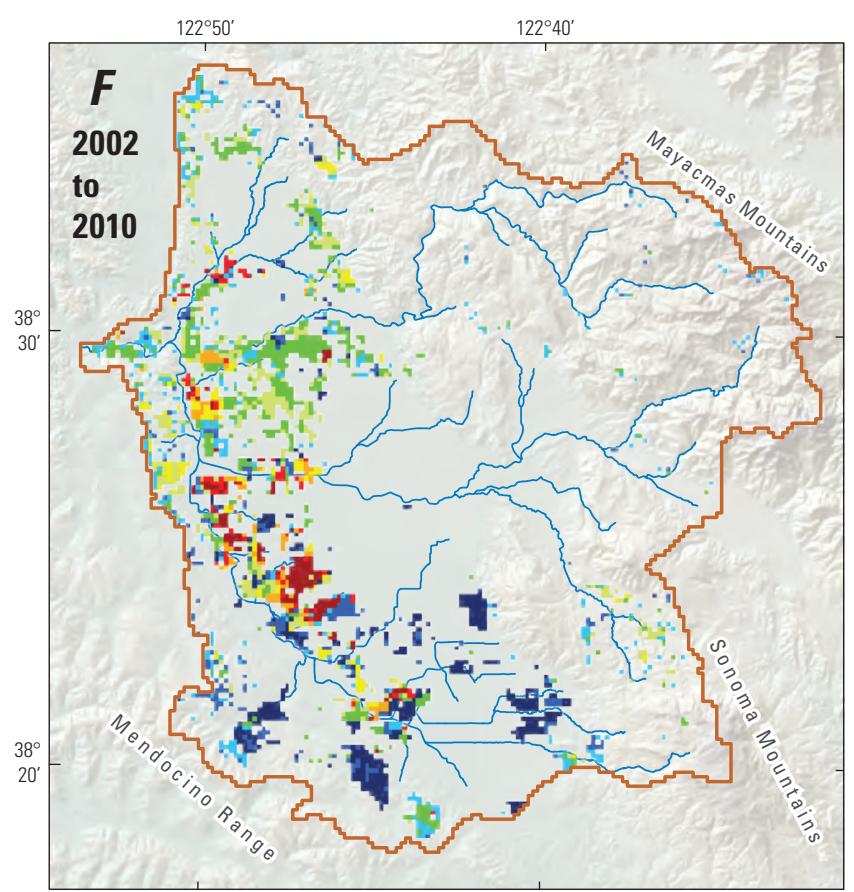

Estimated average annual irrigation, in inches per year, water years 2002 to 2010

\begin{tabular}{|l|l|l|l|l}
$\square$ & 0 to 0.001 & 1.1 to 2 & 5.1 to 10 & 16 to 20
\end{tabular}

\begin{tabular}{l|l|l|l|l|l|l|l|}
0.0011 to 1 & 2.1 to 5 & 11 to 15 & 21 to 25
\end{tabular}

Figure 1-12. - Continued

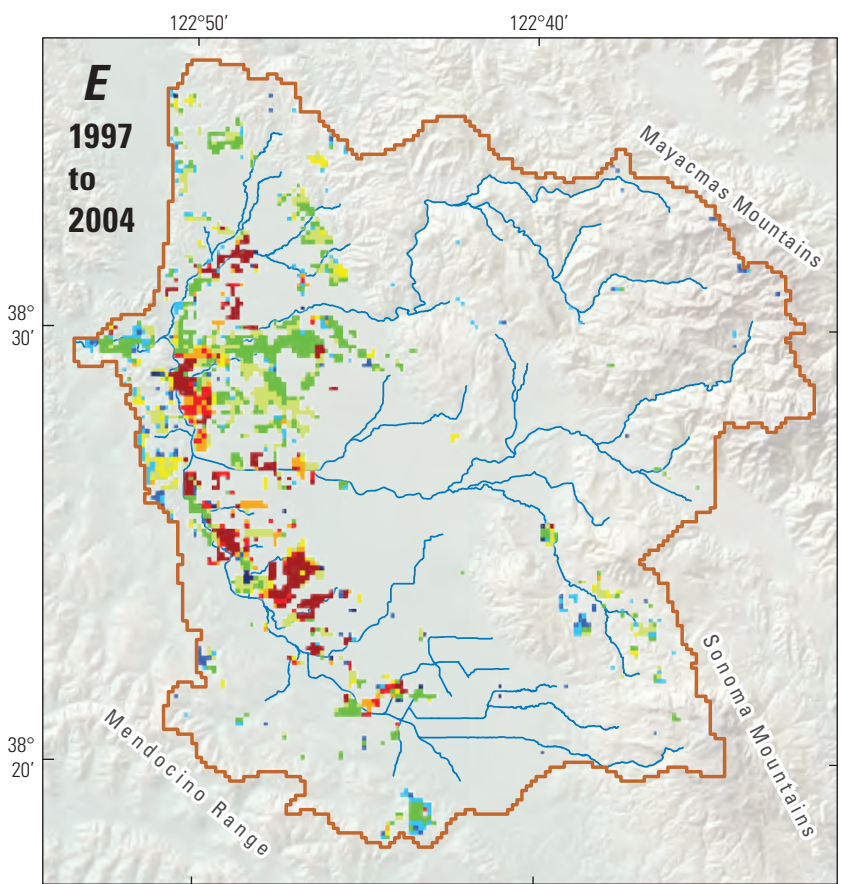

Estimated average annual irrigation, in inches per year, water years 1997 to 2004

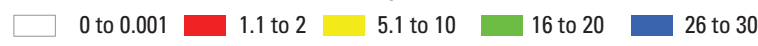

\begin{tabular}{l|l|l|l|l|l}
0.0011 to 1 & 2.1 to 5 & 11 to 15 & 21 to 25
\end{tabular}

\section{EXPLANATION}

_ Santa Rosa Plain watershed and hydrologic-model boundary

_ Stream or creek

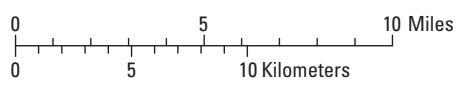


A

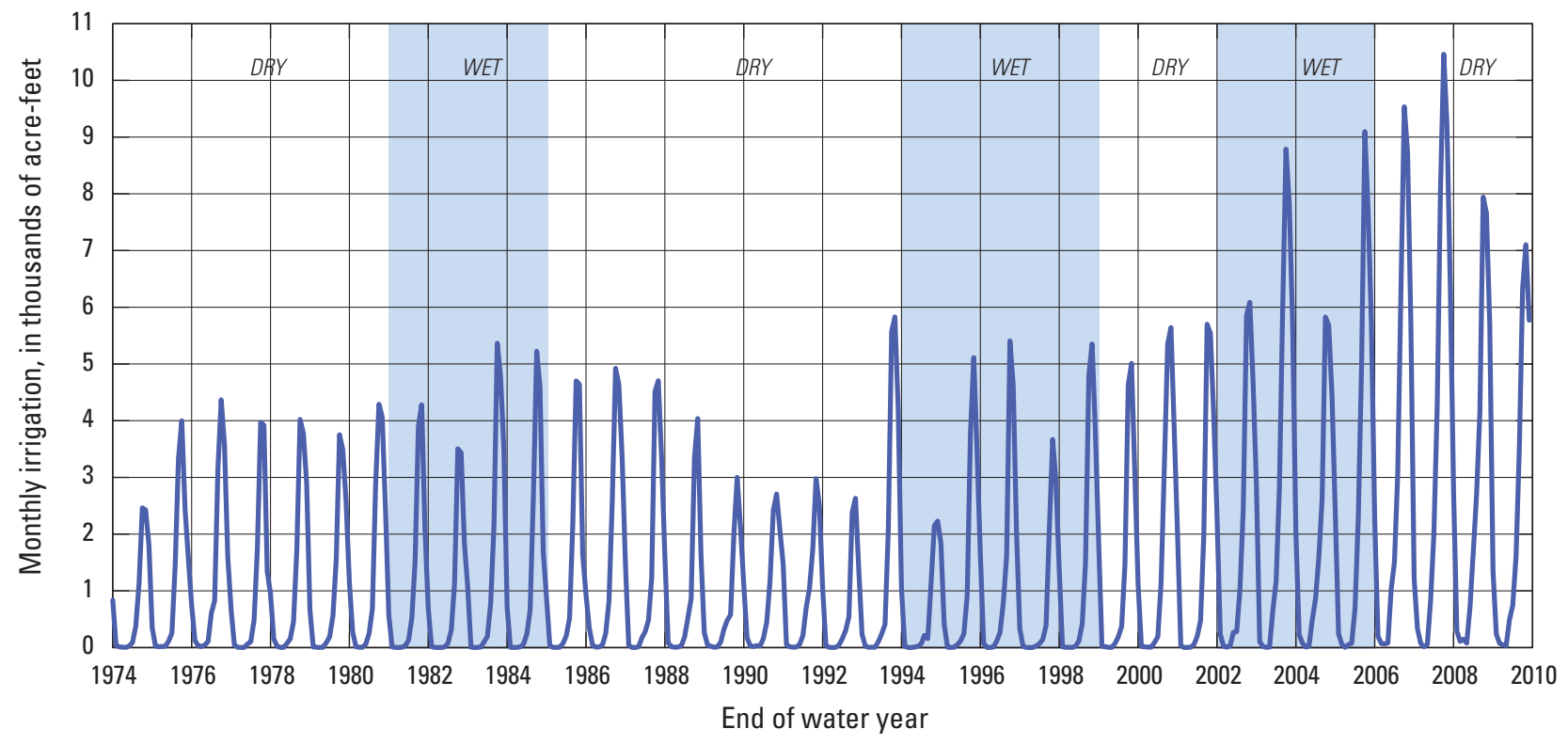

$\boldsymbol{B}$

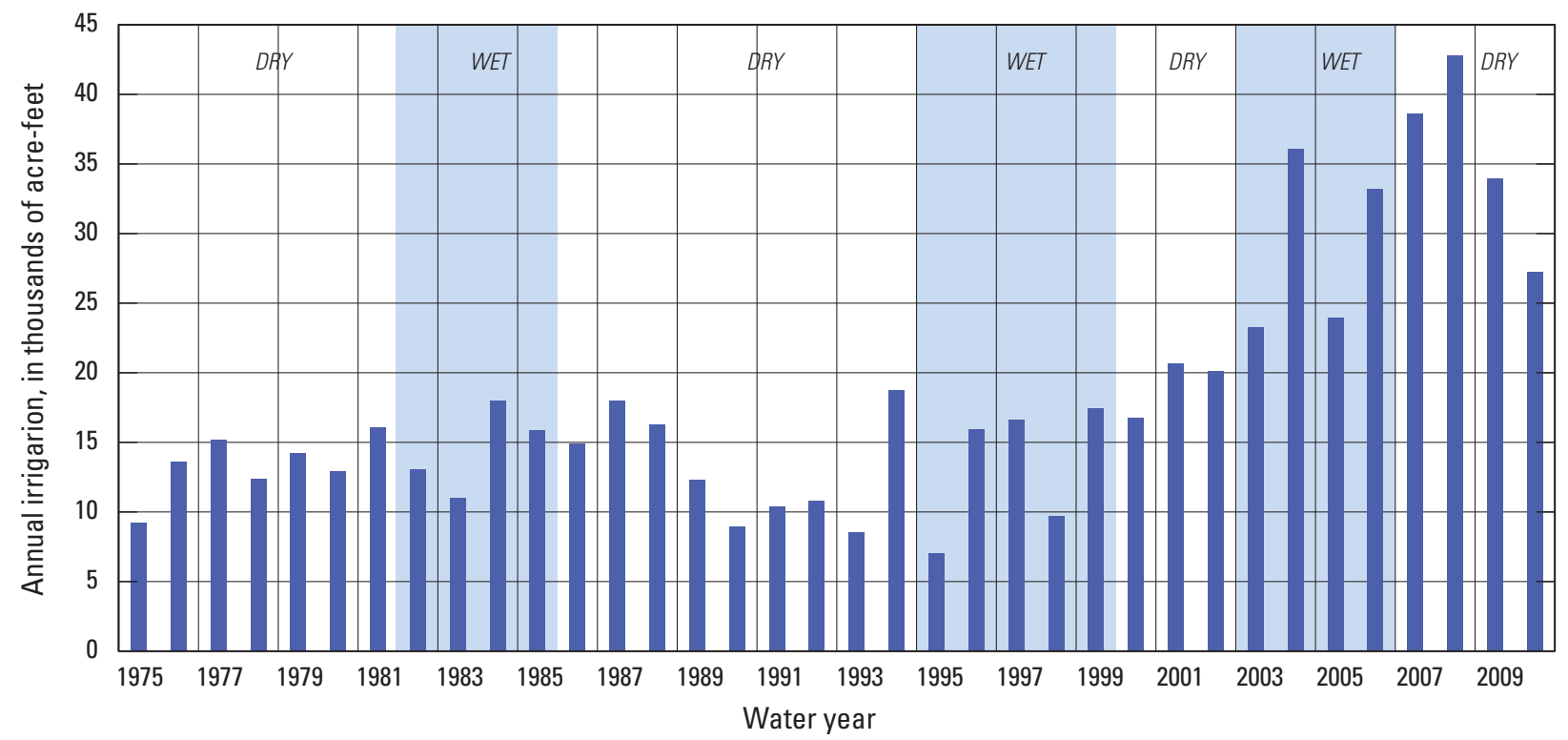

Figure 1-13. Estimates of irrigation used to estimate monthly agricultural pumpage for water years 1975-2010 for the Santa Rosa hydrologic model, Sonoma County, California: $A$, total monthly irrigation; and $B$, total annual irrigation. 


\section{References Cited}

Brush, C.F., Belitz, Kenneth, and Phillips, S.P., 2004, Estimation of a water budget for 1972-2000 for the Grasslands area, central part of the western San Joaquin Valley, California: U.S. Geological Survey Scientific Investigations Report 2004-5180, 49 p.

California Department of Water Resources, 1974, 1974 Sonoma County land use survey data: unpublished data located at Division of Integrated Regional Water Management, North-Central Region, West Sacramento, California, 1:24,000 scale.

California Department of Water Resources, 1979, 1979 Sonoma County land use survey data: unpublished data located at Division of Integrated Regional Water Management, North-Central Region, West Sacramento, California, 1:24,000 scale.

California Department of Water Resources, 1986, 1986 Sonoma County land use survey data: unpublished data located at Division of Integrated Regional Water Management, North-Central Region, West Sacramento, California, $1: 24,000$ scale.

California Department of Water Resources, 1999, 1999 Sonoma County land use survey data: California Department of Water Resources, Sacramento, Calif., digital map accessed on January 28, 2011, http://www.water.ca.gov/ landwateruse/lusrvymain.cfm.

California Department of Water Resources, 2013a, Integrated watershed model (IWFM): California Department of Water Resources, Bay-Delta, Sacramento, Calif., accessed on November 29, 2013, http://baydeltaoffice.water.ca.gov/ modeling/hydrology/IWFM/.

California Department of Water Resources, 2013b, Integrated water flow model-Demand calculator (IDC): California Department of Water Resources, Bay-Delta, Sacramento, Calif., accessed on November 29, 2013, http:// baydeltaoffice.water.ca.gov/modeling/hydrology/IWFM/ IDC/index_IDC.cfm/.

California Irrigation Management Information System, 2005, Meteorological data: Sacramento, Calif., California Department of Water Resources and University of California at Davis, http://www.cimis.water.ca.gov/.
Faunt, C.C., ed., 2009, Groundwater availability of the central valley aquifer, California: U.S. Geological Survey Professional Paper 1766, 225 p.

Hevesi, J.A., Woolfenden, L.R., Niswonger, R.G., Regan, R.S., and Nishikawa, Tracy, 2011, Decoupled application of the integrated hydrologic model, GSFLOW, to estimate agricultural irrigation in the Santa Rosa Plain, California, in Maxwell, R.M., Poeter, E.P., Hill, M.C., and Zheng, Chunmiao, eds., MODFLOW and More 2011: Integrated hydrologic modeling-Conference proceedings, June 5-8, 2011: Golden, CO, International Groundwater Modeling Center, p. 115-119.

Kadir, T.N., and McGuire, R.A., 1987, Santa Rosa Plain ground water model: California Department of Water Resources Central District, Sacramento, Calif., 318 p.

Markstrom, S.L. Niswonger, R.L., Regan, R.S., Prudic, D.E., and Barlow, P.A., 2008, GSFLOW-Coupled groundwater and surface-water FLOW model based on the integration of the precipitation-runoff modeling system (PRMS) and the modular groundwater flow model (MODFLOW-2005): U.S. Geological Survey Techniques and Methods 6-D1, 240 p.

Pittenger, Dennis, and Shaw, David, 2003, What we know about landscape water requirements: CO-HORT, University of California cooperative extension newsletter, v. 5.2, 8 p.

Schmid, Wolfgang, and Hanson, R.T., 2009, The farm process version 2 (FMP2) for MODFLOW -2005-Modifications and upgrades to FMP1: U.S. Geological Survey Techniques in Water Resources Investigations, Book 6, Chapter A32, $102 \mathrm{p}$.

U.S. Department of Agriculture, 2007, Natural resources conservation service, soil survey geographic (SSURGO) database for Sonoma County, California: Natural Resources, U.S. Department of Agriculture, accessed on May 14, 2009, http://SoilDataMart.nrcs.usda.gov. 
Prepared by the Sacramento Publishing Service Center.

For more information concerning this report, contact:

Director

U.S. Geological Survey

California Water Science Center

6000 J Street, Placer Hall

Sacramento, CA 95819

dc_ca@usgs.gov

or visit our Web site at:

http://ca.water.usgs.gov 


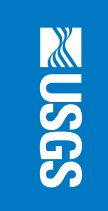

ISSN 2328-0328 (online)

http://dx.doi.org/10.3133/sir20145052

6 Printed on recycled paper 